Mario Gomes Schapiro

\title{
NOVOS PARÂMETROS PARA A INTERVENÇÃO DO ESTADO NA ECONOMIA: \\ PERSISTÊNCIA E DINÂMICA NA ATUAÇÃO DO BNDES EM UMA ECONOMIA \\ BASEADA NO CONHECIMENTO
}

Tese de doutorado apresentada ao Departamento de Direito Econômico e Financeiro, da Faculdade de Direito da Universidade de São Paulo, sob a orientação do Professor Associado Gilberto Bercovici.

São Paulo, 
Um dos inimigos do experimentalismo democrático é o fetichismo institucional: a crença de que concepções institucionais abstratas, como a democracia política, a economia de mercado e uma sociedade civil livre, têm uma expressão institucional única, natural e necessária. O fetichismo institucional é um tipo de superstição que permeia a cultura contemporânea. Ele penetra cada uma das disciplinas mencionadas anteriormente, e informa a linguagem e os debates da política comum. A idéia de esclarecimento, ora antiquada, seria hoje, mais bem aplicada a esforços para afastar o fetichismo institucional que vicia doutrinas ortodoxas em cada uma das disciplinas sociais. Afastá-lo seria o trabalho em tempo integral de uma geração de críticos sociais e cientistas sociais.

(Roberto Mangabeira Unger, O Direito e o Futuro da Democracia) 


\section{SUMÁRIO}

Agradecimentos....................................................................................................................6

Apresentação ..........................................................................................................................12

1. Direito e financiamento ...................................................................................................18

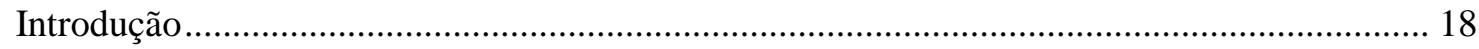

1. O direito como uma variável do financiamento corporativo: por que estudar

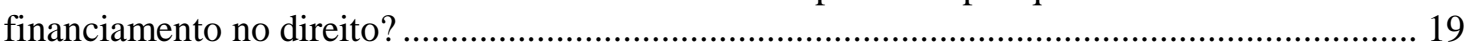

1.1. Uma linha de análise para as relações entre direito e financiamento: a law

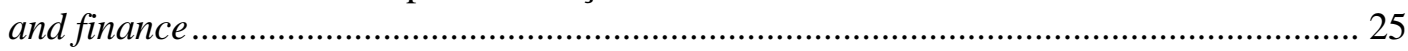

1.2. Uma linha alternativa de análise para as relações entre direito e

financiamento: a relevância das alternativas institucionais.................................................. 34

2. As alternativas institucionais de organização dos sistemas financeiros ................................ 45

3. Por que e como estudar financiamento no direito? Os arranjos institucionais e as ferramentas jurídicas como variáveis de análise da tese........................................................... 54

2. A alternativa de financiamento do desenvolvimento brasileiro ....................................58

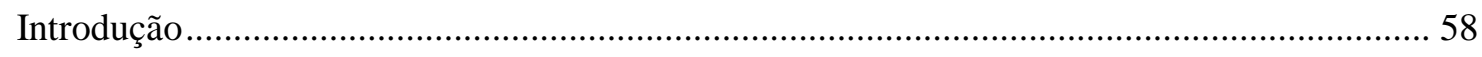

1. Poupança compulsória, programas de desenvolvimento e o Estado como agente

financeiro: a alternativa institucional dos países em desenvolvimento ...................................... 60

2. Formas e razões para a participação do Estado no setor bancário: a regulação institucional do sistema financeiro

3. A regulação institucional no sistema financeiro brasileiro: a atuacão do BNDES no

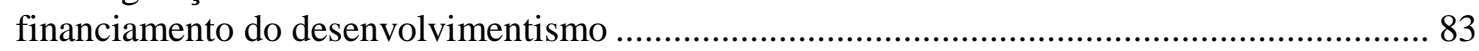

3.1. O BNDES e a intervenção do Estado durante o Plano de Metas ................................. 89

3.2. As reformas da década de 1960 e a intervenção do Estado durante o II PND .............. 92

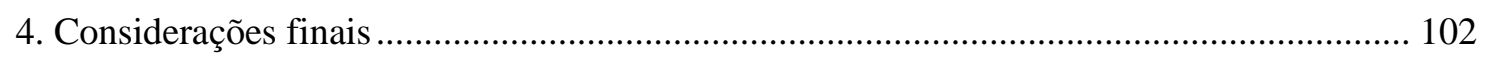

3. A economia baseada no conhecimento ..................................................................104

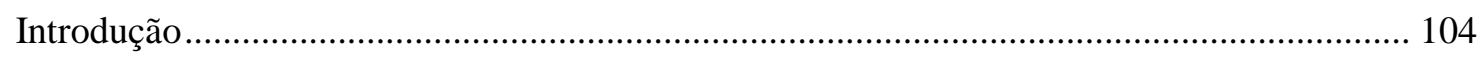

1. O paradigma fordista: rigidez dos fatores, economia de massa e a relevância das corporações e da intervenção estatal....................................................................................... 106

1.1. O papel das corporações no paradigma fordista: coordenação

microeconômica, captação financeira e realização dos investimentos industriais 116

1.2. O papel do Estado na regulação econômica do fordismo: o Estado regulador norte-americano, o Estado interventor europeu e o Estado desenvolvimentista na

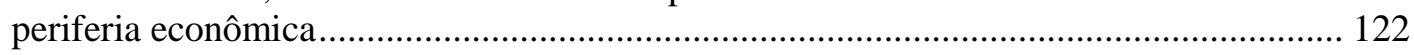

2. A crise do fordismo e o paradigma da economia baseada no conhecimento........................ 129

3. As respostas à crise do fordismo: acumulação flexível e economia das inovações .............. 135

3.1. A regulação microeconômica e as alterações na organização corporativa: as

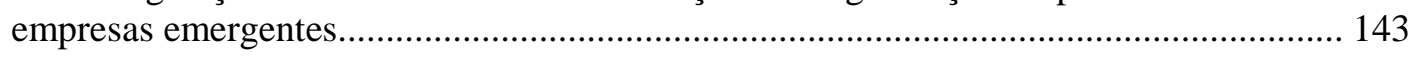

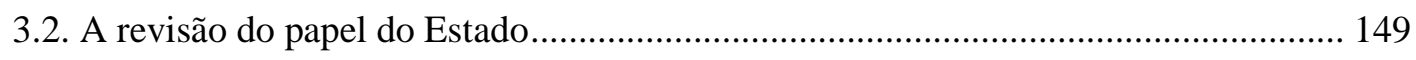

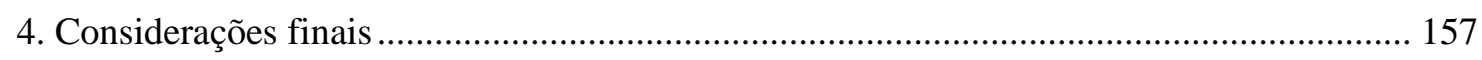

4. As respostas do direito para o financiamento de uma economia baseada no conhecimento .....................................................................................................................160

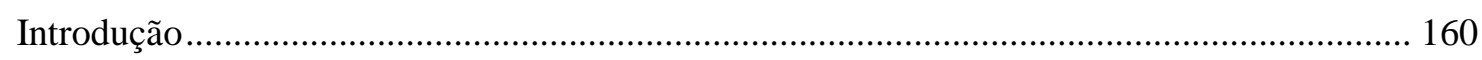


1. O financiamento das inovações: o problema de assimetria das informações e do custo de agência

2. Ferramentas jurídicas e transações econômicas: uma análise funcionalista

2.1. A racionalidade do contrato simples de crédito: autonomia das partes, presentificação e rigidez.

2.2. A racionalidade do contrato relacional: compartilhamento de ganhos e perdas e flexibilidade dos termos

2.3. Limites e possibilidades do financiamento por dívida mobiliária.

2.4. O financiamento das inovações por meio da participação societária: governança descontínua versus governança relacional.

2.5. Visão geral das ferramentas jurídicas de financiamento.

3. O venture capital e o modelo norte-americano de financiamento das inovações:

ferramentas relacionais de participação societária e arranjo institucional de mercado

4. Considerações finais

5. O Banco de Desenvolvimento diante de uma economia baseada no conhecimento

Introdução

1. As ferramentas jurídicas do BNDES e o financiamento das inovações e das empresas emergentes

1.1. O BNDES como um venture capitalist.....

1.2. O BNDES como indutor do mercado de capital de risco.

2. A retomada da política industrial e a terceira fase das inovações jurídico-institucionais: contratos relacionais, intensificação e abrangência dos programas de capital de risco

2.1. A utilização de contratos de operação de crédito para financiamentos de inovação: a experiência dos programas setoriais

2.2. A nova política operacional: níveis de prioridade para a inovação e paradigma contratual relacional

2.3. Capital de risco: intensificação e abrangência das intervenções.

3. Exemplos da dupla atuação do BNDES: a participação societária na Lupatech S.A. e a indução do Bovespa Mais

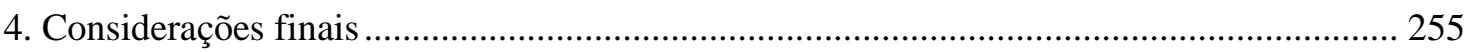

6. Novos parâmetros para a intervenção do Estado na economia...................................257

Introdução

1. As alterações no sistema financeiro nacional e a persistência da alternativa institucional de organização financeira

1.1. As reformas econômicas no sistema financeiro brasileiro

1.2. A persistência da alternativa institucional: a relevância do BNDES como agente de intervenção estatal.

2. Como a literatura de direito e financiamento interpreta a persistência da alternativa institucional? A dependência da trajetória e os limites da tese da convergência

2.1. Alguns exemplos da primazia das alternativas institucionais: a experiência dos países da OCDE.

3. A dinâmica na alternativa institucional: novos parâmetros para a intervenção do Estado.. 290 3.1. A mudança de racionalidade na atuação do Estado no sistema financeiro nacional.

4. Considerações finais 304 


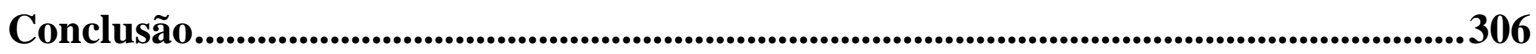

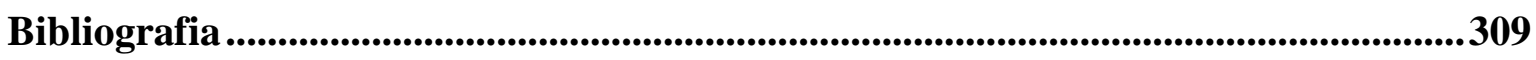

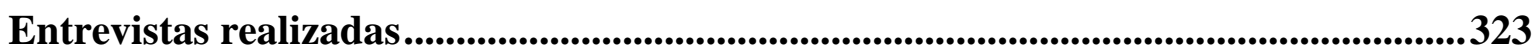

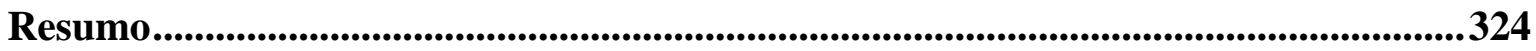

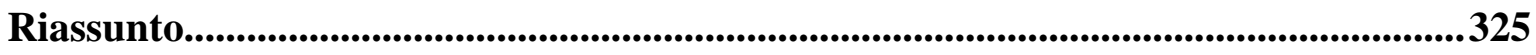

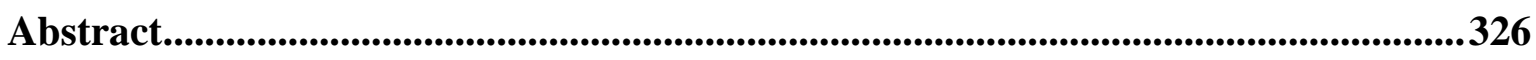




\section{ÍNDICE DE QUADROS}

Quadro 1: Sistemas regulatórios e tipos de arranjos econômicos $\quad$ p. 44

$\begin{array}{ll}\text { Quadro 2: } & \text { Alternativas de sistemas financeiros } 49\end{array}$

Quadro 3: Concentração acionária dos cinco maiores investidores por p. 53 companhia

Quadro 4: $\quad$ Participação dos bancos estatais no total de ativos bancários (\%) - p. 68 2004

$\begin{array}{ll}\text { Quadro 5: } & \text { Síntese da atuação do BNDES } 101\end{array}$

Quadro 6: $\quad$ Evolução da industrialização brasileira (\%) $\quad$ p. 114

Quadro 7: Pedidos de patente de invenção no USPTO p. 142

Quadro 8: Probabilidade dos veículos de financiamento - empresas p. 165 emergentes versus empresas estabelecidas

$\begin{array}{ll}\text { Quadro 9: } & \text { Mercados e hierarquias } 171\end{array}$

Quadro 10: Régua de financiamento - possibilidade de financiamento das p. 187 inovações por meio de dívida mobiliária

Quadro 11: Comparação da probabilidade de utilização das ferramentas - p. 195 financiamento das inovações

Quadro 12: Comparação entre financiamento tradicional e venture capital p. 203

$\begin{array}{ll}\text { Quadro 13: Programas setoriais do BNDES } & \text { p. } 243\end{array}$

Quadro 14: Remuneração básica do BNDES pelo nível de prioridade p. 245

$\begin{array}{lll}\text { Quadro 15: Desembolsos BNDES (valores em R\$) } & \text { p. } 247\end{array}$

Quadro 16: Resumo da participação societária do BNDES p. 250 
Quadro 17: Composição do conselho de administração da Lupatech S.A. (pós p. 253 IPO - 2008)

Quadro 18: Comparação de regras: Novo Mercado - Bovespa MAIS

Quadro 19: Quadro sinótico das formas de participação do BNDES

Quadro 20: Participação das instituições financeiras nas operações de crédito p. 264 $(\%)$

Quadro 21: Participação das instituições financeiras com controle estrangeiro p. 265 $(\%)$

Quadro 22: Tipologia da participação dos governos da OCDE nos programas p. 286 de venture capital

Quadro 23: Recomendações da OCDE para a participação direta do Estado nos programas de venture capital

p. 290

Quadro 24: Tipos de Estado e racionalidades regulatórias 


\section{ÍNDICE DE GRÁFICOS}

$\begin{array}{ll}\text { Gráfico 1: Pedidos de patente no USPTO } & \text { p. } 141\end{array}$

Gráfico 2: Evolução dos desembolsos do BNDES para inovações $\quad$ p. 218

Gráfico 3: Desembolsos anuais do BNDES no mercado de capitais para micro, p. 228 pequenas e médias empresas

Gráfico 4: Carteira de FMIEE do BNDES - Participação no total de fundos p. 235

Gráfico 5: Participação do BNDES no setor de venture capital (participação p. 249 direta e via fundos)

Gráfico 6: Evolução dos desembolsos anuais do BNDES p. 271

Gráfico 7: Desembolsos do BNDES em comparação com emissões primárias de p. 272 ações e de debêntures 


\section{AGRADECIMENTOS}

Esta tese encerra um período relativamente longo de dez anos, iniciado em 1999, quando obtive uma bolsa de iniciação científica da FAPESP. Daí em diante, seguiu-se um mestrado e agora o final da tese de doutorado. Ao longo deste período, muitas pessoas foram importantes, contribuindo para o amadurecimento de algumas das idéias que resultaram na conclusão deste trabalho. Passo a agradecer a todas elas. Antes, porém, registro minha gratidão à Universidade de São Paulo, que permitiu que tudo isso ocorresse.

Entre 1999 e 2000, durante as primeiras atividades de pesquisa, tive a oportunidade de conhecer Gilberto Bercovici, que à época concluía o seu doutorado tínhamos o mesmo orientador. Daí em diante, Gilberto tornou-se não só um amigo, como também veio a ser o meu orientador, seja no mestrado, seja agora no doutorado. Eis aqui uma boa oportunidade para agradecê-lo. Ao longo de toda esta trajetória, Gilberto foi um orientador leal e que soube respeitar as minhas opções de pesquisa, sem, no entanto, deixar de pontuar e criticar sempre que necessário.

Sou também grato aos professores Charles Sabel e David Trubek, com quem tive a oportunidade de debater longamente este trabalho. Sabel foi meu orientador na temporada que passei na Columbia Law School e também foi uma referência intelectual importante nesse trabalho. Alguns de seus artigos e particularmente o seu livro escrito com Michael Piore (The Second Industrial Divide) deram consistência teórica às minhas inquietações acerca do papel do Estado em um contexto pós-keynesiano. Trubek foi um interlecutor generoso, que agregou a este trabalho as preocupações relativas ao direito. Desde os anos 1960, Trubek tem se voltado a analisar a relação entre direito, Estado e desenvolvimento e continua a fazê-lo, estimulando pesquisas empíricas, na linha do law in action, para assim avaliar como estes três elementos têm se ajustado aos novos desdobramentos econômicos. É este um dos objetivos do projeto LANDS (Law and New Developmental State), da Universidade de Wisconsin, do qual Trubek gentilmente convidou-me a participar. A Sabel e a Trubek, fica o meu agradecimento sincero. Sou também grato à professora Tamara Lothian, pela bibliografia recomendada.

O projeto LANDS é coordenado, no Brasil, por Diogo Coutinho e Paulo Mattos, que opinaram sobre algumas das idéias presentes neste trabalho. No âmbito deste projeto realizei diversas entrevistas, entre gestores do BNDES, FINEP e FAPESP. Embora nem todas tenham sido utilizadas neste trabalho, a experiência das entrevistas e a possibilidade de participar de uma pesquisa coletiva foram oportunidades enriquecedoras. Sou, portanto, grato ao Diogo e ao Paulo.

A Diogo Coutinho e a Samuel Barbosa agradeço as valiosas observações realizadas no exame de qualificação, muitas delas estão presentes nesta tese. Fica, ainda, um agradecimento a José Tadeu De Chiara, que me recebeu gentilmente para uma conversa sobre o BNDES - esta conversa ajudou-me a montar o segundo capítulo deste trabalho.

Aos membros do BNDES fica aqui a minha admiração e o meu muito obrigado. Todas as pessoas procuradas foram solícitas e apoiaram a realização desta pesquisa. Da mesma forma, sou grato aos gestores da CVM, em particular a Marcos Pinto, que igualmente ajudaram a realização desta tese. 
Ao longo da tese, tive o privilégio de trabalhar na Escola de Direito da FGV, como Coordenador de Pesquisas e como professor de direito econômico do GV LAW. Nestes três anos, os corredores e a cafeteria ouviram muito das muitas "teses" que eu supunha ter. Cada uma das conversas, cada uma das aulas, foi fundamental para que ao final pudesse ter chegado, enfim, a esta tese. Correndo o risco da injustiça, gostaria de agradecer a alguns dos meus colegas. Oscar Vilhena Vieira, com quem dividia o corredor, não só lançou boas provocações ao meu "desenvolvimentismo jurídico", como também me recomendou para o programa de visiting scholar da Columbia - fica aqui o meu muito obrigado. Emerson Fabiani, Coordenador Executivo da Direito GV, desesperado como eu com o fim da sua tese, foi um amigo generoso, que soube entender e apoiar todas as minhas necessidades e pedidos. Devo a ele a aprovação institucional para um período de licença, no qual pude permanecer no exterior - um muito obrigado é pouco. Também sou grato aos Professores Ary Oswaldo Mattos Filho, Antonio Angarita e Paulo Goldschmidt, os Diretores da Escola, de quem obtive todo o apoio para a realização deste trabalho. Por fim, gostaria ainda de agradecer aos colegas Michelle Ratton, Francisco Satiro, Marcos Paulo Veríssimo, Frederico Turolla, José Garcez, José Rodrigo Rodriguez, Ronaldo Porto Macedo Júnior, Rafael Vanzella, Thomas Junqueira, Fábio Durço, Fábia Veçoso e Ana Elvira Gebara. Mariana Valente ajudou-me na formatação final do trabalho - agradeço pelo capricho e pela sua dedicação.

Devo muito deste trabalho ao professor Glauco Arbix. Foi em uma conversa no CEBRAP que decidi mudar o meu estudo de caso. Desde o ingresso no doutorado, pretendia estudar os novos mecanismos da intervenção estatal na economia e para tanto havia decidido estudar a Petrobrás. No entanto, uma provocação de Arbix levou-me a perigosa decisão de mudar o objeto da pesquisa empírica, faltando dois anos para o fim da tese. Agradeço bastante por aquela conversa. Também sou grato a Ricardo Abramovay e a Álvaro Comin, cujas disciplinas ajudaram-me a definir um caminho teórico de pesquisa.

Aos meus amigos, devo a paciência e a tolerância - convivem comigo fazendo tese há seis anos. Devo a eles também a abnegação de me ouvir falar repetidamente sobre este trabalho. Aos heróis Fernando Rugitsky, Frederico Normanha, Vinicius Marques de Carvalho, Diogo Santana, Fernando Neisser, Catarina Barbieri, Carol Stuchi, Livia Sobota, Alê Octaviani e Alamiro Netto fica o meu especial agradecimento - estendido, ainda, a Maria Fernanda de Moura e Souza e Lia Roston, poupadas da tese, mas amigas há tantos anos que a sua amizade está presente nessas linhas. Rodrigo Surcan, Camila Amaral e Carol Paschoal são grandes amigos que reencontrei no período de visiting scholar.

Fabio Costa de Morais Sá e Silva e Michelle de Morais Sá e Silva foram uma parte da minha família na minha gelada temporada de Nova York. Agradeço a eles pela acolhida, pelo Natal que passamos juntos e pela companhia nas bibliotecas da Columbia sem eles por lá teria sido muito difícil. Sou igualmente grato à Pat, Nick, Toni e Leo, a outra parte da família.

Aos meus pais, Carlos e Dulce, serei sempre grato, a sua obsessão com a minha educação foi o que permitiu que este trabalho fosse feito.

À Helena, sou muito mais do que agradecido. Ela acompanhou cada dia de alegria e de angústia, deu força, estimulou e esteve presente até no período que ficamos distantes. Por tudo isso, dedico este trabalho a ela, com amor. 
Para Helena, com amor. 


\title{
APRESENTAÇÃO \\ O CAMPO, A PERGUNTA E A ESTRATÉGIA METODOLÓGICA DA TESE
}

\begin{abstract}
"Não seria tempo de se admitir modestamente o que outras ciências sociais já admitiram desde a primeira hora: que ao lado de uma análise de conceitos e de categorias, existe um estudo de técnicas? Que ao lado de um direito formal deve haver lugar para um direito aplicado? O direito econômico aparece assim como um dos ramos de direito aplicado, que supõe evidentemente um conhecimento prévio de categorias formais que se situam tradicionalmente na teoria geral do direito privado ou na teoria geral do direito público. E a sua unidade ou, se se preferir, a sua autonomia nos é dada pela sua finalidade: traduzir normativamente os instrumentos de política econômica do Estado. A utilidade do direito econômico concebido nestes termos é inegável. Sob o aspecto formal, ele vem possibilitar o estudo sistemático de várias matérias que dificilmente se enquadrariam nos esquemas tradicionais, e que por isso mesmo, têm sido até o presente relegadas a um injustificável plano secundário, quando não a um silêncio completo por parte da doutrina jurídica oficial."

(Fábio Konder Comparato, O Indispensável Direito Econômico)
\end{abstract}

Em 1965, Fábio Konder COMPARATO publicou o seu artigo seminal $O$ Indispensável Direito Econômico, no qual chamava a atenção dos juristas, sempre enredados com uma leitura liberal do Estado e do direito, de que o capitalismo do século XX colocara em xeque a ideologia de um mercado auto-regulado e imune às iniciativas da regulação pública. Mudava, assim, o centro de gravidade das normatizações encarregadas de disciplinar o funcionamento das atividades econômicas: no lugar dos direitos civil e comercial, voltados a garantir instrumentos para uma ação comercial entre agentes particulares, ganhavam centralidade os institutos e os regulamentos dedicados a garantir uma intervenção pública na coordenação da economia. O direito patrimonial privado cedia, pois, lugar para um direito econômico.

É o direito econômico quem passou a reunir os instrumentos jurídicos que habilitam a intervenção disciplinadora do Estado na economia. Neste domínio, a atuação pública pode ocorrer de duas maneiras: indiretamente ou diretamente. No primeiro caso, trata-se de uma feição mais contemporaneamente conhecida, a do direito regulamentar econômico, verificável nas situações em que o Poder Público estipula as regras do jogo para as atividades exercidas pelos agentes privados. As normatizações setoriais promovidas pelas agências reguladoras, como a ANATEL, a ANP e a ANEEL $^{1}$ são

\footnotetext{
${ }^{1}$ Respectivamente: Agência Nacional de Telecomunicações, Agência Nacional do Petróleo e Agência Nacional de Energia Elétrica.
} 
exemplos deste modo de ação. No segundo caso, o Estado disciplina a realidade econômica por meio de uma intervenção pública presencial e direta: o próprio Estado, valendo-se de suas empresas estatais e de seus bancos públicos, atua nos mercados e assim exerce um controle sobre as variáveis econômicas, como oferta, demanda e preço. A Petrobrás, os Correios, a Caixa Econômica Federal e o BNDES são alguns exemplos destes instrumentos

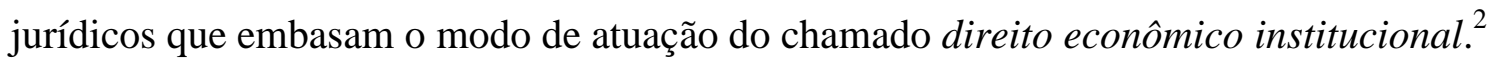

Esta virada, desde a centralidade do direito privado para o direito econômico, não é trivial. Não se trata apenas de uma troca de hegemonia entre tipos de regras, das privadas às públicas. Muito mais do que isso, a afirmação do direito econômico, como faz questão de assinalar o texto de COMPARATO, implica não só uma nova posição do Estado sobre a economia, como também uma reviravolta na forma de compreensão e de estudo do direito.

As crises sucessivas do capitalismo, as falhas de mercado, a concentração do poder econômico e a assimetria entre as nações têm deixado clara a necessidade de os Estados atuarem no espaço econômico, para o quê são definidas políticas públicas e planos de desenvolvimento, bem como os seus correspondentes instrumentos jurídicos de ação. Em uma realidade como esta, o estudo do direito não é apenas formalista, isto é, voltado à construção de suas categorias internas. Para além das convencionais descrições estruturais, em que os juristas dedicam-se a construir os chamados sistemas jurídicos, como, é o caso da doutrina do direito da propriedade ou a doutrina do direito dos contratos, o estudo da regulação pública da economia exige uma abordagem funcionalista. Assim, o direito econômico trouxe para o raciocínio jurídico uma preocupação aplicada, dedicada a temas normalmente não tratados pela ciência do direito de filiação formalista: é o caso das investigações voltadas aos ajustes entre os meios jurídicos e os fins políticos, uma sintonia bastante presente na regulação pública da economia.

É justamente este o campo desta tese: analisar a intervenção do Estado na economia, tendo como objeto imediato de estudo as suas ferramentas jurídicas, em uma perspectiva funcionalista. Parte-se, no entanto, do reconhecimento de que o ambiente contemporâneo não é mais o mesmo que ensejou as primeiras reflexões sobre o direito econômico. Na década de 1960, os juristas dedicados a compreender as novas feições da

\footnotetext{
${ }^{2}$ Ver a respeito VENÂNCIO FILHO, Alberto. A Intervenção do Estado no Domínio Econômico - o direito público econômico no Brasil, Edição Fac-similar da de 1968, Rio de Janeiro, Renovar, 1998.
} 
relação público-privada viam-se às voltas com uma economia planejada e dirigida pelo Estado. Desde lá, não só a forma da intervenção pública indica alterações, como também se vislumbra mudanças na função econômica desempenhada pelo Estado: as suas atribuições parecem não se restringir apenas à provisão da infra-estrutura e dos serviços públicos. Alguns indicadores sugerem que o fomento das inovações e o incentivo do progresso tecnológico ganham, na atualidade, talvez a mesma relevância que os setores intensos em escala e em capital detinham entre as décadas de 1950 e 1980. É neste contexto, posterior à idade do ouro do keynesianismo, que este trabalho procura desenvolver a sua investigação, dedicada a entender os novos ajustes estabelecidos entre o Estado e o mercado, notadamente no campo das empresas emergentes e inovadoras. Particularmente, pretende-se investigar a atuação de um dos instrumentos de intervenção do Estado: o banco público de desenvolvimento.

Para tanto, este trabalho assume dois pressupostos: (i) a existência de alternativas institucionais de organização econômica e financeira e (ii) a consolidação, desde meados da década de 1980, de um novo paradigma econômico, assentado em conhecimento e em inovações.

Como procurará narrar o capítulo 1 deste trabalho, em virtude de suas especifidades históricas e culturais, os países definem diferentes formatos jurídicoinstitucionais de organização econômica e financeira. A adoção deste pressuposto vai de encontro a uma literatura que tem recebido uma considerável notoriedade acadêmica, identificada neste trabalho como Law and Finance. Os autores afinados com esse paradigma têm se voltado a analisar o impacto do sistema jurídico sobre a atividade de financiamento. Para tanto, argumentam que a variável central do financiamento corporativo é definição de um elenco correto de mecanismos jurídicos de proteção dos investidores. Ocorre, contudo, que tais análises, não obstante situarem o debate sobre financiamento no âmbito do direito, assumem uma lente de observação muito estreita, que acaba por desconsiderar a existência de distintas alternativas de organização financeira. Notadamente, as análises de corte Law and Finance tomam a regulação institucional exercida pelos bancos públicos como uma distorção - um arremedo de solução jurídicoinstitucional. 
Este trabalho parte deste estatuto teórico, mas procura ampliar a sua régua de análise, para com isso compreender a atuação dos bancos públicos não como um defeito, mas como uma especificidade, própria de países subdesenvolvidos. Reconhece-se, assim, que nas economias em desenvolvimento, em virtude da relativa insuficiência de meios privados para a concessão de capital, aptos a amparar os investimentos de longo prazo de maturação, ou que envolvessem riscos elevados, o Estado tornou-se o provedor direto dos recursos financeiros. Os dois primeiros capítulos deste trabalho procurarão argumentar que, em boa parte da periferia, a participação do Estado é mais expressiva do que a registrada nos países de centro, indicando uma prevalência do direito econômico institucional em relação ao direito regulamentar econômico, ao menos no ambiente financeiro.

Esta tendência foi originariamente identificada por Alexander GERSCHENKRON ${ }^{3}$, em suas análises dos processos de desenvolvimento de alguns dos países menos desenvolvidos da Europa. Conforme argumenta o autor, a solução estatal tem sido uma espécie de resposta institucional às intensas falhas dos mercados de capitais e dos bancos privados em cumprir o seu papel de financiadores do desenvolvimento capitalista. Não é à toa, portanto, que países como o Brasil, a Coréia do Sul e o México, com um ritmo de desenvolvimento mais tardio, tenham constituído bancos públicos, encarregados da suplência do capital financeiro necessário para levar adiante as suas estratégias de crescimento nacional.

Além da prevalência da regulação institucional na organização financeira, um segundo pressuposto deste trabalho, descrito no capítulo 3 , refere-se à consolidação de um novo tipo de organização econômica mundo afora - uma economia baseada no conhecimento. Um fenômeno identificado neste trabalho com a primazia das inovações como estratégia corporativa e também com o esgotamento do paradigma fordistadesenvolvimentista, que embalou os planos de desenvolvimento implementados entre as décadas de 1950 e 1980.

\footnotetext{
${ }^{3}$ GERSCHENKRON, Alexander. Economic Backwardness in Historical Perspective - a book of essays, $3^{\mathrm{a}}$ reimpressão, Cambridge, London, Belknap Press, 1976.
} 
Para Charles SABEL ${ }^{4}$, a aposta dos formuladores de políticas públicas nos países de terceiro mundo, na fase desenvolvimentista, era a de que a riqueza das nações mais pobres dependeria da viabilização dos mesmos setores industriais que garantiam êxito às nações mais ricas - os setores de bens de consumo, produzidos em série. Um exemplo significativo disso foi o grande esforço público realizado no âmbito do Plano de Metas, no governo Juscelino Kubitschek, para atrair as grandes montadoras de veículos para o país. Uma concepção de desenvolvimento econômico que se espelhava, portanto, no mesmo fenômeno industrial que se processava nos países de centro, em meados do século XX. Era o contexto da hegemonia fordista de produção, que contava com alguns atributos, como, por exemplo: (i) grandes indústrias; (ii) produção seriada; (iii) produção e emprego de massa.

A consolidação de uma economia baseada no conhecimento, entretanto, desarticulou as bases institucionais do capitalismo fordista e tem apresentado novos desafios para a intervenção estatal no domínio econômico. Como relata o capítulo 3, nos países centrais, desde meados da década de 1980, uma parte significativa das vantagens comparativas nas transações comerciais deixou de ser protagonizada por bens econômicos padronizados, fruto de uma produção em série, e passou, gradativamente, a girar em torno de bens diferenciados, customizados e confeccionados por meio de processos produtivos baseados em pesquisa e desenvolvimento. No lugar exclusivo das grandes indústrias, voltaram a ter papel também as pequenas e médias empresas, especializadas em produtos particularizados, voltados a atender nichos de mercados. Neste processo de florescimento de uma economia inovadora, deu-se, por exemplo, o fortalecimento dos distritos industriais, como é o caso da, assim chamada, terceira Itália ou do vale do Silício, nos Estados Unidos.

Esta tese se insere nesse ambiente: volta-se a investigar a forma de atuação de um banco de desenvolvimento em um contexto pós-desenvolvimentista. Nesta etapa, não só o financiamento das inovações tornou-se uma pauta relevante, como a própria organização

\footnotetext{
${ }^{4}$ Para uma descrição desta relação entre o desenvolvimentismo e o fordismo ver SABEL, Charles. Mudança de Modelos de Eficiência e suas Implicações para a Industrialização no Terceiro Mundo, em FOXLEY, Alejandro; MCPHERSON, Michael \& O`DONNELL, Guillermo. Desenvolvimento e Política e as Aspirações Sociais - o pensamento de Albert O. Hirschman, (Trad. Adail Sobral \& Evelyn Massaro), São Paulo, Vértice, 1988, pp. 33-62. A esse respeito, ver também o argumento original do autor expresso no livro PIORE, Michael \& SABEL, Charles. The Second Industrial Divide - possibilities for prosperity, New York, Basic Books, 1985.
} 
da economia indica alterações significativas: boa parte da economia brasileira foi privatizada e exposta à competição internacional. Diante disso, este trabalho é conduzido pela seguinte pergunta chave: em um contexto pós-desenvolvimentista, a intervenção direta Estado, por meio do BNDES, cumpre, ainda, um papel relevante e, se cumpre, há diferenças em relação ao contexto anterior?

A hipótese do trabalho é a de que a resposta para esta pergunta envolve uma tensão. De um lado, supõe-se que o Estado, por meio dos bancos públicos, continua desempenhando um papel relevante na organização financeira nacional - a regulação institucional seria ainda um traço característico do panorama brasileiro. De outro, as demandas de uma economia baseada no conhecimento e a desarticulação do modelo nacional-desenvolvimentista sugerem que esta intervenção estatal esteja assentada em parâmetros diferenciados, mais porosos ao estabelecimento de parcerias com os agentes privados.

Para testar a hipótese este trabalho realizará um estudo de caso sobre a atuação do BNDES no financiamento de empresas emergentes e inovadoras. O cerne desse estudo, apresentado no capítulo 5, são as ferramentas jurídicas e a conseqüente racionalidade do Banco, empregadas nas atividades relacionadas à nova economia. As descrições de seu modo de operação serão, então, interpretadas no último capítulo do trabalho, quando se procurará apresentar o argumento final da tese. Por se tratar de um estudo de caso, as conclusões tendem a se limitar ao âmbito da nova economia e à atuação do BNDES, muito embora possam ser feitas cuidadosas generalizações a partir daí. Ao final do trabalho, espera-se uma conclusão capaz de indicar os novos caminhos pelos quais tem passado a intervenção do Estado na economia. 


\title{
$-1-$ \\ DIREITO E FINANCIAMENTO: \\ AS ALTERNATIVAS INSTITUCIONAIS E AS FERRAMENTAS JURÍDICAS
}

\begin{abstract}
"There is more than one way to move savings from households to industry. A securities market that produces fragmented ownership is only one way, and it is the prevailing way in America."
\end{abstract}

(Mark ROE)

\section{INTRODUÇÃO}

Uma variável decisiva dos estudos e proposições que tomam o desenvolvimento econômico como seu objeto de trabalho é o funcionamento do sistema financeiro, de sua capacidade de crédito e de financiamento das atividades estratégicas para o crescimento das nações. Não sem muita razão. Compete ao sistema financeiro a captação de recursos e a sua realocação em atividades econômicas, que serão capazes de gerar rendas superiores e novas poupanças, em um processo contínuo de geração de riqueza.

A seqüência desta ciranda, quando bem sucedida, garante aos empreendedores um acesso permanente ao crédito, com o qual realizarão investimentos em um patamar superior ao que se poderia esperar, caso dispusessem apenas de seus próprios recursos para as suas atividades de financiamento. Esta atuação do sistema financeiro é socialmente desejável, em virtude dos seus efeitos de escala: se cada agente econômico fosse limitado ao volume de investimentos que pudesse financiar por conta própria, o retorno dessa atividade seria correspondentemente limitado. ${ }^{5}$

É por isso que, a médio e longo prazo, a mobilização de capital pelo sistema financeiro, a sua oferta aos investidores e o seu conseqüente emprego em atividades produtivas, como as industriais, geram retornos econômicos positivos. Tais resultados tendem a se traduzir na elevação permanente do nível da renda nacional e, então, no paulatino desenvolvimento econômico de um país.

Em uma dimensão microeconômica, isto é, voltada às unidades de transação, o processo de financiamento tem como foco de atenção a captação de recursos pelas firmas,

\footnotetext{
${ }^{5}$ Cf. STLIGTZ, Joseph. Government, Financial Markets, and Economic Development, Working Paper $\mathrm{n}^{\mathrm{o}}$.
} 3669, National Bureau of Economic Research, 1991, pp. 1-40. 
por meio dos veículos de financiamento corporativo. É o agregado dessas práticas financeiras que, quando bem equacionado, permite este círculo macroeconômico virtuoso entre investimento, produção e renda. Portanto, a capacidade de captação de recursos pelas empresas é a engrenagem subjacente ao motor do crescimento das nações.

É nesse plano de análise, ainda, que o debate importa para o direito, a quem cabe prover as correspondentes ferramentas jurídicas, que disciplinam as relações entre os financiadores e os empreendedores. As seções a seguir procuram apresentar este campo de trabalho, insistindo, no entanto, que os diferentes países desenvolvem elencos diversificados dessas ferramentas, conforme as respectivas alternativas institucionais, subjacentes ao seu modelo de organização econômica. O reconhecimento desta diversidade é, particularmente, relevante para este trabalho, dedicado à investigar uma destas alternativas de arranjo institucional: um sistema financeiro baseado na atuação de um banco público de desenvolvimento.

A finalidade deste capítulo é, pois, apresentar o referencial analítico sobre o qual se desdobrará esta tese. Para tanto, procurará cumprir três tarefas: (i) localizar o debate sobre financiamento no direito; (ii) descrever uma concepção teórica, bastante hegemônica, sobre a relação direito e financiamento - a matriz Law and Finance - e (iii) apresentar uma proposta alternativa à Law and Finance, que seja capaz de reconhecer a existência de uma pluralidade de modelos, na organização jurídico-institucional dos sistemas financeiros nacionais. Será deste ponto que a tese seguirá para analisar as particularidades do arranjo brasileiro, bem como as suas adaptações aos novos imperativos sugeridos pela economia baseada no conhecimento.

\section{O DiREITO COMO UMA VARIÁVEL DO FINANCIAMENTO CORPORATIVO: POR QUE ESTUDAR FINANCIAMENTO NO DIREITO?}

A consecução da atividade empresarial pressupõe a existência de condições financeiras que habilitem as companhias a desempenhar os seus respectivos objetos sociais. Desprovidas de recursos, as firmas não dispõem dos meios materiais necessários para o desempenho de suas atividades e não é por outra razão que as formas de capitalização das empresas contam com uma atenção especial de administradores e dos demais integrantes de uma corporação. A esses atores compete a definição estratégica de 
selecionar os meios pelos quais os recursos serão obtidos, sendo que o seu universo de escolha resume-se inicialmente a duas possibilidades: (i) a utilização dos recursos internos ou (ii) a captação externa, por meio dos instrumentos de financiamento corporativo.

A utilização dos recursos internos ocorre por meio do reinvestimento dos lucros acumulados que, ao invés de serem compartilhados entre sócios e, eventualmente, funcionários, são alocados em novos projetos corporativos. Esta prática tende a ser observada sempre que houver uma restrição na capacidade de acesso aos veículos de financiamento, como o mercado de créditos ou o mercado de capitais. Em situações como essa, muitas vezes vivenciadas por empresas familiares, em países em desenvolvimento, por exemplo, as opções e as estratégias empresariais são custeadas pelos próprios recursos das sociedades. ${ }^{6}$ O benefício desta opção reside no fato de que nesta via não são despertados problemas e conflitos entre os interesses das companhias e as expectativas de eventuais financiadores externos. Trata-se, por isso, de um padrão de capitalização que apresenta baixa complexidade, no que tange à disciplina dos interesses corporativos.

Ocorre, contudo, que em muitas situações a dotação de recursos próprios é insuficiente para a obtenção das metas e resultados assumidos por uma empresa. Em casos como esse, a ausência de recursos de terceiros pode representar um constrangimento financeiro, apto a limitar a capacidade de realização dos investimentos necessários aos desideratos da sociedade. Para sanar esta deficiência de recursos, as companhias recorrem ao financiamento externo, contando para isso com duas alternativas: (i) a captação por dívida ou (ii) a abertura da sociedade à participação de novos sócios, para além dos fundadores. No primeiro caso, trata-se de tomar um recurso mediante o compromisso de pagamento e esta modalidade admite, por sua vez, duas possibilidades, que são o lançamento de um título mobiliário representativo de uma dívida da sociedade (como uma debênture) ou a contratação de um crédito, perante uma instituição financeira, por

\footnotetext{
${ }^{6}$ Como salientam Maurício MOREIRA \& Fernando PUGA, sobre o financiamento corporativo no Brasil: "Os recursos internos aparecem invariavelmente com a principal fonte de financiamento, seguidos pela emissão de dívida e pelo lançamento de ações. O que talvez possa se considerar surpreendente é o fato de as estrangeiras terem os maiores índices de autofinanciamento. Uma possível explicação estaria no maior porte elou na maior lucratividade dessas firmas. É uma questão, no entanto, que só uma análise multivariada, como a feita abaixo, pode ajudar a resolver. Já os resultados que apontam as firmas de menor porte como mais dependentes de recursos próprios poderiam ser explicados pela sua maior lucratividade e, principalmente, pela relutância do sistema financeiro em lhes conceder empréstimos, em virtude da sua maior taxa de mortalidade", em MOREIRA, Maurício Mesquita \& PUGA, Fernando Pimentel, Como a Indústria Financia o seu Crescimento. Uma análise do Brasil Pós-Real, Instituto de Economia da UFRJ, Revista de Economia Contemporânea - Vol. 5, Edição Especial, 2000. p. 25.
} 
exemplo. Já no segundo caso, os valores aportados não representam um endividamento para a firma, sendo que os novos sócios detêm uma expectativa de colher o retorno na forma de dividendos, assim que a firma apresentar resultados positivos. ${ }^{7}$

Ao seguirem por esse caminho, as empresas passam, no entanto, a enfrentar uma questão não suscitada para aquelas que não demandam aportes externos: a possível assimetria de interesses que pode haver entre os provedores de capital, de um lado, e os administradores da firma, de outro. O ponto do conflito entre ambos reside no fato de que os investidores, credores ou novos sócios, não são responsáveis pela gestão do empreendimento no qual aportam os seus recursos, ao passo que aqueles que se lançam à frente da gestão societária não são os únicos financiadores de sua própria atividade.

Disso resulta aquilo que a teoria econômica costuma denominar por problema de agência, isto é, a garantia dos interesses de um dos atores - o principal - depende da ação de um outro ator - o agente ${ }^{8}$. É exatamente esta a situação vivida por investidores e administradores, num contexto de captação externa de recursos por uma sociedade: os interesses dos financiadores em obter o retorno de seus investimentos depende da ação dos gestores da firma. Estes, por sua vez, estão em franca posição de vantagem em relação aos principais (investidores), pois detêm, no mínimo, meios exclusivos de ação e um conjunto privilegiado de informações. Em um cenário como esse, como se pode garantir que haja uma convergência dos interesses? Como evitar, por exemplo, que ocorram ações estratégicas e exclusivamente voltadas ao próprio interesse dos administradores, em detrimento dos financiadores (principais)? Como também garantir que os financiadores não se valham de uma eventual posição de superioridade econômica para condicionar a atuação das companhias a seu favor e em prejuízo dos sócios minoritários e dos demais stakeholders?

Estas são questões que têm ocupado, há algum tempo, um espaço relevante na literatura jurídica sobre financiamento corporativo. Autores como HANSMANN \&

\footnotetext{
${ }^{7}$ Sobre a capitalização da companhia ver PINTO JUNIOR, Mario Engler. A Capitalização da Companhia, em FINKELSTEIN, Maria Eugênia Reis e PROENÇA, José Marcelo Martins. Direito Societário, São Paulo, Saraiva, 2007, pp. 241-271. O capítulo 4 dessa tese aborda essa questão com mais detalhe.

${ }^{8}$ Sobre a relação agente-principal, ver JENSEN, Michael \& MECKLING, William. Theory of the firm: managerial behaviour, agency costs and ownership structure, Journal of Financial Economics, v. 3, n ${ }^{\circ} .4$, 1976.
} 
KRAAKMAN $^{9}$, na esteira de uma longa tradição que remonta à BERLE \& MEANS ${ }^{10}$, assinalam, por exemplo, que há três tipos principais de problemas de agência na relação entre empresários e investidores: (i) os conflitos potenciais entre acionistas e administradores; (ii) os desentendimentos entre os acionistas majoritários e os minoritários e (iii) as incompatibilidades entre administradores e credores.

A primeira dessas assimetrias exemplifica uma situação clássica, em que os acionistas de uma sociedade aportam o capital e se vêem às voltas com a tentativa de garantir que a gestão societária seja favorável aos seus interesses, sobretudo no que toca à persecução de lucros e à distribuição dos dividendos. No segundo caso, trata-se do problema de agência vivido pelo acionista minoritário, que no papel de principal, busca fazer valer as suas posições dentro da corporação, ao passo que os acionistas majoritários, na qualidade de agentes, podem determinar um roteiro para a firma que seja, a um só tempo, benéfico para eles e prejudicial para os minoritários. ${ }^{11}$ Já o terceiro caso, envolve a relação entre a firma e os demais contratantes, como os credores. Nesta hipótese, o problema de agência surge da possibilidade de a empresa, que é detentora de informações e de uma condição de ação privilegiada, agir em defesa de seus interesses e em prejuízo dos credores. É o caso, entre outros, de um credor financeiro que pode se ver diante de ações estratégicas de uma empresa pré-falimentar. ${ }^{12}$

A narrativa destes potenciais conflitos revela de maneira ilustrativa uma questão bastante evidente: o tema do financiamento corporativo requer uma atuação do direito, ao menos como meio de composição destes interesses. Na realidade, nesse campo, compete ao direito a definição de diversos atributos relevantes, diretamente associados à captação de recursos por parte das firmas, entre os quais podem ser mencionados os seguintes: (i) a definição dos elementos constitutivos de uma empresa; (ii) os limites da responsabilidade dos administradores; (iii) os mecanismos de capitalização das sociedades; (iv) os procedimentos de solução das controvérsias e (v) as regras de falência e de recuperação

9 Ver HANSMANN, Henry \& KRAAKMAN, Reinier. Agency Problems and Legal Strategies, em KRAAKMAN, Reinier, et al. The Anatomy of Corporate Law - a comparative and functional approach, (reimpressão), New York, Oxford, 2006, pp. 21-31.

${ }^{10}$ Cf. BERLE, Adolf \& MEANS, Gardiner. The Modern Corporation \& Private Property, $9^{\mathrm{a}}$ Ed. New Jersey, Transaction Publishers, 2007.

${ }^{11}$ Um exemplo de um possível conflito de interesses entre ambos os grupos, minoritários e majoritários, é uma alienação do controle, defendida e aprovada pelos majoritários, que são possíveis beneficiários da operação, na medida em que podem vir a receber um preço por ação superior ao dos minoritários.

${ }^{12}$ Ver HANSMANN, Henry \& KRAAKMAN, Reinier. Agency Problems and Legal Strategies, op. cit. 
dos ativos. Naturalmente entre essas funções do direito, é, particularmente, relevante aquela voltada à regulação da relação entre os investidores e os empreendedores. Somente o arcabouço jurídico pode estipular caminhos para uma composição dessas posições, permitindo assim a superação, ou ao menos a mitigação, dos mencionados problemas de agência, entre os provedores do capital e os administradores dos empreendimentos objetos de financiamento ${ }^{13}$.

A assimetria entre estas posições é real e o seu equacionamento requer de fato uma intervenção disciplinadora. A literatura de financiamento corporativo está repleta de casos e relatos indicativos de situações indesejáveis vivenciadas por companhias, em virtude de deficiências regulatórias. Dependendo da fragilidade institucional e da tibieza das regras corporativas, administradores podem simplesmente mascarar resultados e se apropriar de recursos, que deveriam ao final ser redistribuídos como dividendos ou pagos como compromissos de uma dívida assumida. Afora episódios drásticos como esse, há diversas outras possibilidades menos evidentes e mais sofisticadas, em que administradores podem se fazer valer de sua posição estratégica para promover os seus interesses, com prejuízos para a própria empresa. Trata-se, por exemplo, de negociações em causa própria, self-dealing, verificável em casos como de uma fixação excessiva de salários e benefícios $^{14}$, ou de episódios em que os administradores, valendo-se das dificuldades de monitoramento de suas atividades, desempenham uma gestão ineficiente, capaz de produzir perdas econômicas e custos de oportunidade ${ }^{15}$.

Para disciplinar essas relações e assim mitigar o conflito de interesses subjacente às operações de financiamento corporativo, o direito conta com dois tipos de ferramentas, segundo a tipologia apresentada por HANSMANN \& KRAAKMAN $^{16}$ : os dispositivos

13 Sobre o papel do direito no financiamento corporativo ver HANSMANN, Henry \& KRAAKMAN, Reinier. Agency Problems and Legal Strategies, op. cit.

${ }^{14}$ Em seu Survey sobre governança corporativa, Andrei Shleifer e Robert Vishny dão como exemplo destas negociações auto-interessadas as atividades das empresas de petróleo russas. Em uma prática reputada como não sendo incomum, pelos autores, os administradores das empresas de petróleo são também proprietários de empresas trading, que, por sua vez, adquirem o óleo a preços abaixo do custo de mercado. A esse respeito ver SHLEIFER, Andrei \& VISHNY, Robert, A Survey of Corporate Governance, The Journal of Finance, vol. 52, no. 2, 1997, pp. 737-783.

${ }^{15}$ A economia, diferentemente da contabilidade, trabalha com a noção de custos, como despesas incorridas e também com a idéia de custos de oportunidade, isto é o custo potencial: tudo aquilo que se deixa de ganhar ao se decidir por um caminho alternativo.

${ }^{16}$ Ver a respeito HANSMANN, Henry \& KRAAKMAN, Reinier. Agency Problems and Legal Strategies, op cit. 
regulatórios e os mecanismos de governança corporativa. Os dispositivos regulatórios são conformados pelo ordenamento jurídico e assumem um caráter prescritivo, voltando-se a apresentar os contornos e conteúdos que devem balizar a relação entre o agente e o principal, no universo de uma corporação. ${ }^{17}$ Além deste conjunto regulatório, o direito também disponibiliza instrumentos normativos para permitir uma auto-regulação das sociedades: a governança corporativa. As regras de governança corporativa apresentam o status de um arranjo contratual entre os atores da firma e dedicam-se a estabelecer os termos por meio dos quais serão processadas as diversas relações existentes entre a companhia e os seus stakeholders. São justamente essas regras de governança que, ao disciplinar a vida interna das sociedades, procuram garantir um pacto de reequilíbrio das assimetrias entre os agentes e o principal. ${ }^{18}$

São por essas funções, portanto, que o direito pode ser entendido como uma variável dos processos de financiamento. $\mathrm{O}$ sucesso de sua intervenção em organizar o ambiente financeiro, disciplinando as relações entre investidores e empreendedores, tende a resvalar na capacidade de captação de recursos, o que, em última análise, repercute no patamar de desenvolvimento econômico dos países. Quanto a isso, não parece existir muita dúvida. As discordâncias começam a aflorar conforme se aprofunda esse debate, e o plano

17 As medidas regulatórias são definidas no ambiente externo às sociedades e a sua incidência sobre a atividade empresarial resulta na imposição de limites e na apresentação de habilitações que servem de guia para a atividade societária. $\mathrm{O}$ foco deste comando normativo é a regulação dos comportamentos dos agentes, impondo aos administradores um código de proibições e exigências que acabam por cercear positivamente a sua, eventual, liberdade exagerada de ação. A exigência de capitalização mínima das companhias, existente em alguns ordenamentos jurídicos, é uma típica medida regulatória voltada a evitar uma súbita bancarrota e nessa conformidade vinculada à proteção dos credores. O mesmo se passa com algumas leis societárias que disciplinam a distribuição dos dividendos para os acionistas, as regras que impõem o dever dos administradores de franquear ao possível investidor amplo conhecimento sobre a vida da empresa ou mesmo as normas que garantem aos acionistas a venda de suas participações societárias, o que tem por finalidade proteger os aplicadores descontentes com o curso dos negócios. Sobre exemplos de medidas regulatórias, ver HANSMANN, Henry \& KRAAKMAN, Reinier. The Basic Governance Structure, em KRAAKMAN, Reinier, et al. The Anatomy of Corporate Law - a comparative and functional approach, op. cit, pp. 33-70.

18 Tanto as regras de cunho regulatório, como as de governança trabalham de modo ex ante, prédeterminando os comportamentos e direitos das partes, como de modo ex post, oferecendo remédios para a reversão das decisões ou para o sancionamento dos comportamentos oportunistas. $\mathrm{O}$ direito de eleger os administradores da companhia, por exemplo, é uma regra de governança de incidência ex ante, pois visa a oferecer um meio de proteção aos acionistas, que é preliminar às ações dos administradores. O mesmo se passa com o direito, ainda que restrito, de dar início a processos decisórios coletivos na sociedade (como a convocação de uma assembléia geral). Em compensação, o direito de remover os administradores ineficientes, ou regulamentos que, porventura, garantem o direito de sair da sociedade, para aqueles investidores descontentes, inserem-se numa chave ex post da proteção jurídica. A esse respeito ver SHLEIFER, Andrei \& VISHNY, Robert, A Survey of Corporate Governance, op. cit. e HANSMANN, Henry \& KRAAKMAN, Reinier. Agency Problems and Legal Strategies, op cit. 
de análise se ocupa de quais ferramentas jurídicas são capazes de garantir bons resultados nas transações financeiras.

Como será visto a seguir, os autores afinados com a matriz Law and Finance têm procurado justificar as distinções no patamar de desenvolvimento financeiro dos países em razão das diferenças existentes entre as suas ferramentas de proteção dos investidores: as economias bem sucedidas contariam com um melhor estoque de dispositivos regulatórios e de mecanismos de governança, do que as economias mais atrasadas. Tais análises acabam, assim, por hierarquizar as ferramentas jurídicas, entre as mais e as menos adequadas. A essa concepção, será contrastada uma outra, assentada na noção de que existem variedades de arranjos institucionais, de tal modo que as diferenças entre as ferramentas jurídicas, forjadas pelos países, não podem ser compreendidas como deficiências, além do que, em muitos casos, soluções distintas, de disciplina dos interesses de investidores e empreendedores, podem gerar resultados funcionalmente semelhantes.

\subsection{UMA LINHA DE ANÁLISE PARA AS RELAÇÕES ENTRE DIREITO E FINANCIAMENTO: A LAW AND FINANCE}

Com a identificação do direito como uma variável dos processos de financiamento, tem se constituído paradigmas interdisciplinares de análise, voltados justamente a verificar o impacto dos atributos jurídicos na indução do ambiente de investimentos. Uma dessas linhas é constituída por um conjunto teórico e empírico de análises conhecido como Law and Finance. O pressuposto de estudos produzidos por autores dessa matriz, como Rafael LA PORTA, Florencio LOPEZ-de-SILANES, Thorsten BECK, Ross LEVINE, Asli DEMIRGÜRÇ-KUNT, Andrei SHLEIFER e Robert VISHNY ${ }^{19}$ é o de que a proteção dos investidores, garantida por meio de um conjunto de regras de propriedade, de determinadas estipulações contratuais, objetivas e desprovidas de

${ }^{19}$ Alguns dos principais trabalhos são: LA PORTA, Rafael; LOPEZ-de-SILANES, Florencio; SHLEIFER, Andrei \& VISHNY, Robert. Law and Finance, Journal of Political Economy, vol. 106, nº. 6, 1998; LA PORTA, Rafael; LOPEZ-de-SILANES, Florencio; SHLEIFER, Andrei \& VISHNY, Robert. Legal Determinants of External Finance, The Journal of Finance, vol. 52, nº. 3, 1997; SHLEIFER, Andrei \& VISHNY, Robert. A Survey of Corporate Governance, The Journal of Finance, vol. 52, no. 2, 1997; LA PORTA, Rafael; LOPEZ-de-SILANES, Florencio; SHLEIFER, Andrei \& VISHNY, Robert. Investor Protection and Corporate Governance, Journal of Financial Economics, $\mathrm{n}^{\circ}$. 58, 2000; BECK, Thorsten; DEMIRGÜRÇ-KUNT, Asli \& LEVINE, Ross. Law, Politics and Finance, paper, mimeo, 2001, disponível em http://papers.ssrn.com/sol3/papers.cfm?abstract id=269118, acesso em 22.09.08 e BECK, Thorsten \& LEVINE, Ross. Legal Institutions and Financial Development, working paper $\mathrm{n}^{\circ}$. 10417, National Bureau of Economic Research, 2004. 
conceitos vagos ou ambíguos, e também por um sistema jurisdicional confiável, célere e eficaz na aplicação do direito, é a variável central para garantir um satisfatório desempenho tanto do mercado de capitais, como dos segmentos de intermediação financeira, como é o caso do sistema bancário. ${ }^{20}$

Diante de um ambiente inseguro, informado por uma parca proteção aos direitos de propriedade de acionistas ou credores, ou ainda por regras contratuais imprecisas e sujeitas a ampla margem de controvérsias, a expectativa dos autores de filiação Law and Finance é a da restrição do interesse e da disponibilidade de investidores em prover capital para empreendimentos de terceiros. Ante ao receio proporcionado por um ambiente institucional débil, que pode potencializar os conhecidos e inerentes problemas de agência, os detentores de capital tenderiam a retrair o seu poder de ação. Ato contínuo, formar-se-ia um quadro de constrangimento financeiro, associado, por sua vez, a um ambiente econômico de menor desenvolvimento relativo.

Não por acaso, LA PORTA, LEVINE, SHLEIFER, VISHNY e outros voltam as suas observações para a organização dos direitos de propriedade, para os atributos do direito contratual e para as características do direito empresarial de diversos países pesquisados. O foco destas investigações é dirigido a uma mensuração da extensão e da efetividade do elenco de direitos de proteção dos investidores, em cada um dos sistemas jurídicos. O pressuposto destas análises é que o papel a ser desempenhado pelo direito seria $o$ de represar as possibilidades de um comportamento oportunista dos administradores, baseados, como visto, nas assimetrias existentes entre estes e os financiadores. A noção com a qual trabalham estes autores é a de que o direito pode, ao disciplinar os termos desta relação, a partir de um elenco de ferramentas, ser um instrumento que desequilibre os resultados de uma análise custo/benefício, em favor de uma administração societária comprometida com os interesses de credores, acionistas e

\footnotetext{
${ }^{20}$ No Brasil, alguns estudos produzidos pela Casa das Garças, um instituto de pesquisas no Rio de Janeiro que reúne alguns egressos ou simpatizantes da chamada escola de economia da PUC-RJ, como Pérsio Arida, Edmar Bacha e André Lara Resende, tem pautado os debates sobre instituições e financiamento, no Brasil, nos moldes da Law and Finance. Em um artigo referência, muito citado recentemente, os autores argumentam que a incerteza jurisdicional brasileira tem como efeito econômico colateral a elevação das taxas de juros relativas a crédito. Ver a respeito ARIDA, Pérsio; BACHA, Edmar \& LARA-RESENDE, André. Credit, Interest, and Jurisdictional Uncertainty: Conjectures on the Case of Brazil, Instituto de Política Econômica Casa das Garças, Rio de Janeiro, 2004, pp. 1-31, disponível em http://www.econ.pucrio.br/material/macroii/Incerteza\%20Jurídica.pdf, acesso em 21.09.08.
} 
cotistas. ${ }^{21}$ Em outros termos, as regras regulatórias ou as de governança, quando bem desenhadas, podem ensejar uma situação real em que é mais custoso para o administrador procurar subterfúgios e estratagemas para fazer valer seus interesses oportunistas, do que propriamente optar por realizar os seus ganhos de modo alinhado com os interesses do conjunto de stakeholders. ${ }^{22}$

Em compensação, ante a ausência de proteção jurídica, o custo de uma gestão oportunista tende a ser pequeno e os incentivos criados pelas carências do arcabouço normativo podem corroborar e fomentar ações auto-interessadas dos agentes (administradores). É por isso que a previsão e o bom funcionamento de um rol de direitos, voltados à proteção dos investidores, é a única forma adequada de conter o peso de decisões e atitudes administrativas prejudiciais aos financiadores. Nesta tarefa, entendem estes autores, os mecanismos formais de proteção dos agentes individuais, como dispositivos contratuais e regras societárias, são preferíveis aos instrumentos informais (como práticas sociais). ${ }^{23}$ Isso significa que, embora os autores reconheçam que os fatores institucionais informais, como a reputação das firmas, ou cultura de investimentos de uma sociedade, possam ser elementos importantes no impulso do fluxo financeiro, são céticos quanto ao êxito daquilo que chamam de modelos de financiamento sem governança ${ }^{24}$. A capacidade de um modelo sustentável de financiamento passa, portanto, com muito mais ênfase, pelas propriedades do direito em oferecer salvaguardas e proteções, do que por atributos informais de regulação dos interesses, menos sujeitos a formalizações e assim sendo mais porosos a manipulações. É essa premissa que sustenta, por exemplo, a concordância de SHLEIFER \& VISHNY ${ }^{25}$ com algumas análises que atribuem as

\footnotetext{
${ }^{21}$ Nos termos dos autores: "At the extreme of no investor protection, the insiders can steal a firm's profits perfectly efficiently. Without a strong reputation, no rational outsider would finance such a firm. As investor protection improves, the insider must engage in more distorted and wasteful diversion practices such as setting up intermediary companies into which they channel profits. Yet these mechanisms are still efficient enough for the insiders to choose to divert extensively. When investor protections is very good, the most the insiders can do is overpay themselves, put relatives in management, and undertake some wasteful projects. After a point, it may be better just pay dividends. As the diversion technology becomes less efficient, the insiders expropriate less and their privet benefits of control diminish. Firms then obtain outside finance on better terms. By shaping the expropriation technology, the law also shapes the opportunities for external finance." Cf. LA PORTA, Rafael; LOPEZ-de-SILANES, Florencio; SHLEIFER, Andrei \& VISHNY, Robert. Investor Protection and Corporate Governance, op. cit. p. 6.

${ }^{22}$ Ver a respeito SHLEIFER, Andrei \& VISHNY, Robert, A Survey of Corporate Governance, op. cit.

23 A diferença entre atributos institucionais formais e informais é apresentada por NORTH, Douglas. Institutions, Institutional Change and Economic Performance, Cambridge, Cambridge University Press, 1990, pp. 3-10.

${ }^{24}$ A esse respeito ver SHLEIFER, Andrei \& VISHNY, Robert. A Survey of Corporate Governance, op. cit.

${ }^{25}$ Ver SHLEIFER, Andrei \& VISHNY, Robert. A Survey of Corporate Governance, op. cit.
} 
dificuldades de levantamento de recursos externos por firmas russas e italianas à deficiência das ferramentas jurídicas de proteção aos investidores verificadas em seus respectivos países.

Assentados nessas premissas, os autores da Law and Finance dedicam-se, então, a realizar estudos de comparação entre os sistemas financeiros nacionais (estudos cross country) e assim estipulam um ranking, hierarquizando os países conforme o nível de proteção jurídica presente em suas transações financeiras. Para tanto, definem a priori um conjunto de ferramentas jurídicas, entendido como o elenco de direitos e garantias que oferece a adequada proteção para a salvaguarda dos interesses dos investidores. Este rol de direitos e garantias, apresentado de forma resumida no quadro abaixo, é, então, aplicado aos ordenamentos de um conjunto de países, previamente classificados em famílias jurídicas, formadas a partir de uma suposta origem jurídica comum. As famílias são: common law, civil law de origem francesa, civil law de origem germânica e o sistema escandinavo. $^{26}$

26 Para justificar a sua classificação, os autores argumentam que as famílias apresentam origens distintas, o
que impactou também a sua evolução. Tais famílias teriam ainda sido difundidas para outros países, às custas
dos processos de transplante institucional. Assim, enquanto o sistema francês teria resultado de um
movimento revolucionário bastante contrário aos privilégios da magistratura e também das intençães
codificadoras de Napoleão, o sistema inglês teria na sua origem a preponderância das Cortes em relação à
Monarquia. A consequiência destas diferenças seria perceptível no enrijecimento do sistema francês, que teria
apostado no modelo jurisdicional do juiz limitado pela codificação estrita - o "juiz boca da lei” -, ao passo
que no modelo inglês a primazia dos Tribunais teria garantido um sistema mais flexível, baseado na
construção do direito pelos casos julgados. Nessa toada, o sistema alemão, embora de origem civil law, é
apresentado como um tipo próprio. Como a sua codificação teria sido formulada de modo a favorecer a
incorporação de princípios, este sistema gozaria de maior maleabilidade para responder aos imperativos
econômicos. Por fim, o sistema escandinavo surge como um outro gênero, identificado pelo seu menor grau
de parentesco com a tradição do direito romano de Justiniano, entendido como uma herança tendente a
mitigar o papel da jurisprudência em favor da positivação de leis e códigos. Os países pesquisados de cada
família são os seguintes: (i) Common Law - Inglaterra, Estados Unidos, Canadá, Hong Kong, Irlanda e
Israel; (ii) Civil Law Francesa - França, Brasil, Chile, Colômbia, Egito e Espanha; (iiii) Civil Law Germânica
- Alemanha, Áustria, Japão, Coréia do Sul, Suíça e Taiwan; (iv) Sistema Escandinavo - Dinamarca,
Finlândia, Noruega e Suécia. Ver a esse respeito, LA PORTA, Rafael; LOPEZ-de-SILANES, Florencio;
SHLEIFER, Andrei \& VISHNY, Robert. Law and Finance, op. cit., pp.1113-1155 e BECK, Thorsten \&
LEVINE, Ross. Legal Institutions and Financial Development, op. cit., pp. 1-46 
Rol de direitos dos acionistas

-Possibilidade de votação não presencial (possibilidade de voto pelo correio, p. ex.);

-Possibilidade de negociar ações a qualquer tempo (inexigência de depósito prévio das ações, preliminarmente aos encontros de acionistas);

\section{Rol do direito dos credores}

-Direito de posse sobre a garantia prestada, independente dos processos de reorganização societária;

- Concessão do direito de preferência à retenção das garantias aos seus titulares nos processos de reorganização;
-Existência de voto proporcional para garantir os interesses dos minoritários;

-Proteção aos acionistas dissidentes (recompra de ações ou possibilidade de questionamentos da política corporativa);

-Preferência na aquisição de novas ações;

-Possibilidade de convocação do encontro de acionistas, ainda que com uma participação não expressiva no capital social. ${ }^{27}$
-Previsão de anuência prévia dos credores para a recuperação da empresa devedora;

- Possibilidade de substituir os administradores durante a reorganização das empresas.

Os direitos apresentados nesta listagem têm como traço convergente o potencial de proteção oferecido aos financiadores, assumidos como agentes atomizados, ante eventuais ações oportunistas dos administradores. No caso do rol de direitos dos acionistas, o direito de votar pelo correio favoreceria a possibilidade de participação e mitigaria assim o custo e as dificuldades de coordenação das ações coletivas, entre acionistas dispersos e pouco dispostos a participar presencialmente de deliberações corporativas. O mesmo sucederia com a plena transferência de ações, mesmo nos momentos que antecedem os encontros societários $^{28}$, o que incentivaria a participação dos acionistas nas assembléias, já que não se veriam diante de uma restrição econômica nos momentos em que exercem o direito de influir nos negócios sociais. Já a existência de previsão de voto proporcional garantiria voz às minorias, de forma a equiparar minimamente sua representação nos órgãos colegiados. Esse seria um direito tão importante, quanto a proteção dos acionistas dissidentes que, ao não concordarem com uma decisão, como uma fusão, por exemplo, poderiam pedir a sua retirada da companhia ou mesmo se valer das instâncias sociais e jurisdicionais para desafiar a posição dos administradores. Por fim, os dois últimos direitos dos acionistas referem-se à proteção de sua participação na sociedade: (i) a garantia de preferência na aquisição de novas ações, para assim evitar a diluição de sua participação

27 Estes direitos são apresentados em LA PORTA, Rafael; LOPEZ-de-SILANES, Florencio; SHLEIFER, Andrei \& VISHNY, Robert. Law and Finance, op. cit

${ }^{28}$ Há sistemas normativos que exigem o depósito das ações como condição de participação das assembléias, gerando assim um período de impossibilidade de realização de negócios. 
relativa e (ii) direito de garantir a sua representação política na corporação, ainda que não detenha participação social expressiva.

A mesma lógica preside o rol de direitos dos credores. A estipulação clara do direito de manutenção das garantias retidas pelos credores, impedindo que passem a ser contabilizadas na massa de passivos, diante de um processo de reorganização societária, asseguraria os emprestadores de capital contra eventuais inadimplências. Da mesma forma é a faculdade de se satisfazer diretamente o débito com a retenção imediata das garantias pelo credor, sem a eventual necessidade de se realizar qualquer ulterior procedimento, como, por exemplo, um leilão dessas garantias, para assim garantir a arrecadação de recursos necessários ao pagamento das dívidas. Por fim, a anuência prévia dos credores, nos processos de reorganização e recuperação de empresas, e a possibilidade de substituição dos administradores trariam para estes gestores constrangimentos, capazes de desincentivar uma gestão oportunista dos recursos de terceiros. ${ }^{29}$

Os resultados alcançados pelos estudos da Law and Finance, a partir de um universo pré-selecionado de direitos e garantias, apontam que os países de common law apresentam uma maior proteção dos acionistas e dos credores. Os países de civil law de origem francesa, por sua vez, seriam dotados dos piores índices de proteção, para ambos os tipos de investidor. No que tange às maiores diferenças para a proteção dos acionistas, vale mencionar que, enquanto os países de common law permitem o voto pelo correio (39\%) e apresentam mecanismos para preservação dos dissidentes, como as ações de classe e os procedimentos internos à companhia (94\%); apenas uma minoria dos países de origem francesa admitem o voto pelo correio (5\%) ou protegem especialmente as minorias sociais (29\%). Essas mesmas diferenças são mantidas quando o dado observado é a proteção dos credores, fazendo com que novamente os pólos opostos sejam ocupados pelos países de common law, de um lado, e de civil law de origem francesa, de outro. ${ }^{30}$

\footnotetext{
${ }^{29} \mathrm{Na}$ pesquisa realizada, LA PORTA et al. atribuíram 1 ponto para existência de cada um destes direitos, em um total de 4 pontos. No caso particular do montante do capital social necessário para convocação de assembléias extraordinárias, a participação social considerada foi a de $10 \%$ do capital social votante. LA PORTA, Rafael; LOPEZ-de-SILANES, Florencio; SHLEIFER, Andrei \& VISHNY, Robert. Law and Finance, op. cit

${ }^{30}$ A única grande diferença, em relação aos resultados para os acionistas, deve-se ao fato de que os países de origem germânica apresentam na média um nível mais alto de proteção dos credores. No agregado, os países de common law atingiram uma média de 4,0 pontos para a proteção dos acionistas e de 3,11 para os credores, seguidos dos países de origem escandinava, com 3,0 para a garantia dos operadores do mercado de capitais e 2,0 para os credores. Em seguida, os países de origem germânica, com 2,33 para ambos os grupos de
} 
Tais dados, argumentam os autores, estão associados a outras duas correlações, quais sejam, o volume da concentração da propriedade do capital social e a dimensão dos mercados de crédito e de capitais, dos respectivos países. Em linha com a premissa que embasa as análises da Law and Finance, os pesquisadores argumentam que a maior extensão da proteção dos financiadores permite uma maior dispersão da propriedade do capital, já que a prevalência das regras de governança corporativa asseguraria os interesses dos acionistas, sem que esses precisem formar blocos concentrados de poder para fazer valer os seus interesses. Seria por isso que os países com um sistema originário da common law tenderiam a gozar de uma maior dispersão acionária, ao passo que os países com um sistema de civil law francesa contariam com uma maior concentração do capital. ${ }^{31} \mathrm{O}$ pressuposto subjacente a esta comparação é o de que a dispersão acionária é um modelo melhor de organização societária, pois permitiria uma participação difusa da poupança dos cidadãos no financiamento da economia.

Com relação à associação entre a extensão dos direitos de proteção dos investidores e o desenvolvimento dos mercados de crédito e de capitais, os estudos da Law and Finance buscam argumentar que há entre estes uma imbricação positiva. ${ }^{32}$ Utilizando alguns indicadores indiretos, como o número de operações de abertura do capital social por ano (IPOs), a quantidade de empresas listadas em bolsas, o conjunto agregado dos empréstimos bancários no setor privado e o valor de face dos títulos de dívida mobiliária

investidores e os países de origem francesa com 2,33 para a extensão das medidas pró-acionistas e 1,58 para a proteção dos credores. A grande inconsistência da pesquisa são as parcas medidas de proteção aos credores disponíveis nos Estados Unidos, que lhe renderam apenas um ponto entre os 4,0 possíveis. Ver LA PORTA, Rafael; LOPEZ-de-SILANES, Florencio; SHLEIFER, Andrei \& VISHNY, Robert. Law and Finance, op. cit. ${ }^{31}$ Curiosamente, muito embora os resultados sejam coerentes com a hipótese no caso dos países de origem francesa, o mesmo não vale para a afirmação relativa aos países de common law, já que a maior dispersão acionária foi encontrada nos países de origem germânica, seguidos pelos países de origem escandinava. Não à toa, os autores caminharam apenas para uma conclusão em moldes negativos, alegando que a menor proteção aos investidores é compensada com a ampliação de sua participação social como forma de proteção. O texto dos autores resume-se a concluir que o modelo francês apresenta os piores índices de proteção e os maiores níveis de concentração do capital social. Sobre a maior dispersão encontrada nos países de origem alemã, o texto não é claro nas razões explicativas deste fenômeno. De toda forma, vale a transcrição da análise referente aos países de civil law ao estilo francês: "in sum, the message of this section is that the quality of legal protection of shareholders helps determine ownership concentration, accounting for the higher concentration of ownership in the French-civil-law countries. The results support the idea that heavily concentrated ownership results from, and perhaps substitutes for, weak protection of investors in a corporate governance system. The evidence indicates that weak laws actually make a difference and may have costs. One of these costs of heavily concentrated ownership in large firms is that their core investors are not diversified." Ver LA PORTA, Rafael; LOPEZ-de-SILANES, Florencio; SHLEIFER, Andrei \& VISHNY, Robert. Law and Finance, op. cit. p. 1151.

${ }^{32}$ LA PORTA, Rafael; LOPEZ-de-SILANES, Florencio; SHLEIFER, Andrei \& VISHNY, Robert. Legal Determinants of External Finance, op. cit. pp. 1131-1150. 
(bonds ou debêntures), os autores argumentam que os resultados alcançados corroboram em parte as hipóteses iniciais: o quantum de proteção jurídica impacta na disponibilidade de investidores em franquear recursos para os projetos liderados por empresários. É por essa razão que os países dotados de um sistema de civil law nos moldes franceses apresentariam mercados de crédito e de capitais com um menor volume de operações, do que os países cuja organização jurídica é legatária da common law. Nestes, a maior e melhor proteção dos investidores estaria associada a um número elevado de empresas listadas em bolsa, a uma atividade mais freqüente de operações de abertura de capital, assim como a um volume expressivo de acionistas não controladores, em relação ao PIB. Os países de common law contariam também com um volume de crédito bancário, em relação ao PIB, superior ao patamar dos países de civil law francesa ${ }^{33}$.

\section{Percorrendo essa mesma trajetória teórica e metodológica, Ross LEVINE chega} a uma conclusão semelhante, em um estudo empírico voltado a compreender o impacto do sistema jurídico no desenvolvimento do setor bancário de alguns países. No artigo intitulado The Legal Environment, Banks, and Long-Run Economic Growth ${ }^{34}$, o foco da pesquisa do autor é compreender se os distintos níveis de desenvolvimento bancário entre os países podem ser explicados pelas eventuais diferenças existentes no sistema jurídico de proteção dos credores ${ }^{35}$. Trata-se de um trabalho que o próprio LEVINE identifica com a agenda da Law and Finance e que procura detalhar para o setor bancário as análises que LA PORTA et al. dirigiram para o conjunto do setor financeiro. A conclusão apresentada pelo autor segue em sintonia com as hipóteses do campo de pesquisa, sustentando então que a desenvoltura específica do setor bancário seria da mesma forma condicionada pelo conjunto de direitos e garantias, expressos nos dispositivos regulatórios e de governança ${ }^{36}$.

${ }^{33} \mathrm{Na}$ média, os países de common law apresentam 35 companhias listadas em bolsa para cada milhão de habitantes, enquanto que os países da tradição francesa contam com uma média de10 empresas listadas. A variação e igualmente significativa para o volume de IPOs no ano, sendo a média dos países de common law em torno de 2.2 operações para cada milhão de habitantes e a média francesa 0.20 para cada milhão. No caso dos mercados de crédito, os países de common law contam com uma participação agregada da dívida de $68 \%$ do PIB e os países de civil law francesa, de 45\% do PIB. Ver LA PORTA, Rafael; LOPEZ-de-SILANES, Florencio; SHLEIFER, Andrei \& VISHNY, Robert. Legal Determinants of External Finance, op. cit. pp. 1131-1150.

${ }^{34}$ Ver LEVINE, Ross. The Legal Environment, Banks, and Long-Run Economic Growth, Journal of Money, Credit and Banking, vol. 30, nº. 3, 1998. pp. 596-613.

${ }^{35}$ A rigor o artigo debate duas questões associadas, quais sejam, a importância do ambiente jurídico para o sistema bancário e a importância do sistema bancário para o crescimento econômico.

${ }^{36} \mathrm{Na}$ realização de seu objeto de pesquisa, o artigo procura avaliar tanto o tipo de direitos dos credores previstos pelos ordenamentos jurídicos nacionais, como a efetividade (enforcement) de sua aplicação. Para tanto, são realizadas simulações estatísticas baseadas num rol de direitos bastante parecido com o utilizado 
A seguinte passagem do autor resume não só o seu argumento, como também muitos dos pressupostos da Law and Finance:

In sum, the legal system matters for banking development. Differences in banking development can be traced back to the legal origin of the country. Even after controlling for the level of economic development, countries with a German legal system tend to have better-developed banks. Moreover, the data identify particular aspects of the legal system that are important for banking-sector development. Countries where the legal system gives a high priority to banks getting the full present value of their loans to firms have better-developed banks. Furthermore, countries where the legal system effectively enforces contracts tend to have better-developed banks than countries that less efficiently enforce contracts $^{37}$.

$\mathrm{O}$ argumento da Law and Finance fecha-se, portanto, centrado na tese de que o direito importa para o desenvolvimento dos mercados financeiros. Nessa linha, a disponibilidade de um investidor tomar parte em um negócio de terceiros é diretamente proporcional ao tipo de proteção jurídica que lhe é conferida. Sendo assim, os distintos resultados financeiros alcançados pelos países, parametrizados no volume de recursos disponíveis para os aportes dos empreendedores, teria como variável relevante a qualidade das regras de governança corporativa e dos instrumentos regulatórios. Em suma, institutions matter, como assinalaria Douglass NORTH.

Essas análises, no entanto, não são isentas de problemas. Muito embora possa-se admitir que as ferramentas jurídicas tenham de fato importância para as atividades de captação de recursos, os estudos da Law and Finance ignoram muitas vezes um fato social

nos trabalhos de LA PORTA et al. O autor seleciona os seguintes três tipos de garantias como instrumentos para os testes: (i) possibilidade de o credor reter as garantias depositadas, independentemente da prevalência de um processo de reorganização societária; (ii) permissão para substituição de administradores diante da recuperação de empresas; (iii) respeito aos credores protegidos por garantias na distribuição dos haveres na falência de um eventual devedor. Além disso, LEVINE também mediu a efetividade do ambiente de proteção aos credores, valendo-se para tanto de dois parâmetros: (i) uma medida denominada RULELAW e (ii) um outro critério designado pelo nome de CONRISK. O indicador RULELAW tem como objetivo medir o nível de cumprimento das obrigações legais e para tanto fundamenta-se nas estatísticas do International Country Risk Guide (ICRG). A métrica apresentada pelo CONRISK, igualmente assentada nos dados do ICRG, indica, numa escala de zero a dez, as chances de um determinado governo desrespeitar os termos de um contrato assinado. Ambos os dados associados (RULELAW e CONRISK), argumenta o autor, oferecem um panorama inter-países quanto a capacidade da efetividade do direito. Por fim, o artigo apresenta referências concernentes à amplitude do setor bancário nos diversos países analisados. Para tanto, a pesquisa ponderou o valor agregado dos empréstimos bancários em relação aos PIB nacionais. Diante desses três conjuntos de informações, quais sejam, indicadores da amplitude de direitos previstos, estimativas da efetividade das obrigações legais e a extensão do sistema bancário dos países, LEVINE pôde verificar a importância do direito para os resultados do sistema bancário. LEVINE, Ross. The Legal Environment, Banks, and Long-Run Economic Growth, op. cit.

${ }^{37}$ LEVINE, Ross. The Legal Environment, Banks, and Long-Run Economic Growth, op. cit. p. 605. 
relevante: a existência de alternativas institucionais diferenciadas de organização das economias de mercado, o que remeteria conseqüentemente ao reconhecimento de um leque diversificado de ferramentas funcionalmente equiparáveis, para além dos conjuntos de direitos e garantias que balizam as suas investigações. Em outros termos, ao tematizar a relevância dos instrumentos jurídicos de proteção, as análises da Law and Finance assumem uma régua de comparação diminuta e que, muitas vezes, não leva em conta que os países podem apresentar soluções jurídicas diversificadas, derivadas de suas vicissitudes sociais e históricas, e que não necessariamente são piores ou melhores. A próxima seção explora uma rota heterodoxa para as relações entre direito e financiamento, sensível à existência de alternativas institucionais.

\subsection{UMA LiNHA ALTERNATIVA DE ANÁlise PARA AS RELAÇÕES ENTRE DIREITO E FINANCIAMENTO: A RELEVÂNCIA DAS ALTERNATIVAS INSTITUCIONAIS}

As análises da Law and Finance conjugam um atributo positivo de pesquisa com uma leitura enviesada e, de certa forma, limitada dos mecanismos de financiamento corporativo. De um lado, a preocupação com a proteção dos investidores e com a sua relação com os empreendedores, tem o mérito de deslocar o eixo do debate financeiro para o campo jurídico-institucional, até então parcamente explorado. De outro, a afirmação dos dispositivos regulatórios e das regras de governança, como variáveis importantes, tem contado com uma abordagem muito estreita e que se ressente de alguma dificuldade em reconhecer a possibilidade da existência de uma variedade de arranjos institucionais entre os países. No limite, a relação jurídica estabelecida entre os acionistas (ou os credores) e os empreendedores pode comportar formulações diversificadas, que extrapolam as possibilidadades pressupostas pela Law and Finance, moduladas pela noção de investidores atomizados, atuando em um regime de mercado competitivo.

O problema deste caminho estreito é que a lente vicia o olhar. As eventuais diferenças existentes na organização dos setores financeiros deixam de ser entendidas, muitas vezes, como variações jurídico-institucionais, para serem traduzidas como desvios de um suposto padrão correto. Ao partirem de um rol de direitos e garantias definidos $a$ priori, estas análises rejeitam de antemão a possibilidade de um elenco alternativo de ferramentas que, embora sejam estruturalmente distintas, possam oferecer resultados semelhantes. Um caso típico é a pouca importância que estes autores atribuem a um 
mecanismo de proteção dos acionistas existente em países da tradição de civil law francesa: a obrigação da partilha dos dividendos por imposição legal. Leis como essa disciplinam de forma mandatória que as empresas partilhem os seus retornos favoráveis com os acionistas, um tipo de garantia que poderia ser entendido como um mecanismo diferenciado de proteção dos investidores. Todavia, LA PORTA et al. ${ }^{38}$ tomam este instrumental como uma solução de segunda mão (um second best), interpretado como um remendo às supostas lacunas existentes nos regimes de origem francesa. Da mesma forma, ao se depararem com a elevada capacidade de captação de crédito bancário pelas grandes empresas asiáticas, em países como Coréia do Sul ou Taiwan, onde aparentemente não haveria um ambiente ótimo de proteção aos credores, os pesquisadores alinhados à Law and Finance atribuem o "desvio" a uma "distorção" daqueles modelos de desenvolvimento: a intervenção do Estado e dos bancos públicos. Assim como no caso da lei sobre dividendos, o argumento vai no sentido de considerar os bancos públicos um arremedo de organização institucional, que busca superar as falhas de proteção dos investidores particulares com a atuação estatal. Esta controvérsia é particularmente relevante para as análises sobre o modelo brasileiro de organização financeira, que como será apresentado no próximo capítulo tem baseado o financiamento de longo prazo na atuação de um banco público de desenvolvimento: o BNDES.

Buscando uma leitura menos estreita, poder-se-ia assinalar de início que, a rigor, o direito e as instituições importam, mas os modelos institucionais são variados. Cada arranjo nacional reflete as diferentes escolhas e preferências sociais, que, por sua vez, reforçam as particularidades históricas, culturais e políticas dos países ${ }^{39}$. Os modelos de organização econômica não são idênticos e não tendem a uma convergência necessária. Diante da tarefa de oferecer mecanismos para a coordenação das atividades financeiras, parece plausível apostar que os países desenham um leque de soluções institucionais mais diversificado, do que supõe a literatura de corte Law and Finance.

\footnotetext{
${ }^{38}$ A esse respeito dizem os autores: "the one remedial measure in table 2, namely mandatory dividend, shows that mandatory dividends are used only in French-civil-law countries. This result is broadly consistent with the rest of our evidence and suggests that mandatory dividends are indeed a remedial legal protection for shareholders who have relatively few other legal rights." Ver LA PORTA, Rafael; LOPEZ-de-SILANES, Florencio; SHLEIFER, Andrei \& VISHNY, Robert. Law and Finance, op. cit. p. 1132.

${ }^{39}$ Sobre a relação entre as variedades institucionais, as escolhas sociais e o direito, ver PISTOR, Katharina. Legal Ground Rules in Coordinated and Liberal Market Economies, working paper n⿳0.30/2005, Columbia Law School, 2005, pp. 1-44.
} 
Alternativamente a um enquadramento institucional monocórdio, alguns pesquisadores têm se valido da noção de variedades de capitalismos, para explicar as diferenças existentes entre os modelos de economias nacionais. É isso que procuram fazer Peter HALL e David SOSKICE ${ }^{40}$, que lançam mão dos tipos ideais economias de mercado liberais e economias de mercado coordenadas, para assim compreender as distinções na forma de organização e no funcionamento dos arranjos institucionais hegemônicos entre as nações desenvolvidas. Cada um destes tipos está associado a um modo específico de organização social e econômica, em cujas bases residem diferenças na composição dos sistemas financeiros e na correspondente organização das estruturas jurídicas, que disciplinam as relações entre investidores e empreendedores.

As economias identificadas por HALL e $\operatorname{SOSKICE}^{41}$ como liberais são aquelas em que as atividades de coordenação entre os agentes privados são mediadas pelos mercados. São as regras de mercado que pautam as decisões e estratégias dos atores econômicos, o que significa dizer que as relações comerciais estabelecidas entre estes são notadamente impessoais, descontínuas e baseadas numa premissa individualista e competitiva de comportamento. O sistema de preços e os demais dados públicos e objetivos do processo econômico são os códigos de referência que balizam a ação dos agentes. No funcionamento de uma economia como esta, os atores não tendem a construção de laços de cooperação, mas a uma organização que conta prioritariamente com dois elementos: os mercados, espaço em que há rivalidade entre os concorrentes, e as firmas, que são resultado da integração de agentes antes isolados ${ }^{42}$. O seu sistema financeiro é baseado no mercado de capitais, que conta com atores financeiros pulverizados e distanciados da vida corporativa. Para os autores, um exemplo típico de uma economia liberal de mercado é a norte-americana, em que as relações comerciais, de

\footnotetext{
${ }^{40}$ Ver HALL, Peter \& SOSKICE, David. Introduction, em HALL, Peter \& SOSKICE, David Varieties of Capitalism - the institutional foundations of comparative advantage, New York, Oxford Press, 2001, pp. 168.

${ }^{41}$ Cf. HALL, Peter \& SOSKICE, David. Varieties of Capitalism, op. cit.

${ }^{42}$ Os tipos firmas e mercados são descritos por Oliver WILLIAMSON. A idéia subjacente é a de que numa economia de mercado os agentes tendem originariamente a atuar isoladamente. Quando os custos das transações entre os agentes se mostram elevados, no entanto, o caminho racional é a sua internalização, o que resulta na organização de uma firma integrada - uma hierarquia. Numa economia como essa, não há relações de cooperação. Ou bem há rivalidade, ou bem, uma hierarquia. A esse respeito ver WILLIAMSON, Oliver. The Economic Institutions of Capitalism - firm, markets, relational contracting, New York, Free Press, 1985, pp. 68-84.
} 
trabalho e de investimento são sustentadas por um lastro jurídico-institucional que estrutura as relações em bases individualistas e descontínuas.

Em contraposição a este modelo, situam-se as economias de mercado coordenadas. ${ }^{43}$ Nestes arranjos, a organização do processo econômico é tributária de laços externos ao ambiente de mercado. No lugar de relações episódicas e pontuais, típicas de um espaço pautado pela rivalidade, em que os intercâmbios justificam-se apenas pelo autointeresse dos agentes nas transações comerciais, emerge um mecanismo de coordenação baseado na colaboração e no relacionamento permanente entre os agentes.

Nesse tipo de ambiente, a atuação econômica dos atores não se vale exclusivamente de dados públicos e informações obtidas impessoalmente, para balizar as suas operações. As relações privadas, as redes internas de monitoramento e o compartilhamento de ações coletivas, entre outros, são atributos relevantes nas decisões de investimento. Como será visto em breve, em economias coordenadas, como a alemã ou japonesa, a governança corporativa pauta-se prioritariamente em enlaces existentes entre financiadores e empresários, que independem muitas vezes do mercado de capitais. Nestes regimes, as barganhas coletivas e as disputas de poder internas às corporações tendem a ser mecanismos de proteção mais corriqueiros, do que a utilização de ferramentas fundadas em uma lógica de adversariedade, adequadas para garantir os interesses de investidores individuais. Coerentemente, neste modelo de organização econômica, ao invés do mercado de capitais e dos investidores atomizados, os elementos chave são os bancos e os investidores institucionais.

Cada um destes arranjos institucionais está associado, por sua vez, a um padrão de direito ou de regulação jurídica, àquilo que Katharina $\operatorname{PISTOR}^{44}$ denomina por normas jurídicas fundamentais (legal ground rules). Sendo assim, enquanto as economias liberais de mercado contam com um conjunto normativo que favorece as iniciativas particulares e a proteção dos indivíduos; as economias coordenadas assentam-se em regras e direitos propícios às ações coletivas. Uma vez demonstrada a existência destas diferenças, ficará ainda mais claro o argumento pretendido: as ferramentas jurídicas importam para o

${ }^{43}$ Cf. HALL, Peter \& SOSKICE, David. Varieties of Capitalism, op. cit.

${ }^{44}$ Ver PISTOR, Katharina. Legal Ground Rules in Coordinated and Liberal Market Economies, op. cit. 
financiamento, mas a variedade de capitalismos impõe uma lente de aumento às análises da Law and Finance.

Os direitos alocados pelas normas jurídicas fundamentais, a que PISTOR ${ }^{45}$ faz referência, compõem-se de instrumentos substantivos e procedimentais que disciplinam a forma de relacionamento entre os agentes econômicos. Concretamente, esta associação entre o sistema jurídico e o tipo de arranjo institucional pode ser verificada nos campos do direito contratual e societário - justamente os responsáveis pela mediação das relações entre investidores e empreendedores. A seguinte passagem da autora sintetiza o fundamento e a finalidade de seu argumento:

This contribution seeks to explain the affinity between the nature of economic systems - coordinated market economis (CMEs) and liberal market economis (LMEs) on the one hand, and legal origin (civil vs. common law systems) on the other. The paper starts with the simple observation that LME tend to be common law jurisdictions, and CMEs civil law jurisdictions. It proposes that the affinity between economic and legal system offers important insights into the foundations of different types of market economies and, in particular differences in the scope of the state vs. the powers of the individual. The main argument is that legal system serves as a coordination device for social preferences. At the most basic level these social preferences are reflected in the allocation of rights and responsibilities either to individuals or away from them to collective or the state. ${ }^{46}$

Nas economias liberais, a liberdade contratual e a autonomia das partes figuram como as características centrais dos acordos entre particulares. O esforço do direito privado é em preservar a liberdade de negociação entre os agentes, eliminando do escopo da regulação contratual a imposição de elementos externos à vontade dos contratantes. Os elementos externos à relação, como a assimetria de poderes entre as partes, as intenções ou os valores dos contratantes, tendem a ter menor importância do que a aposta na capacidade de negociação dos agentes, o que reforça a noção de autonomia privada ${ }^{47}$. O contrato típico de uma economia liberal é um contrato descontínuo, que é menos comprometido com regras de solidariedade e mecanismos distributivos entre os contratantes. Bem ao estilo de um arranjo fundado em relações de mercado, o direito que regula o intercâmbio dos

\footnotetext{
${ }^{45}$ PISTOR, Katharina. Legal Ground Rules in Coordinated and Liberal Market Economies, op. cit.

${ }^{46}$ PISTOR, Katharina. Legal Ground Rules in Coordinated and Liberal Market Economies, op. cit. p. 2.

${ }^{47}$ Sobre a relação destes aspectos com o tipo de organização da economia americana, ver CASPER, Steven. The Legal Framework for Corporate Governance: the influence of contract law on corporate strategies in Germany and United States, em HALL, Peter \& SOSKICE, David. Varieties of Capitalism, op. cit. pp. 387416.
} 
interesses favorece acertos impessoais e distanciados, presumindo que as partes não estabelecem entre si qualquer outra relação, que não a comercial. Como salienta Steven $\mathrm{CASPER}^{48}$, o direito contratual correspondente a este tipo de alternativa institucional segue uma abordagem clássica, que supõe uma racionalidade máxima para os agentes, assumidos como capazes de estipularem os seus termos sem qualquer necessidade de um ente regulador externo.

A contrario sensu, uma economia de mercado coordenada apóia-se em um estilo de direito contratual em que ganham relevo informações contextuais e valorativas, que extrapolam as específicas combinações privadas, em mercado. Diferentemente da presunção liberal de que a transação esgota toda a relação entre as partes, o tom do direito contratual em uma economia coordenada está em franca sintonia com dispositivos externos aos agentes e seus intercâmbios comerciais. Nesse sentido, ganha proeminência a preocupação de que o instrumento contratual seja capaz de prover justiça e equilíbrio nas trocas contratuais. É dizer, o ambiente externo às relações de mercado dos atores, os contextos reais em que estes estão envolvidos, importa para a regulação contratual. Em última instância, nessa noção de contrato não valem apenas as suas cláusulas escritas e acordadas. Os agentes, ao não sustentarem os intercâmbios em relações exclusivamente descontínuas, desenvolvem práticas contratuais reiteradas e permanentes, em uma espécie de vínculo relacional. Como será visto logo a seguir, os sistemas de financiamento das economias coordenadas, como a alemã ou a japonesa, valem-se costumeiramente destes laços relacionais de contratação, fïmados entre bancos e firmas, para regular a relação de investimento, que tem na perenidade uma de suas principais características ${ }^{49}$.

Nesse padrão contratual, não vale apenas aquilo que os negociantes acordaram, em suas transações privadas e isoladas, há que se igualmente respeitar uma espécie de moral pública: a autonomia privada, que é um valor máximo nas economias liberais, é limitada, nas economias coordenadas, pela prevalência de regras diretivas e princípios sociais que regem as relações entre os particulares: é o caso da boa fé, que deve ser

48 CASPER, Steven. The Legal Framework for Corporate Governance: the influence of contract law on corporate strategies in Germany and United States, op. cit.

${ }^{49}$ Sobre os contratos relacionais e o sistema financeiro japonês, ver KOBAYASHI, Ichiro. The Interaction Between Japanese Corporate Governance and Relational Contract Practice, New York University, Journal of Legal \& Business, nº. 269, 2005/2006. 
observado pelas partes, independentemente dos termos ajustados. ${ }^{50}$ Além de princípios sociais, a autonomia das partes, neste modelo, sofre ainda uma segunda limitação, decorrente de um maior arcabouço regulatório incidente sobre os contratos: no lugar da plena liberdade de contratação e de seu controle meramente jurisdicional, as economias coordenadas apresentam leis e regulamentos, que delimitam os espaços reservados para os livres acertos entre os particulares. ${ }^{51}$

Um exemplo concreto desta maior direção pública no terreno dos negócios jurídicos pode ser extraído da exigência prevista em legislações como a alemã ou a japonesa de que as firmas mantenham uma capitalização mínima quando da contratação de dívidas. No mesmo sentido da descrição ora realizada, uma lei como esta tem o sentido de delimitar o espaço de ação daquele que contrata empréstimos privados. Note-se que o tomador de recursos não se obriga apenas a cumprir o acordado no contrato, pagando o empréstimo ao credor, ele deve também se ater aos compromissos impostos por uma lei que disciplina estas relações, para além dos ajustes privados. Em suma, pode-se entender que, nessas economias, a proteção do credor não é dada apenas pelas cláusulas do contrato de crédito, mas também pela regras jurídicas, que dirigem as transações privadas. ${ }^{52}$

Nessa linha, PISTOR ${ }^{53}$ assinala que ao lado do direito contratual, também o direito societário ou empresarial (corporate law) é concomitante com o correspondente tipo de organização institucional. Enquanto as economias liberais de mercado tendem a contar com uma regulação societária vinculada à proteção de investidores individualizados e atomizados, nos moldes do rol de direitos elencados pela Law and Finance, as economias coordenadas têm uma predileção por normas que favorecem uma composição coletiva entre todos os agentes envolvidos com a vida da sociedade, como os credores, acionistas e trabalhadores.

\footnotetext{
${ }^{50}$ Em um artigo que integra o livro de HALL \& SOSKICE, o sociólogo do direito Gunther TEUBNER sugere que essas diferenças de modelo têm gerado recentemente uma irritação (um incômodo) entre os sistemas jurídicos dessas economias. Em virtude da União Européia e da maior comunicação entre os sistemas, a idéia de boa fé tem sido apresentada ao ordenamento britânico, causando assim uma irritação em seu sistema contratual, menos ajustado à observância de regras e princípios sociais. A esse respeito, ver TEUBNER, Gunther. Legal Irritants: how unifying law ends up in new divergences, em HALL, Peter \& SOSKICE, David. Varieties of Capitalism, op. cit., pp. 417-441.

${ }^{51}$ Cf. PISTOR, Katharina. Legal Ground Rules in Coordinated and Liberal Market Economies, op. cit.

52 Sobre essa exigência de capitalização mínima ver HERTIG, Gerard \& KANDA, Hideki, Creditor Protection, em KRAAKMAN, Reinier, et al. The Anatomy of Corporate Law - a comparative and functional approach, op. cit., pp. 71-99.

${ }_{53}$ PISTOR, Katharina. Legal Ground Rules in Coordinated and Liberal Market Economies, op. cit.
} 
Um primeiro aspecto dessa distinção entre ambos os direitos societários pode ser verificado no caráter dispositivo das normas norte-americanas, de um lado, e no estilo mandatório do sistema alemão, de outro. No direito societário norte-americano, a legislação serve como um padrão mínimo (um default), a partir do qual as sociedades desenvolvem diversos desenhos possíveis de organização dos interesses sociais. Na prática, contudo, os estatutos e contratos sociais é que respondem pela distribuição de direitos e deveres, ínsitos a acionistas e administradores. Esse traço contratual do direito societário anglo-saxão explica com bastante propriedade o fato de que o cerne dos direitos de proteção dos financiadores seja estipulado no âmbito das regras de governança corporativa $^{54}$ (em geral o foco de análise da Law and Finance).

Já no ambiente continental, em que vigoram economias coordenadas, a feição da organização societária é outra e conta menos com os instrumentos contratuais e mais com a alocação de direitos e garantias por intermédio de leis e regulamentos. Para além das regras de governança e dos termos estipulados em documentos societários, celebrados entre acionistas e administradores, a pedra de toque destes regimes corporativos é o peso exercido pela legislação na orientação das ações empreendidas pelos atores. É nesse contexto institucional que ganham sentido, por exemplo, situações como, a já mencionada, determinação legal de distribuição de dividendos, existente em países da tradição de civil law de origem francesa, ou mesmo a construção alemã de um parâmetro legislativo que determina a razoabilidade da remuneração dos administradores corporativos. ${ }^{55}$

Além destas variações quanto ao caráter dispositivo ou mandatório dos regimes, os sistemas corporativos em economias liberais e coordenadas apresentam outras duas distinções de igual relevância: (i) uma diferente concepção dos interesses constitutivos das sociedades e (ii) mecanismos procedimentais próprios para assegurar os direitos e garantias dos financiadores. Com relação ao primeiro destes aspectos, trata-se de diferenças de percepção quanto ao universo de atores que compõem a vida da corporação. Enquanto o modelo americano é bastante vinculado à proteção dos acionistas, deixando de fora as

\footnotetext{
${ }^{54}$ Sobre o caráter contratual do direito societário americano, ver PISTOR, Katharina. Legal Ground Rules in Coordinated and Liberal Market Economies, op. cit.

${ }^{55}$ A previsão legal da distribuição de dividendos é encontrada nos países de origem jurídica francesa, ao passo que a adoção de um critério legal para a remuneração dos controladores é verificada na Alemanha. Sobre isso ver PISTOR, Katharina. Legal Ground Rules in Coordinated and Liberal Market Economies, op. cit.
} 
demais categorias (stakeholders), os padrões alemão e japonês entendem a sociedade numa perspectiva coletiva e estabelecem direitos de participação e garantias jurídicas tanto para os acionistas, como para os credores e mesmo para os trabalhadores (originariamente, no sistema alemão, os trabalhadores participam igualmente do conselho de administração das empresas). Decorre disso, segundo HERTIG \& KANDA ${ }^{56}$, a ampla percepção de que os Estados Unidos seria um país menos favorável aos credores (debt-friendly), do que a Alemanha, por exemplo, que é conhecida como um pais que protege os credores (creditorfriendly). Essa percepção não é obra do acaso, de fato, o modelo americano prioriza a proteção dos acionistas, ao passo que o estilo alemão de financiamento conta com um protagonismo do setor bancário e, conseqüentemente, dos credores.

O outro aspecto relevante de diferença entre esses sistemas societários diz respeito justamente aos procedimentos de proteção dos financiadores. Em consonância com as normas fundamentais que organizam os arranjos de cada um dos tipos de economia, o instrumental de defesa dos interesses dos investidores tende a oferecer um arsenal operativo coerente com o perfil individualista ou cooperativista de cada um dos regimes. Em economias liberais, em que prevalece a concepção de uma coordenação via mercado, da qual fazem parte indivíduos rivais, os mecanismos procedimentais de proteção dos financiadores valorizam as ações individuais - assentadas, como dito, em uma lógica de adversariedade. Em compensação, nas economias coordenadas prevalecem meios coletivos de solução das disputas corporativas, a proteção de acionistas e credores passa menos pelo voluntarismo judicial dos descontentes e mais pela instâncias de barganha coletiva internas às sociedades.

No regime anglo-saxão, os acionistas têm, via de regra, o poder de questionar individualmente decisões administrativas, desde que seja evidenciado que seus direitos e interesses foram prejudicados. Da mesma forma, o modelo americano admite a possibilidade de que no caso de ações coletivas de acionistas (class actions), não haja a necessidade de que o proponente obtenha a reunião prévia de seus pares para desafiar alguma decisão dos administradores ${ }^{57}$. Nessa linha, há ainda outros benefícios que

\footnotetext{
${ }^{56}$ HERTIG, Gerard \& KANDA, Hideki, Creditor Protection, op. cit.

${ }^{57}$ Conforme assinala PISTOR: "class action allow individual shareholders to claim that they are acting on part of other aggrieved parties, without having to organize them prior to bringing suit." PISTOR, Katharina. Legal Ground Rules in Coordinated and Liberal Market Economies, op. cit. p. 32.
} 
incentivam a proteção dos acionistas de maneira individual, como a possibilidade ampla de reclamar informações perante os gestores da companhia, ou o direito ao ressarcimento de custos incorridos nas suas contestações corporativas, quando os proponentes vierem a ser vitoriosos ${ }^{58}$.

Já nas economias coordenadas, a lógica de iniciativa dos litígios societários mitiga a amplitude das iniciativas individuais e fortalece as ações efetivamente coletivas. A contestação de temas corporativos exige que os demandantes detenham uma relativa participação no capital social, o que não é muitas vezes trivial. No caso da Alemanha, os descontentes devem fazer prova de que possuem ao menos $5 \%$ do capital social, por ao menos três meses, para questionarem judicialmente as decisões corporativas. Caso sejam vencidos na lide, devem ainda ressarcir os custos incorridos pela companhia. ${ }^{59} \mathrm{Com}$ isso, o modelo alemão, como um exemplo de uma economia coordenada, não incentiva a persecução individual dos interesses dos investidores. Isso é bastante coerente com o seu modelo de governança corporativa, que procura conjugar os grupos sociais numa consertação, em que os acionistas são apenas uma parte e não a parte mais importante do conflito potencial de interesses. Para Katharina PISTOR ${ }^{60}$, ao limitar a liberdade de ação individual, forçando as atuações coletivas, o sistema alemão acaba por privilegiar os mecanismos internos de controle e barganha, em detrimento das reclamações judiciais promovidas por atores isolados.

Desta maneira, a defesa dos investidores vale-se não da confrontação interindividual, como no modelo anglo-saxão, mas dos mecanismos privados de monitoramento e ajuste. Tanto os credores, como os acionistas, coordenam os seus interesses por meio de mecanismos relacionais, baseados na estruturação de uma relação de longo prazo, que

\footnotetext{
58 A seguinte passagem de HANSMANN \& KRAAKMAN esclarece em parte o estilo da regulação corporativa americana: "The regulatory burden on shareholder action in the US law should not be exagerated, however. U.S. securities law can also favor shareholder insurgency. For example, the SEC's Proxy rules can force incumbent managers to make sweeping and often embarrassing disclosures, guarantee that insurgent solicitation materials will reach the company shareholders, and in some cases permit shareholders to piggyback proposals opposed by management at negligible cost on management's own proxy solicitation. In addition, there is a developed U.S case law to protect the integrity of shareholder voting from managerial manipulation. Finally, the U.S. may be the only jurisdiction to permit corporations to compensate successful insurgents ex post for their campaign costs." HANSMANN, Henry \& KRAAKMAN, Reinier, The Basic Governance Structure, em KRAAKMAN, Reinier, et al. The Anatomy of Corporate Law - a comparative and functional approach, op. cit. pp. 42-43.

${ }^{59}$ Cf. PISTOR, Katharina. Legal Ground Rules in Coordinated and Liberal Market Economies, op. cit.

${ }^{60}$ Cf. PISTOR, Katharina. Legal Ground Rules in Coordinated and Liberal Market Economies, op. cit.
} 
permite aos agentes financeiros fiscalizarem continuamente o desempenho da empresa captadora de recursos. Neste modelo, portanto, a proteção dos investidores não é baseada em uma lógica de contraposição de interesses individuais, garantida por um rol de direitos de acionistas e credores, exercidos contrariamente aos administradores. Trata-se, na realidade, de um outro sistema de proteção jurídica, em que ganham apelo as ações em bloco, disponibilizadas por bancos e demais instituições financeiras, e os mecanismos de pressão internos à sociedade. ${ }^{61}$

A tabela abaixo sintetiza este argumento, demonstrando a associação entre o tipo de economia e o seu sistema jurídico. Como tipos ideais, as economias liberais assentam-se em dispositivos regulatórios e mecanismos de governança, substantivos ou procedimentais, voltadas a favorecer interesses individuais. As economias coordenadas, por sua vez, restringem em parte a autonomia privada e fortalecem meios colegiados de composição.

\begin{tabular}{|c|c|c|}
\hline \multicolumn{3}{|c|}{ QUSTEMAS REGULATÓRIOS E TIPOS DE ARRANJOS ECONÔMICOS } \\
\hline & $\begin{array}{c}\text { Economias Liberais de } \\
\text { Mercado }\end{array}$ & $\begin{array}{c}\text { Economias Coordenadas de } \\
\text { Mercado }\end{array}$ \\
\hline $\begin{array}{c}\text { Padrão da Regulação } \\
\text { Substantiva }\end{array}$ & $\begin{array}{c}\text { Primazia da autonomia privada } \\
\text { Favorecimento dos interesses } \\
\text { individuais }\end{array}$ & $\begin{array}{c}\text { Autonomia privada limitada por } \\
\text { regras mandamentais e normas de } \\
\text { moral social }\end{array}$ \\
\hline $\begin{array}{c}\text { Padrão da Regulação } \\
\text { Procedimental }\end{array}$ & $\begin{array}{c}\text { Favorecimento das iniciativas } \\
\text { individuais }\end{array}$ & $\begin{array}{c}\text { Favorecimento dos mecanismos } \\
\text { coletivos e relacionais }\end{array}$ \\
\hline Elaboração própria, a partir de PISTOR (2005) & \\
\hline
\end{tabular}

Diante disso, não parece plausível supor que possa existir um conjunto único de ferramentas adequadas para a proteção dos investidores. A noção de alternativas institucionais indica que, ao lado das instituições, a história também importa. Os sistemas de governança corporativa refletem trajetórias nacionais diferenciadas, que nada mais são, a não ser o resultado da construção de soluções locais, para o problema do financiamento corporativo. Abrindo um pouco mais o espectro de análise, essas distinções conformam diferentes modelos de sistemas financeiros - uma constatação que importa particularmente para se entender o modelo brasileiro, que, assim como verificado em outros países em desenvolvimento, conta com uma economia ainda mais coordenada, em que coube ao Estado o papel de agente financeiro.

${ }^{61}$ Sobre as diferenças entre os modelos e característica de atuação em bloco no modelo nipo-germânico ver ROE, Mark. Some Differences in Corporate Structure in Germany, Japan and the United States, The Yale Law Journal, Vol. 102, no. 8, Symposium: Economic Competitiveness and the Law, 1993, pp. 1927-2003. 


\section{AS ALTERNATIVAS INSTITUCIONAIS DE ORGANIZAÇÃO DOS SISTEMAS FINANCEIROS}

No transcorrer de seus processos históricos, espelhando o nível correspondente de desenvolvimento econômico e as demais vicissitudes locais, os países formularam diferentes modelos de governança, reagindo assim, cada qual à sua maneira, à necessidade de oferta de créditos e de capitais, em um volume necessário para os investimentos de longo prazo. Foi nessa busca particular por soluções institucionais alternativas para o financiamento corporativo, que se desenharam os diferentes formatos de organização financeira, do que decorre a polaridade funcional entre dois clássicos modelos: (i) o anglosaxão, baseado no mercado de capitais e o nipo-germânico, baseado nos bancos e no mercado de créditos. ${ }^{62}$ Invertendo em parte o ponto de observação realizado até então, a seção a seguir contempla uma descrição macroscópica destes sistemas financeiros. Desnecessário detalhar que, subjacente a cada uma dessas fórmulas institucionais, há um correspondente estoque de ferramentas jurídicas de proteção dos investidores.

Nos contextos econômicos em que floresceu o mercado para a provisão de capitais, em um porte compatível com a demanda financeira do setor produtivo, coube à captação mobiliária o suprimento de recursos para os investimentos dos empreendedores. Em compensação, naquelas economias em que o mercado não se consolidou como um fornecedor adequado dos montantes financeiros necessários para o ritmo dos investimentos, foram desenvolvidas instituições financeiras, notadamente os bancos, para o desempenho destes papéis. A seguinte passagem de John ZYSMAN dá conta exatamente destas duas alternativas institucionais:

Very simply, where capital markets emerged to finance industrial development, bank lending has been traditionally limited to short-term purposes. Where the capital markets were neither adequate nor reliable sources of development funds, banks or specialized institutions filled the gap with loans. ${ }^{63}$

Ambos os arranjos institucionais contam com sistemas bancários. A diferença reside no papel que os bancos cumprem em cada um destes modelos. Nas economias baseadas no mercado (economias liberais), os bancos cumprem um papel de agentes

${ }^{62}$ A esse respeito, ver ALLEN, Franklin \& GALE, Douglas. Comparing Financial Systems, Cambridge, London, MIT Press, 2000, pp. 3-23.

${ }^{63}$ ZYSMAN, John. Governments, Markets, and Growth - financial systems and the politics of industrial change, New York, Cornell Paperback, 1984, p. 61. 
financeiros de curto prazo. A intermediação financeira que realizam, isto é, a captação de recursos monetários, de um lado, e o empréstimo de capital, de outro, assenta-se em uma lógica de breve maturação. Neste modelo, compete ao mercado de capitais o papel de financiador corporativo, o que é muitas vezes corroborado pelo teor da regulação financeira.

Ao restringir o papel dos Bancos no financiamento corporativo, limitando, por exemplo, a possibilidade de abertura de filiais, cerceando o rol de serviços financeiros disponíveis ou disciplinando incisivamente a concentração do setor, a regulação financeira pode exercer um papel relevante, contribuindo assim para modelar o formato do sistema financeiro. Foi o que ocorreu no cenário norte-americano, por exemplo. Dentre várias constrições existentes neste panorama, vale destacar o Glass-Steagall Act, de 1933, que proibiu os bancos de atuar em mercados contíguos, como são, por exemplo, o de banco comercial e o de banco de investimento e ainda impediu os bancos comerciais de atuarem no mercado de capitais. Com isso, garantiu uma segmentação dos mercados bancários, restringindo a amplitude de bancos habilitados a exercerem um papel na geração de recursos para as atividades produtivas de longo prazo. ${ }^{64} \mathrm{O}$ resultado foi um fortalecimento do mercado de capitais e das transações descontinuas e atomizadas, próprias de uma economia liberal de mercado.

A contrario sensu, as economias que não assistiram ao surgimento de um mercado de capitais, desenvolveram regulações financeiras voltadas a amplificar o papel dos bancos, com a finalidade de dar a estes atores as condições institucionais necessárias para que cumprissem o papel de efetivos agentes de mobilização e canalização financeira. Por tal razão, no lugar das restrições, foram criados incentivos regulatórios, para que os bancos assumissem as operações de empréstimo de longo prazo. Dada a necessidade de disponibilização de recursos e a ausência do mercado de capitais, o compromisso regulatório foi o de permitir a geração de rendas supra-competitivas para os bancos, como forma de estimular as suas operações de investimento. Neste outro modelo de organização econômica, diferentemente do que se passou no cenário norte-americano, a concorrência bancária foi dissipada, e, em virtude dos processos de fusão e aquisição, os bancos têm apresentado porte significativo e uma fonte estável para a captação dos recursos, fatores

${ }^{64}$ A esse respeito, ver ALLEN, Franklin \& GALE, Douglas. Comparing Financial Systems, op. cit. O capítulo 3 a seguir, apresenta uma reconstrução das medidas do New Deal e comenta o Glass Steagall Act. 
capazes de induzir um tipo de intermediação financeira de longo fôlego. É este o caso dos modelos japonês e alemão.

No contexto japonês, Masahiko AOKI, Hugh PATRICK e Paul SHEARD identificam regras regulatórias dirigidas a conter a concorrência entre os bancos, como é o caso da restrição à entrada de novas firmas bancárias no mercado, o que garantiu, relatam os autores, a formação do sistema do banco principal (Main Bank System): ${ }^{65}$ cada grande firma contava com um grande banco como seu provedor financeiro - o banco principal. As restrições à entrada nesse setor, acompanhadas de regras permissivas de cruzamento societário entre os bancos e as indústrias, ao lado de um controle incisivo realizado pelo Ministério da Fazenda, no sentido de impulsionar a concessão de créditos para as grandes firmas, deram origem a um modelo de organização financeira caracterizado por um verdadeiro acoplamento entre firmas e bancos. ${ }^{66}$ Esta relação de proximidade, lastreada em laços contratuais e societários de caráter relacional, conferiu aos bancos japoneses um papel relevante na governança corporativa das firmas investidas, permitindo assim um exercício permanente de monitoramento financeiro.

O sistema alemão, que, por sua vez, foi fonte inspiradora do modelo japonês, foi igualmente baseado na primazia do sistema bancário e consagrou o paradigma do banco universal (Hausbank System). Em sentido oposto ao verificado no contexto norteamericano, não houve no cenário alemão restrições como as do Glass-Steagall Act. Aos bancos, foi dada a oportunidade de execução de um conjunto amplo de atividades, que se estendeu desde o gerenciamento de contas alimentadas por depósitos, até serviços de seguro, passando pela autorização de subscrição de valores mobiliários e participação societária nas firmas contratantes do financiamento. Além disso, a organização bancária é bastante concentrada, tanto assim que boa parte do financiamento corporativo é realizado

65 Cf. AOKI, Masahiko, PATRICK, Hugh \& SHEARD, Paul. The Japanese Main Bank System: an introductory overview, em AOKI, Masahiko \& PATRICK, Hugh. The Japanese Main Bank System - its relevance for developing and transforming economies, Reprinted, New York, Oxford University Press, 1998, pp. 3-48

66 Cf. AOKI, Masahiko, PATRICK, Hugh \& SHEARD, Paul. The Japanese Main Bank System: an introductory overview, op. cit. Ver a respeito do modelo japonês, ROE, Mark. Some Differences in Corporate Structure in Germany, Japan and the United States, op. cit. e GILSON, Ronald \& ROE, Mark. Understanding the Japanese Keiretsu: overlaps between corporate governance and industrial organization, Yale Law Journal, vol. 102, nº. 4, 1993, pp. 871-906 
pelos três maiores bancos universais - Deutsche, Dresdner e Commerzbank, como indicam ALLEN \& GALE. ${ }^{67}$

Com essa amplitude de atividades e com a possibilidade de concentrar uma parte significativa da gestão financeira, os bancos alemães conseguiram diversificar as suas fontes de retorno; puderam, assim, embrenhar-se no financiamento de atividades de longa maturação e, eventualmente, portadoras de um risco mais acentuado. Para além dos aportes em atividades mais corriqueiras, com resultado visível no curto prazo, como o financiamento de ativos físicos, como máquinas e equipamentos ou do capital de giro das empresas, estes bancos foram responsáveis pelo crédito para grandes operações, como as obras de infra-estrutura, cuja capacidade de pagamento demanda um longo prazo.

Os modelos japonês e alemão são, portanto, bastante representativos de um tipo de arranjo institucional desenhado com a finalidade de substituir as funções que são atribuídas classicamente aos mercados, ao menos na literatura de influência anglo-saxã. Ambos os exemplos confirmam os apontamentos que Alexander GERSCHENKRON ${ }^{68}$ havia feito para o desenvolvimento dos países retardatários, do século XIX. A consolidação do sistema de banco principal no Japão, justamente no seu período de intenso e acelerado crescimento econômico, entre 1950 e 1973, é um bom exemplo da constituição de uma alternativa ao mercado de capitais, incumbida de oferecer uma resposta institucional, compatível com o teor das necessidades nacionais.

Todavia, há situações em que o nível do desenvolvimento e a superação da tensão característica do atraso econômico (tensão formada entre a baixa disponibilidade de capital e as necessidades de financiamento em patamares de países industrializados) determinaram uma solução institucional ainda mais distante do modelo clássico de financiamento via mercados de capitais, ou modelo BERLE \& MEANS ${ }^{69}$ Como será visto no próximo capítulo, para GERSCHENKRON ${ }^{70}$, conforme o contexto histórico-econômico, nem mesmo os bancos privados suprem a falha dos mercados de capitais. Situações de maior

${ }^{67}$ Cf. ALLEN, Franklin \& GALE, Douglas. Comparing Financial Systems, op. cit.

68 GERSCHENKRON, Alexander. Economic Backwardness in Historical Perspective, em GERSCHENKRON, Alexander. Economic Backwardness in Historical Perspective - a book of essays, $3^{\mathrm{a}}$ reimpressão, Cambridge, London, Belknap Press, 1976, pp. 5-30.

${ }^{69}$ Em referência à BERLE, Adolf \& MEANS, Gardiner. The Modern Corporation \& Private Property, op. cit.

${ }^{70}$ GERSCHENKRON, Alexander. Economic Backwardness in Historical Perspective, op. cit. 
carência de recursos, como, por exemplo, a apresentada pelas periferias latino-americana e asiática, na segunda metade do século XX, reclamaram uma participação pública mais pronunciada, com o Estado fazendo as vezes de agente financeiro e responsabilizando-se pelo estímulo econômico: uma terceira alternativa de organização do sistema financeiro, para além dos modelos de mercado e de bancos privados. ${ }^{71}$

Esta variedade de sistemas financeiros foi organizada por John ZYSMAN ${ }^{72}$ em três tipos ideais. Em cada qual, a característica do modelo é tomada a partir do protagonismo da instância responsável pela mobilização e alocação dos recursos para os investimentos de longo prazo. Os três modelos são os seguintes: (i) sistema financeiro baseado no mercado; (ii) sistema financeiro baseado nos bancos e (iii) sistema financeiro baseado nos bancos públicos. O quadro a seguir resume os modelos.

\begin{tabular}{|c|c|c|c|c|c|}
\hline \multicolumn{7}{|c|}{ ALTERNA TIVAS DE SISTEMAS FINANCEIROS } \\
\hline & Inglaterra & EUA & Japão & Alemanha & $\begin{array}{c}\text { Países em } \\
\text { desenvolvimento }\end{array}$ \\
\hline $\begin{array}{c}\text { Participação do } \\
\text { mercado de } \\
\text { capitais }\end{array}$ & Muito relevante & Muito relevante & $\begin{array}{c}\text { Alguma } \\
\text { relevância }\end{array}$ & $\begin{array}{c}\text { Pouco } \\
\text { relevante }\end{array}$ & Pouco relevante \\
\hline $\begin{array}{c}\text { Participação do } \\
\text { sistema } \\
\text { bancário }\end{array}$ & Pouco relevante & Pouco relevante & $\begin{array}{c}\text { Muito } \\
\text { relevante }\end{array}$ & $\begin{array}{c}\text { Muito } \\
\text { relevante }\end{array}$ & $\begin{array}{c}\text { Alguma } \\
\text { relevância }\end{array}$ \\
\hline $\begin{array}{c}\text { Participação do } \\
\text { governo nos } \\
\text { financiamentos }\end{array}$ & Pouco relevante & Pouco relevante & $\begin{array}{c}\text { Alguma } \\
\text { relevância }\end{array}$ & $\begin{array}{c}\text { Alguma } \\
\text { relevância }\end{array}$ & Muito relevante \\
\hline Elaboração própria, a partir de ALLEN \& GALE (2000) e ZYSMAN (1984) \\
\hline
\end{tabular}

Assim, enquanto na Inglaterra e nos Estados Unidos se constituiu um arranjo institucional de mercado, dado que as forças financeiras pulverizadas eram compatíveis com o volume de recursos financeiros demandados pela economia, países como o Brasil figuram no pólo oposto, centrado na figura do banco público, como será tratado a seguir. Entre ambos, situam-se a Alemanha e o Japão, cujos paradigmas financeiros são baseados

71 A opção de participação dos governos para suprir a falha do mercado de capitais e bancário privado também é discutida por Joseph STIGLITZ. Ver STLIGTZ, Joseph. Government, Financial Markets, and Economic Development, op. cit. Notadamente sobre o modelo asiático, ver STIGLITZ, Joseph \& UY, Marilou. Financial Markets, Public Policy, and The East Asian Miracle, World Bank Research Observer, vol. 11, no. 2, 1996, pp. 249-276.

72 ZYSMAN, John. Governments, Markets, and Growth, op. cit. 
no banco privado, bastante associado às indústrias. Tratam-se, portanto, de três diferentes tipos de alternativas jurídico-institucionais de organização financeira.

Esses macro modelos contam, como não poderia deixar de ser, com um elenco próprio de dispositivos regulatórios e de mecanismos de governança para reger as relações entre financiadores e empreendedores. Os sistemas financeiros amparados no mercado são típicos de uma economia liberal, na tipologia empregada por HALL \& SOSKICE. ${ }^{73}$ Conseqüentemente, modulam as relações jurídico-financeiras com as ferramentas identificadas por PISTOR ${ }^{74}$, ou seja, dotadas de uma racionalidade favorável à proteção individualista dos interesses. Neste modelo, há uma considerável pulverização dos títulos mobiliários, o que repercute na criação de um hiato cooperativo entre as firmas e os titulares das ações: o liame entre os financiadores e a empresa tomadora dos recursos é descontínuo, as partes são distantes. Desde o momento da decisão de investir até o resgate dos dividendos, gerados pela companhia, não há a estipulação de um engajamento dos acionistas com a vida e a gestão da empresa. Por essa razão, os mecanismos jurídicos de proteção empregados tendem a se constituir em salvaguardas individuais, contrapostos aos poderes de ação dos administradores. Daí o porquê das virtudes de algumas das garantias elencadas pelo roteiro da Law and Finance, como, por exemplo, a possibilidade de voto a distância, a proteção aos dissidentes e a facilidade de judicialização das controvérsias ferramentas apropriadas para um sistema de investidores pulverizados e atomizados.

Além dessas ferramentas, o adequado funcionamento deste sistema de financiamento, baseado no mercado de capitais, conta com a publicidade das informações, para permitir o acompanhamento dos poupadores, voltados ao valor presentes das companhias. Na hipótese de descontentamento dos investidores com os resultados apresentados, estes tendem a atuar no mercado e não internamente na gestão da companhia: podem decidir pela alienação de suas participações acionárias para uma firma

\footnotetext{
${ }^{73}$ A seguinte passagem de HALL \& SOSKICE, acerca dos laços (ou a falta de laços) que, primordialmente, se estabelecem entre as empresas e os agentes financeiros, naquilo que os autores chamam por economias liberais de mercado, resume bem este ponto: "The terms on which large firms can secure finance are heavily dependent on their valuation in equity markets, where dispersed investors depends on publicly available information to value the company. This applies to both bonds, share issues, and bank lending. Compensation systems that reward top management for increases in net earnings or share prices are common in such economies. Liberal market economies usually lack the close-knit corporate networks capable of providing investors with inside information about the progress of company that allows them to supply finance less dependent on quarterly balance sheets and publicly available information." HALL, Peter \& SOSKICE, David. Varieties of Capitalism, op. cit. pp. 28-29.

${ }^{74}$ PISTOR, Katharina. Legal Ground Rules in Coordinated and Liberal Market Economies, op. cit.
} 
concorrente, que venha a formular, via mercado, uma oferta hostil de aquisição de controle (takeover agressivo). Esse risco potencial incorrido pelos administradores, quando não apresentam um retorno satisfatórios para os seus acionistas, funciona como uma espécie de pressão permanente, em prol de uma gestão financeira eficiente, o que acaba também por salvaguardar os interesses destes acionistas pulverizados. ${ }^{75}$

Os sistemas amparados na prevalência dos bancos, por sua vez, são, como mencionado, próprios de uma economia de mercado coordenada, de modo que a forma predominante de proteção dos investidores conta com dispositivos coletivos, colegiados ou concentrados, em oposição aos instrumentos individualistas. Nessas economias o tipo de coordenação jurídica estimula um relacionamento entre os agentes em um sentido oposto ao verificado nas economias liberais. Os contatos societários entre os bancos e os tomadores de recurso permitem uma relação de proximidade e de longo prazo. Diferentemente do que se passa no regime de mercado, não há a preferência pela descontinuidade nos laços entre os agentes e nem um pressuposto de antagonismo individual na definição das relações econômicas. Ao contrário disso, os agentes estipulam relações continuadas e duradouras no tempo. No lugar da racionalidade da competição, aflora uma relação de intensa participação do banco com a firma, num desenho em que o engajamento dos atores é bastante evidente. ${ }^{76}$

A participação societária no capital social das indústrias propicia uma atuação extensiva dos bancos e um, conseqüente, acesso privilegiado a informações sobre situação das firmas, o que garante uma avaliação aprofundada da vida corporativa, protegendo assim os seus interesses ante ações oportunistas. ${ }^{77}$ Em comparação com os mecanismos

75 Ao comentarem o funcionamento das economias baseadas no mercado de capitais, FERREIRA, FREITAS
\& SCHWARTZ salientam que os mercados privilegiam o financiamento de operações padronizadas,
comumente associadas a critérios únicos e objetivos de mensuração, como são as avaliações baseadas em
evolução quantitativa dos balanços. Isso é bastante evidente quando se constata que nas economias baseadas
nos mercados de capitais, os atores financeiros acabam por incentivar, sobretudo, as operações de curto
prazo, sustentadas em uma lógica instantânea típica das relações econômicas descontínuas. FERREIRA,
Carlos Kawal Leal; FREITAS, Maria Cristina Penido de; \& SCHWARTZ, Gilson. Formato Institucional do
Sistema Monetário e Financeiro - um estudo comparado, em CINTRA, Marcos Antonio Macedo \&
FREITAS, Maria Cristina Penido de. Transformações Institucionais dos Sistemas Financeiros - um estudo
comparado, São Paulo, Fundap, Fapesp, 1998, pp. 13-144.
${ }^{76}$ Ver a respeito HALL, Peter \& SOSKICE, David. Varieties of Capitalism, op. cit.
77 A seguinte passagem de HALL \& SOSKICE, agora sobre o sistema bancário, que é um dos elementos
caracterizadores daquilo que os autores entendem por economias coordenadas de mercado, acentua esta
polaridade: "The financial system or market for corporate governance in coordinated market
economies typically provides companies with access to finance that is not entirely dependent on 
jurídico-institucionais característicos do modelo anglo-saxão, Mark $\mathrm{ROE}^{78}$, ao descrever o funcionamento dos modelos japonês e alemão, salienta três importantes diferenças na disciplina jurídica das relações entre investidores e administradores, são elas: (i) o controle de um bloco acionário (no lugar da pulverização acionária) (ii) o compartilhamento das decisões e da autoridade societária (ao invés da prevalência do administrador da empresas, o CEO) e (iii) poder de ação dos investidores institucionais (que substituem as pressões exercidas pelo mercado, como nas operações de aquisição hostil do controle).

Nestas economias coordenadas, os agentes financeiros detêm uma participação societária em bloco nas empresas beneficiárias dos aportes de recursos, isto é, uma parte considerável do capital social destas firmas é de titularidade de poucos investidores, que utilizam esta posição acionária expressiva nos canais corporativos de decisão, formais e informais. Com isso, a defesa dos interesses dos investidores passa, por exemplo, pelo uso do expressivo direito de voto no conselho de administração ou nas assembléias gerais, bem como pelo exercício informal do poder financeiro, como no caso japonês, em que as firmas costumam organizar encontros para que os administradores apresentem seus planos de negócio aos financiadores. ${ }^{79} \mathrm{~A}$ participação societária em bloco conduz, por sua vez, à possibilidade de influência na gestão da companhia, facultando desta maneira a possibilidade de uma autoridade partilhada. As eventuais discordâncias são solucionadas no âmbito da empresa e não mediadas pelas operações de mercado. Na base deste modelo residem investidores com elevado poder corporativo, ou seja, não se trata de aportadores de recursos individuais e pulverizados, daí porque, enfim, o conjunto de direitos e garantias detém também outras características, tanto do ponto de vista procedimental, como substantivo. $^{80}$

publicly available financial data or current returns. Access to this kind of 'patient capital' makes it possible for firms to retain a skilled workforce through economic downturns and to invest in projects generating returns only in the long run. The core problem here is that, if finance is not to be dependent on balance-sheet criteria, investors must have other ways of monitoring the performance of companies in order to ensure the value of their investments. In general, that means they must have access to what would normally be considered 'private' or 'inside' information about the operation of the company" HALL, Peter \& SOSKICE, David. Varieties of Capitalism, op. cit. pp. $22-23$.

${ }^{78}$ ROE, Mark. Some Differences in Corporate Structure ..., op. cit.

${ }^{79}$ Cf. ROE, Mark. Some Differences in Corporate Structure ..., op. cit.

${ }^{80} \mathrm{Cf}$. ROE, Mark. Some Differences in Corporate Structure ..., op. cit. 
Tais diferenças podem ser visualizadas no quadro abaixo, que apresenta dados da participação acionária dos cinco principais acionistas de três empresas: Daimler-Benz, Toyota e General Motors. Apesar de reportar um cenário de meados dos anos 1990, o quadro é ilustrativo por indicar um grau de concentração bastante diferenciado, sobretudo para Estados Unidos e Alemanha. O caso do Japão, embora pareça indicar uma desconcentração dos investidores, assemelha-se na realidade à situação alemã, pois os bancos, de acordo com $\mathrm{ROE}^{81}$, tendem a atuar de modo sindicalizado (formando uma coalizão de cinco bancos), formando assim um bloco de participação de $20 \%$ e cada firma conta com um deles como o banco representante - o banco principal.

\begin{tabular}{|c|c|c|c|c|c|}
\hline \multicolumn{7}{|c|}{ QUADRO 3 } \\
CONCENTRAÇÃO ACIONÁRIA DOS CINCO MAIORES INVESTIDORES POR COMPANHIA
\end{tabular}

Enfim, os dados apresentados e a comparação entre ambos os modelos deixam claro, portanto, a prevalência de dois sistemas de governança financeira. Em linha com a literatura das variedades de capitalismos, essas distinções podem ser classificadas em duas categorias: (i) a governança descontínua e (ii) a governança relacional. ${ }^{82} \mathrm{~A}$ governança descontínua, típica de uma economia liberal e, conseqüentemente dos sistemas baseados no mercado de capitais, caracteriza-se por não apresentar intermediários entre os poupadores e as firmas e com isso favorece a constituição de relações descontínuas e presentificadoras, amparadas em garantias individuais. Já a governança relacional, própria

${ }^{81} \mathrm{Cf}$. ROE, Mark. Some Differences in Corporate Structure ..., op. cit.

${ }^{82}$ A esse respeito assinalam AOKI \& DINÇ: "our working definition of relational financing is as follows: relational financing is a type of financing in which the financier is expected to make additional financing in a class of uncontractible states in the expectation of future rents over time. We refere to types of financing that are not relational as arm's lengths financing." AOKI, Masahiko \& DINÇ, Serdar. Relational Financing as an Institution and its Viability under Competition, paper, mimeo, Stanford University, 1997, p. 5; disponível em http://www-econ.stanford.edu/faculty/workp/swp97011.pdf, acesso em 18/10/08. 
de uma economia coordenada, baseia-se na prevalência dos investidores institucionais e favorece as relações continuadas, assentando-se nos meios coletivos de proteção. Essa diversidade decorre justamente dos diferentes tipos de soluções desenvolvidas pelos países para lidar com os seus problemas econômicos e financeiros. Cada um desses regimes conta, como visto, com um estoque respectivo de ferramentas jurídicas, que, em sintonia com o arranjo jurídico-institucional, disciplina as relações entre investidores e empreendedores.

\section{POR QUE E COMO ESTUDAR FINANCIAMENTO NO DIREITO? OS ARRANJOS INSTITUCIONAIS E AS FERRAMENTAS JURÍDICAS COMO VARIÁVEIS DE ANÁLISE DA TESE}

Este capítulo procurou argumentar que o financiamento corporativo, isto é, a captação de recursos externos por uma firma, para dar consecução aos seus propósitos empresariais, não ocorre em um vácuo institucional. Diferentemente do que apostavam, originariamente, os autores dedicados ao tema dos investimentos, o aporte de recursos não é apenas uma transferência financeira entre dois agentes, o aplicador e o tomador. Esta transação é, na realidade, mediada por um conjunto de ferramentas jurídicas, também tratadas, neste capítulo, como dispositivos regulatórios e mecanismos de governança. Enquanto os dispositivos constituem-se de regras prescritivas, que incidem sobre a operação financeira, os mecanismos referem-se aos ajustes privados de alocação de direitos, que são firmados entre os respectivos atores. Ambos têm em comum a tarefa de organizar os termos desta relação de transferência de recursos. Cumprem o papel de garantir os interesses do financiador, ante a problemas eventualmente ocasionados pelas condutas dos empreendedores. Da mesma forma, também oferecem um horizonte de previsibilidade para os administradores, no caso de comportamentos indevidos dos investidores. Portanto, a transação financeira é organizada pelo ambiente institucional, notadamente pelas ferramentas dos direitos societário e contratual.

No entanto, tomadas apenas nessa perspectiva, as ferramentas jurídicas parecem externas aos agentes e às suas transações, como se fossem meros instrumentos de intervenção, desvinculados do entorno social e das particularidades institucionais de cada regime econômico. Tratadas desta maneira fria, as ferramentas jurídicas são encaradas como meras peças técnicas, comprometidas tão somente com a geração do máximo retorno possível, naqueles negócios sujeitos à sua guarida. Conseqüentemente, a prevalecer esse 
entendimento, não haveria o porquê de se supor a possibilidade de soluções institucionais variadas para uma mesma finalidade, como as transações financeiras. Em alguma medida, este é o problema de análises que procuram tematizar a relação entre o direito e o financiamento, ignorando o substrato social sobre o qual o ambiente econômico é forjado. É disso que se trata quando a Law and Finance, embora reconhecendo a relevância dos atributos jurídico-institucionais, faz tábula rasa das possíveis diferenças existentes entre os distintos regimes de organização social e econômica.

Não é nova a crítica da sociologia econômica a este tipo de argumento, legado de uma longa tradição do pensamento econômico, que aponta para uma espécie de seleção natural no campo das instituições. De acordo com essa compreensão, que em boa medida tem embalado a chamada Análise Econômica do Direito ${ }^{83}$, o primado da eficiência se encarregaria de selecionar aquelas ferramentas jurídicas provedoras de retornos econômicos satisfatórios, descartando todas as demais, portadoras de soluções supostamente menos adequadas para os interesses dos agentes racionais e maximizadores. A esse entendimento, a sociologia econômica oferece um contra-ponto teórico, enfatizando que as instituições, como o próprio direito, não são externas ao ambiente social. Os aparatos reguladores e os mecanismos de governança, assim como os demais dispositivos de coordenação econômica, são construídos socialmente, ${ }^{84}$ razão pela qual, a sua constituição não se vincula, apenas, à persecução da eficiência. Antes de mais nada, lembraria POLANYI ${ }^{85}$, tais dispositivos estão incrustrados no tecido social.

Com base neste pressuposto conceitual, não parece consistente admitir que exista uma fórmula única e correta de se regular as relações em sociedade, como se houvesse um

${ }^{83}$ Sobre a Análise Econômica do Direito e algumas de suas distinções internas como disciplina teórica, ver ROEMER, Andrés. Introducción al Análisis Económica del Derecho, México, D.F., Fondo de Cultura, 1994. ${ }^{84}$ A sociologia econômica voltou a ganhar notoriedade desde meados dos anos 1980, com autores como Mark GRANOVETTER. Para uma boa reconstrução de seus argumentos ver GRANOVETTER, Mark. Economic Action and Social Structure: The Problem of Embeddedness, v. 91, no. 3, The American Journal of Sociology, 1985. Para uma revisão da sociologia econômica, ver GRANOVETTER, Mark \& SWEDBERG, Richard. The Sociology of Economic Life, $2^{\mathrm{a}}$ ed., Colorado, Westview Press, 2001; SWEDBERG, Richard \& SMELSER, Neil. Introducing Economic Sociology, em SWEDBERG, Richard \& SMELSER, Neil (Editors), The Handbook of Economic Sociology, $2^{\text {a }}$ ed, New York, Princeton University Press, 2005. SWEDBERG, Richard. Max Weber e a Idéia de Sociologia Econômica, Trad. Dinah Abreu Azevedo, Rio de Janeiro, UFRJ, 2005 e STEINER, Philippe. Sociologia Econômica, (trad. Maria Helena Trylinski), São Paulo, Atlas, 2006.

${ }^{85}$ A esse respeito ver POLANYI, Karl. La Economia como Actividad Institucionalizada, em POLANYI, Karl. Comercio y Mercado en los Imperios Antiguos, Trad. Alberto Nicolás, $1^{\text {a }}$ ed., Barcelona, Labor Universitaria, 1976, pp. 289-315; e também POLANYI, Karl. A Grande Transformação - as origens da nossa época, Trad. Fanny Wrobel, $2^{a}$ ed., Rio de Janeiro, Campus, 2000, pp. 62-75. 
darwinismo institucional. Ao contrário disso, lembra Ha-Joon $\mathrm{CHANG}^{86}$, nesse campo, o darwinismo cede espaço para as proposições lamarckistas: como as políticas e as instituições são construções sociais, e não biológicas, e são ainda embasadas em laços e identidades culturais, as qualidades adquiridas por uma geração são transmitidas para as demais. Trata-se do que a literatura denomina de dependência da trajetória institucional (path dependence), ou seja, as escolhas e os caminhos passados condicionam a formação das estruturas institucionais futuras. É a partir daí que se pode entender a noção de alternativas institucionais.

Refletindo a tensão entre a trajetória passada, a busca de novas soluções (path shaping) e a acomodação dos grupos de interesse, é que os países definem os seus arranjos jurídico-institucionais ${ }^{87}$. Este é o caso da relação entre direito e financiamento: os países têm conformado três básicos modelos de organização: (i) baseado no mercado de capitais; (ii) baseado nos bancos privados e (iii) baseado nos bancos públicos. É, isto sim, dentro de cada um desses regimes, configurados nos respectivos ambientes sociais, que ganham vida as correspondentes ferramentas jurídicas (aparatos reguladores e os mecanismos de governança), responsáveis por disciplinar, em cada ambiente, o financiamento corporativo, garantindo assim os recursos para as atividades empresariais, seja na forma de dívida, seja por meio da participação societária.

Portanto, tão ou mais relevante do que entender as razões pelas quais o financiamento passa a ser um tema de preocupação no direito, é compreender os meios como esse tema pode ser abordado. Ao se ampliar a agenda da Law and Finance, a expectativa é de se ganhar em riqueza conceitual e capacidade analítica: o reconhecimento da existência de alternativas de organização financeira, abre espaço para se compreender, por exemplo, o banco público de desenvolvimento - um elemento característico do modelo brasileito de financiamento - não como uma distorção, mas como uma circunstância social e histórica.

${ }^{86}$ Essa metáfora é apresentada em CHANG, Ha-Joon. The Political Economy of Industrial Policy, New York, St Martin's Press, 1994.

${ }^{87} \mathrm{O}$ grau de liberdade, no entanto, não é absoluto. As soluções nacionais despertam influência umas sobre as outras e refletem também os constrangimentos dos grupos de pressão internacionais. O saldo desta composição é o que Roberto Mangabeira UNGER denomina de bricolagem institucional: as soluções são nacionalmente construídas e forjam alternativas, que seguem, por sua vez, algum padrão de regularidade. UNGER, Roberto Mangabeira. Uma Nova Faculdade de Direito no Brasil, disponível em www.law.harvard.edu/unger/portuguese/docs/projetos6.doc, acesso em 22.09.08, pp. 1-29. 
Com esse repertório, de agora em diante, a tese apresenta três momentos chave: (i) a caracterização da alternativa brasileira; (ii) a dinâmica imposta a essa alternativa com a consolidação de uma economia baseada no conhecimento e (iii) as formas de acomodação desta alternativa à esta nova economia, o que será parametrizado pelo tipo de suas ferramentas, utilizadas para regular a relação entre o Banco e as empresas emergentes e inovadoras. 


\section{$-2-$ \\ A ALTERNATIVA DE FINANCIAMENTO DO \\ DESENVOLVIMENTO BRASILEIRO: \\ UM ARRANJO JURÍDICO-INSTITUCIONAL BASEADO NA INTERVENÇÃO DIRETA DO ESTADO \\ NA MOBILIZAÇÃO FINANCEIRA E NO DIRECIONAMENTO DO CRÉDITO}

\section{INTRODUÇÃO}

Para além dos modelos de organização econômica e financeira constituídos pelos países desenvolvidos, as nações em desenvolvimento também forjaram os seus próprios arranjos jurídico-institucionais, com os quais deram consecução aos seus planos de industrialização e crescimento econômico. Notadamente, entre o segundo pós-guerra e o início dos anos 1980, os países do sudeste asiático e da América Latina estabeleceram um ambiente institucional adequado aos objetivos de suas estratégias de desenvolvimento, definindo assim um terceiro formato de regime econômico.

Ao lado dos tipos economias liberais e economias coordenadas, identificados por HALL \& SOSKICE ${ }^{88}$, os países em desenvolvimento conformaram uma ordem econômica singular, marcada pela prevalência do Estado no processo econômico. Em países como a Coréia do Sul e o Brasil, por exemplo, os investimentos industriais, a alocação de recursos financeiros e as estratégias de formação do parque produtivo, entre outros, têm contado, desde meados dos anos 1950, com uma expressiva intervenção do Estado, responsável por uma sucessão de papéis na esfera econômica, desde a regulação dos mercados até a criação de empresas e o controle de diversos segmentos empresariais.

Particularmente no setor financeiro, esta forma de organização do processo econômico caracteriza-se pela ampla presença do Estado que, além de disciplinar os agentes privados, atua diretamente na mobilização das poupanças privadas e no direcionamento dos recursos públicos. Nessa medida, a intervenção estatal vai além de constituir uma infra-estrutura jurídica, disciplinando os mecanismos de proteção dos investidores e de mitigação dos problemas de agência, existentes entre financiadores e administradores. Ao reconhecerem que nesses países os mercados privados de capitais e de

${ }^{88}$ Cf. HALL, Peter \& SOSKICE, David. Varieties of Capitalism, op. cit., pp. 1-68. 
créditos apresentam falhas ainda mais agudas, mostrando-se insuficientes para sustentar os respectivos planos de desenvolvimento, os formuladores de política pública deram consecução a um estilo de organização financeira que conta com o Estado como o seu principal articulador.

Em comparação com os demais estilos de organização econômica, pode-se assumir que o modelo Estado-centrado conta ainda mais com mecanismos coletivos, na constituição de seu sistema de governança financeira. Nessa medida, as economias em desenvolvimento estendem o viés de coordenação presente em regimes como o alemão e o japonês. Como visto no capítulo anterior, no paradigma nipo-germânico, a composição dos interesses conta com dispositivos coletivos de salvaguarda dos investidores e dos demais interessados na vida societária. Diferentemente do que se passa no panorama norteamericano, em que prevalece um padrão individualista de proteção dos investidores, as economias coordenadas de mercado confiam o funcionamento de seu regime de financiamento às barganhas coletivas e à estipulação de laços econômicos entre os grupos financeiros e industriais. Já no caso das economias em desenvolvimento, os mecanismos coletivos de organização financeira são ainda mais pronunciados: é o próprio Estado e os correspondentes recursos fiscais que conformam uma boa parte do sistema financeiro.

Com isso, se as economias liberais de mercado são baseadas no mercado de capitais e na atuação financeira dos indivíduos e se as economias coordenadas sustentamse na primazia dos bancos e na concentração da propriedade acionária, as economias em desenvolvimento contam com os instrumentos estatais de aglutinação e de alocação dos recursos. Um destes instrumentos é o Banco de Desenvolvimento, um tipo de agente financeiro, via de regra constituído pelos governos, e que é dedicado ao financiamento de longo prazo dos setores público e privado, em países subdesenvolvidos.

O objetivo deste capítulo é apresentar este terceiro tipo de governança financeira, que é constitutivo, em particular, do modelo brasileiro de organização econômica. Assim como verificado em outros países em desenvolvimento, como o México, a Indonésia ou Taiwan, no caso brasileiro a ausência do investidor privado foi compensada com a ação direta do Estado, que, em 1952, instituiu o Banco Nacional de Desenvolvimento Econômico - BNDE. Ao longo da trajetória desenvolvimentista do país, o BNDE foi o principal provedor de recursos para os empreendimentos industriais. 
Para cumprir o seu propósito, este capítulo está dividido em três seções: (i) na primeira delas, procurar-se-á caracterizar esta alternativa financeira baseada no Estado, localizando-a como um fenômeno típico dos países subdesenvolvidos; (ii) a segunda parte do capítulo buscará apresentar as formas e as razões para a participação do Estado no setor financeiro e procurará discutir os motivos que levaram os formuladores de política pública a apostar na propriedade pública como uma alternativa de organização deste segmento e (iii) a terceira seção narrará em detalhe a trajetória brasileira, destacando a participação do BNDES, em dois principais períodos do capítulo desenvolvimentista - o Plano de Metas e o II PND.

\section{Poupança compulsória, programas de desenvolvimento e o estado como AGENTE FINANCEIRO: A ALTERNATIVA INSTITUCIONAL DOS PAÍSES EM DESENVOLVIMENTO}

Uma das principais características dos países retardatários reside na dificuldade dos segmentos financeiros privados em captar e disponibilizar recursos para os investimentos de longo prazo. Esta carência de capital de terceiros para amparar as decisões de investimento pode limitar a capacidade de crescimento das unidades produtivas, constrangendo assim o horizonte das estratégias nacionais de desenvolvimento. Os países subdesenvolvidos são bons exemplos desta descrição: via de regra, seus mercados de capitais são atrofiados e incapazes de prover às economias um volume satisfatório de financiamento, capaz de estimular um padrão de investimento condizente com as necessidades de seus agentes econômicos. A manifestação desta deficiência é percebida por diversos sintomas, que vão desde as carências de infra-estrutura física até os índices consideráveis de desemprego, passando pela baixa competência tecnológica das fábricas e o baixo valor agregado da pauta de exportações.

Essa assimetria formada pelas necessidades de uma economia industrial, de um lado, e pelas fragilidades do ambiente financeiro, de outro, foi originariamente identificada por Alexander GERSCHENKRON ${ }^{89}$, como sendo um traço característico das nações retardatárias. Em Economic Backwardness in Historical Perspective, o autor volta-se a analisar as especificidades do progresso e do crescimento das nações européias mais atrasadas, tipicamente a Alemanha e alguns países do leste-europeu, como a Rússia e a

${ }^{89}$ Cf. GERSCHENKRON, Alexander. Economic Backwardness in Historical Perspective, op. cit., pp. 5-30. 
Bulgária, no século XIX. Naquele contexto, a nação desenvolvida e que balizava as estratégias e políticas de crescimento dos demais países era a Inglaterra, que já havia realizado a sua revolução industrial e, com isso, ditava a pauta do comércio internacional e a divisão do trabalho: como nação líder, a Inglaterra desfrutava dos benefícios da moderna organização industrial, dispondo de bens com o máximo valor agregado, enquanto os países retardatários procuravam superar os seus próprios entraves institucionais, para assim realizar o seu progresso industrial. Dentre esses entraves, figurava, justamente, a impotência dos sistemas financeiros nacionais, incapazes de prover recursos para as empreitadas de longa maturação, como eram as propostas de industrialização.

Sucede que esta carência de financiamento, característica dos panoramas russo e alemão, não foi igualmente percebida pela Inglaterra, cujo processo de desenvolvimento industrial foi paulatino, ou seja, consentâneo ao florescimento de um mercado financeiro compatível com as necessidades dos novos produtores. Passo a passo e de maneira sistemática, as rendas geradas pela agricultura e pelo comércio foram canalizadas para o financiamento da revolução industrial e para o estabelecimento de um novo padrão de organização econômica, baseado na fábrica e na vida urbana. Tratou-se, portanto, de um movimento industrial relativamente espontâneo, que obedeceu ao ritmo de crescimento da oferta de capital disponível para os novos investimentos. Todavia, assinala GERSCHENKRON $^{90}$, esta mesma compatibilização, entre o estágio de desenvolvimento do sistema financeiro e as necessidades de recursos apresentadas pelo segmento industrial, não pôde ser desfrutada pelas nações atrasadas.

Uma vez que uma nação, ou um grupo de nações, atingiu um patamar econômico superior, como no caso do desenvolvimento industrial inglês, cria-se para todos os demais países a necessidade de se alcançar este mesmo porte econômico - independentemente dos seus entraves institucionais. É como se houvesse uma corrida de alcance à nação líder, que, por estar à frente, dita o ritmo e o estilo da corrida. Aos demais países corredores não é dada a alternativa de não competir ou de fazê-lo em um ritmo que desconsidere o padrão de evolução das outras economias nacionais. Em outros termos, na medida em que a Inglaterra realizou a revolução industrial, a indústria passou a ser o elemento econômico chave daquele período, capaz de estabelecer o padrão das trocas internacionais e das

${ }^{90}$ GERSCHENKRON, Alexander. Economic Backwardness in Historical Perspective, op. cit. 
necessidades nacionais de consumo. Sendo assim, aos países retardatários não resta outra alternativa, a não ser superar os seus obstáculos, como a tibieza do seu sistema financeiro, ${ }^{91}$ para o quê é necessária a constituição de novos aparatos institucionais.

Seguramente, a principal mensagem do ensaio de GERSCHENKRON é a identificação de um quadro de tensão, característico dos países atrasados. Cientes das proeminentes possibilidades associadas ao desenvolvimento econômico, alcançado pelas nações mais ricas, os países retardatários vêem-se, por outro lado, premidos pelas suas próprias deficiências institucionais, que limitam as suas possibilidades de transformação econômica. O desajuste entre as necessidades de capital dos setores industriais nascentes e a parca desenvoltura do sistema financeiro é um exemplo típico deste quadro de tensão, tratado por GERSCHENKRON. É em razão disso que as nações retardatárias procuram soluções institucionais alternativas, capazes de oferecer respostas aos desafios impostos pela tentativa de superação do atraso. Não por acaso, os arranjos confeccionados neste contexto, embora tenham como finalidade o alcance das economias mais ricas, são diferentes daqueles que foram constituídos pelas nações líderes. Isso porque o desafio dos países atrasados, lembra o autor, é encontrar mecanismos institucionais que sejam, a um só tempo, compatíveis com o nível atual de desenvolvimento destas nações, mas também capazes de promover a alavancagem do seu quadro social e econômico:

It is the main proposition of this essay that in a number of important historical instances industrialization process, when launched at length in a backward country, showed considerable differences, as compared with more advanced countries, not only with regard to the speed of the development (the rate of industrial growth) but also with regard to the productive and organizational structures of industry which emerged from those processes. Furthermore, these differences in the speed and character of industrial development were to considerable extent the result of application of institutional instruments for which there was little or no counterpart in an established industrial country. ${ }^{92}$

Como visto no capítulo anterior, a primazia do setor bancário no financiamento corporativo de algumas economias européias, como a alemã, é um exemplo desta busca por meios institucionais alternativos, capazes de garantir respostas satisfatórias às circunstâncias nacionais. Em comparação com a Inglaterra, a Alemanha não contava com um mercado de capitais denso e profundo, capaz de oferecer o volume de recursos

${ }^{91}$ GERSCHENKRON, Alexander. Economic Backwardness in Historical Perspective, op. cit. p. 7.

${ }^{92}$ GERSCHENKRON, Alexander. Economic Backwardness in Historical Perspective, op. cit. 
necessário para um processo nacional de industrialização, em patamares ingleses. $\mathrm{O}$ volume de mobilização privada dos recursos era compatível com o desenvolvimento da economia alemã, de tal modo que a disponibilidade de recursos dos indivíduos não permitia a formação de um mercado financeiro, em iguais proporções ao verificado na nação líder. A solução para este constrangimento financeiro veio com as medidas institucionais de fortalecimento dos bancos privados, que substituíram a transação financeira atomizada no mercado de capitais por uma mobilização e alocação concentrada dos recursos. De certa forma, pode-se dizer que a ausência de um espontâneo florescimento dos mercados financeiros foi compensada com uma deliberada promoção do segmento bancário, notadamente de suas associações com os setores industriais.

No século XX, essas mesmas vicissitudes, associadas ao atraso das economias nacionais, apresentaram-se novamente. Décadas mais tarde do que a Alemanha, as periferias latino-ameriacanas e do sudeste asiático, majoritariamente especializadas na produção agrária até meados da década de 1950, ressentiam-se do mesmo quadro de tensão descrito por GERSCHENKRON ${ }^{93}$, para os retardatários europeus. Na metade do século passado, o desenvolvimento das nações periféricas no novo mundo passava pela sua capacidade de constituir um parque produtivo com características semelhantes às dos países desenvolvidos. Todavia, tal como percebido nos desdobramentos do século XIX, os países periféricos do século XX também padeciam da sua própria condição econômica retardatária, envolvendo-se em uma espécie de ciclo vicioso que só confirmava a sua condição subdesenvolvida: no médio prazo, a vocação agrária, em um mundo bastante industrializado, impunha a esses países uma troca comercial internacional desigual, estabelecida entre as suas demandas por produtos com alto valor agregado e as suas possibilidades de oferta, assentadas em produtos primários $^{94}$. Este ciclo vicioso, que só reforçava a desigualdade entre as nações industrializadas e agrárias, só seria superado, no entendimento dos formuladores de política pública, com a industrialização destes países, ou seja, com o alcance do mesmo patamar de desenvolvimento industrial apresentado pelos

93 GERSCHENKRON, Alexander. Economic Backwardness in Historical Perspective, op. cit

94 Esta é a conhecida tese da deterioração dos termos de troca desenvolvida pelos economistas da CEPAL (Comissão Econômica para America Latina), que foi o celeiro dos estudos e proposições de estratégias de superação do subdesenvolvimento latino-americano. Essa tese foi originariamente apresentada pelo primeiro secretário executivo da CEPAL, o economista argentino Raul PREBISCH. A esse respeito ver PREBISCH, Raul. O Desenvolvimento Econômico da América Latina e Alguns de seus Problemas Principais, em BIELSCHOWSKY, Ricardo (org). Cinqüenta Anos de Pensamento na CEPAL, (Trad. Vera Ribeiro), Rio de Janeiro, Record, 2000, pp. 69-136. 
países já desenvolvidos. Mas é justamente neste momento que se configurava o quadro de tensão institucional constitutivo dos países subdesenvolvidos: as suas necessidades de transformação industrial não encontravam respaldo na capacidade do ambiente financeiro.

Ocorre, por sua vez, que a situação econômica das periferias no século XX era ainda mais desfavorável do que a verificada pelos países europeus, no período anterior. $\mathrm{Na}$ realidade, a defasagem entre o seu estágio de desenvolvimento e o patamar em que já se encontravam as nações do centro é que era ainda mais acentuada - o progresso industrial na metade do século XX atingira um patamar de sofisticação superior ao do século XIX, com o qual se deparara a Alemanha. Essa circunstância reclamava uma criatividade institucional ainda mais aguçada do que a manifestada pelas primeiras economias atrasadas. De um lado, o processo de catch up tenderia a ser ainda mais intenso e, de outro, as possibilidades da organização financeira mostravam-se menos propensas a suprir às necessidades de capital. Com isso, a alternativa alemã de substituir as carências do mercado de capitais pela participação das instituições financeiras privadas não se mostrava satisfatória para muitos desses países periféricos, seja na América Latina, seja na Ásia. Nestas localidades, o quadro de tensão institucional demandou a constituição de novas alternativas, aptas a sustentar as profundas transformações econômicas que estes países pretendiam imprimir.

Foi este o caso, por exemplo, do padrão brasileiro de desenvolvimento. A insuficiência de seu sistema financeiro privado constituiu-se em um entrave para a consecução de uma trajetória bem sucedida de desenvolvimento. O seu desenvolvimento social e econômico parece ter sido, por vezes, truncado, em razão de uma falha na sua herança evolutiva, notadamente no seu sistema circulatório ${ }^{95}$ : uma menor possibilidade de gerar recursos financeiros para alavancar os empreendimentos capitalistas. O mercado de capitais nunca teve porte suficiente para garantir um suprimento financeiro regular e expressivo para as atividades econômicas; já o sistema bancário, por sua vez, especializouse nas operações de curto prazo e, diferentemente do que ocorreu nos países retardatários da Europa, não cumpriu o papel de emprestador das operações de longo prazo, que

\footnotetext{
95 A metáfora é utilizada por Francisco de OLIVEIRA para descrever o que chama de uma evolução truncada do Brasil, que embora industrializado, ainda padece de problemas de financiamento (problemas circulatórios). Por isso, o Brasil pareceria com um ornitorrinco - um mamífero que, no entanto, bota ovo e tem bico de pato. Ver OLIVEIRA, Francisco. O Ornitorrinco, em OLIVEIRA, Francisco. Crítica da Razão Dualista - O Ornitorrinco, São Paulo, Boitempo, 2003, pp. 125-150.
} 
caracterizam boa parte dos investimentos industriais, intensos em capital e escala. ${ }^{96}$ Uma situação semelhante foi vivenciada também pela Coréia do Sul e pelos demais países da região, como Taiwan. ${ }^{97}$

A resposta a essas intensas falhas dos mercados de capitais e de créditos dos países subdesenvolvidos contou com uma participação direta e intensa dos Estados nacionais. Assentados no diagnóstico de que estas economias contavam com deficiências financeiras mais pronunciadas do que as verificadas nos demais episódios de desenvolvimento industrial, os formuladores de políticas públicas compreenderam que a mera garantia de segurança jurídica não seria suficiente para a consolidação de um sistema financeiro sólido. Tampouco a adoção de medidas institucionais de favorecimento do setor bancário, como a permissão de participações cruzadas em empresas e a sua exclusão do regime de concorrência, foram entendidas como condições suficientes para assegurar um volume de recursos compatível com as estratégias de industrialização. Casualmente, asiáticos e latinos compuseram, de forma semelhante, uma terceira alternativa de organização financeira, em que o Estado supriu diretamente as ausências do financiador privado.

Concomitantemente às políticas desenvolvimentistas desses países, foram criados os bancos públicos, e em especial os bancos de desenvolvimento, responsáveis pela geração de recursos financeiros que estimulassem as inversões econômicas e, assim, permitissem a criação dos parques industriais. Na Coréia do Sul, por exemplo, foram constituídos cinco bancos públicos para a alocação de recursos estratégicos para o projeto de transformação social e econômica. Em 1954, foi criado o KDB (Banco de Desenvolvimento da Coréia), responsável pelos aportes de recursos para as indústrias pesadas, tais como cimento, química e automotiva - atendia, assim, aos desideratos contidos nos planos qüinqüenais de desenvolvimento industrial sul-coreano. Em 1961, foi constituído o IBK (Banco Industrial da Coréia), cujas operações voltavam-se para o apoio às pequenas e médias empresas. Ambos os bancos empreenderam, ao longo de sua história,

\footnotetext{
${ }^{96}$ Sobre as restrições do sistema financeiro brasileiro e a relevância da atuação do BNDES na superação desses gargalos, ver MONTEIRO FILHA, Dulce. Aplicação dos Recursos Compulsórios pelo BNDES na Formação da Estrutura Setorial da Indústria - 1952-1989, Mimeo, Tese de Doutorado apresentada ao Instituto de Economia da UFRJ, 1994.

${ }^{97}$ Sobre o desenvolvimento financeiro do sudeste asiático, em particular sobre a importância da participação estatal, ver STIGLITZ, Joseph \& UY, Marilou. Financial Markets, Public Policy, and the East Asian Miracle, World Bank Research Observer, vol. 11, n. 2, 1996.
} 
um conjunto variado de modalidades financeiras, desde a simples concessão de créditos, até a subscrição de valores mobiliários emitidos pelas companhias. Nestas atividades de financiamentos de longo prazo, o KDB e o IBK foram acompanhados por outros três agentes financeiros públicos: (i) o NACF (Federação Cooperativa de Agricultura Nacional), cuja intervenção dirigia-se ao setor agrícola; (ii) o Korea Eximbank, encarregado dos financiamentos para exportação e (iii) o NFFC (Federação Nacional das Cooperativas Pesqueiras), cuja missão vinculava-se a fomentar a indústria da pesca. ${ }^{98}$

Trilhando um caminho parecido, o Brasil também instituiu um segmento bancário público, responsável pelo aporte de capital necessário à consolidação de uma economia industrial e urbana. Assim foi que, em 1952, o Governo Federal instituiu o BNDE - Banco Nacional de Desenvolvimento Econômico, que fez as vezes de principal fonte do capital de longo prazo para aqueles empreendimentos que, apesar de se mostrarem relevantes e lucrativos, apresentavam um longo período de maturação para o retorno dos recursos investidos. O sistema financeiro brasileiro contou também com outras entidades públicas, igualmente responsáveis pela provisão de recursos dotados de relevância social, mas que muitas vezes não atraíam o interesse dos agentes financeiros. Como será descrito na última seção deste capítulo, a atuação do BNDE se fez acompanhar da do Banco do Brasil, no financiamento agrícola, da do BNH (Banco Nacional de Habitação) e da CEF (Caixa Econômica Federal), na provisão de créditos para o setor imobiliário e de construção civil. Afora os bancos estaduais, que garantiram recursos para os investimentos no âmbito dos Estados da federação.

Os casos brasileiro e sul-coreano, em que o Estado instituiu bancos estatais e agências de fomento para contornar as insuficiências do sistema financeiro privado, são, na realidade, apenas dois exemplos de um verdadeiro paradigma de organização institucional, adotado por boa parte dos países subdesenvolvidos, na metade final do século XX. Como lembram YEYATI, MICCO \& PANIZZA ${ }^{99}$, os economistas do desenvolvimento, como

98 Sobre os bancos públicos e os bancos de desenvolvimento em diversos países, ver NOVAES, Ana. Intermediação Financeira, Bancos Estatais e o Mercado de Capitais: a experiência internacional, em PINHEIRO, Armando Castelar e OLIVEIRA FILHO, Luiz Chrysostomo (org.). Mercado de Capitais e Bancos Públicos - análise e experiências comparadas, Rio de Janeiro, São Paulo, Contra Capa, ANBID, 2007, pp. 35-132.

99 YEYATI, Eduardo Levy; MICCO, Alejandro \& PANIZZA, Ugo. Should the Government be in the Banking Sector? The Role of State-Owned and Development Banks, paper apresentado no seminário Governments and Banks: Responsibilities and Limits, Inter-American Development Bank (IDB), Lima, Peru, 
Arthur LEWIS, Alexander GERSCHENKRON e Gunnar MYRDAL, assinalavam no campo teórico aquilo que muitos governos empreenderam no âmbito de suas políticas públicas: o Estado deveria cumprir um papel preponderante no setor bancário. Foi de fato o que ocorreu entre o fim do segundo pós-guerra e o início dos anos 1980, período em que se desdobrou um considerável contingente de programas de desenvolvimento: basta ver que nessa época os Estados, nos países em desenvolvimento, detinham cerca de $70 \%$ dos ativos dos maiores bancos nacionais. ${ }^{100}$

De fato, até a onda de privatização e reformas econômicas ocorridas nas décadas de 1980 e 1990, identificadas no próximo capítulo desta tese como eventos associados à crise do paradigma fordista-desenvolvimentista, os países periféricos basearam parte significativa de suas operações financeiras nos bancos públicos. Um levantamento apresentado por YEYATI, MICCO \& PANIZZA ${ }^{101}$, revela que, até os anos 1990, no sudeste asiático e no oriente médio, o Estado apresentava uma participação superior a $60 \%$ no setor bancário. Na América Latina, até a realização das desestatizações, a participação pública neste setor também era elevada e remontava a $64 \%$, contando com casos bem acima desta média, como o mexicano, cuja propriedade pública no segmento bancário situava-se em torno de $82 \%$ dos ativos totais. Não deixa de ser expressivo que somente esta fração do continente americano, ainda em 2004, respondia por 152 dos 550 bancos de desenvolvimento existentes no mundo. ${ }^{102}$

Esses dados, relativos ao último período do século $\mathrm{XX}$, confirmam, portanto, aquilo que GERSCHENKRON ${ }^{103}$ já havia assinalado para o caso da Rússia, em uma comparação com o desenvolvimento da Alemanha: a sua posição ainda mais desfavorável reclamava um arranjo institucional próprio, capaz de suprir a ausência do mercado de capitais e também as carências do sistema bancário. Vem daí a configuração de uma terceira alternativa institucional de organização financeira, afinada com os países de menor desenvolvimento econômico: a participação direta do Estado, que desempenha um papel de

2004, diponível em http://www.bid.org.uy/res/publications/pubfiles/pubWP-517.pdf, acesso em 14.12.2008, pp. 5-47.

${ }_{100}$ YEYATI, Eduardo Levy; MICCO, Alejandro \& PANIZZA, Ugo. Should the Government be in the Banking Sector?, op. cit.

101 YEYATI, Eduardo Levy; MICCO, Alejandro \& PANIZZA, Ugo. Should the Government be in the Banking Sector?, op. cit.

${ }^{102}$ Dados apresentados em YEYATI, Eduardo Levy; MICCO, Alejandro \& PANIZZA, Ugo. Should the Government be in the Banking Sector?, op. cit.

${ }^{103}$ GERSCHENKRON, Alexander. Economic Backwardness in Historical Perspective, op. cit. 
agente financeiro. Uma visão panorâmica do sistema bancário de alguns países confirma que a prevalência desta alternativa financeira é um traço característico dos países em desenvolvimento: a tabela abaixo apresenta uma comparação da participação dos bancos estatais no total do setor bancário, para os países latino-americanos, asiáticos e desenvolvidos. É notável que, enquanto nos Estados Unidos e na Inglaterra essa participação inexiste, na Índia, atinge $70 \%$ e no Brasil, $42 \%$.

\begin{tabular}{|c|c|}
\hline \multicolumn{2}{|c|}{ QUADRO 4} \\
\hline PARTICIPAÇãO DOS Bancos ESTATAIS NO TOTAL DE ATIVOS BANCÁRIOS (\%) - 2004 \\
\hline Países da América Latina & 38,3 \\
\hline Argentina & 42,2 \\
\hline Brasil & 18,0 \\
\hline Chile & 18,2 \\
\hline México & \\
\hline Países da Ásia & 49,9 \\
\hline Indonésia & 34,4 \\
\hline Coréia do Sul & 16,4 \\
\hline Tailândia & 70,5 \\
\hline Índia & \\
\hline Países Desenvolvidos & 17,9 \\
\hline Alemanha & 4,8 \\
\hline França & 11,7 \\
\hline Suíça & 8,6 \\
\hline Japão & 0,0 \\
\hline Reino Unido & 0,0 \\
\hline Estados Unidos & \\
\hline Elaboração própria, a partir de NOVAES (2007) &
\end{tabular}

No âmbito da literatura empregada nesse trabalho, a primazia do Estado na organização financeira dos países subdesenvolvidos pode ser tratada conceitualmente como um terceiro tipo de alternativa institucional. Para além dos tipos economias liberais e economias coordenadas, identificadas por HALL \& SOSKICE $^{104}$, e também por PISTOR $^{105}$, o modelo de desenvolvimento das periferias do século XX sugere se tratar de um outro paradigma de organização financeira - a coordenação pública da economia de mercado. Em comparação com as economias coordenadas, em que a organização do financiamento corporativo assenta-se em mecanismos relacionais de governança e na restrição da plena autonomia privada (ver quadro 1), a coordenação pública da economia de mercado parece confiar em uma coletivização das questões financeiras em escala ainda maior. O papel do Estado, que nas economias coordenadas já superava as funções que lhe

${ }^{104}$ Cf. HALL, Peter \& SOSKICE, David. Varieties of Capitalism, op. cit.

105 PISTOR, Katharina. Legal Ground Rules in Coordinated and Liberal Market Economies, op. cit. 
são atribuídas nas economias liberais, ganha ainda mais relevância nos países em desenvolvimento. Para além da provisão das ferramentas de proteção dos investidores, desempenhada nas economias baseadas no mercado e da adoção de medidas indutoras do comportamento privado ou de regras que garantem a ampla participação societária, verificadas nas economias coordenadas, nas economias de coordenação pública, o Estado figura como um verdadeiro demiurgo no processo financeiro.

A base da organização financeira, neste terceiro tipo de alternativa jurídicoinstitucional, conta, de um lado, com a mobilização pública da poupança e, de outro, com o controle estatal da alocação dos recursos. Em outras palavras, cabe aos agentes estatais captar diretamente os recursos financeiros junto ao público, para assim constituir um montante propício, a ser destinado aos planos de desenvolvimento industrial. Essa atribuição pública não encontra paralelo nem nas economias baseadas no mercado de capitais, nem nas economias baseadas nos bancos. Nas economias liberais, os recursos financeiros provêm, normalmente, das poupanças privadas, que espontaneamente migram para o financiamento corporativo, como um resultado das iniciativas individuais de aplicação financeira. Já no caso das economias coordenadas, são as instituições financeiras bancárias que respondem por essa intermediação, desde o depósito das poupanças privadas até o seu direcionamento para os projetos de longo prazo. Nas economias baseadas nos bancos públicos, no entanto, a formação dessa base de poupança mostra-se insatisfatória, em muitos casos, de tal forma que a superação desse embaraço conta com uma formação compulsória da poupança, por meio da intervenção do Estado.

A mobilização da poupança é comumente estabelecida com a instituição de tributos, cuja arrecadação garante a formação de disponibilidades financeiras, superando assim a carência de recursos privados. Para Paulo MENDONÇA ${ }^{106}$, nesses países a intervenção pública interfere na decisão voluntaria de poupar: pela via da tributação, os recursos individuais são canalizados para a formação de uma renda pública e assim sustentam os investimentos de longo prazo. A criação do BNDES é exemplificativa dessa formação compulsória de poupança: desde a sua instituição, o Banco tem contado com recursos captados pela capacidade fiscal do Estado. Em 1951, por exemplo, a lei no 1474

\footnotetext{
${ }^{106}$ MENDONÇA, Paulo Augusto Furtado. A Intervenção do Estado Brasileiro no Setor Financeiro: estudo sobre o Banco Nacional de Desenvolvimento Econômico e Social, Dissertação de Mestrado apresentada na Faculdade de Direito da USP, São Paulo, 2005, pp. 62-87.
} 
instituiu o Fundo de Reaparelhamento Econômico, formado pela cobrança de um valor adicional ao imposto de renda e em 1952, a lei $n^{\circ}$. 1628 transferiu ao BNDES a gestão desses recursos, que constituíram a base financeira inicial do Banco. Recentemente, com a Constituição de 1988, o BNDES passou a administrar 40\% dos recursos destinados ao Fundo de Amparo ao Trabalhador, que foi instituído pela lei $\mathrm{n}^{\circ}$. 7998, de 11 de janeiro de 1990 - um fundo com natureza fiscal. ${ }^{107}$

Como será tratado com detalhe a seguir, os recursos mobilizados de forma compulsória pelo Estado são também alocados de acordo com os critérios dos agentes públicos. Isso significa que, nesta alternativa institucional, a intervenção estatal não só altera as condições espontâneas de poupança, como também modifica o destino da alocação financeira, alterando ambas as fases subseqüentes do processo de financiamento: a seleção e a execução dos projetos. ${ }^{108}$ Para STIGLITZ $^{109}$, a seleção e a execução são etapas do financiamento de que se encarregam os agentes financeiros, uma vez encerrada a captação dos recursos. Na seleção, os agentes costumam escolher aqueles projetos corporativos que apresentem maior potencial de rentabilidade e menor risco, atributos estes que para serem alcançados dependem também do monitoramento, realizado pelos investidores durante a fase de execução. Ocorre, por sua vez, que nos sistemas baseados nos bancos estatais o critério de seleção e a forma da execução das operações financeiras assumem racionalidades distintas daquelas apresentadas pelos agentes financeiros privados. Os agentes estatais internalizam nos critérios de decisão a intenção de se promover o desenvolvimento nacional. Dessa forma, as considerações de risco e de retorno, habitualmente empregadas pelos agentes financeiros, são ladeadas pela verificação do mérito das operações financiadas, isto é, pela sua capacidade de gerar externalidades positivas para os planos nacionais de desenvolvimento. ${ }^{110}$ Essa forma de atuação está associada, por sua vez, à existência da propriedade estatal no sistema financeiro, que, como

107 Cf. CURRALERO, Claudia Regina Baddini. A Atuação do Sistema BNDES como Instituição Financeira de Fomento no Período 1952-1996, Dissertação de Mestrado apresentada no Instituto de Economia da UNICAMP, 1998, pp. 45-84. Ver também MENDONÇA, Paulo Augusto Furtado. A Intervenção do Estado Brasileiro no Setor Financeiro, op. cit.

108 Para MONTEIRO FILHA: "a intervenção estatal no financiamento do investimento altera os processos de seleção, execução e incentivos. Passa a ser possível o rompimento dos limites ao endividamento das empresas. Com a vinculação dos investimentos à política governamental estabelece-se assim outros critérios de seleção". Cf. MONTEIRO FILHA, Dulce. Aplicação dos Recursos Compulsórios pelo BNDES na Formação da Estrutura Setorial da Indústria - 1952-1989, op. cit. p. 31.

${ }^{109}$ STLIGTZ, Joseph. Government, Financial Markets, and Economic Development, op. cit.

110 Sobre os critérios de decisão do BNDES, ver CURRALERO, Claudia Regina Baddini. A Atuação do Sistema BNDES como Instituição Financeira de Fomento no Período 1952-1996, op. cit. pp. 11-44. 
será visto adiante, permite articular os retornos econômicos individuais aos benefícios sociais.

Para além do sistema financeiro, a coordenação pública da economia de mercado conta também com agentes públicos no setor produtivo, perfazendo assim um setor produtivo estatal, composto por empresas públicas e sociedades de economia mista, sob controle do Estado. Estas figuras jurídicas, cuja descrição escapa dos propósitos deste trabalho, são previstas pelos ordenamentos jurídicos nacionais, incumbidas da execução daquelas atividades empresariais que são dotadas de uma intensidade de recursos e de um longo prazo de maturação dos investimentos, costumeiramente não suportados pelos respectivos atores privados. Nos países em desenvolvimento, os setores de infra-estrutura, por exemplo, além do financiamento estatal, têm se valido tradicionalmente da propriedade empresarial pública. Um exemplo disso é a organização deste segmento no Brasil, onde os investimentos em telecomunicações, energia elétrica, gás e petróleo foram todos executados pelas empresas estatais que, entre 1950 e 1980, proveram a base material para boa parte dos demais investimentos industriais. ${ }^{111}$

Sendo assim, aos dispositivos individualistas das economias liberais, voltados a oferecer uma proteção procedimental e substantiva ao acionista atomizado, e aos dispositivos coletivos e relacionais das economias coordenadas, o estudo das alternativas de organização dos países em desenvolvimento agrega um terceiro tipo de arsenal jurídicoinstitucional: a propriedade estatal. É principalmente a partir dos bancos públicos que estes países têm estabelecido o funcionamento de seu padrão de governança financeira. No lugar das poupanças individuais, das ferramentas jurídicas de proteção dos investidores e da alocação privada dos recursos, balizada em critérios de rentabilidade, os entraves sócioeconômicos das nações mais pobres têm reclamado um arranjo jurídico-institucional alternativo, no qual prevalecem a poupança compulsória, os bancos estatais e a adoção de

111 As funções do setor produtivo estatal são bem descritas por Luciano COUTINHO e Henri-Philippe REICHSTUL, para quem as funções do Estado nos países periféricos, na fase de industrialização, precisava ser mais pronunciada, para suprir a carência de capital privado: "portanto, no capitalismo retardatário o Estado não pode limitar-se às funções clássicas de administração fiscal e monetária: as condições objetivas do desenvolvimento the impõem a tarefa de criar e acumular capital produtivo, centralizar e intermediar o capital financeiro além de supervisionar, ordenadamente, a constituição da base pesada do sistema industrial." Ver a respeito COUTINHO, Luciano \& REICHSTUL, Henri-Philippe. O Setor Produtivo Estatal e o Ciclo, em MARTINS, Carlos Estevam. Estado e Capitalismo no Brasil (org.). São Paulo, Hucitec CEBRAP, 1977, p. 59. 
parâmetros financeiros menos estreitos - capazes de contemplar as metas desenvolvimentistas estipuladas pelos planos governamentais.

\section{Formas e razões para a PARTICIPAÇÃo do ESTAdo No SETOR baNCÁrio: A REGULAÇÃO INSTITUCIONAL DO SISTEMA FINANCEIRO}

A descrição da alternativa institucional dos países em desenvolvimento indica que a coordenação pública da economia de mercado é, de fato, o seu traço característico. A questão que se pode suscitar daí em diante é o motivo desta coordenação ser realizado, predominantemente, pela propriedade pública no âmbito do sistema financeiro. A literatura de direito e economia reconhece, já há algum tempo, que os mercados apresentam falhas, que justificam a intervenção estatal, com o fito de corrigir os problemas localizados nas trocas entre os particulares. Com o mercado financeiro não é diferente, em suas transações também são verificados problemas como a assimetria de informações, a concentração do poder econômico e as externalidades, tal como igualmente percebido nos demais setores da economia. Para essas falhas de mercado, costuma-se recomendar um rol diversificado de medidas reguladoras, tais como a obrigação de revelação das informações (disclosure), o controle das concentrações no mercado (direito antitruste), a estipulação de preços, para mitigar as externalidades (princípio do poluidor pagador) e, sobretudo, a estipulação de direitos de propriedade, para assegurar os interesses dos indivíduos. ${ }^{112}$

Mesmo assim, não obstante o repertório de medidas existentes, a superação das falhas dos mercados financeiros em países em desenvolvimento tem contado com um tipo definido de solução jurídico-institucional: a propriedade estatal, também chamada de regulação institucional. Há razões para isso? A resposta a esta questão é controvertida na literatura voltada às análises de direito, instituições e financiamento. De um lado, figuram aqueles que vêem a intervenção estatal como um defeito, uma distorção típica dos países menos desenvolvidos; de outro, há os que entendem essa intervenção como a manifestação de uma trajetória histórica - uma solução institucional compatível com as necessidades e as possibilidades atinentes a determinados modelos de desenvolvimento econômico.

\footnotetext{
112 Sobre as falhas de mercado e as alternativas de regulação, ver BREYER, Stephen. Regulation and its Reform, Harvard, Harvard University Press, 1982.
} 
Representando o primeiro grupo, os autores da Law and Finance têm apresentado análises críticas sobre a opção pela propriedade estatal no segmento bancário. Esses estudos indicam que a prevalência dos bancos estatais acarreta prejuízos econômicos, que superam até mesmo o âmbito financeiro. Não só os bancos públicos são mais ineficientes do que os bancos privados, argumentam os autores, como ainda contribuem para um ambiente econômico com menor desenvolvimento financeiro e com patamares deprimidos de crescimento econômico. Seguindo essa linhagem teórica, a instituição da propriedade pública no sistema financeiro é uma alternativa insatisfatória que, ao procurar remediar a carência de ferramentas jurídicas apropriadas para a proteção dos investidores privados, provoca efeitos colaterais na organização financeira e econômica dos países.

Boa parte dessas conclusões é apresentada no artigo Government Ownership of Banks, elaborado por LA PORTA, LOPEZ-de-SILANES \& SHLEIFER ${ }^{113}$. Tal como nos demais artigos da Law and Finance, os autores realizaram um extenso estudo de comparação entre os sistemas financeiros de 92 países (estudo no formato cross-country), distribuídos em diversos continentes. A proposta da investigação era justamente testar os apontamentos de GERSCHENKRON e dos demais economistas do desenvolvimento, a respeito do papel e da relevância da intervenção direta do Estado no setor financeiro. Para tanto, os autores conduziram a pesquisa balizados pelas seguintes quatro questões: (i) qual a dimensão da participação do Estado no setor bancário?; (ii) em que tipo de países essa participação é mais expressiva?; (iii) os bancos estatais promovem um desenvolvimento financeiro subseqüente, nos respectivos países? e (iv) os bancos estatais promovem crescimento econômico?

Os resultados alcançados pelas comparações de LA PORTA et al. ${ }^{114}$ indicam que, em 1995, época da investigação, a participação estatal era expressiva, correspondendo a cerca de $42 \%$ da composição societária dos dez maiores bancos, situados nos países pesquisados. Conforme o nível de desenvolvimento, no entanto, essa proporção pode ainda ser maior ou menor, assinalam os autores. Os países mais pobres, ou aqueles com sistemas financeiros menos desenvoltos, contam com uma intervenção direta do Estado mais amplificada do que os países ricos, ou aqueles que detêm densos ambientes financeiros.

${ }^{113}$ LA PORTA, Rafael et al. Government Ownership of Banks, Harvard Institute of Economic Research, Discussion Paper n ${ }^{\circ} .1890,2000$, pp. 2-30.

${ }^{114}$ LA PORTA, Rafael et al. Government Ownership of Banks, op. cit. 
Divididos os países pela origem de seus sistemas legais, como é recorrente nas análises da Law and Finance, LA PORTA et al. ${ }^{115}$ assinalam que os países de common law são os que apresentam a menor incidência de participação dos governos no setor bancário, ao passo que nos países herdeiros da tradição de civil law francesa, a presença direta do governo nesse segmento é a mais expressiva. É também nesses países que os bancos de desenvolvimento figuram com mais freqüência. ${ }^{116}$

As razões apresentadas pelos autores para estas diferenças, quanto ao teor da participação estatal, remontam ao argumento central dos estudos com viés Law and Finance: os países de origem francesa, em relação aos países de common law ou mesmo de civil law na tradição germânica, apresentam um ambiente institucional debilitado, contando com uma menor proteção jurídica aos investidores privados. Essas mesmas características, para LA PORTA et al. ${ }^{117}$, estão presentes em todos os demais países em que a participação pública no setor bancário é expressiva. São as economias com maior intervenção estatal (medido pelo teor da regulação pública ou pela freqüência com que ocorrem controles de preço, p. ex.); com um menor índice de "rule of law", com menor proteção aos direitos de propriedade e, finalmente, com expressiva participação de empresas estatais, os ambientes em que prevalece a propriedade pública no setor bancário. Para os autores, a estatização financeira é uma espécie de substituto institucional, na realidade, um arremedo de solução, ante as fragilidades da organização jurídica subjacente aos mercados.

A conclusão da pesquisa aponta para as deficiências deste modelo, sugerindo que a primazia dos bancos estatais não está associada a resultados positivos, nem para o funcionamento do sistema bancário, nem tampouco para o conjunto da economia nacional. Procurando com isso refutar os argumentos desenvolvimentistas de GERSCHENKRON, LA PORTA et al. ${ }^{118}$ sustentam que, entre 1960 e 1995, os países baseados na propriedade pública não registraram eficiência nas atividades do setor bancário e também não galgaram constituir um desenvolvimento financeiro satisfatório: os autores sugerem uma correlação negativa entre a presença de bancos estatais e o incremento do restante do sistema financeiro. Trata-se do efeito conhecido por crowding out, isto é, a intervenção pública ao

\footnotetext{
${ }^{115}$ LA PORTA, Rafael et al. Government Ownership of Banks, op. cit.

${ }^{116}$ Cf. LA PORTA, Rafael et al. Government Ownership of Banks, op. cit.

${ }^{117}$ LA PORTA, Rafael et al. Government Ownership of Banks, op. cit.

${ }^{118}$ LA PORTA, Rafael et al. Government Ownership of Banks, op. cit
} 
competir com o setor privado, limita as possibilidades de florescimento dos mercados de créditos e de capitais. Da mesma forma, as análises estatísticas sugerem, ainda, uma correspondência negativa entre a existência de um setor financeiro público e o crescimento econômico dos países - as economias baseadas em bancos estatais apresentam menores taxas de crescimento.

Com isso, os autores ${ }^{119}$ terminam por apontar uma certa carência de realismo das abordagens desenvolvimentistas, argumentando, amparados em uma auto-intitulada visão política, que a participação do governo, porque baseada em motivos e critérios políticos, leva a uma necessária distorção do funcionamento da economia. Diferentemente do que apostariam os teóricos do desenvolvimento, a politização dos mercados, ao invés de proporcionar resultados positivos para a superação do atraso, acarreta, isto sim, ineficiências, capazes de comprometer o desempenho das economias. É por esta razão que, para a matriz Law and Finance, os arranjos baseados na coordenação pública das economias de mercado são insatisfatórios e apresentam uma performance menos favorável, do que os arranjos baseados na participação privada e na extensa proteção jurídica dos investidores. O ceticismo dessa visão política encontra paralelos na literatura sobre as falhas de governo - um conjunto de avaliações e proposições que balizou o panorama intelectual das reformas de mercado, realizadas nas décadas de 1980 e 1990. Ao assinalar que as falhas da atuação econômica dos Estados são ainda mais relevantes que as falhas do mercado, a concepção das falhas de governo transmite uma desconfiança sobre a capacidade de intervenção do Estado e, não por acaso, balizou as iniciativas de privatização, inclusive daquelas realizadas no setor financeiro - a isso se voltará no final do próximo capítulo deste trabalho.

Todavia, apesar da veemência das conclusões de LA PORTA et al. ${ }^{120}$ e da relativa difusão dos argumentos céticos, como os da visão política e das falhas de governo, não parece ser líquido e certo que os bancos estatais desempenhem necessariamente um papel ineficiente e prejudicial às economias nacionais. É esta a conclusão de analises teóricas e empíricas igualmente voltadas para as relações estabelecidas entre o ambiente jurídico, as instituições e os sistemas financeiros, porém não alinhadas ao paradigma Law and

${ }^{119}$ LA PORTA, Rafael et al. Government Ownership of Banks, op. cit.

${ }^{120}$ LA PORTA, Rafael et al. Government Ownership of Banks, op. cit. 
Finance. Para autores como STALLINGS \& STUDART ${ }^{121}$, por exemplo, que realizaram uma ampla pesquisa sobre o ambiente financeiro latino-americano, a propriedade estatal de bancos não contém uma inexorável fórmula de insucesso.

Trajetórias como as do BNDES, no Brasil, que encontra paralelos na história do $\mathrm{KDB}$, na Coréia do Sul, são, para os autores, exemplos de bancos públicos bem sucedidos e capazes de suprir satisfatoriamente a carência de financiadores privados. Particularmente no caso brasileiro, STALLINGS \& STUDART ${ }^{122}$ destacam que o BNDES tem cumprido uma missão importante na provisão de crédito de longo prazo e, mais recentemente, na oferta de recursos para as pequenas empresas, sem com isso incorrer nos vícios apontados por LA PORTA et al. ${ }^{123}$ Seja no caso do BNDES, seja no do KDB, não há indicações de prevalência da discricionariedade política, de práticas recorrentes de corrupção e gestão fraudulenta ou de prejuízos para o conjunto das economias nacionais. Antes disso, os autores afirmam a relevância da intervenção de tais bancos para a garantia de recursos aos empreendimentos industriais, ante as ausências dos bancos privados e do mercado de capitais, nos respectivos países. ${ }^{124}$ Com isso, não partilham das mesmas recomendações de política costumeiramente apresentadas pelos partidários das falhas de governo e, portanto, não sugerem a privatização do sistema financeiro como uma condição necessária para o desenvolvimento de todos os países latino-americanos - são tolerantes com a propriedade estatal.

Essa mesma percepção é partilhada por YEYATI, MICCO \& PANIZZA ${ }^{125}$, no trabalho Should the Government be in the Banking Sector? The Role of State-Owned and Development Banks. O artigo rejeita as causalidades necessárias presentes nas análises Law and Finance, e discute a imbricação supostamente existente entre a existência da propriedade estatal, a eficiência dos bancos públicos e o atrofiamento do restante do setor financeiro.

${ }^{121}$ STALLINGS, Barbara \& STUDART, Rogério. Finance for Development - Latin America in Comparative Perspective, Economic Comission for Latin America and the Caribbean - UN, Washington, 2006, pp. 222258.

${ }^{122}$ STALLINGS, Barbara \& STUDART, Rogério. Finance for Development, op. cit.

${ }^{123}$ LA PORTA, Rafael et al. Government Ownership of Banks, op. cit.

${ }^{124}$ STALLINGS, Barbara \& STUDART, Rogério. Finance for Development, op. cit.

125 YEYATI, Eduardo Levy; MICCO, Alejandro \& PANIZZA, Ugo. Should the Government be in the Banking Sector?, op. cit. 
Em primeiro lugar, os autores refutam a suposta ineficiência inerente aos bancos estatais. Argumentam, para tanto, que boa parte dos bancos públicos, sobretudo os bancos de desenvolvimento, cumpre propósitos sociais, tais como o financiamento de projetos portadores de menor lucratividade ou a universalização da captação bancária, e, por esta razão, a sua rentabilidade não pode ser comparada com a dos bancos privados. Isto é, uma eventual taxa menor de retorno não pode ser entendida como um parâmetro de ineficiência dos bancos estatais, já que a maximização dos resultados pode não ser o seu único objeto social. Além disso, salientam os autores, a menor lucratividade dos bancos estatais não é uma verdade necessária: casos como o brasileiro e o peruano, cujos bancos públicos apresentam rentabilidade semelhante a dos concorrentes privados, evidenciam que a propriedade estatal pode também resultar em um desempenho financeiro favorável. ${ }^{126}$ Portanto, assinalam, não há uma ineficiência inerente ao setor bancário público, seja porque esse critério de mensuração pode ser estreito demais para avaliar as atividades desenvolvidas pelos agentes estatais, seja porque mesmo cumprindo papéis adicionais aos executados pelos bancos privados, os bancos públicos podem também atingir patamares privados de retorno.

Em segundo lugar, superada a questão da ineficiência inerente, YEYATI, MICCO \& PANIZZA ${ }^{127}$ colocam em dúvida a alegada primazia explicativa da visão política em relação à visão desenvolvimentista: para os autores não há evidências de que a propriedade estatal obstaculize o desenvolvimento financeiro e o crescimento econômico. $\mathrm{O}$ fato de que em países mais pobres, menos desenvolvidos e portadores de um ambiente financeiro frágil, a incidência de bancos estatais é maior não corrobora o ceticismo da visão política e pode, inclusive, estar alinhado com as proposições desenvolvimentistas. Afinal de contas, para essa abordagem, quanto maior o quadro de tensão institucional, mais necessária é a participação do Estado. Na realidade, há nesse debate aquilo que os autores reconhecem como um problema de causalidade: os países são subdesenvolvidos por que contam com a propriedade estatal (visão política) ou contam com esta alternativa por serem subdesenvolvidos (visão desenvolvimentista)? ${ }^{128}$ Para YEYATI, MICCO \& PANIZZA ${ }^{129}$,

\footnotetext{
${ }^{126}$ Sobre o Brasil e o Peru, ver YEYATI, Eduardo Levy; MICCO, Alejandro \& PANIZZA, Ugo. Should the Government be in the Banking Sector?, op. cit.

127 YEYATI, Eduardo Levy; MICCO, Alejandro \& PANIZZA, Ugo. Should the Government be in the Banking Sector?, op. cit.

${ }^{128}$ Para ilustrar a dificuldade em estabelecer esta correlação e dessa forma mitigarem as observações afinadas com a visão política, os autores comparam este tipo de pesquisa com uma hipotética investigação dirigida a
} 
em suma, a causalidade pode ser oposta ao que supõem os autores da Law and Finance, de tal forma que são os países menos desenvolvidos e com menor progresso financeiro que demandam soluções institucionais alternativas, como é o caso da propriedade pública.

Admitindo que essa causalidade figure nos termos propostos pelos autores afinados com a visão desenvolvimentista e retomando a discussão proposta no início desta seção, resta compreender o que justificaria a intervenção estatal nos mercados financeiros e qual o propósito da propriedade pública? Em outros termos, se de fato a incidência de bancos estatais é um reflexo e não uma causa do subdesenvolvimento das nações, cumpre entender, então, a razão desta atuação direta do Estado nos mercados financeiros de países em desenvolvimento. Afinal de contas, poder-se-ia imaginar que as eventuais falhas de mercado, que impedem o seu pleno funcionamento, a partir de transações privadas, seriam mitigáveis com uma intervenção indireta do Estado - uma intervenção regulatória ou disciplinadora. Aliás, a literatura sobre regulação financeira consolidou, ao longo do século $\mathrm{XX}$, um relativo conhecimento acerca dos principais problemas de funcionamento destes mercados, assim como das técnicas e dos correspondentes instrumentos de intervenção, aptos a aplacar estas falhas. Mesmo assim, o desenvolvimento dos países da periferia econômica conta, sobremaneira, com uma intervenção direta do Estado, manifestada na forma de bancos públicos e bancos de desenvolvimento. A que isso se deve?

Para se compreender as razões desta participação direta do Estado, há que se considerá-la uma modalidade de intervenção regulatória adequada para a superação de um determinado tipo de falha econômica, qual seja, a dissociação entre o retorno privado e os ganhos públicos. Por razões atinentes ao funcionamento interno das economias, em alguns setores constitui-se este tipo de falha: os sinais de mercado podem desincentivar o empreendimento de determinados negócios econômicos, cujos ganhos importam não só para o próprio investidor, mas também para os demais agentes econômicos. A constituição de alguns segmentos econômicos, por exemplo, mostra-se demasiadamente custosa, arriscada e de longa maturação, de tal maneira que tendem a não ser percebidos como uma

explicar a correlação positiva entre visitas a hospitais e pessoas doentes. Seria um equívoco supor que as pessoas ficam doentes pelo fato de ir a hospitais - a causalidade, nesse caso, é reversa: pessoas doentes é que vão a hospitais. Ver a respeito YEYATI, Eduardo Levy; MICCO, Alejandro \& PANIZZA, Ugo. Should the Government be in the Banking Sector?, op. cit. p. 28.

${ }^{129}$ YEYATI, Eduardo Levy; MICCO, Alejandro \& PANIZZA, Ugo. Should the Government be in the Banking Sector?, op. cit. 
oportunidade rentável para os investidores privados. Todavia, tais investimentos podem importar para o conjunto de uma economia, pois são portadores de externalidades positivas, isto é, são capazes de gerar benefícios para o conjunto do mercado. Trata-se de um problema verificável, entre outros, nos setores de infra-estrutura, em que os altos custos envolvidos e o longo prazo de recuperação dos aportes realizados podem despertar uma dissociação entre os interesses privados, de um lado, e os potenciais ganhos coletivos, provenientes da realização do empreendimento, de outro. Essa divergência entre o retorno privado e o ganho social pode gerar, enfim, uma alocação de recursos insuficiente para este tipo de segmento, se os financiadores não se interessarem em garantir uma oferta de capital nestas situações, dado o seu maior risco de insucesso e a menor apropriabilidade dos resultados no curto prazo - ainda que se tratem de projetos relevantes para o funcionamento da ordem econômica. ${ }^{130}$

Este é um tipo de problema particularmente relevante para os países retardatários, sobretudo na fase de industrialização. Isso porque a superação do subdesenvolvimento pressupõe a constituição de novos setores econômicos, ou seja, de novas especialidades produtivas, até então inexistentes nestas economias. Trata-se, com isso, de prover recursos para novos empreendimentos e assim apoiar a constituição de novos mercados: é disso que se trata ao se transformar uma nação especializada na atividade agrária em um país baseado na indústria. Conseqüentemente, para que essa empreitada seja exitosa, não só são necessários recursos abundantes, muitas vezes indisponíveis pelos agentes privados, como também o seu direcionamento deve superar a percepção corrente de rentabilidade privada. É nesse ponto que pode se constituir uma divergência entre os interesses financeiros privados e os imperativos públicos: a percepção dos investimentos portadores de maior rentabilidade pode residir naqueles segmentos já consolidados e não naqueles que podem importar para o fomento de um novo modelo de especialização econômica. É por isso que para a visão desenvolvimentista, ainda que o sistema financeiro dos países subdesenvolvidos funcionasse corretamente, apresentando escala e volume de recursos satisfatórios, para atender toda a demanda dos empreendedores, a alocação destes montantes poderia, ainda assim, ser um problema para as estratégias de desenvolvimento.

${ }^{130}$ A esse respeito ver CEPAL, O Desenvolvimento Recente do Sistema Financeiro da América Latina, em SERRA, José. (coord.) América Latina - ensaios de interpretação econômica, $2^{\text {a }}$ Ed. Rio de Janeiro, Paz e Terra, 1979, pp. 108-149. Ver também YEYATI, Eduardo Levy; MICCO, Alejandro \& PANIZZA, Ugo. Should the Government be in the Banking Sector? op. cit. 
No limite, um sistema financeiro eficiente pode não permitir a superação do gap existente entre a especialização produtiva presente e o pretendido patamar de superação econômica.

Essa questão foi expressamente tratada pela CEPAL, em um artigo de 1971, intitulado O Desenvolvimento Recente do Sistema Financeiro da América Latina. ${ }^{131}$ Neste trabalho, a comissão compara duas formas distintas de funcionamento do sistema financeiro: (i) a função neutra e (ii) a desenvolvimentista. $\mathrm{O}$ argumento resume-se a mostrar que um funcionamento neutro do sistema financeiro pode não atender às necessidades do projeto de desenvolvimento, mesmo que se trate de um funcionamento ótimo. $\mathrm{Na}$ atuação neutra, os mercados de crédito e de capitais são capazes de desembolsar os recursos de que dispõem para as atividades que se mostram rentáveis, garantindo assim uma correspondência entre as margens de ganhos dos empreendimentos e os interesses financeiros dos investidores. Nesse sistema, os projetos com viabilidade e retorno tendem a ser supridos pela oferta de capital, podendo se supor uma aplicação eficiente dos recursos. A questão levantada pela CEPAL, no entanto, é a de que um funcionamento neutro, mesmo quando atingindo o máximo da eficiência financeira, pode ainda assim deixar de atender a duas condições importantes do projeto de transformação econômica: (i) o volume de recursos disponível no mercado pode não ser adequado às necessidades do projeto de desenvolvimento, em virtude da carência de poupança privada e (ii) a aplicação dos recursos pode preferir os setores tradicionais, não se concentrando naquelas atividades que, em razão das externalidades de que são portadoras, sejam efetivamente relevantes para o programa de crescimento industrial. São por esses dois motivos (carência de recursos e destino do capital) que, para a CEPAL, os países subdesenvolvidos requereriam uma organização financeira capaz de, em primeiro lugar, aumentar o volume de recursos disponíveis e, em segundo lugar, alocá-los em atividades estratégicas para os desideratos públicos. Portanto, a intervenção do Estado tem algo mais a cumprir, que não apenas a garantia de um ótimo funcionamento financeiro neutro.

O diagnóstico da CEPAL, que balizou as formulações de políticas públicas desenvolvimentistas na América Latina, guarda semelhanças com a racionalidade subjacente aos planos de intervenção estatal ocorridos no sudeste asiático. Estudos dedicados a interpretar este modelo de desenvolvimento sugerem que os formuladores de

${ }^{131}$ CEPAL, O Desenvolvimento Recente do Sistema Financeiro da América Latina, op. cit. 
política pública também procuraram contornar, no âmbito da organização financeira, a divergência entre retornos privados e sociais. Para tanto, assinalam STIGLITZ \& UY ${ }^{132}$, os Estados não só cuidaram de estabelecer uma disciplina regulatória dos mercados financeiros, para assim garantir o seu funcionamento saudável, como, principalmente, articularam uma atuação direta na formação da poupança e no direcionamento do crédito. Nota-se assim que, para além de uma regulação indireta (prudencial e sistêmica), com a finalidade de preservar a higidez do sistema financeiro, os países asiáticos também se ativeram às falhas que ultrapassavam o funcionamento neutro de seus mercados. Para isso viabilizaram meios de direcionamento público do crédito, como são os bancos estatais. Assim como os latino-americanos, constituíram uma regulação institucional do sistema financeiro.

No campo do direito econômico, a regulação institucional, ao lado da regulação indireta, é uma das formas de regulação pública da economia. Na regulação indireta, o Poder Público estipula as regras do jogo e os incentivos para as atividades exercidas pelos agentes privados, de modo que a obtenção dos resultados visados conta com o comportamento dos indivíduos, que estão sujeitos aos balizamentos e estímulos públicos. Já no caso da regulação institucional, o Estado disciplina a realidade econômica por meio de uma intervenção presencial e direta: são os próprios agentes públicos, como as empresas estatais, que atuam nos mercados e assim exercem algum controle sobre as variáveis econômicas. Com isso, diferentemente do que se passa na intervenção indireta, na regulação institucional os resultados desejados pelo regulador são alcançados diretamente - sem depender da indução do comportamento particular. ${ }^{133}$

Nessa medida, a propriedade pública pode ser entendida como uma forma de regulação econômica que garante ao Estado um controle da organização financeira, para com isso programar o direcionamento dos recursos, conforme as necessidades dos

${ }^{132}$ STIGLITZ, Joseph \& UY, Marilou. Financial Markets, Public Policy, and the East Asian Miracle, op. cit. ${ }^{133}$ Sobre as formas de intervenção do Estado na economia, ver Alberto VENÂNCIO FILHO que divide o direito econômico em dois campos: (i) o direito regulamentar econômico e (ii) o direito institucional econômico. VENÂNCIO FILHO, Alberto. A Intervenção do Estado no Domínio Econômico - o direito público econômico no Brasil, Edição Fac-similar da de 1968, Rio de Janeiro, Renovar, 1998, pp. 83-88. Ver, ainda, Eros Roberto GRAU, que também divide a intervenção do Estado em dois campos: (i) a intervenção no domínio econômico, isto é, a intervenção direta do Estado, que se subdivide em (a) absorção, quando o estado monopoliza um setor ou (b) participação, quando o Estado atua em conjunto com outros agentes; (ii) intervenção sobre o domínio econômico, isto é, a intervenção indireta, que se subdivide também em dois campos - (c) direção da economia privada e (d) indução dos agentes. Ver GRAU, Eros Roberto. A Ordem Econômica na Constituição de 1988. 5ª ed., São Paulo, Malheiros, 2000, pp. 123-165. 
programas de desenvolvimento. Dada a constatação de que a assimetria entre os padrões de retorno é tanto maior, quanto mais ambiciosa vier a ser a plataforma de incremento econômico, a intervenção pública volta-se a substituir a atuação dos mercados financeiros privados, funcionalizando as decisões de investimento para, com isso, garantir recursos aos respectivos setores estratégicos. É, pois, este o caso dos bancos estatais, cuja instituição tem como finalidade prover recursos para aquelas atividades parcamente amparadas pelos agentes privados, mas igualmente relevantes para o sucesso do programa de desenvolvimento.

Notadamente no caso dos bancos de desenvolvimento, que, em relação aos demais bancos estatais, são considerados agentes financeiros especializados, pois contam com uma fonte de recursos baseada na captação fiscal e a sua atuação concentra-se nos investimentos de longo prazo ${ }^{134}$, reconhece-se um papel econômico adicional: além da provisão de recursos para aqueles setores que poderiam amargar uma sub-alocação, os bancos de desenvolvimento são igualmente relevantes na qualidade de experimentadores institucionais. É essa a proposição apresentada por Beatriz de $\mathrm{AGHION}^{135}$, para quem os bancos de desenvolvimento importam também como instituições financeiras que se dispõem a adquirir e disseminar técnicas e ferramentas financeiras, adequadas à provisão de recursos de longo prazo e de alto risco.

As garantias articuladas pela propriedade pública e pela captação de recursos por intermédio da poupança compulsória garantiriam a essas entidades uma maior tolerância ao risco e a conseqüiente possibilidade de experimentar novos instrumentos e procedimentos de contratação. Abrem-se, assim, possibilidades para que os bancos de desenvolvimento detenham meios apropriados para estruturar operações com novos setores, cujo funcionamento pode ser desconhecido dos demais agentes financeiros, habituados a tratar com os ramos tradicionais.

Portanto, a atuação direta do Estado não só importa por conta da disponibilidade de recursos, como também por permitir a formação de novas habilidades de transação

\footnotetext{
${ }^{134}$ Essa definição de banco de desenvolvimento é de TORRES FILHO, Ernani Teixeira. Direcionamento do Crédito: o papel dos bancos de desenvolvimento e a experiência recente do BNDES, em PINHEIRO, Armando Castelar e OLIVEIRA FILHO, Luiz Chrysostomo (org.). Mercado de Capitais e Bancos Públicos, op. cit., pp. 277-304.

${ }^{135}$ Ver AGHION, Beatriz Armendáriz de. Development Banking, Journal of Development Economics, vol. 58, 1999, pp. 83-100.
} 
financeira, que, em um primeiro momento, sustentam a intervenção da regulação institucional e, em um segundo momento, são difundidas para os demais agentes financeiros. Em suma, um papel de desbravador de novas oportunidades financeiras. Um tipo de atuação manifestada, por exemplo, pelo BNDES ao longo de sua história e que recentemente tem sido constatada no financiamento de empresas emergentes: o Banco não só tem aberto um novo mercado no Brasil, como também tem difundido modelos de contratação para os demais agentes financeiros - a isso se voltará nos capítulos 5 e 6 deste trabalho.

\section{A REGULAÇÃo INSTITUCIONAL NO SISTEMA FINANCEIRO BRASILEIRO: A ATUACÃO DO BNDES NO FINANCIAMENTO DO DESENVOLVIMENTISMO}

As seções anteriores indicam que a regulação institucional garantida pela propriedade pública pressupõe, originariamente, uma sobreposição entre a organização dos mercados financeiros e as metas substantivas dos planos estatais. Isto é, a parcela pública do sistema financeiro não só preenche a falta do agente privado, nas operações de maior risco e com longo prazo de maturação, como também é um instrumento da política desenvolvimentista do Estado. ${ }^{136}$ Embora possa parecer uma sobreposição sutil, há nessa conjugação um traço relevante para se compreender a trajetória do sistema financeiro nacional. A atuação dos bancos estatais, e principalmente do BNDES, esteve a serviço das finalidades da política pública apresentada pelo Governo Federal, cumprindo, dessa maneira, uma atribuição que extrapola o suprimento da carência de capitais.

Isso significa que a intervenção desses agentes obedeceu a uma racionalidade substantiva $^{137}$, marcada pela consecução de resultados e finalidades econômicas, estipuladas previamente pelos gestores do Estado, nos respectivos instrumentos de planejamento econômico. Concretamente, pode-se dizer que o BNDES pautou a sua

\footnotetext{
${ }^{136}$ Sobre este papel do banco de desenvolvimento como instrumento da política econômica do Estado, ver NUSDEO, Fábio. Banco de Desenvolvimento, em Enciclopédia Saraiva do Direito, v. 10, São Paulo, Saraiva, 1977 , pp. 247-253.

137 A noção de racionalidade substantiva é discutida por TEUBNER e faz referência a um padrão de intervenção estatal vinculada à produção de resultados nas esferas social e econômica. Trata-se de uma característica do Estado constituído no contexto do fordismo, apresentado no próximo capítulo. Esse debate será retomado no último capítulo do trabalho, quando então se argumentará que a racionalidade de intervenção do Estado tem obedecido novos parâmetros, com a identificação de uma economia baseada no conhecimento. A racionalidade substantiva cede lugar a uma espécie de racionalidade reflexiva. Sobre essa questão ver TEUBNER, Gunther. Substantive and Reflexive Elements in Law, Law \& Society Review, vol. $17, \mathrm{n}^{\circ} .2,1983$, pp. 239-285.
} 
atuação financeira, ao longo do período desenvolvimentista, no cumprimento de metas e tarefas detalhadamente estabelecidas pelo governo, tais como as elencadas pelo Plano de Metas e pelo II PND. Por essa razão, os seus contratos de colaboração financeira, em cada etapa do processo de industrialização, priorizaram aqueles segmentos econômicos selecionados como sendo os setores estratégicos de cada período. O direcionamento do crédito auxiliou, nessa medida, na composição de uma espécie de capitalismo de Estado, que, para Thomas TREBAT ${ }^{138}$, foi uma das características do modelo brasileiro de desenvolvimento econômico. Em boa medida, neste modelo, as decisões privadas concernentes à alocação dos recursos e a espontaneidade de uma economia de mercado foram parcialmente substituídas pela capacidade decisória do Estado, que assumiu o papel de um verdadeiro timoneiro na condução da economia nacional.

O antecedente desta assunção pública do compromisso de superação do subdesenvolvimento, que, paulatinamente, marcou a atuação do Estado brasileiro desde o fim da República Velha ${ }^{139}$, foi a primazia da interpretação industrial sobre a interpretação agrária. Até meados da década de 1950, o panorama político e intelectual do país ainda assistia a um debate entre aqueles que apostavam na vocação agrária da economia, como a fórmula correta de galgar o crescimento nacional, contra aqueles que, a despeito das vantagens comparativas do Brasil, entendiam que a industrialização é que deveria ser o carro chefe da organização econômica nacional. A vitória do segundo grupo sobre o primeiro, manifestada pela completa hegemonia do projeto industrializante, a partir da segunda metade da década de 1950, ensejou a confecção de uma correspondente estratégia de desenvolvimento, que permitiu a transformação dos panoramas social e econômico. ${ }^{140}$

A chamada estratégia nacional-desenvolvimentista, amparada nos diagnósticos e nas recomendações de política formuladas no âmbito da Comissão Econômica para a América Latina - CEPAL, assentou-se em uma mobilização pública dirigida a fomentar a industrialização nacional. O pressuposto compartilhado pelos partidários dessa concepção

138 TREBAT, Thomas. Brazil's State-Owned Enterprises - a case study of the state as entrepreneur, New York, Cambridge, 1983, pp. 10-29.

${ }^{139}$ Sobre o Estado Desenvolvimentista brasileiro a partir de 1930, ver BERCOVICI, Gilberto. Desigualdades Regionais, Estado e Constituição, São Paulo, Max Limonad, 2003.

${ }^{140}$ Este argumento é apresentado por BRESSER PEREIRA, que apresenta uma leitura do período, em que, segundo o autor, a interpretação nacional-desenvolvimentista derrotou a concepção agrária, ensejando assim uma nova estratégia de atuação para o Estado. Sobre isso, ver BRESSER PEREIRA, Luiz Carlos. Crise Econômica e Reforma do Estado no Brasil - para uma nova interpretação da América Latina, (trad. Ricardo Ribeiro e Martha Jalkauska), São Paulo, 34, 1996, pp. 29-40. 
era o de que o desenvolvimento industrial pressupunha uma intervenção ativa do Estado, capaz de alterar a especialização agrária e a ocupação rural, que, até então, pareciam ser um destino manifesto do país. Do contrário, isto é, relegada esta questão apenas à livre iniciativa, era pouco provável que o processo industrial desencantasse, seja em razão da carência de recursos privados, seja pela já mencionada desvinculação dos critérios de rentabilidade (privada e social) - ainda mais aguda naquele contexto. Sendo assim, para dar consecução à promoção pública do processo de transformação social e econômica, foram confeccionados os planos estatais, que articulavam os meios institucionais, como, por exemplo, a propriedade pública sobre o setor bancário, e as correspondentes finalidades econômicas.

Neste período, o desiderato de transformar a realidade brasileira ensejou a instituição de um complexo aparato público, encarregado de articular políticas de crescimento e de redistribuição da renda, com vistas a impulsionar o panorama social e econômico do país. Tratava-se, pois, da manifestação periférica de um fenômeno mais amplo, ocorrido no restante das economias capitalistas, no segundo pós-guerra: a participação do Estado na coordenação econômica. Como será especificamente tratado no capítulo seguinte deste trabalho, a organização fordista da produção, que pautou os cenários econômicos da grande maioria das economias de mercado nessa época, esteve associada a dois atributos institucionais: o Estado Keynesiano e a grande corporação. Na periferia econômica, por sua vez, a reprodução desse modelo teve de contar com os correspondentes ajustamentos institucionais, já que nesses países não se tratava apenas de calibrar as intercorrências de uma economia de massa, mas também de estimular o seu desenvolvimento, em um ambiente econômico ainda parcamente industrializado. Por essa razão, salienta BERCOVICI, o Estado brasileiro foi algo mais do que um Estado Keynesiano ou um Estado Social - uma noção ainda empregada pelo direito constitucional brasileiro para descrever o tipo de Estado construído a partir de 1950, mas que parece uma idéia fora de lugar:

E este é um dos grandes problemas dos estudos sobre o desenvolvimento brasileiro: a falta de uma reflexão mais aprofundada sobre o Estado. Apesar da sua importância para o desenvolvimento, não existe uma análise sistemática sobre a questão institucional do Estado por parte dos teóricos desenvolvimentistas. A ênfase no papel do Estado é derivada de uma concepção da ação política em que a racionalidade técnica tinha um papel decisivo: o Estado formulava e concretizava a racionalidade mediante o planejamento e a política de desenvolvimento. É, justamente, a condição do Estado desenvolvimentista como Estado periférico, na 
realidade, que exige que ele seja algo mais do que o Estado Social tradicional. A estrutura do Estado Social europeu e as intervenções keynesianas na economia são insuficientes para a atuação do Estado na América Latina. A teoria de Keynes valoriza, também, os centros nacionais de decisão para a obtenção do pleno emprego. Entretanto, se a luta contra o desemprego exige a atuação do Estado, esta é muito mais necessária para promover as modificações estruturais necessárias para a superação do subdesenvolvimento. ${ }^{141}$

A reflexão sobre as características institucionais do contexto desenvolvimentista, sugerida por BERCOVICI, indica, portanto, que o projeto de industrialização teve de contar com uma intervenção ainda mais vigorosa do Estado, que, em países como o Brasil, acabou por assumir a responsabilidade pela provisão do parque produtivo nacional. A instituição deste Estado promotor do desenvolvimento, que se consolidou na segunda metade da década de 1950, foi iniciada nas décadas anteriores, quando o Governo Federal empreendeu sucessivos esforços de reaparelhamento da máquina pública, para sustentar um engajamento ativo dos agentes estatais na industrialização do país.

Nesse contexto, que antecedeu ao Plano de Metas, implementado entre 1956 e 1961, foram realizadas diversas análises e proposições de política voltadas a garantir uma coordenação pública das atividades produtivas e, assim, favorecer uma transição do modelo de desenvolvimento. Foi esse o caso da reforma administrativa realizada, em 1937, pelo Governo Vargas, que culminou na criação de um corpo burocrático profissional, no âmbito do DASP ${ }^{142}$, da missão Cooke, de 1942, do Relatório Simonsen, de 1944, e do Plano Salte, de 1948, dedicados a realizar diagnósticos, apresentar propostas e estabelecer medidas condizentes com o desafio da industrialização, como a tentativa de racionalização do processo orçamentário, proposto pelo Plano Salte. ${ }^{143}$ Foi nesse contexto também que se realizaram os estudos e as conseqüentes proposições da Comissão Mista Brasil-Estados Unidos, ocorrida entre 1951 e 1953, que resultaram na criação do Banco Nacional de Desenvolvimento Econômico - BNDE, sabidamente um dos mais importantes agentes de intervenção daí em diante.

${ }^{141}$ BERCOVICI, Gilberto. O Estado Desenvolvimentista e seus Impasses: uma análise do caso brasileiro, em Separata do Boletim de Ciência Econômicas, Universidade de Coimbra, nº. XVLI, 2004, pp. 17-18.

${ }^{142}$ O DASP era uma espécie de órgão administrativo do governo, que recrutava e geria os servidores públicos. Sobre essa reforma administrativa, como um antecedente institucional do Plano de Metas, ver LAFER, Celso. JK e o Programa de Metas - processo de planejamento e sistema político no Brasil (19561961), (trad. Maria Victoria Benevides), Rio de Janeiro, FGV, 2002, pp. 65-114.

${ }^{143}$ Cf. LAFER, Celso. O Planejamento no Brasil - observações sobre o Plano de Metas (1956-1961), em LAFER, Betty Mindlin. Planejamento no Brasil, $3^{\text {a }}$ ed., São Paulo, Perspectiva, 1975, pp. 29-50. 
A Comissão Mista Brasil-Estados Unidos foi formada com técnicos de ambos os países, com a finalidade de identificar os principais entraves ao crescimento nacional e de apresentar algumas medidas institucionais para superação desses problemas. Em boa medida, as conclusões da Comissão concentraram-se nas deficiências do setor de infraestrutura e na correspondente busca de soluções financeiras para a sua mitigação. Como saldo resultante dessas análises, adveio um acordo, segundo o qual o governo brasileiro teria acesso a um volume de créditos internacionais e, em contrapartida, deveria mobilizar internamente este mesmo volume de recursos. Foi para gerir esta poupança e destiná-la a investimentos em setores estratégicos que foi criado o $\mathrm{BNDE}^{144}$, por meio da lei $\mathrm{n}^{\mathrm{o}}$. 1.628, de 1952 , sob a forma de autarquia.

A mobilização da contrapartida nacional foi garantida com a, já mencionada, instituição de um adicional ao Imposto de Renda, que compôs o Fundo de Reaparelhamento Econômico (FRE), administrado pelo BNDES. Nesse período inicial, que se estendeu entre 1952 e 1956, cerca de $80 \%$ dos recursos do Banco foram provenientes do $\mathrm{FRE}^{145}$, sendo destinados às áreas identificadas pela Comissão Mista Brasil-Estados Unidos como pontos de estrangulamento ao crescimento econômico: transporte ferroviário e eletrificação. Dados apresentados por Dulce Corrêa MONTEIRO FILHA $^{146}$, em um trabalho dedicado a descrever as aplicações dos recursos compulsórios do Banco, indicam que, nessa etapa, o setor de transporte ferroviário recebeu $66 \%$ dos desembolsos e o segmento de energia elétrica, $19,8 \%$ do total de colaborações financeiras. Dando sequiência a essa política, que justificou a criação do Banco, o Governo Federal estabeleceu, em 1954, o Plano Nacional de Eletrificação e por meio da lei nº 2.308 , de 1954, constituiu o fundo federal de eletrificação, com recursos provenientes de tributação específica. Tais recursos foram igualmente destinados ao Banco estatal, que adquiriu mais uma fonte de recursos para financiar os correspondentes empreendimentos na área.

Desde essa primeira fase, portanto, marcada pela composição dos primeiros mecanismos de poupança compulsória e pelo início das atividades de direcionamento do crédito, já se manifestava na atuação do BNDES um traço característico, que informaria a

\footnotetext{
${ }^{144}$ Daqui em diante, utilizar-se-á a sigla atual do Banco - BNDES.

${ }^{145}$ Cf. CURRALERO, Claudia Regina Baddini. A Atuação do Sistema BNDES como Instituição Financeira de Fomento no Período 1952-1996, op. cit., pp. 15-24

${ }_{146}$ MONTEIRO FILHA, Dulce. Aplicação dos Recursos Compulsórios pelo BNDES na Formação da Estrutura Setorial da Indústria - 1952-1989, op. cit., pp. 66-72.
} 
sua trajetória até meados da década de 1980: a sua sintonia com a edificação do Estado Desenvolvimentista. Nesse período, o Banco figurou como um corpo burocrático especializado, que, passo a passo, forjou uma expertise técnica e, assim, credenciou-se para realizar a política de investimentos do Governo Federal. De um lado, os formuladores de política pública podiam contar com um agente público habilitado, capaz de desempenhar a intervenção financeira; de outro, os administradores do Banco, sem perder a autonomia e a especificidade técnica ${ }^{147}$, vincularam a sua missão aos desideratos dos planos estatais de desenvolvimento econômico. Daí o porquê da consideração inicial de que, nesta fase, verificou-se uma verdadeira sobreposição entre a forma institucional da organização financeira e a atuação do Estado Desenvolvimentista. Entre 1950 e 1980, o BNDES não foi apenas um agente financeiro controlado pelo Estado, foi, na realidade, um agente financeiro a serviço dos desígnios do Governo Federal: os seus critérios de seleção, as suas regras de contratação e de execução financeira vincularam-se às prioridades estipuladas pelos condutores do programa de desenvolvimento.

Nesse contexto, dois períodos chamam particularmente a atenção, em razão da sistematicidade e da concatenação da intervenção estatal: o Plano de Metas e o II PND. ${ }^{148}$ Nestes dois capítulos do processo de industrialização, foi bastante evidente o esforço do Governo Federal em implementar planos econômicos, assentados na definição de mecanismos e na estipulação de finalidades. Naturalmente, o BNDES foi um dos atores protagonistas de ambas as experiências.

\footnotetext{
${ }^{147}$ Essa questão é trabalhada por Luciano MARTINS, para quem a forma inicial de autarquia permitiu ao Banco estabelecer uma política de recrutamento profissional, que lhe garantiu um corpo técnico superior ao padrão da administração pública brasileira: "fenômenos esses grandemente facilitados pelo fato de o Banco ter sido constituído sob a forma de autarquia, o que lhe permitiu desenvolver uma política de recrutamento $e$ formação de quadros menos sujeita às condições inibitórias prevalecentes na administração central, onde predominava a burocracia 'tradicional"'. Para o autor, é esta condição que deu ao Banco um papel de think tank, participando ativamente da formulação e execução dos planos nacionais de desenvolvimento. Ver MARTINS, Luciano. Estado Capitalista e Burocracia no Brasil pós-64, Rio de Janeiro, Paz e Terra, 1985, pp. 87-88.

${ }^{148}$ A literatura sobre política industrial no Brasil costuma apresentar o Plano de Metas e o II PND como os exemplos mais efetivos de planejamento e de política industrial. Ver a respeito SUZIGAN, Wilson \& VILLELA, Annibal. Industrial Policy in Brazil, Campinas, Unicamp, 1997, pp. 31-44.
} 


\subsection{O BNDES E A INTERVENÇÃO DO ESTADO DURANTE O PLANO DE METAS}

O Plano de Metas, de Juscelino Kubitschek, é identificado, por Celso LAFER ${ }^{149}$, como a primeira iniciativa sistemática de coordenação pública da economia brasileira. Até então, as sucessivas iniciativas de planejamento mostraram-se algo erráticas e pontuais e, conquanto já assinalassem a tendência de estipular finalidades a serem perseguidas pelos agentes estatais, careciam de um efetivo plano governamental, que contemplasse diagnósticos, mecanismos, recursos e um elenco de prioridades articuladas ao projeto de desenvolvimento industrial. Foi apenas no governo JK que os mecanismos de ação pública foram coordenados, de modo a pautar a sua atuação em prol da execução de um conjunto de metas previamente selecionadas. Nesse contexto, coube ao BNDES o desempenho de um papel chave, seja no financiamento do plano, seja na sua coordenação.

A rigor, o Banco participara já da formulação do Plano de Metas, cuja concepção foi esboçada no âmbito de um grupo de análises e proposições que, tal como os anteriores, voltou-se a investigar os entraves ao incremento industrial do país e a apresentar as conseqüentes medidas saneadoras. Foi no âmbito da Comissão CEPAL-BNDE, cujos trabalhos se iniciaram em 1953, que se formaram algumas das idéias norteadoras do Plano de Metas, particularmente, a compreensão de que o caminho da industrialização era definitivamente a vocação do país. ${ }^{150} \mathrm{~A}$ sua concepção definitiva, já no governo JK, assumiu o propósito de incrementar o crescimento e o nível de renda da população, um objetivo que foi materializado na estipulação de 5 setores prioritários, que reuniam, por sua vez, 30 metas específicas. Os setores eram: energia, transportes, alimentação, indústria de base e educação.

Para a sua formulação, o Governo JK partiu da identificação dos pontos de estrangulamento, dos pontos de germinação e da demanda derivada. ${ }^{151}$ Os pontos de estrangulamento referiam-se àqueles setores cuja organização representava um impedimento para o funcionamento adequado do conjunto da economia. É por essa razão

\footnotetext{
${ }^{149}$ Cf. LAFER, Celso. O Planejamento no Brasil - observações sobre o Plano de Metas (1956-1961), op. cit.

150 Para CURRALERO, os resultados da comissão CEPAL-BNDE representam uma ruptura com os entendimentos prevalecentes na Comissão Mista Brasil-Estados Unidos. Para a autora, nesta primeira comissão ainda figurava a preferência pela vocação agrária. Ver CURRALERO, Claudia Regina Baddini. $A$ Atuação do Sistema BNDES como Instituição Financeira de Fomento no Período 1952-1996, op. cit., pp. 1124.

${ }^{151}$ LAFER, Celso. O Planejamento no Brasil - observações sobre o Plano de Metas (1956-1961), op. cit.
} 
que os segmentos energia, transportes e alimentação, identificados como defasados em relação às necessidades do país, foram elencados pelo Plano. ${ }^{152}$ Os pontos de germinação eram aqueles cujo incremento poderia significar a produção de externalidades positivas, contribuindo para o florescimento do mercado interno. Para LAFER ${ }^{153}$, os investimentos em Brasília e na construção de rodovias exemplificam alguns pontos de germinação. Por fim, havia as metas provenientes da compreensão de demanda derivada, ou seja, segmentos que deveriam ser promovidos porque importavam para a viabilização de outras metas, como é o caso da indústria de insumos para veículos. ${ }^{154} \mathrm{O}$ relato desses componentes de formulação do Plano indicam a pretensão substantiva de sua intervenção: o Estado não só estipulou os setores relevantes para a economia, como também assumiu a tarefa de estabelecer as conexões entre as cadeias produtivas, para assim constituir, de fato, um parque industrial no país.

Notadamente quanto ao BNDES, com a implementação do Plano, o Banco passou do papel de formulador para o de executor. Ao lado da Carteira de Exportação do Banco do Brasil (CACEX), responsável pela área de comércio exterior, e da Superintendência da Moeda e do Crédito (SUMOC), responsável pela política monetária, o BNDES foi um dos pilares do Plano de Metas. Couberam ao Banco duas atribuições principais, quais sejam, garantir financiamento para os setores prioritários e permitir a captação externa de recursos, servindo como garantia do Governo brasileiro, ante os credores internacionais.

No atendimento da primeira dessas atribuiçõos, o BNDES concentrou as suas operações de colaboração financeira nos setores de energia elétrica e siderúrgico componentes da indústria de base. Uma análise da distribuição dos recursos no período revela que, entre 1957 e 1963, as contratações financeiras do setor siderúrgico representavam 48,6\% do total das operações do Banco. Para Cláudia CURRALERO ${ }^{155}$, o crescimento dos financiamentos ao setor siderúrgico foi a novidade desta fase, em que o BNDES teve participação ativa na constituição de importantes plantas industriais do ramo, como a Usiminas e a Cosipa. Uma evolução semelhante ocorreu no setor elétrico, que no período anterior (1952-1956) havia respondido por 19,8\% das colaborações financeiras e

${ }^{152}$ LAFER, Celso. O Planejamento no Brasil - observações sobre o Plano de Metas (1956-1961), op. cit.

${ }^{153}$ LAFER, Celso. O Planejamento no Brasil - observações sobre o Plano de Metas (1956-1961), op. cit.

${ }^{154}$ LAFER, Celso. O Planejamento no Brasil - observações sobre o Plano de Metas (1956-1961), op. cit.

${ }^{155}$ CURRALERO, Claudia Regina Baddini. A Atuação do Sistema BNDES como Instituição Financeira de Fomento no Período 1952-1996, op. cit. 
passou a deter $33,4 \%$ do universo de desembolsos. ${ }^{156}$ Já as metas relativas ao setor de transporte, em especial o ferroviário, de que se ocupara o Banco, entre 1952 e 1956, saíram da sua alçada direta em 1957, quando foi constituída a Rede Ferroviária Federal S.A. RFFSA, uma empresa estatal dedicada à construção e operação das estradas de ferro brasileiras.

O financiamento destes setores contou com explícitas condições indutoras, presentes nos contratos de colaboração financeira. Para além dos critérios de seleção utilizados pelo Banco, que pautavam a decisão de concessão dos recursos pelo mérito dos projetos e pela sua pertinência ao plano do Governo, a execução contratual contava também com uma especificidade - uma taxa de juros inferior à inflação do período. Com essa medida, o custo real dos empréstimos era diminuído, indicando assim que a atuação do Banco assumia a racionalidade de uma verdadeira agência de fomento, disposta a subsidiar as intenções de investimento. ${ }^{157}$ Como será visto a seguir, uma política semelhante, porém dirigida às empresas privadas, ocorreu durante o II PND, quando os contratos de colaboração financeira disciplinavam uma regra de correção monetária inferior à inflação, permitindo uma transferência indireta de recursos públicos aos projetos industriais.

Ao longo da gestão JK, o BNDES cumpriu também um segundo papel, o de agente financeiro do Tesouro nacional. A captação de recursos no exterior, revela Celso LAFER $^{158}$, era dificultada pela carência de garantias de que dispunha o país. Foi para reverter esse quadro que o Governo Kubitschek criou ou reorganizou diversos fundos federais, cuja dotação independia do confuso processo de composição do orçamento público que, à época, não contava com uma adequada capacidade de formulação. ${ }^{159}$ Para contornar as incertezas da peça orçamentária, os gestores do Plano de Metas lançaram mão

\footnotetext{
${ }^{156}$ Cf. MONTEIRO FILHA, Dulce. Aplicação dos Recursos Compulsórios pelo BNDES na Formação da Estrutura Setorial da Indústria - 1952-1989, op. cit., pp. 66-82.

${ }^{157}$ As taxas de juros variavam entre $8 \%$ ao ano para projetos de infra-estrutura e $11 \%$ ao ano para indústrias de base. A esse respeito ver CURRALERO, Claudia Regina Baddini. A Atuação do Sistema BNDES como Instituição Financeira de Fomento no Período 1952-1996, op. cit., pp. 11-24.

${ }^{158}$ LAFER, Celso. JK e o Programa de Metas - processo de planejamento e sistema político no Brasil, op. cit.

${ }^{159}$ Não havia uma confecção profissional do orçamento público, com uma efetiva capacidade de previsão de receitas e despesas. Aliás, a lei do orçamento público só viria a ser promulgada em 1964 - a lei 4.320. Além disso, a peça orçamentária era muitas vezes realizada com muita antecedência e com isso ficava defasada em relação à inflação. Sobre esse ponto, ver LAFER, Celso. JK e o Programa de Metas - processo de planejamento e sistema político no Brasil, op. cit., pp. 65-114
} 
de um artifício previsto na Constituição de 1946 - os fundos especiais e, com isso, conseguiram vincular receitas a áreas estratégicas ${ }^{160}$. Os recursos destes fundos que, em sua maioria foram destinados ao Banco, não só incrementaram a poupança compulsória à sua disposição, como também foram utilizados pelo BNDES como garantia de empréstimos contratados no exterior, seja pelas empresas estatais, seja pelas empresas privadas. A gestão destes recursos contribuiu para um expressivo aumento no volume de recursos disponíveis pelo Banco: entre 1956 e 1961, o montante financeiro apresentou uma variação superior a $350 \%$, em relação à fase inicial de suas operações. ${ }^{161}$

Com essas atribuições, pode-se dizer que, ao longo do Plano de Metas, o BNDES consolidou a sua posição na organização burocrática brasileira, tornando-se o agente financeiro do desenvolvimentismo nacional. Assentado em mecanismos compulsórios de poupança e no direcionamento do crédito, conforme as prioridades apresentadas pelo plano de desenvolvimento, o Banco passou a conformar a regulação institucional do sistema financeiro nacional.

\subsection{AS REFORMAS DA DÉCADA DE 1960 E A INTERVENÇÃO DO ESTADO DURANTE O II PND}

Encerrado o Plano de Metas, em 1961, o país atravessou um período de profundas reformas institucionais, dedicadas a recompor a capacidade tributária do Estado e a disponibilidade financeira da economia. Tais alterações, processadas a partir de 1964, introduziram importantes inovações no panorama jurídico, marcando o direito público brasileiro, desde então. Nesse conjunto de medidas, a SUMOC, por exemplo, que respondia pela política monetária, foi extinta e em seu lugar foi criado o Banco Central do Brasil, por meio da lei $\mathrm{n}^{\circ} .4595$, de 1964, que lhe atribuiu poderes regulatórios no sistema financeiro. Já a lei $\mathrm{n}^{\circ}$. 4728, de 1965, institucionalizou o mercado de capitais nacional, isso com a intenção de apresentar ao país uma nova fonte de financiamento de longo prazo e

\footnotetext{
160 Alguns fundos já existiam, mas foram reorganizados para os propósitos do Plano. Os fundos eram os seguintes: Fundo Rodoviário Federal, criado pelo decreto-lei 8.463/45; Fundo Nacional de Pavimentação, instituído pela lei 2.698/53; Fundo de Renovação e Melhoramento das Ferrovias, decreto 37.686/55; Fundo Federal de Eletrificação, lei 2.308/54; Fundo Aeronáutico; Fundo Portuário Nacional, lei 3.241; Fundo da Marinha Mercante, lei 3.381/58. A esse respeito, ver LAFER, Celso. JK e o Programa de Metas - processo de planejamento e sistema político no Brasil, op. cit.

161 Dados apresentados por CURRALERO, Claudia Regina Baddini. A Atuação do Sistema BNDES como Instituição Financeira de Fomento no Período 1952-1996, op. cit., p. 22.
} 
assim permitir uma transição, desde um modelo baseado nos bancos, e notadamente nos bancos estatais, para um regime assentado no mercado de capitais. ${ }^{162}$

Em 1967, as reformas seguiram rumo à organização administrativa do Estado. O decreto-lei $\mathrm{n}^{\mathrm{o}}$. 200, de 1967, instituiu um novo conjunto de regras e disposições concernentes à Administração Pública, positivando os elementos jurídicos constitutivos da Administração Indireta, tais como as autarquias, as empresas públicas e as sociedades de economia mista. Esta medida, dedicada sobretudo ao setor produtivo estatal, foi empreendida por Hélio Beltrão, no Ministério do Planejamento, e teve como objetivo, relata Carmen ALVEAL ${ }^{163}$, dotar os agentes estatais de maior autonomia operacional. Nesse sentido, a proposta de reforma estava alinhada com a política econômica empregada por Roberto Campos e Octavio Gouveia de Bulhões, voltada a garantir o realismo tarifário para as empresas estatais. A disposição da reforma administrativa e a orientação da política econômica era garantir autonomia financeira e capacidade operacional para os agentes do Estado, que deveriam galgar a capacidade de auto-financiar as suas atividades, contando para isso com uma precificação correta das tarifas, compatível com os seus custos e as necessidades de investimento. ${ }^{164}$

Ainda neste período, a organização do setor financeiro e, em especial, do setor bancário, foi particularmente modificada. Para permitir uma melhor capacidade de financiamento da economia brasileira, foram editados diversos atos normativos, para assim reorganizar o funcionamento deste segmento econômico, compartimentalizando os seus ramos de atividade. A expectativa dos formuladores desta política pública era a de que tais iniciativas resultassem em uma diversificação do sistema bancário, que passaria então a desempenhar a intermediação financeira em sucessivos mercados de crédito. Aos bancos

\footnotetext{
${ }^{162}$ Para Otávio YAZBEK, "se pretendia migrar, no país, de um modelo bank-based para um modelo marketbased”, ver a respeito YAZBEK, Otávio. Regulação do Mercado Financeiro e de Capitais, Rio de Janeiro, Elsevier, 2007, p. 261.

${ }^{163}$ A análise da autora refere-se especificamente à Petrobrás, que teria se beneficiado destas medidas. Ver a respeito ALVEAL, Carmen. Os Desbravadores - a Petrobrás e a construção do Brasil industrial, Rio de Janeiro, Relume Dumará: ANPOCS, 1994, pp. 85-105.

${ }^{164}$ A seguinte passagem de COUTINHO \& REICHSTUL sobre essas medidas ilustram as suas finalidades: "o plano do Ministério do Planejamento para as empresas estatais era, então, de lhes dotar de 'eficiência' operacional semelhante a de empresas privadas, de forma que aquelas pudessem acumular por moto próprio. Para tal, foram tomadas medidas saneadoras tais como: contração das folhas de pagamento para eliminação do 'empreguismo', racionalização dos estoques, reconstituição do capital de giro etc. E, mais importante, liberaram-se os preços e tarifas administradas pelas empresas com objetivo de assegurar o autofinanciamento." COUTINHO, Luciano \& REICHSTUL, Henri-Philippe. O Setor Produtivo Estatal e o Ciclo, op. cit. pp 71-72.
} 
comerciais, caberia a intermediação entre os recursos provenientes de depósitos e a concessão de créditos de curto prazo. Já aos bancos de investimento, cuja criação foi autorizada pela lei 4.728/65 (lei do mercado de capitais), caberia uma atuação especializada, direcionada a créditos de prazo mais longo (superior a um ano), sendo vedado, entretanto, o recebimento de depósitos à vista. ${ }^{165} \mathrm{~A}$ tais bancos, facultava-se também a possibilidade de realizar operações com valores mobiliários. ${ }^{166}$

No sistema financeiro público, as alterações institucionais ficaram por conta de quatro eventos: (i) a regulação dos bancos estaduais de desenvolvimento; (ii) a atribuição de uma missão específica ao Banco do Brasil; (iii) a criação do Banco Nacional de Habitação e (iv) um pouco mais tarde, em 1971, a transformação do BNDES, de autarquia em empresa pública. ${ }^{167}$ Os bancos de desenvolvimento foram instituídos pelo mesmo artigo 29 da lei 4.728/65, que autorizou o funcionamento dos bancos de investimento, sendo posteriormente regulamentados pelas resoluções do Banco Central $n^{\circ}$. 93/68 e $n^{\circ}$. 394/76, que restringiram o uso desta denominação (banco de desenvolvimento) para as instituições financeiras públicas, organizadas no âmbito dos Estados da federação e encarregadas das operações de crédito de longo prazo ou de investimento (subscrição de valores mobiliários). ${ }^{168}$ Com relação ao Banco do Brasil, em razão da concepção de segmentar o sistema bancário, foi-lhe atribuída a responsabilidade pelo financiamento agrícola. Por fim, para a atividade imobiliária, foi criado, pela lei $\mathrm{n}^{\circ}$. 4.380, de 1964, o Banco Nacional de Habitação, que administraria os recursos provenientes de um fundo de poupança compulsória, o FGTS (fundo de garantia por tempo de serviço). ${ }^{169}$

165 Cf. NUSDEO, Fábio. Bancos de Investimento, em Enciclopédia Saraiva do Direito, v. 10, São Paulo, Saraiva, 1977, pp. 253-256.

${ }^{166}$ A segmentação desse mercado e a estipulação de tarefas bem definidas para cada um dos agentes sugere que o modelo norte-americano (market-based) de regulação financeira, caracterizada por uma separação entre as áreas de atuação dos bancos de investimento e dos bancos comerciais, foi quem serviu de inspiração para as reformas legislativas da década de 1960.

${ }^{167}$ A transformação foi prescrita na lei $\mathrm{n}^{\circ}$. 5.662, de 1971, que ainda autorizou a transformação do Banco em sociedade de economia mista, a critério do Poder Executivo, ver NUSDEO, Fábio. Banco Nacional de Desenvolvimento Econômico, em Enciclopédia Saraiva do Direito, v. 10, São Paulo, Saraiva, 1977, pp. 223225.

${ }^{168}$ Cf. NUSDEO, Fábio. Bancos de Desenvolvimento, op. cit. Um exemplo de banco de desenvolvimento estadual foi o BADESP, em São Paulo.

${ }^{169}$ Pelas regras do FGTS, as empresas deveriam compulsoriamente depositar em uma conta vinculada o montante de $8 \%$ do valor pago como salário ao trabalhador. O fundo resultante seria utilizado como verba indenizatória para os trabalhadores e as suas disponibilidades financeiras seriam utilizadas pelo BNH, para os financiamentos imobiliários. Ver TEIXEIRA, Natermes Guimarães. Origem do Sistema Multibancário Brasileiro, Campinas, Unicamp, 2000, p. 43 (nota de rodapé). 
A finalidade de tais reformas, ocorridas nos mercados de crédito, de capitais e no âmbito da administração pública, foi a de diversificar as fontes de financiamento da economia brasileira. De fato, a intenção subjacente à criação do aparato regulador do mercado de capitais, à segmentação do sistema bancário e ao realismo tarifário das estatais foi a de mitigar a coordenação pública da economia e, com isso, favorecer os espaços privados de transação. A proposta era fomentar uma maior independência do crescimento econômico em relação aos agentes públicos, mitigando assim o caráter Estado-centrado do desenvolvimento econômico. Isso é bastante evidente na proposta de autonomia financeira das empresas estatais, que supostamente não mais dependeriam dos recursos públicos, como os do BNDES, para as suas políticas de investimento.

Em particular, no que se referia ao sistema financeiro, argumenta YAZBEK ${ }^{170}$, as reformas intencionavam aprofundar o seu funcionamento no conjunto da economia brasileira, o que significava proporcionar uma diversificação dos veículos e modalidades de financiamento, aumentando assim as opções disponíveis para os agentes econômicos (para a literatura, um financial deepening). O êxito desta amplificação, de acordo com MONTEIRO FILHA ${ }^{171}$, pode ser notado na maior capacidade do mercado em garantir crédito para o setor imobiliário e para o segmento de bens de consumo duráveis, que viria ainda a ser beneficiado, em 1974, com a promulgação da lei $n^{\circ} .6 .099$, que disciplinou o mercado de arrendamento mercantil.

Entretanto, afora alguns bons resultados obtidos na diversificação do estoque de ferramentas financeiras e no alargamento dos mercados de crédito e de capitais, que passaram a contar com novas entidades, como os bancos de investimento, uma questão decisiva permaneceu sem solução: a superação da falha do mercado privado em prover recursos para um tipo determinado de empreendimento industrial, portador de intensas externalidades positivas, mas considerado arriscado e de longo prazo de maturação. Nessa medida, apesar da realização de inúmeras reformas legislativas e infra-legais, a regulação institucional, baseada na poupança compulsória e no crédito direcionado, permaneceu como a alternativa nacional de financiamento da industrialização, sobretudo, porque os bancos de investimentos e o mercado de capitais não supriram essas necessidades de

${ }^{170}$ YAZBEK, Otávio. Regulação do Mercado Financeiro e de Capitais, op. cit.

171 MONTEIRO FILHA, Dulce. Aplicação dos Recursos Compulsórios pelo BNDES na Formação da Estrutura Setorial da Indústria - 1952-1989, op. cit., pp. 47-56. 
recursos. ${ }^{172}$ Sendo assim, tão logo o Governo Federal viu-se às voltas com a necessidade de implementar um novo aparato de planejamento econômico de fôlego, o BNDES assumiu o encargo de financiar a proposta desenvolvimentista, foi o que ocorreu durante o II PND.

A apresentação do II PND, em 1974, deveu-se, formalmente, às exigências contidas no Ato Complementar nº 43 , de 1969, com redação dada pelo Ato Complementar $\mathrm{n}^{\circ}$. 76, de 1969, cujo dispositivo determinava que, a cada início de gestão, o Executivo deveria apresentar um programa de atuação para o período subseqüente. Em razão disso, em 10 de setembro de 1974, o presidente Geisel promulgou a lei $n^{\circ}$. 6.151/74, que dispunha sobre o II Plano Nacional de Desenvolvimento. Do ponto de vista substantivo, a formulação deste plano respondia às intercorrências de um momento delicado vivido pela economia brasileira. O começo da década de 1970 fora marcado pela crise do petróleo, tratada no próximo capítulo como um fator incidental, que contribuiu para a crise do paradigma fordista-desenvolvimentista. Foi para contornar os efeitos dessa crise e estender as taxas de crescimento registradas entre 1967 e 1973, durante o chamado "milagre brasileiro", que o Governo Federal lançou mão de uma estratégia de investimentos públicos, voltada a completar a matriz produtiva brasileira.

O diagnóstico de vulnerabilidade externa, provocada pelo aumento dos preços internacionais e percebida na forma de desajustes no balanço de pagamentos do país, associada ao cenário de instabilidade no comércio internacional, em razão da desconstituição do acordo de Bretton Woods, que desde o segundo pós-guerra regia os termos de troca entre os países, levaram o Governo Federal a conceber um amplo plano de intervenção. A sua finalidade precípua foi a de internalizar na economia nacional uma maior quantidade de segmentos produtivos, valendo-se, portanto, de uma estratégia já conhecida das demais intenções desenvolvimentistas: a substituição de importações. Desta vez, o alvo da política industrial foram os setores da indústria pesada, tais como bens de capital (máquinas e equipamentos) e insumos básicos (siderurgia, papel e celulose, e

${ }^{172} \mathrm{O}$ mercado de capitais era muito incipiente e os bancos de investimento concentraram a sua atuação em operações de médio prazo e no financiamento do capital de giro das empresas. Ver MONTEIRO FILHA, Dulce. Aplicação dos Recursos Compulsórios pelo BNDES na Formação da Estrutura Setorial da Indústria - 1952-1989, op. cit. pp., 47-56. 
química e fertilizantes, entre outros), cuja definitiva implementação permitiria a consolidação de um novo padrão produtivo, prioritariamente nacional. ${ }^{173}$

Em comparação com o Plano de Metas, para além de novas prioridades setoriais, como os setores da indústria pesada, as diferenças apresentadas pelo II PND cingiam-se também ao tipo de agente econômico beneficiário. Distintamente do que se verificara no governo $\mathrm{JK}$, em que as empresas estatais foram as maiores tomadoras dos financiamentos e benefícios públicos, o plano de Geisel voltou-se para as empresas privadas. A razão para isso residia no entendimento compartilhado pelos formuladores do II PND de que a empresa privada nacional figurava, àquele momento, como o pilar mais frágil da chamada tríplice aliança ${ }^{174}$ : o consórcio formado entre o Estado, as empresas multinacionais e as empresas nacionais, que compunha o panorama institucional do desenvolvimento brasileiro.

Partindo dessa percepção, o plano elegeu o empresariado nacional como o grupo prioritário, o que resultou na confecção de medidas específicas de proteção e fomento. Deste elenco, fizeram parte, por exemplo, as iniciativas de estímulo às fusões de empresas, que poderiam obter no âmbito do COFIE (Comissão de Fusão e Incorporação de Empresas), reduções no Imposto de Renda, caso a operação societária viesse a ser considerada relevante, para a formação de um grupo empresarial nacional. Algo semelhante foi realizado pela lei 6.404, de 1976 - a Lei das S.A., cujos dispositivos favoreciam a constituição de conglomerados empresariais nacionais. Todos estes mecanismos partilhavam da mesma lógica subjacente, qual seja, a intenção deliberada de formar grandes empresas nacionais, o que, como será visto no próximo capítulo, correspondia à lógica prevalecente deste contexto, ainda marcado pelos atributos de uma economia fordista.

No que tange à atuação do BNDES neste período, três atributos merecem ser destacados: (i) a concentração dos financiamentos em favor das empresas privadas,

\footnotetext{
173 Sobre a concepção do II PND, ver GREMAUD, Amaury Patrick \& PIRES, Julio Manuel. II Plano Nacional de Desenvolvimento - II PND (1975-1979), em KON, Anita (org.) Planejamento no Brasil II, São Paulo, Perspectiva, 1999, pp. 67-101.

${ }^{174}$ A tese da tríplice aliança foi formulada por Peter EVANS, para quem o desenvolvimento brasileiro contou com uma aliança de três atores: o Estado, o capital privado nacional e o capital privado multinacional. A esse respeito ver EVANS, Peter. A Tríplice Aliança - as multinacionais, as estatais e o capital nacional no desenvolvimento dependente brasileiro, Trad. Waltensir Dutra, 2ª ed. Rio de Janeiro, Zahar, 1982.
} 
pertencentes aos setores priorizados pelo II PND; (ii) a definição de um novo instrumento de colaboração financeira - as participações societárias e (iii) a implementação de programas dirigidos à capitalização das empresas nacionais - indicando uma aproximação com as operações no mercado de capitais.

Com relação à prevalência das empresas privadas, trata-se de uma tendência apresentada pelo Banco desde 1968, quando, pela primeira vez, o volume de desembolsos dirigidos à iniciativa privada superou as contratações com agentes públicos. Ao longo do II PND, foi dado seguimento a este padrão de atuação: em 1974, as empresas privadas respondiam por $66 \%$ dos desembolsos aprovados e o setor público, por 34\%; já em 1978, a participação privada foi de $87 \%$ e a do setor público, 13\%. Neste universo de empresas privadas, os segmentos mais favorecidos foram aqueles selecionados pelo II PND. Dados apresentados por MONTEIRO FILHA $^{175}$ e CURRALERO $^{176}$ revelam que o direcionamento do crédito concentrou-se nos seguintes setores: (i) insumos básicos, com $48 \%$ das colaborações financeiras aprovadas no período (principalmente siderurgia, química e fertilizantes, papel e celulose); (ii) infra-estrutura, responsável por $30 \%$ das aprovações (com ênfase para energia elétrica e transporte ferroviário) e (iii) bens de capital e equipamentos, com $7 \%$ das aprovações (em especial, equipamentos mecânicos e elétricos).

O apoio financeiro às empresas privadas reclamou a constituição de uma nova ferramenta jurídica de colaboração financeira - a participação societária, que viria a ser uma modalidade de atuação particularmente relevante anos mais tarde, quando o BNDES veio a assumir o papel de venture capitalist de empresas emergentes (como relatará o capítulo 5 deste trabalho). Por ora, nesta fase, a utilização da subscrição de ações, como mecanismo de financiamento dos investimentos, deveu-se à intenção de fortalecer e consolidar grupos empresariais nacionais, ainda carentes de um satisfatório patamar de capitalização. Para tanto, o BNDES constituiu três empresas subsidiárias especializadas em

175 MONTEIRO FILHA, Dulce. Aplicação dos Recursos Compulsórios pelo BNDES na Formação da Estrutura Setorial da Indústria - 1952-1989, op. cit., pp. 97-110.

${ }^{176}$ CURRALERO, Claudia Regina Baddini. A Atuação do Sistema BNDES como Instituição Financeira de Fomento no Período 1952-1996, op. cit., pp. 31-40. 
participações, que depois vieram a formar a BNDESpar ${ }^{177}$ : (i) EMBRAMEC, para operações no setor de bens de capital; (ii) FIBASE, para o setor de insumos básicos e (iii) a IBRASA, para empreendimentos em empresas nacionais em geral. Muito embora as participações devessem ser temporárias e minoritárias, em alguns casos do conjunto de 95 empresas beneficiárias, esta participação se transformou em majoritária e também delongada no tempo. Foi por esta razão que nos anos 1980, quando mudou a perspectiva de atuação do Banco, ocorreram as primeiras privatizações, que depois credenciaram o BNDES a ser o gestor do programa nacional de desestatização, implementado na década de 1990.

Com a constituição das empresas de participação, o BNDES passou, então, a deter dois tipos de ferramentas jurídicas para a realização das colaborações financeiras: os contratos de crédito e as subscrições acionárias. A primeira modalidade, tradicionalmente empregada, responde pelas operações de renda fixa, isto é, o contrato de crédito estipula desde o seu momento inicial as obrigações financeiras atribuídas ao tomador, que, via de regra, são formadas pelo pagamento do montante principal, adicionado dos juros e eventuais correções monetárias. A segunda forma de colaboração financeira, por sua vez, é composta por uma renda variável, já que os ganhos do Banco são obtidos na forma de dividendos e, portanto, sujeitos ao desempenho da companhia. A possibilidade de utilizar veículos de renda variável deu versatilidade aos financiamentos realizados pelo Banco, que passaram também a apoiar empreendimentos de maior risco e com menor capacidade de previsão dos resultados: um tipo de intervenção que, à época, não era comum para os demais agentes do mercado financeiro nacional. Confirmando assim os apontamentos de Beatriz de $\mathrm{AGHION}^{178}$, a experiência institucional com a estruturação de participações societárias, foi um antecedente das operações de capital de risco no país, tanto para aquelas empregadas pelo BNDES, a partir dos anos 1990, como para o próprio mercado brasileiro, que viria a se constituir anos mais tarde, a partir do pioneirismo do Banco.

Ao lado dessas participações societárias, conduzidas diretamente pelas suas subsidiárias, a disposição de favorecer a empresa nacional contou também com uma

\footnotetext{
${ }^{177}$ No início da década de 1980, em 1982, operou-se uma reorganização societária no âmbito do Banco e as três subsidiárias foram agrupadas em uma única empresa, a BNDESpar, que desde então responde pelas operações com participação societária.

${ }^{178}$ Ver AGHION, Beatriz Armendáriz de. Development Banking, op. cit.
} 
terceira forma de atuação - o incentivo à capitalização da empresa nacional. Para cumprir este propósito, o Banco instituiu, em 1976, o PROCAP - programa de apoio à capitalização de empresa privada nacional. As linhas de crédito deste programa garantiam recursos subsidiados, na forma de renda fixa, (taxa de juros entre 4 a 5\% ao ano e limitação da correção monetária) para que os agentes econômicos, como os bancos de investimento, criados pelas reformas supracitadas, adquirissem participações em empresas nacionais. A finalidade do PROCAP era evidente: estimular a subscrição de ações para assim ampliar a capitalização das empresas privadas - uma iniciativa que ainda favorecia o mercado de capitais nacional. ${ }^{179}$ As finalidades do PROCAP foram complementadas pelas do FINAC (financiamento a acionistas), cujas linhas de crédito, igualmente subsidiadas, eram dirigidas aos acionistas, com a intenção de estimular a aquisição de valores mobiliários que resultassem no aumento do capital social das respectivas empresas.

Com este elenco diversificado de instrumentos, o BNDES cumpriu os desideratos do II PND. Assim como ocorrido durante o Plano de Metas, o Banco funcionalizou a sua atuação financeira para dar viabilidade aos objetivos da política governamental. Para tanto, tal como ocorrera antes, balizou os seus critérios de seleção no mérito e na relevância dos projetos, procurando financiar os setores estratégicos para o plano de desenvolvimento. A seleção baseada preferencialmente no mérito e menos na rentabilidade dos empreendimentos, esteve associada a uma execução contratual favorável aos interesses das firmas tomadoras, que, entre outras coisas, limitava a correção monetária dos contratos. Tal possibilidade, de conceder recursos com taxas favoráveis e subsidiadas, era garantida pelas fontes compulsórias de captação, que atribuíam ao Banco recursos com baixo (ou nenhum) custo de captação. No II PND, o BNDES pôde ainda contar com uma maior base financeira, decorrente dos recursos do arrecadados pelas contribuições do PIS-PASEP, que haviam passado para a sua administração em $1974^{180}$.

\footnotetext{
${ }^{179}$ Sobre o PROCAP, ver MARTINS, Luciano. Estado Capitalista e Burocracia no Brasil pós-64, op. cit., pp. 119-120.

${ }^{180}$ O PIS, Programa de Integração Social, e o PASEP, Programa de Formação do Patrimônio do Servidor Público, foram criados em 1970, respectivamente pelas leis complementares 7 e 8, de 1970, e consistiam em contribuições cobradas sobre a folha de pagamento das empesas privadas (PIS) e dos servidores públicos (PASEP). Foram alocados para o BNDES, em 1974.
} 


\begin{tabular}{|c|c|c|}
\hline \multicolumn{3}{|c|}{$\begin{array}{c}\text { QUADRO } 5 \\
\text { SÍNTESE DA ATUAÇÃO DO BNDES }\end{array}$} \\
\hline & $\begin{array}{c}\text { Recurso de poupança } \\
\text { compulsória }\end{array}$ & Direcionamento do crédito \\
\hline Plano de Metas & $\begin{array}{c}\text { Adicional do IR } \\
\text { Fundo Federal de Eletrificação }\end{array}$ & $\begin{array}{l}\text { Setor ferroviário } \\
\text { Setor elétrico } \\
\end{array}$ \\
\hline II PND & Contribuições PIS-PASEP & $\begin{array}{l}\text { Insumos básicos } \\
\text { Bens de capital }\end{array}$ \\
\hline
\end{tabular}

O encerramento do II PND, em 1979, marcou também o fim do período desenvolvimentista. Ao longo da década de 1980, o Brasil sofreu com uma significativa crise econômica, um reflexo de uma crise maior que se processava também nas demais economias de mercado - a desorganização da economia fordista. No panorama interno, as taxas de inflação crescentes no país contribuíram para um cenário de incerteza e instabilidade do arranjo jurídico-institucional. Até a metade da década de 1980, a intervenção do Estado oscilava entre as iniciativas de retorno à agenda desenvolvimentista e as iniciativas de alteração deste modelo. Deste este período, nenhum plano de desenvolvimento veio a ser efetivamente implementado novamente.

A atuação do BNDES se desincumbiu, então, de atender às metas e prioridades setoriais estipuladas pelos instrumentos de planejamento. Com isso, podem-se registrar duas tendências para a sua intervenção: (i) uma diversificação de suas atividades, sobretudo a partir da década de 1990, quando o Banco passou a financiar setores como o de serviços ${ }^{181}$ e (ii) a adoção de uma racionalidade pragmática, identificada em uma paulatina aproximação de suas operações em relação ao restante do mercado financeiro. Como parte deste processo, no final dos anos 1980, o BNDES se antecipou ao restante dos agentes de Estado e deu início à privatização das empresas privadas que haviam passado à sua gestão. Nesse período, também foi iniciada uma revisão dos critérios de seleção dos solicitantes de recursos: em 1989, foi criada a área de crédito do Banco, que passou a realizar análises de risco e em 1997, o risco de crédito passou a ser efetivamente um critério de decisão - as operações de colaboração financeira poderiam ser rejeitadas, caso apresentassem risco elevado. O mérito deixara de ser o critério prioritário do Banco. ${ }^{182}$

${ }^{181}$ Ver a respeito ALÉM, Ana Cláudia. O Desempenho do BNDES no Período Recente e as Metas da Política Econômica, Texto para Discussão, no. 65, BNDES, 1998, pp. 2-23.

182 A esse respeito, ver CURRALERO, Claudia Regina Baddini. A Atuação do Sistema BNDES como Instituição Financeira de Fomento no Período 1952-1996, op. cit. 
Estas transformações, que se fizeram acompanhar de uma maior atuação do BNDES no mercado de capitais, a partir dos anos 1990, estavam alinhadas ao contexto de crise do Estado e de reformas econômicas, ocorridas no país. Revelando alguma semelhança com as alterações processadas nos anos 1960, as recentes reformas de mercado também procuraram ampliar os espaços da participação privada, reorientando, assim, o funcionamento da alternativa institucional, que sustentou o desenvolvimentismo econômico. Assim como ocorrido nos 1960, tudo aponta, no entanto, para uma persistência da alternativa institucional, sobretudo nos novos setores, surgidos em função da economia baseada no conhecimento.

\section{CONSIDERAÇões FINAIS}

O esforço deste capítulo foi o de constituir e caracterizar um terceiro tipo de arranjo jurídico-institucional, para além daqueles que HALL \& SOSKICE e PISTOR já haviam apontado para as economias desenvolvidas. Foi com este propósito que se identificou o dispositivo da regulação institucional, que cumpre, nos países em desenvolvimento, um papel relevante na organização dos seus sistemas financeiros. No lugar dos mecanismos de proteção aos acionistas individuais ou das ferramentas que estimulam a coordenação relacional da governança corporativa, entre os bancos e as empresas, os países subdesenvolvidos têm contado com a participação direta do Estado, que faz as vezes de agente financeiro. No desempenho deste papel, os bancos públicos, notadamente os bancos de desenvolvimento, valem-se de mecanismos compulsórios de poupança, que são, por sua vez, direcionados para os segmentos econômicos selecionados pelo Estado, no âmbito dos seus programas de industrialização.

As razões para esta modalidade de organização jurídico-institucional deve-se às assimetrias ínsitas ao processo de desenvolvimento, que impõe às nações atrasadas um padrão de necessidades, equiparáveis às das economias já desenvolvidas. No caso da periferia econômica, a defasagem financeira dos poupadores privados e o menor amadurecimento das demais instituições financeiras têm reclamado uma expressiva participação do Estado, capaz de contornar as carências econômicas.

O panorama brasileiro parece ser um retrato fiel deste modelo. O desenvolvimento do país contou com uma atuação ativa do Estado que, ao longo das décadas de 1930, 1940 
e 1950 instituiu um aparato administrativo capaz de permitir uma coordenação pública da economia. É deste movimento que nasceu o BNDES, um dos maiores bancos de desenvolvimento do mundo. Entre 1952 e 1980, o Banco liderou o financiamento de longo prazo no Brasil, sendo um agente do Estado Desenvolvimentista, seja pela concessão de créditos para os setores escolhidos pelo governo, seja pela introdução de inovações na forma de contratação. Neste período, o Banco atuou como uma agência de fomento, dando viabilidade financeira ao estilo Estado-centrado de crescimento nacional.

Nas décadas de 1980 e 1990, esta forma de atuação do Estado, e conseqüentemente do Banco, sofreu alterações. Acusando o golpe da crise do fordismo, descrito no próximo capítulo, o arranjo jurídico-institucional desenvolvimentista foi desarticulado. Este processo costuma contar com duas interpretações antagônicas: de um lado, figuram aqueles que vêem nas reformas econômicas e nas privatizações dos anos 1990 o surgimento de um novo modelo de desenvolvimento, baseado no mercado, em que os agentes estatais, como os bancos públicos, por exemplo, tenderão a perder espaço; de outro, residem os que enxergam tais medidas liberalizantes como descaracterizadoras do modelo brasileiro, sugerindo que os novos mecanismos da ação estatal estão desalinhados em relação à sua adequada formulação - são incorretos.

A seqüência desta tese procurará refutar ambos os entendimentos. Inegavelmente, o desenvolvimentismo entrou em crise, mas isso não significou uma completa mudança da alternativa jurídico-institucional: os bancos estatais, e sobretudo o BNDES, persistem como agentes relevantes na organização financeira do país - desempenhando, assim, a regulação institucional. Por outro lado, os lampejos de uma economia baseada no conhecimento têm demandado uma reacomodação destes atores, capaz de garantir o desempenho de seus papéis em um ambiente privatizado e em que empresas emergentes e inovadoras passam a importar e reclamar ferramentas apropriadas de financiamento. Os próximos capítulos procurarão tratar deste movimento da alternativa jurídico-institucional, tendo como objeto imediato de análise a atuação do BNDES no financiamento da nova economia. 


\section{$-3-$ \\ A ECONOMIA BASEADA NO CONHECIMENTO: \\ A CRISE DO PARADIGMA FORDISTA-DESENVOLVIMENTISTA, AS POSSIBILIDADES DE PROSPERIDADE DAS INOVAÇÕES E A DEMANDA POR NOVOS ARRANJOS JURÍDICO- INSTITUCIONAIS}

\section{INTRODUÇÃO}

Os capítulos anteriores exploraram a variedade de arranjos institucionais que têm presidido a organização dos sistemas financeiros. Os respectivos modelos foram caracterizados em função do tipo predominante de organização encarregada do provimento do financiamento corporativo. Como visto, enquanto o modelo anglo-saxão tem baseado esta atividade no funcionamento do mercado de capitais, o padrão nipo-germânico tem contado, em boa medida, com a preponderância dos bancos privados. Já no financiamento industrial do desenvolvimentismo brasileiro, esta tarefa coube diretamente ao Estado.

Todos estes regimes institucionais foram construídos em função de uma trajetória histórica, constitutiva de cada um dos países. Respondendo a vicissitudes nacionais e reagindo aos respectivos ambientes jurídico-institucionais, cada nação moldou um característico formato de sistema financeiro. Nos Estados Unidos, a disponibilidade de capital privado para investimento, associado à representatividade social dos administradores corporativos, culminou na promulgação de um ato normativo restritivo à atuação dos bancos - o Glass Steagall Act - que fortaleceu ainda mais os traços peculiares daquele regime de financiamento. Da mesma forma, condições sociais locais e disposições normativas nacionais foram igualmente importantes para fortalecer o papel dos investidores institucionais, como os Bancos, tanto na Alemanha, como no Japão. Naturalmente, esta associação também esteve presente na definição do arranjo brasileiro, que procurou responder à carência de capital privado nacional com os mecanismos compulsórios de poupança e com a alocação direcionada dos recursos.

A definição de todos esses modelos esteve associada a um contexto históricoeconômico em que as idiossincrasias nacionais e a correspondente capacidade doméstica de responder a essas peculiaridades era bastante acentuada. Em outras palavras, durante um período significativo do século XX, que se estendeu entre os anos 1950 e 1980, conhecido 
como a era do consenso keynesiano, os países tiveram relativa liberdade para compor uma variedade de fórmulas jurídico-institucionais, sendo a pluralidade de sistemas financeiros apenas uma amostra disso. Estas três décadas estiveram associadas a um tipo de padrão produtivo conhecido por fordismo, que encerrava tanto uma técnica industrial, baseada na produção seriada de larga escala, como um tipo de relação social e um modo de regulação econômica. No plano financeiro, o fordismo demandou o desenho de arranjos e instrumentos que, embora fossem nacionalmente forjados, atendiam ao propósito genérico de capitalizar a grande indústria de massa.

Aceita-se como premissa de análise deste trabalho que este paradigma tecnoprodutivo apresentou, no entanto, sinais de fadiga na década de 1970 e em seu lugar tem se consolidado, paulatinamente, um paradigma alternativo, a economia baseada no conhecimento. Conforme essa interpretação, em reação à crise do fordismo e do keynesianismo, podem-se verificar novas estratégias corporativas, que se afastam dos traços de uma produção padronizada e de massa e apostam na segmentação dos mercados e na inovação de processos e produtos. O redirecionamento do mundo corporativo teria suporte em um padrão diferenciado de intervenção pública: compromissada com a difusão do conhecimento e com a promoção sistêmica da competitividade e da capacidade de inovação, mas afinada com instrumentos de intervenção menos diretivos ou substantivos. Notadamente no que importa ao Brasil, essa recomposição resvalaria no cerne do arranjo jurídico-instucional desenvolvimentista, que tinha na atuação direta do Estado um de seus pilares de sustentação - em especial, no sistema financeiro.

O objetivo deste capítulo é justamente retratar este percurso, que se inicia na descrição de uma economia fordista-keynesiana e alcança a caracterização deste novo paradigma de organização econômica. Para tanto, esta seção assumirá a reconstrução dessa transição realizada por quatro autores, que são referências intelectuais nesse relato, são eles: Michael PIORE \& Charles SABEL, David HARVEY e Bob JESSOP. São estes os autores que têm protagonizado a identificação deste novo regime de acumulação, na expressão costumeiramente utilizada por HARVEY e JESSOP, pautando assim a literatura que tem se encarregado de descrever essa nova economia das inovações, como é o caso, no Brasil, de José Eduardo CASSIOLATO, Helena LASTRES, João Carlos FERRAZ e Glauco ARBIX, entre outros. Espera-se, ao final deste capítulo, uma descrição deste novo panorama social e econômico, que permitirá discutir, no restante da tese, as respectivas 
características assumidas pelo arranjo-jurídico institucional em face dos desdobramentos desta economia baseada no conhecimento.

Para tanto, o capítulo esta divido em outras quatro seções: (i) na primeira delas, procurar-se-á identificar os atributos da economia fordista, que de alguma forma influenciou as estratégias desenvolvimentistas da periferia econômica; (ii) na segunda parte, trata-se de narrar a crise deste paradigma, sugerindo que parte da crise do modelo brasileiro esteve associada às turbulências vivenciadas pelas economias de centro, nas décadas de 1970 e 1980; (iii) a terceira seção, volta-se a identificar a economia baseada no conhecimento como sendo uma resposta à crise do fordismo e como tal está associada a uma reorganização jurídico-institucional; (iv) a quarta seção apresenta as considerações finais.

\section{O PARADIGMA FORDISTA: RIGIDEZ DOS FATORES, ECONOMIA DE MASSA E A RELEVÂNCIA DAS CORPORAÇÕES E DA INTERVENÇÃO ESTATAL}

O fordismo é a expressão empregada para descrever um modelo de organização da produção industrial que apresentava um rol de características bastante definidas. Deste conjunto faziam parte uma determinada técnica produtiva, um tipo específico de relação de trabalho, um correspondente modelo de eficiência, um característico produto fabril e um espectro de consumo. O fordismo formava, assim, um paradigma tecno-produtivo, isto é, um conjunto coerente de soluções técnicas para os desafios da produção industrial ${ }^{183}$. O nome do padrão produtivo foi um legado de Henry FORD, cujas linhas de montagem de automóveis funcionaram como um exemplo cabal desta prática produtiva, que se tornou difundida nos Estados Unidos em meados da Primeira Guerra Mundial, consolidando-se nos demais países ocidentais (e alguns orientais) após a Segunda Guerra Mundial.

\footnotetext{
${ }^{183}$ A idéia de paradigma tecno-produtivo é trabalhada pelo autores neo-schumpeterianos, que formulam este conceito a partir da noção de paradigma científico de Thomas KUHN. O paradigma científico pode ser entendido como um padrão consolidado de explicações para os fatos naturais e que ao se firmar como paradigma exclui outras explicações alternativas. De forma semelhante, um paradigma tecnológico é uma solução tecnológica e que ao se assumir como paradigma exclui outras possíveis. A esse respeito ver DOSI, Giovanni. Mudança Técnica e Transformação Industrial - a teoria e uma aplicação à indústria de semicondutores, (trad. Carlos D. Szlak), Campinas, Unicamp, 2006, pp. 29-53.Ver também LASTRES, Helena Maria Martins \& FERRAZ, João Carlos. Economia da Informação, do Conhecimento e do Aprendizado, em LASTRES, Helena \& ALBAGLI, Sarita (org.). Informação e Globalização na Era do Conhecimento, Rio de Janeiro, Campus, 1999, pp. 27-57.
} 
A técnica produtiva fordista consistia na racionalização máxima da produção, mediante uma segmentação do processo produtivo, de modo a maximizar a divisão do trabalho. Com isso, não só o trabalho se tornava mais rápido e eficiente, já que a rotina e a repetição garantiam maior agilidade para a produção, como também abriam-se possibilidades para uma ampliada automação das indústrias. O desmembramento das etapas de produção permitia a introdução de máquinas dedicadas, isto é, especializadas em oferecer um único tipo de produto. A rigorosa divisão das etapas do trabalho e a utilização de máquinas de propósito específico garantiu ao fordismo uma elevada produtividade industrial, resultando assim em um maior volume de produtos por tempo de produção.

A relação entre o fracionamento das tarefas e o seu impacto nos ganhos de eficiência, que foi radicalizada pelo regime fordista, já tinha sido tratada por uma longa tradição de autores, que ia desde Adam SMITH até Fredrick TAYLOR, que em 1911 publicou os Princípios da Administração Científica, tornando-se, assim, um dos grandes teóricos da gestão empresarial do período. ${ }^{184}$ Nas indústrias comandadas por Henry FORD, as possibilidades teóricas desses ganhos de eficiência e produtividade não só passaram a ser realidade, como foram ainda estendidas, em razão da introdução de algumas inovações produtivas. Para além de racionalizar e automatizar a produção, FORD introduziu, por exemplo, uma nova concepção de linha de montagem, em que o trabalhador permanecia parado em seu posto, reduzindo assim eventuais perdas com deslocamentos dentro da planta industrial $^{185}$. Foram feitos como esse que se difundiram para as demais empresas contemporâneas.

Uma técnica produtiva como a fordista, calcada no desmembramento das funções dentro da fábrica, trazia consigo uma determinada forma de relação de trabalho. Na

\footnotetext{
${ }^{184}$ Em The Second Industrial Divide - possibilities for prosperity, Michael PIORE \& Charles SABEL apresentam uma reconstrução da associação entre o fordismo e a idéia de progresso. Nesse percurso situam uma corrente teórica de autores que entendem o desenvolvimento como um processo de crescente produtividade desencadeado pela racionalização da produção, de tal modo que a produção em série do início do século XX seria o ponto de chegada deste trajeto. Para os autores, essa concepção do desenvolvimento como racionalização conta com Adam SMITH, que via a divisão do trabalho como um grande responsável pelo acréscimo de eficiência produtiva e também com Karl MARX, que identificava na mecanização do trabalho fragmentado um incremento aos ganhos obtidos com a divisão de tarefas. Ver a esse respeito PIORE, Michael \& SABEL, Charles. The Second Industrial Divide - possibilities for prosperity, New York, Basic Books, 1984, pp. 19-48.

${ }^{185}$ Essa referência à inovação de FORD é apresentada por HARVEY, David. A Condição Pós-Moderna uma pesquisa sobre as origens da mudança cultural, (trad. Adail Ubirajara Sobral \& Maria Stela Gonçalves), São Paulo, Loyola, 1989, pp. 121-134.
} 
medida em que o trabalhador detinha uma tarefa específica, via de regra adjacente à uma máquina de propósito especializado, não se demandava que essa mão de obra apresentasse alguma qualificação superlativa. O ofício na planta fordista não envolvia concepção e nem tampouco demandava uma multiplicidade de habilidades. A própria proposta de simplificação das etapas de produção, como forma de racionalizar o processo industrial, pressupunha um operário com baixa especialização profissional. Tanto quanto a máquina, o trabalhador fordista dedicava-se a cumprir uma tarefa, rigidamente atribuída. ${ }^{186}$

Um regime como esse, em que os meios de produção, físicos e humanos, como as máquinas, os equipamentos e a força de trabalho, eram dedicados e, assim sendo, encarregados de cumprir tarefas específicas, previamente determinadas, tinha como resultado uma elevada escala de produção, o que estava associado a um subjacente modelo de eficiência. Na medida em que os recursos cumpriam funções técnicas específicas, havia ganhos proporcionais com o aumento da quantidade de bens produzidos - configurando assim uma economia de escala. Em outros termos, como os meios materiais e humanos já estavam empregados e eram vinculados ao cumprimento de uma tarefa específica, a racionalidade daquele regime apontava para a obtenção de ganhos, conforme fosse ampliado o número de tarefas cumpridas pelos respectivos responsáveis. Em última instância, um operário encarregado de apertar parafusos na lataria de um automóvel seria tanto mais econômico para a firma, quanto mais parafusos fossem apertados por hora. Assim, ao lado de uma técnica fragmentada de trabalho e de um trabalhador parcamente especializado, a larga escala de produção apresentava-se como uma das características típicas deste contexto econômico.

O funcionamento da engrenagem fordista contava também com um determinado tipo de produto fabril. Os ganhos de escala e o emprego de uma técnica produtiva de elevada segmentação estavam associados à produção de bens padronizados. Tratava-se de um corolário deste regime produtivo, já que a linha de montagem para ser eficiente deveria

\footnotetext{
${ }^{186} \mathrm{O}$ fato de o trabalhador ter uma tarefa determinada não significava uma especialização, uma vez que não se tratava de uma habilidade profissional, mas sim de um exercício constante e repetitivo de produção. É diferente nesse sentido de um profissional dotado de elevada aptidão técnica, como um artesão, a quem incumbe a formulação e a execução de um repertório variado de atividades congêneres. É bem verdade que a planta industrial também apresentava trabalhadores especializados, mas a fonte de dinamismo era a produção seriada, em linha de montagem, operada por trabalhadores com baixa qualificação. A esse respeito ver JESSOP, Bob. The Future of Capitalist State, (Reimpressão), Cambridge, Polity Press, 2005, pp. 55-94. Ver também PIORE, Michael \& SABEL, Charles. The Second Industrial Divide, op. cit.
} 
produzir bens em série, dotados de uma mesma medida, pois do contrário haveria a necessidade de se reposicionar e reajustar máquinas e trabalhadores. Na fábrica de automóveis de FORD, em Michigan, por exemplo, a linha de montagem dedicava-se à produção de um veículo standard, de baixo custo e produzido em uma larga escala - o modelo Ford $\mathrm{T}^{187}$.

O ciclo produtivo do paradigma fordista encerrava-se com um determinado espectro de consumo, o consumo de massa. Os bens padronizados, provenientes de um processo produtivo baseado na redução de custos, que fora permitida pela ampliação da escala, constituíam uma oferta ampliada, dirigida, por sua vez, ao consumo em uma escala igualmente significativa. Com isso a economia fordista completava um círculo virtuoso, descrito por Bob JESSOP: a produção em massa apresentava ganhos de produtividade em virtude da escala industrial, tais ganhos eram expressos na forma de um aumento da renda, o que, então, implicava ganhos salariais e um consequiente aumento do poder de consumo das massas de trabalhadores, o que, afinal, garantia uma plena utilização dos fatores de produção e com isso uma realimentação ascendente do espiral de crescimento econômico $^{188}$. Este movimento foi antevisto já em 1914 por Henry FORD, que implementou a famosa jornada de oito horas e cinco dólares, franqueando assim aos seus operários tempo livre e condições financeiras para o consumo. ${ }^{189}$

A observação deste ciclo consistente de produção e consumo, associado à difusão deste paradigma tecno-produtivo pelos mais variados segmentos industriais na metade do século XX, transmite a percepção de que o fordismo era de fato não um paradigma dentre tantos outros, mas sim uma solução industrial inexorável. A idéia subjacente a esta percepção é a de que se trataria de um patamar industrial de superação, uma espécie de curso forçado, em termos de racionalização e produtividade. Percepção equivocada, no entanto. Ao menos para a literatura que admite a noção de paradigmas tecno-produtivos.

A despeito da sensação de progresso e de plena integração com a fase madura do capitalismo, o fordismo, tanto quanto os demais paradigmas tecnológicos, não trazia

\footnotetext{
${ }^{187}$ A esse respeito ver PIORE, Michael \& SABEL, Charles. The Second Industrial Divide, op. cit., pp. 49-72.

${ }^{188}$ Como lembra JESSOP, conquanto pudesse existir setores que funcionassem em outras bases, estas eram as características dos setores líderes das economias. Sobre isso e sobre o círculo virtuoso acima descrito, ver JESSOP, Bob. The Future of Capitalist State, op. cit.

${ }^{189}$ Sobre a relação entre tempo livre, poder de compra e geração de demanda, ver HARVEY, David. A Condição Pós-Moderna, op. cit.
} 
consigo um destino manifesto, como se fosse uma decorrência lógica e necessária do processo industrial. Tratou-se na verdade da consolidação de uma alternativa de organização social e industrial, que para tanto contou com uma composição dos grupos de interesse e com a definição de um correspondente anteparo institucional, que lhe deu guarida e viabilidade. Do contrário, sem os mecanismos jurídico-institucionais de salvaguarda, como a grande corporação e a intervenção estatal, nada garantiria que o fordismo não se enredasse na teia de suas próprias contradições ${ }^{190}$.

Para reforçar este ponto, em um exercício de reconstrução histórica PIORE \& SABEL $^{191}$ sustentam que, ao longo do século XIX, dois paradigmas industriais estavam em rota de colisão: a produção em massa e a produção flexível. Diferentemente da primeira, a produção flexível (craft production) contava com máquinas de aplicação universal, dotadas de uma ampla capacidade de utilização, em uma diversidade de sistemas de produção. Contava ainda com um trabalhador especializado, capaz de formular e executar atividades que demandavam uma elevada habilidade técnica e mental. Esse sistema de produção permitia que os insumos, máquinas e mão de obra, fossem adaptáveis às necessidades e às vontades do público consumidor, permitindo assim a possibilidade de se confeccionar produtos customizados e especializados. Dada a habilidade múltipla dos trabalhadores, que dominavam um conjunto de técnicas produtivas, e a utilização de máquinas de propósitos gerais, esse sistema industrial organizava a produção em famílias de produtos, como, por exemplo, vestuário, sapatos, ferramentas e máquinas industriais. Dentro dessa família de produtos havia, por sua vez, flexibilidade, de tal modo que o ritmo e o estilo da produção de cada item era tão cambiante, quanto a própria demanda ${ }^{192}$.

Um exemplo da vitalidade do regime industrial flexível seriam os distritos industriais europeus, que marcaram a produção industrial continental no século XIX. ${ }^{193}$ Voltados para a produção de artefatos de qualidade e de luxo, os distritos industriais

\footnotetext{
${ }^{190}$ Essa é uma tese bastante central do livro de PIORE \& SABEL, a que também faz referência HARVEY. A esse respeito ver PIORE, Michael \& SABEL. Charles. The Second Industrial Divide, op. cit., pp. 19-48 e HARVEY, David. A Condição Pós-Moderna, op. cit.

${ }^{191}$ PIORE, Michael \& SABEL, Charles. The Second Industrial Divide, op. cit.

${ }^{192}$ Esses traços são bastante evidentes na indústria contemporânea da moda, que alterna estilos e padrões a cada temporada. Na base desse segmento há um tipo de profissional que não dissocia a concepção e a execução do produto e é capaz de alternar o ciclo produtivo em função do comportamento do consumidor. Esta flexibilidade não estava presente na típica indústria fordista. Sobre a especialização flexível, ver PIORE, Michael \& SABEL, Charles. The Second Industrial Divide, op. cit.

193 A descrição do funcionamento dos distritos industrias pode ser vista em PIORE, Michael \& SABEL, Charles. The Second Industrial Divide, op. cit., pp 19-48.
} 
contavam com profissionais detentores de uma habilidade técnica comparável à de um artesão. Com uma formação profissional bastante diversa da dos operários fordistas, os "artesãos" industriais detinham uma técnica específica de produção e pertenciam a uma categoria profissional designada pelo ofício de que se encarregavam. A prevalência deste tipo de produção na Europa postergou a consolidação do fordismo, que só ganhou terreno de fato depois da $2^{\mathrm{a}}$ guerra, muito depois das inovações de processo e de produto apresentadas por FORD. A seguinte passagem de David HARVEY, situa bem essa polaridade de regimes industriais:

\begin{abstract}
A tecnologia de linha de montagem para a produção em massa, implantada em muitos pontos dos Estados Unidos, tinha um desenvolvimento muito fraco na Europa antes da metade dos anos 30. A indústria de automóveis européia, com exceção da fábrica da FIAT em Turim, permanecia em sua maior parte uma indústria artesanal de alta habilidade (embora organizada corporativamente), produzindo carros de luxo para consumidores de elite, sendo apenas ligeiramente influenciada pelos procedimentos de linha de montagem na produção em massa de modelos mais baratos antes da Segunda Guerra Mundial. Foi preciso uma enorme revolução das relações de classe (uma revolução que começou nos anos 30, mas só deu frutos nos anos 50) para acomodar a disseminação do fordismo à Europa ${ }^{194}$.
\end{abstract}

Mas se esta descrição tem alguma fidelidade histórica, o que então permitiu a franca hegemonia do fordismo, a partir da década de 1950? Dentre tantos fatores que podem explicar um processo social, há dois que parecem estar bastante associados à hegemonia do fordismo: (i) uma vitória conceitual deste regime industrial como um paradigma tecno-econômico, e (ii) a definição de um arranjo jurídico-institucional propício ao seu florescimento.

A supremacia do fordismo como regime de organização industrial deveu-se, em primeiro lugar, à sua consolidação como um paradigma tecno-produtivo e a conseqüente

\footnotetext{
${ }^{194}$ HARVEY, David. A Condição Pós-Moderna, op. cit. pp. 123-124. A rigor, até o final da primeira guerra mundial, a indústria alemã de bens de capital e ferramentas industriais, por exemplo, mostrava-se tão competitiva quanto a norte-americana e isso justamente pela sua capacidade de produção especializada aos propósitos do consumidor. Comentando as diferenças entre ambos os estilos industriais, PIORE \& SABEL assinalam que enquanto o sistema fordista norte-americano privilegiava a capacidade de marketing, a produção flexível dos distritos alemães concentrava-se nas virtudes técnicas do produto industrial. Segundo os autores, outros tantos distritos industriais como Sheffield, Birmingham e Saint-Étienne, compartilhavam o mesmo êxito de uma indústria especializada, assistindo a introdução de importantes inovações tecnológicas, como no caso do desenvolvimento das fibras artificiais, como o Nylon e o Tergal, pelos produtores do distrito de Lyon, notabilizado pela indústria de tecidos e pelas confecções. Ver a respeito PIORE, Michael \& SABEL, Charles. The Second Industrial Divide, op. cit.
} 
derrocada de outros regimes alternativos ${ }^{195}$. Para a literatura que admite a idéia de paradigmas tecno-produtivos, a consolidação de uma via tecnológica, assim como de um padrão científico, não representa uma necessária superioridade técnica do modelo vencedor. Partindo-se do pressuposto de que existe um conjunto de alternativas científicas, no caso dos paradigmas científicos, ou de alternativas tecnológicas, quando se trata de uma paradigma tecno-produtivo, a seleção de um conjunto de soluções está bastante associada aos recursos de poder dos grupos interessados. Notadamente no caso dos paradigmas tecno-produtivos, a detenção de meios para a promoção de uma alternativa industrial, em detrimento de outra, é particularmente relevante. Assumindo a existência de alternativas técnicas igualmente viáveis, a opção por um regime ou por outro refletiria, conforme esta leitura, muito mais uma correlação de forças, do que propriamente uma ascética seleção natural, modulada pelo valor da eficiência. Os recursos de poder são variáveis particularmente importantes neste processo de seleção, dado que políticas econômicas e instrumentos regulatórios podem significar o arbitramento de uma competição tecnológica entre postulantes igualmente habilitados ${ }^{196}$.

No embate entre o fordismo e a produção flexível, a disputa foi arbitrada em favor do primeiro. As condições institucionais formuladas no período favoreceram a organização da indústria de massa e relegaram aos distritos industriais uma condição conceitual de inviabilidade técnica. No limite, argumentam PIORE \& SABEL ${ }^{197}$, até o momento da definição de qual o caminho vencedor, o progresso técnico pode ser descrito como uma árvore de galhos igualmente viáveis. A opção por um dos galhos como direção correta, todavia, faz dos demais meras possibilidades inadequadas, transmitindo assim a certeza de que o rumo escolhido era de fato o único realmente possível. Foi esse o caso do fordismo. ${ }^{198}$

195 Sobre isso ver PIORE, Michael \& SABEL. Charles. The Second Industrial Divide, op. cit
196 A seguinte passagem de PIORE \& SABEL permite uma boa compreensão deste ponto: “ in analogy to
scientific revolutions, technological branching points - or divides - mark not just the moments at which
political context and their associated markets push industrial development down a divergent path; they also
mark the consolidation of new visions of efficient production - new technological paradigms, or
trajectories.” PIORE, Michael \& SABEL, Charles. The Second Industrial Divide, op. cit. p. 44 .
${ }_{197}$ PIORE, Michael \& SABEL, Charles. The Second Industrial Divide, op. cit., pp. 19-48.
${ }^{198}$ A seguinte passagem de HARVEY parece corroborar as análises de PIORE \& SABEL, de que o fordismo
foi um processo socialmente construído e não uma decorrência natural de sua imanente eficiência: "o modo
como o sistema fordista se estabeleceu constitui, com efeito, uma longa e complicada história que se estende
por quase meio século. Isso dependeu de uma miríade de decisões individuais, corporativas, institucionais e
estatais, muitas delas escolhas políticas feitas ao acaso ou respostas improvisadas às tendências de crise do 
Foi esse também o caso do desenvolvimentismo, nos países da periferia do capitalismo. Os países latino-americanos e asiáticos, tributários da economia do desenvolvimento, assumiram a lógica de progresso fordista, procurando então racionalizar os processos produtivos e desenvolver indústrias de massa, sobretudo de bens de consumo duráveis, como é o caso da indústria automotiva brasileira. ${ }^{199}$ Amparada na crítica das vantagens comparativas estáticas, que relegavam a estes países a especialização em produtos primários, a economia do desenvolvimento assumiu uma interpretação e uma conseqüente estratégia política, dirigidas a garantir a estes países a internalização do mesmo círculo virtuoso verificado na industrialização dos países desenvolvidos.

Em particular na América Latina, como visto no capítulo anterior, os diagnósticos da CEPAL apontavam os problemas da manutenção da especialização agrária, indicando que, no médio prazo, os latino-americanos perdiam recursos nas trocas com os países industriais, a famosa tese da deterioração dos termos de troca. ${ }^{200}$ A reversão deste processo demandava a industrialização destes países, aos moldes das economias de centro. Somente a alteração do destino original e a implementação do programa de industrialização é que permitiriam, de acordo com esse argumento, o desenvolvimento econômico, traduzido por Raul PREBISCH ${ }^{201}$ em um espiral positivo muito semelhante ao descrito por JESSOP, para o fordismo. Para PREBISCH, o incremento técnico industrial levaria a um aumento de produtividade, e com isso a um maior rendimento dos fatores, o que estaria associado, por sua vez, a uma ampliação da renda e dos salários de toda a coletividade. De forma semelhante, Celso FURTADO ${ }^{202}$ também tomava o desenvolvimento como um processo

capitalismo, particularmente em sua manifestação na Grande Depressão dos anos 30." HARVEY, David. A Condição Pós-Moderna, op. cit. pp. 122-123.

${ }^{199}$ Essa tese é desenvolvida por SABEL, nos seguintes termos: "a economia política clássica considerava o surgimento da produção em massa como uma precondição da industrialização. Esse ponto de vista moldou a economia do desenvolvimento no pós-guerra e as escolhas estratégicas das elites do Terceiro Mundo especialmente na América Latina." Sobre a inspiração fordista do desenvolvimento da periferia, ver SABEL, Charles. Mudança de Modelos de Eficiência e suas Implicações para a Industrialização no Terceiro Mundo, op. cit. p. 33.

${ }^{200}$ A esse respeito ver PREBISCH, Raul. O Desenvolvimento Econômico da América Latina e Alguns de seus Problemas Principais, op. cit., pp. 69-136.

${ }^{201}$ Sobre o argumento da CEPAL e o círculo virtuoso da industrialização ver PREBISCH, Raul. $O$ Desenvolvimento Econômico da América Latina e Alguns de seus Problemas Principais, op. cit.

${ }^{202}$ Celso FURTADO tinha uma compreensão ampla sobre o desenvolvimento, tomando-o em como um processo de racionalização produtiva e como um processo de desenvolvimento humano, em que figura associado à satisfação dos desejos e necessidades humanas. No que toca ao enfoque econômico, em particular, a lógica sobre a qual se assenta é semelhante à do fordismo, isto é, amparado na noção de maximização do progresso técnico. A esse respeito vale a seguinte passagem do autor: "O conceito de desenvolvimento tem sido utilizado, com referência à história contemporânea, em dois sentidos distintos. $O$ 
de racionalização das técnicas produtivas: seria esta a maneira de se garantir uma maior eficácia da produção e a conseqüente geração e difusão da riqueza. O resultado dessas premissas conceituais pode ser visto na tabela abaixo, que apresenta uma evolução dos setores industriais brasileiros, ao longo do período desenvolvimentista e ilustra justamente um crescimento acelerado dos setores relacionados à produção em massa - bens de consumo duráveis (como os automóveis) e os bens de capital.

\begin{tabular}{|c|c|c|}
\hline \multicolumn{2}{|c|}{ QUADRO 6 } \\
\hline EVOLUÇão DA INDUSTRIALIZAÇÃO BRASILEIRA (\%) \\
\hline Períodos & $1950-1955$ & $1956-1959$ \\
\hline Indústria de transformação & 8,8 & 11,1 \\
\hline Consumo durável & 25 & 22,7 \\
\hline Consumo não-durável & 6,2 & 6,5 \\
\hline Bens intermediários & 12,2 & 11,3 \\
\hline Bens de capital & 12,3 & 34,8 \\
\hline Fonte: CURRALERO apud BONELLI & \\
\hline
\end{tabular}

Seja no centro, seja na periferia, o fato é que a viabilidade deste paradigma tecnoprodutivo pressupunha o desenho de um apropriado substrato institucional, capaz de mitigar alguns de seus mais intrincados problemas, como a garantia de uma capacidade de consumo permanente e a formação das condições de infra-estrutura, sobretudo para os países retardatários. Diferentemente da técnica produtiva dos distritos industriais, a produção fordista não detinha a propriedade de absorver uma oscilação continuada da demanda. ${ }^{204} \mathrm{Da}$ mesma forma como os bens eram padronizados e não se sujeitavam a gostos e preferências particulares, a produção fordista também não admitia a maleabilidade do volume de produção. Na indústria de massa, independentemente do quantum consumido, os fatores de produção permaneciam rigidamente à disposição do empreendedor, que contava, então, com pouca margem de manobra.

primeiro diz respeito à evolução de um sistema social de produção à medida que este, mediante a acumulação e o progresso das técnicas, torna-se mais eficaz, ou seja, eleva a produtividade do conjunto de sua força de trabalho." FURTADO, Celso. Introdução ao Desenvolvimento - enfoque histórico-estrutural, $3^{\mathrm{a}}$ Ed., Rio de Janeiro, Paz e Terra, 2000, p. 21.

${ }^{203}$ CURRALERO, Claudia Regina Baddini. A Atuação do Sistema BNDES como Instituição Financeira de Fomento no Período 1952-1996, op. cit. apud BONELLI, R. Ensaios sobre Política Econômica e Industrialização no Brasil, Rio de Janeiro, SENAI/DITEC/DPEA, CIET, 1995.

${ }^{204}$ Cf. PIORE, Michael \& SABEL, Charles. The Second Industrial Divide, op. cit e também JESSOP, ao comentar às funções do que ele chama KWNS (Keynesian Welfare National State): "the KWNS attempted to adjust effective demand to the supply -driven needs of Fordist mass production with its dependence on economies of scale and full utilization of relatively inflexible means of production." JESSOP, Bob. The Future of Capitalist State, op. cit. p. 59. 
À distinção dos funcionários do regime de especialização flexível, o operário fordista detinha um repertório profissional pequeno e bastante associado ao tipo de função fragmentada que lhe fora atribuída. Já as máquinas empregadas neste regime cumpriam tarefas bastante delimitadas, e não podiam ser facilmente reempregadas em outros usos e atribuições. Tratava-se, portanto, de um regime de produção em que havia baixa mobilidade dos fatores. Com isso, diante de um eventual problema cíclico de consumo, a única opção reservada ao empreendedor seria amargar perdas com uma larga escala de produtos confeccionados e não consumidos. A outra opção, igualmente ruim, seria reduzir a capacidade de produção, o que significaria igualmente um prejuízo, já que os fatores de produção não funcionariam com a plena utilização possível, implicando assim um considerável custo de oportunidade ${ }^{205}$.

Por tais razões, uma variável crítica para a viabilidade deste regime era a capacidade de se amortecer as oscilações de demanda. Somente desta maneira seria possível assegurar que os recursos fossem efetivamente empregados e o seu uso remunerado com um fluxo continuado de vendas, garantindo assim o círculo virtuoso descrito acima por Bob JESSOP. Tratava-se, portanto, de se sustentar um mercado consumidor permanente, como salientam PIORE \& SABEL na seguinte passagem:

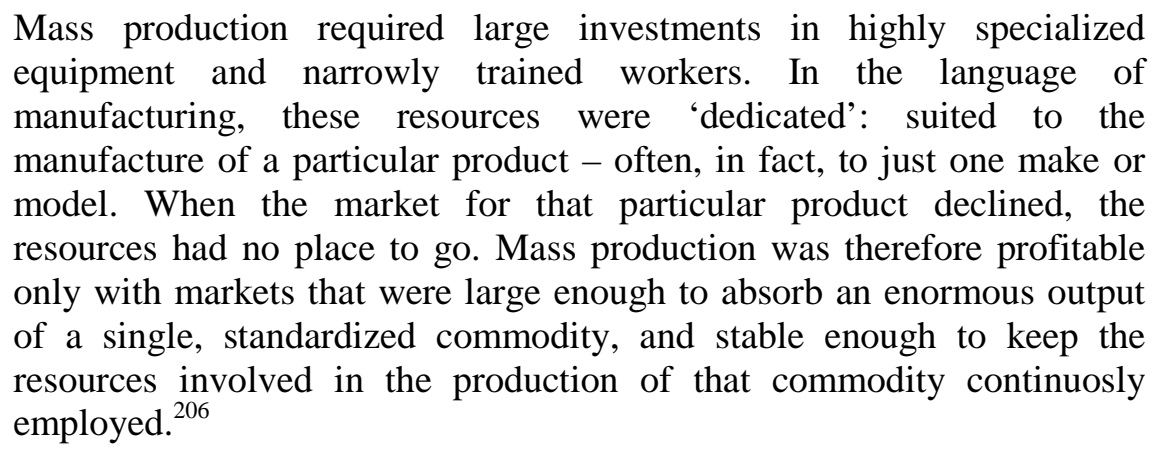

O equacionamento deste problema contou com dois dispositivos institucionais, um deles voltado para a administração da demanda nos segmentos de mercado e o outro vinculado a proteger o conjunto da economia contra flutuações pronunciadas. $\mathrm{O}$ primeiro destes dispositivos foi a organização corporativa dos setores industriais, responsável por uma coordenação microeconômica do processo produtivo. O segundo, encarregado da

${ }^{205}$ Sobre essa rigidez do fordismo e a necessidade de uma demanda estável, ver PIORE, Michael \& SABEL, Charles. The Second Industrial Divide, op. cit., pp. 49-72 e 73-104. Ver também HARVEY, David. A Condição Pós-Moderna, op. cit. pp. 121-134.

${ }^{206}$ PIORE, Michael \& SABEL, Charles. The Second Industrial Divide, op. cit. p. 49. 
gestão macroeconômica, foi o Estado Keynesiano ${ }^{207}$, em suas múltiplas feições locais, entre as quais o Estado Desenvolvimentista, que ao lado da geração da demanda, incumbia-se, ainda, da provisão do capital, como visto no capítulo anterior.

\subsection{O PAPEL DAS CORPORAÇÕES NO PARADIGMA FORDista: COORDENAÇÃo MICROECONÔMICA, CAPTAÇÃO FINANCEIRA E REALIZAÇÃO DOS INVESTIMENTOS INDUSTRIAIS}

A julgar por essa descrição do sistema fordista, que enfatiza a rigidez dos fatores e a parca capacidade de adaptação dos elementos produtivos aos ciclos econômicos, fica evidente a necessidade de se garantir um permanente mercado consumidor para os produtores de massa. A criação de um mercado consumidor cativo, como forma de evitar eventuais temporadas de subconsumo, contou com as estratégias de concentração do poder econômico, por meio da formação das grandes corporações. Foi desta maneira que os empreendedores fordistas procuraram evitar a competição acirrada, capaz de dividir o universo de consumidores e gerar uma indesejada oscilação no patamar de vendas. ${ }^{208}$

A formação das corporações e o domínio dos mercados garantia ainda para os industriais do período a possibilidade de planejar a sua estratégia comercial, permitindo assim um certo horizonte de previsibilidade para ações de médio e longo prazo, como a realização de investimentos ou a adoção de novas tecnologias. A rigor, a organização destes grandes grupos, assentados em uma racionalidade administrativa burocrática, convergia com as expectativas de estabilidade e gestão compassada do fluxo econômico, que caracterizavam o sistema industrial do fordismo. ${ }^{209} \mathrm{Na}$ realidade, o papel que as

\footnotetext{
207 Ver a esse respeito HARVEY, David. A Condição Pós-Moderna, op. cit.; JESSOP, Bob. The Future of Capitalist State, pp. 55-94 e PIORE, Michael \& SABEL, Charles. The Second Industrial Divide, op. cit., pp. 73-104. A seguinte passagem de JESSOP ilustra o papel dos diversos mecanismos reguladores do fordismo. Esta seção abordará apenas dois destes mecanismos, seguindo assim a abordagem sugerida por PIORE \& SABEL. Mesmo assim, vale a descrição de JESSOP: "as a mode of economic regulation, Fordism can be considered in terms of five structural forms of regulation: the enterprise form and modes of competition, the wage relation, the nature of monetary emission and credit relations, the form and functions of the state, and the manner of its insertion into international regimes." JESSOP, Bob. The Future of Capitalist State, op. cit. p. 57.

${ }^{208}$ Sobre essa associação entre concentração do poder econômico e garantia da demanda, ver PIORE, Michael \& SABEL, Charles. The Second Industrial Divide, op. cit., pp.49-72.

${ }^{209}$ Sobre a prevalência da grande corporação nesse período, HARVEY assinala que: "utilizava-se o grande poder corporativo para assegurar o crescimento sustentado de investimentos que aumentassem a produtividade, garantissem o crescimento e elevassem o padrão de vida enquanto mantinham uma base estável para a realização de lucros." HARVEY, David. A Condição Pós-Moderna, op. cit. p. 129.
} 
grandes corporações cumpriam ultrapassava a disposição de monopolizar e garantir mercados. Tratava-se, isto sim, da constituição de um sistema de coordenação microeconômica, alternativo ao sistema de preços, que, a um só tempo, propiciava a manuteção do mercado consumidor e ainda permitia uma concatenação entre os diversos agentes econômicos. Esperava-se, com isso, eliminar possíveis desajustes existentes nas cadeias produtivas que, porventura, pudessem prejudicar a capacidade permanente de venda e de consumo - um fator ínsito a este modelo de organização industrial.

A coordenação pelos preços é típica de uma economia neoclássica, isto é, uma economia perfeitamente competitiva. Em um ambiente de concorrência perfeita, presumese a existência de uma pluralidade de agentes econômicos, dotados de plena informação acerca do funcionamento dos mercados e titulares de fatores de produção com plena mobilidade. Em uma economia como essa, característica de um período que se estendeu dos séculos XIX ao início do XX, os desequilíbrios de oferta e demanda resvalavam no valor dos preços relativos, que acabavam por pautar as decisões dos agentes econômicos. Perdas de consumo, por exemplo, poderiam ser compensadas com a mobilidade para mercados adjacentes, assim como uma eventual escassez de oferta poderia ter o efeito de atrair novos empreendedores, atraídos pela majoração temporária dos preços. Mas eram justamente estas oscilações que os empreendedores fordistas procuravam evitar: seus recursos não detinham mais essa plena mobilidade.

Sendo assim, as corporações significaram também uma resposta para garantir uma organização da produção, alheia às descontinuidades do mercado, ou seja, um dispositivo capaz de evitar quaisquer formas de interrupção da atividade industrial. A substituição da regulação oferecida pelos mercados competitivos veio na forma de estratégias empresariais horizontais e verticais ${ }^{210}$. No plano horizontal, tratava-se de eliminar o excesso de competição, garantindo-se uma demanda estável. Já no plano vertical, cuidava-se, em regra, das integrações entre produtores e distribuidores, com vistas a evitar descasamentos de interesses, que viessem a resultar em soluções de continuidade do processo produtivo. A constituição destes mecanismos extra-concorrenciais de coordenação tiveram início em acordos e contratos entre unidades independentes, voltados a disciplinar tanto as condições de concorrência, como os compromissos de produção e distribuição. Paulatinamente, esses

210 Sobre o papel das corporações na coordenação microeconômica, ver por todos PIORE, Michael \& SABEL, Charles. The Second Industrial Divide, op. cit., pp. 49-72 
instrumentos foram substituídos por laços mais vigorosos, permitidos pelas fusões horizontais e verticais, que deram, enfim, origem ao universo das grandes corporações. ${ }^{211}$

Paralelamente à esta função de coordenação microeconômica, as corporações também desempenharam um outro papel relevante para a viabilização do fordismo: a realização de um expressivo volume de investimentos, atinente à larga escala de produção e às máquinas e equipamentos intensos em capital. A concentração do poder econômico representou uma conseqüente centralização do capital, o que garantiu a disponibilidade de recursos para a realização destes investimentos. No contexto norte-americano, foi essa massa financeira gerida pelas corporações que garantiu a realização de projetos industriais notabilizados pelos custos irrecuperáveis (sunk costs), como foi o caso dos setores de utilidade pública, notadamente comunicações, iluminação, energia elétrica e transportes ferroviários.

Este último setor, aliás, foi particularmente relevante. Foram os desdobramentos ocorridos no segmento ferroviário que em boa medida balizaram a conformação societária deste período. Em virtude dos altos custos associados à implantação das estradas de ferro, foi nesse ramo que se vislumbrou pioneiramente o fenômeno da concentração e da cartelização do poder econômico. ${ }^{212}$ Já no século XIX, por exemplo, as corporações de

${ }^{211}$ Cf. PIORE, Michael \& SABEL, Charles. The Second Industrial Divide, op. cit.

${ }^{212}$ Não à toa, a campanha de oposição dos consumidores norte-americanos contra os excessos das grandes corporações, que culminou com a promulgação de uma das primeiras legislações antitruste do mundo - o Sherman Act, de 1890 - tinha como foco as companhias dedicadas ao transporte ferroviário. A esse respeito, assinala Calixto SALOMÃO FILHO: "para entender o significado do Sherman Act é necessária rápida análise do estado da economia e da sociedade norte-americana no final do século passado. Na segunda metade do século passado, época do início do movimento antitruste, que levou à promulgação do Sherman Act, três fatores influenciavam decisivamente a vida econômico-social norte-americana. Em primeiro lugar, como conseqüência direta da guerra civil, tinha-se verificado um grande fortalecimento e uma grande concentração industrial, sobretudo no nordeste dos Estados Unidos. A maior tolerância dos Estados em aceitar tarifas altas por parte de todas as indústrias direta ou indiretamente relacionadas ao esforço bélico foi, sem dúvida, um fator de grande estímulo às concentrações. Em especial, dois setores foram objeto de fortíssima concentração: telégrafos e estradas de ferro. No setor telegráfico, a famosa Western Union já em 1866 tinha adquirido quase a totalidade dos concorrentes. O monopólio das estradas de ferro, por outro lado, vincula-se diretamente ao segundo dos fatores acima mencionados. É ele o descontentamento do setor agrário. O setor rural americano é tido como um dos principais responsáveis pela promulgação do Sherman Act." Em um trecho adiante o autor apresenta o terceiro fator de influência para o Sherman Act, destacando a concentração do poder econômico em virtude da consolidação de uma indústria de massa: "Finalmente, o terceiro fator determinante do movimento antimonopolista é a rápida transformação da economia americana, ocorrida a partir de 1865. De uma economia baseada na pequena empresa e no espírito empresarial individual, os EUA, após a guerra, começam rapidamente a transformar-se em uma economia em que a concentração de capitais é cada vez mais necessária. É a era da produção em massa, que requer investimentos fixos elevados, os quais, por sua vez limitam o número de novas empresas no mercado." SALOMÃO FILHO, Calixto. Direito Concorrencial - as estruturas, São Paulo, Malheiros, 1998, pp. 51-53. 
estradas de ferro anteciparam boa parte dos comportamentos e estratégias que viriam a se tornar realidade no mundo empresarial somente no século XX. Para além da expressiva concentração econômica, foram essas companhias que inauguraram o financiamento corporativo realizado por meio da emissão de ações ${ }^{213}$.

A capitalização das companhias pelo mercado de capitais tornou-se uma marca característica desta fase econômica dos Estados Unidos. A concentração do poder corporativo e a expressiva centralização do capital contribuíram para uma alteração substantiva na organização societária norte-americana. Isso porque a consolidação da grande corporação tornou economicamente inviável a manutenção de uma estrutura concentrada da propriedade societária nas mãos de poucos empreendedores. $\mathrm{O}$ volume de recursos acumulados pelas empresas não era mais compatível com um modelo de sociedade dominado por um grupo restrito de acionistas originários. A propósito, é justamente este um dos pontos centrais da tese clássica de BERLE \& MEANS, The Modern Corporation \& Private Property, que assinala a associação entre a concentração do poder econômico e o movimento de dispersão acionária, causador de uma diluição do poder dos acionistas das empresas. ${ }^{214}$

Este movimento também esteve associado ao (e contribuiu para o) desenvolvimento do mercado de capitais, que se forjou na esteira das grandes corporações, provendo as elevadas somas de recursos, necessárias para a manutenção das políticas de investimentos das sociedades anônimas. Foi neste momento que se deu início à conformação deste modelo de financiamento corporativo, amparado na captação de recursos em bolsa e caracterizado por uma significativa dispersão acionária, como visto no primeiro capítulo.

\footnotetext{
213 Como salientam PIORE \& SABEL a esse respeito, "many of the solutions later adopted in other industries were obviously modeled on railroad practice (...) The railroads also made critical contributions to the development of the capital markets through which the new organizational entities were financed, and to the scientific and engineering know-how upon which many of the new industries were based." PIORE, Michael \& SABEL, Charles. The Second Industrial Divide, op. cit., p. 68.

${ }^{214} \mathrm{O}$ seguinte trecho dos autores dá uma boa medida deste movimento da dispersão acionária associada à concentração do poder econômico: "accompanying the concentration of economic power, growing out of it, and making it possible, has come an ever wider dispersion of stock ownership. This in turn has brought about a fundamental change in the character of wealth, - in the relation between the individual and his wealth, the value of that wealth and the nature of property itself." BERLE, Adolf \& MEANS, Gardiner. The Modern Corporation \& Private Property, op. cit. p. 47.
} 
Retomando o argumento desta seção, pode-se dizer, portanto, que as corporações permitiram a solução de dois embaraços institucionais que compunham a engrenagem fordista, no contexto da economia norte-americana. De um lado, coube a elas garantir a coordenação microeconômica, impedindo as indesejáveis oscilações de mercado (seja pela retração do consumo, seja por problemas de coordenação da produção). De outro, sustentaram a capacidade de investimento e de financiamento dos extensos empreendimentos industriais, contando para tanto com a captação de recursos privados de forma pulverizada, no âmbito do mercado de capitais. Pode-se dizer que a solução de ambos estes problemas contribuiu para a consolidação do fordismo, nos Estados Unidos.

O passo seguinte a essa consolidação foi a difusão deste paradigma tecnoprodutivo para as economias européia, japonesa e também para outros países, como os latino-americanos, cujos planos de desenvolvimento assumiram em boa medida o estilo fordista de organização industrial. $\mathrm{O}$ passo deste processo não foi, todavia, curto: a assimilação do fordismo pelos demais países levou algo mais do que trinta anos. Não se tratou tampouco de um processo prêt-à-porter de expansão de um modelo econômico. Ao contrário, a substituição do regime flexível pela rigidez fordista contou com adaptações sob medida às variedades institucionais locais. Particularmente no que tange às corporações, a customização do sistema fordista ficou bastante evidente no que se refere às formas de financiamento empresarial.

É bem verdade que no Japão e na Alemanha, por exemplo, a produção em escala de bens padronizados, associada à necessidade de se estabilizar a demanda e o conjunto da produção industrial, também deu margem à concentração do poder econômico. No entanto, esta concentração não esteve vinculada, como no caso norte-americano, a uma dispersão acionária, nem tampouco a um impulso no funcionamento dos mercados de capitais. Como já relatado no primeiro capítulo, a Alemanha e o Japão conformaram um sistema de financiamento alternativo.

Em ambos os países, o modelo de desenvolvimento fordista contou com uma articulação próxima entre as empresas e os bancos privados (que dispunham de relações próximas com o Estado). Em boa parte dos casos, estes bancos eram acionistas das 
empresas, configurando assim um desenho de participações societárias cruzadas ${ }^{215}$. Notase daí que o lastro institucional deste tipo de modelo fordista contava com laços relacionais de coordenação. Em especial no regime japonês, era bastante flagrante esta sobreposição societária entre firmas e destas com os bancos, o que levou Ronald GILSON \& Mark $\mathrm{ROE}^{216}$ a argumentarem que estas participações cruzadas, para além de serem uma fórmula de governança corporativa, eram, na verdade, um mecanismo particular de organização da produção industrial. Como as empresas detinham em muitos casos participação social recíproca e os bancos participavam de diversas firmas, os eventuais impasses entre fornecedores e distribuidores, ou entre concorrentes, poderiam ser dirimidos no ambiente interno aos próprios conglomerados. No limite, pode-se supor que, assim como a concentração do poder econômico acompanhada da dispersão acionária foram os meios pelos quais as companhias norte-americanas galgaram resolver as questões de coordenação microeconômica e de financiamento, o liame societário entre firmas e bancos foi o que mitigou estes problemas nas versões européia e japonesa do sistema fordista.

Enfim, no contexto do pós-Segunda Guerra, o paradigma fordista havia se tornado hegemônico nas principais economias do mundo. Estados Unidos, França, Alemanha, Itália e Japão tinham já forjado, cada qual à sua maneira, os mecanismos institucionais apropriados para lidar com os problemas de demanda e de capital atinentes a este sistema industrial. Do relato destes mecanismos ficou ausente, no entanto, um dos mais relevantes dispositivos de estabilização utilizados por estes países, ao lado das corporações, e que foi decisivo na consolidação fordista, ao menos desde a crise financeira de 1929: a intervenção do Estado.

\footnotetext{
${ }^{215}$ Sobre as diferenças no financiamento destas empresas fora do contexto americano, assinalam PIORE \&SABEL: "In Japan, as in France, most long-term investment capital is supplied to industry through banks, not the open securities market; and the Japanese authorities, like the French, were able to use control of the Bank of Japan (par of the Ministry of Finance and the perpetual creditor of large 'city' banks with direct connection to industry) as a way of funneling cheap credit to favored sectors and firms." PIORE, Michael \& SABEL, Charles. The Second Industrial Divide, op. cit., p. 161.

${ }^{216}$ Ver a respeito GILSON, Ronald \& ROE, Mark. Understanding the Japanese Keiretsu: overlaps between corporate governance and industrial organization, op. cit, pp. 871-906.
} 


\subsection{O PAPEL dO ESTAdo NA REgUlaÇÃO ECONÔMICA DO FORDISMO: O ESTADO REGULADOR NORTE-AMERICANO, O ESTADO INTERVENTOR EUROPEU E O ESTADO DESENVOLVIMENTISTA NA PERIFERIA ECONÔMICA}

A concentração do poder econômico e a sua organização corporativa responderam às necessidades de estabilização da demanda e do processo produtivo no ambiente microeconômico, mas esta era uma resposta limitada, constrita ao espaço das unidades de mercado. Para além dos ajustes internos aos setores e cadeias produtivas, sobreveio a necessidade de se evitar também as indesejadas flutuações cíclicas no quadro macroeconômico, que ameaçavam a continuidade das escalas industriais de produção. Ficasse a gestão da demanda a cargo exclusivamente das estratégias corporativas de organização dos mercados, a resposta institucional aos desafios do fordismo teria sido incompleta: por mais estáveis e coordenados que fossem as unidades econômicas, nada as garantiria contra os eventuais solavancos ocorridos nos grandes agregados econômicos. Coube, assim, ao chamado Estado Keynesiano, por meio de uma regulação pública da economia, oferecer as condições de sustentabilidade e estabilização para o conjunto da economia fordista, poupando-a dos dissabores de crises e ciclos depressivos pronunciados. $^{217}$

A bem da verdade, a regulação pública da economia já se havia mostrado como uma alternativa virtuosa durante a Primeira Guerra Mundial, quando o esforço bélico desmontou a crença liberal dos livres mercados e as economias vivenciaram uma primeira experiência de planejamento. ${ }^{218}$ No entanto, foi com a crise financeira norte-americana de 1929 que a necessidade e as virtudes desta intervenção pública entraram em cena de maneira definitiva, protagonizando um modelo de organização institucional que perduraria ao menos pelos próximos cinqüenta anos do século XX. A queda de Wall Street e o contágio de diversas outras economias, inclusive a brasileira, abalou a confiança no poder de auto-regulação dos mercados e evidenciou, como lembra David HARVEY, os limites da capacidade de resposta do poder corporativo ante a crise instalada. ${ }^{219}$

${ }^{217}$ Cf. PIORE, Michael \& SABEL, Charles. The Second Industrial Divide, op. cit., pp. 73-104.

218 Cf. COMPARATO, Fábio Konder. O Indispensável Direito Econômico, em Revista dos Tribunais, vol. 353, 1965, pp. 453-472.

${ }^{219}$ A seguinte passagem de HARVEY ilustra este ponto: "era tal a crença de Ford no poder corporativo de regulamentação da economia como um todo que a sua empresa aumentou os salários no começo da Grande Depressão na expectativa de que isso aumentasse a demanda efetiva, recuperasse o mercado e restaurasse a confiança da comunidade de negócios. Mas as leis coercitivas da competição se mostraram demasiado fortes mesmo para o poderoso Ford, forçando-o a demitir trabalhadores e cortar salários. Foi necessário o New 
O fato novo percebido com a crise de 1929 foi a definitiva incapacidade dos agentes de mercado em depurar as crises cíclicas do capitalismo. A crise evidenciara o problema de coordenação macroeconômica que assolava a economia fordista: diferentemente do que ocorrera em outros momentos da economia, o tamanho das plantas industriais e a sua inaptidão para lidar com as alternâncias de picos e vales limitavam as possibilidades de uma absorção das crises econômicas pela própria auto-regulação dos mercados. ${ }^{220}$

Sendo assim, na medida em que os agentes econômicos não se mostravam capazes de solucionar os problemas privados de oferta e demanda, houve a necessidade de suplementar a governança privada com os instrumentos de regulação pública. Tratou-se de um processo em que as bases de organização da economia de mercado deixaram paulatinamente de ser estruturadas pelas ferramentas do direito patrimonial privado para serem regidas pelos dispositivos do direito público da economia. Os elementos do direito privado, que até então garantiam a organização das transações econômicas, como a propriedade privada, a autonomia do contrato e a empresa, não eram mais instrumentos suficientes para compensar as fragilidades da economia industrial ${ }^{221}$. A esses institutos foram agregados os mecanismos do direito econômico, como as leis de planejamento, os regulamentos públicos, as agências de controle, as empresas estatais e as políticas de indução, entre outros, todos voltados a permitir a intervenção reguladora do Estado na economia.

Deal de Roosevelt para salvar o capitalismo - fazendo, através da intervenção do Estado, o que Ford tentara fazer sozinho." HARVEY, David. A Condição Pós-Moderna, op. cit. p. 122.

${ }^{220}$ Para PIORE \& SABEL, até a consolidação do fordismo, as crises em uma economia concorrencial eram auto-processadas, por meio de ciclos de retração e reaquecimento internos aos próprios mercados. A eventual queda de consumo, por exemplo, era costumeiramente compensada com a redução de custos de mão de obra, cujo efeito era o de uma retração na economia, causando conseqüentemente uma redução nas taxas de juros; o que afinal, incentivava a retomada dos investimentos, a geração de empregos e renda, levando então a uma recuperação econômica. É justamente esse círculo de recuperação que o tipo fordista de organização industrial inviabilizava. Como as escalas de produção eram já demasiadamente grandes e produziam uma capacidade de oferta permanentemente excessiva, o sistema contava com superprodução permanente. Com isso, uma eventual crise de sub-consumo não tinha o mesmo efeito de favorecer a redução dos custos dos insumos e assim facilitar a obtenção de recursos financeiros para novos investimentos. Em um regime de super oferta, como o fordista, uma oscilação negativa no poder de compra gerava desemprego e com isso uma redução ainda mais pronunciada da capacidade de demanda dos consumidores, aumentando assim o hiato entre a super produção e o sub-consumo. Em outros termos, as plantas e as escalas de produção fordistas eram rígidas e não admitiam a possibilidade de atuar em um ambiente que alternasse permanentemente retração e reaquecimento, o que determinaria um periódico ajuste na capacidade produtiva. Diferentemente disso, o funcionamento adequado desta economia contava com a plena produção e o pleno consumo. Ver PIORE, Michael \& SABEL, Charles. The Second Industrial Divide, op. cit. pp. 73-104.

${ }^{221}$ A esse respeito ver COMPARATO, Fábio Konder. O Indispensável Direito Econômico, op. cit. 
Uma das primeiras experiências notáveis dessa reorganização jurídica da economia foi um conjunto de tentativas, erros e acertos que compuseram a resposta norteamericana para a crise de 1929 - o New Deal. Iniciado em 1933, com o Presidente Roosevelt, o New Deal conjugou um universo de medidas regulatórias e de políticas públicas, direcionadas em um primeiro momento à recuperação econômica no cenário póscrise, mas que, às custas de um verdadeiro experimentalismo institucional ${ }^{222}$, produziram um significativo rearranjo jurídico do ambiente econômico norte-americano. Foi essa repactuação que emprestou aos mercados os remédios necessários para a prevenção das flutuações e dos espirais de crise, permitindo assim a constituição de uma fase duradoura de bons resultados comerciais.

Assim como ocorrera com as corporações, no âmbito microeconômico, a intervenção pública inaugurada com o New Deal refutou os imperativos de uma economia de mercado concorrencial. Desde a sua primeira fase, verificaram-se iniciativas evidentes de planejamento econômico, notadamente com duas das mais propaladas de suas iniciativas legislativas, ambas de 1933: (i) o National Industrial Recovery Act (NIRA) e (ii) o Agricultural Adjustment Act (AAA). Ambas as leis tinham em conta que os setores industrial e agrário enfrentavam turbulências decorrentes do excesso de oferta, o que redundava em uma manutenção dos preços relativos em patamares inferiores às expectativas de empreendedores e produtores. Para contornar este desequilíbrio, tanto o NIRA como o AAA estimulavam acordos entre concorrentes, para controlar o excesso de oferta e assim recuperar o nível de preços. Muito embora essas duas primeiras iniciativas tenham sido declaradas inconstitucionais pela Suprema Corte alguns anos depois, sua base de racionalidade figurou em outras medidas de reequilíbrio econômico. ${ }^{223}$

${ }^{222}$ A história do New Deal foi repleta de idas e vindas, com diversos impasses jurídicos, como a persistente
posição contrária da Suprema Corte, que declarou inconstitucionais as primeiras medidas programas por
Roosevelt. Foi desse embate jurisprudencial e das revisões às falhas apresentadas por algumas das medidas
que o conjunto dessa obra foi forjado, constituindo assim um acidental planejamento da economia. Sobre o
New Deal e principalmente sobre as suas sucessivas experiências institucionais, ver PIORE, Michael \&
SABEL, Charles. The Second Industrial Divide, op. cit. e FRIEDMAN, Lawrence. American Law in the $20^{\text {th }}$
Century, New Haven, Yale University Press, 2002 .
${ }^{223}$ Exemplo disso foram os casos do Wagner Act, de 1935, do Fair Labor Act, de 1938 e do Robinson-
Patman Act, de 1936. Inspirados nas disposições do NIRA, que garantiam um salário mínimo e reconheciam
os direitos de negociação coletiva, os Acts trabalhistas (Wagner e Fair Labor), ao regularem o mercado de
trabalho garantiram as condições institucionais para a proteção dos interesses dos trabalhadores, como a
possibilidade de organização e representação sindical. Desta maneira, proporcionaram indiretamente, por
meio das campanhas salariais, a possibilidade de elevação do poder de compra e um decorrente aumento da
capacidade de demanda do conjunto da economia. Já no caso do Robinson-Patman Act, tratou-se de uma
legislação antitruste comprometida com a proteção dos pequenos distribuidores e restritiva ao uso do poder 
Ao lado destas medidas legislativas, voltadas a reorganizar as bases de funcionamento da economia de mercado, o New Deal também contou com dispositivos regulatórios, como novas agências de controle e com ações de caráter promocional. No campo dos atos de controle, cuja finalidade foi a de impor limites a uma economia ainda desregulada, importam, particularmente para este trabalho, os casos do Securities and Exchange Act e do Glass Steagall Act. Ambas as legislações, ao tratarem do funcionamento do sistema financeiro, lidaram justamente com uma das áreas mais vulneráveis da economia norte-americana e que havia sido o epicentro dos problemas de 1929. Talvez por isso, estes Acts tenham procurado impor condicionalidades expressivas à atuação dos agentes financeiros. No caso do Securities and Exchange Act, de 1934, cuidouse de se redesenhar e fortalecer o sistema de fiscalização do mercado de capitais, deslocando da Federal Trade Comission (FTC) para uma nova agência, a Securities and Exchange Comission $(S E C)^{224}$, as competências reguladoras dos negócios mobiliários. Ainda mais significativo foi o caso do Glass Steagall Act, de 1933, dirigido ao setor bancário. Os seus efeitos ultrapassaram o contexto do New Deal e, como já visto no primeiro capítulo, impactaram a própria conformação do arranjo financeiro da economia norte-americana. Ao proibir que os bancos comerciais realizassem operações no mercado de capitais e simultaneamente impedir que os bancos de investimento atuassem no varejo bancário, o Glass Steagall Act restringiu uma atuação financeira bastante freqüente para os bancos de outros países: a de acionista corporativo. Com isso, acabou por confirmar as características do modelo de financiamento norte-americano, igualmente tributário da centralização do capital e da concentração do poder econômico, ocorridas no início do século XX. ${ }^{225}$

de compra e de barganha das grandes cadeias comerciais, na aquisição de seus insumos (o poder de compra era entendido como uma vantagem competitiva das grandes cadeias que prejudicava a capacidade comercial de pequenos compradores). Sobre essas medidas, ver FRIEDMAN, Lawrence. American Law in the $20^{\text {th }}$ Century, op. cit

${ }^{224}$ De acordo com Lawrence FRIEDMAN, o Securities and Exchange Act permitiu uma fiscalização mais rigorosa do mercado de capitais, impondo regras de conduta aos agentes financeiros e às instituições como a New York Securities Exchange - NYSE (a bolsa de Nova York), passando ainda a exigir regras de publicidade para os atos societários. A esse respeito, ver FRIEDMAN, Lawrence. American Law in the $20^{\text {th }}$ Century, op. cit

${ }^{225}$ Sobre o modelo americano, observa STIGLITZ: "Com a lei Glass-Steagall, os Estados Unidos rejeitaram o caminho seguido por outras nações, tais como Japão e Alemanha, que não separaram banco comercial de banco de investimento - acredito que em nosso evidente benefício." O Glass-Steagall Act só veio a ser revogado em meados nos anos 1990, no bojo do movimento de desregulação da economia. Para alguns analistas, parte da crise atual do mercado imobiliário norte-americano deve-se a essa desregulação financeira. Sobre a década de 1990 e a composição de interesses que levou ao abandono do Glass-Steagall Act, ver 
Por fim, no terreno das medidas de promoção e de redistribuição da renda, foram significativas a construção do aparato de seguridade social, com o Social Security Act, de 1935, e a implementação dos programas de gasto público, investidos de uma lógica tipicamente keynesiana: direcionados a administrar o nível da demanda agregada. Notadamente no que se refere a estes últimos, é bastante evidente o aumento da participação governamental, tanto na geração de renda, como na manutenção do aquecimento da economia. Um indicador deste crescente envolvimento do poder público no estímulo do setor privado pode ser visto no aumento significativo das despesas públicas em relação ao PIB. Enquanto em 1925 e 1929 as despesas públicas federais atingiram respectivamente $3,1 \%$ e $3,0 \%$ do PIB, em 1935, 1940, 1945 e 1950, os dados correspondentes foram de 9,0\%, 9,6\%, 29,6\% e 15,1\% do PIB, subindo ainda mais daí em $\operatorname{diante}^{226}$.

Com esse rol de mecanismos, leis e políticas, o New Deal firmava pioneiramente novos princípios diretores para a intervenção do Estado na economia. Completava-se, assim, o arranjo institucional sobre o qual o fordismo pôde se estabelecer, consagrando-se a chamada era da regulação ${ }^{227}$, na qual coube ao Poder Público o desempenho de funções constitutivas da economia fordista. ${ }^{228}$ Nesse período, coube ao Estado, de um lado, amparar a capacidade de investimento das economias, por meio da definição de políticas industriais, consubstanciadas em financiamentos públicos, subvenções econômicas e incentivos fiscais, além da realização de obras de infra-estrutura, que importavam para o florescimento dos negócios privados. De outro, coube à intervenção pública a manutenção

STIGLITZ, Joseph. Os Exuberantes Anos 90 - uma interpretação da década mais próspera da história, (trad. Sylvia Maria Cristovão dos Santos, Dante Mendes Aldrighi, José Francisco de Lima Gonçalves e Roberto Mazzer Neto), São Paulo, Companhia das Letras, 2003, pp. 178-181.

${ }^{226}$ Esses dados são apresentados por PIORE, Michael \& SABEL, Charles. The Second Industrial Divide, op. cit., pp. 73-104.

${ }^{227}$ A expressão é utilizada por Ha-Joon CHANG, que faz uma excelente reconstrução das relações entre Estado e economia. Para tanto, ver CHANG, Ha-Joon. The Economics and Politics of Regulation, Cambridge Journal of Economics, nº. 21, 1997, pp. 703-728.

${ }^{228}$ A essas funções do Estado na economia fordista, pode ser acrescida a tarefa de manejo dos conflitos distributivos. A esse respeito ver ARIENTI, Wagner Leal. Do Estado Keynesiano ao Estado Schumpeteriano, Revista de Economia Política, vol. 23, $\mathrm{n}^{\mathrm{o}}$. 4, 2003, pp. 97-113. A seguinte passagem de David HARVEY, dá uma boa medida do papel desempenhado pelo Estado na organização do ciclo fordista: "Na medida em que a produção de massa, que envolvia pesados investimentos em capital fixo, requeria condições de demanda relativamente estáveis para ser lucrativa, o Estado se esforçava por controlar ciclos econômicos com uma combinação apropriada de políticas fiscais e monetárias no período pós-guerra. Essas políticas eram dirigidas para as áreas de investimento público - em setores como o transporte, os equipamentos públicos etc. - vitais para o crescimento da produção e do consumo de massa e que também garantiam um emprego relativamente pleno.” HARVEY, David. A Condição Pós-Moderna, op. cit. p. 129. 
do poder de compra e de demanda dos trabalhadores, o que foi garantido pela consecução de uma extensa lista de obras e de serviços públicos pelo Estado, o que, no limite, favorecia a sua capacidade de consumo. ${ }^{229}$

A construção histórica deste Estado keynesiano assumiu, no entanto, feições particulares e conformidades locais, apresentando variações de estilo e de intensidade nos respectivos formatos nacionais de regulação. Os países europeus e o Japão, por exemplo, produziram um Estado regulador com características mais interventoras do que o norteamericano. Fora dos Estados Unidos e em alguma medida da Inglaterra, as funções de estabilização da economia eram desempenhadas com uma participação pública mais pronunciada. Concretamente, isso significou a utilização de instrumentos de atuação mais vigorosos do que o exercício de um balizamento indireto da economia, que foi a marca característica do New Deal. A maior utilização de leis para o planejamento econômico e a intervenção direta do Estado, por meio de empresas estatais, foram recursos mais recorrentes nos demais países fordistas. Mesmo quando se tratava de regulação indireta, a ação pública era ainda menos condescendente com os fundamentos de uma economia liberal de mercado ${ }^{230}$.

Sendo assim, não parece exagero assumir que nesses outros modelos os veículos da intervenção do Estado extrapolavam, em boa medida, a correção das falhas do mercado e dirigiam-se de fato a suplementar a atuações dos agentes privados. Era disso que se tratava nas políticas industriais japonesas, que deliberadamente planejavam a organização dos setores industriais, incentivando ondas de cartelização e de fusões, a fim de evitar guerras de preço e os decorrentes riscos à realização dos investimentos. ${ }^{231}$ De certa forma,

\footnotetext{
${ }^{229}$ Tais serviços assumiram, na realidade, a natureza de um salário indireto, capaz de transferir renda para os segmentos favorecidos pelas utilidades públicas universalizadas pelo Estado, o que no limite favorecia a sua capacidade de consumo. Essa dicção de salário indireto para os serviços públicos é empregada por OLIVEIRA, Francisco. O Surgimento do Antivalor - capital, força de trabalho e fundo público, em OLIVEIRA, Francisco. Os Direitos do Antivalor - a economia política da hegemonia imperfeita, Petrópolis, Vozes, 1997, pp. 19-48.

${ }^{230}$ A seguinte passagem de PIORE \& SABEL é ilustrativa desse argumento: "In the United States, mass markets seemed to result from technological progress, symbolized by the railroad; the states's role (in coordinating industrial activities) seemed only to complement the activities of the firms, whose autonomy was established without any exercise of public authority. In the four countries under discussion, mass production firms and their markets were deliberately shaped by the state (...)." PIORE, Michael \& SABEL, Charles. The Second Industrial Divide, op. cit. p. 163.

${ }^{231}$ Nesse sentido, é bastante significativo que os ordenamentos antitruste fora dos Estados Unidos tenham se caracterizado pela maior tolerância com acordos e cooperações de empresas. Sobre as diferenças entre os modelos de disciplina concorrencial, ver AMSDEN, Alice \& SINGH, Ajit. The Optimal Degree of
} 
também era esse o caso de empresas estatais como o IRI (Instituto da Reconstrução Industrial Italiana), que figurava como um grande conglomerado estatal, responsável pela realização de um consistente volume de investimentos diretos na economia. ${ }^{232}$

Foi esse também o caso de uma outra variante desse modelo institucional, assentada, por sua vez, na idéia de uma economia mista, nacionalmente gerida, em que os dispositivos públicos importavam para o florescimento de uma economia industrial de massa: a coordenação pública da economia de mercado. Como visto, a economia política do desenvolvimentismo trazia consigo muitos dos pressupostos acima relatados, a exemplo da identificação do papel estratégico do Estado na direção do processo de industrialização. Essa intervenção pública apresentava, na verdade, uma dupla atuação: o Estado, de um lado, financiava a acumulação, por meio dos mecanismos de poupança compulsória, geridos pelo BNDES, por exemplo, e de outro, realizava diretamente parte do programa de investimentos, por meio das empresas estatais, como a Petrobrás, a Siderbrás, a Telebrás e a Eletrobrás. Tais empresas se incumbiram de suprir a carência de uma centralização do capital, apta a promover o programa industrial de investimentos. O chamado setor produtivo estatal cumpriu, no Brasil, parte das tarefas de capitalização e de coordenação desempenhadas pela sociedades anônimas norte-americanas. ${ }^{233}$

Apesar dessas diferenças, o resultado funcional destes diversos modelos de intervenção estatal foi semelhante. Sejam as economias liberais, sejam as economias coordenadas, sejam ainda as de coordenação pública, todas trabalharam, ainda que à sua maneira, para gerenciar os problemas de demanda e apoiar as necessidades de investimentos em plantas industriais dotadas de largas escalas de produção, viabilizando assim a consolidação do paradigma fordista. Do New Deal norte-americano ao Welfare State europeu, passando pelas variações de Estados desenvolvimentistas, é certo que cada qual a seu modo se prontificou a cumprir a função estabilizadora dessa economia industrial.

Competition and Dynamic Efficiency in Japan and Korea, European Economic Review, nº 38, 1994, pp. 941-951 e NUSDEO, Ana Maria de Oliveira. Defesa da Concorrência e Globalização Econômica - o controle da concentração de empresas, São Paulo, Malheiros, 2002, pp. 75-135.

${ }^{232}$ Sobre o IRI, ver HOLLAND, Stuart. State Entrepreneurship and State Intervention, em HOLLAND, Stuart. (editor) The State as Entrepreneur - new dimensions for public entreprise: the IRI state shareholding formula, New York, International Arts and Sciences Press Inc, 1972, pp. 5-44.

${ }^{233}$ COUTINHO, Luciano \& REICHSTUL, Henri-Philippe. O Setor Produtivo Estatal e o Ciclo, op. cit. 


\section{A CRISE DO FORDISMO E O PARADIGMA DA ECONOMIA BASEADA NO CONHECIMENTO}

O paradigma fordista e os seus correspondentes atributos jurídico-institucionais ofereceram uma resposta satisfatória aos imperativos da economia industrial até meados dos anos 1970. Entre as décadas de 1950 e 1970, os Estados Unidos, os principais países europeus, o Japão e alguns representantes da periferia econômica, tanto asiática, como latino-americana, apresentaram patamares consideráveis de crescimento econômico e uma relativa estabilidade social. ${ }^{234}$ Sobretudo nos países desenvolvidos, o desemprego e as taxas de inflação mantiveram-se dentro de padrões administráveis e países emergentes como o Brasil e Coréia do Sul, por exemplo, cresceram a uma taxa média anual de 6,5\% ao ano $\left(1950\right.$ - 1979). ${ }^{235}$ No entanto, a partir dos anos 1970, no mundo desenvolvido, e, sobretudo, a partir dos anos 1980, no universo dos países em desenvolvimento, estes resultados ruíram. Em seu lugar, entraram em cena as percepções e os diagnósticos de crise. Particularmente no Brasil, foi nesse período que se encerrou o longo ciclo desenvolvimentista, iniciado com o Plano de Metas e reforçado pelo II PND. ${ }^{236}$ Tratou-se, na verdade, não apenas de uma crise no regime industrial, mas sim de uma crise do conjunto do paradigma tecno-produtivo. ${ }^{237}$

Para além desses sinais de fadiga do maquinário fordista, uma constelação de tantos outros tornava inequívocas as interpretações de crise econômica e institucional, que dominaram tanto a agenda da produção intelectual, como o debate público sobre diagnósticos e propostas. ${ }^{238}$ As crises econômicas sucessivas, que até há pouco pareciam ter sido banidas do ambiente capitalista, voltaram a assolar reiteradamente as economias desenvolvidas. Acompanhadas de dois indesejados convidados, a estagnação econômica e a inflação, as crises provocaram um intrincado cenário de estagflação que percorreu boa

\footnotetext{
${ }^{234}$ Ver a respeito CHANG, Ha-Joon. The Economics and Politics of Regulation, op. cit.

235 Dados apresentados por COUTINHO, Luciano. Brasil e Coréia do Sul - paralelos, sucessos e desastres, em FIORI, José Luís (org.). Estados e Moedas no Desenvolvimento das Nações, Petrópolis, Vozes, 1999, pp. 351-378.

${ }^{236}$ Sobre a crise do desenvolvimentismo e sua relação com a crise da dívida dos anos 1980 ver CARNEIRO, Ricardo. Desenvolvimento em Crise - a economia brasileira no último quartel do século XX, São Paulo, IE Unicamp, 2002, pp. 47-111 e para a associação dessa crise principalmente com a crise fiscal do Estado, ver BRESSER PEREIRA, Luiz Carlos. Crise Econômica e Reforma do Estado, op. cit.

${ }^{237}$ O sucesso do fordismo entre 1950 e 1973 é debatido por HARVEY, David. A Condição Pós-Moderna, op. cit. e PIORE, Michael \& SABEL, Charles. The Second Industrial Divide, op. cit. A tese de que essa crise não foi apenas uma crise no regime, mas do regime fordista é apresentada por JESSOP, Bob. The Future of Capitalist State, op. cit. pp. 45-94.

${ }^{238}$ Boa parte do debate critico sobre a regulação pública da economia dos anos 1970 é caudatária desta crise. Para uma revisão desta literatura ver CHANG, Ha-Joon. The Economics and Politics of Regulation, op. cit.
} 
parte desse período. Não à toa, as economias de massa viram-se diante do problema de retração da demanda e da conseqüente percepção de uma permanente capacidade excedente ${ }^{239}$.

Diante desse quadro, as bases institucionais do fordismo passaram por dois processos sucessivos: em um primeiro momento, pôde se constatar uma tentativa de sua reiteração; já na fase subseqüente, vislumbrou-se a crítica e a rejeição de seus fundamentos. Inicialmente, as respostas para a crise econômica do fordismo foram formuladas dentro dos seus próprios quadrantes institucionais: a grande corporação e o Estado keynesiano. ${ }^{240}$ De um lado, as tentativas de recuperar, o não muito distante, cenário de prosperidade contaram com políticas de caráter keynesiano, com os governos procurando manusear os remédios habitualmente administrados em cenários de eminência de crise. De outro, as corporações procuraram estratégias baseadas na radicalização das noções fordistas, como por exemplo, as tentativas de definir produtos capazes de ser confeccionados e consumidos em uma escala mundial. ${ }^{241}$ As respostas colhidas de parte a parte, todavia, não foram suficientes para superar os problemas do regime industrial. Não impediram, portanto, nem o diagnóstico de crise e nem tampouco a procura de novas alternativas de organização produtiva. O desfecho desse impasse veio na forma de novas estratégias corporativas, que culminaram no florescimento de um novo paradigma industrial: o pós - fordismo ou a economia baseada no conhecimento.

Mostrada a fotografia da economia dos anos 1970, convém igualmente apresentar o filme que antecedeu a esse cenário. Afinal de contas, o fordismo e o consenso keynesiano pareciam ser uma solução satisfatória para a gestão do processo industrial. Havia ganhos de produtividade, os trabalhadores contavam com renda e poder de compra e os Estados detinham meios para prevenir ou remediar possíveis desajustes entre oferta e demanda. Como entender então a crise e a perda de primazia desse regime? A interpretação dos autores utilizados nesse trabalho procura apontar, ainda que com pequenas variações, para uma sequiência de fatores que contribuíram, desigualmente, para a produção dessa crise.

\footnotetext{
${ }^{239}$ Cf. HARVEY, David. A Condição Pós-Moderna, op. cit., pp. 135-162.

${ }^{240}$ Cf. PIORE, Michael \& SABEL, Charles. The Second Industrial Divide, op. cit., pp. 194-220.

${ }^{241}$ Este foi o caso do "carro mundial", uma estratégia das montadoras de veículos, relatada por PIORE \& SABEL, por meio da qual tais firmas pretenderam responder à crise constituindo uma escala mundial de produção de veículos, com um carro padrão que poderia ser produzido e adquirido em diversos países. Cf. PIORE, Michael \& SABEL, Charles. The Second Industrial Divide, op. cit., pp. 194-220.
} 
Em uma tentativa de sistematizar essas leituras, parece razoável indicar dois tipos de causa: (i) as incidentais e (ii) a estrutural. Tanto os argumentos de PIORE \& SABEL ${ }^{242}$, como de HARVEY $^{243}$ ou JESSOP ${ }^{244}$, apontam para a existência de uma série de percalços ocorridos nos anos 1970, o que se pode chamar de crises incidentais, mas todos eles insistem em atributo estrutural para essa crise: a limitação do próprio paradigma tecno-econômico.

Os chamados fatores incidentais assolaram as economias fordistas ao longo dos anos 1970 e embora cada qual partilhasse de uma natureza e de uma forma particular de manifestação, todos eles causaram um mesmo efeito sobre o sistema econômico: trouxeram imprevisibilidade para um regime orquestrado pelo sentido da rigidez. Com isso, contribuíram para solapar as bases do paradigma tecno-produtivo, cuja maior carência era justamente a manutenção da estabilidade e da capacidade de planejamento.

O primeiro desses fatores veio no campo trabalhista, por meio de uma onda de protestos sociais que tomou conta da esfera pública norte-americana e européia, já no final dos anos 1960, notadamente em 1968. Liderado por diversos vetores sociais, os movimentos de contestação tinham um apoio consistente de uma camada de trabalhadores que estava excluída dos acordos salariais e das proteções sindicais constitutivas do regime fordista. As pressões pela inclusão e pela equiparação de benefícios resultaram em uma desarticulação dos arranjos trabalhistas, orientados a seguir um pacto entre a proteção dos interesses do trabalhador e a capacidade produtiva do regime. Os protestos salariais organizados fora deste eixo institucional teriam contribuído ora para a definição de políticas salariais ad hoc, gerando, assim, um descontrole sobre a gestão dos custos salariais, ora para a contratação de segmentos ainda mais marginalizados, com salários sub-competitivos. Seja num caso, seja no outro, a desagregação do ambiente trabalhista comprometia a capacidade de organização e planejamento da corporação fordista. ${ }^{245}$

O segundo fator que contribuiu para este cenário de desestabilização foi a crise do sistema monetário internacional, edificado no fim da Segunda Guerra Mundial, em Bretton Woods. Entre os acordos firmados na conferência, um era particularmente

\footnotetext{
${ }^{242}$ PIORE, Michael \& SABEL, Charles. The Second Industrial Divide, op. cit., pp. 165-193.

${ }^{243}$ HARVEY, David. A Condição Pós-Moderna, op. cit., pp. 135-162.

${ }^{244}$ JESSOP, Bob. The Future of Capitalist State, op. cit., pp. 55-94.

${ }^{245}$ Ver a esse respeito HARVEY, David. A Condição Pós-Moderna, op. cit. pp. 135-162 e PIORE, Michael \& SABEL, Charles. The Second Industrial Divide, op. cit, pp. 165-193.
} 
relevante para a administração do comércio internacional: a fixação de uma taxa internacional de paridade cambial, o dólar-ouro. Por esse regime, a moeda padrão para as transações internacionais seria o dólar, que, por sua vez, teria um valor fixo: trinta e cinco dólares correspondiam a uma onça de ouro. A definição deste parâmetro emprestava certa rigidez ao comércio internacional, já que os países signatários não poderiam arbitrar livremente o valor da moeda nessas transações. A intenção desta paridade monetária foi evitar uma plena discricionariedade nacional nas políticas comerciais, garantindo assim um equilíbrio cambial entre os mercados exportadores e importadores dos países. Pois foi justamente este acordo que foi denunciado pelos Estados Unidos, no começo dos anos 1970. Daí em diante passou a vigorar um regime monetário flexível, em que o dólar deixou de ser a única reserva de valor para as transações internacionais e o seu valor passou ainda a ser arbitrado livremente pelos ajustes de oferta e demanda. Naturalmente, a saída do regime do dólar-ouro trouxe instabilidade para o sistema fordista, já que, diferentemente do que ocorria até então, exportadores e importadores não saberiam de antemão o custo cambial de suas operações. ${ }^{246}$

Um terceiro fator incidental apontado pelos autores é recorrentemente assinalado com uma das causas efetivas para a precipitação da crise econômica mundial dos anos 1970: as crises do petróleo de 1973 e 1979. Repentinamente, e por motivos alheios ao sistema econômico, o preço do combustível da economia fordista foi drasticamente aumentado, passando de um patamar de US\$ 3,00 o barril, em setembro de 1973, para US\$ 12,00, em dezembro daquele ano. Anos depois do primeiro choque, quando as economias já o haviam absorvido, sucedeu uma segunda crise de aumentos abruptos, com o preço do barril chegando a US\$37,00, no início dos anos 1980. Ambos os choques impactaram de maneira significativa as economias de mercado. $\mathrm{O}$ seu efeito mais evidente foi o aumento de custo dos insumos e a geração de inflação. Sua consequiência menos explícita foi a de trazer imprevisibilidade quanto aos rumos da economia. Diante da incerteza quanto aos desdobramentos da crise do petróleo, a reação corporativa foi a de retrair os planos de expansão, o que agregou à inflação um componente recessivo. ${ }^{247}$

\footnotetext{
${ }^{246}$ Cf. PIORE, Michael \& SABEL, Charles. The Second Industrial Divide, op. cit.

${ }^{247}$ Ver PIORE, Michael \& SABEL, Charles. The Second Industrial Divide, op. cit. Sobre a crise do petróleo e seu impacto no desenvolvimentismo brasileiro, ver CARNEIRO, Ricardo. Desenvolvimento em Crise, op. cit.
} 
Por fim, um último elemento de desestabilização do contexto fordista, ocorrido já no início dos anos 1980, foi particularmente relevante para os países em desenvolvimento, notadamente para os latino-americanos. Tratou-se do aumento de juros pelo Federal Reserve (Banco Central americano). Em resposta à pressão inflacionária, as autoridades americanas elevaram as suas taxas de juros, o que provocou consequiências na capacidade de pagamento da dívida externa brasileira. Esse foi um fator decisivo para os problemas da crise fiscal do Estado, que se manifestariam ao longo dos anos $1980 .{ }^{248}$

Diante de todos esses eventos, não parece equivocado assumir que os fatores incidentais da crise de fato contribuíram para a ocorrência de desajustes institucionais, percebidos na forma de desequilíbrios, aumentos de custos e incertezas, que contaminaram o conjunto do ambiente econômico. Desta maneira, tais episódios facilitaram um funcionamento desordenado das economias nacionais, que, como visto, estavam ancoradas em uma técnica produtiva dotada de rigidez. Entretanto, mesmo sem ignorar tais efeitos, as interpretações para a crise derradeira do paradigma fordista atribuem a derrocada do regime à prevalência de um outro fator: um atributo de natureza estrutural. De acordo com essa leitura, o esgotamento do conjunto fordista de produção esteve associado a problemas de excesso de produção e de saturação dos mercados consumidores. Para David HARVEY, cuidou-se de uma crise de superacumulação ${ }^{249}$, para Charles SABEL, uma crise clássica de limitação dos mercados. ${ }^{250}$

Passadas quase duas décadas de expansão contínua de uma especialização produtiva baseada na confecção em série e no correspondente aumento da escala de consumo, as evidências do período apontam para uma incapacidade dos mercados em absorver o ritmo da produção. Dados apresentados por PIORE \& SABEL ${ }^{251}$ para ilustrar este argumento indicam, de fato, uma universalização bastante completa dos bens de consumo padronizados e uma conseqüente restrição nas possibilidades de manutenção do patamar fordista de produção e comercialização: entre 1950 e 1979, por exemplo, dobrou o número de veículos per capita; além disso, nos 1970, 99\% das residências norteamericanas tinham televisão, ao passo que em 1953, apenas $47 \%$ contavam com o

\footnotetext{
${ }^{248}$ Cf. CARNEIRO, Ricardo. Desenvolvimento em Crise, op. cit.

${ }^{249}$ HARVEY, David. A Condição Pós-Moderna, op. cit., pp. 163-176.

250 SABEL, Charles. Mudança de Modelos de Eficiência e suas Implicações para a Industrialização no Terceiro Mundo, op. cit. pp. 33-60.

${ }^{251}$ PIORE, Michael \& SABEL, Charles. The Second Industrial Divide, op. cit. pp. 184-186.
} 
aparelho, da mesma forma que mais de $99 \%$ das casas já detinham geladeiras, rádios e 90\% delas, contavam com utensílios domésticos, como máquinas de lavar.

A limitação da capacidade de demanda da economia norte-americana encontrava paralelo em outros países, que passaram igualmente a conformar sua especialização industrial em torno do regime fordista. Com isso, também a capacidade de ampliação dos mercados pela via da exportação já se mostrava uma alternativa sujeita a restrições. É exemplificativo disso o fato de que o setor automotivo japonês não só deixara de consumir veículos norte-americanos, como passara a ser um grande exportador de automóveis, inclusive para os Estados Unidos. ${ }^{252}$ Algo semelhante ocorrera com as periferias econômicas, asiáticas e latino-americanas. Os respectivos projetos industriais transformaram o ambiente produtivo desses países, que, de dependentes de produtos industrializados, passaram a ser exportadores de bens manufaturados ou, ao menos, sujeitos a uma menor dependência de produtos industrializados importados. Países como a Coréia do Sul, na esteira do modelo japonês, transformaram-se em centros de exportação industrial e passaram a disputar a pauta comercial internacional. Já o Brasil (e alguns de seus vizinhos na América do Sul) baseou sua estratégia de industrialização justamente em políticas de substituição das importações: um modelo que igualmente oferecia restrições a uma plena absorção do produto industrial das nações desenvolvidas e ainda permitia algum patamar de exportação. ${ }^{253}$

Portanto, ao lado dos aumentos de custos e das oscilações de consumo proporcionados pelos fatores incidentais, as economias fordistas enfrentaram também um acirramento da competição, associado à saturação dos mercados consumidores. Diante desse cenário, os intérpretes convergiram na identificação de uma crise do paradigma tecno-produtivo: suas soluções técnicas e o seu arcabouço jurídico-institucional não respondiam mais de maneira suficiente aos problemas da organização produtiva. $\mathrm{O}$ argumento da crise fecha-se então com o reconhecimento das alternativas, indicando que diante das flutuações e incertezas econômicas e da constrição dos mercados, as corporações e os Estados procuraram novas formas de atuação: ao lado da rigidez, mecanismos flexíveis de produção e de regulação; em paralelo aos limites do mercado dado, a inovação de novos produtos.

${ }^{252}$ Cf. PIORE, Michael \& SABEL, Charles. The Second Industrial Divide, op. cit., pp. 165-193.

${ }^{253}$ Cf. PIORE, Michael \& SABEL, Charles. The Second Industrial Divide, op. cit. 


\section{AS RESPOSTAS À CRISE DO FORDISMO: ACUMULAÇÃO FLEXíVEL E ECONOMIA DAS INOVAÇÕES}

As respostas apresentadas pelas corporações à crise do fordismo, tal como identificadas pela literatura empregada neste trabalho, assumiram duas rotas convergentes e complementares de atuação: os processos produtivos e os produtos industriais. Por um lado, as firmas passaram a se ressentir da necessidade de reorganizar as rotinas de produção, a fim de lidar com um cenário econômico fluído e de demanda oscilante, bem diferente, portanto, do contexto fordista. Por outro, necessitavam de mecanismos para contornar a limitação da própria capacidade do mercado, que se havia mostrado saturado para os produtos padronizados, confeccionados na base da linha de montagem. É da solução destas questões que tem emergido, paulatinamente, os traços característicos da organização industrial pós-fordista: (i) um regime produtivo flexível e capaz de se adaptar às flutuações e incertezas da demanda e (ii) a busca de inovações permanentes, que permitam a criação de novos produtos, novas marcas e com isso novos mercados, para além dos existentes. Ambas as características tem dado causa a um outro paradigma tecnoeconômico, conhecido como economia baseada no conhecimento, que, assim como o fordismo, também apresenta os seus elementos característicos: uma técnica produtiva determinada, um produto fabril, um espectro de consumo, um correspondente modelo de eficiência e um tipo específico de relação de trabalho, aos quais estão associados os correspondentes mecanismos jurídico-institucionais.

A técnica produtiva da economia baseada no conhecimento conforma-se pela flexibilidade da produção. É a capacidade de adaptação a mercados oscilantes e às flutuações nos gostos e preferências dos consumidores que baliza este tipo de produção industrial. Por esta razão, o tipo ideal da macroempresa fordista, dotada de uma organização societária integrada, que unia em uma mesma companhia todos os elos da fase de produção, tende a ceder lugar a um outro tipo ideal de arranjo corporativo, baseado em laços contratuais horizontais, firmados entre fornecedores e produtores. Neste modelo, a coordenação das atividades entre pólos de uma mesma cadeia prescinde de uma integração societária, sustentando-se na constituição de uma rede de contratos de longo prazo, entre os respectivos atores do processo produtivo. ${ }^{254}$

\footnotetext{
${ }^{254}$ Ver a respeito HARVEY, David. A Condição Pós-Moderna, op. cit., pp. 135-162.
} 
Em relação ao padrão fordista, a estipulação de liames por meio de redes de contrato garante a possibilidade de uma coordenação industrial porosa a alterações e renegociações, tanto quantitativas, como qualitativas, dos bens contratados. Permite também a possibilidade de sincronizar o ritmo da produção entre fornecedores e produtores, evitando, assim, o desperdício de recursos com a formação de estoques. Essa é uma das principais características do chamado sistema just in time de produção, em que produtores e fornecedores independentes atuam de forma cooperada e simultânea. Diferentemente da linha de produção, em que prevalecia a lógica de fases sucessivas de montagem, no arranjo flexível há uma interação permanente entre os fornecedores e os produtores, o que assegura maiores e mais rápidas possibilidades de ajustes, acertos ou revisões no processo produtivo. ${ }^{255}$

Esses atributos não só permitiram às organizações a possibilidade de adaptação às oscilações do ambiente econômico, como igualmente abriram caminho para a superação do segundo problema apresentado pela crise do paradigma fordista: a saturação dos mercados, o que foi viabilizado por um tipo diferenciado de produto fabril. Para tanto, os produtos deixam de ser exclusivamente padronizados e o que passou a importar foi a sua capacidade de atrair a demanda pelos seus atributos qualitativos. Com isso, abriu-se espaço para uma outra opção de disputa comercial: a criação de novos produtos e produtos customizados, dedicados a conquistar novos nichos de mercado. Em suma, uma clássica competição schumpeteriana, ao invés de um padrão neoclássico de concorrência. ${ }^{256}$

Distintamente da competição por preços de produtos padronizados, a conquista do consumidor por meio das inovações permite uma segmentação do mercado, gerando uma variedade de espectros de consumo. Na realidade, como os produtos deixam de ser atrativos apenas pelas suas vantagens de custo, passam a competir em diferentes faixas de

${ }^{255}$ Cf. HARVEY, David. A Condição Pós-Moderna, op. cit.

256 A concorrência neoclássica assume a existência de alguns pressupostos, como agentes racionais e mercados perfeitamente competitivos. Esta competição ocorre dentro de um equilíbrio de mercado e a variável de disputa é o preço. Já a noção de concorrência schumpeteriana tem como base um entendimento dinâmico do processo de competição, em que o móbil da rivalidade intercapitalista é a busca de inovações e conseqüentes nichos de mercado. O processo é dinâmico porque o resultado da competição é o rompimento da norma, isto é, do equilíbrio, em um processo contínuo pela busca de novos produtos. Sobre essas diferenças ver POSSAS, Mario, Concorrência Schumpeteriana, em KUPFER, David \& HASENCLEVER, Lia. Economia Industrial - fundamentos teóricos e práticas no Brasil, Rio de Janeiro, Campus, 2002, pp. 415429 e SCHAPIRO, Mario Gomes. Política Industrial e Disciplina da Concorrência pós-Reformas de Mercado - uma avaliação institucional do ambiente de inovação tecnológica, Dissertação de Mestrado defendida na Faculdade de Direito da USP, 2005, pp. 86-123. 
preferência e, por conseguinte, de renda. Neste processo, cabe aos produtores um empenho constante na geração de novos produtos, ou, ao menos, na realização de alterações parciais nos bens existentes, como forma de assegurar a sua capacidade de comercialização. Inovação, nesse sentido, assim como entendido também pelo Manual de Oslo da $\mathrm{OCDE}^{257}$, não está necessariamente associada a transformações densamente tecnológicas. Trata-se, na verdade, de alterações incrementais (ou radicais, em alguns casos) em produtos ou em processos produtivos, com a finalidade de obter ganhos competitivos. No limite, a inovação é uma estratégia de diferenciação de produtos, cujo propósito é a consequiente conquista de novas e diferentes faixas de mercado.

A conseqüência desta prioridade para a diferenciação e para a inovação de produtos, acompanhada da decorrente alteração dos padrões de competição, é a relativização do modelo de eficiência vigente até então. Como a conquista do consumidor pelo baixo preço de bens padronizados perde parte da primazia nas estratégias corporativas, a extensão da linha de montagem e da escala de produção deixam de figurar como os elementos balizadores da produtividade. A firma eficiente é aquela capaz de produzir um leque de inovações permanentes e um conseqüente conjunto de novos produtos. Como, por sua vez, este processo envolve habilidade e conhecimento, o ganho de eficiência econômica não advém da escala de produção, mas sim da possibilidade de gerar o maior número de inovações e produtos diferenciados com um mesmo universo de conhecimento técnico. Por tal razão, a relevância da economia de escala é ofuscada pelas economias de escopo.

Naturalmente, os atributos deste novo paradigma tecno-econômico apresentam implicações para o universo da relação de trabalho. Neste campo, o esgotamento do fordismo gera uma reestruturação do trabalho organizado, apontando para dois vetores de mudança: (i) a aparição de relações de trabalho alternativas ao padrão regulado de emprego

257 Pelo Manual de Oslo, que é adotado pelos órgãos da administração pública brasileira, inovação em produto e processo (TPP) compreende: “as implantações de produtos e processos tecnologicamente novos e substanciais melhorias tecnológicas em produtos e processos. Uma inovação TPP é considerada implantada se tiver sido introduzida no mercado (inovação de produto) ou usada no processo de produção (inovação de processo) (...)" OECD, Manual de Oslo - proposta de diretrizes para a coleta e interpretação de dados sobre inovação tecnológica, (trad. Paulo Garchet), OECD - FINEP, 1997. p. 54. Uma definição semelhante consta do art. $2^{\circ}$, inciso IV, da Lei 10.973/04 - a Lei da Inovação: “Art. 2ํ Para os efeitos desta Lei, considera-se: IV - inovação: introdução de novidade ou aperfeiçoamento no ambiente produtivo ou social que resulte em novos produtos, processos ou serviços." 
e (ii) a valorização da qualificação técnica e das habilidades de um grupo de profissionais especializados. Como exemplos deste primeiro sentido de mudanças, pode-se constatar a existência de novas feições para a jornada de trabalho, de que são parte os contratos temporários, os ritmos flexíveis de produção (ajustáveis aos picos e vales da demanda) e os mecanismos de remuneração baseados em bonificações e prêmios, condicionados à obtenção de resultados. Faz parte também deste primeiro vetor a desconcentração do contingente profissional, o que é permitido pela terceirização e subcontratação externa de boa parte da força de trabalho, que antes pertencia aos quadros da firma fordista. ${ }^{258}$

Por outro lado, como a capacidade de inovação conta sobremaneira com a habilidade dos funcionários, já que uma parte sensível das descobertas advém do cotidiano, do conhecimento prático, chamado por Giovanni DOSI $^{259}$ de learning by doing, uma firma inovadora requer um segmento de funcionários especializados. Somente desta maneira, com funcionários habilitados a desempenhar a concepção e a execução de tarefas, pode-se percorrer o trajeto da inovação, que parte muitas vezes da identificação de possibilidades de incremento nos produtos a partir da própria observação das rotinas de produção, ou da interação com clientes e fornecedores. Por fim, como a produção é flexível, as empresas tendem a migrar para os mercados adjacentes, para ampliar o espectro de competição. Por causa disso, é necessário que o trabalhador detenha múltiplas competências, que o permitam uma continuada adaptação ao ritmo da produção.

Curiosamente, estratégias de organização não rígidas e voltadas a produzir bens customizados aos gostos e desejos dos consumidores era justamente o que caracterizava o paradigma tecno-produtivo flexível, nos já mencionados distritos industriais do século XIX. De fato, era a capacidade de produzir bens especializados e notabilizados pela qualidade técnica, ou pela marca, e não tanto pelo preço, que diferenciava estes distritos das indústrias de produção em massa. Como então explicar o renascimento deste paradigma, diante de indústrias dotadas de uma produtividade fordista e titulares de escalas ótimas de produção? Seria um retrocesso, voltar-se aos parâmetros de distritos do século XIX?

\footnotetext{
${ }^{258}$ A descrição das alterações no mundo do trabalho é feita por HARVEY, David. A Condição Pós-Moderna, op. cit. e JESSOP, Bob. The Future of Capitalist State, op. cit., pp. 135-162.

${ }^{259}$ DOSI, Giovanni. The Nature of Innovative Process, em DOSI, Giovanni; FREEMAN, Chris; NELSON, Richard; SILVERBERG, G. \& SOETE, Luc. (Ed.) Technical Change and Economic Theory, London, Pinter Publishers, 1988, pp. 221-238.
} 
$\mathrm{O}$ argumento apresentado por PIORE \& SABEL, na verdade o feixe condutor de The Second Industrial Divide, é o de que a crise do fordismo abriu espaço para uma segunda era industrial, caracterizada por uma organização industrial flexível e voltada à confecção de novos produtos. A retomada do paradigma da especialização flexível, no entanto, não engendrou qualquer refluxo no caminho do progresso, já que essa redescoberta veio associada a um novo patamar de conhecimento científico e tecnológico, capaz de permitir uma produção segmentada e cambiante, sem descuidar, contudo, de um patamar satisfatório de produtividade e eficiência. ${ }^{260} \mathrm{Em}$ resumo, o fato novo apresentado desde o quartel final do século XX foi a crescente intensidade de conhecimento utilizada nos processos produtivos. Com isso, a disputa industrial amparada em inovações e diferenciação de produtos tornou-se tão ou mais competitiva do que a aquela baseada em escalas eficientes de produção, como assinala o trecho a seguir:

What is distinctive about the current crisis is that the shift toward greater
flexibility is provoking technological sophistication - rather than
regression to simple techniques. As firms have faced the need to redesign
products and methods to address rising costs and growing competition,
they have found new ways to cut the costs of customized production. And
the more they have narrowed tha gap in cost between mass and craft
production, the easier it has become to draw customers away from the
formerly cheaper mass-produced goods. Technological dynamism has
thus allowed a shift from a purely reactive strategy, aimed at survival, to
an expansive strategy, which has threatened to cut ground away from
mass production. In short, craft has challenged mass production as the
paradigm.

Para os autores, que apresentam um registro da década de 1980, a viabilidade do paradigma flexível esteve particularmente associada ao desenvolvimento tecnológico no campo da computação. O computador, como ferramenta de trabalho, permitiu a existência de meios para uma programação ajustável da produção. Desta maneira, tornou-se desnecessária a adaptação física de máquinas e equipamentos, sempre que fosse necessário introduzir modificações quantitativas ou qualitativas nos bens confeccionados. A coordenação informatizada do processo industrial garantiu, portanto, possibilidades de reprogramação da produção, o que, por sua vez, deu viabilidade à confecção de produtos sujeitos a constantes alterações. Com esse instrumental, o caráter artesanal da

${ }^{260}$ Cf. PIORE, Michael \& SABEL, Charles. The Second Industrial Divide, op. cit., pp. 251-280.

${ }^{261}$ PIORE, Michael \& SABEL, Charles. The Second Industrial Divide, op. cit. p. 207. 
especialização flexível tornou-se economicamente sustentável, já que a produção adquiriu uma rotina com ritmo e escala industriais. ${ }^{262}$

Um registro semelhante pode ser feito para a década de 1990. Assim como verificado no período anterior, também nos anos 1990 algumas análises indicam que a intensificação da competição baseada em inovação esteve associada ao progresso técnico no setor de informática e tecnologias da informação. De acordo com o relatório da OCDE de 2000, intitulado A New Economy? - the changing role of innovation and information technology in growth, ${ }^{263}$ o crescimento da produtividade em diversos setores econômicos, em alguns países, deveu-se a novas formas informatizadas de comunicação, principalmente a internet. O desenvolvimento desse segmento favoreceu a realização de inovações na organização da produção, como, por exemplo, a coordenação de trabalhos em rede, e a realização de negócios por meio do comércio eletrônico.

É bem verdade que o emprego econômico do conhecimento científico e tecnológico não é um fato novo para o capitalismo. Foi, pois, justamente a sua utilização nos processos de produção que respaldou as sucessivas rodadas de inovações tecnológicas, bem como a introdução de novas máquinas e equipamentos, desde meados da Revolução Industrial. Inegavelmente, a máquina a vapor, o tear, a luz elétrica, o motor a combustão, a extração da energia nuclear, e tantas outras, foram inovações, de produto ou de processo, que impactaram a produção industrial, as pautas comerciais e o próprio processo de crescimento. Aliás, se o conhecimento e as inovações não fossem mecanismos indutores de desenvolvimento, ao permitirem rendas supra-competitivas, SCHUMPETER ${ }^{264}$ não teria baseado nessa possibilidade a sua teoria do desenvolvimento econômico. O que há de novo então? Como explicar a reabilitação do paradigma flexível?

O fato novo é que a fase iniciada em meados dos anos 1970, no mundo desenvolvido, tem representado uma aplicação exponencial do conhecimento e do progresso técnico na produção e na definição de novos produtos e processos. Nesta fase, diferentemente das demais, as inovações são permanentes e intensas. Uma das

${ }^{262}$ Cf. PIORE, Michael \& SABEL, Charles. The Second Industrial Divide, op. cit., pp. 251-280.

${ }^{263}$ OECD, A New Economy? - the changing role of innovation and information technology in growth, Paris, 2000, pp. 49-71.

${ }^{264}$ Cf. SCHUMPETER, Joseph. A Teoria do Desenvolvimento Econômico - uma investigação sobre lucros, capital, crédito, juro e o ciclo econômico, (trad. Maria Silvia Possas), $3^{\text {a }}$ ed., São Paulo, Nova Cultural, 1988. 
características decisivas do pós-fordismo, portanto, é a crescente utilização do conhecimento como fator de produção, razão pela qual Bob JESSOP prefere identificar essa fase como uma Economia Baseada no Conhecimento.

É bastante ilustrativo desse argumento o gráfico a seguir, em que é apresentada uma evolução dos pedidos de patente no USPTO, o órgão norte-americano de propriedade intelectual. Entre 1980 e 2000, em uma comparação entre Estados Unidos e Japão, duas das economias mais dinâmicas da fase atual do capitalismo, pode-se verificar taxas crescentes de patenteamento, o que indica um incremento das atividades fundadas em conhecimento, como pesquisas e desenvolvimento de novos produtos.

Pedidos de patente de invenção no USPTO

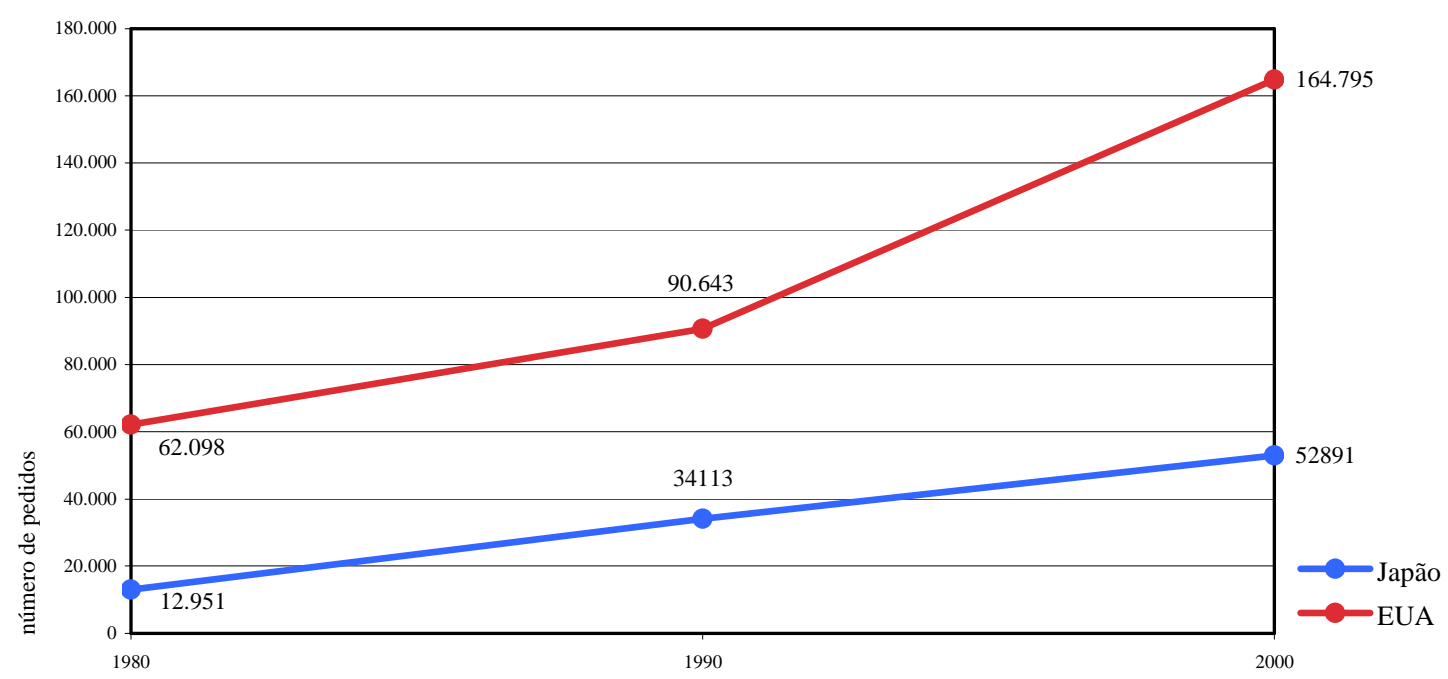

Gráfico 1. Fonte: USPTO

Muito embora as patentes não sejam um indicador fiel da taxa de inovação, ainda mais tendo como parâmetro um único órgão nacional, não deixa de ser significativo o maiúsculo crescimento também apresentado pelos demais países mais ricos. Nas duas últimas décadas do século XX, Alemanha, Reino Unido, Canadá e Coréia do Sul apresentaram uma elevação expressiva no volume de pedidos de patentes, como indica o quadro abaixo. 


\begin{tabular}{|c|c|c|c|c|c|}
\hline \multicolumn{7}{|c|}{ QUDADRO 7 } \\
\hline Países & 1980 & 1990 & 2000 & Variação (\%) $1980 / 90$ & Variação (\%) $1990 / 00$ \\
\hline EUA & 62.098 & 90.643 & 164.795 & 46 & 81,8 \\
\hline Japão & 12.951 & 34.113 & 52.891 & 163,4 & 55 \\
\hline Alemanha & 9.669 & 11.261 & 17.715 & 16,5 & 57,3 \\
\hline Reino Unido & 4.178 & 4.959 & 7.523 & 18,7 & 51,7 \\
\hline Canadá & 1.969 & 3.511 & 6.809 & 78,3 & 38,9 \\
\hline França & 3.331 & 4.771 & 6.623 & 43,2 & 636,1 \\
\hline Coréia & 33 & 775 & 5.705 & $2.248,5$ & \\
\hline Fonte: United States Patent and Trademark Office & & \\
\hline
\end{tabular}

Dados igualmente relevantes e representativos deste crescimento de importância do conhecimento na produção econômica podem ser extraídos do comportamento dos membros da OCDE. Nesse sentido, é significativo que no ano 2000 esses países tenham despendido 4,8\% do PIB em investimentos com a formação de conhecimento, em especial com a educação superior e com o setor de software. Da mesma forma, tais países alocaram em média, em 2001, 2,3\% do PIB com atividades estritamente ligadas com a geração de inovações, isto é, aportes em P\&D (pesquisa e desenvolvimento de novos produtos e processos), sendo que entre 1995 e 2001 os investimentos em P\&D cresceram continuamente, a uma taxa de $4,7 \%$ ao ano. ${ }^{265}$

É certo, no entanto, que a revitalização do paradigma flexível não tem como variável causal qualquer tipo de determinismo técnico. Muito embora o conhecimento científico e tecnológico tenha tido um efeito indutor para a economia das inovações, a viabilidade de um novo paradigma tecno-econômico é resultante de um processo social. Conforme essa linha de argumentação, desenvolvida por PIORE \& SABEL ${ }^{266}$, foi a reorganização e repactuação dos interesses sociais, de um lado, e a resistência de grupos e arranjos políticos, de outro, que permitiu a formação de uma nova dinâmica do trabalho e da produção. Os limites do mercado fordista eram antes de mais nada limites sociais, sustentados em algumas variáveis desta natureza. É bastante evidente que o limite imposto ao crescimento da renda dos trabalhadores e do seu poder de compra atendia aos interesses de uma dada correlação de forças sociais. Algo semelhante se passava com a falta de interesse privado em uma coordenação pública do processo industrial, que resultasse, por exemplo, em uma racionalização do número de empresas competidoras. Ou, ainda, na falta de consenso internacional, para se celebrar um novo acordo de estabilização, aos moldes

\footnotetext{
${ }^{265}$ Dados apresentados por ARBIX, Glauco. Inovar ou Inovar - a indústria brasileira entre o passado e o futuro, São Paulo, Papagaio, 2007, pp. 35-65.

${ }^{266}$ PIORE, Michael \& SABEL, Charles. The Second Industrial Divide, op. cit., pp. 251-280.
} 
de Bretton Woods. Sendo assim, o desenvolvimento da informática e da internet foram inegáveis instrumentos relevantes, mas para impulsionar um processo social de organização produtiva já em gestação.

O saldo deste processo, enfim, em parte forjado pelas resistências da herança institucional (path dependence) e em parte resultado de um novo arranjo de interesses (path shapping) ${ }^{267}$, foi a consolidação de um novo paradigma tecno-produtivo, que traz consigo um novo formato de círculo virtuoso. A dinâmica fordista descrita por Bob JESSOP $^{268}$, fundada na associação escala-produtividade-renda, é agora suplantada por um outro trajeto, igualmente apresentado pelo autor. Nesse novo ciclo, a produção flexível garante ganhos de produtividade baseados nas economias de escopo; a renda gerada nessa atividade é compartilhada com trabalhadores especializados e titulares de um remuneração elevada e que, por isso, podem dispor de hábitos de consumo voltados a produtos diferenciados, que geram, então, lucros supra-competitivos para os respectivos ofertantes; tais lucros são parcialmente reinvestidos no permanente processo de inovação e na definição de novos produtos, aptos assim a conquistar novos clientes e novas faixas de consumo.

Assim como no caso do fordismo, este círculo virtuoso também está associado a respectivos atributos jurídico-institucionais. No plano corporativo, a grande empresa deixou de ser o único veículo de organização microeconômica, passando a dividir a atenção com as empresas emergentes. Já no campo da intervenção pública, a era da regulação foi parcialmente revista e o Estado passou por reformas orientadas para uma desregulação dos mercados. São essas as questões das seções a seguir.

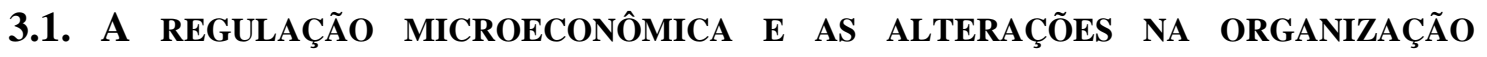 CORPORATIVA: AS EMPRESAS EMERGENTES}

No âmbito microeconômico, as pautas de estabilização apresentadas pelo paradigma da economia baseada no conhecimento apontam para outros compromissos, distintos daqueles verificados sob a égide do fordismo. Diferentemente do que se verificou

\footnotetext{
${ }^{267}$ Sobre a dialética entre path dependence e path shapping ver JESSOP, Bob. The Future of Capitalist State, op. cit. pp. 133-139.

${ }^{268}$ Cf. JESSOP, Bob. The Future of Capitalist State, op. cit.
} 
naquela economia industrial, na especialização flexível a rigidez dos fatores não é particularmente um problema. Da mesma forma, a produção dos segmentos inovadores não contempla, necessariamente, uma vasta escala de produção e nem tampouco afina-se com a manufatura de bens padronizados. Sendo assim, a variável crítica da regulação microeconômica não é a manutenção das condições de mercado e de demanda, que, como visto, foram alcançadas por meio das estratégias de concentração, conglomerização e verticalização dos mercados. Na medida em que a superação da crise do fordismo encontrou guarida na economia das inovações e na segmentação das faixas de consumo, a variável crítica desta regulação é a criação de novos mercados. ${ }^{269}$

Com isso, esta regulação microeconômica assume características que a diferenciam tanto de uma coordenação amparada em bases econômicas neoclássicas, típica do século XIX, como também de um mecanismo ajustado ao fordismo. De um lado, não se trata de um ambiente caracterizado por agentes atomizados, partilhando de um contexto tendente ao equilíbrio, em que os atores concorrem em condições de extrema rivalidade, tendo a disputa em preços como seu componente estratégico. De outro, não se trata também de uma economia já estabelecida e carente de um mercado consumidor, como a fordista. Se se tratasse do primeiro modelo de organização econômica, poder-se-ia apostar em uma auto-regulação dos mercados, aos moldes do que ocorria na fase concorrencial do capitalismo. Se se tratasse, por sua vez, do fordismo, caberia à regulação microeconômica garantir artificialmente as condições para que fosse alcançado este equilíbrio, ainda que contando com firmas concentradas e fatores com baixa mobilidade. A economia baseada no conhecimento, todavia, traz consigo uma necessidade particular e diferenciada: a manutenção da capacidade permanente de inovação. ${ }^{270}$

Muito embora as inovações mostrem-se rentáveis quando exitosas, encerram um grau de incerteza que em muitos casos pode ocasionar a retração dos empreendedores. Trata-se de um problema subjacente às inovações, como assinala Giovanni DOSI ${ }^{271}$, ao comentar a natureza deste processo. Na realidade, a incerteza é, antes de tudo, um corolário deste tipo de atividade econômica, que pressupõe a descoberta de fórmulas não existentes.

\footnotetext{
${ }^{269} \mathrm{O}$ argumento é desenvolvido por PIORE, Michael \& SABEL, Charles. The Second Industrial Divide, op. cit., pp. 251-280.

${ }^{270}$ Este argumento é apresentado por PIORE, Michael \& SABEL, Charles. The Second Industrial Divide, op. cit.

${ }^{271}$ DOSI, Giovanni. The Nature of Innovative Process, op. cit.
} 
Como assinala DOSI, a busca de um produto ou de um processo novo, por definição, não admite um roteiro certo dos desdobramentos experimentais. O grau desta imprevisibilidade é, ainda, diretamente proporcional à amplitude do processo inovativo: as inovações incrementais, isto é, dedicadas a produtos ou processos já existentes, apresentam um componente de incerteza menor do que uma inovação radical, dedicada a criar um nicho de mercado absolutamente novo. Em compensação, uma inovação radical bem sucedida garante uma exclusividade temporária de mercado e conseqüentemente a possibilidade de se auferir rendas schumpeterianas. Por estas razões, a manutenção da capacidade permanente de inovação não é uma tarefa trivial.

O empreendedor vive, na realidade, um dilema, ao navegar em um ambiente de incerteza: pode apostar na possibilidade de êxito e de conquista de mercados, mas pode igualmente se ver diante dos riscos do fracasso e do desperdício de investimentos. As chances de erro são uma possibilidade real: uma proposta de um novo produto ou de um novo processo pode falhar tanto em seus atributos técnicos, como comerciais. Na primeira situação, é o caso de um projeto que, embora se mostre como um piloto viável, não apresenta viabilidade técnica, quando produzido em escala industrial. Entre tantas possibilidades de projetos mal sucedidos, podem ocorrer episódios em que o custo final da produção, por exemplo, não é competitivo, ou casos em que o tipo de material empregado em laboratório apresenta incompatibilidades com o uso doméstico. Já na segunda situação, o problema é de êxito comercial, isto é, embora tecnicamente viável, o produto pode não representar os ganhos de demanda esperados. ${ }^{272}$ Sendo assim, o processo de inovação encerra, a um só tempo, possibilidades de ganhos supra-competitivos e a iminência de fracassos retumbantes - em uma atividade cuja decisão corporativa é mediada pela incerteza.

O resultado disso pode ser um sub-investimento nesta estratégia ${ }^{273}$, o que no médio prazo, entretanto, pode representar um outro efeito colateral: a perda de posições de mercado pelos agentes menos inovadores. Sobretudo nos mercados mais dinâmicos, esse comportamento pode significar perda de competitividade e uma efetiva impossibilidade de

\footnotetext{
${ }^{272}$ Sobre ambas as formas de incerteza, ver FREEMAN, Chris \& SOETE, Luc. The Economics of Industrial Innovation, $3^{\text {a }}$ ed., Massachusetts, MIT Press, 1999, pp. 242-264.

273 Os riscos de investimento sub-ótimo são discutidos por FREEMAN, Chris \& SOETE, Luc. The Economics of Industrial Innovation, op. cit.
} 
se manter como agente econômico do processo concorrencial. Essa é uma possibilidade plausível, discutida na literatura sobre inovação, em particular nos setores de intenso progresso técnico. A seguinte passagem de Chris FREEMAN \& Luc SOETE, dois economias dedicados a este tema, ilustra o argumento:

Yet not to innovate is to die. Some firms actually do elect to die. Firms
which fail to introduce new products or processes in the chemical,
instruments or eletronics industries cannot usually survive, because their
competitors will pre-empt the market with product innovations, or
manufacture standard products more cheaply with new processes.
Consequently, if they wish to survive despite all their uncertainties about
innovation, most firms are on an innovative treadmill. They may not wish
to be offensive innovators, but they can often scarcely avoid being
defensive or imitative innovators. Changes in technology and in the
market and the advances of their competitors compel them to try and
keep pace in one way or another. ${ }^{274}$

Diante disso, a economia baseada no conhecimento revela-se como portadora de uma intensa falha de mercado: inovar importa e pode levar a resultados positivos, mas os riscos envolvidos não são convidativos, em muitas ocasiões. Em decorrência disso, a constituição de um ambiente econômico sustentável, assentado no círculo virtuoso descrito por Bob JESSOP, capaz de garantir uma especialização econômica dotada de taxas expressivas de crescimento e de elevados níveis de renda, reclama a superação destes problemas de organização microeconômica. Para tanto, a coordenação institucional incumbe-se de um duplo papel ${ }^{275}$ : de um lado, procura desenvolver mecanismos que mitiguem a incerteza; de outro, aposta na constituição de um ambiente sistêmico de competição dinâmica, para fomentar estratégias competitivas semelhantes às descritas por FREEMAN \& SOETE.

No que tange à incerteza, parte de seus problemas tendem a ser incumbidos ao Estado, que como será visto afastou-se gradativamente da manipulação das variáveis macroeconômicas, tendendo a se concentrar em uma intervenção schumpeteriana, em que as políticas industriais, com um caráter microeconômico, são direcionadas ao fomento da inovação. Quanto à criação de um ambiente sistêmico de promoção da competitividade, no qual as firmas sejam induzidas a concorrer por inovações e não por preços, ${ }^{276}$ mitigando

\footnotetext{
${ }^{274}$ FREEMAN, Chris \& SOETE, Luc. The Economics of Industrial Innovation, op. cit. p. 266.

${ }^{275}$ Cf. PIORE, Michael \& SABEL, Charles. The Second Industrial Divide, op. cit., pp. 251-280.

276 A idéia de um ambiente sistêmico para promover estratégias de inovação é apresentada por POSSAS, Mario. Competitividade: Fatores Sistêmicos e Política Industrial - implicações para o Brasil, em CASTRO,
} 
assim os desincentivos representados pela percepção de incerteza, é uma pauta atribuída ao universo corporativo.

A formação deste universo de competidores, que lastreiam a sua rivalidade em conhecimento, e não apenas em custos, conta justamente com o desempenho das firmas novas. A geração de um mercado dinâmico pressupõe as empresas não como um instrumento de gestão da demanda existente, como no fordismo, mas como um fator indutor de uma nova competição. Em outros termos, a viabilidade deste ambiente dinâmico pressupõe o florescimento constante de novas empresas emergentes, portadoras de futuro e dispostas a desenvolver novos produtos e novos processos. Trata-se das chamadas firmas start-ups, organizadas em torno de concepções e propostas produtivas, muitas vezes desenvolvidas em ambientes de pesquisa, como incubadoras universitárias.

São essas empresas que, quando bem sucedidas, impulsionam dinamicamente a competição do mercado, trazendo, inclusive, pressão para as firmas já consolidadas (incumbents). Como emergentes, estas organizações têm como única pauta comercial a implementação de suas inovações, apesar das incertezas envolvidas nessas atividades. Detêm, portanto, incentivos para realizar o seu plano de negócios, de cujo resultado depende a sua própria sobrevivência. A relevância destas firmas para a nova economia é salientada também pelos estudos da OCDE, como indica a seguinte passagem de um de seus relatórios:

Small start-up firms have gained proeminence in the innovation process, as they are important sources of new ideas and innovations. In emerging areas, where demand patterns are unclear, risk are large, and the technology has not been worked out, small firms have an advantage over large established firms. They can be more flexible, are more specialised and may also be better at channelling creativity and providing the right incentives than large firms. New mechanisms, such as venture capital and the associated entrepreneurial expertise, have allowed these firms to grow rapidly. ${ }^{277}$

Sendo assim, a nova economia traz como uma de suas características a diversidade das formas corporativas. Diferentemente do padrão fordista, na economia baseada no conhecimento não apenas as grandes empresas, já detentoras de uma significativa participação de mercado, estão habilitadas a obterem retornos econômicos

Antônio Barros de; POSSAS, Mario Luiz \& PROENÇA, Adriano. Estratégias Empresariais na Indústria Brasileira: discutindo mudanças, Rio de Janeiro, Forense, 1996, pp. 71-117.

277 OECD, A New Economy?, op. cit. p. 42. 
favoráveis. Ao lado dessas, figuram diversos exemplos de empresas emergentes que trouxeram inovações de produto ou de processo relevantes para a dinâmica econômica de seus mercados, alterando assim a composição concorrencial destes setores. Alguns dos casos mais representativos desta possibilidade de competição, a partir de firmas originalmente inovadoras e pequenas podem ser ilustrados por casos de sucesso, como a Apple, a Microsoft e a Google, entre outras.

Mesmo no Brasil, tem se verificado um fenômeno semelhante, com a formação daquilo que Glauco ARBIX denomina de novo empreendedorismo. ${ }^{278}$ De acordo com o autor, um grupo restrito de empresas tem despontado como vetores permanentes de inovação, assumindo uma estratégia de competição baseada no conhecimento e na diferenciação de produtos. Este grupo, formado por um universo de 1.199 empresas, de um total de 72.000 (empresas com mais de dez empregados), figura como a parcela mais dinâmica da indústria brasileira. Veja-se a esse respeito que, não obstante representem um segmento populacional minoritário, respondem por $25,9 \%$ do faturamento industrial e apresentam a maior média de remuneração mensal, situada em torno de R \$1.200,00 (um mil e duzentos reais). ${ }^{279}$ É este grupo de vanguarda, responsável pela introdução do maior volume relativo de inovações no mercado, que encerra, para ARBIX, o padrão de êxito empresarial a ser difundido para os demais setores do empresariado brasileiro.

Um dos problemas para a consolidação deste segmento emergente reside justamente nas condições de seu financiamento. Muito embora as grandes corporações e os projetos de larga escala, que foram hegemônicos na economia fordista, também apresentassem dificuldades neste campo, dada a intensidade de capital necessário para dar consecução aos seus planos de investimento, as empresas inovadoras têm a seu desfavor um alto patamar de incerteza. Esse atributo pode não apenas ocasionar situações de subinvestimento por parte das empresas, como acima relatado, mas também cenários de subfinanciamento, em razão do receio de financiadores externos - como será tratado no

\footnotetext{
${ }^{278}$ ARBIX, Glauco. Novo Empreendedorismo no Brasil? Em ARBIX, Glauco. Inovar ou Inovar, op. cit. pp. 105-142.

${ }^{279}$ A pesquisa apresentada por ARBIX dividiu as empresas em três categorias: (i) firmas que inovam e diferenciam produtos; (ii) firmas especializadas em bens padronizados e (iii) firmas que não diferenciam produtos e têm menor produtividade. O primeiro grupo conta com 1.199 empresas e responde por $25,9 \%$ do faturamento. O segundo grupo apresenta 15.311 empresas $(21,3 \%$ do total) e detém $62,6 \%$ do faturamento. Já o terceiro grupo conta com 55.495 empresas $(77,1 \%$ do total) e representa $1,3 \%$ do faturamento. Tais dados estão disponíveis em ARBIX, Glauco. Novo Empreendedorismo no Brasil? Em ARBIX, Glauco. Inovar ou Inovar, op. cit.
} 
próximo capítulo, os custos de agência são elevados, em virtude do teor de assimetria de informações existente entre investidores e empreendedores.

O tratamento dessa questão, no Brasil, passa por dois planos institucionais convergentes: (i) o primeiro deles é o das ferramentas jurídicas e (ii) o segundo é relativo à intervenção do Estado, que como visto é um elemento chave do sistema financeiro nacional. Tal como argumentado no primeiro capítulo, as ferramentas importam, pois podem dirimir as assimetrias entre investidores e empreendedores, permitindo assim a provisão de capital necessário para os projetos corporativos - com as inovações não é diferente. A esse tema voltar-se-á no próximo capítulo deste trabalho, dedicado a retomar o debate jurídico sobre o financiamento, tendo como foco de análise as especificidades das empresas emergentes e portadoras de ativos intangíveis. Já com relação à atuação do Estado, convém relatar o processo de revisão teórica e política ocorrida em função da crise do fordismo: em boa medida, os mecanismos de ação do BNDES na nova economia, notadamente os novos tipos de ferramentas utilizadas nestas operações, decorrem dessas alterações, vivenciadas no âmbito da intervenção pública, em razão da mudança de paradigma tecno-produtivo.

\subsection{A REVISÃo DO PAPEL DO ESTADO}

A definição do papel do Estado em uma economia baseada no conhecimento tem como antecedente as reações teóricas e de políticas públicas provocadas pela crise do fordismo e que culminaram em uma revisão da regulação pública da economia. Para Wagner ARIENTI ${ }^{280}$, isso se deve ao fato de que o Estado Keynesiano era identificado como o elemento chave da organização pública da economia fordista, assumindo, em conseqüência disso, parte do ônus pela crise do paradigma. Por esta razão, a idéia força desse período foi a da desestatização da economia, promovida por reformas orientadas para o favorecimento dos mercados. ${ }^{281}$ Com isso, o quadro institucional, constituído no contexto do New Deal, bem como as suas variações, no ambiente Europeu, e nos países da periferia latino-americana, foi desarranjado entre as décadas de 1980 e de 1990, o que representou

\footnotetext{
${ }^{280}$ Cf. ARIENTI, Wagner Leal. Do Estado Keynesiano ao Estado Schumpeteriano, op. cit.

${ }^{281}$ Sobre a desregulação da economia, ver CHANG, Ha-Joon. The Economics and Politics of Regulation, op. cit.
} 
um abrandamento dos mecanismos públicos de coordenação do processo econômico. Uma amostra particularmente relevante deste processo foi a contenção da manipulação governamental sobre as variáveis macroeconômicas (juros, câmbio e gasto público), utilizadas até então como instrumentos de gestão da economia fordista. ${ }^{282} \mathrm{Um}$ outro sinal foi a privatização das empresas e bancos públicos, nos países em que a participação estatal era mais pronunciada, como no Brasil.

Diante da persistência dos problemas vividos com a crise, ganharam força diagnósticos acadêmicos e recomendações de política unidos pelo ceticismo quanto às virtudes do modelo de capitalismo regulado. Foi nesse momento que galgaram primazia intelectual algumas teses acadêmicas voltadas a argumentar que as falhas do governo, na intervenção econômica, eram ainda mais prejudicais do que as próprias falhas do mercado que haviam demandado a regulação estatal. Argumentos como os de STIGLER ${ }^{283}$, por exemplo, dedicados a sustentar que os reguladores não eram movidos pelo interesse público, mas sim por motivos privados, fruto do inexorável processo de captura a que estão sujeitos, passaram a ecoar no debate público - influenciando inclusive a agenda da reforma do Estado no terceiro mundo. ${ }^{284}$

282 A seguinte passagem de CHANG comenta este abandono do instrumental keynesiano: "The continued lagging economic performance in the developed countries since the mid-1970s discredited, rightly or wrongly, their former models of economic management that relied on keynesian aggregate demand management and extensive government regulation." CHANG, Ha-Joon. The Economics and Politics of Regulation, op. cit. p. 712.

${ }^{283}$ Para um survey mais completo destas teorias que embalaram a reforma do Estado, ver CARVALHO, Vinicius Marques de. Estado e Setor Privado na Gestão dos Serviços de Saneamento Básico no Brasil: uma análise jurídica a partir do exemplo francês. Tese de Doutorado, apresentada no Departamento de Direito Comercial da Faculdade de Direito da USP em co-tutela com a Universidade de Paris I, 2007, pp. 154-168.

${ }^{284}$ A criação no Brasil da noção de autarquias em regime especial, no contexto da reforma do Estado é um exemplo disso. Tratava-se de uma figura nova no direito administrativo e que teve a intenção de permitir a constituição de agências reguladores com independência funcional, em que os conselheiros gozassem de mandato fixo e independentes do mandato do Presidente da República. A intenção era evitar assim que fossem capturados por interesses alheios aos da própria regulação. A única diferença, no entanto, reside no fato de que o maior temor de captura no Brasil não era dos agentes privados, como na descrição de STIGLER, mas sim do próprio governo. A seguinte passagem de Floriano Azevedo MARQUES NETO é exemplificativa desta influência: "A discussão em torno da independência coloca-nos diante do risco de captura da agência. Embora o tema da captura enseje grandes reflexões, identificamos quatro graves riscos de captura: (...) o segundo refere-se à captura por contaminação de interesses. Esta se manifesta com a assunção pelo órgão regulador dos valores e interesses do regulado, como se fossem os interesses gerais da coletividade, e pela aceitação dos problemas destes atores como problemas incontornáveis e empecedores da implementação dos objetivos eleitos para o setor. (...) Por último há o risco de captura pelo poder político, traduzida no atrelamento da atividade regulatória aos interesses conjunturais do bloco do poder, às vicissitudes eleitorais. (...) Os antídotos, aqui, correspondem à existência de mecanismos legais de reforço à independência da agência, à rejeição de qualquer mecanismo de atrelamento (em especial desvarios como os contratos de gestão)." MARQUES NETO, Floriano Azevedo. A Nova Regulação Estatal e as Agências Independentes, em SUNDFELD, Carlos Ari. Direito Administrativo Econômico, São Paulo, Malheiros, 2000. 
Também partilharam dessa notoriedade autores como Harold DEMSETZ ${ }^{285}$ e William BAUMOL ${ }^{286}$ que, ao oferecerem modelos de regulação alternativos, supostamente capazes de substituírem a necessidade de uma intervenção estatal nos mercados, traziam soluções para as críticas desferidas por STIGLER. A proposta de DEMSETZ, por exemplo, é a da possibilidade de concorrência pelo mercado: em situações de monopólio natural, em que não se pode presumir a competição entre os agentes, a garantia de bem estar, usualmente obtida pela regulação pública, poderia ser alcançada na seleção do candidato mais eficiente. Em suma, algo como um processo de licitação poderia estabelecer condições de concorrência, capazes de garantir a escolha de um candidato com as melhores condições econômicas (menor estrutura de custos, maior produtividade), mitigando assim a necessidade de uma intervenção regulatória permanente.

Uma racionalidade semelhante constava das propostas de BAUMOL, apresentadas anos mais tarde, sobre os mercados contestáveis. Tal como DEMSETZ, o autor também relativiza a necessidade de regulação pública dos monopólios naturais, argumentando que alguns desses mercados são caracterizados pelas baixas barreiras à entrada de novos concorrentes, o que os tornam mercados contestáveis. Com isso, os eventuais abusos praticados por um monopolista poderiam ser auto-regulados pelos seus próprios competidores potenciais. ${ }^{287}$ Essas concepções, aliadas ao ceticismo de teorias como as da captura ou de algumas outras, como as que identificam a existência de grupos de interesse orbitando a regulação (os rent seekings), formaram as bases teóricas para uma redefinição da agenda política e institucional.

No que tange à organização do sistema financeiro, anos mais tarde do que as formulações concernentes às falhas de governo, alguns autores passaram a defender a tese da visão política - igualmente informada por um ceticismo quanto às possibilidades de atuação do Estado nos mercados de crédito e de capital. Como visto no capítulo 2, de modo

pp. 89-90. Sobre o conceito original de captura, ver STIGLER, George. The Theory of Economic Regulation, The Bell Journal of Economics and Management Science, no. 2, 1971, pp. 3-21.

${ }^{285}$ DEMSETZ, Harold. Why Regulate Utilities, Journal of Law and Economics, Vol. 11, 1968.

${ }^{286}$ Ver a respeito BAUMOL, William. PANZER, J. \& WILLIG, D. Contestable Markets and the Theory of Industrial Structure, Nova York, Harcourt Brace Jovanovich, 1982.

${ }^{287}$ Para uma reconstrução dessas teorias ver CHANG, Ha-Joon. The Economics and Politics of Regulation, op. cit. e CARVALHO, Vinicius Marques de. Estado e Setor Privado na Gestão dos Serviços de Saneamento Básico no Brasil, op. cit. 
semelhante a STIGLER, autores como LA PORTA, LOPEZ-de-SILANES e SHLEIFER ${ }^{288}$ advogam que a intervenção do Estado no sistema financeiro não é informada pelo interesse público - o que neste caso seria equivalente a uma atuação autenticamente desenvolvimentista. Tal como os reguladores auto-interessados, os agentes estatais também instrumentalizariam os bancos públicos, para assim atender aos seus interesses políticos, prejudicando não só a eficiência dos bancos do Estado, como também de todo o restante da economia. Por esta razão, a melhor forma de organização do sistema financeiro seria a sua desestatização e o correspondente reforço da proteção privada dos investidores.

Os diagnósticos céticos da visão política encontram respaldo em um outro conjunto de análises, conhecido por visão de agência. Para os partidários desta abordagem, a participação direta do Estado no setor bancário pode não garantir a consecução dos resultados pretendidos, isso em razão dos custos de agência envolvidos na intervenção pública. De acordo com essa interpretação, muito embora o mercado apresente falhas que reclamam uma intervenção reguladora, a organização burocrática, mesmo quando bem intencionada, apresenta custos e ineficiências que comprometem a sua capacidade de ação: por mais meritória que sejam as razões da atuação pública, a sua inefetividade compromete o desempenho do seu papel à frente dos mercados. ${ }^{289}$ Demais disso, a intervenção pública no sistema financeiro, principalmente quando realizada diretamente, como no caso brasileiro, apresentaria uma outra deficiência: a possibilidade de inibir o desenvolvimento dos demais agentes deste mercado, devido ao problema de crowding out. Como os agentes públicos contam com uma poupança mobilizada compulsoriamente, acabam por drenar recursos que, normalmente, seriam canalizados para o restante do sistema financeiro - uma situação que estaria ainda associada a um efeito colateral: a alocação ineficiente destes montantes, que são direcionados pelos bancos estatais, eivados de visões políticas e custos de agência. ${ }^{290}$

\footnotetext{
${ }^{288}$ LA PORTA, Rafael et al. Government Ownership of Banks, op. cit. No Brasil, alguns autores têm protagonizado um debate semelhante, ver a respeito PINHEIRO, Armando Castelar. Bancos Públicos no Brasil: para onde ir? em PINHEIRO, Armando Castelar \& OLIVEIRA FILHO, Luiz Chysostomo (org). Mercado de Capitais e Bancos Públicos - análise e experiências comparadas, op. cit. pp. 159-263.

${ }^{289}$ A apresentação dessa visão é feita por YEYATI, Eduardo Levy; MICCO, Alejandro \& PANIZZA, Ugo. Should the Government be in the Banking Sector?, op. cit.

${ }^{290}$ Para uma análise crítica dos bancos públicos brasileiros, que seriam geradores de custos como o crowding out, ver PINHEIRO, Armando Castelar. Bancos Públicos no Brasil: para onde ir?, op. cit. Também a esse respeito, ARIDA, Pérsio. Mecanismos Compulsórios e Mercados de Capitais: propostas de política econômica, Instituto Casa das Garças, Texto para Discussão nº. 8, 2005, pp. 1-9 disponível em http://iepecdg.com/DISK\%201/Arquivos/TPD/TPD8IEPE.pdf, acesso em 08.12.08.
} 
Entre 1980 e 1990, ecoando parte destes diagnósticos conceituais, foram gestados os novos caminhos para a política pública e para a intervenção econômica do Estado, centrados nas propostas de retração da participação governamental na esfera privada. Nesse campo, conforme o contexto institucional, dois tipos de medidas deram consecução à revisão do papel do Estado, foram elas: (i) a desregulação setorial e (ii) a adoção de uma lógica privada pelos agentes do Estado. Com relação à primeira dessas medidas, trataram-se de eventos bastante característicos das economias liberais, como no cenário norte-americano, em que a participação do Estado fora constituída, desde o New Deal, pela via da regulação, isto é, de forma indireta. Já o segundo tipo de reforma, foi o fio condutor dos processos de desestatização tanto na Europa, como, principalmente, nos países latinoamericanos, em que o modelo de intervenção pública contou, sobremaneira, com a ação direta do Estado na economia.

Notadamente quanto à desregulação setorial, uma boa parte das regras de funcionamento dos mercados, constituídas sob a égide do consenso keynesiano, foi relaxada nos idos de 1980. A bem da verdade, a desregulação da economia foi a primeira resposta oferecida pelos formuladores de políticas públicas à crise econômica dos anos 1970. ${ }^{291}$ Procurando com isso restabelecer as condições de investimento e, assim, superar o estado de recessão e de inflação, por que passava a economia norte-americana, o novo governo, de filiação republicana, procurou rever regras e limitações impostas aos operadores privados, em diversos setores. ${ }^{292}$ Os controles de preço e das condições de oferta de serviços, em segmentos como telecomunicações, energia e combustíveis, entre outros, foram eliminados, ou ao menos, reduzidos, ao longo dos anos $1980 .{ }^{293}$ A intenção dessas alterações foi a de favorecer a disciplina do mercado, em detrimento dos controles públicos, constituídos para delimitar os meios de exercício das atividades e os custos das respectivas tarifas. $^{294}$

${ }^{291}$ Cf. PIORE, Michael \& SABEL, Charles. The Second Industrial Divide, op. cit., pp. 181-183.

${ }^{292}$ PIORE, Michael \& SABEL, Charles. The Second Industrial Divide, op. cit.

${ }^{293}$ Cf. PIORE, Michael \& SABEL, Charles. The Second Industrial Divide, op. cit.

${ }^{294}$ No direito antitruste norte-americano, por exemplo, também ocorreu uma desregulação. Por meio de uma legislação federal, o National Cooperative Research Act, foi alterado um procedimento secular de controle dos acordos anti-competitivos, garantindo assim um afrouxamento das regras de concorrência. Desde o Sherman Act, de 1890, os acordos entre concorrentes eram condenados de maneira per se, não desfrutando assim das possibilidades de uma regulação flexível, como ocorre no caso de julgamentos das fusões e das aquisições. Em 1984, contudo, o NCRA abriu uma exceção a esse entendimento, para franquear os dispositivos flexíveis da regra da razão às cooperações de empresas voltadas ao desenvolvimento tecnológico. Uma medida, aliás, que, para além de garantir a desregulação, também apontou para a indução 
Um setor cujas bases foram particularmente alteradas desde a crise do fordismo, impactando assim a nova economia, foi o da regulação financeira. Entre 1979 e 2000, este segmento da economia norte-americana vivenciou medidas destinadas a promover a desregulação de suas atividades, buscando assim prover maior mobilidade para o capital financeiro e um conseqüente impulso ao provimento de recursos e investimentos corporativos. Em 1979, o Employee Retirement Security Act suprimiu da legislação previdenciária privada alguns dos limites impostos às suas políticas de aplicação financeira. Com isso, as entidades de previdência passaram a poder investir em empresas emergentes de capital de risco (venture capital), o que garantiu um montante de capital significativo para as empresas emergentes, como as do Vale do Silício ou da Rota 128, na região de Massachusetts. ${ }^{295}$ Anos mais tarde, mas ainda refletindo este movimento de desregulação da economia, uma outra alteração substantiva sucedeu no setor bancário: o Glass Steagall Act foi revogado. Desde o final dos anos 1990, os bancos de investimento e os bancos comerciais puderam passar a atuar conjuntamente, o que deu causa, segundo Joseph STIGLITZ ${ }^{296}$, à formação de grandes conglomerados financeiros, como o J.P.

de arranjos entre empresas emergentes, buscando assim diminuir, por meio do estímulo às parcerias, os custos e incertezas do progresso técnico. Como sabido, o direito antitruste norte-americano apresenta dois procedimentos de julgamento dos casos: (i) o per se e (ii) a regra da razão. Os casos sujeitos ao primeiro procedimento, como cartéis e acordos anti-competitivos, são condenados per se, isto é, independentemente dos efeitos que possam gerar na economia. Já os casos submetidos à regra da razão, como as fusões, contam com uma disciplina flexível: são analisados caso a caso e só são rejeitados se os efeitos negativos (custos da operação) à economia de mercado forem superiores aos ganhos de eficiência apresentados (benefícios). A origem disso nos Estados Unidos vem de um entendimento jurisprudencial, segundo o qual a proibição de atos de concentração só poderia prevalecer nas situações em que a operação se mostrasse unreasonable (contrária à regra da razão). No Brasil, os artigos 20 e 21 (controle de condutas) e 54 (controle de estruturas) da lei concorrencial (lei 8.884/94) contemplam para todos os casos a regra da razão.

${ }^{295}$ O Employee Retirement Security Act (ERISA) alterou o conceito de prudência financeira (prudent man rule), que baliza as alocações de recurso pelas entidades de previdência privada. Com isso, nos anos 1980, em menos de uma década, só o número de organizações de capital de risco praticamente dobrou, passando de 331, em 1982, para 657, em 1988. Foi nesse contexto que se registraram algumas importantes operações financeiras deste setor. Diversas companhias que entre os anos 1990 e início dos anos 2000 tornaram-se detentoras de consideráveis participações de mercado, tiveram o seu processo de capitalização realizado, entre o fim dos anos 1970 e o início dos 1980, por meio dos investimentos de venture capital. No setor de informática, por exemplo, as empresas Apple, Cisco, Microsoft e Netscape são conhecidos casos de sucesso desta fase do capital de risco americano, assim como as empresas Starbucks, Staples, Midway Airlines e Federal Express, no setor de serviços ou a Genetch, no ramo de biotecnologia. Para essa reconstrução ver FREEMAN, John. Venture Capitalist and Modern Capitalism, em NEE, Victor \& SWEDBERG, Richard. The Economic Sociology of Capitalism, New Jersey, Princeton, 2005, pp. 144-167.

${ }^{296}$ Sobre esse período, fazendo expressa referência à formação da bolha especulativa das chamadas indústrias dot.com, assinala STIGLITZ: "Todos queriam participar. À medida que os novos empreendimentos surgiam, as grandes instituições de investimento vendiam seus títulos mobiliários para o público - para fundos de pensão e outros investidores institucionais e para os clientes varejistas, por meio de uma vasta rede de corretagem. Nos anos 90, a capacidade dos Estados Unidos para financiar a inovação financeira causou inveja ao mundo." STIGLITZ, Joseph. Os Exuberantes Anos 90, op. cit. p. 165. 
Morgan Chase e o Citigroup, contribuindo também para um grande afluxo de recursos neste período, boa parte dos quais canalizados para os empreendimentos inovadores.

Já nos países em que a regulação pública da economia foi forjada pela via das empresas estatais, como nos países latino-americanos, a revisão do papel do Estado contou com a adoção de uma lógica privada pelos agentes do Estado. ${ }^{297}$ A gestão governamental procurou assim assumir os parâmetros de eficiência e de produtividade típicos da iniciativa privada. O desdobramento deste propósito contou com um conjunto de medidas, desde alterações legislativas destinadas à reorganização da administração pública, até novos mecanismos de gestão, passando pela privatização, que concretizou boa parte desta política. Fez ainda parte deste conjunto de medidas, a abertura de capital das empresas estatais e a adoção de regras de governança corporativa por algumas destas companhias. O mesmo pôde se verificar com a adoção de novos controles orçamentários e financeiros, dedicados a garantir um orçamento público equilibrado, alterando desta maneira a lógica keynesiana, amparada na possibilidade de se incorrer em déficits orçamentários.

No Brasil, em particular, este cipoal de medidas compôs a chamada reforma do Estado, ocorrida nos anos 1990. O diagnóstico de que partiram os seus formuladores foi igualmente o da crise fiscal do Estado, que teria ensejado a conseqüente perda de suas possibilidades de intervenção. Para BRESSER PEREIRA ${ }^{298}$, um dos autores e executores desta proposta, dois fatores foram decisivos para a precipitação desta crise: (i) o aumento abrupto dos juros norte-americanos no início da década de 1980, que como visto foi um fator incidental à crise do fordismo; e (ii) a extemporânea manutenção das políticas nacionais de subvenção a diversos setores econômicos, ao longo dos anos 1980, em um contexto em que o Estado já padecia da falta de condições financeiras. Ambos os fatores, de acordo com essa leitura, provocaram a propalada crise fiscal, isto é, a incapacidade

297 A seguinte passagem de CHANG, assinala este fenômeno: "Although very significant deregulation (and privatization) have been, at least until now, confined to the US and the UK, other developed countries also moved, in varying degrees and speeds, towards deregulation and a general reduction in government involvement in the economy, through spending cuts, sales of state assets (if not wholesale privatization), introduction of more commercial criteria into the operations of public enterprises and welfare provision, and the introduction of more 'market-oriented'methods of regulation such as franchise bidding and 'yardstick competition'." CHANG, Ha-Joon. The Economics and Politics of Regulation, op. cit. p. 712.

298 BRESSER PEREIRA, além de um dos principais autores nesse tema foi também Ministro da Administração e Reforma do Estado, no Governo do Presidente Fernando Henrique Cardoso, comandando a implementação das reformas. Sobre as noções conceituais destas políticas, ver BRESSER PEREIRA, Luiz Carlos. Crise Econômica e Reforma do Estado - para uma nova interpretação da América Latina, op. cit. 
financeira do Estado para responder às demandas sociais e econômicas, o que comprometia a saúde de toda a economia do país. ${ }^{299}$

Essa identificação do Estado como o epicentro dos problemas econômicos é bastante evidente em uma comparação apresentada por BRESSER PEREIRA entre a crise dos anos 1980 e 1990, com a crise de 1929: para o autor, enquanto em 1929 tratou-se de uma crise do mercado, para cuja solução foi construído o aparato keynesiano, a crise contemporânea foi uma crise do Estado, cujo remédio seriam as reformas orientadas para o mercado. $^{300}$ Vem daí, portanto, a agenda de revisão do papel atribuído à intervenção pública na economia: o Estado deveria passar, sempre que possível, da condição de provedor direto para a de regulador e indutor indireto dos processos de mercado.

A consecução dessa agenda de transformação da intervenção estatal foi viabilizada por um extenso rol de medidas jurídico-institucionais, que alteraram sensivelmente os quadrantes do direito administrativo e econômico brasileiros, na década de 1990. As figuras administrativas dispostas no decreto-lei 200/67, até então o principal marco regulador da administração pública, tais como empresas públicas, sociedades de economia mista e autarquias, perderam parte de sua centralidade. Passaram a dividir espaço com autarquias em regime especial (agências reguladoras) e empresas estatais dotadas de uma racionalidade diferenciada, como é o caso da Petrobrás e do Banco do Brasil, que abriram o capital, passaram a emitir valores mobiliários, inclusive no exterior, e adotaram regras de governança corporativa. Além destas medidas, a privatização de 37 grupos empresariais entre 1990 e 2000, a promulgação da Lei de Responsabilidade Fiscal e da emenda ao artigo 37 da Constituição Federal, que definiu a eficiência como um princípio da administração pública (ao lado dos princípios originais, moralidade, legalidade, publicidade e impessoalidade), compuseram esta macro revisão do papel do Estado na economia brasileira.

Tais reformas também tiveram efeito no setor financeiro estatal. Entre 1995 e 2002, foram privatizados 18 bancos públicos. Essas medidas se fizeram acompanhar de

\footnotetext{
299 Sobre isso ver BRESSER PEREIRA, Luiz Carlos. Crise Econômica e Reforma do Estado - para uma nova interpretação da América Latina, op. cit.

300 Cf. BRESSER PEREIRA, Luiz Carlos. Reforma do Estado nos Anos 90 - lógica e mecanismos de controle, Lua Nova Revista de Cultura e Política, nº. 45, 1998, pp. 49-95.
} 
uma reestruturação no ambiente bancário federal, com a mudança dos padrões de regulação e a adoção de regras de governança corporativa pelos bancos estatais. ${ }^{301}$

Algo semelhante já ocorria com o BNDES, desde o final da década de 1980, quando o Banco passou a introduzir critérios de risco e de rentabilidade nas avaliações das propostas de colaboração financeira. Uma maior proximidade com o mercado de capitais, parametrizado no volume de operações e na definição de parcerias com os demais agentes financeiros, também é um indicador de uma mudança qualitativa na sua forma de intervenção. A rigor, desde o fim do II PND, como já antecipou o capítulo 2, o BNDES tem assumido uma racionalidade de atuação distinta da de uma autêntica instituição financeira de desenvolvimento que, em regra, sujeita a sua intervenção aos ditames dos planos de desenvolvimento do governo. ${ }^{302}$ É nesse contexto, de revisão do papel do Estado, ante uma economia baseada no conhecimento, que se localizam as novas formas de atuação do BNDES, que se valem de ferramentas usualmente manuseadas pelos agentes financeiros, para assim amparar empresas emergentes e inovadoras: uma mudança de pauta e de racionalidade, descrita em detalhe nos próximos capítulos.

\section{CONSIDERAÇõES FINAIS}

O presente capítulo teve o propósito de servir como um elo de ligação entre as duas partes desta tese: partindo da definição das alternativas de organização financeira, a missão desta seção era situar um cenário de transição institucional no panorama econômico. Nesta descrição, iniciada com os elementos reguladores do fordismo e encerrada com os traços constitutivos da economia baseada no conhecimento, dois vetores são particularmente importantes: (i) a definição de uma nova pauta para a atuação econômica, baseada nas inovações e nas empresas emergentes e (ii) a revisão do papel do Estado, que, em função dos novos atributos econômicos, assume uma racionalidade distinta de atuação, diferente daquela que embalou o consenso keynesiano.

\footnotetext{
${ }^{301}$ No último capítulo deste trabalho, essas alterações no sistema financeiro são descritas com mais detalhes.

${ }^{302}$ A tese de descaracterização do BNDES como instituição financeira de desenvolvimento é formuldada por Cláudia CURRALERO, em A Atuação do Sistema BNDES como Instituição Financeira de Fomento no Período 1952-1996, op. cit., pp. 45-84 e 85-123.
} 
A questão que se coloca daí em diante, por autores como Bob $\mathrm{JESSOP}^{303}$, é a de qual intervenção estatal é correspondente às necessidades de uma economia baseada no conhecimento. Assumindo o pressuposto de que o Estado e o mercado são elementos coconstitutivos e que, assim sendo, a atividade econômica demanda um corresponde arranjo institucional, é que se procura compreender qual tipo de ação pública resulta desta transição de paradigmas.

Para tanto, há que se levar também em consideração que este engate entre Estado e mercado é particularmente forjado no âmbito de cada uma das alternativas institucionais. Isso significa que a forma de atuação e as correspondentes funções desempenhadas pelo Estado, nesse novo contexto, também respondem a uma dependência da trajetória (path dependence), a que estão sujeitos os diversos sistemas econômicos nacionais. Por esta razão, no caso brasileiro, em que o Estado tem tido um papel chave na regulação institucional do sistema financeiro, a organização da nova economia tende a contar mais uma vez com uma participação relevante dos agentes públicos, notadamente do BNDES.

Por outro lado, embora possa se cogitar da manutenção do arranjo institucional, ou seja, da prevalência do Estado à frente dos financiamentos de longo prazo e de maior risco, as tensões provenientes de um novo paradigma econômico abrem também espaço para uma reestruração de caminhos (path shaping). No caso concreto, isso significa uma alteração na forma de intervenção do banco de desenvolvimento, impulsionada por novas demandas e pelas alterações nas correlações de força subjacentes ao ambiente jurídicoinstitucional. Afinal de contas, como visto, a reforma do Estado, ocorrida no Brasil, voltouse a rever a forma e a função de sua intervenção econômica - resultando daí a mencionada adoção de uma racionalidade privada pelos agentes públicos.

O saldo de ambos os fenômenos, path dependence e path shaping, será relatado nos capítulos 5 e 6 deste trabalho, quando se procurará analisar, a partir de um estudo de caso, os mecanismos desenvolvidos pelo BNDES para acompanhar os imperativos de uma economia baseada no conhecimento. Antes disso, porém, o próximo capítulo apresentará as respostas que o direito pode oferecer para as necessidades desta nova economia:

${ }^{303}$ JESSOP, Bob. The Future of Capitalist State, op. cit. 
ferramentas de direito contratual e societário, habilitadas a mitigar os custos de agência existentes nos empreendimentos de empresas emergentes. 


\section{$-4-$ \\ AS RESPOSTAS DO DIREITO PARA O FINANCIAMENTO DE UMA ECONOMIA BASEADA NO CONHECIMENTO: A CAIXA DE FERRAMENTAS JURÍDICAS E O MODELO AMERICANO DE VENTURE CAPITAL}

\section{INTRODUÇÃO}

A consolidação de uma economia baseada no conhecimento traz um particular desafio: o financiamento de empresas emergentes, portadoras de ativos intangíveis e de estratégias corporativas voltadas para as inovações de produto e de processo. Este tipo de investimento, como visto, é detentor de um grau elevado de incerteza, marcado pelo longo prazo de maturação dos resultados e, via de regra, desprovido de mecanismos de garantia habitualmente utilizados nas operações financeiras. Tais características problemáticas são ainda acentuadas quando se trata de apoiar empreendimentos inovadores realizados por pequenas e médias empresas, que no mais das vezes não detêm sequer um acervo de bens e patrimônios, nem tampouco um fluxo de caixa considerável capaz de assegurar as suas necessidades de financiamento. $\mathrm{O}$ risco deste investimento, portanto, é alto, o que tende a agravar os problemas de assimetria entre financiadores e empreendedores, mencionados no primeiro capítulo deste trabalho.

Mesmo assim, os exemplos já assinalados ao longo desta tese indicam que a competitividade e a rentabilidade de empresas inovadoras justificam os eventuais insucessos a que esta especialização econômica está associada. Eis, portanto, o motivo que explica o envolvimento dos mais variados países no desenho de políticas industriais ativas, calcadas em instrumentos adequados, a fim de impulsionar a capacidade de inovação de suas economias.

A viabilidade destes programas e o conseqüente êxito nacional na pauta comercial que preside a economia do conhecimento pode contar, por sua vez, com um estoque de respostas confeccionado no âmbito do direito, notadamente no ramo privado do direito empresarial. Boa parte das dificuldades associadas ao financiamento de empresas emergentes, titulares de ativos incertos e intangíveis, pode ser mitigada com a utilização de ferramentas jurídicas apropriadas, seja no âmbito das participações societárias, seja no caso 
dos contratos de crédito. Trata-se, por exemplo, da estruturação de mecanismos de governança corporativa que sejam aptos a reduzir os acentuados problemas de assimetria de informação prevalecentes entre os empreendedores inovadores e seus financiadores. Da mesma forma, um desenho contratual que seja capaz de lidar com a imprevisibilidade inerente às atividades inovadoras, sem com isso expor os investidores a um risco exacerbado, pode permitir a realização de uma operação de crédito para uma firma iniciante.

Partindo destas considerações, a intenção deste capítulo é apresentar um estoque das ferramentas jurídicas que podem permitir o financiamento corporativo de empresas inovadoras. Para tanto, na primeira parte desta seção serão confrontadas as opções de financiamento por meio de dívida e as alternativas de capitalização por meio da participação societária. Já na segunda parte, procurar-se-á descrever o modelo norteamericano de financiamento de empresas emergentes, que sabidamente tem uma dimensão e volume bastante significativos. Aparentemente o êxito deste padrão de financiamento tem como explicação a conjugação de dois distintos atributos: um padrão de governança corporativa relacional, próprio dos arranjos institucionais de economias coordenadas, com as possibilidades de liquidez típicas do mercado de capitais americano.

Para assinalar estas questões, este capítulo contará ainda com o aporte teórico da literatura neo-institucionalista, com particular ênfase às análises de Oliver WILLIAMSON. Esta abordagem oferece um critério satisfatório para análises que procuram associar os tipos de ferramentas jurídicas, de um lado, aos padrões de transação econômica, de outro. Com isso espera-se obter, ao final do capítulo, um mapeamento das ferramentas jurídicas mais apropriadas para o financiamento de ativos intangíveis. Espera-se também uma descrição do funcionamento destes instrumentos no âmbito de uma particular alternativa institucional, a norte-americana, onde se desenvolveu o modelo de venture capital usualmente utilizado no financiamento da nova economia. É o que segue.

\section{O FINANCIAMENTO DAS INOVAÇÕES: O PROBLEMA DE ASSIMETRIA DAS INFORMAÇÕES E DO CUSTO DE AGÊNCIA}

No contexto de uma economia baseada no conhecimento, em que os limites aos mercados saturados de bens padronizados são transpostos com a segmentação das faixas de 
consumo e com a introdução de novos produtos e processos produtivos, a inovação tornase um tipo recorrente de estratégia corporativa. Como tal, assim como ocorre com os demais projetos desenvolvidos por uma empresa, esta estratégia também demanda um montante de recursos para ser viabilizada, os quais, por sua vez, podem ser obtidos interna ou externamente. Os recursos internos, como visto no primeiro capítulo, decorrem de receitas acumuladas ou do reinvestimento dos lucros percebidos pela firma, ao passo que o capital externo pode ser provido por duas formas: (i) a constituição de um dívida ou (ii) a internalização de novos provedores do capital, na forma de sócios do empreendimento. Particularmente no caso dos projetos de inovação, convém concentrar a análise na hipótese do financiamento, seja porque boa parte das empresas são emergentes e portanto não contam com saldos acumulados para investimento próprio ${ }^{304}$, seja porque é nesta segunda opção que residem as maiores dificuldades a serem dissipadas por ferramentas jurídicas.

As adversidades do financiamento de estratégias de inovação, e que justamente reclamam a confecção de ferramentas jurídicas apropriadas, residem na maior assimetria de informações a que estão sujeitos estes investimentos. Conseqüentemente, pode-se assumir que os custos de agência, descritos no primeiro capítulo como sendo inerentes a todas as modalidades de captação externa, são ainda mais significativos quando se trata de aportar recursos nesta modalidade de estratégia corporativa. Isso se deve ao fato de que a inovação, como já salientado no capítulo anterior, apresenta um componente de incerteza, o que remete à imprevisibilidade quanto ao desfecho dos projetos objeto de financiamento. ${ }^{305}$ Diferentemente de um ativo tangível, como uma obra de infra-estrutura ou uma máquina, os ativos intangíveis, que compõem o cerne de um projeto de inovação, apresentam maiores dificuldades para serem medidos e avaliados. Além disso, não

\footnotetext{
${ }^{304}$ Sobre a dificuldade de financiamento das inovações, ver MELO, Luiz Martins de. O Financiamento das Empresas Inovadoras: alternativas para discussão, paper, mimeo, 2005, pp. 1-14, disponível em www.ie.ufrj.br/eventos/seminarios/pesquisa/texto_11_10.pdf, acesso em 01.10.2008.

305 Ao comentar os atributos de incerteza das inovações e o impacto acarretado na obtenção de financiamento, MELO observa que quanto maior a incerteza, maior a escassez de recursos externos e mais pronunciada é a tendência de sub-investimento. A seguinte passagem do autor resume este ponto: "essas três características da relação entre incerteza técnica e de mercado, não se referem somente a impossibilidade de se mensurar a incerteza, mas ao fato que a inovação é um fenômeno heterogêneo e diversificado e algumas categorias de inovações são por sua própria natureza, mais incertas do que outras. Isso significa que, a inovação em geral, não é um tipo de evento que ocorre de forma contínua e repetitiva, igualmente, por toda a economia. Se ela ocorreu uma vez, de uma determinada maneira, não é por isso que se saberá e se poderá prever quando e como ocorrerá de novo. Esta é uma diferença fundamental entre o processo de inovação e a espécie de eventos que o sistema financeiro e os bancos aceitam bancar o risco." MELO, Luiz Martins de. O Financiamento da Inovação Industrial, Tese de Doutorado apresentada no Instituto de Economia da Universidade Federal do Rio de Janeiro, 1994, p. 43.
} 
permitem uma programação fixa acerca da evolução de suas fases de realização: a obtenção de um novo princípio ativo de um medicamento, por exemplo, não admite a mesma programação em etapas do que a construção de uma estrada. De mais a mais, há uma certeza razoável de que a estrada será construída, mas não se pode pressupor com a mesma confiança que a pesquisa e o desenvolvimento de uma nova fórmula obtenham resultados técnicos e comerciais certos e exitosos.

Os ativos intangíveis, como o conhecimento, além de padecerem de uma maior dificuldade no planejamento de seus desdobramentos, também encerram uma outra desvantagem em relação aos ativos físicos: não podem servir de garantias dos financiamentos contraídos para a sua própria constituição. No caso de obtenção de recursos para a compra de um equipamento, por exemplo, a própria peça financiada pode ser gravada com ônus real, constituindo-se, assim, na própria garantia de adimplemento da dívida contraída para a sua aquisição. Essa possibilidade, por óbvio, não existe quando se trata de aportar recursos para a pesquisa de novos materiais. Até mesmo o desenho de operações financeiras costumeiramente realizadas para contornar a ausência de condições presentes de pagamento e voltadas a assegurar o adimplemento da dívida com as receitas futuras, como no caso do project finance ${ }^{306}$, enfrentam dificuldades para serem empregadas em projetos de inovação. No caso do financiamento de projetos, a garantia de pagamentos do credor é dada pelo penhor dos recebíveis, o que pressupõe um nível de previsibilidade de receitas futuras não existente em estratégias voltadas à inovação. Portanto, no que tange ao tipo de ativo a ser financiado, a aposta em inovação amplifica os custos de agência, já que agrega às assimetrias entre financiador e financiado o problema da imprevisibilidade e da conseqüente dificuldade de garantia dos interesses dos aportadores de recursos.

\footnotetext{
306 O financiamento de projeto (project finance) é uma modalidade de contratação financeira em que o projeto é segregado das demais atividades do empreendedor, costumeiramente com a constituição de uma empresa específica - uma sociedade de propósitos específicos (SPE). Cabe à SPE realizar o empreendimento e saldar o financiamento com as receitas advindas do negócio. A esse respeito assinala José Virgílio Lopes ENEI: "partindo-se para uma perspectiva jurídica e ressaltando apenas as características fundamentais do financiamento de projetos em prol de uma maior síntese, este pode ser definido como uma rede de contratos coligados que, alocando riscos às diversas partes envolvidas, visa a permitir que o empresáriopatrocinador, ou sociedade por ele constituída, capte recursos para o desenvolvimento e exploração de um empreendimento segregado, oferecendo como garantia aos credores, de forma exclusiva ou preponderante, as receitas e bens do próprio empreendimento financiado." ENEI, José Virgilio Lopes. Project Finance financiamento com foco em empreendimentos (parcerias público-privadas, leveraged buy-outs e outras figuras afins), São Paulo, Saraiva, 2007, pp. 38-39. O pressuposto deste arranjo, portanto, é a previsibilidade das receitas, que não existe nos financiamentos de inovação.
} 
Mas não é só o tipo de ativo que alimenta a assimetria entre as partes do financiamento deste tipo de projeto. As empresas, quando emergentes, também tornam esses financiamentos uma atividade de risco para os investidores. Distintamente de uma empresa madura, em um setor econômico tradicional, uma empresa emergente não tem atributos econômicos capazes de mitigar as chances reais de insucesso de sua empreitada. Em primeiro lugar, por ser uma firma nascente, não apresenta um histórico (track record), que permita a um investidor avaliar se se trata de uma empresa com bons resultados passados - a empresa não tem currículo. Demais disso, tais companhias não costumam apresentar patrimônio, o que é natural, haja vista se tratar de uma firma nova e detentora de um acervo de bens imateriais, como o conhecimento científico e tecnológico de seus sócios. Com isso, não têm como apresentar as garantias reais habitualmente exigidas por instituições financeiras para a concessão de créditos. Por fim, empresas emergentes recém saídas de incubadoras universitárias (realizaram processo de spin off), podem apresentar déficit de gestão, já que os seus fundadores são originariamente pesquisadores e não propriamente administradores de empresa, o que aumenta a sensação de risco dos investidores.

Estas questões são tratadas na literatura encarregada dos problemas de financiamento da nova economia, cujas análises apontam para uma limitação das fontes de financiamento para as empresas emergentes e encarregadas de estratégias inovadoras. ${ }^{307}$ De um lado, a ausência de garantias e a impossibilidade de se firmar um cronograma fixo de pagamentos pode comprometer a sua capacidade de financiamento pelo setor bancário, cujas concessões de crédito tendem a ser asseguradas por bens e direitos e também pela estipulação clara das obrigações financeiras. De outro, a falta de previsibilidade e de histórico pregresso tornam improvável a opção do mercado de capitais, por meio de uma captação pública de recursos, já que em comparação com outras possibilidades de investimento, as firmas emergentes apresentam um risco desproporcional. Esta limitação financeira é resumida no quadro abaixo, em que são apresentadas as probabilidades de obtenção de recursos para cada fase de desenvolvimento das firmas.

${ }^{307}$ MELO, Luiz Martins de. O Financiamento das Empresas Inovadoras, op. cit. 


\begin{tabular}{|c|c|c|c|c|c|}
\hline & \multicolumn{4}{|c|}{$\begin{array}{c}\text { QUADRO } 8 \\
\text { ProbabILIDADE DOS VEÍCULOS DE FINANCIAMIENTO } \\
\text { EMPRESAS EMERGENTES VERSUS EMIPRESAS ESTABELECIDAS }\end{array}$} & \\
\hline \multirow{2}{*}{$\begin{array}{c}\text { Veículos } \\
\text { financeiros }\end{array}$} & & Estágio & lesenvolvimento & empresa & \\
\hline & $\begin{array}{l}\text { Empresa na } \\
\text { fase semente } \\
\text { (concepção) }\end{array}$ & $\begin{array}{l}\text { Empresa } \\
\text { iniciante } \\
\text { (start up) }\end{array}$ & Estágio inicial & $\begin{array}{c}\text { Empresa } \\
\text { estabelecida }\end{array}$ & $\begin{array}{c}\text { Empresa } \\
\text { madura }\end{array}$ \\
\hline $\begin{array}{c}\text { Lucros } \\
\text { acumulados }\end{array}$ & $\begin{array}{l}\text { Pouco } \\
\text { provável }\end{array}$ & $\begin{array}{c}\text { Pouco } \\
\text { provável }\end{array}$ & $\begin{array}{c}\text { Pouco } \\
\text { provável }\end{array}$ & $\begin{array}{l}\text { Bastante } \\
\text { provável }\end{array}$ & $\begin{array}{l}\text { Bastante } \\
\text { provável }\end{array}$ \\
\hline $\begin{array}{c}\text { Abertura do } \\
\text { capital }\end{array}$ & $\begin{array}{l}\text { Pouco } \\
\text { provável }\end{array}$ & $\begin{array}{l}\text { Pouco } \\
\text { provável }\end{array}$ & $\begin{array}{l}\text { Pouco } \\
\text { provável }\end{array}$ & $\begin{array}{l}\text { Bastante } \\
\text { provável }\end{array}$ & $\begin{array}{l}\text { Bastante } \\
\text { provável }\end{array}$ \\
\hline $\begin{array}{c}\text { Financiamento } \\
\text { bancário }\end{array}$ & $\begin{array}{c}\text { Pouco } \\
\text { provável }\end{array}$ & $\begin{array}{c}\text { Pouco } \\
\text { provável }\end{array}$ & $\begin{array}{l}\text { Bastante } \\
\text { provável }\end{array}$ & $\begin{array}{l}\text { Bastante } \\
\text { provável }\end{array}$ & $\begin{array}{l}\text { Bastante } \\
\text { provável }\end{array}$ \\
\hline
\end{tabular}

Retornando ao ponto inicial desta seção, pode-se ter em conta que os atributos de incerteza, atinentes aos ativos baseados em conhecimento, e os riscos de insucesso, oferecidos pelas empresas emergentes, tornam o financiamento das inovações particularmente problemático. Este constrangimento financeiro, por sua vez, é tanto maior quanto menos estabelecida for a companhia: as empresas ainda em fase de gestação, que estão na "fase semente", podem ter ainda mais dificuldades de obtenção de recursos do que as firmas emergentes e iniciantes - que já enfrentam mais dificuldades do que empresas maduras.

No cerne desses problemas reside a questão de assimetria de informações: em relação a outras formas de financiamento, um investimento em inovação, em uma empresa emergente, não admite a mesma possibilidade de verificação do que é devido de cada parte. $^{308}$ Em outros termos, em muitas situações, pode não ser possível, para o financiador, estabelecer com clareza se o empreendedor-pesquisador deve insistir em novos testes, para assim recuperar os valores já aportados ou se deve desistir do desenvolvimento de novas rodadas de pesquisa - evitando, assim, consumir mais recursos. Dada esta assimetria de conhecimento entre o empreendedor e o financiador, o horizonte de calculabilidade é mais estreito, o que dificulta a avaliação de qual a estratégia ótima a ser perseguida. $\mathrm{O}$ resultado disso pode se refletir na cautela e na restrição de recursos para alguns segmentos deste mercado.

\footnotetext{
${ }^{308}$ TRIANTIS, George. Financial Contract Design in the World of Venture Capital, Chicago Law Review, v. 68, 2001, pp. 1-18.
} 
É diante desse cenário que a questão volta para os quadrantes do direito. Que tipo de ferramenta jurídica pode ser adequada para garantir recursos financeiros a projetos que, se bem sucedidos, podem resultar em ganhos expressivos para os respectivos empreendedores? Como o principal problema a ser resolvido neste tipo de estratégia corporativa é o da assimetria de informações, causado pela parca previsibilidade dos projetos, seja em razão dos ativos, seja em virtude das empresas envolvidas, o desenho das respectivas ferramentas jurídicas tem como tarefa mitigar a distância existente entre os investidores e os tomadores de recurso. Isso significa que tanto os títulos constitutivos de uma dívida, como os representativos de uma participação societária, têm que se ver com a questão de favorecer os mecanismos de monitoramento e de troca de informações, a fim de com isso diminuir os custos de agência e permitir o financiamento de estratégias portadoras de um risco mais elevado. É por esta razão que as ferramentas jurídicas aptas a constituir laços de sociedade e de engajamento entre os agentes tendem a ser mais utilizadas neste segmento financeiro do que instrumentos assentados na mútua rivalidade entre partes distanciadas. Nessa linha, as seções a seguir procurarão indicar que, enquanto as participações societárias relacionais são a forma mais habilitada de reduzir os custos de agência, os contratos sinalagmáticos são os instrumentos menos aptos a reger o financiamento das inovações.

Para se entender as razões desta preferência por um tipo de ferramenta em detrimento de outro, será apresentado um inventário de possibilidades, baseado em duas formas de análise: (i) uma externa ao direito, baseada em uma análise econômica dos dispositivos jurídicos e responsável por prover um critério funcionalista de associação entre os tipos de ferramentas e as formas de transação; e (ii) uma outra interna, que responde por uma anatomia dos institutos jurídicos, com a finalidade de justapor as potencialidades de cada instrumento às descrições providas pela análise econômica. Ao final desta seção, a proposta é a apresentação de uma régua, cuja escala varia entre as ferramentas menos habilitadas e as mais propensas a superar as assimetrias atinentes ao financiamento das inovações. 


\section{FERRAMENTAS JURÍDiCAS E TRANSAÇões ECONÔMICAS: UMA ANÁLISE FUNCIONALISTA}

A economia dos custos de transação, que compõe um dos ramos da chamada Nova Economia Institucional ${ }^{309}$, dispõe de um instrumental de trabalho que pode ser útil às análises jurídicas, sobretudo àquelas que tenham a pretensão de realizar uma abordagem funcional dos institutos reguladores das transações econômicas. Partindo do mesmo pressuposto teórico da economia institucional, segundo a qual as trocas são mediadas por instituições, como o contrato ou as sociedades, a economia dos custos de transação assume que as intermediações entre os agentes diferem quanto aos seus atributos (e conseqüentemente quanto aos seus custos de negociação) e por tal razão reclamam distintas ferramentas para serem processadas.

O custo de transação, utilizado recorrentemente como critério desta associação entre ferramentas e transações, é na verdade um parâmetro, que informa os custos supostamente incorridos pelos agentes, em suas negociações econômicas. ${ }^{310} \mathrm{Em}$ um mercado perfeitamente competitivo, dotado de agentes racionais, com ampla liberdade de escolha, as negociações não apresentariam tais custos, já que não haveria a necessidade de negociação: as partes transacionariam livremente e sem precisar fixar regras, obrigações,

309 Este é um campo bastante amplo e que reúne distintas linhas de pesquisa. Todas elas têm como pressuposto uma crítica interna às bases da economia neoclássica, que não leva em conta a mediação institucional dos processos econômicos. Dentro deste campo institucional, no entanto, podem se reconhecer dois tipos de enfoque: (i) o do ambiente institucional e (ii) o dos mecanismos de governança. A primeira linha ocupa-se dos arranjos institucionais das economias, tais como: os seus sistemas de propriedade, suas regras de contratação, etc... Os estudos de Douglass NORTH são bastante exemplificativos desta abordagem. A segunda linha volta-se à analisar, dentro de um dado ambiente institucional, quais desenhos de governança são mais ou menos apropriados para uma dada transação - esta é a linha da economia dos custos de transação, cuja referência é Oliver WILLIAMSON. A seguinte passagem de NORTH comentando o plano de análise de WILLIAMSON ilustra este argumento: "maximizing behavior by the firm can take the form of making choices within the existing set of constraints or of altering the constraints. The modern literature on the firm by WILLIAMSON and others explores the most efficient governance structure and organization within the existing institutional constraints." NORTH, Douglass. Institutions, Institutional Change and Economic Performance, op. cit. p. 79. Para essa distinção ver também WILLIAMSON, Oliver. Transaction Cost Economics and Organization Theory, em SMELSER, Neil \& SWEDBERG, Richard. The Handbook of Economic Sociology, Princeton, Princeton University Press, 1994.

${ }^{310} \mathrm{O}$ pressuposto ideal de que partem estas análises é o de que o mercado, caso fosse partilhado por agentes econômicos dotados de plena racionalidade, transacionando ocasionalmente bens simplificados, seria a instância mais eficiente para a realização das trocas entre os agentes: neste ambiente não haveria custos de transação. Tais transações hipotéticas, que contariam com bens padronizados, acontecidas com pouca freqüência e que não apresentariam qualquer imprevisibilidade na sua execução, não apresentariam dificuldades de negociação, que não pudessem ser superadas pelo próprio entendimento entre as partes. Sendo assim, o custo desta troca seria nenhum, pois não haveria a necessidade de se incorrer em gastos com ferramentas jurídicas (ou instituições), como o desenho de contratos ou quaisquer outros meios de governança. $O$ custo de transação provêm da diferença entre as trocas ideais e as reais: o papel das instituições é prover arranjos ótimos para procurar aproximar ambos os custos. 
prazos etc. No entanto, os próprios economistas institucionais assumem que, no mundo real, nem os agentes detêm plena racionalidade, a ponto de sempre poderem escolher e prever as melhores opções, nem tampouco as transações mostram-se tão simplificadas que não requeiram qualquer formalização institucional. Desta maneira, economistas como WILLIAMSON $^{311}$ têm em conta que todas as trocas apresentam algum custo de negociação para serem realizadas, tal como o atrito está presente no movimento físico de todos os corpos. Sendo assim, compete aos agentes selecionar aqueles mecanismos de governança que ao regularem os termos de uma transação o façam da maneira menos custosa possível. Em outros termos, nesta abordagem, o ideal a ser perseguido pelas ferramentas jurídicas que intermedeiam os negócios econômicos é aproximar-se, tanto quanto possível, de uma situação de mercado, em que os custos de transação tendem a zero. $\mathrm{O}$ afastamento deste contexto, por sua vez, com a constituição de uma estrutura de governança entre as partes, far-se-á no limite e na proporção das necessidades impostas pelas próprias dificuldades de viabilização da negociação.

A escala de alternativas de governança varia desde o contrato simples entre partes mutuamente rivais (uma situação próxima de uma troca em mercado) até a constituição de uma sociedade entre os negociantes, adotada nos casos em que os custos da transação são tão elevados que a opção mais satisfatória é a integração de ambos os agentes em uma firma - ambos são excluídos do mercado. Para estabelecer quais situações comportam um governança simples e baseada na competição e quais demandam a supressão da rivalidade e a constituição de uma hierarquia, a literatura neo-institucionalista assume tipos ideais de transação. Cada um dos tipos apresenta um grau de complexidade e conseqüentemente reclama um respectivo dispositivo jurídico. Para WILLIAMSON ${ }^{312}$, os tipos de transação podem variar conforme três atributos, sendo eles: (i) o grau de padronização ou especialização do bem econômico transacionado; (ii) a freqüência com que os bens são negociados e (iii) a previsibilidade ou incerteza a que esta transação está sujeita.

As transações mais simples são aquelas que envolvem bens não específicos, sejam estas negociações ocasionais ou freqüentes. Para tais bens pode-se presumir a existência de mercado, isto é, há pluralidade na oferta e na demanda. Pelo lado da oferta, por se tratar de um bem padronizado não há nada que o singularize, de tal forma que não

\footnotetext{
${ }^{311}$ WILLIAMSON, Oliver. The Economic Institutions of Capitalism, op. cit., pp. 68-84.

${ }^{312}$ WILLIAMSON, Oliver. The Economic Institutions of Capitalism, op. cit.
} 
há barreiras à entrada que impeçam ou dificultem um eventual ofertante de partilhar deste mercado. Em suma, não há especificações que impeçam qualquer agente econômico de disputar este segmento e por essa razão há competição entre os fornecedores. Da mesma forma, do lado do consumidor, a padronização dos bens permite uma fácil comparação de preço e qualidade, por exemplo. O comprador pode assim decidir com qual dos fornecedores contratará a compra deste produto. Trata-se, portanto, de um bem standard, de fácil intermediação, tanto para os vendedores, como para os consumidores ${ }^{313}$.

Tome-se o exemplo do mercado internacional de soja. O produto é uma commodity, isto é, um bem padronizado. A soja oferecida neste mercado detém especificações técnicas, os ofertantes estão pulverizados (nenhum deles é capaz de dominar o mercado a ponto de controlar os preços da oferta) e os consumidores, igualmente atomizados (podem comparar os produtos e escolher as condições comerciais que melhor os aprouver). Como se trata de um mercado competitivo, os bens são de fácil substituição, por causa disso não há a necessidade de estipulação de compromissos duradouros entre fornecedores e consumidores. Caso sobrevenha uma frustração numa dada transação, o custo da troca de fornecedor ou a perda de um consumidor não é alto o bastante para que seja necessário o estabelecimento de um arranjo contratual prolongado no tempo, destinado a submeter ambas as partes. É o caso, portanto, de uma regulação simplificada, na forma de um contrato descontínuo ou simples. Portanto, em uma situação de mercado (quase perfeito), a necessidade de dispositivos jurídicos é restrita e volta-se a estabelecer um patamar mínimo de formalização entre as partes: estas permanecem independentes, não se comprometendo com um laço obrigacional superior ao da instantaneidade da troca.

Esse não é o caso, entretanto, daquelas transações que ocorrem freqüentemente e em que os bens econômicos são bastante específicos, contendo atributos particulares para uma dada relação comercial. Um exemplo possível é o fornecimento contínuo de um motor de turbina de avião para uma empresa de aviação. Em casos como este há uma dependência recíproca: o fornecedor conta, quase que exclusivamente, com as aquisições do comprador e este, por sua vez, depende do fornecedor para garantir a produção de seus aviões. A eventual interrupção do fornecimento ou dos pedidos de compra implicará à

\footnotetext{
${ }^{313}$ Para uma descrição da imagem do mercado na economia neoclássica e para uma crítica da nova economia institucional, ver GRANOVETTER, Mark. Economic Action and Social Structure: The Problem of Embeddedness, The American Journal of Sociology, v.91, nº. 3, 1985.
} 
parte inocente um prejuízo econômico bastante elevado, já que a substituição da contraparte mostra-se de difícil verificação, num prazo razoável. Em situações como essa não se pode presumir a existência de mercado: não há pluralidade de oferta e de demanda. As partes são, isto sim, mutuamente dependentes.

Este tipo de transação econômica não é, pela sua própria natureza, descontínua como são as trocas em um mercado competitivo. Conseqüentemente, na ausência de mecanismos de governança que mitiguem os riscos de um comportamento oportunista, típico das relações que são baseadas na mútua rivalidade (relações de mercado), os riscos envolvidos nessa negociação podem dificultar ambas as atividades econômicas (a do fornecedor e a do consumidor). Para superar estes custos de transação, fornecedores e consumidores estipulam reciprocamente laços de cooperação e não de rivalidade. A mútua dependência (hold up) reclama uma governança das relações que favoreça a proximidade dos agentes, em um desenho oposto ao do antagonismo de mercado: ambos tem a perder se atuarem de modo competitivo. A organização de transações continuadas nestas bases conta, de acordo com WILLIAMSON ${ }^{314}$, com duas alternativas de governança, que são mais interventivas do que os dispositivos reguladores das trocas com bens padronizados: (i) a governança bilateral ou híbrida, estipulada por meio de um contrato em bases relacionais, em que os agentes permanecem juridicamente independentes, mas assumem uma relação continuada de intensa cooperação e (ii) a governança unificada, em que fornecedor e consumidor deixam de comercializar como partes isoladas e constituem uma organização hierárquica de suas atividades - uma sociedade.

Em suma, as transações que contam com bens padronizados e que ocorrem ocasionalmente tendem a ser organizadas por um dispositivo simples: contrato clássico ou liberal. As transações com alguma especialidade, nas quais o bem negociado é específico para aquela relação econômica, como no caso de contratos entre produtores de insumo e fabricantes, demandam uma coordenação mais complexa do que a oferecida por um contrato simples e podem requerer um contrato de longo prazo, com uma estipulação minuciosa de sanções e meios de solução das controvérsias. Já as transações freqüentes que envolvem bens super especializados trazem tantas dificuldades de negociação para as partes, dados os riscos de prejuízo de uma eventual solução de continuidade, que a melhor

${ }^{314}$ WILLIAMSON, Oliver. The Economic Institutions of Capitalism, op. cit. 
estrutura de governança possível é suprimir a rivalidade de mercado existente entre os agentes contratantes, resultando assim na constituição de uma sociedade entre elas, ou nos termos de WILLIAMSON, em uma hierarquia. O quadro abaixo ilustra esta régua de possibilidades formada pelos seguintes extremos: contrato simples para trocas padronizadas, de um lado, e constituição de sociedades para permitir negócios que envolvem bens ultra-específicos e de transação recorrente, de outro.

\begin{tabular}{|c|c|c|c|c|}
\hline \multicolumn{7}{|c|}{$\begin{array}{c}\text { QUADRO 9 } \\
\text { Tipo de } \\
\text { transação }\end{array}$} & $\begin{array}{c}\text { Ocasional com } \\
\text { bens padronizados }\end{array}$ & $\begin{array}{c}\text { Freqüente com } \\
\text { bens padronizados }\end{array}$ & $\begin{array}{c}\text { Ocasional/freqüente } \\
\text { com bens } \\
\text { especializados }\end{array}$ & $\begin{array}{c}\text { Freqüente com } \\
\text { bens ultra } \\
\text { especializados }\end{array}$ \\
\hline $\begin{array}{c}\text { Tipos de } \\
\text { ferramentas }\end{array}$ & $\begin{array}{c}\text { Contrato simples - } \\
\text { transação em } \\
\text { mercado }\end{array}$ & $\begin{array}{c}\text { Contrato simples } \\
\text { ou de longo prazo } \\
\text { - transação em } \\
\text { mercado }\end{array}$ & $\begin{array}{c}\text { Contrato relacional } \\
\text { - estrutura híbrida }\end{array}$ & $\begin{array}{c}\text { Constituição de } \\
\text { uma sociedade - } \\
\text { hierarquia }\end{array}$ \\
\hline
\end{tabular}

Há ainda um último atributo das transações que deve ser levado em conta nos exercícios de ajuste entre transações e ferramentas: a incerteza. Algumas relações, para além de tratar com produtos especializados, devem ainda lidar com a incerteza que está presente na negociação de alguns bens econômicos. Diferentemente do risco, a incerteza não pode ser calculada e traz para o ambiente das transações um problema crítico de imprevisibilidade ${ }^{315}$. Exemplos concretos de incerteza econômica podem ser conferidos nos ativos intangíveis, em especial nos investimentos dirigidos à obtenção das inovações de produto e de processo. Como visto, a literatura sobre inovação tecnológica chama a atenção para este fato, indicando que o desenvolvimento de um novo produto é tipicamente uma atividade com elevado grau de contingência e que impede uma estimativa prévia acerca do seu sucesso - técnico ou comercial. Ante a situações de incerteza como esta, a nova economia institucional é ainda mais reticente quanto às possibilidades de regulação das transações via contrato descontínuo. As respostas satisfatórias para situações como esta

\footnotetext{
${ }^{315}$ A incerteza funda-se na ausência de possibilidade de se fazer prognósticos e de com isso se antecipar os resultados possíveis de uma operação - não há meios adequados de previsão. Essa diferença entre risco e incerteza foi originariamente explorada pelo economista Frank KNIGHT, autor de Risk, Uncertainty and Profit, e responsável por uma importante crítica interna aos cânones da economia neoclássica, que até então assumia vigorosamente a máxima racionalidade dos agentes, o que pressupunha a sua capacidade extensa de julgamento e de decisão. A lição de KNIGHT serviu, entre tantas outras questões, para indicar a limitação dessa racionalidade ampliada, mostrando que em determinadas situações a análise estatística e os juízos de probabilidade baseados nas ocorrências passadas é impossível. Em casos como este, contata-se um cenário de incerteza quanto ao futuro. Ver KNIGHT, Frank. Risk, Uncertainty and Profit, New York, Dover, 2006, pp. 232-263.
} 
contam com o desenho de uma sociedade ou ao menos de um contrato relacional, que seja capaz de reforçar os laços de cooperação entre as partes. ${ }^{316}$

Deste modo, com base no critério dos custos de transação, pode-se admitir que cada tipo particular de transação econômica está associada a um determinado dispositivo de governança, desenhado para mediar as relações entre as partes. Nas transações financeiras, passa-se o mesmo. A única diferença destes negócios reside no fato de que o bem transacionado é um aporte de recursos, voltado a permitir a realização dos projetos empresariais do agente tomador. Conforme os tipos de ativos financiados, diz novamente a economia dos custos de transação, sobrevém a necessidade de um tipo específico de ferramenta. Quanto mais simples os ativos, mais próximos os agentes estão de uma situação de mercado e, portanto, menor a necessidade de intervenção institucional. A contrario sensu, quanto mais específicos e incertos estes bens, maiores os riscos envolvidos para os credores e, conseqüentemente, maior a necessidade de se constituir mecanismos jurídicos que excluam as partes envolvidas da rivalidade do mercado.

Em uma transação financeira, da mesma forma como verificado nas demais trocas, os agentes também dispõem de duas alternativas básicas para acessarem os recursos necessários para as suas atividades: podem contar com a constituição de uma dívida, ou optarem pela internalização dos financiadores, hipótese em que o capital é fornecido por meio da participação societária dos investidores. A primeira alternativa é a mais simples: trata-se de se recorrer ao mercado de dívida e, tal como nas demais transações econômicas, contratar com outros agentes independentes o fornecimento do produto, no caso o aporte financeiro. No segundo caso, a provisão dos recursos necessários a uma dada atividade é

\footnotetext{
${ }^{316}$ Como salienta WILLIAMSON na transcrição a seguir, o alto nível de insegurança, se casado com uma natureza de especificidade dos ativos transacionados, reclama a constituição de uma estrutura de governança que mitigue o acirrado individualismo do mercado e fomente a formação de laços cooperativos (referidos no texto abaixo como acordos bilaterais): "Transactions with mixed investments attributes pose especially interesting organizational problems. Unless an appropriate market-assisted governance structure can be devised, such transaction may 'flee' to one of the polar extremes as the degree of uncertainty increases. One possibility would be to sacrifice valued design features in favor of a more standardized good or service. Market governance would then apply. Alternatively, the valued design features could be preserved (perhaps even enhanced) and the transaction assigned to internal organization instead. Sometimes, however, it will be feasible to devise nonstandard contracts of the kinds discussed in chapter 7 and 8. Where that is done (and is not prohibited by public policy), bilateral contracting relations between nominally autonomous contracting agents can often survive the stresses of greater uncertainty." WILLIAMSON, Oliver. The Economic Institutions of Capitalism, op. cit. p. 80.
} 
internalizada, o que corresponde à constituição de uma sociedade (hierarquia) nas situações acima descritas. $^{317}$

De acordo com essa literatura, os projetos corporativos financiáveis por meio de uma dívida apresentam características semelhantes aos bens suscetíveis de serem regulados pelos contratos simples, em regime de mercado. São empreendimentos em que os riscos associados ao emprego dos recursos não é elevado, pois permitem a estipulação de um cronograma fixo de pagamento dos juros e da dívida principal. Em regra, são objetos não específicos, que apresentam liquidez e asseguram o credor contra um eventual risco de inadimplemento. O financiamento de aquisição de uma máquina ou de um equipamento, por exemplo, é tipicamente realizável por meio de um contrato simples de crédito, já que os ativos financiados podem não ser específicos e nem dotados de incerteza. $\mathrm{O}$ fato de não serem específicos atribui ao financiador a garantia de que, caso seja necessário, pode ser dado outro uso a estes bens, a título de remuneração do montante franqueado: o bem financiado pode ser facilmente vendido, por exemplo, como forma de se recuperar os valores emprestados e não pagos. Além disso, como se trata de bens físicos, podem ser gravados com ônus real, servindo como garantias de seu próprio financiamento. ${ }^{318}$

Este tipo de transação, assim como as trocas de produtos padronizados, ocorre em um ambiente de mercado, que pode ser o de créditos ou o de capitais. Se se tratar de um mercado de créditos, os recursos serão disponibilizados por meio de uma intermediação realizada por alguma instituição financeira, como um banco, por exemplo. Neste caso, o negócio será regulado por um contrato simples de crédito, em que serão disciplinadas as obrigações de pagamento do devedor. Quando se tratar da constituição de uma dívida no mercado de capitais, o agente tomador obtém o capital demandado pela emissão de valores mobiliários de dívida, como são as debêntures, no mercado nacional ou os bonds, no

317 Sobre as alternativas de financiamento corporativo, assinala Roberta ROMANO: "there are two mechanisms by which corporations raise capital: issuing debt and issuing equity." ROMANO, Roberta. Foundations of Corporate Law, New York, Foundation Press, 1993. p. 119. Ver também PINTO JUNIOR, Mario Engler. A Capitalização da Companhia, op. cit., pp. 242-271.

318 A associação entre os projetos corporativos mais simples e o seu financiamento por meio de dívida é apresentada por WILLIAMSON: "thus the (corporate finance) decision to use debt or equity to support individual investment projects is closely akin to the (vertical integration) decision to make or buy individual components or subassemblies. Not only is the 'market mode' (debt; outside procurement) favored if asset specificity is slight, but the costs of the market mode go up relatively as the contractual hazards increase. Also, the disabilities of internal organization (equity, internal supply) turn critically in both instances on the impossibility of 'selective intervention."'WILLIAMSON, Oliver. Corporate Finance and Corporate Governance, The Journal of Finance, vol. 43, n. 3, 1988. p. 576. 
mercado internacional. ${ }^{319}$ Como traço comum reside o fato de que tanto o contrato de crédito, como o título de dívida apresentam os arranjos de governança mais simples para a captação financeira de uma firma: além do contrato ou do título, não demandam qualquer outra estrutura institucional e as partes (empreendedor e financiador) permanecem independentes. É por esta razão que a obtenção de recursos via constituição de dívidas mostra-se como a alternativa mais simples e menos custosa para uma empresa. ${ }^{320}$

Entretanto, há situações em que, a depender do nível de especificidade e de riscos envolvidos, há pouca probabilidade de que um empreendedor consiga obter recursos de terceiros na forma de dívida, seja por meio de um contrato de crédito, seja pelo lançamento de uma dívida mobiliária. Ainda assim, caso consiga tais recursos, em virtude de o financiamento se dirigir a projetos corporativos com ativos ultra-específicos, isto é, somente empregáveis para fins daquela utilização, ou de resultado incerto, como é o caso do desenvolvimento de um novo produto ou um novo processo, os termos deste ajuste podem ser muito adversos para o agente tomador. Em outros termos, diante de um risco elevado de inadimplemento ou da ausência de garantias efetivas para assegurar o pagamento do crédito contraído, o emprestador tende a estipular um custo alto, que seja capaz de aplacar os riscos incorridos com a operação. Em situações como essa, dotadas de incerteza ou em que o bem financiado é ultra-específico, ambas as partes tendem a ter vantagens se constituírem o equivalente a uma hierarquia, como assinala a seguinte passagem de WILLIAMSON:

The TCE approach maintains that some projects are easy to finance by debt and ought to be financed by debt. These are projects for which physical asset specificity is low to moderate. As asset specificity becomes great, however, the preemptive claims of the bondholders against the investment afford limited protection - because the assets in question have limited redeployability. Not only does the cost of debt financing therefore increase, but the benefits of closer oversight also grow. The upshot is that equity finance, which affords more intrusive oversight and involvement through the board of directors (and, in publicly held firms, permits share

\footnotetext{
${ }^{319}$ Sobre essas diferenças entre as transações financeiras, ver WILLIAMSON, Oliver. Corporate Finance and Corporate Governance, op. cit., pp. 567-591.

${ }^{320}$ Este é um argumento pouco intuitivo, mas verdadeiro. Em tese, como os acionistas compartilham o risco do negócio, o pagamento de dividendos deve ser maior do que o que se pagaria para um credor, para com isso remunerar o risco incorrido pelos sócios. Portanto, sempre que possível, a companhia tende a encontrar uma estrutura ótima de financiamento, em que os projetos menos complexos serão financiados pelo endividamento. Sobre a preferência da dívida sobre a participação, em casos como esse, ver PINTO JUNIOR, Mario Engler. A Capitalização da Companhia, op. cit.
} 
ownership to be concentrated), is the preferred financial instrument for projects where asset specificity is great. ${ }^{321}$

Nesta hipótese, ao invés de buscar recursos por meio de endividamento no mercado de crédito ou de capitais (debt), o empreendedor internaliza os financiadores na sociedade, por meio de sua participação societária (equity). Desta maneira, os financiadores passam então a compartilhar não só dos riscos, mas também dos benefícios do empreendimento. Em situações como essa, a participação societária tende a apresentar maiores benefícios para os investidores, já que o êxito do empreendimento garante ao financiador uma participação nos lucros, que tende a ser superior ao ganhos obtidos com o eventual pagamento de créditos, nos casos de dívida. ${ }^{322}$ Em contrapartida, a captação de recursos por meio da participação encerra maiores custos institucionais: para além do título de participação, as sociedades têm de estipular órgãos de representação (conselho de administração) e de fiscalização (conselho fiscal) para a proteção dos interesses de todos aqueles que assumem os riscos do negócio. Daí o porquê desta modalidade ser empregada apenas nos casos que reclamam maior complexidade econômica.

Portanto, com base no critério dos custos de transação pode-se admitir que cada uma das ferramentas jurídicas (contrato simples, contrato relacional e sociedade) é adequada a um tipo particular de transação financeira. Quanto mais simples e previsível uma negociação, mais simples pode ser a correspondente ferramenta - é o campo do contrato simples. Por sua vez, quanto mais específico o bem transacionado e maior imprevisibilidade quanto ao desfecho do negócio, mais sofisticada precisa ser a respectiva ferramenta de intermediação - é o campo dos contratos relacionais e das sociedades. Como será visto a seguir, o financiamento das inovações conta preferencialmente com ferramentas de participação societária e menos com dispositivos associados a crédito e a pagamentos programados de dívidas.

\footnotetext{
${ }^{321}$ Nesta passagem TCE refere-se à transaction cost economy. WILLIAMSON, Oliver. Corporate Finance and Corporate Governance, op. cit. p. 589.

${ }^{322}$ Ao comentarem a possibilidade de contratação financeira por meio de dívida, dirigida a projetos de inovação, Michael CARNEY e Eric GEDAJLOVIC lembram que nada incentiva um banco, por exemplo, a fazê-lo. De um lado, se o projeto falhar, lembram os autores, é muito provável que o credor não tenha como reaver seu investimento, dada a possível ruína financeira da empresa tomadora. Já se o projeto vier a ser bem sucedido, o banco terá como retorno, apenas e tão somente, o capital emprestado acrescido dos juros - o mesmo que teria num financiamento de baixo risco. Por esta razão, defendem o modelo de venture capital, que enseja a participação societária dos investidores e conseqüentemente a possibilidade de obterem um retorno mais expressivo, caso o empreendimento mostre-se vitorioso. CARNEY, Michael \& GEDAJLOVIC, Eric. East Asian Financial Systems and the Transition from Investment-Driven to Innovation-Driven Economic Development, International Journal of Innovation Management, vol. 4, no. 3, 2000, pp. 253-276.
} 
Para se entender as razões disso, no entanto, é importante alternar o ponto de observação, para assim analisar as propriedade regulatórias dos instrumentos jurídicos, desde uma perspectiva interna. Partindo da tipologia e do referencial oferecidos pela economia dos custos de transação, as seções a seguir procurarão desvendar a racionalidade jurídica de cada uma das ferramentas acima narradas. Trata-se, assim, de se voltar para uma análise das estruturas do direito, buscando, com isso, compreender o que faz cada um desses dispositivos um instrumento adequado para lidar com cada tipo de transação econômica.

\subsection{A RACIONALIDADE DO CONTRATO SIMPLES DE CRÉDITO: AUTONOMIA DAS PARTES, PRESENTIFICAÇÃO E RIGIDEZ}

A forma mais simples de regulação de uma transação econômica é disciplinada por um contrato sinalagmático clássico, também chamado de contrato simples ou descontínuo $^{323}$. A descrição deste tipo ideal de contrato realizada pela doutrina, apresenta um tipo de negócio jurídico assentado em três princípios operativos principais: (i) a autonomia e rivalidade das partes, (ii) a presentificação do desdobramentos futuros e (iii) a completude e rigidez da regulação. São estas três características que, ao comporem a racionalidade desta regulação contratual, tornam-na pouco propícia a lidar com situações que envolvem respectivamente: (i) a necessidade de compartilhamento dos riscos, (ii) a alta incidência de contingências e (iii) as adaptações freqüentes aos termos pactuados.

No âmbito do contrato clássico, ambas as partes detêm autonomia de sua vontade, isto é, são capazes de estipular as recíprocas regras do jogo desde um momento original: ao devedor, cumpre o pagamento de uma prestação e ao credor compete a contraprestação. Tudo se passa como se as partes fossem absolutamente conscientes de todos os itens do compromisso assumido e ainda plenamente habilitadas a estipular com precisão qual o comportamento a ser esperado pela contra-parte, que dará então por satisfeita a obrigação constituída. No caso de um contrato de crédito estruturado nessas bases, a prestação devida é composta pelo montante principal tomado como empréstimo, acrescido

\footnotetext{
323 A teoria liberal dos contratos é comumente identificada com a chamada teoria clássica. Nesta, o individualismo e a autonomia privada são as duas concepções-balizas de expressiva relevância. Sobre essa identidade e também sobre alguma particularidade que distingue a teoria liberal e a teoria clássica, ver ATIYAH, P. S. The Liberal Theory of Contract, em ATIYAH, P. S. Essays on Contract, Oxford, Clarendon Press, 1986.
} 
dos correspondentes juros. Já a contra-prestação resume-se ao dever do credor de fornecer o crédito contratado.

Esta descrição, de um instrumento contratual informado pela máxima racionalidade auto-interessada das partes, é reforçada pela previsão doutrinária e legal de remédios contratuais, a serem empregados nas hipóteses de inadimplemento dos compromissos assumidos. Sendo assim, o princípio da autonomia da vontade, ao pressupor que as partes são capazes de assentir sobre todos os termos do ajuste, de tal modo que se consiga saber desde sempre o que é devido por cada qual, é o que sustenta esta objetivação contratual, que pretende prescrever com a máxima clareza os termos estipulados, os comportamentos devidos e as conseqüências do inadimplemento. ${ }^{324}$

A presunção desta capacidade ampla de autonomia das partes provém justamente da imagem modal assumida pelo doutrina jurídica para este tipo de contrato: uma projeção liberal do funcionamento dos mercados. De acordo com esta imagem, os contratantes são indivíduos racionais e que maximizam os seus interesses, de forma que cada qual procura defender aquilo que lhe parece ser o máximo benefício disponível. Como lembra ATIYAH ${ }^{325}$, um contrato de procedência teórica liberal de fato pressupõe uma sociedade igualmente liberal, imbuída de valores associados à promoção dos sujeitos de direito (indivíduos), estes sim entendidos como o núcleo das ações sociais. Em conseqüência disso, presume-se que as trocas entre estes agentes ocorrem em um ambiente de antagonismo, no qual cada parte compromete-se com a defesa de seus próprios interesses individuais. Ambos os contratantes têm na perseguição de seus auto-interesses a pauta que motiva a realização dos contratos. A imagem subjacente desta economia competitiva e individualista conflui, então, para a construção dos citados princípios operativos, que valorizam os atributos individuais e fomentam a mútua rivalidade, deixando pouco

\footnotetext{
${ }^{324}$ Para uma análise a respeito da importância do consentimento para a teoria clássica do contrato, ver a crítica apresentada por Ian MACNEIL, que traz uma apresentação da teoria liberal dos contratos: "Fifth, classical contract law draws clear lines between being in and not being in a transaction; e.g., rigorous and precise rules of offer and acceptance prevail with no hal-way houses where only some contract interests are protected or where losses are shared." MACNEIL, Ian. Contracts: adjustment of long-term economic relations under classical, neoclassical and relational contract law. Northwestern University Law Review, v. $72, \mathrm{n}^{\circ} .6,1988$, p. 864.

${ }^{325}$ ATIYAH, P. S. The Liberal Theory of Contract, op. cit.
} 
espaço para o estímulo de relações jurídicas baseadas na cooperação e na convergência de interesses. $^{326}$

A conseqüência concreta desta concepção, teórica e legal, de contraposição dos interesses e de rivalidade entre os contratantes, é a alocação recíproca de ônus e benefícios entre as partes. Como de fato não há uma comunhão dos interesses, o regulamento deste contrato não estabelece uma relação de convergência e de cooperação entre os agentes, por meio da qual poderiam dividir os encargos e os benefícios. Na confecção de um contrato nestas bases, à cada parte imputa-se uma obrigação e uma conseqüente sanção, caso a prestação devida não seja adimplida: os agentes, portanto, assumem individualmente os encargos e desfrutam privadamente dos resultados alcançados. ${ }^{327}$ Trata-se, em suma, de uma transação que o direito classicamente denomina de relação de intercâmbio de interesses, em oposição àqueles acordos identificados por um compartilhamento das intenções, comumente conhecidos como contratos de comunhão de escopo.

${ }^{326}$ A seguinte passagem de Robert GORDON, sobre composição da mútua rivalidade entre agentes egoístas como a característica da regulação liberal dos contratos ilustra este argumento: " $O$ direito contratual clássico, como a economia política clássica, pressupunha um mundo social povoado por sujeitos autoconstituintes, auto-suficientes, cada um perseguindo seus projetos individuais e vendo outras pessoas ou como ameaças ou como meios de realizar esses projetos. Um contrato era uma das interações ocasionais, cuidadosamente circunscritas, que uniam, por um momento solitário, alguns desses seres isolados, com o fim de exploração mútua. Esse individualismo hobbesiano não é, em absoluto, o único modelo de direito contratual clássico, como Duncan Kennedy demonstrou, mas é seu modelo dominante e também o modelo do economismo moderno, que agora busca ressuscitá-lo." GORDON, Robert. Macaulay, Macneil e a Descoberta da Solidariedade e do Poder no Direito Contratual, (tradução Marcos de Campos Ludwig, Revisão técnica José Rodrigo Rodrigues), Revista Direito GV, nº 5, 2007, p. 190. O texto transcrito de Robert GORDON, apesar de conjugar os verbos no passado e assim associar a teoria liberal a um momento pretérito, deixa, por outro lado, bastante claro que este modelo ainda embasa a imaginação de juristas, e mais recentemente, dos economistas encarregados da análise econômica do direito, que, via de regra, sustentam suas avaliações em um direito de corte liberal. Um bom exemplo da apropriação econômica deste tipo de estrutura contratual pode ser visto na seguinte passagem do economista Pérsio ARIDA: "Do ponto de vista da racionalidade econômica, o princípio fundamental do Direito é o do pacta sunt servanda. No entanto, o respeito aos contratos, tal qual entendido pelos economistas, tem sido relativizado pelas mudanças na hermenêutica jurídica decorrente do predomínio de constitucionalistas sobre civilistas. Na nossa história recente, a introdução, no texto constitucional e no Código Civil, de conceitos como função social da propriedade privada ou a boa-fé objetiva, sem que tenham sido acompanhados de uma jurisprudência coerente e consolidada que permita antever seu impacto sobre as decisões dos juízes em casos de litígio, certamente dificulta o respeito aos contratos tal qual concebido por economistas." ARIDA, Pérsio. A Pesquisa em Direito e em Economia: em torno da historicidade da norma, versão revisada do paper apresentado no Simpósio O que é pesquisa em Direito, organizado pela Direito GV, 2002, p. 10. disponível em

http://iepecdg.com/DISK\%201/Arquivos/Leiturassugeridas/Pesquisa\%20em\%20Economia\%20e\%20em\%20 Direito.25042005.pdf, acesso em 10.10.2008.

${ }^{327}$ MACEDO Jr., Ronaldo Porto. Contratos Relacionais e Defesa do Consumidor, 2a ed. São Paulo, RT, 2007, pp. 121-196. 
Correspondentemente, com partes auto-interessadas, obrigações e sanções adjudicadas individualmente, os termos contratuais reguladores deste tipo de transação esforçam-se também por presentificar todas as situações a que estas partes estão ou estarão sujeitas. Faz parte deste tipo de contrato, a intenção de se estabelecer um termo completo, capaz de prever desde sempre todas as contingências e desdobramentos futuros. ${ }^{328}$ De um lado, as partes se esforçam em realizar um planejamento racional da transação, capaz de prever meticulosamente os passos do ajuste; de outro, definem remédios ou sanções contratuais para induzir o cumprimento daquilo que foi acordado, sob pena de compensação da parte inocente. ${ }^{329}$

É nesse sentido que se pode afirmar que esta proposta de regulação dos contratos gira em torno da garantia de precisão e de completude dos termos pactuados, para que assim as relações jurídicas sejam dotadas de significativa previsibilidade. Ao procurar definir no presente os desdobramentos futuros, o contrato busca circunscrever com nitidez o conjunto de obrigações pactuadas e não cogita da validade de outras obrigações, que não as formalmente assentidas. Por tais razões, um contrato de tipo descontínuo é um bom instrumento de regulação daqueles arranjos de governança definidos por WILLIAMSON como estruturas de mercado: o padrão de transação econômica é de tipo spot e, portanto, pode ser perfeitamente normatizável por um instrumento rígido, amparado na rivalidade mútua e na alocação recíproca de ônus e benefícios.

Em compensação, um termo contratual completo desde a sua celebração favorece a estabilidade do acordado, em detrimento da flexibilidade do ajuste. O contrato assim constituído é rígido e competente, portanto, para regular as situações precisas ou de curta duração, mas não está habilitado a lidar com situações imprevistas. ${ }^{330} \mathrm{Se}$, de fato, seu

328 Sobre a relação entre a regulação clássica do contrato e a sua pretensão presentificadora, assinala MACNEIL: Any contract law system necessarily must implement certain norms. It must permit and encourage participation in exchange, promote reciprocity, reinforce role patterns appropriate to particular kinds of exchange relations, provide limited freedom for exercise of choice, effectuate planning, and harmonize the internal and external matrixes of particular contracts. A contract law system reinforcing discrete contract transactions, however, must add two further goals: enhancing discreteness and enhancing presentiation." MACNEIL, Ian. Contracts: adjustment of long-term economic relations under classical, neoclassical and relational contract law. Northwestern University Law Review, v. 72, nº. 6, 1988, p. 862.

${ }^{329}$ Cf. MACAULAY, Stewart. Non-Contractual Relations in Business: a Preliminary Study, American Sociological Review, v. 28, 1963, pp. 55-67.

${ }^{330}$ A rigor, o tipo ideal do contrato clássico não incorpora regras de acomodação e como lembra MACNEIL, as adaptações são feitas fora do contrato: diante de situações imprevisíveis como, por exemplo, a impossibilidade de se antever a quantidade de matéria prima necessária para a produção industrial, a solução apresentada por um contrato típico é a celebração de sucessivos ajustes, sendo cada qual responsável pelo 
ponto alto é a clareza do acordado, pode-se dizer que estes mesmos atributos comprometem a sua regulação quando se está diante de situações dotadas de elevado grau de contingência, como é o caso de um financiamento de ativos intangíveis, que enfrenta dificuldades de ser regulado por termos rígidos e presentificadores.

Dado estes atributos, pode-se ter em conta que as idiossincrasias deste tipo de financiamento não tendem a ser domesticáveis por arranjos contratuais que apresentem uma racionalidade descontínua. Seja pela pretensão de regular no presente toda a experiência futura, seja pela alocação recíproca de ônus e benefícios, que impede um compartilhamento de ganhos, ou mesmo pela rigidez dos termos, não parece plausível supor que seja este o caminho adequado para disciplinar transações financeiras para projetos de inovação. Como será visto, toda a indústria do venture capital tem seu êxito assegurado justamente pela capacidade de estipular acordos flexíveis e adaptáveis às enormes variações inerentes ao desenvolvimento de novos produtos e novos processos.

\subsection{A RACIONALIDADE DO CONTRATO RELACIONAL: COMPARTILHAMENTO DE GANHOS E PERDAS E FLEXIBILIDADE DOS TERMOS}

Um contrato relacional não é uma construção da dogmática jurídica. Clientes não procuram advogados demandando destes a redação de um contrato relacional, como fazem, por exemplo, com um contrato de compra e venda. Da mesma forma, juízes não adjudicam direitos e não decidem conflitos tipificando um contrato como sendo relacional, como fazem, por exemplo, com a identificação de um contrato de concessão ou um contrato de leasing. O código civil não apresenta esta figura como um de seus tipos contratuais e a doutrina civilista brasileira também não oferece uma descrição normativa a seu respeito. No entanto, a teoria relacional dos contratos oferece a descrição de uma racionalidade contratual, que pode responder em parte aos limites demonstrados pela racionalidade do contrato liberal.

A bem da verdade, o contrato relacional identifica um tipo de relação contratual entre as partes, caracterizada pela estipulação de um arranjo pró-cooperativo, em que se constata uma partilha dos riscos e benefícios e se verifica um processo continuado de

estabelecimento da quantidade de certeza planejável no curto prazo. MACNEIL, Ian. Contracts: adjustment of long-term economic relations under classical, neoclassical and relational contract law, op. cit., pp. 855905. 
negociação entre os agentes. A formalização dogmática desta relação toma o contrato como um processo e se vale de desenhos formais que permitam esta imbricação entre as partes. Entre tantos outros, é o caso, por exemplo, de contratos entre empresas que permitam a um dos contratantes participar do conselho de administração da contra-parte ou de dispositivos que admitem a participação de um dos contratantes no retorno financeiro obtido pelo outro agente, em situações em que ambas as partes importam igualmente para a consecução dos resultados. Em outros termos, o contrato relacional não é uma descrição de uma estrutura contratual, como é o caso do contrato de locação, mas sim uma categoria que identifica funcionalmente uma forma de relacionamento contratual entre agentes: uma relação que costuma contar com o estabelecimento de laços de comunhão de escopo na regulação do acordado.

A contra-face deste maior engajamento das partes, em um laço tendente ao compartilhamento e não apenas ao antagonismo, é um estímulo para preservar a relação estabelecida, tratando o contrato, nestes casos, como se este fosse um processo. À distinção do que se verifica num contrato descontínuo, aquilo que foi inicialmente planejado pode estar sujeito a sucessivas repactuações. Faz parte da racionalidade do contrato relacional, portanto, o comprometimento com a busca de soluções para os impasses, de tal forma que as partes não se prendem ao status quo representado pelo momento de celebração original. Daí porque, um contrato em bases relacionais mitiga os dois atributos típicos da teoria liberal: a presentificação e a descontinuidade.

Sobretudo em negócios de longuíssimo prazo e associados a um horizonte de incerteza, os termos contratados não são impeditivos de uma constante renegociação, já que não há a intenção e nem a possibilidade, dada a imprevisibilidade associada a muitas destas transações, de se buscar a presentificação de todas as questões futuras ${ }^{331}$. Este é o caso do contrato de previdência privada, por exemplo, que, ao estabelecer regras para uma

\footnotetext{
${ }^{331}$ A seguinte passagem de MACEDO Jr. é exemplificativa deste ponto: "os contratos descontínuos tendem a 'tornar presente' (to presentiate') o futuro, isto é, 'fazer ou tornar presente num lugar ou tempo, ou fazer com que seja percebido ou reconhecido como presente. A presentificação, neste sentido, é o processo pelo qual se visa antecipar todo o futuro para o presente através do planejamento e estabelecer a vinculação total do futuro àquilo que é planejado no presente. No limite ideal, tornar presente o futuro é tornar o futuro cem por cento predeterminado no presente. Os contratos relacionais tendem, ao contrário, a 'fundir passado, presente e futuro' num continuum no qual, todavia, o presente, não importa quão aguda seja a consciência que dele se tem, é parte tanto do passado como do futuro e eles, por sua vez, partem do mesmo presente. Nesse sentido, nos contratos relacionais as partes reconhecem os limites para se presentificar o futuro e deixam de pretender tão intensamente fazer isto, tal como se configurava o ideal do pensamento liberal clássico.” MACEDO Jr., Ronaldo Porto. Contratos Relacionais e Defesa do Consumidor, op. cit. p. 168.
} 
situação futura e sujeita a indeterminações econômicas, deve assumir a contingência como um dado da realidade. Com isso, o desenho formal das cláusulas contratuais será tanto mais efetivo quanto mais sensível e aberto for às necessidades de uma continuada repactuação dos termos ajustados. Para atender a esta finalidade, sem transmitir insegurança às partes, nem investir em uma regulação assimétrica do acordado, o desenho dos contratos tende a apresentar respostas mais satisfatórias se internalizar a racionalidade relacional. Desta maneira, podem ser constituídos mecanismos para permitir reacomodações pactuadas, como é o caso de cláusulas programadas de revisão ou o direito de participação dos interessados na fiscalização dos negócios contratados. ${ }^{332}$

$\mathrm{Na}$ realidade, a abordagem relacional do contrato procura internalizar uma tensão entre a estabilidade e a flexibilidade, como lembra MACNEIL. ${ }^{333}$ Em situações de longo prazo e de incerteza, as partes de um contrato tanto desejam segurança, traduzida na estabilidade dos termos celebrados, como também procuram preservar a flexibilidade dos laços, a fim de que o contrato possa se ajustar a situações novas e imprevistas. É para acomodar esta tensão que os contratos dotados de uma racionalidade relacional têm de recorrer à disposição de valores originalmente extra-contratuais, como a boa-fé. Por meio deste expediente podem ser criadas balizas para guiar o laço acordado entre as partes, mantendo-as integradas. No limite, diretrizes como estas oferecem aos agentes um parâmetro de comportamento, capaz de ditar as posturas a serem seguidas, em um contexto sujeito a alterações regulatórias.

Em suma, a internalização de uma racionalidade relacional no desenho formal do contrato volta-se a garantir, de um lado, procedimentos de ajuste e adaptação, e de outro, mecanismos que aproximem os agentes, permitindo assim um compartilhamento de propósitos entre indivíduos legalmente independentes. Tais atributos do contrato relacional tornam-no um híbrido de contrato e de sociedade. Por esta razão, é um tipo de ajuste que pode ser visto como uma alternativa à constituição de uma sociedade integral - uma integração vertical, como lembram GOETZ \& $\operatorname{SCOTT}^{334}$. A sua conveniência em relação a

\footnotetext{
${ }^{332}$ Especificamente sobre este ponto, ver MACEDO Jr., Ronaldo Porto. Contratos Relacionais e Defesa do Consumidor, op. cit

${ }^{333}$ MACNEIL, Ian. Contracts: adjustment of long-term economic relations under classical, neoclassical and relational contract law, op. cit.

334 GOETZ, Charles \& SCOTT, Robert. Principles of Relational Contracts, Virginia Law Review, Vol. 67, $n^{\circ} .6,1981$, pp. 1089-1151.
} 
uma sociedade é a preservação de uma maior independência jurídica entre as partes, garantindo, ao mesmo tempo, instrumentos de compartilhamento de riscos e benefícios.

Em virtude destes atributos, os contratos assentados em bases relacionais, assim como as sociedades, estão associados às estruturas de governança que WILLIAMSON destaca para a coordenação das trocas idiossincráticas. Como se procurou mostrar ao longo desta seção, os contratos capazes de regular processualmente os compromissos podem amparar transações que não são realizáveis no ambiente de mercado competitivo. São, assim, uma solução próxima de uma hierarquia. A opção pela contratação ou pela sociedade vai depender da capacidade das cláusulas do contrato em mitigar os riscos, as incertezas e as contingências, da mesma forma que o faz uma hierarquia. Quando isso ocorrer de forma satisfatória, o contrato pode vir a se constituir numa ferramenta viável para disciplinar o financiamento de ativos intangíveis, por exemplo.

No próximo capítulo, ao tratar da experiência concreta do BNDES no financiamento das inovações voltar-se-á a este ponto, ao se referir às regras excepcionais desenhadas pelo Banco para permitir a concessão de créditos para empreendimentos de risco. Notadamente, regras específicas de juros e a possibilidade de participação nos resultados são expedientes contratuais utilizados pelo Banco para financiar empresas inovadoras por meio da concessão de crédito.

\subsection{LIMITES E POSSIBILIDADES DO FINANCIAMENTO POR DÍVIDA MOBILIÁRIA}

Uma alternativa à obtenção de financiamento por meio de endividamento no mercado de créditos é o mercado de capitais. Nesta hipótese, a firma tomadora que demanda recursos para os seus projetos corporativos, pode obter os montantes financeiros por meio da emissão de valores mobiliários com a natureza de dívida. Os eventuais investidores, dispostos a disponibilizar capital para a firma emissora, aportam uma dotação de recursos na companhia, mediante a subscrição de um valor mobiliário. Com isso, passam a receber, via de regra, um pagamento periódico, a título de remuneração de seu investimento, e podem, conforme o tipo de título subscrito, reaver num prazo previamente 
estipulado, a quantia principal aportada. No mercado nacional esta possibilidade é representada pela debênture e no mercado internacional pelos bonds. ${ }^{335}$

Assim como verificado no contrato de crédito, o titular dos valores mobiliários simples representativos de dívida não se torna sócio da empresa tomadora, nem tampouco assume quaisquer riscos associados à atividade realizada pela companhia. Tanto em um caso, como no outro, o direito dos credores é o de reaver o capital disponibilizado e não se estipula entre as partes qualquer outra relação de cooperação ou compartilhamento dos resultados. O pressuposto de ambos é a previsibilidade dos pagamentos devidos, seja pelos agentes que contrataram os créditos, seja pelos que emitiram os títulos de dívida. Sendo assim, há uma considerável segurança para o agente que disponibiliza os recursos, já que, de antemão, são estabelecidas as condições e os prazos de seu pagamento. Mesmo em caso de ruína financeira, caso a empresa tomadora se veja diante de um processo falimentar, os titulares de dívidas podem ser salvaguardados, seja porque estes valores podem estar associados a garantias reais, seja porque podem preferir aos demais credores, na satisfação das dívidas corporativas.

No entanto, assim como há distinções entre os limites do contrato simples e os do contrato relacional, existem possibilidades de desenho dos valores mobiliários representativos de dívidas que são portadores de maior flexibilidade. Concretamente, isso significa a construção de ferramentas que permitem atenuar alguns dos atributos típicos das transações constitutivas de dívida, em especial a sua intenção presentificadora e a rigidez no estabelecimento das obrigações. Exemplos destas possibilidades são, respectivamente, a possibilidade de dispensar a exigência de garantias reais como obrigação acessória do devedor e a opção de substituir o pagamento regular de juros pela participação dos titulares nos resultados da companhia, entre outras variações. ${ }^{336}$

No caso da debênture, a legislação societária brasileira permite diversas alternativas de emissão, que contam com diferentes regimes de garantias, com

\footnotetext{
${ }^{335}$ A debênture e o bond são valores mobiliários já que são instrumentos de capitalização das companhias que contam com empréstimos obtidos a partir de captação entre terceiros. No caso da debênture, os títulos podem ser subscritos por um grupo privado de investidores ou dirigidos a quaisquer interessados, nos casos de subscrição pública. Todos os direitos do debenturista e os deveres da companhia emissora constam do escritura de emissão que acompanha o título e regula a relação entre o investidor e a empresa emissora.

336 Sobre as possibilidades de engenharia financeira utilizando-se debêntures, ver SANTOS, Durval Jose Soledade. Debêntures: um instrumento moderno de aplicação e captação de recursos, Revista do BNDES, Rio de Janeiro, v. 13, 2006, pp. 35-54.
} 
possibilidades variadas de estipulação dos pagamentos devidos e ainda com distintas opções de prazo para o resgate do valor principal pelo subscritor. Com estas variações, a debênture pode tanto assumir uma feição presentificadora e descontínua, em moldes semelhantes ao verificado no contrato simples de crédito, como apresentar características que a aproximam de um veículo de participação acionária, em que há um efetivo compartilhamento dos riscos entre o tomador e o investidor.

No que tange às garantias, a lei societária (lei 6.404/76) admite quatro modalidades de emissão deste valor mobiliário. A primeira hipótese é a de uma debênture assegurada por uma garantia real, que é oferecida pela empresa tomadora. Com isso, caso a companhia sofra um revés financeiro e se veja insolvente, o subscritor do título pode recuperar parte de seu investimento com o levantamento da garantia. Naturalmente, para as empresas emergentes o inconveniente desta modalidade é justamente a necessidade de depósito de uma garantia real, muitas vezes indisponível para firmas em uma fase iniciante (start up). Nos demais casos, não há exigência de se depositar uma garantia e os direitos do debenturista oscilam conforme o tipo de regime da emissão. Trata-se das seguintes modalidades: (i) debênture com garantia flutuante, (ii) quirografária e (iii) subordinada ${ }^{337}$.

No primeiro caso alternativo (debênture flutuante), o crédito devido ao subscritor tem primazia sobre os credores comuns (quirografários); no segundo, não há qualquer regime especial de proteção e o debenturista disputa o montante que lhe é devido com os demais credores, numa eventual falência da companhia. Por fim, a debênture subordinada detém prioridade de pagamento do quantum devido apenas em relação aos acionistas, que como sabido recebem os dividendos do saldo restante depois de adimplido o pagamento de todos os exigíveis da companhia. Em resumo, as modalidades (i) debênture com garantia flutuante, (ii) debênture quirografária e (iii) debênture subordinada, em relação à debênture com garantia real, são ferramentas mais propícias para a estruturação de operações financeiras, quando se trata de empresas emergentes. Embora resultem em uma proteção ao investidor aparentemente menor, permitem que empresas desprovidas de patrimônio possam obter financiamento via endividamento. ${ }^{338}$

\footnotetext{
${ }^{337}$ Sobre essas possibilidades de emissão das debêntures, ver EIZIRIK, Nelson; GAAL, Ariádna; PARENTE, Flávia \& HENRIQUES, Marcus de Freitas. Mercado de Capitais - regime jurídico, 2a . ed., Rio de Janeiro, Renovar, 2008, pp. 65-78.

${ }^{338}$ Cf. SANTOS, Durval Jose Soledade. Debêntures, op. cit.
} 
Com relação às regras de pagamento e prazo de resgate, a debênture é igualmente flexível e comporta diversos desenhos financeiros. A forma mais simples de estruturação de uma operação de dívida com este veículo é disciplinar um regime de pagamento de juros fixos, com um prazo previamente determinado para o pagamento do montante principal. No entanto, para além dessa possibilidade, a debênture comporta alternativas menos rígidas, como por exemplo, a previsão de que parte dos juros (ou os juros integrais) devidos seja adimplida com a participação do subscritor (credor) nos lucros a serem obtidos pela firma devedora. Com isso, o título de dívida, assentado em pagamentos fixos, aproxima-se bastante de um instrumento de participação, dada a possibilidade de assegurar apenas rendas variáveis ao credor. Esta alternativa pode ainda ser ampliada, caso não seja sequer previsto um prazo para o resgate do valor aportado, opção verificada na chamada debênture perpétua. Neste caso, a remuneração do investidor advém dos resultados percebidos pela firma, que, por sua vez, não se obriga a pagar o montante principal em um prazo previamente estabelecido. ${ }^{339}$

Por fim, a debênture pode, ainda, admitir a sua plena conversibilidade em ação, o que significa, operacionalmente, a transferência de seu registro: de item exigível, para a sua consignação como capital da companhia. Em outros termos, a debênture admite ser convertida em um instrumento de participação, deixando de ser um veículo de dívida. Com isso, o subscritor passa a ser um acionista da companhia e assim como todos os demais, titular de um universo de direitos de participação na vida societária, incluindo o recebimento de dividendos proporcionais ao êxito comercial alcançado pela empresa. A viabilidade efetiva dessa possibilidade, reconhecida pelo direito positivo e pela doutrina, depende dos termos disciplinados na escritura de emissão da debênture. ${ }^{340}$

Com isso, do ponto de vista da utilização dos valores mobiliários de dívida para o financiamento das inovações, as possibilidades abertas pela debênture relativizam em parte as descrições da nova economia institucional. Embora o diagnóstico de que o mercado de dívida mostre-se limitado para o financiamento de ativos incertos e específicos seja, de fato, compatível com as possibilidades reveladas pela debênture de tipo mais simples, as alternativas mais sofisticadas, que admitem, inclusive, a participação nos lucros e prazo indefinido, indicam uma reversão das tendências de presentificação e de descontinuidade

${ }^{339}$ EIZIRIK, Nelson, et. al. Mercado de Capitais - regime jurídico, op. cit.

${ }^{340}$ EIZIRIK, Nelson, et. al. Mercado de Capitais - regime jurídico, op. cit. 
dos títulos de dívida. Desta maneira, as debêntures, ao permitirem possibilidades de compartilhamento de riscos e de benefícios, parecem demonstrar capacitação para serem empregadas como ferramentas deste tipo de operação financeira. A partir destas considerações, o quadro abaixo apresenta uma régua que oscila entre a menor e as maiores possibilidades de utilização desta ferramenta.

\begin{tabular}{|c|c|c|c|}
\hline \multicolumn{4}{|c|}{$\begin{array}{l}\text { RÉGUA DE FINANCIAMENTO } \\
\text { POSSIBILIDADE DE FINANCIAMENTO DAS INOVAÇÕES POR MEIO DE }\end{array}$} \\
\hline Menor possibilidade & & & Maior possibilidade \\
\hline $\begin{array}{c}\text { Debênture simples com } \\
\text { exigência de garantia e } \\
\text { prazo de pagamento } \\
\text { fixo }\end{array}$ & $\begin{array}{c}\text { Debênture sem } \\
\text { exigência de garantia e } \\
\text { com a possibilidade de } \\
\text { renda variável } \\
\text { (participação nos } \\
\text { lucros) }\end{array}$ & $\begin{array}{l}\text { Debênture perpétua, } \\
\text { com renda variável }\end{array}$ & $\begin{array}{l}\text { Debênture perpétua, } \\
\text { com renda variável e } \\
\text { conversível em ação. }\end{array}$ \\
\hline
\end{tabular}

Como será visto no capítulo 5, que traz um estudo de caso acerca das ferramentas e da racionalidade de atuação do BNDES no segmento de empresas inovadoras, a debênture foi um instrumento bastante utilizado pelo Banco. Isso porque, de um lado, garante uma proteção ao investidor que permanece como titular de um título exigível; de outro, sua flexibilidade permite que até mesmo empresas emergentes possam se valer deste veículo de financiamento corporativo.

\subsection{O FINANCIAMENTO DAS INOVAÇÕES POR MEIO DA PARTICIPAÇÃO SOCIETÁRIA: GOVERNANÇA DESCONTÍNUA VERSUS GOVERNANÇA RELACIONAL}

O financiamento por meio da participação, em relação à dívida, acarreta para o investidor custos superiores de agência e menor proteção relativa. Diferentemente dos credores, os acionistas não dispõem de um crédito a ser exigido, mas apenas a expectativa de recebimento de dividendos. Por esta razão, não só para as firmas, mas também para os investidores, a opção pela dívida é uma modalidade preferível. Entretanto, há empreendimentos corporativos que, como já argumentado, não podem contar com recursos de credores, dados os riscos e incertezas envolvidos. Um exemplo disso são as firmas e projetos que não apresentam uma lucratividade corrente, conquanto possam vir a representar empreendimentos de bastante sucesso, no futuro. O mesmo ocorre nos casos em que o resultado do empreendimento é menos previsível ou nas hipóteses em que o tomador não dispõe de mecanismos para assegurar o financiamento, no contexto presente. 
Em situações como essa, lembra STLIGTZ ${ }^{341}$, o mais razoável é o empreendedor compartilhar os riscos do negócio com o financiador, pois desta maneira, pode se ver livre da necessidade de prestar garantias e ainda evitar um compromisso rígido com o pagamento de dívidas contraídas. Já o financiador tem como benefício a expectativa de um retorno variável, que, na hipótese de sucesso do empreendimento, pode representar um ganho econômico mais expressivo do que aquele associado à satisfação do crédito acrescido dos juros.

Conseqüentemente, transações financeiras que envolvem ativos com estas características demandam ferramentas habilitadas a uma disciplina que, de um lado, distribua equitativamente os riscos e, de outro, seja suscetível a um amplo leque de adaptações, ante as inúmeras contingências que podem ocorrer no curso do financiamento. Por estas razões, o aporte de recursos em uma empresa emergente ou em projetos com maior risco de insucesso, por exemplo, encontram na participação societária uma resposta satisfatória, ainda que este instrumento apresente custos superiores ao verificado nas ferramentas de dívida ${ }^{342}$.

A estruturação de uma operação financeira por meio da participação acionária, por sua vez, assim como verificado nos financiamentos realizados por meio de endividamento, também admite modalidades alternativas de disciplina das relações estabelecidas entre investidores e tomadores. Conforme o tipo de distribuição dos títulos, a intervenção dos financiadores pode ser pulverizada ou concentrada. No primeiro caso, trata-se de uma forma descontínua de relação societária, notabilizada pela atomização acionária dos investidores. No segundo, dá-se o oposto: poucos investidores detêm uma participação substancial no capital social, consubstanciando, assim, um formato relacional de governança corporativa. Embora ambos os tipos de participação sejam mais adequados para aportes de recursos em empresas emergentes do que os instrumentos de dívida, o

${ }^{341}$ Cf. STLIGTZ, Joseph. Government, Financial Markets, and Economic Development, op. cit., pp. 1-40.

${ }^{342}$ A esse respeito ver PINTO JUNIOR, Mario Engler. A Capitalização da Companhia, op. cit. A seguinte passagem de SHLEIFER \& VISHNY indica justamente a relevância do mecanismo de participação para estas situações: "Equity is the most suitable financing tool when debt contracts are difficult to enforce, i.e., when no specific collateral can be used to back credit and when near-term cash flows are insufficient to service debt payments. Young firms, and the firms with intangible assets, may need to be equity financed simply because their assets have little or no liquidation value. If they are financed by debt, their managers effectivelly give full control to the bank from the start. This may be especially problematic when the firm's value consists primarily of future growth opportunities, but the bank's debt claim and unwillingness to take equity give it little interest in the upside and a distorted incentive to liquidate." Cf. SHLEIFER, Andrei \& VISHNY, Robert. A Survey of Corporate Governance. op. cit. p. 765. 
modelo de concentração acionária mostra-se uma alternativa de financiamento ainda mais apropriada para situações idiossincráticas, como é o caso das inovações e dos ativos intangíveis. $^{343}$

A governança corporativa descontínua tem como pressuposto o fato de que os acionistas estão dispersos e distantes - dada a sua pulverização. A representação de seus interesses é realizada principalmente por meio do voto e da correspondente eleição dos membros do conselho de administração, uma instância societária competente para fiscalizar e aprovar atos e decisões empreendidos pelos dirigentes da companhia ${ }^{344}$. No desempenho desta atuação, o conselho de administração procura mitigar os problemas de agência, com a intenção de aproximar as decisões dos administradores dos interesses manifestados pelos acionistas, assim como busca impedir que os dirigentes corporativos, valendo-se da distância dos investidores, assumam posturas em benefício próprio, mas em prejuízo da sociedade. Neste padrão de governança, no entanto, as atividades do conselho não são propriamente interventivas na gestão da companhia, o que ensejaria um acompanhamento intenso e regular do cotidiano das empresas. Na realidade, o tipo de monitoramento realizado tende a se concentrar nos episódios de crise, de tal forma que a sua participação, como instância de observação e aconselhamento, mostra-se mais efetiva nos eventos corporativos extraordinários do que no acompanhamento dos atos societários $\operatorname{ordinários}^{345}$.

\footnotetext{
${ }^{343}$ Sobre os modelos de governança e sua associação com as alternativas institucionais, ver VITOLS, Sigurt. Varieties of Corporate Governance: comparing Germany and the UK, em HALL, Peter \& SOSKICE, David. Varieties of Capitalism - the institutional foundations of comparative advantage, op. cit. Ver também SHLEIFER, Andrei \& VISHNY, Robert. A Survey of Corporate Governance. op. cit e AOKI, Masahiko \& DINÇ, Serdar. Relational Financing as an Institution and its Viability under Competition, op. cit., pp. 3-39. Ver ainda ROMANO, Roberta. Corporate Law and Corporate Governance, vol. 3, nº. 2, 1996, pp. $277-313$.

344 Sobre os direitos dos acionistas e a forma de seu exercício em diversos modelos corporativos, ver HANSMANN, Henry \& KRAAKMAN, Reinier. The Basic Governance Structure, em KRAAKMAN, Reinier, et al. The Anatomy of Corporate Law - a comparative and functional approach, op. cit.

${ }^{345}$ Essa avaliação é partilhada, por exemplo, por Roberta ROMANO, que analisa diversos estudos empíricos voltados a compreender o papel exercido pelo conselho de administração, nas companhias abertas nos Estados Unidos. No artigo Corporate Law and Corporate Governance, ROMANO reconhece duas hipóteses nas análises voltadas a avaliar o trabalho dos conselhos de administração, uma forte e a outra fraca. Os estudos menos conclusivos são justamente aqueles baseados em uma hipótese forte, segundo a qual há uma correlação positiva entre a existência de conselhos de administração ativos e presentes e empresas com resultados econômicos favoráveis. Já os estudos mais consistentes são aqueles baseados em uma hipótese fraca: o conselho de administração costuma atuar eficazmente em eventos extraordinários, como são os momentos de crise corporativa. Na lógica de funcionamento deste modelo de governança, portanto, as decisões ordinárias são menos dadas a uma intervenção ativa dos conselheiros. Ver ROMANO, Roberta. Corporate Law and Corporate Governance, op. cit.
} 
Ao lado dessa atuação fiscalizadora interna exercida pelo conselho de administração, o modelo de governança descontínua conta também com uma outra relevante instância de controle, igualmente associada à proteção dos interesses dos investidores. Trata-se de um controle externo exercido pelo próprio movimento do mercado de capitais (quanto mais intenso o mercado, mais efetivo é o controle). No âmbito deste modelo de financiamento, os administradores de empresa são vigiados permanentemente pelos demais atores concorrentes e caso suas empresas venham a apresentar um resultado econômico aquém das expectativas dos investidores, estes dirigentes podem estar sujeitos a uma oferta hostil de aquisição de controle, o que poderá, enfim, afastá-los da administração da companhia. Essa fiscalização externa é garantida pela dispersão acionária característica deste modelo, como é o caso da realidade financeira norte-americana: os acionistas de uma companhia listada em bolsa, insatisfeitos com a rentabilidade de seu investimento, podem a qualquer momento ceder às propostas de aquisição, realizadas por algum investidor disposto a assumir o controle de uma empresa carente de resultados expressivos.

O traço característico deste padrão de governança corporativa, portanto, é a complementaridade dessas duas instâncias de monitoramento: (i) o conselho de administração e (ii) o mercado de capitais. No âmbito interno, a disciplina do comportamento dos administradores e a representação dos acionistas é realizada pelo conselho, que, por sua vez, é complementado por um mecanismo externo: a ameaça latente oferecida pelos agentes do mercado, que a qualquer momento podem fazer de administradores menos bem sucedidos um alvo fácil de tomadas hostis de controle. ${ }^{346}$

Esse modelo de governança, entretanto, não é imune a problemas. O parco envolvimento dos investidores com o cotidiano das empresas e a combinação de um conselho de administração passivo com um mercado de capitais demandante de resultados econômicos objetivos e positivos podem gerar consequiências negativas. Como lembram Ian AYRES \& Peter CRAMTON ${ }^{347}$, o déficit de disciplina interna, causado pelo distanciamento de acionistas e do próprio conselho de administração pode resultar, por

\footnotetext{
${ }^{346}$ Para Roberta ROMANO, a atuação do mercado de capitais é supletiva das eventuais falhas apresentadas pelo monitoramento exercido pelo conselho de administração. Ver ROMANO, Roberta. Corporate Law and Corporate Governance, op. cit.

${ }^{347}$ Cf. AYRES, Ian \& CRAMTON, Peter. Relational Investing and Agency Theory, Cardozo Law Review, vol. 15, 1994, pp. 1-18.
} 
exemplo, em uma fiscalização interna deficiente, que pode se mostrar incapaz de mitigar os problemas de agência presentes nesta modalidade de financiamento. Em compensação, o tipo de verificação exercido pelo mercado, baseado em indicadores de rentabilidade presente, pode resultar em um controle míope, que é capaz de penalizar administradores de projetos portadores de futuro, mas que não apresentam resultados máximos no curto $\operatorname{prazo}^{348}$.

Essas falhas de governança podem ser particularmente relevantes no financiamento de projetos de inovação, marcados pela baixa capacidade de aferição dos resultados parciais, dada a elevada contingência a que estes ativos estão associados, e caracterizados pelo longo prazo de maturação. De um lado, em empresas emergentes dedicadas ao desenvolvimento de novos produtos ou novos processos produtivos, como visto, a assimetria de informações é mais expressiva do que a verificada em empresas dedicadas a investimentos tradicionais (com ativos físicos). De outro, este tipo de investimento demanda paciência, já que a obtenção de uma rentabilidade expressiva não ocorre de imediato. Para contornar ambos os problemas, os mecanismos de governança tendem a ser mais satisfatórios se, a um só tempo, garantirem meios para um monitoramento interno mais rigoroso e presente, do que o verificado no modelo descontínuo, e ainda apaziguarem as ameaças externas do mercado, que podem inibir planos de investimentos mais arriscados.

Em razão disso, a administração dos conflitos societários na nova economia tem se valido de um padrão relacional de governança corporativa, verificado originalmente nos sistemas coordenados de mercado, como o alemão e o japonês ${ }^{349}$. Como visto no primeiro

\footnotetext{
${ }^{348}$ Para ambas essas criticas, ver Ian AYRES \& Peter CRAMTON: "according to the 'distorted discipline' school, managers fear losing their jobs following a hostile takeover. As a result, they are pressured to maximize short-term stock price to the detriment of the fundamental value of the corporation. The 'deficient discipline' school argues that managers capture boards of directors and that consequently, the boards fail to monitor management behavior. Thus, we might usefully distinguish between situations where good managers might mistakenly be fired (distorted discipline), and those where bad managers might mistakenly be retained (deficient discipline). An important goal of corporate governance is to efficiently reduce both of these types of error." AYRES, Ian \& CRAMTON, Peter. Relational Investing and Agency Theory, op. cit. p. 3.

${ }^{349}$ Desde o final dos anos 1980 e começo dos anos 1990, os modelos japonês e alemão têm recebido alguma atenção dos pesquisadores de corporate law nos Estados Unidos. De um lado, a consolidação da nova economia, baseada em inovações e de outro, a crise no movimento do mercado de capitais americano em meados da década de 1980, contribuíam para a percepção de que o modelo continental teria virtudes. Em 1993, por exemplo, foi realizada na Columbia Law School a Conference on Relational Investing, cujo propósito foi debater o tipo relacional de governança corporativa e a possibilidade de sua utilização no ambiente institucional americano. A esse respeito ver AYRES, Ian \& CRAMTON, Peter. Relational
} 
capítulo, diferentemente do padrão americano, o modelo relacional de governança foi forjado justamente como uma alternativa à carência de um mercado de capitais vivida por estes países. Por tal razão, este modelo conta com premissas de funcionamento diferenciadas: no lugar da pulverização dos investidores e do duplo acompanhamento societário (conselho e mercado), a participação societária dos investidores é concentrada e duradoura. Com essa forma de participação em bloco, o investidor relacional detém uma estrutura de incentivos diferente, que se reflete em um outro tipo de envolvimento com a companhia. Respondem assim a ambos os problemas de monitoramento do modelo descontínuo: os riscos de um controle interno deficiente e as chances de um acompanhamento externo míope.

Em primeiro lugar, a posição do investidor em bloco dentro da sociedade favorece uma atuação positiva no monitoramento dos administradores. A concentração acionária confere ao titular um significativo poder de voto nas deliberações corporativas, o que lhe atribui uma ascendência sobre os dirigentes da firma. Além disso, como a participação ativa no acompanhamento da empresa articula mais benefícios do que custos, a utilização deste poder de influência não é só possível, como é também provável. Isso se deve ao fato de que os ganhos provenientes de um monitoramento ativo da gestão empresarial são diretamente relacionados ao volume de participação societária do investidor, enquanto os custos desta fiscalização não são incrementados na mesma ordem. A explicação para este fato é um intuitivo ganho de escala: o custo de monitoramento do empreendedor é relativamente o mesmo para qualquer acionista, ao passo que os benefícios apropriados, proporcionados por eventuais aperfeiçoamentos no comando da firma monitorada, serão tanto maiores, quanto mais significativa for a participação societária. Sendo assim, titulares de um bloco acionário tendem a participar ativamente do desempenho corporativo, já que podem obter ganhos expressivos com a melhoria de

Investing and Agency Theory, op. cit. Ainda sobre este ponto, assinala Jeffrey GORDON: "the hostile takeover became important in the 1970s and 1980s at least in part because of the legal, practical and cultural barriers to internal shareholder mobilization at a time of accelerating economic change. The low rate of internal shareholder intervention to replace managers who followed suboptimal strategies opened up opportunities for takeover entrepreneurs. As events in the late 1980s demonstrated, however, hostile takeovers were not an ideal intervention mechanism." Cf. GORDON, Jeffrey. Institutions as Relational Investors: a new look at cumulative voting. Columbia Law Review, vol 94, no. 1, 1994. p. 125. Para uma crítica desta visão, acusada de procurar transplantar para o universo americano o padrão relacional de governança, ver ROMANO, Roberta. Corporate Law and Corporate Governance, op. cit. 
performance da empresa da qual são investidores ${ }^{350}$. Com isso, podem ser mitigados os custos de agência e a assimetria de informações existentes na relação entre investidores e empreendedores de firmas emergentes.

Em segundo lugar (e como um desdobramento do primeiro) acionistas relacionais, ao substituírem o controle exercido pelo mercado por um monitoramento interno intenso, tendem a ser mais generosos com o desenvolvimento de projetos corporativos de longo prazo. Com uma participação ativa no acompanhamento do desempenho dos administradores, este tipo de investidor pode se valer de informações subjetivas e estranhas aos parâmetros habituais de mensuração dos analistas de mercado. Concretamente, a vivência interna da corporação franqueia ao acionista relacional um conhecimento do potencial dos planos societários, o que pode vir a permitir apostas na obtenção de resultados positivos, como projetos de longa maturação ${ }^{351}$. Como também a concentração de um bloco de participação protege a companhia de uma eventual tomada hostil, administradores encarregados do desenvolvimento de novos produtos e novos processos podem contar com um horizonte de tranqüilidade para o desempenho de suas funções. ${ }^{352}$

Em razão destas características, este tipo de governança corporativa tem se difundido como um instrumento de regulação societária, para além dos contextos institucionais das economias coordenadas. Mesmo na economia norte-americana, alguns segmentos, notabilizados por uma elevada assimetria de informações ou pela necessidade de uma participação presente dos investidores no cotidiano das empresas, têm se caracterizado pela participação societária em bloco. Exemplos disso são os investimentos em empresas emergentes, na forma de venture capital, e as compras alavancadas de companhias (leveraged buy outs - LBOs), muitas vezes realizadas por atores financeiros interessados na recuperação e subseqüente venda das empresas. Em ambos os casos, as operações pressupõem uma aquisição concentrada de ações, com a finalidade de permitir ao titular um efetivo acompanhamento do desempenho corporativo, podendo assim participar da gestão da sociedade, até mesmo como conselheiro de negócios.

\footnotetext{
${ }^{350}$ Sobre este ponto ver AYRES, Ian \& CRAMTON, Peter. Relational Investing and Agency Theory, op. cit.

${ }^{351}$ Cf. AOKI, Masahiko \& DINÇ, Serdar. Relational Financing as an Institution and its Viability under Competition, op. cit.

352 ver AYRES, Ian \& CRAMTON, Peter. Relational Investing and Agency Theory, op. cit. Ver ainda GORDON, Jeffrey. Institutions as Relational Investors: a new look at cumulative voting. op. cit.
} 
Nesse sentido, é interessante notar que até mesmo os críticos ao modelo relacional de governança, como é o caso de Roberta ROMANO, sobretudo no que se refere à sua adaptação a ambientes baseados em laços de mercado, como é o contexto norteamericano, confirmam as suas vantagens comparativas para transações financeiras com setores emergentes. $\mathrm{O}$ seguinte trecho da autora, cujo argumento se sustenta na economia dos custos de transação, indica justamente esta posição. Assumindo uma postura menos entusiasta que a defendida por autores como AYRES \& CRAMTON, ROMANO corrobora a noção de que uma participação em bloco, associada a um monitoramento ativo, pode ser relevante para o financiamento de empresas emergentes, dedicadas a projetos de inovação:

\begin{abstract}
Using the insight of transaction cost economics, the need to match transactions and governance structures, we can provide an alternative scenario for when relational investors might be more capable directors than their designers, that is less problematic than AYRES and CRAMTON's model in that it mitigates the conflict of interest problem, but that is also more limited in scope, because it applies only to a specific subset of firms. The relevant firms are those with (i) the most nonredeployable assets, that is, firms with a substantial amount of intangible assets or tangible assets that are highly specialized to the business; and (ii) the most uncertain cash flow from their assets, that is, new firms whose ability to develop the value of assets is largely unknown, or firms in industries that have particularly volatile customer demand or technological needs. For such firms, it is at least arguable that not only is equity financing preferable to debt, but concentrated equity is preferable to diffuse ownership, because there is a greater need to ensure timely access to information and immediate ability to control management since the equity investment can be squandered without ready market $\operatorname{detection}^{353}$.
\end{abstract}

Com esse formato societário, assentado em uma composição acionária concentrada (não necessariamente majoritária) e em um engajamento dos investidores no monitoramento corporativo, a governança relacional desponta assim como a ferramenta jurídica mais afinada com o ritmo dos financiamentos em ativos intangíveis. Isso se deve ao fato de que a participação em bloco garante aos investidores poderes de ação ante a um empreendimento incerto e dado a contingências: a base amplificada de informações e a maior influência nas instâncias societárias permitem uma avaliação contínua dos planos de investimento e habilitam ainda uma participação ativa na orientação dos rumos a serem seguidos pelo empreendedor. Em resumo, se a participação acionária mostra-se um

${ }^{353}$ ROMANO, Roberta. Corporate Law and Corporate Governance, op. cit. p. 302. 
instrumento apropriado para as transações financeiras que demandam o compartilhamento dos riscos, a sua estruturação com características relacionais é particularmente apropriada para aquelas situações em que o grau de incerteza e de assimetria de informações é ainda mais proeminente.

\subsection{VISÃO GERAL DAS FERRAMENTAS JURÍDICAS DE FINANCIAMENTO}

A partir da identificação dos atributos dos ativos, realizada pela economia dos custos de transação e com base na descrição das possibilidades regulatórias das ferramentas jurídicas, pode-se concluir que quanto maior o grau de especificidade e de imprevisibilidade dos bens transacionados, mais relevante se torna a utilização de instrumentos constitutivos de uma relação de associação ou de parceria. Por tal razão, a probabilidade de utilização de cada uma das ferramentas jurídicas descritas, no financiamento de ativos intangíveis, tende a ser tanto mais elevada, quanto maior for a sua capacidade de estabelecer laços de proximidade entre investidores e tomadores. É desta maneira que o direito responde ao desafio de disciplinar conflitos de interesse ante situações mutáveis, contingentes e assimétricas. O quadro a seguir procura sintetizar estas posições, apresentando uma escala de probabilidades de utilização das ferramentas jurídicas neste tipo de transação financeira.

\begin{tabular}{|c|c|c|c|c|c|}
\hline \multicolumn{6}{|c|}{$\begin{array}{c}\text { QUADRO } 11 \\
\text { COMPARAÇÃO DA PROBABILIDADE DE UTILIZAÇÃO D } \\
\text { FINANCIAMENTO DAS INOVACÕES }\end{array}$} \\
\hline Pouca pro & $\begin{array}{l}\text { abilidade } \\
\text { ) }\end{array}$ & \multicolumn{3}{|c|}{ Alguma probabilidade } & $\begin{array}{c}\text { Maior } \\
\text { Probabilidade } \\
(+)\end{array}$ \\
\hline $\begin{array}{c}\text { Contratos } \\
\text { descontínuos } \\
\text { de } \\
\text { empréstimo }\end{array}$ & $\begin{array}{c}\text { Títulos } \\
\text { descontínuos } \\
\text { de dívida }\end{array}$ & $\begin{array}{l}\text { Contratos de } \\
\text { empréstimo } \\
\text { relacionais }\end{array}$ & $\begin{array}{c}\text { Títulos de } \\
\text { dívida com } \\
\text { renda variável e } \\
\text { sem garantias } \\
\text { reais }\end{array}$ & $\begin{array}{c}\text { Participação } \\
\text { acionária } \\
\text { descontínua }\end{array}$ & $\begin{array}{c}\text { Participação } \\
\text { acionária } \\
\text { relacional } \\
\text { (em bloco, com } \\
\text { monitoramento } \\
\text { ativo) }\end{array}$ \\
\hline
\end{tabular}

As ferramentas descontínuas, isto é, assentadas no distanciamento entre as partes e voltadas à presentificação dos termos ajustados tendem a oferecer respostas menos satisfatórias aos problemas de agência e de assimetria de informações. Não por acaso, o contrato e os títulos de dívida simples, ao apresentarem estruturas regulatórias rígidas, como é o caso de um cronograma fixo de pagamentos aos credores e ainda demandarem 
garantias contra as intercorrências futuras, figuram como as ferramentas menos prováveis de serem utilizadas nestas transações. Conforme ambos os atributos (descontinuidade e presentificação) são relaxados, aumentam as possibilidades de emprego dos respectivos instrumentos. Nesse sentido, contratos baseados em uma lógica relacional, portanto mais abertos ao compartilhamento de riscos e a adaptações de percurso, oferecem a ambos, investidores e empreendedores, uma solução mais satisfatória do que o contrato simples. O mesmo se passa com os títulos mobiliários abertos à possibilidade de suspender a exigência de garantias e sujeitos a uma remuneração por meio de rendas variáveis, que desobrigam o tomador do recurso de adimplir com uma regularidade pré-fixada a dívida contraída.

A participação societária, enfim, é, entre todos, a ferramenta mais propícia a este tipo de investimento. Em relação ao contrato e aos títulos simples, a sociedade representa o outro extremo da régua de instrumentos. Como as partes são sócias, há uma plena divisão de riscos e lucros e, por conta disso, não há uma necessidade de se presentificar os termos: ônus e benefícios são administrados de modo simultâneo à ocorrência dos episódios. Ainda dentro deste quadrante da participação societária, o desenho relacional da governança é ainda mais adaptado a lidar com situações contingentes e assimétricas, dado que neste modelo o engajamento dos atores é ainda maior do que o verificado nas participações pulverizadas.

Muito embora essa régua possa apenas apresentar uma variação de probabilidades, já que não seria factível oferecer uma resposta definitiva, que desse conta de todas as possibilidades de ajuste entre as partes, a experiência do financiamento dos setores emergentes parece corroborar a sua disposição. A forma de estruturação das operações de capital de risco, conforme descreve a literatura encarregada dos instrumentos reguladores do venture capital, tem se valido majoritariamente da participação acionária em bloco, com investidores ativos e regras de governança que habilitam uma intervenção constante na gestão societária. A seção seguinte apresentará esta modalidade de financiamento, desenvolvida no contexto norte-americano para suprir as necessidades financeiras de empresas emergentes. Como se procurará argumentar, o venture capital nos Estados Unidos combina duas curiosas características: uma governança corporativa relacional e a intensidade do mercado de capitais como ambiente preferencial para os desinvestimentos. 


\section{O VENTURE CAPITAL E O MODELO NORTE-AMERICANO DE FINANCIAMENTO DAS INOVAÇÕES: FERRAMENTAS RELACIONAIS DE PARTICIPAÇÃO SOCIETÁRIA E ARRANJO INSTITUCIONAL DE MERCADO}

O venture capital pode ser descrito como uma ferramenta de investimento em empresas emergentes, de acordo com a qual o aporte de capital ocorre por meio de uma participação societária concentrada, a cargo de aplicadores especializados, que dispõem de mecanismos para acompanhar ativamente a gestão da empresa investida. A instituição deste tipo de mecanismo jurídico deu-se originariamente nos Estados Unidos, em meados da década de $1950^{354}$, com a finalidade de superar as dificuldades apresentadas pelas pequenas empresas ou empresas dedicadas a novas tecnologias de captarem recursos para desenvolverem seus projetos corporativos. $\mathrm{O}$ alto risco deste tipo de investimento, baseado muitas vezes em uma mera projeção de potencialidades, associado ainda a outras dificuldades empresariais, como a falta de expertise gerencial dos novos empreendedores, dificultava a captação financeira deste segmento no mercado de capitais. ${ }^{355}$

Foi justamente para contornar estas dificuldades que apareceu a ferramenta jurídica do venture capital, cujo papel é o de intermediar a relação entre os investidores, dispostos a uma aplicação de risco, e as empresas emergentes, que demandam recursos para dar consecução aos seus projetos inovadores. Para permitir este ajuste entre ambos os atores, o venture capitalist, comumente uma pessoa jurídica, atua de forma supletiva ao mercado de capitais, ou seja, incumbe-se de uma gestão financeira completa e especializada, capaz de mitigar as assimetrias de informação e os problemas de agência, que tendem a obstruir a relação direta entre poupadores individuais e empresas tomadoras. A sua aparição e consolidação no contexto norte-americano, marcado pela captação pública de recursos em bolsa, é, portanto, sintomática: neste ambiente de livre mercado, o capitalista de risco atua como um mediador especializado, naquelas transações em que os

\footnotetext{
354 A primeira experiência de venture capital ocorreu em 1946, para permitir a utilização empresarial de novas tecnologias desenvolvidas durante a $2^{\text {a }}$ guerra. Para superar as dificuldades financeiras de algumas empresas, foi constituído, pelo ex-professor de negócios da Universidade Harvard, George Doriot, em parceria com empresários locais, um fundo de investimento de risco chamado American Research and Development. A ARD captava recursos privados e investia em empresas emergentes de tecnologia. Os investidores tinham cotas das participações da ARD, que por sua vez, aportava recursos nas empresas emergentes. Os investidores obtinham retorno conforme estas empresas apresentassem resultados positivos. A esse respeito ver GOMPERS, Paul \& LERNER, Josh. The Venture Capital Revolution. The Journal of Economic Perspectives, vol. 15, nº 2 (Spring), 2001, pp. 145-168.

${ }^{355}$ Cf. GOMPERS, Paul \& LERNER, Josh. The Venture Capital Revolution, op. cit.
} 
investidores anônimos carecem da expertise necessária para cumprir o seu papel de financiador universal da economia.

Ao longo das primeiras décadas deste setor, entre os anos 1950 e 1970, a forma jurídica prevalecente das organizações de venture capital foi a de fundo de investimento (closed-end fund). Neste formato, os investidores eram cotistas de um fundo de capital de risco, cujos gestores cuidavam das aplicações financeiras, realizadas na forma de participação societária, em empresas de base tecnológica. Conforme as empresas apresentassem resultados positivos, os aportadores eram remunerados pelos seus investimentos. Caso, no entanto, algum cotista pretendesse antecipar o seu retorno, a regulação desta atividade admitia a possibilidade de alienação de sua participação no fundo para qualquer outro interessado. ${ }^{356}$

A partir da década de 1980, entretanto, a estruturação jurídica das entidades de capital de risco deixou de ser feita por meio dos fundos e passou a ser realizada sob a forma de limited partnership. ${ }^{357}$ Trata-se de uma forma societária típica do direito societário norte-americano, que apresenta dois tipos de participantes: (i) o general partner, que, neste caso, é encarregado da captação dos recursos e da realização dos investimentos e está sujeito a todos os riscos do negócio; e (ii) o limited partner, o investidor individual, que não se envolve na gestão da sociedade e tem a sua responsabilidade limitada à integralização da sua parcela de representação. ${ }^{358}$ Em comparação com o fundo, a forma de limited partnership trazia algumas vantagens, tais como benefícios tributários e a limitação temporal de sua existência. Particularmente, a previsão do prazo de validade é uma garantia para os investidores: estabelece um horizonte temporal para os aportes financeiros,

\footnotetext{
${ }^{356}$ Cf. GOMPERS, Paul \& LERNER, Josh. The Venture Capital Revolution, op. cit.

357 Sobre a utilização da limited partnership como instrumento recorrente do venture capital, ver SAHLMAN, William A. The Structure and Governance of Venture-Capital Organizations, Journal of Financial Economics, n. 27, 1990, pp. 473-521. Ver também GOMPERS, Paul \& LERNER, Josh. The Venture Capital Revolution, op. cit.

358 Para uma descrição a respeito ver SAHLMAN. A seguinte passagem do autor apresenta uma boa descrição deste tipo societário: "limited partners cannot participate in the active management of a fund if their liability is to be limited to the amount of their commitment. General partners, in contrast, bear unlimited liability, so they can conceivably lose much more than they commit in capital." SAHLMAN, William A. The Structure and Governance of Venture-Capital Organizations, op. cit. p. 490. Ver também a descrição contida em CARVALHO, Antonio Gledson de; RIBEIRO, Leonardo de Lima \& FURTADO, Cláudio Vilar. A Indústria de Private Equity e Venture Capital - primeiro censo brasileiro, São Paulo, Saraiva, 2006, pp. 39-65.
} 
evitando assim a ocorrência de prejuízos desmesurados, causados por aportes sucessivos de recursos em empreendimentos mal sucedidos. ${ }^{359}$

Neste modelo de limited partnership, que tem sido desde então a forma jurídica prevalecente das organizações de capital de risco nos Estados Unidos, a sequiência das tarefas do venture capitalist - administrado pelo general partner - tem início com a captação de recursos entre os investidores - os limited partners, a fim de, com isso, formar um montante financeiro, a ser destinado a um conjunto de empresas (portfólio). Estas, por sua vez, são rigorosamente selecionadas pelo intermediário de risco, que se vale de seu conhecimento especializado tanto financeiro, como dos respectivos setores a que estas firmas pertencem. A responsabilidade do general partner tem início já neste processo de seleção das firmas, uma vez que, superada a obtenção do capital, a sua principal incumbência é a montagem de uma carteira de investimentos com qualidade e potencial de retorno.

No processo de escolha, o propósito do general partner é diferenciar os projetos arriscados e portadores de futuro, daqueles que não tendem a ter qualquer resultado promissor. O passo seguinte é aportar um montante de recursos em cada uma destas empresas, responsabilizando-se pelos resultados alcançados, perante os investidores. Neste ciclo, que tem uma duração média de 7 a 10 anos, a última de suas atribuições é a realização dos desinvestimentos, isto é, a alienação das participações societárias adquiridas, para assim prover um retorno líquido aos investidores. ${ }^{360} \mathrm{Bem}$ se vê, com isso, que o venture capitalist não é apenas um aplicador financeiro, mas sim um gestor ativo de recursos, com considerável conhecimento dos setores econômicos com os quais se envolve.

\footnotetext{
${ }^{359}$ Nos anos 1970 e 1980 este setor vivenciou algumas alterações institucionais relevantes. Além da adoção da limited partnership como forma jurídica, foi particularmente importante a alteração das regras de investimento dos fundos de previdência privada, ocorrida em 1979, que passou a admitir aplicações em veículos de venture capital.

${ }^{360}$ Para uma descrição do venture capital como ferramenta financeira, ver principalmente SAHLMAN, William A. The Structure and Governance of Venture-Capital Organizations, op. cit. Ver também KAPLAN, Steven \&STRÖMBERG, Per. Venture Capitalists as Principals: contracting, screening and monitoring, The American Economic Review, vol. 91, nº. 2, 2001, pp. 426-430; e WRIGHT, Mike \& ROBBIE, Ken. Venture Capital and Private Equity: a review and sinthesis, Journal of Business Finance \& Accounting, $\mathrm{n}^{\circ}$. 25, (june/july), 1998, pp. 521-570.
} 
Notadamente, no que tange à relação entre o venture capitalist e a empresa investida, trata-se, desde o seu início, de um ajuste distinto do que se verifica em uma operação tradicional de financiamento. A rigor, o venture capital não é uma operação do mercado de capitais, isto é, uma captação pública de recursos em bolsa, mas sim uma transação societária privada. Trata-se, portanto, de uma modalidade de private equity, em que o aporte de recursos ocorre por meio de uma subscrição particular dos valores mobiliários. Isso se deve ao fato de que estas empresas não apresentam rentabilidade presente e nem dispõem de indicadores objetivos, para balizar as chances de resultado futuro. Não detêm, portanto, atratividade para uma captação pública de recursos. As suas chances de capitalização dependem, isto sim, de um investidor especializado, um venture capitalist, capaz de reconhecer, por meio de parâmetros subjetivos, as suas potencialidades de retorno - suprindo, assim, os limites apresentados pelo processo de seleção do mercado.

Uma vez aportados os recursos iniciais, dado o contexto de incerteza e de assimetria das informações, a variável crítica deste tipo de investimento é a capacidade do intermediário em monitorar o desempenho das firmas investidas. É por esta razão que a subscrição privada dos valores mobiliários assenta-se tipicamente na aquisição de um bloco de participação. Desta maneira, o intermediário de risco pode exercer uma atuação bastante ativa na gestão da sociedade, valendo-se, para tanto, de alguns expedientes, tais como: (i) o acompanhamento informal da evolução dos resultados, em reuniões periódicas de aconselhamento dos empreendedores e (ii) a participação formal no conselho de administração da empresa, respaldada no direito múltiplo de voto. No desempenho deste monitoramento, o venture capitalist, lembra SAHLMAN ${ }^{361}$, costuma, inclusive, participar da definição das estratégias de negócio dos empreendedores, além de mediar as relações da firma com outros atores e parceiros de seu segmento econômico, com vistas, assim, a auxiliar na obtenção dos resultados positivos. Trata-se, pois, de um veículo de investimento marcado pela presença constante do provedor financeiro no cotidiano da empresa. É desta maneira que a entidade de risco procura dirimir os problemas de

\footnotetext{
${ }^{361}$ Sobre esse engajamento na firma, assinala SAHLMAN: "venture capitalists sit on board of director, help recruit and compensate key individuals, work with suppliers and customers, help establish tactics and strategy, play a major role in raising capital, and help structure transactions such as mergers and acquisitions. They often assume more direct control by changing management and are sometimes willing to take over day-to-day operations themselves". SAHLMAN, William A. The Structure and Governance of Venture-Capital Organizations, op. cit. p. 508.
} 
assimetria de informações e, ainda, promover melhorias de governança em empresas costumeiramente incipientes.

Uma segunda característica das participações de venture capital, tal como descreve a literatura norte-americana, é a liberação paulatina dos recursos, condicionada aos estágios de avanço do empreendimento. Como muitas vezes é impossível traçar antecipadamente um cronograma físico-financeiro de realizações, já que o tipo do projeto pode não comportar um planejamento prévio, a injeção dos recursos financeiros ocorre conforme o estado da arte da execução dos negócios. Com isso, cada aporte de recursos volta-se a permitir um progresso parcial no desenvolvimento do projeto: o montante liberado é limitado e suficiente apenas para permitir um quantum de realizações, até a próxima rodada de recursos. ${ }^{362}$ Do contrário, caso fosse despendido todo o volume financeiro de uma só vez, poderiam ocorrer dois tipos de problema: de um lado, os recursos poderiam ser liberados e os resultados, não alcançados; de outro, poderia haver um descasamento entre as necessidades de recursos e o ritmo das atividades de pesquisa e de desenvolvimento, comprometendo, assim, a obtenção dos novos produtos e processos. Para contornar ambos os problemas é que o modelo norte-americano de venture capital constitui uma gestão financeira flexível.

O efeito colateral positivo dessa liberação paulatina dos recursos é o reforço do poder de monitoramento do venture capitalist. Na medida em que o montante financeiro não é entregue em uma só rodada, o intermediário de risco mantém uma ascendência sobre o tomador. No limite, o titular do recurso tem sempre à sua disposição a opção de desistir do negócio, deixando de aportar montantes adicionais de capital. O risco desse acontecimento atribui ao investidor um poder de pressão sobre o tomador, o que se reflete em sua participação pronunciada nas definições empresariais. ${ }^{363}$ Isto só é possível, por sua vez, porque a forma jurídica desta relação é a de uma sociedade: os aportes de recursos não são previamente contratados e não geram ao intermediário de risco uma obrigação de pagamento continuado ao tomador.

Para além da seleção criteriosa, do monitoramento ativo e da liberação paulatina dos recursos, esta ferramenta jurídica também apresenta como traço característico a

\footnotetext{
${ }^{362}$ Ver SAHLMAN, William A. The Structure and Governance of Venture-Capital Organizations, op. cit. ${ }^{363}$ Ver SAHLMAN, William A. The Structure and Governance of Venture-Capital Organizations, op. cit.
} 
previsão de mecanismos de salvaguarda dos investimentos realizados (garantia da liquidez dos investimentos). Para assegurar os seus interesses financeiros (e dos investidores por ele representados), o venture capitalist conta com instrumentos diferenciados de governança, destinados a preservar, tanto quanto possível, o retorno de suas aplicações, ante um possível malogro do empreendimento. Dois exemplos destes instrumentos, usualmente consignados nos acordos de acionistas, conforme apontado por uma pesquisa empírica realizada entre atores deste segmento, são: a opção de venda (put) e o tag along $^{364}$.

A opção de venda (put) é um instrumento societário que garante ao venture capitalist a opção de vender a sua participação para o empreendedor, que, neste caso, é obrigado a comprá-la. Deste modo, a put acaba por cumprir dois papéis: em primeiro lugar assegura ao intermediário de risco a certeza de que a sua aplicação alcançará algum retorno; em segundo, serve como um instrumento de pressão, da mesma forma que a liberação paulatina de recursos, pois atribui ao venture capitalist um poder de negociação em relação ao empreendedor. ${ }^{365}$ Já o tag along integral, igualmente consignado no acordo de acionistas, garante ao venture capitalist o direito de vender as suas participações pelas mesmas condições obtidas pelos empreendedores. Na hipótese de um empreendedor resolver se desfazer de sua participação, alienando o seu bloco acionário para um terceiro, o capitalista de risco costuma prever o direito de fazer o mesmo. Sendo assim, um eventual comprador de uma empresa emergente só poderia adquirir as ações do empreendedor se também adquirir, pelos mesmos valores, as do venture capitalist. Desta maneira, o intermediário pode se precaver de negociações de mercado que, conquanto possam satisfazer o empreendedor, prejudiquem os seus interesses e dos limited partners, a quem o general partner deve prestar contas sobre o desempenho das aplicações.

Enfim, todos estes mecanismos jurídicos, como a participação societária em bloco e a participação ativa nas instâncias deliberativas da companhia, que compõem o elenco básico do venture capital, garantem condições de monitoramento e de execução financeira ajustados a situações em que prevalece a assimetria de informações e a alta

\footnotetext{
${ }^{364}$ Sobre a pesquisa empírica, ver SAHLMAN, William A. The Structure and Governance of VentureCapital Organizations, op. cit.

${ }^{365}$ Existem dois tipos básicos de opção: (i) a opção de venda, conhecida pelos operadores e advogados de mercado de capitais como put e (ii) a opção de compra, também chamada de call. Neste segundo caso, tratase do inverso: o titular da call tem o direito de chamar a compra de uma participação. Sobre a utilização da put no venture capital, ver SAHLMAN, William A. The Structure and Governance of Venture-Capital Organizations, op. cit.
} 
incidência de ativos intangíveis, fatores que dificultam as transações financeiras na ausência de um intermediário especialista ${ }^{366}$. Não por acaso, Steven APPEL ${ }^{367}$, no capítulo sobre pequenas empresas do Handbook of Corporate Financing, indica justamente que é esta a ferramenta adequada para o financiamento das fases iniciais de uma empresa (seed capital e start up), sobretudo quando envolvida em atividades corporativas de pesquisa e desenvolvimento (P\&D). Algumas dessas caracterísitcas são sumarizadas no quadro abaixo, que apresenta os principais atributos do venture capital, evidenciando as suas diferenças em relação ao financiamento corporativo tradicional.

\begin{tabular}{|c|c|c|}
\hline \multicolumn{3}{|c|}{$\begin{array}{c}\text { QUADRO } 12 \\
\text { FINANCIAMIENTO TRADICIO }\end{array}$} \\
\hline Atributo & $\begin{array}{l}\text { Financiamento corporativo } \\
\text { tradicional }\end{array}$ & Venture Capital \\
\hline $\begin{array}{l}\text { Capacidade de comercialização } \\
\text { das participações em mercado }\end{array}$ & $\begin{array}{c}\text { Alta } \\
\text { (participações têm alta liquidez) }\end{array}$ & $\begin{array}{c}\text { Baixa } \\
\text { (participações têm baixa liquidez) }\end{array}$ \\
\hline $\begin{array}{l}\text { Monitoramento exercido sobre } \\
\text { os administradores }\end{array}$ & Passivo (indireto) & Ativo (direto) \\
\hline $\begin{array}{l}\text { Papel do mercado no controle } \\
\text { do desempenho corporativo }\end{array}$ & $\begin{array}{l}\text { Alto (ofertas de aquisição de } \\
\text { controle) }\end{array}$ & $\begin{array}{l}\text { Baixo (pouco interesse do } \\
\text { mercado) }\end{array}$ \\
\hline Acesso a recursos & $\begin{array}{c}\text { Captação pública } \\
\text { (mercado de capitais) }\end{array}$ & $\begin{array}{l}\text { Investidores especializados } \\
\text { (subscrição privada) }\end{array}$ \\
\hline Especificidade dos ativos & Baixa & Alta (ativos intangíveis) \\
\hline Liberação dos recursos & Única & Paulatina \\
\hline $\begin{array}{l}\text { Disponibilidade de informações } \\
\text { sobre o projeto corporativo }\end{array}$ & $\begin{array}{l}\text { Informação pública dos } \\
\text { balanços e lucratividade }\end{array}$ & $\begin{array}{c}\text { Inexistência de parâmetros } \\
\text { públicos e objetivos - dependência } \\
\text { de avaliação interna }\end{array}$ \\
\hline
\end{tabular}

\footnotetext{
${ }^{366}$ Sintetizando este argumento, a seguinte passagem de ALLEN \& GALE reforça as virtudes de um desenho relacional nas operações com ativos intangíveis: "This control of the access to additional finance is not restricted to the termination or extension of credit conditional on the partnership's assessment of the issuing company's prospect. The general partners monitor the issuing company and furnish managerial assistance in order to add value to their investment. Their influence is amplified by their control of access to additional funding. Their general control of access to additional capital allows them to be much more flexible in aiding or restricting the flow of capital, something that would be difficult with an explicit contract. If more capital is needed to take advantage of unforeseen opportunities or to meet higher-than-anticipated expenses, the partnership can provide it or facilitate its provision by a third party. Similarly, if less is needed, they can scale back their planned investments. The information they get by actively participating in the management of the investment and the flexibility that comes from renegotiating the amount of financing as they go along, together allow for a degree of 'completeness' in providing contingent finance that would be very difficult to achieve in an explicit contract and certainly would be difficult to arrange if the issuing company had to deal with a large number of less-well-informed direct investors. Here the advantages of a long-term relationship with an intermediary seem clear." ALLEN, Franklin \& GALE, Douglas. Comparing Financial Systems, op. cit. pp. 321-322.

367 APPEL, Steven. Small Business finance: sources of capital, em ALTMAN, E. I. Handbook of Corporate Finance, New York, Wiley, 1986.
} 
A adequação desta ferramenta a investimentos em empresas emergentes reside justamente em seus atributos relacionais de governança, que permitem uma substituição parcial do mercado de capitais, seja como instância de captação dos recursos, seja como ambiente de controle externo do desempenho das companhias. No lugar de ambos, atua o venture capitalist que, de um lado, capta recursos e aporta investimentos em transações inter-partes e, de outro, transfere os parâmetros externos de verificação de desempenho para uma gestão interna, sustentada no acompanhamento e no auxílio gerencial. Uma ferramenta, portanto, com traços típicos de uma economia coordenada, que como visto, contorna as relações de mercado com a constituição de laços privados duradouros. Mas, curiosamente, o venture capital não é originário e nem característico desta alternativa institucional e muito embora a sua governança societária tenha atributos relacionais, a pujança deste tipo de investimento tem sido própria do contexto norte-americano. Como entender essa aparente contradição?

$\mathrm{Na}$ realidade, os atributos relacionais do venture capital garantem, de fato, a suplência das falhas do mercado nas fases de captação e de aplicação dos recursos. Em ambas, o enlace privado permite a viabilização de negócios que não tenderiam a ocorrer em um contexto de pulverização e atomização dos investidores. No entanto, no ambiente norte-americano, tais elementos são paradoxalmente articulados com o sucesso do mercado de capitais. Na realidade, nesse ambiente institucional, o mercado de capitais completa as virtudes da governança relacional, aparecendo como um elemento chave na terceira fase do ciclo de investimento de risco: a alienação das posições. Como já foi mencionado, superadas as etapas de captação e de aplicação dos recursos, o intermediário de risco tem de se desfazer de suas participações, para assim gerar resultados financeiros. É neste momento que, para Bernard BLACK e Ronald GILSON ${ }^{368}$, a existência do mercado de capitais importa: as operações de desinvestimento ocorrem com maior êxito por meio da abertura do capital das empresas na bolsa (initial public offering - IPO).

Para se entender este argumento, é relevante ter em conta que, ao lado do monitoramento ativo e da liberação paulatina do recursos, uma outra característica típica destes investimentos é a sua limitação temporal. O venture capital notabiliza-se por uma participação societária finita. A proposta subjacente a este veículo financeiro é a de aportar

${ }^{368}$ BLACK, Bernard \& GILSON, Ronald. Venture Capital and the Structure of Capital Markets - banks versus stock markets, Journal of Financial Economics v. 47, 1998, pp. 243-277. 
recursos, por meio de uma subscrição de valores mobiliários, limitando no tempo a duração desta sociedade. Trata-se, portanto, de mais uma diferença em relação a um empreendimento convencional, em que as partes afinam os seus interesses, comprometem os recursos e têm um horizonte de atuação conjunta não previamente circunscrito. Não é isso que se passa no venture capital: a sociedade formada tem data para começar e uma estimativa de tempo para perdurar. Findo este período, compete ao venture capitalist prover o desinvestimento, por meio da alienação de suas participações societárias. Pode-se com isso entender que, tão relevante quanto os mecanismos de governança, dirigidos a apaziguar a assimetria de informações, são as opções de saída, que garantem a remuneração dos investidores e do próprio general partner.

A literatura especializada identifica algumas possibilidades de saída destes investimentos, para além da abertura de capital na bolsa. ${ }^{369}$ Uma alternativa de desinvestimento é a chamada venda estratégica, na qual as participações do intermediário são adquiridas por um outro investidor, via de regra, uma empresa já estabelecida no segmento em questão e que se volta a adquirir uma participação em um eventual concorrente futuro. Uma segunda possibilidade é a recompra das participações do capitalista de risco pelos próprios sócios originais da empresa investida. Em alguns casos, esta operação de resgate dos valores mobiliários pelos empreendedores conta com o exercício de uma opção de venda (put) do venture capitalist, que coloca as suas participações para serem adquiridas pelos administradores e controladores da empresa investida.

No entanto, o ponto sustentado por BLACK \& GILSON ${ }^{370}$ e também por outros autores como CARNEY \& GEDAJLOVIC ${ }^{371}$, é que em comparação com estas outras alternativas de saída, a abertura do capital em bolsa é a opção mais vantajosa. Em primeiro lugar, quando o desinvestimento é feito pela alienação das participações em bolsa, o retorno obtido pelo venture capitalist tende a ser maior. ${ }^{372}$ Além disso, a alienação na bolsa acarreta ganhos indiretos, tanto na relação estabelecida entre os investidores e o

${ }^{369}$ Ver por todos, BLACK, Bernard \& GILSON, Ronald. Venture Capital and the Structure of Capital Markets, op. cit.

${ }^{370}$ BLACK, Bernard \& GILSON, Ronald. Venture Capital and the Structure of Capital Markets, op. cit.

371 CARNEY, Michael \& GEDAJLOVIC, Eric. East Asian Financial Systems and the Transition from Investment-Driven to Innovation-Driven Economic Development, op. cit.

${ }^{372}$ Cf. BLACK, Bernard \& GILSON, Ronald. Venture Capital and the ...,op. cit. 
intermediário, como nos ajustes entre este último e as empresas investidas. Tais benefícios têm sido relevantes, argumentam os autores, para a consolidação deste veículo financeiro.

No primeiro caso, isto é, na relação entre os investidores (limited partners) e o gestor do investimento (general partner), o fato de se tratar de uma transação de mercado garante publicidade e possibilidade de comparação: após o IPO, os investidores podem avaliar, a partir do volume financeiro alcançado, o desempenho de seu respectivo gestor. Como, por sua vez, os gestores dependem de uma captação constante de recursos, para apostas em novos empreendimentos, sabem que a sustentabilidade de seus negócios depende dos resultados colhidos nas operações de abertura de capital. Os bons aplicadores tendem a captar recursos com mais facilidade, dada a reputação adquirida com as operações pretéritas no mercado. Reside nisso, portanto, um conveniente incentivo para comportamentos diligentes destes gestores, sobretudo, nas fases anteriores do investimento, pois boa parte do sucesso na saída depende da qualidade das empresas selecionadas e do cuidado no monitoramento subseqüente. ${ }^{373}$

Algo semelhante se passa na relação entre o gestor e a empresa investida: o IPO encerra incentivos de comportamento para os empreendedores, em relação aos capitalistas de risco. A razão disso é a possibilidade oferecida por esta modalidade de desinvestimento para que os sócios originais recuperem o controle integral de seu próprio negócio. Isso porque, quando esta operação é bem sucedida, o investidor relacional aliena as suas participações para acionistas pulverizados, o que reconduz os sócios originais à condição de plenos administradores de sua companhia. Mas, para que a saída do venture capitalist efetivamente ocorra por meio de um IPO, a empresa investida deve apresentar boas condições de negociação, isto é, precisa estar madura. Sendo assim, há um estímulo permanente para que os empreendedores sejam bons administradores, para assim obter um bom desempenho e provocar uma saída do venture capitalist via mercado. ${ }^{374}$

São, pois, estes ganhos diretos e indiretos representados pelo desinvestimento em bolsa, que explicam, para BLACK \& GILSON ${ }^{375}$, a superioridade norte-americana nos investimentos em venture capital. A estrutura de incentivos e as possibilidades superiores

\footnotetext{
${ }^{373}$ Cf. BLACK, Bernard \& GILSON, Ronald. Venture Capital and ..., op. cit.

${ }^{374}$ Cf. BLACK, Bernard \& GILSON, Ronald. Venture Capital and ..., op. cit

${ }^{375}$ BLACK, Bernard \& GILSON, Ronald. Venture Capital and ..., op. cit.
} 
de retorno, permitidas pelas transações em bolsa, são vantagens comparativas deste arranjo institucional. Eis, portanto, o venture capital. Uma ferramenta jurídica originária do contexto norte-americano, estruturada na forma de limited partnership, que conjuga dois atributos distintos: uma governança relacional e um arranjo de mercado. Foi esse o veículo que amalgamou os interesses financeiros com as criações de empresas emergentes, normalmente situadas em dois parques tecnológicos: o Vale do Silício e a região de Massachusetts. Em alguma medida, boa parte dos resultados positivos dessa nova economia, nos Estados Unidos, esteve assentada nesse aparato jurídico-institucional.

\section{CONSIDERAÇÕES FINAIS}

Apresentadas as particularidades associadas ao financiamento das inovações e das empresas emergentes, que, em regra, são os atores chave de uma economia baseada no conhecimento, este capítulo procurou assinalar as respostas oferecidas pelo direito para este tipo de financiamento corporativo. Notadamente, a seção conjugou dois planos de análise, sendo um deles referente ao âmbito das ferramentas jurídicas e o outro relacionado ao arranjo jurídico-institucional, característico do ambiente financeiro norte-americano.

Com relação ao primeiro destes planos, a abordagem tratou das ferramentas contratuais e societárias que importam para os investimentos em inovação. Em virtude das contingências e das incertezas dos empreendimentos, as ferramentas mais apropriadas são aquelas que asseguram às partes um compartilhamento dos riscos e benefícios e, ainda, garantem um monitoramento ativo do desempenho do agente inovador. É por esta razão que os títulos de dívida com renda variável, os contratos dotados de uma racionalidade relacional e, em especial, a participação societária, notadamente, quando assentada em um bloco acionário, foram consideradas as ferramentas de uso mais provável neste tipo de transação.

Já com relação ao ambiente institucional, os estudos têm indicado a relevância do mercado de capitais para a constituição deste segmento econômico, nos Estados Unidos. Como a capacidade de saída dos negócios é um dos quesitos mais relevantes para o êxito deste tipo de investimento, a existência de um mercado que favoreça as operações de desinvestimento tem aparecido como uma significativa variável jurídico-institucional: 
garante uma rota de saída permanente para aqueles que desejarem se desfazer de suas participações societárias (desinvestimentos).

No entanto, embora se reconheça que o mercado de capitais tenha importância para o bom funcionamento dos investimentos de risco, tem-se igualmente em conta que existe uma variedade de alternativas institucionais de organização do ambiente econômico. A despeito das virtudes do mercado de capitais, a premissa deste trabalho é a de que cada regime econômico, porque vinculado a uma dada trajetória jurídico-institucional, apresenta particulares conformações para o funcionamento de seus sistemas financeiros. Como já se procurou argumentar, a prevalência do mercado de capitais no panorama norte-americano não se deve ao acaso. A sua forma de organização é tributária de uma história específica, da qual foram protagonistas o limite imposto ao papel dos bancos e o favorecimento à emissão de títulos acionários. Em outros termos, a plena vigência do mercado de capitais, assentada em investidores anônimos e pulverizados, depende de um arranjo jurídicoinstitucional que é próprio de determinados contextos e sua replicação, nesses mesmos termos, não é nem viável e nem possível.

Diante disso, recoloca-se uma questão subjacente a esta pesquisa: como e por meio de quais instrumentos jurídicos, os sistemas financeiros que não são originariamente baseados no mercado de capitais procuram se inserir em uma economia baseada no conhecimento? A proposta do próximo capítulo é justamente apresentar um estudo de caso que oferece uma resposta a esta questão: a atuação do BNDES no financiamento das empresas emergentes. 


\title{
$-5-$ \\ O BANCO DE DESENVOL VIMENTO DIANTE DE UMA \\ ECONOMIA BASEADA NO CONHECIMENTO: \\ ESTUDO DE CASO SOBRE AS INOVAÇÕES NAS FERRAMENTAS JURÍDICAS DO BNDES E O FINANCIAMENTO DAS EMPRESAS INOVADORAS
}

\begin{abstract}
"To sum up, venture capital, IPOs and the stock market are not the only way of promoting ICT development. Venture capital is perfectly compatible with bank based systems and, indeed, in the developing country context, the government itself may well be the best venture capitalist."

(Ajit Singh, Alaska Singh \&Bruce Weisse, Information technology, venture capital and the stock market)
\end{abstract}

\section{INTRODUÇÃO}

No caso brasileiro, em que o financiamento do desenvolvimento tem se baseado majoritariamente na ação direta do Estado no direcionamento do crédito, a provisão de recursos para a nova economia também tem passado, em boa medida, pelas agências estatais, em especial pelo BNDES. Para responder às particularidades de uma economia baseada no conhecimento, o Banco tem desenvolvido um novo conjunto de mecanismos societários e contratuais, aptos a lidar com ativos intangíveis, empresas emergentes e projetos eivados de incerteza.

No desempenho desta atribuição, podem ser reconhecidos dois caminhos convergentes, sendo o primeiro deles assentado em uma intervenção direta e o outro em uma atuação indireta. No primeiro caso, o BNDES tem procurado agir de modo supletivo, mitigando a carência do investidor privado. Nesse formato, o Banco mimetiza o comportamento de um intermediário de risco e atua como se fosse um venture capitalist, provendo recursos para empresas emergentes e projetos de inovação. Além desta intervenção direta, o capítulo buscará indicar que o BNDES também tem atuado de um modo indireto, para induzir a organização de um verdadeiro mercado de capital de risco no país. Nesta tarefa, além de constituir parcerias com outros investidores privados, formando, assim, boa parte dos fundos de investimento existentes neste segmento, o Banco também tem tido um papel relevante como um organizador institucional do setor. Antecipando-se ao comportamento do agentes privados e agindo como um autêntico experimentador institucional, o BNDES tem introduzido inovações jurídicas, que depois acabam por se irradiar para os demais atores do mercado de capitais. 
Ambas as formas de intervenção não revelam apenas o desenho criativo de ferramentas jurídicas, apropriadas ao financiamento das inovações, indicam algo mais: uma racionalidade diferenciada de atuação do BNDES e, por conseguinte, do Estado. No desempenho de sua função desenvolvimentista, em um contexto pós-fordista, o Banco tem combinado o propósito de impulsionar os setores baseados em conhecimento, com instrumentos típicos dos agentes do mercado financeiro. Como se procurará narrar neste e no próximo capítulo, o BNDES parece, assim, reeditar, em novas bases, uma característica das empresas estatais, classicamente apresentada pelos estudos da ciência política brasileira: a sua face bifronte. Análises como a de Sulamis $\operatorname{DAIN}^{376}$ ou a de Carmen ALVEAL $^{377}$ já argumentaram que as empresas estatais costumam assumir uma dupla racionalidade, pois tem de, a um só tempo, comportar-se como empresa, para cumprir as suas metas setoriais, e também como agente de políticas públicas, para dar consecução aos planos e políticas industriais do governo. No caso do BNDES, a sua atuação na nova economia parece recombinar estes campos, em um novo contexto marcado por uma economia privatizada e internacionalizada: o Banco apóia setores emergentes e induz o segmento de risco, em um comportamento sugestivo de um agente público de desenvolvimento, mas o faz valendo-se de ferramentas forjadas no mercado de capitais e reconhecidas pelos operadores privados como sendo os mecanismos adequados para este tipo de investimento.

Para descrever estas funções exercidas pelo Banco, este capítulo está dividido em outras quatro seções: (i) a primeira dedica-se a descrever as tais novas ferramentas de intervenção, narrando assim as funções do BNDES como venture capitalist e como indutor do mercado de risco; (ii) a segunda, situa esta atuação nos anos mais recentes, em que o Brasil voltou a adotar políticas industriais; por fim, (iii) na terceira parte, são apresentados dois exemplos de casos, que ilustram estas duas formas de intervenção do BNDES (a direta e a indireta). A última seção traz as considerações finais do capítulo.

\footnotetext{
376 Para Sulamis DAIN há uma dupla atribuição a esses agentes, uma "dicotomia entre a empresa estatal como unidade produtiva e eventual subsistema de poder e como instrumento da política econômica." DAIN, Sulamis. Empresa Estatal e Política Econômica no Brasil, em MARTINS, Carlos Estevam (org.). Estado e Capitalismo no Brasil, São Paulo, Hucitec - CEBRAP, 1977, p. 142.

${ }^{377}$ Comentando o duplo papel do setor produtivo estatal, assinala ALVEAL: "no caso específico dos atores do SPE, a lógica do Jano bifronte condiciona-os, funcionalmente, a acionar a sua face estatal - orientada para a realização de objetivos políticos e de ordem macroeconômica - e sua face empresarial - orientada para a realização de objetivos de natureza estritamente microeconômica." ALVEAL, Carmen. Os Desbravadores - A Petrobrás e a Construção do Brasil Industrial, op. cit. p. 43.
} 


\section{AS FERRAMENTAS JURÍDICAS DO BNDES E O FINANCIAMENTO DAS INOVAÇÕES E DAS EMPRESAS EMERGENTES}

O BNDES tem dado passos na configuração de um novo estoque de ferramentas jurídicas, apto a garantir mecanismos apropriados de investimentos em projetos de inovação e empresas emergentes. Ao menos no que tange a estes segmentos econômicos, têm-se aprimorado tanto o padrão de contratação das operações de crédito, nas chamadas operações de renda fixa, como as regras de participação societária, nas operações de renda variável. As regras contratuais, por exemplo, têm caminhado para uma vertente de parceria, indicando uma lógica relacional de contratação e, portanto, abdicado do imperativo de presentificação, que classicamente identifica o contrato sinalagmático. Da mesma forma, as participações societárias do Banco têm combinado instrumentos típicos do venture capital, como um monitoramento ativo e a estipulação de alternativas de saída da empresa investida, com as necessárias adaptações ao ambiente brasileiro, que padece da falta de um mercado de capitais denso, capaz de garantir rotas facilitadas de desinvestimento. Assim, seja nas operações de crédito, seja nas operações societárias, o fato é que o BNDES tem procurado novos parâmetros jurídicos para fomentar os empreendimentos inovadores.

A razão pela qual o Banco vem procurando novas soluções para um trabalho que já faz há mais de meio século, isto é, o financiamento corporativo, deve-se ao fato de que os seus mecanismos regulares de colaboração financeira têm se mostrado inadequados para aplacar as vicissitudes dos investimentos em ativos imateriais, incertos e de longa duração. A rigor, não há nada de estranho neste desalinhamento. O Banco, como visto, foi projetado como um instrumento de financiamento de uma estratégia de desenvolvimento calcada em ativos físicos, que priorizou ora a construção da infra-estrutura básica do país, durante o Plano de Metas (1956-1961), ora a ampliação da capacidade produtiva da indústria nacional, sobretudo, durante o II Plano Nacional de Desenvolvimento (1974-1979). ${ }^{378}$

\footnotetext{
${ }^{378}$ Muito embora os contratos possam contar com uma grande variedade de cláusulas e de instrumentos de proteção dos direitos do Banco como credor, uma operação de crédito típica, como a que se está descrevendo, é regulada pela Resolução BNDES 665/87 - Disposições Aplicáveis aos Contratos, em que constam as condições jurídicas que presidem o desenho das operações contratuais. Notadamente, quanto ao tema do risco (presente na quarta situação acima descrita) e da correspondente proteção ao BNDES, uma operação de crédito padrão, conta com dois instrumentos básicos: a estipulação de garantias reais e a disposição de sanções no caso de um eventual inadimplemento financeiro. É a partir destes mecanismos, portanto, que se vai procurar presentificar os riscos futuros do negócio jurídico, assegurando o Banco contra a possibilidade de um projeto meritório resultar em prejuízo financeiro. No que tange às garantias, o art. 27 da Resolução
} 
Como visto no capítulo 2, as operações de colaboração financeira do BNDES podem ser formalizadas em dois tipos de veículos: as operações de renda fixa e as participações societárias $^{379}$, com renda variável. A primeira modalidade consiste em um contrato de crédito ou em uma aquisição de debênture - em qualquer dos casos o Banco desembolsa uma quantidade pré-determinada de recursos e o solicitante obriga-se a pagar o financiamento, acrescido dos juros, e a realizar o correspondente projeto. Neste tipo de colaboração financeira, não há um maior envolvimento do Banco com a gestão empresarial do beneficiário, as partes figuram como agentes independentes. Já as operações de renda variável são operacionalizadas com a subscrição de valores mobiliários emitidos pelas empresas solicitantes de recursos - um mecanismo de colaboração financeira utilizado desde o II PND, quando foram instituídas as empresas de participação EMBRAMEC, IBRASA e FIBASE, posteriormente reorganizadas no âmbito da BNDESpar. A decisão de qual modalidade de financiamento será empregada compete às áreas operacionais do Banco, durante o processo de análise e estruturação da operação, quando se procurará compatibilizar o risco, o retorno e a relevância do projeto.

No tipo padrão de contrato de colaboração financeira, em operações de renda fixa, cuja disciplina é dada pela Resolução BNDES 665/87 - que estabelece as condições gerais de contratação do Banco - as regras do ajuste firmam um cronograma físicofinanceiro de realizações e de pagamentos, a serem atendidos pelos contratantes. Os beneficiários do crédito são obrigados, portanto, a respeitar o cronograma de pagamentos e os prazos de realização do projeto financiado pelo Banco. Ambas as obrigações são disciplinadas separadamente, de modo que o pagamento dos recursos obtidos não exime o tomador de realizar o correspondente projeto. ${ }^{380}$ Para garantir o atendimento das obrigações de fazer, são estipuladas sanções no caso de não atendimento dos prazos de

665/87, disciplina que o BNDES deve exigir nas suas operações de crédito o depósito de garantias reais (hipotecas, penhor, entre outros), num valor que seja no mínimo $30 \%$ superior ao montante do crédito contratado. A razão para tanto é fornecer ao credor um direito oponível contra todos, que desde o primeiro momento da contratação assegure o Banco de um eventual não pagamento do crédito devido. Diz o texto da Resolução: "Resolução 665/87. Art. 27 - O valor da garantia real deve corresponder, no mínimo, a 130\% (cento e trinta por cento) do valor da dívida, exceto se regulamento específico estabelecer índice diverso para as operações por ele regidas." BNDES, Resolução 665/87 - Disposições Aplicáveis aos Contratos, 1987. Ainda nos termos art. $6^{\circ}$, inciso II desta Resolução, a concessão de garantia julgada suficiente pelo BNDES é uma condição suspensiva do contrato, isto é, até a sua perfeita prestação a colaboração financeira não é implementada.

${ }^{379}$ Ver a esse respeito BNDES, Resolução 665/87 - Disposições Aplicáveis aos Contratos, 1987.

${ }^{380}$ De acordo com o parágrafo primeiro do art. 12 da Resolução 665/87: "o pagamento da divida nao extingue a obrigação de realizar o projeto relativo à colaboração financeira concedida pelo BNDES, no prazo que este estabelecer." BNDES, Resolução 665/87 - Disposições Aplicáveis aos Contratos, op. cit. 
realização do empreendimento. Nesta circunstância, pode ocorrer a incidência de multas e a sustação imediata de todos os desembolsos. Já no que toca aos compromissos de pagamento dos recursos concedidos, é articulado um conjunto de sanções que incide nos caso de descumprimento dos compromissos contratuais. Na hipótese de inadimplência financeira, a Resolução 665/87 admite, por exemplo, a possibilidade de que seja decretado o vencimento antecipado de toda a dívida contraída, isso cumulado com a aplicação de multas pelo atraso no pagamento das prestações devidas e com o pagamento de juros anuais moratórios, sobre as parcelas vencidas (artigos 41 a 46 da Resolução 665/87). Notase, portanto, que este tipo padrão de contratação apresenta um caráter de contrato presentificador, disposto a regular no presente todas as intercorrências futuras, estabelecendo obrigações e as respectivas penalidades, nos casos de inadimplemento.

Há operações, no entanto, que apresentam menor capacidade de previsão quanto ao volume e ao prazo do retorno e, por esta razão, durante a fase de enquadramento, a celebração de termos contratuais rígidos e presentificadores mostra-se inapropriada. Para estas situações, assim como para os negócios que não contam com uma rentabilidade presente, capaz de assegurar um atendimento seguro do cronograma de pagamentos, a estruturação da operação pode ocorrer mediante participação societária do BNDES. Nestes casos, o Banco subscreve valores mobiliários e compartilha os riscos do empreendimento com a empresa investida. Com isso, provê recursos para projetos com possbilidades de êxito, sem ficar adstrito aos limites das ferramentas de renda fixa, mitigando ainda chances de insucesso, por meio de um maior acompanhamento da vida societária da empresa tomadora. O meio de formalização da participação societária, por excelência, é a subscrição de ações emitidas pela empresa. Uma outra possibilidade é a emissão de debêntures conversíveis em ações ou ainda de debêntures conjugadas com bônus de subscrição, que embora sejam instrumentos de renda fixa, porquanto fixam os montantes devidos desde a emissão do título, podem ser convertidos em instrumentos de renda variável.

A subscrição de valores mobiliários, com exceção das debêntures simples, não assegura ao BNDES uma renda fixa, na forma de pagamentos previamente estipulados quando da assinatura do contrato ou da aquisição do título. Particularmente, quando envolve a emissão de ações, a operação também não apresenta as garantias exigidas nas colaborações financeiras de crédito. Nestes casos, os interesses do Banco são garantidos 
pelos mecanismos societários, como, por exemplo, a celebração de um acordo de acionistas, entre os representantes do Banco e os controladores da empresa beneficiária. No limite, no caso de insucesso empresarial, o Banco contará com os instrumentos dispostos pelo procedimento falimentar. Em compensação, no caso de êxito do empreendimento, o retorno a ser percebido pelo BNDES, na forma de dividendos, pode superar o patamar de pagamentos de uma operação de crédito - daí porque se trata de uma operação de renda variável.

Ocorre, contudo, que ambas estas formas de estruturação das colaborações financeiras apresentam limitações para amparar as necessidades financeiras da nova economia. O desajuste entre estas ferramentas e as necessidades de uma economia baseada no conhecimento deve-se ao fato, já discutido no capítulo anterior, de que as características do financiamento de ativos intangíveis e empresas emergentes diferem sensivelmente das qualidades verificadas nos investimentos físicos. Como mencionado, os investimentos em ativos físicos apresentam uma maior calculabilidade do retorno econômico a ser esperado pelo empreendimento. Além disso, o financiamento de aportes em ativos tangíveis, como a aquisição de máquinas e equipamentos, pode ser mais facilmente garantido, já que o próprio objeto da operação financeira pode ser dado em garantia, assegurando assim o seu próprio financiamento. Os investimentos em ativos intangíveis, no entanto, apresentam um maior grau de incerteza quanto ao seu sucesso e não podem constituir garantias com o próprio objeto do financiamento. ${ }^{381}$ Nesse terreno, a situação das pequenas e médias empresas de base tecnológica é ainda mais complicada, na medida em que, muitas vezes, padecem de um déficit de governança interna e carecem até mesmo de rentabilidade suficiente para acautelarem o crédito demandado. ${ }^{382}$

\footnotetext{
${ }^{381}$ Um exemplo do desconforto com as condições tradicionais de contratação do crédito, para investimentos em inovação, pode ser vista nas declarações dos empreendedores desse setor. Durante o IV ENITEC (Encontro Nacional da Inovação Tecnológica), Roberto Nicolsky, diretor da PROTEC (Sociedade PróInovação Tecnológica, entidade de classe do setor) classificou como erro técnico as tentativas do BNDES de estabelecer linhas de financiamento (operações de crédito) para a inovação. No seu entendimento, o alto risco destes investimentos faz com que as empresas evitem assumir obrigações financeiras rígidas. Para Nicolsky, os empréstimos são um veículo adequado quando o ente tomador realiza projetos que apresentam certeza de retorno, o que permite a assunção de um compromisso financeiro. Na cobertura jornalística que o jornal Valor Econômico fez sobre a IV ENITEC, Nicolsky assim resumiu a sua posição: "no mundo todo, não se financia projetos de pesquisa e desenvolvimento, se subvenciona, porque esse tipo de investimento é de alto risco", em Valor Econômico, Linha para inovação emperra e BNDES baixa juro para 4,5 \% ao ano, na edição de 15,16 e 17 de junho de 2007.

382 Cf. PINTO, Luciane Gorgulho. Capital de Risco: uma alternativa de financiamento às pequenas e médias empresas de base tecnológica - o caso do CONTEC, revista do BNDES, Rio de Janeiro, nº. 7, jun, 1997, pp.
} 
Concretamente, no caso das operações de crédito, o problema reside no fato de que as empresas emergentes ainda não contam com um patrimônio físico e detêm, portanto, pouca capacidade de cumprir com as exigências relativas à prestação de garantias. Além disso, como, via de regra, a sua necessidade de investimento é superior ao fluxo de caixa gerado, o comprometimento de parte de sua rentabilidade com a obrigação de pagamentos de juros, fixados desde a celebração do financiamento, pode ser economicamente inviável $^{383}$. Já a forma padrão de participação societária, embora possa resolver os problemas dos atributos presentificadores e da prestação de garantia, típicos da renda fixa, não se mostra igualmente apropriada para operações com empresas emergentes. Isso se deve ao fato de que o tipo de participações societárias desenvolvido pelo Banco foi construído para garantir alavancagem financeira de setores tradicionais, em que a rota de expansão econômica é, de certa forma, previsível. Em outros termos, a motivação da intermediação do BNDES, via participação, esteve, em regra, vinculada à provisão de um elevado montante de recursos, para projetos de longa duração e de grande porte, em setores como: química, papel e celulose, metalurgia, siderurgia, fertilizantes, máquinas e equipamentos: setores relativamente consolidados, cuja margem de contingência é menor do que a verificada em empresas emergentes, dedicadas a projetos de inovação. A seguinte passagem de Luciane Gorgulho PINTO, ao comentar o formato das participações societárias tradicionalmente desenvolvidas pelo BNDES, indica justamente que estas foram formuladas em um contexto de uma economia física e especializada em grandes investimentos, o que trazia dificuldades para a sua utilização em operações com pequenas empresas emergentes:

De forma geral, as operações da BNDESpar sempre estiveram relacionadas, de forma primordial, às grandes empresas. Isto se deveu, em parte, às características dos setores apoiados pela política industrial do II PND e, em parte, à necessidade de encontrar liquidez para os seus investimentos, em um contexto de mercado de capitais concentrados. Embora tenham sido realizados alguns investimentos em pequenas e

1-41. A avaliação das dificuldades de contratação com empresas emergentes foi feita por Fábio Sotelino, Superintendente da Área de Capital Empreendedor do BNDES, em entrevista realizada no dia 17.07.2008.

${ }^{383}$ Ver a esse respeito o trabalho de Luciane Gorgulho PINTO: "os empréstimos feitos a novas empresas, quando ocorrem, geralmente têm taxas de juros elevadas e prazos curtos. As saídas de caixa destinadas ao pagamento de juros, resgates e amortizações são encargos onerosos para empresas jovens, que requerem substanciais influxos de capital durante os estágios iniciais de crescimento". Cf. PINTO, Luciane Gorgulho. Capital de Risco: uma alternativa de financiamento às pequenas e médias empresas de base tecnológica - o caso do CONTEC, op. cit. p. 2. 
médias empresas, até mesmo em estágio nascente, estes ocorreram sempre de forma tópica, sem nenhuma intenção mais estruturada ${ }^{384}$.

O problema deste tipo de intervenção societária, desenhada para operações com grandes empresas, especializadas em uma economia tangível, é a carência de ao menos dois mecanismos relevantes para preservação dos interesses do investidor, quando utilizada para operações com empresas inovadoras: (i) um monitoramento ativo, capaz de garantir um acompanhamento do negócio, que seja condizente com um perfil empresarial portador de incerteza e normalmente dotado de um déficit gerencial e de governança e (ii) um planejamento de saída dos negócios, em médio prazo, seja para evitar perdas diante de um projeto mal sucedido, seja para realização de lucros, nas empreitadas exitosas. Como o nível de contingência e de incerteza nos setores emergentes é maior, a manutenção prolongada da participação societária pode ser inconveniente. Além disso, há que se considerar que as empresas emergentes são agentes econômicos ainda incipientes e, geralmente, dedicadas a formar novos nichos de mercado, cuja evolução é, muitas vezes, imprevisível - o que amplifica os riscos do negócio.

Sendo assim, quando foi identificada pelo Banco uma nova demanda de recursos, proveniente de empresas que já sinalizavam os indícios de uma economia baseada no conhecimento, foi igualmente diagnosticada a necessidade de se confeccionar novas ferramentas jurídicas e um outro padrão de intervenção financeira, convergente com os atributos da nova economia. Para superar os embaraços jurídico-institucionais, é que o BNDES passou a estabelecer novos paradigmas contratuais e societários para estruturar as suas operações de colaboração financeira. Desde o final da década de 1980 e início da década de 1990, o Banco tem se embrenhado no desenho de instrumentos jurídicos que garantam o financiamento de atividades de risco. Em 1991, antes mesmo de qualquer regulação da CVM sobre o venture capital, o BNDES implementou um programa piloto denominado CONTEC - condomínio para a capitalização de empresas de risco, dedicado a experimentar novas fórmulas de contratação financeira, adequadas a estes novos segmentos econômicos - o Banco passou a atuar como se fosse um venture capitalist, dispondo de regras inovadoras de governança e de participação nas empresas investidas.

\footnotetext{
${ }^{384}$ PINTO, Luciane Gorgulho. Capital de Risco: uma alternativa de financiamento às pequenas e médias empresas de base tecnológica - o caso do CONTEC, op. cit. p. 23.
} 
Ao longo daquela década, o CONTEC evoluiu e deu origem a um segundo tipo de intervenção do Banco: a indireta. Com isso, além de participar do capital de empresas diretamente, o BNDES passou também a se associar a outros investidores privados, constituindo com estes fundos mistos de investimentos. Por meio dessa forma de intervenção, o Banco não só garantiu recursos para os investimentos em inovação, como também exerceu um papel pró-ativo na articulação do mercado de capitais de risco brasileiro. Como será detalhado a seguir, este consórcio público-privado tem sido relevante para estruturar o próprio segmento de venture capital no mercado financeiro, que conta com uma expressiva participação do agente estatal: ainda em 2008, dos 28 fundos mútuos de investimento dedicados a empresas emergentes registrados na CVM, 15 contavam com a participação do BNDES.

Alguns anos depois dessas primeiras iniciativas, em 2004, quando o Governo Federal apresentou uma nova agenda de política industrial, focada no fomento das inovações tecnológicas e na competitividade das indústrias, o Banco, que já detinha experiência com o capital de risco, passou a intensificar as suas atuações nesta área. $\mathrm{O}$ resultado foi um aumento do número de programas e a confecção de mais um novo conjunto de mecanismos de atuação: desta vez as inovações jurídicas foram introduzidas também na área de renda fixa, com a adoção de regras contratuais apropriadas aos financiamentos de ativos intangíveis.

É bem verdade que a participação quantitativa destes segmentos no conjunto das operações do Banco ainda é minoritária. As colaborações financeiras do BNDES continuam tendo nos setores ditos tradicionais os seus clientes preferenciais. Basta ver que em 2007, por exemplo, quando o Banco desembolsou cerca de R \$ 60 bilhões (sessenta bilhões de reais) em financiamentos e capitalizações, o orçamento planejado para o fomento das inovações alcançava um montante próximo de $\mathrm{R}$ \$ 1 bilhão (um bilhão de reais $)^{385}$. Em anos anteriores, pode-se constatar uma desproporção semelhante, ou até mais

\footnotetext{
${ }^{385}$ Em 11 de junho de 2007, o Jornal Valor Econômico publicou uma matéria que questionava a atuação do BNDES na implementação da nova política industrial, que como sabido prioriza os investimentos em inovação. O título da matéria foi: BNDES contraria política industrial e concentra apoio em setores tradicionais. De acordo com a reportagem, "a política industrial do atual governo, iniciada em março daquele ano, criou mecanismos de estímulo aos setores de software, máquinas e equipamentos, fármacos e semicondutores. Mas essa aposta não transparece nos números do banco. A expectativa dos analistas é a de que o novo presidente da instituição, Luciano Coutinho, leve adiante seu propósito de focar mais na política industrial." em Valor Econômico, 11 de junho, de 2007.
} 
aguda, indicando que a intervenção predominante do BNDES ainda gira em torno dos segmentos industriais e de infra-estrutura.

Entretanto, isso não significa que o BNDES vivencie uma inércia institucional. Como se procurará detalhar a seguir, se a participação financeira das inovações ainda é minoritária, há boas evidências para se argumentar que o Banco tem reagido aos desafios apresentados pela economia baseada no conhecimento. Uma análise cuidadosa aponta para a existência de modificações qualitativas, no âmbito de seus mecanismos de governança, e até mesmo impactos quantitativos, percebidos pelo aumento do montante de financiamentos direcionados para projetos de inovação. A evolução do volume de desembolsos sugere um expressivo incremento dos aportes para este segmento.

Evolução dos desembolsos do BNDES para inovações

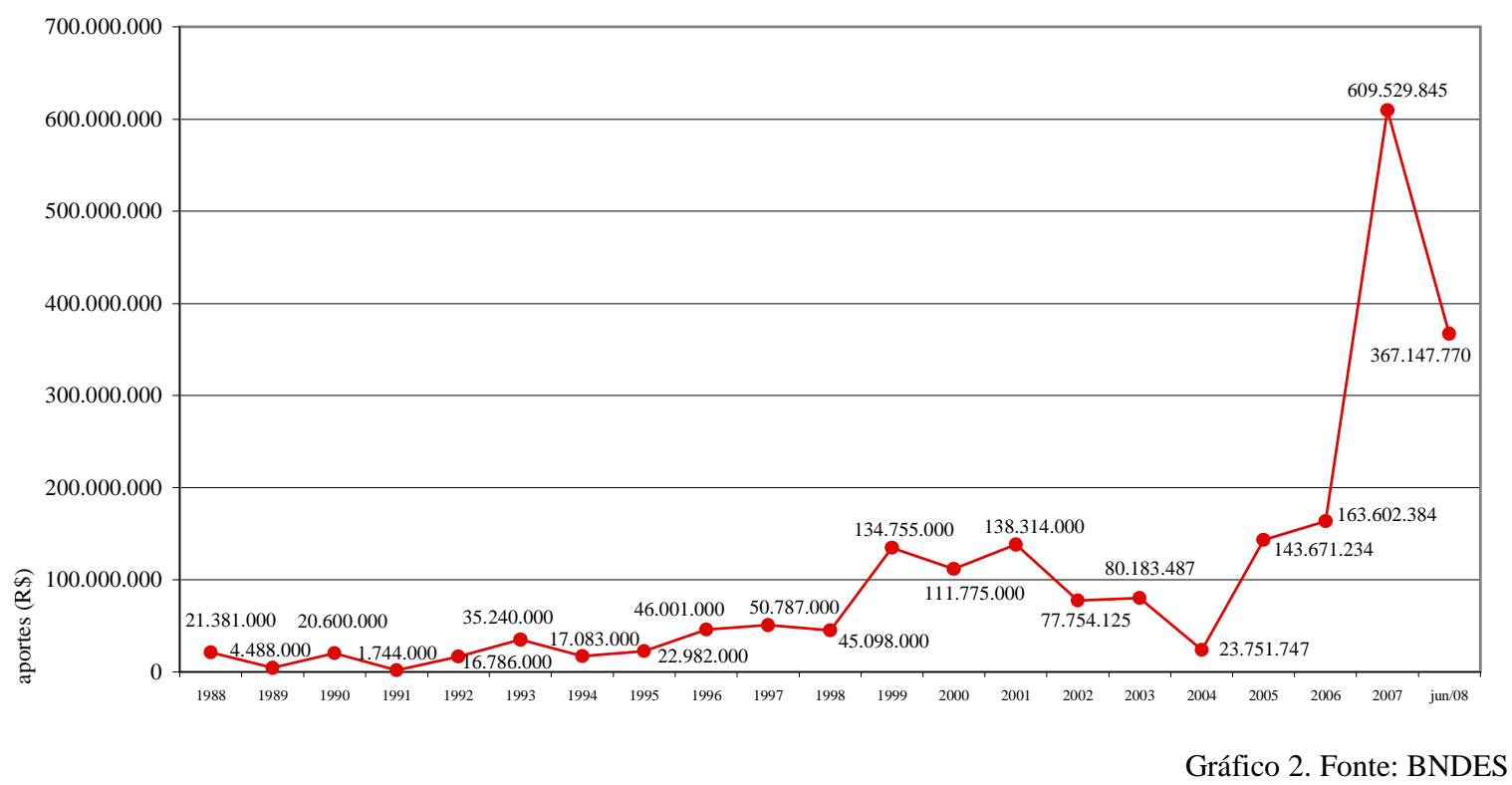

Um evento emblemático que sintetiza esta busca por mecanismos alternativos de financiamento, adequados aos ditames da nova economia, foi a mudança formal da política operacional do Banco, um instrumento que disciplina as modalidades de contratação e orienta a sua atuação na economia. Em 21.12.2005, a Diretoria do BNDES aprovou as suas Novas Políticas Operacionais, que, entre outras coisas, passaram a dispensar a exigência de garantias reais nas colaborações financeiras dedicadas a inovação, quando o valor do 
financiamento não supera $\mathrm{R} \$ 10$ milhões (dez milhões de reais) ${ }^{386}$. Também merece destaque a recriação recente (2004) de um fundo de tecnologia - o FUNTEC - lançado originariamente na década de 1970, para prover recursos a projetos tecnológicos, com um caráter não reembolsável.

Tais alterações qualitativas, que serão descritas em detalhe nas próximas seções, parecem estar associadas a resultados positivos, quanto à ampliação do volume de recursos e de operações destinadas a empresas emergentes e projetos de inovação. Em uma breve comparação pode se notar que entre 1991 e 1996, o CONTEC garantiu um montante aproximado de $\mathrm{R} \$ 38$ milhões (trinta e oito milhões de reais), para um total de 20 empresas atendidas $^{387}$. Nessa época inicial, foram também constituídos 5 fundos de investimentos, que contavam com a participação do BNDES, como um dos cotistas, ao lado de investidores privados. O programa de fundos contava com um orçamento de cerca de $\mathrm{R} \$$ 8,5 milhões (oito e meio milhões de reais). Dez anos mais tarde, em 2007, só no financiamento indireto (via fundos), o BNDES contabilizava uma participação em 15 fundos de investimento, voltados exclusivamente para empresas inovadoras (fundos de venture capital), isso de um total de 28 fundos em empresas emergentes, registrados na Comissão de Valores Mobiliários.

Este mesmo crescimento pode ser constatado para as operações diretas, tanto nas de renda variável (participação societária), como nas de renda fixa (contrato de financiamento). Em apenas 18 meses, entre 2007 e o primeiro semestre de 2008, foram realizadas 17 operações societárias com empresas emergentes, quase alcançando assim o volume de negócios realizados entre 1991 e 1996 pelo CONTEC (20 operações). As operações de crédito, que passaram a garantir financiamentos para inovação com mais ênfase a partir de 2005, com a mudança das regras de contratação do Banco, também apresentaram um resultado considerável em 2007: ao final deste ano, registrava-se um

\footnotetext{
${ }^{386}$ Ver a esse respeito as Novas Políticas Operacionais do BNDES, definidas em 21.12.2005. BNDES, Políticas Operacionais, 2005.

${ }^{387}$ Incluídas neste montante as participações diretas e as indiretas. Dados apresentados em PINTO, Luciane Gorgulho. Capital de Risco: uma alternativa de financiamento às pequenas e médias empresas de base tecnológica - o caso do CONTEC, op. cit.
} 
acumulado de 53 operações e um valor total empregado da ordem de $\mathrm{R} \$ 600$ milhões (seiscentos milhões de reais) em desembolsos financeiros. ${ }^{388}$

As próximas seções dedicam-se a descrever esta trajetória, tendo como foco de sua narrativa os dilemas e as correspondentes alternativas jurídicas construídas para garantir o financiamento da nova economia.

\subsection{O BNDES COMO UM VENTURE CAPITALIST}

A percepção do surgimento de novas demandas de financiamento, voltadas para ativos intangíveis e conhecimento, provocou uma reação do BNDES, já no início dos anos 1990. Na qualidade de principal agente financiador do desenvolvimento brasileiro, o Banco procurou manter a sintonia com estas novas tendências de vanguarda produtiva, com a intenção de não perder espaço naquilo que já se identificava como uma nova economia. Tal intervenção justificava-se pelas exíguas dimensões do mercado de capitais de risco existente no país, que, na entrada da década de 1990, não se mostrava efetivamente constituído: entre 1988 e 1993, o mercado de risco brasileiro contabilizava, em média, a abertura de 3 novos veículos de investimento e de 1 nova organização gestora de recursos por ano, enquanto que a economia americana registrava, em 1988, 658 firmas de venture capital. ${ }^{389}$

Para superar esta lacuna, o BNDES implementou, em 1991, um pioneiro e alternativo instrumento jurídico de financiamento de empresas emergentes: um condomínio, funcionalmente estruturado na forma de um fundo contábil, para a capitalização de empresas, nos moldes do capital de risco - o CONTEC (programa de capitalização de empresas de base tecnológica). Neste programa, o BNDES assumiu um papel de venture capitalist, isto é, o Banco passou a adquirir diretamente participações societárias em empresas emergentes, buscando com isso suprir a falha na geração espontânea desta classe de investidores no país. Para isso, estabaleceu mecanismos diferenciados de participação societária, que garantissem a possibilidade de firmar

\footnotetext{
388 Dados apresentados por FINGERL, Eduardo Rath. Congresso ABVCAP 2008, apresentação de power point, mimeo, 2008.

${ }^{389}$ Dados apresentados por CARVALHO, Antonio Gledson de; RIBEIRO, Leonardo de Lima \& FURTADO, Cláudio Vilar. A Indústria de Private Equity e Venture Capital, op. cit e SAHLMAN, William. The Structure and Governance of Venture Capital Organizations, op cit.
} 
sociedade com empresas inicipientes, atentando, principalmente, para os mecanismos de monitoramento e de desinvestimento.

Aos moldes do que se verifica nos investimentos de risco, os gestores do CONTEC procuraram estabelecer regras de governança que assegurassem ao Banco um monitoramento ativo, capaz de garantir um acompanhamento presente dos empreendimentos. Para tanto, seja em acordos de acionistas ou na escritura de emissão das debêntures, fazia-se constar cláusulas que garantissem ao Banco uma influência relevante no curso da empresa investida, tais como: (i) a exigência de que as empresas beneficiárias fossem transformadas em sociedades anônimas; (ii) a obrigação de publicação dos demonstrativos contábeis; (iii) o desembolso paulativo dos recursos; (iv) a garantia de poder de veto sobre decisões dos administradores e (v) assento no conselho de administração da empresa tomadora.

A exigência de transformação em sociedade anônima tinha o propósito de garantir uma disciplina societária mais rígida, já que a empresa passaria a ser regida pela lei 6.404/76, o que ensejava, entre outras coisas, a obrigatoriedade de realização de auditorias e uma maior proteção aos interesses de acionistas minoritários. Além disso, as empresas do CONTEC tinham a obrigação de publicar os demonstrativos contábeis, uma exigência que a Lei das S.A. fazia apenas para as empresas de capital aberto, como lembra Luciane Gorgulho PINTO ${ }^{390}$, mas que foi adotada também para as companhias incluídas no programa (que eram fechadas), isso como forma de aumentar a capacidade de acompanhamento dos investimentos.

Nestas empresas, a participação do Banco era limitada a $40 \%$ do capital social ${ }^{391}$ e os recursos eram desembolsados de forma paulatina, como é próprio do venture capital. Desta maneira, o BNDES tinha a possibilidade de condicionar a realização dos desembolsos ao bom desempenho do projeto financiado: o primeiro aporte de capital tinha como limite um montante médio de $\mathrm{R} \$ 2$ milhões (dois milhões de reais), sendo que as demais injeções de capital poderiam superar este valor inicial, até um total de R 6 milhões

\footnotetext{
${ }^{390}$ Cf. PINTO, Luciane Gorgulho. Capital de Risco: uma alternativa de financiamento às pequenas e médias empresas de base tecnológica - o caso do CONTEC, op. cit.

${ }^{391}$ Cf. PINTO, Luciane Gorgulho. Capital de Risco: uma alternativa de financiamento às pequenas e médias empresas de base tecnológica - o caso do CONTEC, op. cit.
} 
(seis milhões de reais) - o limite máximo fixado pelo programa ${ }^{392}$. Por fim, a possibilidade do monitoramento ativo era facilitada pelo direito de assento no conselho de administração da empresa, o que permitia um acompanhamento pari passu do empreendimento, algo que era ainda reforçado pela exigência de prestação de informações regulares ao Banco, a quem também cabia uma autorização prévia, e a conseqüente possibilidade de veto, nas decisões de investimento formuladas pela firma - como nos casos de mudança de ramo ou nicho de mercado.

Ao lado das experiências com as regras de monitoramento, o CONTEC teve também de estabelecer novos parâmetros para formalização dos investimentos, em um formato apropriado para os tipos de ativos e de agentes tomadores. Em função das especificidades das empresas participantes (de alto risco e com baixo faturamento - de até $\mathrm{R}$ \$ 15 milhoes) e da ainda diminuta expertise do Banco, que à época inaugurava o mercado de risco no país, os gestores do programa tiveram de constituir as primeiras referências nesse segmento, sopesando, por exemplo, custos e benefícios dos veículos de participação societária. Foi dessas primeiras avaliações, que decorreu a opção pelo uso das debêntures conversíveis, ao invés da subscrição direta de ações.

Muito embora a participação por via acionária pudesse parecer o modo mais apropriado para lidar com firmas emergentes, os gestores do CONTEC deram preferência às debêntures conversíveis ou às debêntures associadas a bônus de subscrição. Procuraram com isso mitigar as incertezas financeiras assumidas pelo Banco, que aportaria pela primeira vez recursos em empresas parcamente consolidadas e voltadas a explorar segmentos de resultado incerto. No limite, julgava-se que a condição de acionista, desde o primeiro investimento, poderia limitar a governabilidade do Banco, pois impediria uma avaliação futura acerca da conveniência e da oportunidade daquela sociedade: caso o Banco se visse diante de um iminente insucesso da empresa beneficiária, não haveria um lapso de tempo oportuno para eventualmente rever a adequação da sociedade.

A subscrição acionária apresentava, no entendimento dos gestores do CONTEC, dois outros inconvenientes: (i) a necessidade de uma emissão de ações com valores elevados e (ii) a conseqüente dificuldade de liquidação destas ações. Conforme relata

\footnotetext{
392 Descrição contida em PINTO, Luciane Gorgulho. Capital de Risco: uma alternativa de financiamento às pequenas e médias empresas de base tecnológica - o caso do CONTEC, op. cit.
} 
Durval Soledade SANTOS, um dos principais atores da montagem do programa e que chegou a ser Diretor da BNDESpar, em 1993, a dificuldade do aporte de capitais em empresas emergentes era o casamento entre o grande volume de recursos desembolsado pelo Banco, vis-a-vis o parco capital social das firmas beneficiárias. Para algumas empresas apoiadas pelo CONTEC, um aporte de R 2 milhões (dois milhões de reais) poderia conduzir o BNDES a deter uma participação social muito superior ao limite de 40\%. Para contornar esta situação, as ações subscritas pelo BNDES contavam com um preço de emissão elevado, a fim de diluir o aporte de capital em um montante de ações que conduzisse o Banco a uma condição minoritária ${ }^{393}$. Todavia, a resolução deste problema inicial na subscrição das ações levava a uma segunda dificuldade: na liquidação de empresas mal sucedidas, ou mesmo na alienação daquelas companhias que obtiveram êxito, o valor das ações de titularidade do Banco era muito oneroso, o que poderia comprometer a sua capacidade de reaver os recursos investidos, sobretudo, pela pequena escala deste mercado no Brasil.

Foi por estas razões que as debêntures conversíveis em ações ganharam projeção dentro das operações de mercado de capitais da BNDESpar. A injeção inicial de recursos passou a ser feita com a aquisição de debêntures emitidas pela empresa, que diferentemente das ações, garantiam ao Banco um maior espaço de decisão: a conversão em ações só ocorreria caso o Banco entendesse que o ritmo e o rumo dos investimentos compensasse a sua transformação em sócio minoritário. Para os gestores do CONTEC, a debênture conversível respondia satisfatoriamente também aos problemas percebidos com a subscrição de ações, garantindo, nos casos de sucesso, os eventuais bônus de que os acionistas são titulares, como o recebimento de dividendos, sem se comprometer, necessariamente como sócio de empresas mal sucedidas, desde o primeiro aporte de capital. ${ }^{394}$ Demais disso, a utilização das debêntures respondia também às dificuldades, acima relatadas, relativas ao ajuste entre o aporte de capital necessário e a manutenção do controle da sociedade nas mãos do empreendedor. Em primeiro lugar, a aquisição de

\footnotetext{
${ }^{393}$ O artigo 11 da lei 6.404/76 (Lei das S.A.) faculta dois regimes de valor para as emissões de ação: com ou sem valor nominal. Nas hipóteses em que as ações forem emitidas sem valor nominal, há liberdade para que os fundadores, num momento inicial, fixem o preço de emissão. Foi por meio deste dispositivo legal, previsto no art. 14 da Lei 6.404/76, que se procurou casar uma injeção significativa de capitais do BNDES, sem que o Banco passasse a ser controlador das empresas. Entrevista concedida por Durval SOLEDADE, no dia 29.04.08, na sede da Comissão de Valores Mobiliários.

${ }^{394}$ Essa reconstrução foi feita por Durval SOLEDADE, em entrevista realizada no dia 29.04.08, na sede da Comissão de Valores Mobiliários, da qual o entrevistado era Diretor.
} 
debênture garantia um aporte de capital, sem que isso impactasse a composição da sociedade (seria feito via dívida e não via participação) e em segundo lugar, porque a conversão podia ser feita de forma paulatina ${ }^{395}$.

Ainda nesse campo, duas outras inovações introduzidas pelo BNDES em suas operações foram relevantes para os financiamentos do CONTEC: (i) a não exigência de garantias reais para subscrição das debêntures e (ii) a criação de alternativas à cobrança de juros fixos. O lançamento de debêntures subordinadas, possibilidade prevista no art. 58, parágrafo $4^{\circ}$ da lei 6.404/76, evitava a necessidade de o emissor (a empresa beneficiária) oferecer garantias reais, descaracterizando assim a principal desvantagem comparativa desta modalidade de financiamento para as empresas emergentes. Além disso, buscou-se um padrão de estruturação das operações em que a forma de pagamento da dívida contraída pelo emissor fosse mais ajustada às necessidades das empresas amparadas pelo CONTEC. Ao invés de apenas prever pagamentos de juros fixos e programados, típicos em uma debênture simples, algumas operações permitiam o pagamento por meio de uma repartição dos lucros alcançados ou pela combinação de pagamentos fixos e variáveis ${ }^{396}$.

Foi, portanto, o desenvolvimento destes parâmetros de transação financeira que permitiram ao Banco implementar uma nova faceta na sua regulação institucional: o papel de venture capitalist. Valendo-se de experimentos e programas-piloto, o Banco buscou construir referências para a estruturação de operações com empresas particularmente idiossincráticas. Ao estabelecer regras diferenciadas de monitoramento, sensivelmente mais interventivas do que se verifica habitualmente em sua participações societárias, e definir um padrão operacional, baseado em debêntures com flexibilidade, o BNDES procurou contornar os entraves institucionais decorrentes da ausência de um mercado de

\footnotetext{
395 Entrevista com Durval SOLEDADE, realizada no dia 29.04.08, na sede da Comissão de Valores Mobiliários. Sobre isso, assinala SOLEDADE em artigo: "Como resultado, as operações através de participação acionária, inicialmente as mais utilizadas, deram lugar à subscrição de debêntures, conversíveis ou simples agregadas a bônus de subscrição. Estas debêntures, com prazo de carência e resgate predefinidos, são títulos que podem ser convertidos em ações da empresa em qualquer momento dentro desse prazo e das condições estabelecidas. As vantagens do seu uso são: permitir melhor visibilidade do investimento; ter um prazo maior para a decisão sobre a conversão; e contar com uma alternativa adicional de liquidez para os investimentos. SANTOS, Durval Soledade, et al. Fundos de Empresas Emergentes: novas perspectivas de capitalização para pequenas e médias empresas, Revista do BNDES, s/n., pp. 12-13, disponível em http://www.bndes.gov.br/conhecimento/revista/durval.pdf. Acesso em 25.12.2008, e PINTO, Luciane Gorgulho. Capital de Risco: uma alternativa de financiamento às pequenas e médias empresas de base tecnológica - o caso do CONTEC, op. cit.

396 Cf. SANTOS, Durval Soledade, et al. Fundos de Empresas Emergentes: novas perspectivas de capitalização para pequenas e médias empresas, op. cit., pp. 1-19.
} 
capitais pujante. Nesse roteiro, ao lado das regras de monitoramento e da definição dos veículos, foi formulada uma outra inovação institucional, dedicada a compatibilizar as iniciativas do venture capital estatal com um ambiente carente de rotas de desinvestimento: uma alternativa de saída do BNDES, independente das negociações em mercado.

Como visto no capítulo anterior, o financiamento de risco é presidido pela lógica de uma rotatividade cíclica, de modo que as empresas recebem recursos por um período de tempo delimitado, e, em seguida, o financiador aliena a sua participação societária. Garantir essa possibilidade de saída era particularmente importante para o BNDES, que, ao longo de sua história, assumiu o controle de um bom número de empresas que tomavam recursos, não cumpriam seus compromissos financeiros e passavam, assim, à titularidade do Banco ${ }^{397}$. Importava, de fato, evitar que o CONTEC fizesse do BNDES não um venture capitalist, mas um gestor de massas falidas.

O problema é que a dificuldade enfrentada no âmbito do programa para garantir mecanismos de saída era justamente causada pela ausência de um mercado de capitais ou mesmo de um segmento privado de risco, o que não deixava de ser um impasse institucional: fôra justamente a carência de um mercado de capitais bem desenvolvido que determinara a criação de um programa público de capital de risco. Ficava claro assim que o êxito do BNDES como venture capitalist demandava soluções de direito societário capazes de garantir meios alternativos para o desinvestimento.

Para permitir a sua saída do negócio, independentemente da abertura do capital da empresa na bolsa de valores, o Banco contava com dois instrumentos possíveis: (i) a alienação de suas participações em uma venda estratégica para algum terceiro investidor interessado ou (ii) a definição de incentivos que levassem o próprio controlador a recomprar parcela de suas ações. Dada a imprevisibilidade de ocorrência de uma venda estratégica, buscou-se constituir uma possibilidade de saída sobre a qual o Banco detivesse

\footnotetext{
397 Ao longo de sua história o BNDES assumiu o controle de diversas empresas privadas, seja em razão de colaborações financeiras formalizadas inicialmente pela participação societária, seja em razão das chamadas "operações hospitais", em que o Banco assumia empresas com a intenção de evitar a sua falência. Em razão disso, já no Governo Sarney a BNDESpar sofreu um processo de saneamento financeiro, que consistiu na privatização de boa parte destas empresas. Foi por causa desta experiência com a venda de ativos para a iniciativa privada, aliás, que, na década de 1990, o Banco tornou-se o gestor do programa nacional de desestatização. A esse respeito ver PINHEIRO, Armando Castelar. Privatização no Brasil: Por que? Até onde? Até quando? em GIAMBIAGI, Fábio \& MOREIRA, Mauricio Mesquita. A Economia Brasileira nos Anos 90, Rio de Janeiro, BNDES, 1999, pp. 147-182.
} 
maior controle. Foram construídas duas soluções, ainda utilizadas em operações de risco do Banco: (i) a definição de regras especiais para o resgate das ações e (ii) a previsão de uma opção de venda contra o empreendedor (put).

A possibilidade de resgate das ações é prevista na Lei das S.A. (art. 44, parágrafo primeiro), que autoriza a companhia a reservar parte de seu lucro para resgatar ações dispersas no mercado. No entanto, uma particularidade das empresas apoiadas pelo programa reclamava uma estruturação criativa, para dar efetividade a esta possibilidade legal: normalmente, pequenas empresas emergentes não dispõem de uma folga financeira espontânea, para, assim, poder readquirir ações detidas pelos demais acionistas. A solução encontrada foi a construção de um mecanismo regulado de resgate: na ocasião do aporte de capitais pelo Banco, o acionista controlador obrigava-se a reservar anualmente uma parcela do faturamento, que era destinado para a formação de um fundo, cuja finalidade era a de permitir uma espécie de resgate à prazo. Esta obrigação poderia constar do Estatuto Social da empresa, que a partir de um período de carência (via de regra um ano após a emissão das ações), passava a contribuir para o fundo de resgate. Ao final deste período, caso não ocorresse o efetivo resgate das ações, o BNDES dispunha de uma opção de venda (put) contra o controlador, que se comprometia, então, a adquirir os valores mobiliários ${ }^{398}$. Esse procedimento de resgate das ações, cujo efeito para a companhia era quase similar a de uma dívida, dado o compromisso com a formação do fundo de pagamentos, garantiu uma possibilidade real de saída do BNDES no âmbito do CONTEC. Concretamente, as operações de resgate, ao contornarem a desvantagem da ausência de um mercado de capitais, que garantisse liquidez e rotas de saída para os investidores, permitiam alguma proteção para o Banco.

Foi, enfim, com este arsenal jurídico que as operações financeiras do CONTEC passaram a ser viabilizadas. O saldo final desta primeira fase (até meados de 1996) confirma a adequação destas ferramentas e indica um resultado positivo. Embora o programa tenha tido uma envergadura pequena, contemplando apenas 20 empresas e um

\footnotetext{
${ }^{398}$ Informação apresentada em entrevista realizada com Durval Soledade SANTOS, em entrevista realizada no dia 29.04.08, na sede da Comissão de Valores Mobiliários. Ver também GONÇALVES, Eduardo. Financiamento de Empresas de Base Tecnológica: algumas evidências da experiência brasileira, Revista Econômica do Nordeste, v. 33, nº 1, jan-mar, 2002 e SANTOS, Durval Soledade, et al. Fundos de Empresas Emergentes: novas perspectivas de capitalização para pequenas e médias empresas, op. cit.
} 
aporte global da ordem de $\mathrm{R} \$ 30$ milhões (trinta milhões de reais) ${ }^{399}$, as empresas apoiadas apresentaram conjuntamente um faturamento da ordem de US\$ 130 milhões (valor relativo a 1996) e empregaram mais de 1700 pessoas. No que tange ao êxito dos projetos, Luciane Gorgulho PINTO ${ }^{400}$ destaca as inovações trazidas pela empresa Bio Fill, que desenvolveu uma película à base de celulose para ser utilizada em casos de queimadura - o produto teve sucesso comercial e recebeu proteção patentária no exterior.

Entre 1996 e 2002, o Banco também manteve as suas atuações diretas, por meio da subscrição de valores mobiliários pela BNDESpar. Neste campo, em 1999, deu-se, por exemplo, a criação de dois outros programas, sendo um deles voltado a empresas de menor porte, o CONTEC simplificado ${ }^{401}$, e o outro dedicado a formar novos administradores de investimentos, por meio do lançamento de dois fundos exclusivos da BNDESpar: Brasil 21 e Fire (fundo de investimento de recursos em empresas emergentes). Já no ano 2000, um registro importante ficou por conta da criação de um programa de capital de risco para pequenas e médias sociedades anônimas. O programa contava com um orçamento inicial de R 300 milhões (trezentos milhões de reais), tendo a possibilidade de comprometer até R \$ 500 milhões (quinhentos milhões de reais) nos anos seguintes. O aporte de capital dirigia-se a empresas com faturamento maior do que aquelas atendidas pelo CONTEC, voltando-se a companhias com faturamento líquido anual de até R \$ 60 milhões e que não pertencessem a grupo econômico com faturamento líquido anual superior a $\mathrm{R} \$ 120$ milhões. Conforme narra o relatório anual do ano 2000, este programa estava em linha com o planejamento estratégico do Banco para os anos compreendidos entre 2000 e 2005, que tinha como uma de suas prioridades o apoio às pequenas e médias empresas e o incentivo ao mercado de capitais $^{402}$.

Afora estes resultados, os ganhos mais significativos parecem ter ocorrido no âmbito jurídico-institucional. Com o CONTEC, o Banco adquiriu um novo conjunto de

\footnotetext{
${ }^{399}$ Excluído deste valor as operações indiretas via fundos e companhias de investimento.

400 PINTO, Luciane Gorgulho. Capital de Risco: uma alternativa de financiamento às pequenas e médias empresas de base tecnológica - o caso do CONTEC, op. cit.

401 Ver BNDES, Relatório Anual 1999, disponível em www.bndes.gov.br, acesso em 16.05.08. Enquanto o CONTEC dirigia-se a empresas com faturamento líquido anual de até $\mathrm{R} \$ 15$ milhões, o CONTEC simplificado ampara empresas com faturamento líquido anual de até R $\$ 7$ milhões, sendo que a injeção de capital era limitada a R\$ 1 milhão. Sobre esses programas ver BASTOS, Valéria Delgado. Incentivo à Inovação: tendências internacionais e no Brasil e o papel do BNDES junto às grandes empresas, Revista do BNDES, Rio de Janeiro, v. 11, nº. 21, jun, 2004, pp. 107-138.

${ }^{402}$ Ver BNDES, Relatório Anual 2000, disponível em www.bndes.gov.br, acesso em 16.05.08.
} 
ferramentas jurídicas e uma particular racionalidade de intervenção. Desde então, o BNDES não só tem revelado uma disposição de apoiar a nova economia, mas também a intenção de o fazer de modo a mimetizar a atuação de um verdadeiro agente de mercado, na forma de um venture capitalist. Não por acaso, as soluções apresentadas para a administração dos problemas relacionados ao risco e ao perfil dos empreendedores foram encontradas no âmbito do direito privado, notadamente o societário. Em outros termos, o caminho para garantir a estruturação de operações financeiras com empresas emergentes percorreu uma trilha calcada em instrumentos jurídicos alinhados com as expectativas dos agentes financeiros.

No limite, na implantação deste programa de capital de risco, o Banco procurou atuar como se fosse um investidor profissional, manipulando ferramentas societárias e customizando-as para as necessidades específicas da realidade nacional. O pragmatismo subjacente à estruturação das operações sugere, portanto, a adoção de uma gramática semelhante à utilizada pelos operadores de mercado, um idioma distinto daquele utilizado outrora, quando o BNDES se portava como uma agência de fomento, submetendo as avaliações de risco ao mérito dos projetos.

Desembolsos anuais do BNDES no mercado de capitais para micro, pequenas e médias empresas

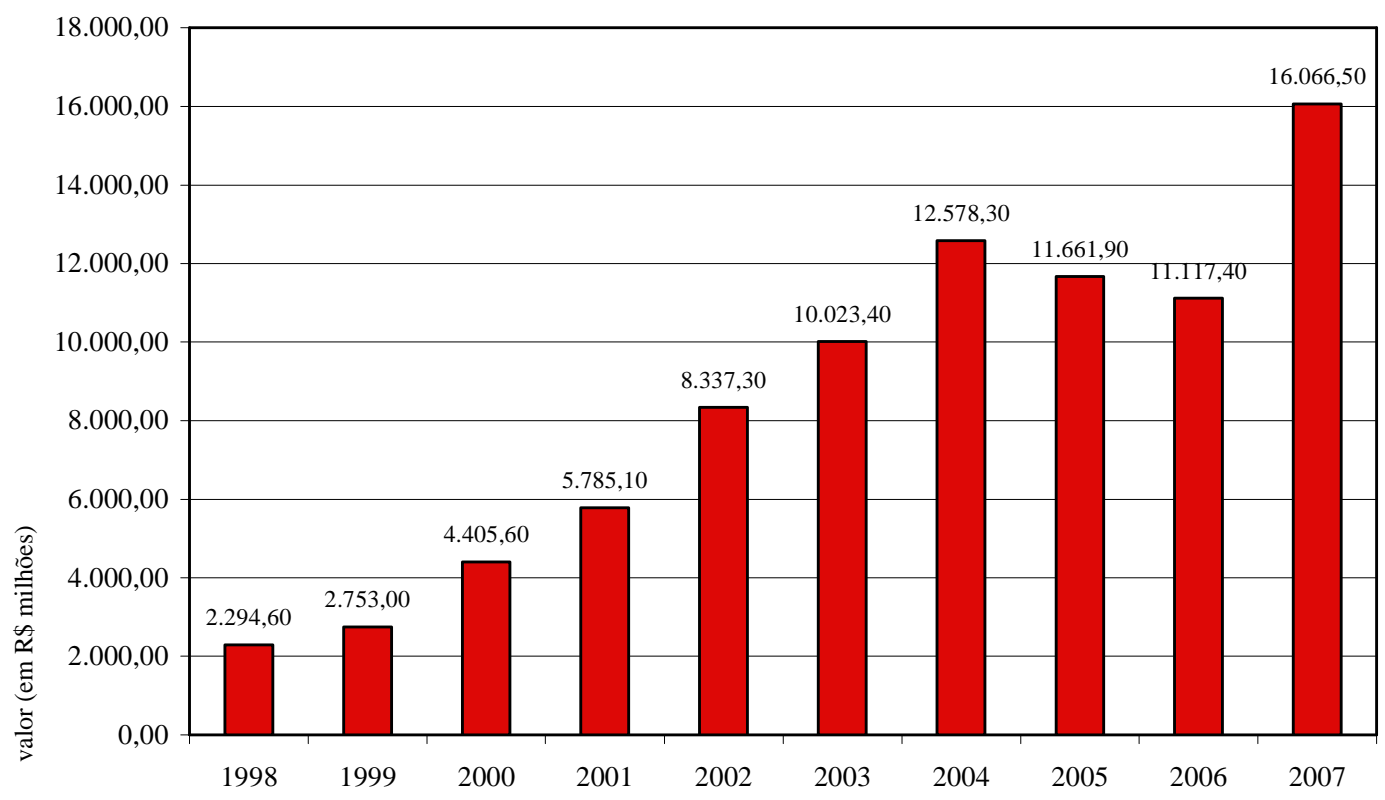

Gráfico 3. Fonte: BNDES. 
Não deixa de chamar a atenção, desse estilo de atuação, o crescimento das operações do Banco, dirigidas a pequenas e médias empresas, que são realizadas por meio da área de mercado de capitais. Embora nem todas as operações sejam direcionadas a empresas emergentes, sugerem um modus operandi diferenciado, em que se pode constatar uma aproximação entre o agente estatal e os demais atores do sistema financeiro.

\subsection{O BNDES COMO INDUTOR DO MERCADO DE CAPITAL DE RISCO}

Para além desta atuação direta, respaldada em soluções de direito societário, o Banco assumiu também o objetivo de induzir a constituição de um segmento privado de capital de risco, no país. Esta iniciativa do BNDES visava a solucionar o impasse representado por duas dificuldades percebidas durante a execução do CONTEC. A primeira delas, já relatada, dizia respeito aos problemas com os desinvestimentos, por isso, a intervenção do Banco também se dirigiu a fomentar um mercado para negociações de valores mobiliários, o que constituiria uma outra alternativa, para além dos procedimentos de resgate acionário e de venda estratégica. $\mathrm{O}$ segundo problema a ser equacionado referiase à falta de capilaridade dos recursos e a necessidade de difundi-los pelas demais regiões do país.

O desempenho deste papel indutor ia ao encontro desta nova racionalidade do Banco, em atuar alinhado com os dispositivos do mercado de capitais: na atuação indireta, o Banco não se dirigia diretamente a operações com empresas, mas voltava-se, isto sim, a fomentar a própria criação de uma indústria privada de capital de risco no Brasil. Uma iniciativa importante, nesse sentido, foi a articulação conduzida pela BNDESpar, em parceria com a Comissão de Valores Mobiliários, para a criação de uma espécie de bolsa de valores para empresas emergentes. Como sabido, as bolsas de valores apresentam exigências para as companhias listadas que muitas vezes são de difícil cumprimento por empresas emergentes, o que obstaculiza a realização dos desinvestimentos por meio da abertura do capital. A necessidade de um patamar mínimo de liquidez, para garantir atratividade, entre outros, tornam desinteressante para estas empresas a opção de atuação em bolsa. Em função disso, tem se verificado, em alguns países, a criação de mercados especializados, voltados a atender o porte e as necessidades de empresas de base tecnológica - a NASDAQ, norte-americana, é o exemplo mais eloqüente. 
Em 1996, a BNDESpar, na qualidade de um dos principais atores do mercado de capitais brasileiro, empreendeu esforços para a criação da Sociedade Operadora do Mercado de Acesso (SOMA). A SOMA era um mercado de balcão organizado, isto é, um ambiente institucional auto-regulado, em que as transações ocorreriam por meios eletrônicos, entre investidores profissionais. Para viabilização desta proposta, o BNDES comprometeu-se com recursos e também com a listagem de empresas de sua carteira, para assim alavancar este novo mercado. A intenção evidente era propiciar desde o seu surgimento uma quantidade atrativa de operações, por meio da colocação de papéis de empresas lucrativas. Os esforços resultaram na publicação, pela Comissão de Valores Mobiliários, da Instrução Normativa $n^{\circ} .243$, de 01 de março de 1996, que regulamentava o novo mercado de acesso, criando assim a SOMA. A seguinte passagem de SANTOS et. al. descreve o engajamento do Banco e assinala as expectativas despertadas com a criação da SOMA:

\begin{abstract}
Além do desenvolvimento dos mecanismos de liquidez, acima descritos e circunscritos diretamente às operações individuais, a BNDESpar vem desenvolvendo gestões - em conjunto com a CVM e os principais agentes do mercado - para a implementação de um Mercado de Balcão Organizado, destinado principalmente à negociação de ações de empresas de menor porte. Recentemente regulamentado pela CVM através da Instrução 243, de 01.03.96, este mercado terá custos bem inferiores ao de capitais convencionais e conferirá liquidez aos papéis das pequenas e médias empresas, contribuindo para o aumento dos investimentos nestas sociedades anônimas. A Bolsa de Valores do Paraná, em conjunto com a Bolsa de Valores do Rio de Janeiro (BVRJ), criou, em 25.06.96, a Sociedade Operadora do Mercado de Acesso (SOMA), que conta com a BNDESpar entre os seus fundadores. ${ }^{403}$
\end{abstract}

Muito embora este mercado de acesso tenha sido absorvido pela Bovespa (bolsa de valores de São Paulo), no processo de unificação das bolsas e não tenha se constituído em uma efetiva alternativa para os desinvestimentos, a atuação do BNDES neste caso traz, em si, elementos significativos. A percepção de que havia a necessidade de se criar um mercado de capitais, adequado para operações de risco, e a convergência de esforços para a sua viabilização indicam uma particular direção estratégica de intervenção. Ao lado das tradicionais ações financeiras, dedicadas a substituir a falha do ambiente de mercado, o BNDES passava também a induzir a sua consolidação, para assim permitir um incremento institucional na viabilidade de suas colaborações financeiras. Esta forma de atuação

${ }^{403}$ SANTOS, Durval Soledade, et al. Fundos de Empresas Emergentes: novas perspectivas de capitalização para pequenas e médias empresas, op. cit. pp. 14-15. 
sintetiza os traços que caracterizariam daí em diante a atuação do Banco no estímulo das empresas emergentes, qual seja, uma intervenção de fomento que assume o mercado não como um rival, mas como um veículo de complementaridade.

Nesse contexto, o Banco partilhava do diagnóstico de que o segmento privado de capital de risco, embora ainda ausente, importava para a viabilidade do financiamento desta nova economia. De um lado, porque a constituição deste mercado mitigaria os já mencionados problemas relacionados com a saída dos investimentos e, de outro, porque a pluralidade de oferta permitiria resolver um outro problema enfrentado pelo BNDES, que a esta época era um dos únicos agentes deste setor: a falta de capilaridade dos investimentos. Como se tratava de aportes de capital para pequenas empresas, que estão pulverizadas por todo o país, um dos entraves a ser solucionado era, justamente, garantir que os recursos fossem alcançados por companhias portadoras de futuro de todas as regiões.

Em compasso com as diligências voltadas a constituir um mercado de acesso, o Banco passou também a atuar para incentivar a participação dos agentes privados, nos financiamentos de venture capital. Para tanto, foram constituídas as CCRs - companhias regionais de capital de risco. A idéia destas companhias era atrair sócios privados regionais que, juntamente com o sócio estatal, capitalizassem as correspondentes companhias, que então aportariam recursos em empresas emergentes. Nascia, assim, uma modalidade de atuação do BNDES que tem perdurado desde então: a formação de parcerias públicoprivadas para a constituição de veículos de investimento em capital de risco.

Nesta primeira fase (até 1996), foram constituídas duas CCRs, uma para atuação na região Nordeste (Pernambuco Participações) e a outra na região Sul (CRP - Caderi) ${ }^{404}$. A participação do Banco em cada CCR era limitada a 30\% do capital social, podendo chegar a $40 \%$, caso a companhia tivesse um investimento significativo em empresas de base tecnológica. O limite de recursos de cada uma das CCRs era de R\$ 1 milhão (um milhão de reais) por empresa ${ }^{405}$. Nestas companhias de risco, o BNDES detinha assento no

\footnotetext{
${ }^{404}$ Informações obtidas na entrevista concedida por Durval SOLEDADE, no dia 29.04.08. A esse respeito, ver também GONÇALVES, Eduardo. Financiamento de Empresas de Base Tecnológica: algumas evidências da experiência brasileira, op. cit. e PINTO, Luciane Gorgulho. Capital de Risco: uma alternativa de financiamento às pequenas e médias empresas de base tecnológica - o caso do CONTEC, op. cit.

${ }^{405}$ Cf. PINTO, Luciane Gorgulho. Capital de Risco: uma alternativa de financiamento às pequenas e médias empresas de base tecnológica - o caso do CONTEC, op. cit.
} 
conselho de administração da empresa, o que permitia a sua participação ativa nas decisões de investimento.

Sendo assim, a atuação do Banco desdobrava-se em duas pontas: as ações diretas e as indiretas. No desempenho das primeiras, muito embora o agente estatal viesse a substituir a carência dos atores privados, desempenhava o seu papel através de ferramentas e procedimentos afinados com as expectativas dos agentes financeiros ${ }^{406}$. Em paralelo a esta forma de intervenção, o Banco também envidava esforços e recursos para constituir um segmento privado de capital de risco no país, como no caso das CCRs e mesmo da SOMA. Nesse papel, assumia uma função indutora e dava, assim, cumprimento a um comando normativo contido em seu estatuto social, que lhe atribui a missão de incentivar o desenvolvimento do mercado de capitais no Brasil.

\subsubsection{OS FUNDOS MÚTUOS DE INVESTIMENTO EM EMPRESAS EMERGENTES}

Foi deste caldo de cultura que nasceu um dos mecanismos mais importantes para o financiamento do capital de risco no país, até o presente contexto: os fundos de investimento. A experiência com as CCRs, sobretudo a dificuldade em atrair sócios privados, levou o BNDES, em 1993 e 1994, a participar, em conjunto com a Associação Brasileira de Analistas de Mercado de Capitais (ABAMEC), da formulação e implementação das bases de um novo instrumento para viabilizar os investimentos em empresas emergentes, fomentando desta forma o mercado nacional de capital de risco. Com a chegada de Thomás Tosta de Sá à presidência da CVM, foi editada, em 1994, a Instrução Normativa $n^{\circ}$. 209, autorizando a instituição dos Fundos Mútuos de Investimento em Empresas Emergentes ${ }^{407}$.

De acordo com o primeiro censo brasileiro de venture capital e private equity ${ }^{408}$, até 1994, os meios utilizados para a realização de investimentos em empresas emergentes eram as empresas holdings, como as CCRs. Uma alternativa que continha, no entanto,

\footnotetext{
${ }^{406}$ O BNDES, por exemplo, foi pioneiro em realizar operações com opções, introduzindo cláusulas de put e call em suas negociações. Informação colhida na entrevista com Durval Soledade SANTOS, realizada em 29.04 .08

${ }^{407}$ Informações obtidas na entrevista concedida por Durval Soledade SANTOS, no dia 29.04.08 e também em entrevista realizada com Thomas Tosta de SÁ, em 17.07.08.

${ }^{408}$ Cf. CARVALHO, Antonio Gledson de; RIBEIRO, Leonardo de Lima \& FURTADO, Cláudio Vilar. A Indústria de Private Equity e Venture Capital, op. cit., pp. 55-65.
} 
deficiências jurídicas e assim dificultavam uma viabilização plena deste tipo de investimento. Diferentemente das companhias, o fundo de investimento tem a natureza jurídica de um condomínio e é inspirado no veículo norte-americano para capital de risco, a limited partnership. Com isso resolvia quatro inconvenientes apresentados pelas holdings: (i) mitigava riscos societários dos administradores, (ii) aliviava os encargos tributários, (iii) possibilitava a captação de recursos internacionais e dos fundos de previdência e (iv) continha uma limitação temporal de existência, o que facilitava o encerramento de suas atividades. O êxito dos fundos de investimento como ferramenta jurídica pode ser verificado nos dados de sua utilização no mercado de venture capital e private equity: em 2005, cerca de dez anos depois da Instrução Normativa 209, dos 97 veículos de investimento em atuação no Brasil, 44 eram constituídos sob a forma de fundos de investimento e apenas 20, sob a forma de holding. ${ }^{409}$

No tocante à primeira vantagem comparativa, a inspiração no instituto norteamericano é bastante evidente. Como visto, a limited partnership consiste em uma sociedade com graus distintos de responsabilidade e de envolvimento, conforme a posição do participante. Neste arranjo, enquanto os investidores assumem o papel de limited partner, tendo a sua responsabilidade restrita às suas cotas e a sua participação é distante do cotidiano da sociedade; o general partner, este sim, assume todas as responsabilidades de gerenciamento dos recursos da sociedade e tem um poder amplo para as decisões financeiras. Tal como este último, o administrador do fundo é quem responde pela política de investimento do veículo e não pode ser facilmente destituído de sua posição pelos cotistas. Em relação aos diretores de uma empresa holding, por exemplo, a condição do administrador do fundo é menos sujeita a contestações, motivadas por eventuais divergências quanto aos resultados apresentados. Como estes administradores são ainda remunerados pelo desempenho do fundo, a proteção de seu cargo e a garantia de sua permanência à frente do veículo tende a ser um estímulo importante para o seu recrutamento $^{410}$.

\footnotetext{
${ }^{409}$ Neste montante de 44 fundos estão incluídos também os fundos de private equity (voltados para empresas maiores que as emergentes), regulados pela Instrução CVM 391 e os fundos disciplinados pelas Instruções CVM 302 e 409. Um outro dado expressivo são as Limited Partnership, que respondem por 29 dos veículos, constituídos fora do país. Para esses dados ver CARVALHO, Antonio Gledson de; RIBEIRO, Leonardo de Lima \& FURTADO, Cláudio Vilar. A Indústria de Private Equity e Venture Capital - primeiro censo brasileiro, op. cit. pp. 58-59.

${ }^{410}$ Ver a respeito CARVALHO, Antonio Gledson de; RIBEIRO, Leonardo de Lima \& FURTADO, Cláudio Vilar. A Indústria de Private Equity e Venture Capital - primeiro censo brasileiro, op. cit.
} 
Além disso, tal como na limited partnership, a incidência dos ganhos é sujeita à tributação apenas no resgate das cotas e é proporcional à participação de cada investidor, diferentemente do que ocorre em uma Sociedade Anônima, na apuração dos investimentos. Nesta, a tributação não é escalonada pela participação societária, pois quem recolhe os tributos é a própria sociedade, o que equaliza para todos os membros uma mesma taxa de pagamento. Por sua vez, no caso dos fundos de investimento, os lucros apurados como ganhos de capital só são tributados na ocasião em que o investidor se desfizer de suas cotas e ainda de forma proporcional à sua participação ${ }^{411}$.

Quanto à captação financeira, há duas vantagens na constituição de fundos: a possibilidade de arrecadação de recursos no exterior e a facilidade para a participação dos fundos de pensão. Com relação aos recursos provenientes de investidores estrangeiros, o fundo de investimento contorna a limitação existente na Lei das S.A., segundo a qual apenas empresas de capital aberto podem receber este tipo de recurso. Mesmo quando se trata de condomínios fechados ao público em geral, como é o caso dos fundos de investimento em empresas emergentes, há autorização para captação no estrangeiro. Já no que se refere aos fundos de pensão, que respondem por um volume expressivo de capitais disponíveis para investimentos, a sua legislação tem limitado a sua participação em companhias fechadas, mas tem permitido a aplicação financeira em fundos de investimento. Muito embora a entrada dos fundos de pensão como investidores dos fundos de investimento tenha ocorrido apenas em 2001, a constituição deste veículo foi quem pavimentou uma alternativa para a utilização destes recursos.

Em virtude destas vantagens decorrentes da nova moldura jurídico-institucional, o BNDES deu início, em 1996, a um programa de participação (via BNDESpar) em fundos fechados de investimento ${ }^{412}$, tendo, assim, um papel pioneiro na estruturação e na difusão destes instrumentos financeiros. Ao se tornar cotista de fundos privados, o Banco dava viabilidade econômica aos veículos e desempenhava um papel indutor deste segmento econômico, que só passou a ter dimensão mais significativa no começo dos anos $2000^{413}$.

\footnotetext{
411 Cf. CARVALHO, Antonio Gledson de; RIBEIRO, Leonardo de Lima \& FURTADO, Cláudio Vilar. A Indústria de Private Equity e Venture Capital - primeiro censo brasileiro, op. cit.

${ }^{412}$ Informação disponível no Relatório Anual do BNDES de 2005, ver BNDES, Relatório Anual 2005, disponível em www.bndes.gov.br, acesso em 16.05.08

413 Sobre a importância do BNDES neste segmento, destacam CARVALHO, RIBEIRO \& FURTADO:

“Esses fatores evidenciam três elementos importantes para o desenvolvimento futuro da indústria: (...) 3)
} 
A carência deste mercado e a conseqüente relevância da participação do BNDES como agente financeiro é apreensível com a notícia de que entre 1995 e 2000 foram constituídos uma média de apenas 2 novos fundos por ano; e em 2002, ano em que se verificou um recorde de registro de novos fundos, o montante alcançou 6 novos veículos. ${ }^{414} \mathrm{O}$ gráfico a seguir apresenta a participação relativa do BNDES no segmento de fundos mútuos de investimento em empresas emergentes: sua relevância é expressiva, mesmo com o crescimento deste mercado.

Carteira de FMIEE do BNDES - Participação no total de fundos

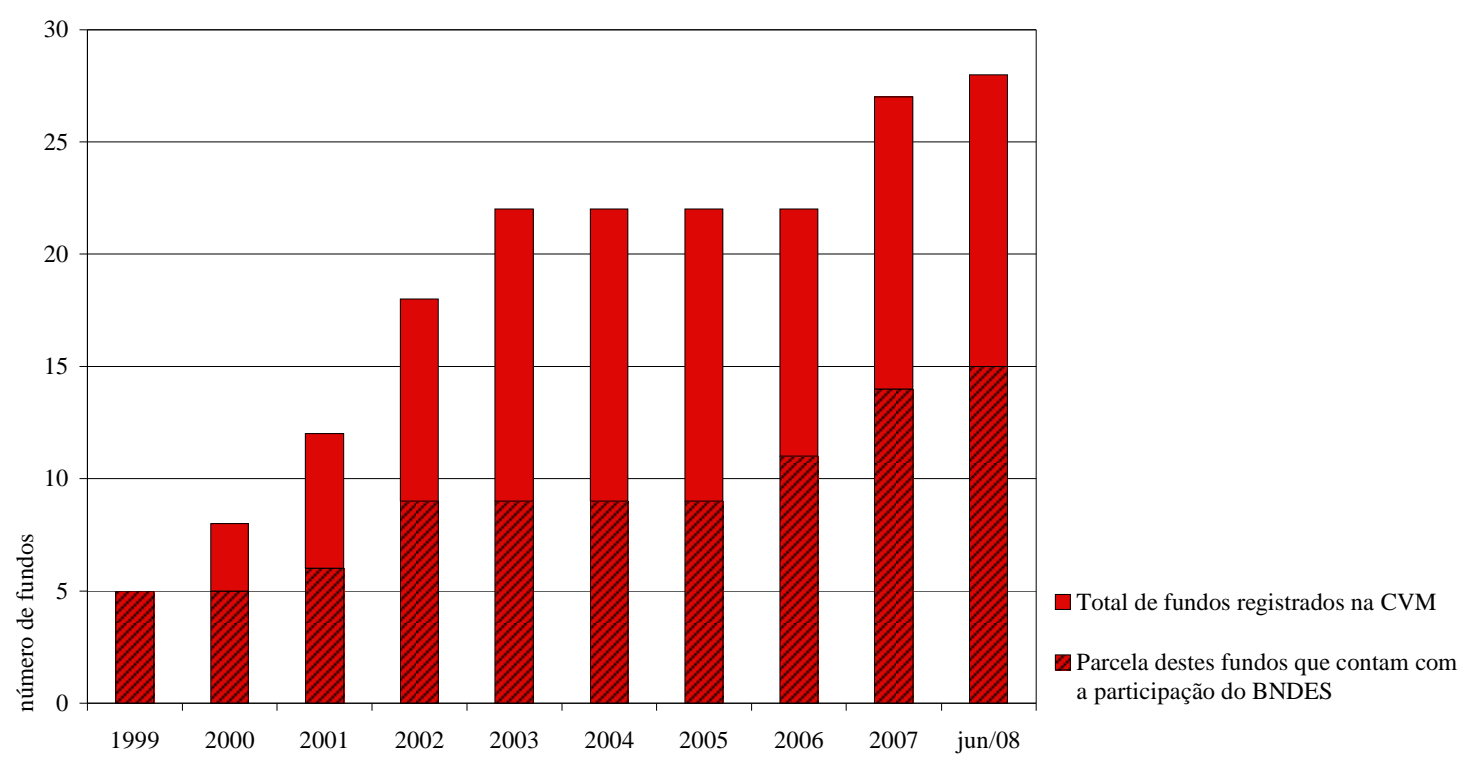

Gráfico 4. Fonte: BNDES e CVM

No desempenho do papel de incentivador desta indústria, a intervenção do BNDES não tem se limitado aos aportes financeiros. A sua contribuição também tem proporcionado ativos imateriais para os fundos apoiados. De um lado, a marca BNDES confere uma espécie de selo de qualidade aos fundos dos quais o Banco participa, ampliando assim a sua capacidade de captação. De outro, a experiência de mercado, a amplitude de sua carteira de investimentos e a qualidade de seu corpo técnico têm

interesse explícito do governo no desenvolvimento da indústria de PE/VC, participando por meio de agências de fomento à inovação e empreendedorismo e do Banco Nacional de Desenvolvimento Econômico e Social (BNDES) como cotista de fundos destinados a capital semente e venture capital e apoiando a criação de fundos de governança e liquidez (PIPEs)." p. 123. Em CARVALHO, Antonio Gledson de; RIBEIRO, Leonardo de Lima \& FURTADO, Cláudio Vilar. A Indústria de Private Equity e Venture Capital, op. cit. ${ }^{414}$ Fontes: CVM e CARVALHO, Antonio Gledson de; RIBEIRO, Leonardo de Lima \& FURTADO, Cláudio Vilar. A Indústria de Private Equity e Venture Capital - primeiro censo brasileiro, op. cit. 
permitido ao Banco articular uma rede de relações com empresas e atores financeiros bastante significativa para os fundos dedicados a investimentos de risco ${ }^{415}$. Um exemplo concreto, nesse sentido, relativo a um apoio não financeiro prestado ao mercado, aparece no censo brasileiro da indústria de private equity e venture capital, no item relacionado à procedência dos gestores dos fundos privados de investimento. A pesquisa mostra que a passagem prévia pelo Banco é uma importante fonte de experiência para estes gestores, levando os autores a concluir que há uma externalidade positiva gerada pelo BNDES: a formação de gestores para as organizações privadas de private equity e venture capital ${ }^{416}$.

Dando seguimento a esta política financeira e imaterial de constituição de fundos mistos de investimento, em 1999, o Banco articulou a criação de um veículo para atuação na região sul do pais: o RSTec, um fundo mútuo de investimento, constituído em uma parceria com a Companhia Riograndense de Participações. Ao fim daquele ano a BNDESpar contabilizava cotas de participação em 5 outros fundos de investimento, o equivalente ao universo total de fundos registrados na CVM.

Algo semelhante ocorreu no ano 2000. Depois da constituição de um fundo na região do Rio Grande do Sul no ano anterior, o Banco estruturou um veículo semelhante em Santa Catarina. A vertente catarinense dos fundos mútuos de investimento em empresas emergentes - o SCTec - era formado por uma parceria entre o BNDES, o BID, o SEBRAE e o Instituto Euvaldo Lodi, com um patrimônio de cerca de R \$ 24 milhões (vinte e quatro milhões de reais). Neste ano ainda foram registradas 4 novas operações realizadas por fundos já existentes, num montante total de R\$ 21 milhões (vinte e um milhões de reais $)^{417}$. No ano seguinte, em 2001, a atuação do Banco consistiu em reforçar estes veículos: verificou-se uma injeção de capital no montante aproximado de R 15 milhões

\footnotetext{
${ }^{415}$ Essas avaliações foram feitas por dois entrevistados, em momentos diferentes: Durval Soledade SANTOS e Eduardo SÁ, sendo este último chefe do departamento de fundos do BNDES. Ambas as entrevistas ocorreram no dia 29.04.08, sendo a primeira realizada na CVM e a segunda na sede do BNDES. Sobre a relevância que o BNDES tem neste segmento, a seguinte passagem de Valéria Delgado BASTOS, economista do BNDES, dá uma idéia de que a trajetória e a consolidação do Banco como agente de desenvolvimento importa para a estruturação de um canal de financiamento para as empresas inovadoras: "não há como prescindir de instituições como o BNDES, com tradição no fornecimento de crédito de longo prazo, com fontes estáveis de recursos e grandes empresas como clientes tradicionais." BASTOS, Valéria Delgado. Incentivo à Inovação: tendências internacionais e no Brasil e o papel do BNDES junto às grandes empresas, op. cit. pp. 131-132.

416 Ver CARVALHO, Antonio Gledson de; RIBEIRO, Leonardo de Lima \& FURTADO, Cláudio Vilar. A Indústria de Private Equity e Venture Capital, op. cit.

${ }^{417}$ Ver BNDES, Relatório Anual 2000, disponível em www.bndes.gov.br, acesso em 16.05.08.
} 
(quinze milhões de reais) nos fundos Fire, RSTec e SCtec, por meio da subscrição de $\operatorname{cotas}^{418}$. Em meados de 2002, cerca da metade dos fundos registrados na CVM contava com participações do BNDES.

\section{A RETOMADA DA POLÍTICA INDUSTRIAL E A TERCEIRA FASE DAS INOVAÇÕES JURÍDICO- INSTITUCIONAIS: CONTRATOS RELACIONAIS, INTENSIFICAÇÃO E ABRANGÊNCIA DOS PROGRAMAS DE CAPITAL DE RISCO}

A partir de 2004, o quadro jurídico-institucional conformado ao longo da década de 1990 ganhou novo fôlego e direção. Passados dez anos em que a opção do Governo Federal foi a de não implementar uma política industrial no país, valendo-se de um entendimento de que a intervenção do Estado na seleção e promoção de setores distorcia indevidamente o regime de mercado $^{419}$, foi definido um novo pacote de medidas e incentivos para o segmento industrial brasileiro. Tratava-se da Política Industrial, Tecnológica e de Comércio Exterior (PITCE), desenhada pelos Ministérios da Fazenda e Desenvolvimento, Indústria e Comércio, com a participação do Instituto de Pesquisas Econômicas Aplicadas (IPEA). ${ }^{420}$

O alvo desta nova política foi a promoção da competitividade e da capacidade de inovação do conjunto do setor industrial brasileiro. Além disso, a política trazia ainda uma seleção de quatro setores prioritários: (i) software, (ii) bens de capital, (iii) fármacos e medicamentos e (iv) semicondutores. A opção por estes setores deveu-se à sua intensidade de pesquisa e desenvolvimento, ao seu potencial de indução do processo de inovação nas demais cadeias produtivas e ao impacto causado na pauta do comércio internacional ${ }^{421}$. Na concepção da PITCE figurava o pressuposto de que na nova economia um dos elementos chave para o progresso econômico seria a capacidade de inovação das empresas, um fator relevante não só para o mercado interno, como também para o comércio internacional, cuja

\footnotetext{
${ }^{418}$ Ver BNDES, Relatório Anual 2001, disponível em www.bndes.gov.br, acesso em 16.05.08.

419 À época, esse entendimento foi bem expressado numa máxima cunhada pelo então Ministro da Fazenda, Pedro Malan, segundo a qual a "melhor política industrial é não ter política industrial". Para tanto ver CAMPANÁRIO, Milton de Abreu \& SILVA, Marcello Muniz da. Fundamentos de uma Nova Política Industrial, em FLEURY, Maria Tereza Leme \& FLEURY, Afonso (org.). Política Industrial 1, São Paulo, PubliFolha/FEA-USP, 2004.

${ }^{420}$ Ver Ministério do Desenvolvimento, Indústria e Comércio, Diretrizes da Política Industrial, Tecnológica e de Comércio Exterior, 2004.

${ }^{421}$ Cf. CARVALHO Jr., Armando Mariante. A Política Industrial e o BNDES, Revista do BNDES, Rio de Janeiro, v. 12, $\mathrm{n}^{\circ} .23,2005$, pp. 17-28.
} 
pauta tem valorizado os produtos com intensidade em pesquisa, tecnologia e inovação ${ }^{422}$. Essa percepção está bastante evidente no documento Diretrizes de Política Industrial, Tecnológica e de Comércio Exterior, que estabelece as linhas mestras da nova política:

A Política Industrial, Tecnológica e de Comércio Exterior tem como
objetivo o aumento da eficiência econômica e do desenvolvimento e
difusão de tecnologias com maior potencial de indução do nível de
atividade e de competição no comércio internacional. Ela estará focada
no aumento da eficiência da estrutura produtiva, aumento da capacidade
de inovação das empresas brasileiras e expansão das exportações. Esta é a
base para uma maior inserção do país no comércio internacional,
estimulando os setores onde o Brasil tem maior capacidade ou
necessidade de desenvolver vantagens competitivas, abrindo caminhos
para inserção nos setores mais dinâmicos dos fluxos de troca
internacionais. ${ }^{423}$

Diferentemente das demais iniciativas de política industrial registradas no país, a PITCE, propriamente dita, não foi estipulada por meio de lei - as suas medidas foram elencadas em um documento não normativo do Governo Federal, destinado a apresentar as suas principais diretrizes. Mesmo assim, foi promulgado um conjunto inicial de três leis que construíram os seus macro-fundamentos jurídico-institucionais, trataram-se das leis 10.973/04 (a Lei da Inovação), 11.080/04 (a Lei da ABDI) e 11.196/05 (Lei do Bem). A lei 10.973/04, a chamada Lei da Inovação, disciplinou, entre outros, os mecanismos de proteção às inovações, as regras para facilitar a estipulação de parcerias entre governos, empresas e instituições cientifico-tecnológicas, para a geração de novos produtos e processos, bem como os dispositivos dirigidos à promoção das inovações pelas agências de fomento. Já a lei 11.080/04, autorizou a criação da Agência Brasileira de Desenvolvimento Industrial (ABDI), a quem se incumbiu a tarefa de coordenação das ações da PITCE, que estariam distribuídas entre o BNDES, a FINEP (Financiadora de Estudos e Projetos), o

${ }^{422}$ Esta perspectiva de que a coordenação pública importava para a promoção industrial está bastante em evidência no documento de apresentação da PITCE. A seguinte passagem é um bom exemplo disso: “As diretrizes que se seguem consideram as políticas de governo como um conjunto integrado, articulando simultaneamente o estímulo à eficiência produtiva, ao comércio exterior, à inovação e ao desenvolvimento tecnológico como vetores dinâmicos da atividade industrial. Nos anos 90, apesar da modernização e do aumento da produtividade em vários setores industriais, o país não conseguiu ampliar a sua base exportadora nem reverter a tendência de queda de participação no comércio internacional. Assim, o Brasil tem apresentado um desempenho externo aquém de suas potencialidades. Apresentamos taxa de crescimento de exportações menor do que a de vários países em desenvolvimento. A taxa média de crescimento do comércio mundial foi de 7,5\% ao ano entre 1984 e 2002, enquanto a do comércio brasileiro foi de 4,6\% ao ano, no mesmo período. Em razão disso, a participação do país no comércio internacional caiu, no período, de 1,39\% para 0,79\% do total." Ministério do Desenvolvimento, Indústria e Comércio, Diretrizes da Política Industrial, Tecnológica e de Comércio Exterior, 2004, pp. 4-5.

${ }^{423}$ Ministério do Desenvolvimento, Indústria e Comércio, Diretrizes da Política Industrial, Tecnológica e de Comércio Exterior, op. cit. pp. 2-3. 
Ministério da Fazenda e o Ministério da Ciência e Tecnologia. Por fim, a lei 11.196/05, a Lei do Bem, instituiu regimes tributários diferenciados, suspendendo, assim, a exigência de pagamento dos tributos PIS e COFINS, para os setores de tecnologia da informação, software e bens de capital, desde que cumprissem as metas de desempenho de importação ou de exportação.

Em compasso com este novo quadro normativo, que reorganizou a agenda da intervenção pública na economia, o BNDES também passou a redirecionar a forma de sua atuação. Em um primeiro momento, o Banco procurou alterar a sua política operacional, o que implicou em uma mudança no custo dos recursos desembolsados e nas regras contratuais, para com isso favorecer o financiamento das inovações. Estas alterações culminaram em uma reorganização interna do Banco, cujo resultado foi a criação da Área de Mercado de Capitais, em 2005, o que tonificou as operações de renda variável, que, como sabido, são relevantes para as empresas emergentes. Um dos desdobramentos desta intensificação dos desembolsos voltados às empresas inovadoras foi a constituição, em 2007, de um novo fundo de investimentos, o CRIATEC, dedicado às empresas "semente", isto é, empresas em uma fase ainda antecedente ao estágio empresarial da firmas emergentes - um setor com um patamar de risco ainda mais acentuado e que não tem despertado interesse dos agentes privados, como será detalhado a seguir. O saldo alcançado com a definição de uma nova política operacional e de novas linhas e programas, articulados com os propósitos da PITCE, foi uma ampliação dos desembolsos relacionados com inovação, tanto na renda fixa, como na renda variável.

Em 2008, o esforço de retomada da política industrial foi reforçado: o Governo Federal estabeleceu um novo conjunto de medidas e incentivos, sistematizados na Política de Desenvolvimento Produtivo (PDP). Apresentada na sede do BNDES, a PDP apresenta entre os seus objetivos, os seguintes: (i) ampliar a capacidade de oferta (da economia brasileira); (ii) preservar a robustez do balanço de pagamentos; (iii) elevar a capacidade de inovação e (iv) fortalecer as micro e pequenas empresas. Em relação à PITCE, a PDP selecionou um volume mais abrangente de setores, tais como: o complexo industrial da saúde, o aeronáutico, o de microeletrônica e o de inclusão digital. ${ }^{424}$ No que se refere particularmente às inovações e à atuação do BNDES, a PDP resultou na criação de duas

${ }^{424}$ As informações sobre a PDP estão disponíveis em http://www.desenvolvimento.gov.br, acesso em 11.01.09. 
novas linhas de financiamento: (i) inovação tecnológica e (ii) capital inovador - com orçamento estimado de R $\$ 6$ bilhões (seis bilhões de reais), até 2010, além da previsão dos investimentos realizados por meio dos demais veículos financeiros, como é o caso da participação acionária, seja diretamente, seja por meio dos fundos de investimento. Os efeitos de ambas as políticas industriais e a conseqüente ampliação da intervenção do Banco no segmento de inovação, com o emprego de novas ferramentas de financiamento, são descritos a seguir.

\subsection{A UTILIZAÇÃo DE CONTRATOS DE OPERAÇÃo DE CRÉditTo PARA FINANCIAMENTOS DE INOVAÇÃO: A EXPERIÊNCIA DOS PROGRAMAS SETORIAIS}

A conjuntura institucional favorável ao fomento das empresas inovadoras refletiuse na apresentação (ou na reformulação) de dois programas setoriais de crédito $^{425}$ : um destinado ao setor de software e o outro ao setor de fármacos. Formulados em linha com a PITCE, ambos os programas tinham como foco o incentivo à inovação nos respectivos setores e para tanto continham regras de contratação mais favoráveis em relação aos dispositivos de uma operação padrão. A partir de então, ao lado dos aportes de risco via participação societária, o Banco também passou a realizar seus desembolsos para projetos de inovação por meio de operações de renda fixa, formalizadas em contratos, dotados de uma racionalidade relacional.

Na percepção do BNDES, tanto o setor de software, como o de fármacos tinham um porte econômico significativo, com alta intensidade de inovação, mas ainda parcamente desenvolvidos pela indústria nacional. De acordo com as estimativas do Relatório Anual de 2003, o mercado de software respondia naquele ano por um volume aproximado de US\$ 9,5 bilhões (nove e meio bilhões de dólares), sendo majoritariamente caracterizado pela alta presença de importações. Às empresas brasileiras cabia uma participação de mercado em torno de $12 \%$, na confecção de produtos e de $17 \%$ na oferta de serviços do setor ${ }^{426}$. Uma realidade semelhante foi identificada no setor farmacêutico, cujo faturamento no Brasil respondia, em 2003, por algo em torno de US\$ 5,5 (cinco e meio bilhões de dólares), o equivalente a $11^{\text {a }}$ posição no volume mundial desta indústria. Neste

\footnotetext{
425 A atuação do BNDES pode ocorrer por meio de linhas de crédito e de programas. As linhas são permanentes e os programas são transitórios.

${ }^{426}$ Para estes dados ver BNDES, Relatório Anual 2003, op. cit.
} 
segmento, o relatório do BNDES apontou uma participação multinacional correspondente a $70 \%$ das vendas no mercado interno ${ }^{427}$. Foi para reverter em parte este quadro, que impactava a balança comercial, dada a elevada presença de importações, e para permitir a nacionalização do processo de inovação, que foram definidos os dois mencionados programas de crédito: o Prosoft e o Profarma.

O programa de software havia sido instituído, originariamente, em 1997, mas foi reformulado e ampliado, para atender aos objetivos da política industrial: passou a contar com três áreas, uma destinada a financiar as exportações (prosoft-exportação), a outra, voltada a incentivar o crescimento das empresas de software (prosoft-empresa) e uma terceira, comprometida com o impulso da comercialização do software, por meio da facilitação do crédito (prosoft-comercialização) ${ }^{428}$. Por trás destas alterações, estavam regras contratuais mais flexíveis e um custo financeiro diferenciado.

No que tange especificamente às regras de contratação, o Prosoft passou a dispensar a exigência de garantias reais para as operações cujo montante não superasse $R$ \$ 6 milhões (seis milhões de reais). Com isso, o Banco inaugurava uma forma diferenciada de apoio a empresas inovadoras, que viria a ser depois consolidada com a alteração da Política Operacional, em 2005: a definição de um contrato com regras de compartilhamento de riscos e descasado da necessidade imperativa de meios

427 No relatório de 2003, pode-se ler o seguinte diagnóstico acerca da dependência do país no setor farmacêutico. Note-se que ao final do texto, há a menção da criação de medidas específicas para este setor, o que, de fato, veio a ocorrer em 2004: "A indústria farmacêutica nacional é um exemplo da dependência externa a que o país está sujeito com relação à importação de farmoquímicos e de medicamentos antigos no mercado. A maioria absoluta dos farmoquímicos importados não apresenta barreiras de patentes, além de suas rotas de síntese química serem bem conhecidas. Do total do valor FOB das importações de farmoquímicos em 1998, 83\% tinham patentes originais anteriores a 1977, sendo que 47\% eram anteriores a 1962. Não há uma predominância da importação de produtos da fronteira tecnológica, o que implica a geração de maior margem através da fixação de preços de transferência de farmoquímicos antigos, cujos gastos em pesquisa e desenvolvimento $(P \& D)$ já foram amortizados. O BNDES tem fomentado a indústria de insumos, materiais e equipamentos médico-hospitalares e odontológicos, a qual se destaca pelo nível crescente da sua base tecnológica e pelo caráter social inerente aos serviços de saúde. A situação atual mostra a presença majoritária de pequenas e médias empresas de capital nacional, de estrutura familiar e com necessidades de apoio à atualização tecnológica. Nesse sentido, o Banco tem elaborado um diagnóstico que embasará políticas operacionais específicas orientadas para esse segmento.” BNDES, Relatório Anual 2003, op. cit.

${ }^{428}$ As novas regras do Prosoft foram bem recebidas pelos investidores do setor. Em uma comparação das duas fases do programa (de 1997 a 2004 e de 2004 a 2007), fica evidente o aumento expressivo do volume de recursos. Em uma matéria sobre os dez anos do Prosoft, o jornal Valor Econômico compara o desempenho do programa em ambos os períodos. Entre 1997 e 2004, segundo o jornal apenas 28 empresas utilizaram os recursos disponíveis, num total de $\mathrm{R} \$ 58,4$ milhões. Ao passo que entre março de 2004 e julho de 2007, o Prosoft movimentou R 773 milhões, atendendo 127 empresas. Em Valor Econômico, BNDES avalia futuro de programa para apoiar setor de TI, 09 de agosto de 2007. 
presentificadores - como as garantias reais. Além desta modalidade, estruturada por meio de contrato, havia também, no Prosoft, a possibilidade de participação acionária do Banco, na forma de capital de risco. Com a Política de Desenvolvimento Produtivo - PDP, o programa de 2004 foi reformulado e o limite de $\mathrm{R} \$ 6$ milhões para dispensa de garantias foi ampliado para $\mathrm{R} \$ 10$ milhões (dez milhões de reais). Além disso, a participação do Banco, que era limitada a $85 \%$ do total financiado, foi aumentada para $100 \%$, naquelas operações que estivessem dentro das prioridades da PDP. ${ }^{429}$

O Profarma, desenhado com características semelhantes ao Prosoft, foi igualmente apresentado em 2004. As regras atinentes às suas colaborações financeiras também contemplavam a utilização de contratos com regras flexíveis e moldáveis ao curso do empreendimento, assim como a participação societária do BNDES. Notadamente, quanto às operações de renda fixa, chama a atenção uma inovação no desenho contratual, qual seja, a possibilidade de se firmar um contrato de risco. Neste caso, a remuneração do Banco poderia ser proveniente dos resultados gerados futuramente pelo projeto ${ }^{430}$. Esta alternativa indica um paradigma distinto de contratação, mais próximo de uma parceria, ou de um contrato relacional, do que de um termo descontínuo. No limite, o Banco partilhava dos riscos e dos possíveis benefícios.

Deste modo, com a definição de ambos os programas, o Banco dava concretude à política industrial e, em particular, reforçava seu estoque de ferramentas jurídicas. Além de dar continuidade ao capital de risco, atuando por meio de participações societárias em empresas de software ou de fármacos, o BNDES também passou a desenvolver meios contratuais, em operações de renda fixa, compatíveis com as idiossincrasias dos setores inovadores. Dirigidos a empresas em uma fase posterior de amadurecimento, mas ainda carentes de plena previsibilidade em seus planos de negócios, os contratos flexíveis surgiram como um meio termo entre uma operação tradicional, com bases presentificadoras, e as participações acionárias, em que o Banco torna-se sócio do risco empreendido. O quadro abaixo resume estas inovações contratuais, destacando a dispensa de garantias reais e a possibilidade de participação nos resultados do projeto.

${ }^{429}$ Informações disponíveis em www.bndes.gov.br, acesso em 18.05.08.

430 A esse respeito, consultar as regras do programa Profarma Inovação, disponíveis em http://www.bndes.gov.br/programas/industriais/profarma inovacao.asp, acesso em 20.05.08. Assim como o Prosoft, o Profarma também foi alterado em função da Política de Desenvolvimento Produtivo, mas a possibilidade de participação nos resultados já estava presente no programa. 


\begin{tabular}{|c|c|c|c|}
\hline \multicolumn{4}{|c|}{$\begin{array}{c}\text { QUADRO } 13 \\
\text { ROGRAMAS SETORIAIS DO BNDI }\end{array}$} \\
\hline Programa & \multicolumn{2}{|c|}{$\begin{array}{l}\text { Formas de participação do } \\
\text { BNDES }\end{array}$} & $\begin{array}{l}\text { Cláusulas inovadoras nos } \\
\text { contratos de financiamento }\end{array}$ \\
\hline Prosoft & $\begin{array}{l}\text { Operação de } \\
\text { crédito }\end{array}$ & $\begin{array}{c}\text { Participação } \\
\text { societária }\end{array}$ & Dispensa de garantias reais \\
\hline Profarma & $\begin{array}{l}\text { Operação de } \\
\text { crédito }\end{array}$ & $\begin{array}{c}\text { Participação } \\
\text { societária }\end{array}$ & $\begin{array}{l}\text { Participação do Banco nos } \\
\text { resultados do projeto }\end{array}$ \\
\hline Fonte: BNDES & & & \\
\hline
\end{tabular}

Nesta primeira etapa da política industrial, em 2005, além de novos parâmetros contratuais, foi ainda recuperado um fundo contábil do BNDES, criado em 1972, para prover recursos não reembolsáveis para os segmentos de tecnologia - o FUNTEC (fundo tecnológico). Este fundo, que, na década de 1970, garantiu recursos para os centros tecnológicos de empresas brasileiras, como a METAL LEVE, a EMBRAER e a $\mathrm{COFAP}^{431}$, voltou a ser utilizado para alocar recursos em áreas de fronteira, com risco comercial ainda mais elevado, do que o verificado em empresas emergentes.

Os recursos do FUNTEC têm sido dirigidos às instituições científicas e tecnológicas, com a finalidade de serem utilizados em setores como: software, semicondutores, biomassa e biotecnologia, entre outros. Na aplicação dos recursos, não há a exigência de garantias e nem tampouco a obrigação de ressarcimento do Banco. A única obrigação assumida pelos beneficiários é restrita ao cumprimento do projeto tecnológico. Cabe às partes, isto sim, delimitarem, conforme o disposto na lei de inovação, um regime compartilhado de propriedade intelectual, entre os pesquisadores, os institutos tecnológicos e as eventuais firmas parceiras - isso com o propósito de garantir apropriação do conhecimento pelas instituições científicas e pelos pesquisadores brasileiros. ${ }^{432}$ Com a definição da Política de Desenvolvimento Produtivo, em maio de 2008, o FUNTEC teve o seu orçamento ampliado e à lista original de setores alvo, adicionaram-se ainda: energias renováveis, meio ambiente e saúde.

\footnotetext{
${ }^{431}$ Informação obtida em entrevista com Durval SOLEDADE, no dia 29.04.08.

432 Informação obtida em entrevista com Yolanda RAMALHO, Superintendente de Planejamento do BNDES, realizada no dia 17.07.08.
} 


\subsection{A NOVA POLÍtiCA OPERACIONAL: NÍVEIS DE PRIORIDADE PARA A INOVAÇÃo E PARADIGMA CONTRATUAL RELACIONAL}

As alterações institucionais inauguradas com a introdução de padrões flexíveis de contratação, como verificado nos casos do Prosoft e do Profarma e com a revitalização do FUNTEC, foram intensificadas, em 21 de dezembro de 2005, quando foi aprovada a revisão da Política Operacional do Banco. A partir de então, a introdução de inovações no processo produtivo brasileiro passou a ser uma prioridade do BNDES, o que esteve associado a novas regras contratuais, à criação de linhas de crédito específicas e à estipulação de um custo diferenciado para estes financiamentos.

Subjacente a esta alteração estava a percepção de que o apoio às inovações configurava a nova tarefa a ser desempenhada pela atuação desenvolvimentista do Estado. O próprio texto de apresentação da nova Política Operacional procurava enfatizar a consolidação desta nova fase, ressaltando que, assim como ocorrido em outros momentos da história, o Banco dava início a um novo capítulo na indução do capitalismo brasileiro. Desta vez, o ineditismo não ficaria por conta da indústria de infra-estrutura, como ocorrido no Plano de Metas, ou da indústria de base, como verificado no II PND, mas sim pelo apoio à competitividade e às inovações. Em certa passagem, o texto de abertura do documento traz a seguinte avaliação da intervenção do Banco:

Ao longo de sua história, de mais de 50 anos, o conteúdo concreto destes grandes objetivos foi, diversas vezes, revisto. Há fortes indícios de que o BNDES se encontre hoje, mais uma vez, diante de um destes momentos históricos, em que os seus objetivos estratégicos devem ser redefinidos e atualizados (...). No que toca ao apoio à exploração de novas oportunidades, a aceleração, por toda parte, das mudanças tecnológicas, e a ela associada, a agilização da competição, impõem à economia brasileira rápidos avanços no que concerne à geração e difusão de inovações. $\mathrm{O}$ apoio do Banco privilegiará, neste terreno, a exploração de possibilidades de avanço (por vezes já antevistos pelas empresas) que na longa quase-estagnação que a economia brasileira começa a superar, não puderam ser aproveitadas. A estas possibilidades, até o presente reprimidas, combinam-se muitas outras a serem detectadas e exploradas. Essas oportunidades conformam uma nova fronteira de crescimento, centrada na inovação e, portanto, plenamente sintonizada com a Política Industrial, Tecnológica e de Comércio Exterior (PITCE) lançada pelo Ministério do Desenvolvimento, Indústria e Comércio, em março de 2004. Alguns avanços em direção à inovação já vêm inegavelmente sendo feitos no âmbito do BNDES (como, por exemplo, mediante o Profarma). Daqui por diante, contudo, o apoio à inovação além de não 
ficar restrito a segmentos tecnologicamente sofisticados da indústria, passa a constar entre as prioridades máximas do BNDES $^{433}$.

A afirmada prioridade conferida à inovação com a nova Política Operacional foi materializada em três instrumentos institucionais: (i) uma nova regra para definição dos custos dos financiamentos; (ii) parâmetros contratuais flexíveis e (iii) linhas de crédito específicas. Foram então criadas duas linhas de crédito, em caráter permanente, para financiar os desembolsos destinados a apoiar projetos de inovação: a linha denominada "Inovação P, D e I" e uma outra chamada "Inovação Produção". As duas contavam com um custo financeiro pré-definido, com condições mais favoráveis do que as verificadas nas contratações de tipo padrão. A linha de crédito "Inovação P, D e I", por exemplo, apresentava uma taxa de juros fixa de $6 \%$ (um valor inferior a TJLP), a ser adicionada ao spread (percentual de risco) do agente tomador. ${ }^{434}$

O mesmo se passava com a linha de crédito "Inovação Produção", que foi classificada pela nova Política Operacional como prioridade de nível "AA" - o que reduziu o custo final de suas colaborações financeiras. A rigor, com esta nova Política, o BNDES passou a trabalhar com 5 níveis de prioridade. Para cada uma delas, havia uma correspondente taxa de remuneração do Banco. Particularmente, para as operações enquadradas na linha "Inovação Produção", passava a haver uma isenção da cobrança dos custos operacionais do Banco, fazendo com que o custo final de seu crédito fosse composto apenas pela TJLP e pelo spread de risco do agente tomador. O quadro a seguir apresenta esta relação entre os níveis de prioridade e o custo repassado para o solicitante.

\begin{tabular}{|c|c|}
\hline \multicolumn{2}{|c|}{ QUADRO 14 } \\
REMUNERAÇÃo BÁSICA DO BNDES PELO NÍVEL DE PRIORIDADE \\
Nível de Prioridade & Custo da Remuneração \\
\hline AA & $0,0 \%$ ao ano \\
\hline A & $1,0 \%$ ao ano \\
\hline B & $1,5 \%$ ao ano \\
\hline C & $2,0 \%$ ao ano \\
\hline D & $3,0 \%$ ao ano \\
\hline Fonte: Políticas Operacionais (2005), BNDES \\
\hline
\end{tabular}

${ }^{433}$ BNDES, Políticas Operacionais, 2005. pp. 5-6.

${ }^{434}$ Normalmente as operações de colaboração financeira do BNDES têm a seguinte composição de custos: custo de captação dos recursos (via de regra TJLP) + spread do agente + custo operacional do Banco. 
Ambas as linhas de colaboração financeira, ao apresentarem uma disciplina de custos inferiores ao verificado nas contratações padrão, continham um propósito indutivo, voltado a fomentar as operações de crédito dedicadas à inovação. Exemplo disso foi a reação do Banco à redução da TJLP, pelo Conselho Monetário Nacional, que chegou ao patamar de 6,5\% ao ano em 2007: o BNDES entendeu por bem ampliar os incentivos para ambas as linhas de crédito e reduziu a taxa de juros para projetos de inovação para 4,5\% ao ano. Na realidade, como a intenção destas linhas era gerar uma discriminação financeira positiva ao crédito para inovação, a redução do custo da TJLP impulsionou este maior desconto para as taxas de inovação, sob pena de se dissiparem os benefícios desta contratação. O menor custo dos recursos estava também associado a regras contratuais mais flexíveis, desenhadas para aplacar as incertezas associadas a estes empreedimentos. A alteração mais relevante foi a supressão da exigência de garantias reais nas operações de crédito com valores de até $\mathrm{R} \$ 10$ milhões. Com isso, foi removida uma obrigação que podia ser um obstáculo para empresas detentoras de projetos portadores de futuro, mas desprovidas de bens físicos para assegurar o crédito.

Ao fim deste ano de 2007, ambas as linhas contavam já com um volume de aprovações e de liberações expressivo. ${ }^{435}$ Só o montante efetivamente desembolsado alcançava cerca de R $\$ 130$ milhões (cento e trinta milhões de reais), indicando assim que as operações de crédito, formalizadas em contratos com características relacionais, também poderiam ser utilizadas como veículos de financiamento das inovações, ao lado das participações societárias.

${ }^{435}$ Cf. FINGERL, Eduardo Rath. Congresso ABVCAP 2008 - investimento, energia e infra-estrutura, apresentação de PowerPoint, paper mimeo, 2008. 


\begin{tabular}{|c|c|c|c|c|c|c|}
\hline \multicolumn{7}{|c|}{$\begin{array}{c}\text { QUADRO } 15 \\
\text { DESEMIBOLSOS BNDES - (VALORES EM R\$) }\end{array}$} \\
\hline ANO & FUNTEC & CRIATEC & $\begin{array}{c}\text { INOVAÇÃO } \\
\text { PD\&I }\end{array}$ & $\begin{array}{l}\text { INOVAÇÃO } \\
\text { PRODUÇÃO }\end{array}$ & $\begin{array}{l}\text { PROFARMA } \\
\text { INOVAÇÃO }\end{array}$ & $\begin{array}{l}\text { PROSOFT } \\
\text { EMPRESA }\end{array}$ \\
\hline 1999 & - & - & - & - & - & 4.300 .000 \\
\hline 2000 & - & - & - & - & - & 12.775 .000 \\
\hline 2001 & - & - & - & - & - & 9.335 .000 \\
\hline 2002 & - & - & - & - & - & 17.467 .125 \\
\hline 2003 & - & - & - & - & - & 5.064 .487 \\
\hline 2004 & - & - & - & - & - & 5.346 .747 \\
\hline 2005 & - & - & - & - & 6.000 .000 & 66.903 .234 \\
\hline 2006 & 2.754 .043 & - & - & 5.600 .311 & 4.551 .000 & 52.380 .030 \\
\hline 2007 & 20.647 .312 & 3.200 .000 & 19.572 .894 & 110.581 .072 & 4.014 .991 & 138.769 .576 \\
\hline Jun/2008 & 31.345 .557 & 800.000 & 21.339 .942 & 28.048 .719 & 2.432 .370 & 118.971 .182 \\
\hline TOTAL & 54.746 .913 & 4.000 .000 & 40.912 .836 & 144.230 .102 & 16.998 .362 & 431.312 .380 \\
\hline
\end{tabular}

Fonte: BNDES

Em 2008, em virtude da implementação da Política de Desenvolvimento Produtivo, as linhas "Inovação P, D e I" e "Inovação Produção" foram substituídas por novas linhas de crédito, intituladas "Inovação Tecnológica" e "Capital Inovador". A linha Inovação Tecnológica, volta-se a financiar os projetos de inovação das firmas solicitantes e para tanto conta com dois veículos: as operações de renda variável e as operações de renda fixa - com taxas de juros de 4,5\% ao ano (inferior ao valor da TJLP) e com a possibilidade de dispensa das garantias reais. Já a outra linha de crédito, "Capital Inovador", representa uma mudança de paradigmas nas colaborações financeiras do Banco: o objeto de suas contratações não é um produto ou um projeto específico, como uma máquina ou um equipamento, mas um ativo imaterial: a capacidade de inovação das empresas. O objeto de sua contratação é a própria empresa, a sua capacidade em se tornar um agente permanente de inovação: trata-se de uma espécie de "meta-financiamento". O fim último da intervenção é o de constituir um ambiente sistêmico de inovação na empresa tomadora, capaz de promover permanentemente a sua competitividade. ${ }^{436}$

\footnotetext{
${ }^{436}$ A descrição oficial da linha é a seguinte: "objetivo: apoiar empresas no desenvolvimento de capacidade para empreender atividades inovativas em caráter sistemático. Isso compreende investimentos em capitais tangíveis, incluindo infra-estrutura física, e em capitais intangíves (*). Tais investimentos deverão ser consistentes com as estratégias de negócios das empresas e ser apresentados conforme modelo de Plano de Investimento em Inovação (PII)." Descrição apresentada em http://www.bndes.gov.br/inovacao/default.asp, acesso em 04.12.08.
} 


\subsection{CAPITAL DE RISCO: INTENSIFICAÇÃO E ABRANGÊNCIA DAS INTERVENÇÕES}

Diferentemente do que se passou com as operações de renda fixa, as de renda variável já contavam, desde o CONTEC, com um aparato jurídico-institucional customizado para as empresas emergentes e inovadoras. As virtudes da participação societária, as regras de monitoramento e as alternativas de desinvestimento, como verificado no caso do resgate paulatino das ações, já eram mecanismos conhecidos pelo Banco. O mesmo se passava com os fundos de investimentos, concebidos pelo próprio BNDES cerca de dez anos antes da PITCE. Por tal razão, o efeito da política industrial foi majoritariamente de intensificar a predisposição do Banco em atuar como venture capitalist e como indutor do mercado de capitais de risco - as ferramentas já tinham sido constituídas.

Nesse passo, em abril de 2005, foi introduzida uma importante modificação na organização institucional do Banco, que esteve associada a um incremento das operações com renda variável, dirigidas às empresas emergentes: foi criada uma área específica de mercado de capitais. A partir daquele momento, as operações com valores mobiliários passaram a contar com um corpo destacado de técnicos, o que facilitaria a estruturação e o acompanhamento das operações ${ }^{437}$. Dando seguimento a estas modificações, esta Área de Mercado de Capitais foi, ainda, subdividida, em 2008, e passou a contar com uma superintendência exclusivamente dedicada às operações com empresas emergentes: a Superintendência de Capital Empreendedor. A especialização da burocracia do Banco teve o propósito de concentrar uma experise naquelas operações que, como visto, apresentam especificidades em relação às demais formas de financiamento corporativo, sobretudo, no que diz respeito à necessidade de monitoramento do negócio. ${ }^{438}$

Essas alterações na organização burocrática do BNDES estiveram associadas a uma maior participação do Banco nas operações com empresas emergentes e inovadoras,

\footnotetext{
${ }^{437}$ Sobre isso diz o Relatório Anual do BNDES de 2005: "A Área de Mercado de Capitais (AMC) foi criada em abril de 2005 e começou a operar um mês depois. A sua criação decorreu da necessidade de aprimorar e desenvolver as operações de renda variável do Sistema BNDES, apoiando e enfatizando o pequeno investidor, em consonância com a política industrial do governo federal. Nesse sentido, destaca-se a formação do Departamento de Inovação em Pequenas e Médias Empresas e Fundos de Investimento (DEIN)." Ver BNDES, Relatório Anual 2005, p. 70, disponível em www.bndes.gov.br, acesso em 21.05.08

${ }^{438}$ A informação sobre a divisão da área de mercado de capitais e as justificativas para a criação de uma área especializada em empresas emergentes foi apresentada por Fábio Sotelino, o Superintendente dessa nova área de Capital Empreendedor, em entrevista realizada na sede do BNDES, em 17.07.2008.
} 
seja na constituição de fundos de investimento, seja nas participações societárias diretas. Em 2008, por exemplo, o Banco participava de 15 fundos, do total de 28 registrados na CVM. Nas operações diretas a atividade foi igualmente crescente. Os dados abaixo indicam um aumento do engajamento na subscrição de valores mobiliários de firmas inovadoras, entre 2005 e 2008. Além disso, em comparação com números contabilizados pelos cinco anos iniciais do CONTEC, entre 1991 e 1996, é bastante evidente a ampliação relativa do volume de colaborações financeiras, nos anos posteriores a 2005. Afora o crescimento dos aportes de recursos, só no biênio 2006 e 2007, o número total de operações de capital de risco superou a quantidade de negócios realizados durante os cinco anos do CONTEC.

Participação do BNDES no setor de Venture Capital (participação direta e via fundos)

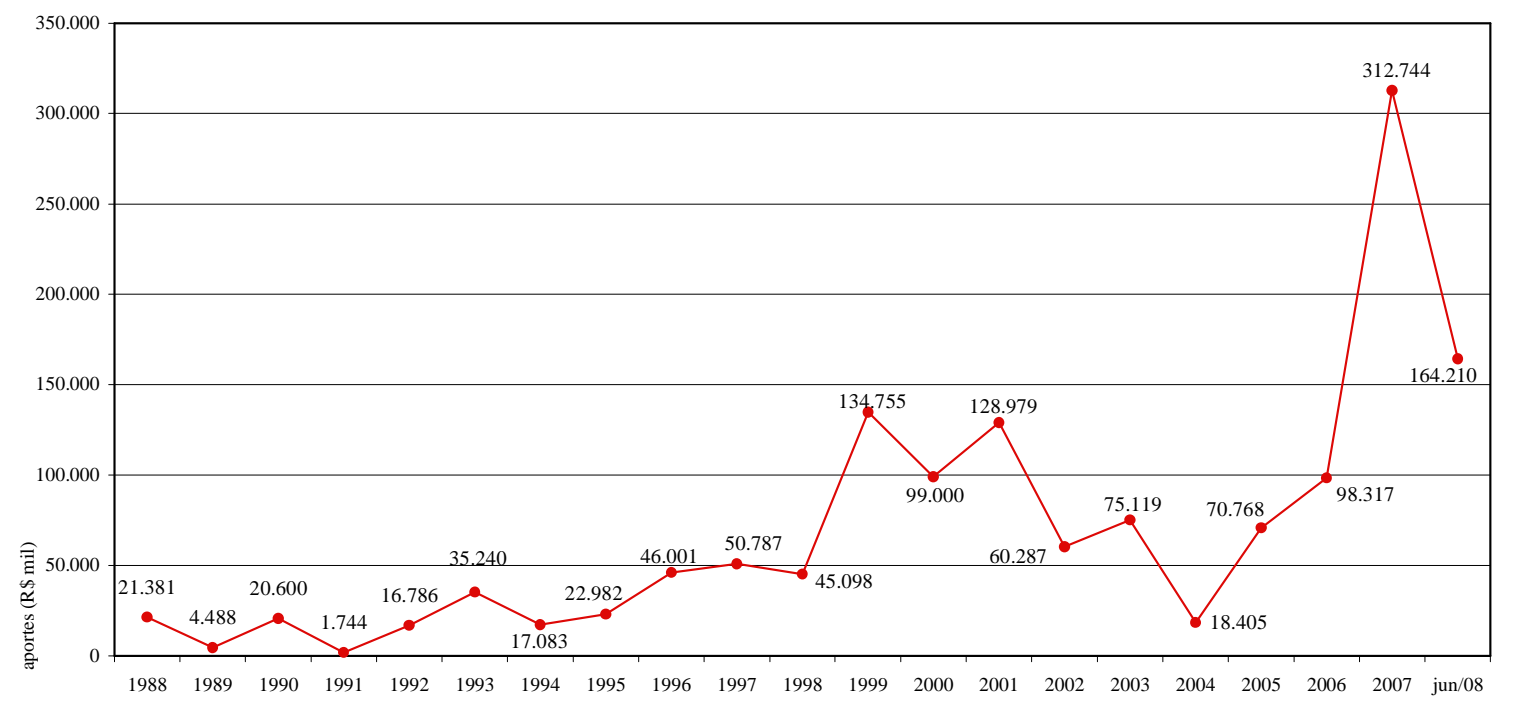

Gráfico 5. Fonte: BNDES.

Com relação às ferramentas jurídicas utilizadas nas operações com valores mobiliários, curiosamente, voltou a ganhar proeminência, neste período, a subscrição de ações. Muito embora a experiência do CONTEC tenha apontado as virtudes das debêntures, que se mostraram um veículo flexível, capaz, inclusive, de admitir pagamentos aos moldes da renda variável (sem juros fixos), as operações recentes com capital de risco têm privilegiado as ações. Tal se deve, a uma mudança de entendimento dos gestores da Área de Mercado de Capitais, que passaram a conceber a debênture como uma alternativa menos favorável: por se tratar de dívida, ainda que conversível, a emissão de debênture 
pode comprometer a capacidade de endividamento das empresas, dificultando, por exemplo, a captação de recursos para o capital de giro. ${ }^{439}$

Seja como for, o fato é que as participações diretas têm sido feitas, preferencialmente, pela via acionária. Esta subscrição de ações, por sua vez, tem sido acompanhada da previsão de algumas regras societárias específicas, voltadas a preservar os direitos do BNDES. O quadro a seguir apresenta um resumo de algumas destas regras, assim como dos veículos utilizados para os investimentos e os principais meios empregados nos desinvestimentos. Em particular, as regras de governança têm procurado garantir mecanismos de liquidez (possibilidades de se desfazer da sociedade), formas de monitoramento e o direito de aprovar previamente a realização de negócios que tenham impacto na gestão da sociedade investida.

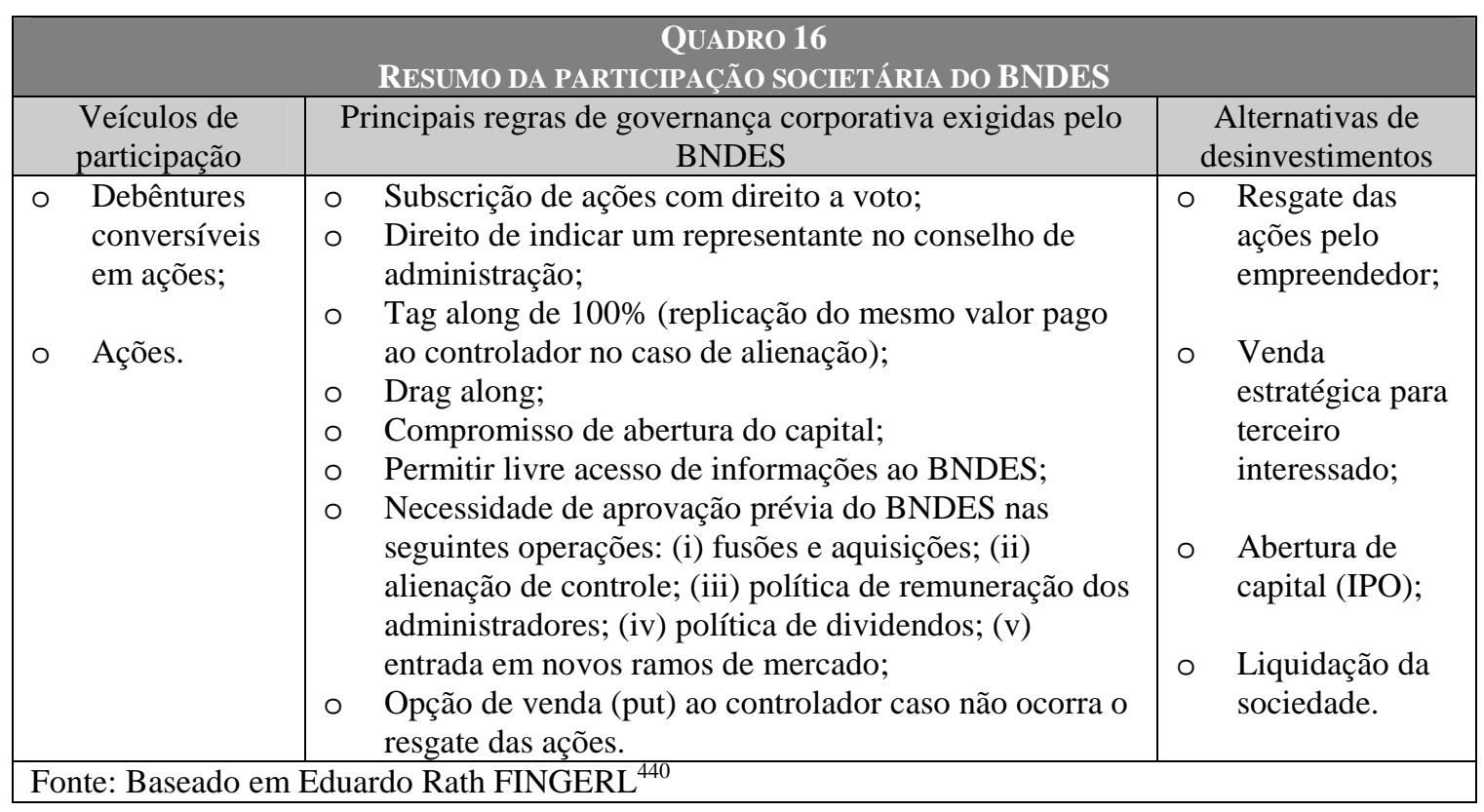

A inovação neste período foi a constituição de um fundo de investimento para empresas nascentes - o CRIATEC, em 2007, que significou uma ampliação na abrangência dos programas de capital de risco. ${ }^{441}$ Em relação aos demais fundos de investimentos em

\footnotetext{
${ }^{439}$ Informação apresentada em entrevista, realizada no dia 17.07.2008, com Fábio Sotelino - Superintendente da Área de Capital Empreendedor do BNDES.

440 FINGERL, Eduardo Rath. Desenvolvendo a Governança Corporativa, 2006, apresentações da Alta Administração do BNDES, disponível em www.bndes.gov.br, acesso em 21.05.08.

${ }^{441}$ O CRIATEC conta com um capital comprometido de R $\$ 80$ milhões, empregados pelo BNDES. No processo de constituição do CRIATEC, o BNDES selecionou no mercado, por meio de um processo seletivo,
} 
empresas emergentes, a diferença do CRIATEC fica por conta de dois atributos: (i) o foco de sua política de investimento e (ii) a sua forma de governança. Quanto à sua política de investimentos, trata-se de um fundo de "capital semente" (seed money), ou seja, os seus recursos são dirigidos para empresas nascentes, ainda mais incipientes do que as companhias emergentes. Tais empresas apresentam uma constituição bastante recente, figurando muitas vezes, ainda, como agentes incubados nos projetos tecnológicos de universidades e institutos científicos e tecnológicos. Em razão deste foco de atuação, o CRIATEC procurou constituir um aparato de governança capaz de garantir capilaridade na seleção e no correspondente monitoramento das empresas. Para tanto, além do Gestor central, o consórcio privado formado pela Antera Gestão de Recursos e pelo Instituto de Inovação, escolhido pelo BNDES por meio de um processo seletivo, o fundo conta também com gestores regionais, dedicados a prospectar novas oportunidades de negócio em diversas localidades do país, como Florianópolis, Campinas, Rio de Janeiro, Belo Horizonte, Fortaleza e Belém ${ }^{442}$.

O setor de "capital semente" constitui uma das maiores falhas do mercado de capitais de risco. Tanto nos países da OCDE, como, principalmente, nos países subdesenvolvidos, este tipo de recurso é o que mais encontra resistência entre os investidores. Isso se deve ao fato de que as empresas nascentes apresentam um porte econômico e um nível de consolidação bastante frágil, o que impõe uma taxa de risco ainda mais elevada do que as já verificadas nos empreendimentos iniciais (start up). No caso brasileiro esta tendência é corroborada pelos indicadores apresentados pelo Censo Brasileiro de Private Equity e Venture Capital, de todas as fases do capital de risco, a fase "semente" é, de fato, a mais carente de recursos: das 204 empresas que receberam capital de risco, no Brasil, durante o período de realização do Censo, apenas 36 destas, ou seja $11,8 \%$, situavam-se no estágio de capital semente. ${ }^{443}$ Há nesse programa, portanto, uma espécie de atuação desbravadora do BNDES que, assim como realizado no âmbito do

um consórcio privado, formado pela Antera Gestão de Recursos e pelo Instituto de Inovação, para ser o gestor do fundo (uma espécie de general partner). A este consórcio foi incumbida a gestão da política financeira do CRIATEC, estabelecida pelo cotista no Comitê de Investimentos. Ver www.bndes.gov.br/programas/outros/criatec.asp

${ }^{442}$ Sobre o CRIATEC ver www.fundocriatec.com.br e www.bndes.gov.br/programas/outros/criatec.asp

${ }^{443}$ Dados apresentados em CARVALHO, Antonio Gledson de; RIBEIRO, Leonardo de Lima \& FURTADO, Cláudio Vilar. A Indústria de Private Equity e Venture Capital, op. cit., p. 35. 
CONTEC há quase 20 anos, parece procurar lançar as bases para um novo segmento financeiro no setor de capital de risco brasileiro.

\section{EXEMPLOS DA DUPLA ATUAÇÃo DO BNDES: A PARTICIPAÇÃo SOCIETÁRIA NA LUPATECH S.A. E A INDUÇÃO DO BOVESPA MAIS}

Como relatado nas passagens anteriores, a atuação do BNDES no financiamento da nova economia tem contado com duas intervenções complementares: (i) a atuação direta, seja por meio das operações de renda fixa, seja principalmente pelas operações de renda variável e (ii) a atuação indireta, verificada nas articulações destinadas a constituir um segmento de capital de risco no país. Para ilustrar com detalhe ambas estas formas de ação, convém descrever dois casos paradigmáticos, que resumem as iniciativas do BNDES, ante os imperativos da nova economia: os casos da Lupatech S.A. e do Bovespa Mais. Enquanto a Lupatech S.A. representa uma típica e bem sucedida atuação direta do Banco, o Bovespa Mais é uma manifestacão de sua intervenção indutora, voltada ao fomento deste mercado na economia nacional.

A Lupatech S.A. é uma empresa do Rio Grande do Sul, formada na década de 1990 (precisamente em 1995), cujo plano de negócios propunha-se a estabelecer peças de complexidade tecnológica, na área de infra-estrutura da indústria de energia. A empresa dedica-se à produção de válvulas para a exploração de gás e petróleo, em águas profundas, e cabos para a ancoragem de plataformas de exploração de petróleo - empreendimentos que contam com atividades intensas de pesquisa e desenvolvimento na área de engenharia.

A sua relação com o BNDES se estabeleceu em 2001, quando a empresa emitiu o montante de $\mathrm{R}$ \$ 7,085 milhões (sete milhões e oitenta e cinco mil reais) em debêntures conversíveis. Em setembro de 2003, este estoque de debêntures foi convertido em ações e o Banco passou a ser acionista da Lupatech S.A. Ainda em setembro de 2003, a empresa realizou uma segunda emissão de debêntures, igualmente conversiveis em ações, no valor de R\$ 8 milhões (oito milhões de reais) e que vieram a ser convertidas em ações, em dezembro de 2005 . $^{444}$

${ }^{444}$ Informação apresentada, em comunicação eletrônica, por Nestor Perini, Presidente da Lupatech S.A. 
O desinvestimento do BNDES ocorreu em março de 2006, quando a empresa abriu o capital (realizou um IPO) no Novo Mercado, da BOVESPA. Na ocasião, a emissão primária de ações foi equivalente a R \$ 155,049 milhões (cento e cinqüenta e cinco milhões e quarenta e nove mil reais), dos quais o fundo de pensão Petros passou a ser titular de $6,87 \%$ e outros acionistas, dispersos no mercado, passaram a deter 52,03\% do capital social. Nesta operação, a participação do BNDES recuou de 19,8\% para 11,48\% das ações da Lupatech S.A., indicando que, conquanto o Banco não tenha se desfeito de toda a sua participação, alienou uma parcela de seu bloco acionário como forma de recuperar os investimentos feitos até então. ${ }^{445}$ Como, no entanto, o Banco seguiu na empresa, na qualidade de acionista, permaneceu com um assento em seu Conselho de Administração, confirmando assim a política de acompanhamento societário definida alguns anos antes, quando do desenho do CONTEC.

\begin{tabular}{|c|c|}
\hline \multicolumn{2}{|c|}{ QUADRO 17} \\
\hline Nestor Perini & Presidente \\
\hline Clovis Meurer & Conselheiro independente \\
\hline José Teófilo Abu-Jamra & Conselheiro \\
\hline Luiz Gonzaga de Mello Belluzzo & Conselheiro independente \\
\hline Fabio Sotelino da Rocha & Suplente - representante do BNDES \\
\hline Marcelo Cabrera da Costa $^{446}$ & Conselheiro - representante do BNDES \\
\hline José Mauro Mettrau Carneiro da Cunha & Conselheiro independente \\
\hline José Coutinho Barbosa & Conselheiro independente \\
\hline
\end{tabular}

Os desdobramentos ocorridos no caso da Lupatech S.A. e com algumas outras empresas apoiadas pelo BNDES, como a Bematech S.A., que realizaram a abertura de capital no mercado de valores mais exigente da BOVESPA (Novo Mercado) são relativamente inusuais, em relação aos registros da literatura de venture capital. Como já tratado neste trabalho, o caráter ainda incipiente das empresas emergentes, associado à menor liquidez de suas ações, faz com que a sua listagem em mercados de valores

\footnotetext{
445 As informações relativas à composição da empresa após a abertura do capital são apresentadas em http://www.lupatech.com.br/lupatech/ri/index_pt.html, acesso em 25.12.2008.

${ }^{446}$ No site da Lupatech S.A., Marcelo Cabrera da Costa é apresentado como um dos responsáveis pela criação do CONTEC. A sua presença no Conselho de Administração de uma empresa beneficiária dos aportes de venture capital, sugere uma consolidação do programa: "Marcelo Cabrera da Costa: Graduado em contabilidade pela UFRJ, o Sr. Cabrera iniciou no BNDES como analista de investimentos em 1980 e em 1991 ele foi parte do grupo que criou o Programa Contec que direcionou as decisões de investimento do BNDESPAR no capital social de pequenas e médias empresas operando no setor de tecnologia. Em 1994, ele se tornou gerente do BNDES e participou no lançamento do primeiro fundo de empresas emergentes no Brasil. Em 2005 ele foi promovido a Diretor de Departamento do BNDES na área de mercado de capitais." Ver http://www.lupatech.com.br/lupatech/ri/index_pt.html, acesso em 25.12.2008.
} 
disputados por empresas já consolidadas seja, muitas vezes, uma opção inviável - daí o porquê de iniciativas voltadas a constituir espaços institucionais adequados ao perfil de empresas de tecnologia, é este o caso da norte-americana NASDAQ e da européia EASDAQ.

Partindo desse mesmo diagnóstico, a BOVESPA, em março de 2006, deu sequiência à proposta de criação de um ambiente bursátil propício às operações de empresas emergentes: instituiu o BOVESPA MAIS. Trata-se de um mercado que, aos moldes da SOMA, tende a facilitar a chegada destas firmas ao mercado, contando para isso com uma menor quantidade de exigências regulatórias e com facilidades, para auxiliar a completa profissionalização de sua estrutura de governança: as empresas que vierem a ser listadas no BOVESPA MAIS poderão contar, por exemplo, com cursos de formação para a relação com os investidores, dedicados aos gestores da empresa e também com o auxílio de consultores independentes, contratados pela BOVESPA, para analisarem o seu desempenho.

\begin{tabular}{|c|c|}
\hline $\begin{array}{r}\text { QUAI } \\
\text { COMPARAÇÂ } \\
\text { NOVO MERCADC }\end{array}$ & $\begin{array}{l}18 \\
\text { DE REGRAS } \\
\text { BOVESPA MAIS }\end{array}$ \\
\hline Novo Mercado & Bovespa Mais \\
\hline $\begin{array}{l}\text { Conselho de Administração com no mínimo cinco } \\
\text { membros, dos quais } 20 \% \text { devem ser independentes }\end{array}$ & $\begin{array}{l}\text { Não há exigência de cinco membros e nem de } \\
\text { conselheiros independentes }\end{array}$ \\
\hline $\begin{array}{l}\text { Demonstrações financeiras em padrão internacional } \\
\text { (IFRS ou USGaap) }\end{array}$ & $\begin{array}{c}\text { Aceita-se o padrão nacional BRGaap, para as } \\
\text { demostrações financeiras }\end{array}$ \\
\hline Tradução das informações trimestrais para o inglês & Não é obrigatória a tradução \\
\hline Circulação (free float) de $25 \%$ das ações & $\begin{array}{l}\text { A empresa tem até sete anos para obter um free } \\
\text { float de } 25 \%\end{array}$ \\
\hline $\begin{array}{l}\text { Obrigatoriedade de dispersão nas distribuições } \\
\text { públicas }\end{array}$ & $\begin{array}{c}\text { A empresa não é obrigada a dispersar os seus } \\
\text { valores mobiliários, pode realizar operações } \\
\text { concentradas }\end{array}$ \\
\hline
\end{tabular}

Sucede que até o início de 2008, o BOVESPA MAIS não detinha nenhuma empresa listada. Para alavancar o início de suas operações, foi articulada, entre os agentes do mercado financeiro, uma primeira operação de abertura de capital - da empresa NUTRIPLANT S.A., uma firma paulista dedicada ao ramo de micronutrientes para o setor de fertilizantes. A abertura do capital ocorreu em 13 de fevereiro de 2008 e contou com o BNDES como um dos adquirentes de $10,79 \%$ das ações colocadas na Bolsa. 
Nesta operação, a entrada do BNDES ocorreu na fase de desinvestimento, aparentemente um momento extemporâneo para a atuação de um venture capitalist. Qual a justificativa para isso? Na realidade, a participação do Banco nesse caso teve outra racionalidade: o alvo da intervenção não era propriamente a Nutriplant S.A. Tratava-se, isto sim, de uma atuação motivada por razões diferentes, das que justificaram a sociedade com a Lupatech S.A.: a finalidade da aquisição destas ações foi a de permitir a realização do negócio, para assim desbravar o BOVESPA MAIS - que ainda conta apenas com a Nutriplant S.A. como única empresa listada. Cuidou-se, portanto, de um tipo de intervenção vinculado à criação de mercado e que, assim sendo, detém a mesma concepção indutora presente nos esforços de criação da SOMA e, em alguma medida, na constituição dos fundos de investimento. ${ }^{447}$

\section{CONSIDERAÇÕES FINAIS}

Desde meados dos anos 1990, o BNDES tem definido um novo estoque de ferramentas jurídicas, dedicadas ao financiamento de empresas emergentes e inovadoras. A partir das iniciativas de um programa piloto, o CONTEC, instituído em 1991, o Banco tem administrado uma intervenção modulada para as especificidades da nova economia, contando para isso com regras de governança e veículos financeiros que propiciam injeção de capital, capacidade de monitoramento e rotas de saída compatíveis com o teor de incerteza que ronda os investimentos em inovação. Para tanto, as ferramentas forjadas nesse campo provém de ramos privados do direito, notadamente os direitos societário e contratual. Não à toa, tratam-se de dispositivos afinados com a atuação dos demais agentes de mercado, que têm no BNDES um relevante parceiro, seja como investidor direto, seja como indutor deste segmento.

\footnotetext{
${ }^{447}$ Foi este o tom do noticiário especializado. Em matéria do dia 20 de junho de 2008, a Gazeta Mercantil apresentava a possbilidade de o Banco repetir a operação da Nutriplant com outras empresas, como a Teikon e BRQ. Na matéria intitulada "BNDES pode alavancar lista do Bovespa Mais", constava a seguinte descrição: "o BNDESpar pode ser, indiretamente, o grande alavancador da Bovespa Mais, o segmento da bolsa paulista destinado às empresas de menor porte que querem acessar o mercado de capitais. Na reunião com cerca de 200 analistas, investidores e consultores ontem na Bovespa, as interessadas na listagem Teikon e BRQ apresentaram expectativas e atuações distintas - mas com um fator comum. As duas empresas tiveram alavancagem com a entrada do BNDES na estrutura acionária, geralmente como debenturista, tomando fôlego para estudar o mercado de capitais. O banco de desenvolvimento também detém 10,79\% da Nutriplant, a única empresa listada na Bovespa Mais." Gazeta Mercantil, 20 de junho de 2008, investnews.
} 
Ao longo dos anos 2000, especialmente com a definição de duas políticas industriais - a PITCE, de 2004, e a PDP, de 2008, registra-se um adensamento de seu engajamento na provisão deste perfil de recursos. Ao lado das ferramentas forjadas na década anterior, constituíram-se outras alternativas, como os contratos de renda fixa e os montantes não reembolsáveis do FUNTEC. De todos estes, chama particularmente a atenção a composição do fundo CRIATEC, voltado a suprir uma carência do segmento de risco: o aporte de recursos para a fase "semente" das empresas. Além disso, o CRIATEC traz ainda um atributo que merece destaque: a seleção de um gestor privado para administrar a política de investimentos do fundo, uma iniciativa que vai ao encontro da lógica de parceria público-privada que tem embalado as intervenções do BNDES na área. $\mathrm{O}$ quadro abaixo faz um resumo dos principais programas e veículos de financiamento existentes.

\begin{tabular}{|c|c|}
\hline \multirow{2}{*}{ QUADRO SINÓTICO DAS FORMAS DE PARTICIPAÇÃo DO BNDES } \\
\hline Formas de financiamento & Veículos \\
\hline I) Recursos não reembolsáveis & Funtec \\
\hline \multirow{2}{*}{$\begin{array}{c}\text { II) Crédito às empresas } \\
\text { (operação de renda fixa) }\end{array}$} & Inovação P, D \&I / Inovação Tecnológica \\
\cline { 2 - 2 } & Inovação Produção / Capital Inovador \\
\cline { 2 - 2 } & Prosoft \\
\hline \multirow{2}{*}{ III) Apoio via Participação Societária } & Pundos para empresas emergentes \\
\cline { 2 - 2 } & Fundo para empresa semente - CRIATEC \\
\cline { 2 - 2 } & Participação direta do BNDES \\
\hline Fonte: BNDES & \\
\hline
\end{tabular}

Enfim, o sentido da atuação do BNDES nestes segmentos parece confirmar os apontamentos do capítulo 3 deste trabalho. O paradigma da economia baseada no conhecimento não só tem ensejado o florescimento de estratégias corporativas dedicadas às inovações e aos ativos imateriais, como também está articulado a um arranjo jurídicoinstitucional mais poroso à atuação dos agentes privados. É, pois, este o caso destas novas ferramentas jurídicas: embora manuseadas por um banco público, que cumpre um papel tipicamente desenvolvimentista, ao desbravar novos horizontes e possibilidades de negócio, podem ser igualmente utilizadas pelos agentes de mercado que, de mais a mais, também podem ser sócios do Banco, nos fundos de investimento. 


\title{
NOVOS PARÂMETROS PARA A INTERVENÇÃO DO ESTADO NA ECONOMIA: PERSISTÊNCIA E DINÂMICA DA ALTERNATIVA INSTITUCIONAL
}

\begin{abstract}
"O desenvolvimento econômico não ocorre por geração espontânea e o Brasil precisa da atuação do Estado para promover o aumento do bem estar da sociedade. De fato, o BNDES foi criado justamente por que o mercado não resolve tudo, isto é, certos setores e atividades estratégicos para a economia dependem do apoio do Governo para o seu desenvolvimento. Isto era verdade no passado e continua sendo verdade hoje. Obviamente, as necessidades da economia e as formas de atuação do BNDES mudam ao longo do tempo e nós devemos nos adaptar à realidade de hoje. Hoje o Estado precisa atuar mais na coordenação e no incentivo às decisões de mercado do que na intervenção direta na economia. Não se trata de voltar ao período em que o desenvolvimento econômico era capitaneado por empresas estatais. Trata-se, hoje, de desenvolver novas formas de atuação do Estado para promover o progresso tecnológico e social da economia, de modo consistente com a estabilidade fiscal e monetária, e em um contexto de maior abertura comercial e financeira do que no passado." (Guido MANTEGA, $\boldsymbol{O}$ BNDES e o Novo Ciclo de Desenvolvimento)
\end{abstract}

\section{INTRODUÇÃO}

A atuação do BNDES como banco de desenvolvimento tem sido uma espécie de metonímia do padrão brasileiro de organização financeira. Como tantas vezes descrito ao longo deste trabalho, a regulação institucional do Estado, materializada na provisão de recursos de longo prazo para os setores produtivos tem configurado uma alternativa institucional, construída nacionalmente e que por tal razão tem respondido às vicissitudes históricas e especificidades locais do país. Nessa medida, compõe com a mesma dignidade um universo de possibilidades de governança dos arranjos financeiros, de que são exemplos os sistemas baseados no mercado de capitais ou aqueles sustentados na predominância dos bancos universais ou principais. Uma vez afastada a régua estreita da Law and Finance, o banco de desenvolvimento e a atuação financeira do Estado deixam de ser entendidos como um desvio e passam, então, a ser compreendidos como uma solução jurídico-institucional, capaz de compensar as lacunas do mercado de crédito privado ou as oscilações erráticas do mercado de capitais, sobretudo nos países subdesenvolvidos. É este o caso do BNDES e do modelo brasileiro. 
O reconhecimento desta alternativa de organização financeira, que no caso brasileiro foi responsável pelo suprimento de crédito e de capital nas fases mais agudas do projeto desenvolvimentista industrial, não significa, todavia, uma acomodação inercial deste regime. Como descrito no terceiro capítulo desta tese, a crise do paradigma fordista trouxe consigo desafios institucionais, como, por exemplo, o reposicionamento do papel do Estado e de seus mecanismos de ação, diante de uma economia aberta, privatizada e carente de suporte para empresas emergentes e inovadoras. Essa alteração, vivenciada pelas economias nacionais desde os anos 1980 e 1990, foi particularmente relevante para os países que, como o Brasil, confiavam ao Estado um papel protagonista na organização econômica e financeira. Em outras palavras, se o rescaldo da afirmação de uma economia baseada no conhecimento representou uma desregulação financeira nas economias liberais de mercado, como a norte-americana, no caso brasileiro as medidas de revisão do papel do Estado atacaram o próprio pilar da governança financeira.

Um exemplo visível de tais alterações, que se sucederam à crise do paradigma fordista-desenvolvimentista, pode ser constatado na própria atuação do BNDES. Diferentemente do que ocorrera durante o Plano de Metas e o II PND, o Banco deixou de funcionalizar a sua intervenção para o atendimento de prioridades setoriais, previamente definidas pelo Governo Federal. Além disso, as políticas de concessão de crédito passaram a incluir análises de risco e deixaram assim de se basear exclusivamente no mérito pródesenvolvimento dos projetos financiados. Ao lado disso, não só o retorno dos empréstimos passou a deter importância para as operações do banco, como também ocorreu uma aproximação com o mercado de capitais. Em suma, a partir das décadas de 1980 e 1990, o Banco passou a atuar em linha com os agentes de mercado, ora se valendo deste ambiente para captar recursos, ora o utilizando como meio para a estruturar as operações financeiras com as empresas solicitantes. Os exemplos do CONTEC e da sua atuação como venture capitalist que ocorreu daí em diante, assim como as operações indiretas realizadas em parceria com os fundos de investimento privados, resultam desta alteração na sua forma de intervenção.

Tais modificações, que se passaram no contexto de um novo paradigma tecnoprodutivo, desafiam as categorias do direito econômico brasileiro, habitualmente dispostas a lidar com um Estado interventor e dotado de uma racionalidade jurídica substantiva, isto é, orientada pela persecução de resultados econômicos, definidos nos instrumentos de 
planejamento econômico. Como então tratar a atuação de um Banco de Desenvolvimento que assume parâmetros privados, mimetiza agentes de mercado, e a um só tempo desempenha um papel relevante na conformação de um ambiente financeiro favorável aos investimentos em inovação? A dúvida não se coloca sem razão: até há pouco a identidade do padrão financeiro baseado no Estado e a intervenção estatal desenvolvimentista, amparada nesta racionalidade substantiva, eram traços perfeitamente sobrepostos: o desenho do modelo nacional de governança corporativa servia aos propósitos de um modelo estatal de desenvolvimento. É com o desmonte do aparato desenvolvimentista, processado no Brasil na década de 1990, que aparecem as dificuldades de compreensão: de um lado, a intervenção pública não parece responder à mesma racionalidade e às mesmas características do período fordista-desenvolvimentista; de outro, a atuação do BNDES continua sendo relevante para o atendimento das novas demandas surgidas com $a$ economia baseada no conhecimento.

Partindo da literatura sobre os padrões de governança financeira e de uma revisão das categorias da teoria do direito, a finalidade deste último capítulo é justamente propor uma interpretação sobre o sentido desta atuação do Estado, por meio do BNDES. Para tanto, esta seção terá dois desafios. O primeiro deles é o de responder se, mesmo com as alterações provocadas pela economia baseada no conhecimento, há uma persistência do modelo brasileiro, isto é, se o Estado continua a desempenhar, de modo relevante, uma regulação institucional no âmbito do sistema finnceiro. O segundo deles é, uma vez demonstrada a persistência desta alternativa institucional, conceituar as alterações havidas na forma de intervenção do Estado. Ao final, espera-se com este capítulo encerrar o argumento da tese, indicando que - sim - o Estado persiste como um agente relevante da alternativa jurídico-institucional de organização financeira, mas há neste processo uma acomodação dinâmica, associada à mudança de paradigma econômico - daí o porquê do argumento de novos parâmetros para a intervenção do Estado na Economia.

\section{As ALTERAÇÕES NO SISTEMA FINANCEIRO NACIONAL E A PERSISTÊNCIA DA ALTERNATIVA INSTITUCIONAL DE ORGANIZAÇÃO FINANCEIRA}

Uma parcela considerável das operações de financiamento corporativo ocorridas no sistema financeiro brasileiro, como já mencionado ao longo deste trabalho, tem sido realizada pelos bancos públicos e em especial pelo BNDES. Sobretudo durante o período 
desenvolvimentista, que se estendeu entre 1950 e 1980, a intervenção direta do Estado como agente financeiro foi quem garantiu os recursos de longo prazo para as empreitadas industriais. Desta maneira, as instituições financeiras estatais acabaram por desempenhar um papel que, nos países desenvolvidos, foi tradicionalmente exercido pelos agentes privados, sejam os bancos, no contexto europeu continental, ou o mercado de capitais, no panorama anglo-saxão. No Brasil, em compensação, o mercado de capitais e o segmento bancário privado foram caracteristicamente tímidos ao prover recursos de longo prazo, compatíveis com as necessidades do nascente setor industrial. Essa circunstância reclamou uma atuação estatal pronunciada, capaz de dirimir a falha de ambos os mercados - o de créditos e o de capitais - viabilizando assim o funding necessário para a instalação de plantas industriais e para aquisição de novas tecnologias.

O modelo de desenvolvimento econômico forjado nesse ambiente contou, portanto, com uma ampla participação estatal, que compensou a ausência de capital privado com a mobilização e direção dos recursos, valendo-se para tanto dos mecanismos de poupança compulsória. Ao setor produtivo estatal coube a atribuição de suprir a ausência do agente privado em setores portadores de escala e detentores de uma intensidade de capital, o que representava uma barreira à entrada às companhias particulares. Já o setor financeiro estatal, sobretudo o BNDES, voltou-se a prover crédito e capital para as empresas públicas e privadas, dada a ausência de outras fontes financeiras. É em razão destes atributos que a variedade nacional de organização capitalista tem sua identidade associada à atuação econômica do Estado, que, no mais das vezes, cumpriu um elenco diversificado de tarefas, desde a provisão da produção até a garantia dos recursos, passando ainda pela promulgação de leis e regras, voltadas a proteger e estimular os setores considerados prioritários para o desenvolvimento da economia.

Desde meados dos anos 1990, entretanto, este arranjo jurídico-institucional que compôs a alternativa desenvolvimentista tem sido revisto e reformado, resultando assim em uma alteração no papel econômico exercido pelo Estado. Este processo de reformas econômicas, que contou com um abrandamento dos controles públicos sobre as ações da livre iniciativa, é concomitante com uma transição maior do próprio regime capitalista, identificada pela literatura empregada por este trabalho como a passagem de uma economia fordista para uma economia baseada no conhecimento. Mais do que a consolidação de um paradigma tecno-produtivo, notabilizado pela relevância das 
estratégias corporativas inovadoras, a economia baseada no conhecimento traduz também um rearranjo institucional. Concretamente, um dos resultados deste processo foi a relativização da preponderância da intervenção pública, que fôra um traço típico do contexto keynesiano-desenvolvimentista. A maciça privatização das empresas estatais é um confiável indicador da ocorrência deste fenômeno.

Notadamente no âmbito do setor financeiro brasileiro, estas transformações foram repercutidas na forma de reformas jurídico-institucionais, cujo resultado aparente pode sugerir uma redução da abrangência do segmento financeiro estatal, uma ampliação do setor bancário privado, em especial sob controle estrangeiro, e um aumento no volume das operações do mercado de capitais. À primeira vista, as modificações pelas quais passou o sistema financeiro indicariam uma descaracterização da alternativa institucional brasileira, de tal forma que a relevância dos bancos públicos e do BNDES, em especial, passaria a figurar como um evento pertencente ao passado. O modelo brasileiro apresentaria assim uma convergência com arranjos financeiros de países desenvolvidos, que são menos tributários do Estado e mais vinculados à atuação dos agentes privados.

No entanto, uma análise mais detida revela que o BNDES continua a desempenhar um papel relevante no desenvolvimento econômico do país, particularmente, ao conceder recursos para operações de maior risco e prazo de maturação, superando assim os limites ainda existentes no mercado financeiro privado. Particularmente, a consolidação do mercado de risco e a expansão de suas fronteiras para novas áreas, como no caso do programa CRIATEC (para empresas "sementes"), sugerem que o desbravamento das novas oportunidades financeiras conta, sobremaneira, com a intervenção do Estado, que persiste, portanto, como um dos elementos constitutivos da alternativa institucional brasileira, apesar das reformas econômicas recentemente processadas.

\subsection{AS REFORMAS ECONÔMICAS NO SISTEMA FINANCEIRO BRASILEIRO}

Seja em função da abertura da economia, que permitiu novas modalidades de captação de recursos, seja em razão da retração do aparato estatal, ou mesmo em virtude do programa de estabilização monetária - o Plano Real -, que reduziu drasticamente as taxas de inflação brasileiras, reclamando assim uma recomposição do segmento bancário, o fato é que o setor financeiro brasileiro acompanhou o ritmo das alterações institucionais 
sucedidas no país nas últimas duas décadas. ${ }^{448}$ Os resultados deste processo foram a privatização de parte dos bancos públicos, com a conseqüente redução da participação relativa do Estado no setor bancário, a ampliação da oferta privada de créditos, a internacionalização do sistema bancário brasileiro, além de um aumento do volume das operações de captação na bolsa de valores. Também fizeram parte deste panorama, as inovações introduzidas pelo BNDES, que, como visto, resultaram na adoção de novos mecanismos e na conformação de uma racionalidade diferenciada de atuação - mais afinada com o mercado de capitais.

Tais transformações estavam alinhadas às medidas de reorganização institucional dirigidas ao universo de instituições financeiras estatais. Com o encerramento do capítulo desenvolvimentista, o setor bancário público foi objeto de programas e políticas de reestruturação, seja na forma de privatização, seja no estímulo à adoção de condutas e regras de governança similares às dos bancos privados. Foi este o caso do PROES (Programa de Incentivo à Redução do Setor Público Estadual na Atividade Bancária), implementado pelo Governo Federal, em 1997, com vistas a incentivar a privatização dos bancos públicos estaduais. Pelas regras do PROES, instituído pela Medida Provisória ${ }^{\circ}$. 1.514-4, de 29 de novembro de 1996, os Estados da federação que aderissem ao programa receberiam um aporte de recursos necessários para recapitalizar as suas instituições financeiras, tornando-as aptas a serem privatizadas. O resultado alcançado foi expressivo: houve uma redução no número de bancos estaduais, que passaram de 32, em 1995, para 14, em $2003{ }^{449}$

Em 2001, os bancos públicos federais foram objeto de um programa semelhante, embora não tenha resultado na privatização ou na liquidação dos agentes financeiros federais. O PROEF (Programa de Fortalecimento das Instituições Financeiras Federais),

${ }^{448}$ Com o fim da inflação, os bancos perderam uma fonte de receitas que era proveniente da flutuação da moeda. Com isso, houve uma reorganização do sistema bancário; entre 1995 e 2002, 62 bancos múltiplos e 12 bancos comerciais deixaram de operar, o que aumentou a concentração do setor e reclamou a implementação de programas federais voltados a consolidar o setor. Foi o caso do PROER, para os bancos privados, do PROEF, para os bancos públicos federais e do PROES, para os bancos públicos estaduais. A esse respeito, ver CINTRA, Marcos Antonio Macedo. A reestruturação patrimonial do sistema bancário brasileiro e os ciclos de crédito entre 1995 e 2005, em CARNEIRO, Ricardo. A Supremacia dos Mercados e a política econômica do Governo Lula, São Paulo, UNESP, 2006, pp. 321-346.

${ }^{449}$ Cf. CINTRA, Marcos Antonio Macedo. A reestruturação patrimonial do sistema bancário brasileiro e os ciclos de crédito entre 1995 e 2005, op. cit. Ver também STALLINGS, Barbara \& STUDART, Rogério. Finance for Development - Latin America in Comparative Perspective, Economic Comission for Latin America and the Caribbean - UN, Washington, 2006, pp. 222-258. 
instituído pela Medida Provisória nº 2.196, de 28 de junho de 2001, também teve como propósito reestruturar o sistema bancário público e para tanto deu causa a um conjunto de reformas institucionais. Uma de suas primeiras medidas, de cunho regulatório, voltou-se às regras de supervisão dos bancos federais, com a finalidade de oferecer mecanismos de controle semelhantes aos existentes para os bancos privados: o PROEF incorporou os padrões de capitalização e endividamento estipulados nos acordos de Basiléia. Em linha com a alteração dos parâmetros de supervisão, o PROEF estimulou os bancos federais a adotarem comportamentos e instrumentos de governança inspirados nas instituições financeiras privadas, resultando, por exemplo, na incorporação de regras de governança corporativa pelo Banco do Brasil - uma das empresas estatais a dispor deste dispositivo de auto-controle societário. Além disso, no curso do programa, o Governo Federal procurou garantir a solvabilidade das instituições públicas ${ }^{450}$, e para tanto transferiu as dívidas de difícil recuperação para a uma nova sociedade estatal - a EMGEA (empresa gestora de ativos): uma sociedade de propósito específico, cuja criação foi autorizada pela Medida Provisória $n^{\circ}$. 2.196-3, de 24 de agosto de 2001 e que, entre outras coisas, assumiu as obrigações e responsabilidades da Caixa Econômica Federal, perante o Fundo de Garantia por Tempo de Serviço. ${ }^{451}$

A contra-face das reformas institucionais ocorridas nos bancos públicos foi a conseqüente redução deste segmento no conjunto do sistema financeiro nacional. Em 1996, por exemplo, os bancos estatais (incluindo bancos federais e estaduais) respondiam por $50,91 \%$ de todos os ativos do sistema financeiro nacional, enquanto os bancos privados detinham 38,28\% destes ativos. Em 2006, passados dez anos, período em que ocorreram as principais alterações institucionais, os bancos públicos passaram a deter $29,64 \%$ dos ativos do segmento financeiro, enquanto os bancos privados nacionais incrementaram a sua participação, respondendo por $47,12 \%$ do universo total. ${ }^{452}$

Algo semelhante ao verificado na composição patrimonial do setor bancário,

\footnotetext{
${ }^{450}$ Esta medida já havia sido implementada, em 1996, quando ocorreu uma operação de recapitalização do Banco do Brasil, por meio de um aporte de R $\$ 8$ bilhões (oito bilhões de reais), realizado parcialmente pelo Governo Federal e parcialmente pelo fundo de pensão PREVI. Cf. CINTRA, Marcos Antonio Macedo. A reestruturação patrimonial do sistema bancário brasileiro e os ciclos de crédito entre 1995 e 2005, op. cit. p. 326.

451 A esse respeito ver, CINTRA, Marcos Antonio Macedo. A reestruturação patrimonial do sistema bancário brasileiro e os ciclos de crédito entre 1995 e 2005, op. cit. e STALLINGS, Barbara \& STUDART, Rogério. Finance for Development, op. cit.

${ }^{452}$ Dados do Banco Central do Brasil, disponíveis em www.bcb.gov.br, acesso em 05.12.08.
} 
ocorreu com a oferta de crédito. No ano 2000, os bancos privados (nacionais e estrangeiros) disponibilizaram um montante de crédito superior ao fornecido pelas instituições financeiras públicas - invertendo assim um padrão de funcionamento do sistema bancário. Os dados do Banco Central do Brasil, apresentados na tabela abaixo, indicam que em 1996, os bancos públicos eram responsáveis por 58,09\% de todo o crédito bancário, ao passo que os bancos privados (nacionais e estrangeiros) figuravam com uma participação de $41,38 \%$. Já em 2006 , os bancos estatais passaram a responder por $31,88 \%$ do crédito, enquanto os bancos privados (nacionais e estrangeiros) ofertavam $65,86 \%$ dos empréstimos.

\begin{tabular}{|c|c|c|c|c|c|c|}
\hline \multicolumn{7}{|c|}{ QUADRO 20 } \\
\hline PARTICIPAÇÃO DAS INSTITUIC̃ÕES FINANCEIRAS NAS OPERAÇÕES DE CRÉDITO (\%) \\
\hline Tipo de Instituição & 1996 & 1998 & 2000 & 2002 & 2004 & 2006 \\
\hline Bancos Estaduis & 23,48 & 8,86 & 5,12 & 4,78 & 4,41 & 3,72 \\
\hline Banco do Brasil & 10,62 & 12,05 & 10,58 & 16,17 & 19,36 & 20,05 \\
\hline CEF & 23,99 & 32,31 & 28,74 & 7,61 & 7,48 & 8,11 \\
\hline $\begin{array}{c}\text { Bancos Privados } \\
\text { Nacionais }\end{array}$ & 31,87 & 30,97 & 31,66 & 39,73 & 41,31 & 40,18 \\
\hline $\begin{array}{c}\text { Bancos Controle } \\
\text { Estrangeiro }\end{array}$ & 9,51 & 14,88 & 19,75 & 29,94 & 23,82 & 25,68 \\
\hline \begin{tabular}{l} 
Cooperativas de Crédito \\
\hline Fonte: Banco Central do Brasil (www.bcb.gov.br)
\end{tabular} & 1,53 & 0,93 & 1,14 & 1,77 & 2,14 & 2,26 \\
\hline
\end{tabular}

Ainda no segmento bancário, a reorganização institucional processada desde o final do período desenvolvimentista esteve associada a um outro fenômeno - a internacionalização do setor. Tal como ocorrido em outros segmentos da economia nacional, também no setor bancário, a privatização foi acompanhada de uma ampliação da participação estrangeira, como se pode, aliás, notar com as operações de crédito, apresentadas no quadro 20, acima. Em dez anos, entre 1996 e 2006, o número de instituições financeiras sob controle estrangeiro quase dobrou, saltando de 25 para 48 unidades. Essa ampliação do número de atores sob controle estrangeiro também se refletiu na composição dos ativos do setor bancário: entre 1996 e 2006, este grupo passou do patamar de $10,51 \%$ dos ativos totais para $21,70 \%$ do total. $^{453}$

O dado curioso é que esta significativa internacionalização do setor bancário ocorreu a despeito do artigo 192 da Constituição Federal (que trata do sistema financeiro), cujo caput prescrevia (e prescreve) a necessidade de lei complementar para regular a participação do capital estrangeiro no sistema financeiro. Como esta lei complementar não

${ }^{453}$ Dados do Banco Central do Brasil, disponíveis em www.bcb.gov.br, acesso em 05.12.08. 
chegou a ser promulgada, o Governo Federal garantiu a realização desta reestruturação patrimonial contornado a ordenação constitucional. Para tanto, valeu-se de uma abertura contida no parágrafo único do art. 52 do Ato das Disposições Constitucionais Transitórias: a possibilidade de autorizar ad hoc, mediante decreto, a instalação de grupo financeiro internacional, caso isso fosse de interesse do governo ou uma obrigação prevista em acordos de reciprocidade internacional. Foi desse modo que se autorizaram as operações financeiras de bancos relevantes para o mercado bancário brasileiro, como o $\mathrm{HSBC}, \mathrm{ABN}$ AMRO e Santander, entre outros. A tabela a seguir permite uma avaliação da relativa internacionalização do setor bancário brasileiro, a despeito do comando constitucional e do conseqüente controle democrático. ${ }^{454}$

\begin{tabular}{|c|c|c|c|c|c|c|}
\hline \multicolumn{7}{|c|}{ QUADRO 21 } \\
\hline \multicolumn{2}{|c|}{ PARTICIPAÇÃO DAS INSTITUIC̃ES FINANCEIRAS COM CONTROLE ESTRANGEIRO (\%) } \\
\hline & 1996 & 1998 & 2000 & 2002 & 2004 & 2006 \\
\hline Número de instituições & 25 & 43 & 57 & 56 & 49 & 48 \\
\hline Participação no crédito & 9,51 & 14,88 & 25,16 & 29,94 & 25,12 & 25,68 \\
\hline $\begin{array}{c}\text { Participação nos } \\
\text { depósitos }\end{array}$ & 7,17 & 15,14 & 21,14 & 19,82 & 19,92 & 19,33 \\
\hline $\begin{array}{c}\text { Participação nos ativos } \\
\text { bancários }\end{array}$ & 10,51 & 18,38 & 27,41 & 27,38 & 22,43 & 21,70 \\
\hline $\begin{array}{c}\text { Participação no } \\
\text { patrimônio líquido }\end{array}$ & 11,41 & 21,86 & 28,31 & 32,89 & 27,09 & 18,47 \\
\hline Fonte: Banco Central do Brasil & & & & & \\
\hline
\end{tabular}

As alterações processadas no panorama bancário brasileiro, direcionadas a incrementar a parcela privada do mercado de crédito, tiveram paralelo nas modificações ocorridas no mercado de capitais. Também nesse ambiente foram adotadas medidas institucionais, voltadas a impulsionar o volume de captações de recursos. Assim como no setor bancário, o pressuposto de tais reformas foi o de fortalecer o mercado como espaço privilegiado para a realização de transações financeiras. Com isso, o financiamento

454 A vigente redação do art. 192 é a seguinte: "O sistema financeiro nacional, estruturado de forma a promover o desenvolvimento equilibrado do País e a servir aos interesses da coletividade, em todas as partes que o compõem, abrangendo as cooperativas de crédito, será regulado por leis complementares que disporão, inclusive, sobre a participação do capital estrangeiro nas instituições que o integram." (Redação dada pela Emenda Constitucional $n^{\circ} 40$, de 2003). Já o artigo 52 da ADCT, assim dispõe: "Até que sejam fixadas as condições do art. 192, são vedados: (Redação dada pela Emenda Constitucional $n^{\circ} 40$, de 2003) I - a instalação, no País, de novas agências de instituições financeiras domiciliadas no exterior; II - o aumento do percentual de participação, no capital de instituições financeiras com sede no País, de pessoas físicas ou jurídicas residentes ou domiciliadas no exterior. Parágrafo único. A vedação a que se refere este artigo não se aplica às autorizações resultantes de acordos internacionais, de reciprocidade, ou de interesse do Governo brasileiro." Note-se, portanto, que a internacionalização do setor ocorreu baseada em uma exceção contida no Ato das Disposições Constitucionais Transitórias, uma brecha jurídica como salienta Marcos CINTRA. Sobre esse ponto ver CINTRA, Marcos Antonio Macedo. A reestruturação patrimonial do sistema bancário brasileiro e os ciclos de crédito entre 1995 e 2005, op. cit. 
corporativo poderia passar a contar com uma fonte perene de recursos, reduzindo assim a dependência do segmento financeiro público.

As principais modificações jurídico-institucionais ocorridas no mercado de capitais foram processadas nos primeiros anos da década de 2000, alguns anos mais tarde, portanto, do que as alterações introduzidas no setor bancário. No plano legislativo, em 31 de outubro de 2001, foi promulgada a lei 10.303, que estabeleceu um novo marco regulador para as operações em bolsa. As suas principais disposições tiveram como objeto o ambiente da governança societária, com vistas a oferecer dispositivos de proteção aos acionistas minoritários, para com isso permitir um reequilíbrio de forças nas companhias. Este é o caso, por exemplo, da alteração promovida na Lei das S.A. (lei 6.404/76), cuja redação original autorizava as sociedades anônimas a emitir até $2 / 3$ (dois terços) das ações sem direito a voto; com a nova lei este limite foi reduzido para 1/2 (metade) do universo de ações. Nesse mesmo sentido, a nova lei reestabeleceu a proteção ao acionista minoritário, em caso de alienação do controle da companhia pelo majoritário (tag along): o minoritário passou a dispor do direito de oferecer as suas ações por um montante de até $80 \%$ do valor pago ao controlador. ${ }^{455} \mathrm{O}$ fim último de medidas como esta ou de outros mecanismos também previstos pela nova lei, como o fortalecimento institucional da CVM (Comissão de Valores Mobiliários), foi o de oferecer condições de segurança e previsibilidade, capazes de atrair investidores e conseqüentemente recursos para as empresas que optassem por emitir valores mobiliários.

O passo dessa reforma legislativa foi coordenado com alterações no ambiente de auto-regulação do mercado de capitais. A Bolsa de Valores de São Paulo - BOVESPA -, que desde 2000 passou a ser a única bolsa de valores do país, introduziu regimes voluntários de regras de governança a serem observados pelas empresas listadas. Com isso, além do mercado tradicional, a bolsa paulista definiu outros três tipos de mercados de valores, diferenciados em função do tipo de regulamento a que as empresas estariam sujeitas. Tratam-se dos mercados de nível 1, nível 2 e do Novo Mercado, criados entre os anos 2000 e 2001, que apresentam regras próprias de governança para as companhias.

${ }^{455} \mathrm{Na}$ realidade o tag along já existia na legislação brasileira, mas havia sido suprimido, em 1997, pela lei 9.457, que suprimiu os artigos 254 e 255 da lei das S.A., facilitando assim as aquisições de controle no contexto das privatizações. Ver SALOMÃO FILHO, Calixto. Efeitos Concorrenciais do Direito Societário, em SALOMÃO FILHO, Calixto. O Novo Direito Societário, São Paulo, Malheiros, 1998, pp. 201-212. 
As empresas que pretendem atuar no nível 1 da Bovespa, por exemplo, devem se dispor a apresentar uma política de transparência, amparada na apresentação periódica de informações aos acionistas e possíveis investidores. As sociedades listadas no nível 2 obrigam-se, entre outras coisas, a garantir o direito de voto aos preferencialistas em algumas situações societárias, como as operações de fusão ou incorporação, assim como assumem o compromisso de utilizar padrões internacionais de demonstrações financeiras, obedecendo aos parâmetros europeus ou aos norte-americanos. O Novo Mercado conta com um universo ainda maior de exigências, com vistas a atrair empresas com regras estreitas de governança corporativa. Entre algumas de suas regras, podem ser destacadas as seguintes: (i) o Conselho de Administração deve contar com no mínimo $20 \%$ de representantes independentes; (ii) 25\% das ações devem ser mantidas em livre negociação no mercado (free float); (iii) só podem ser emitidas ações com direito a voto (não há ações preferenciais no Novo Mercado) e (iv) o tag along é superior ao da lei 10303/01 - em caso de alienação do controle, os minoritários têm direito ao mesmo valor percebido pelo controlador (tag along de $100 \%) .{ }^{456}$

Tal como notado no setor bancário, também em sede do mercado de capitais as medidas jurídico-institucionais estiveram associadas a uma ampliação de sua participação no financiamento corporativo. $\mathrm{O}$ volume de emissões primárias de ações e de títulos de dívida (debêntures) apresentou uma variação positiva nos últimos anos. O ano de 2007, em particular, contou com um volume expressivo de operações de abertura de capital (IPOs) na bolsa. Só no Novo Mercado, foram 41 empresas, um aumento considerável em relação a 2006, quando ocorreram 23 operações desse tipo.

De alguma forma, boa parte destas alterações na forma de atuação do sistema financeiro nacional já havia sido antecipada pelo próprio BNDES, ao longo dos anos 1980, como assinala Karen Fernandez COSTA. ${ }^{457}$ Em 1986, no planejamento estratégico do Banco para o biênio 1988-90, o cenário chave escolhido pelo corpo técnico para balizar a intervenção do Banco, daí em diante, foi o da integração competitiva. Essa escolha demarcava uma diferença acentuada com o cenário prevalecente no planejamento estratégico anterior, realizado em 1985, para o biênio 1985-87. Neste, a projeção eleita era

\footnotetext{
${ }^{456} \mathrm{O}$ inteiro teor destas regras pode ser obtido em www.bovespa.com.br

${ }^{457}$ COSTA, Karen Fernandez. A transformação do BNDES e sua influência da política de Estado do Brasil na década de 90, paper apresentado no XXVIII encontro anual da ANPOCS, 2004.
} 
ainda a da retomada do desenvolvimento, o que situava o Banco novamente como um agente do desenvolvimentismo, apostando assim numa reedição do estilo de intervenção do Estado, que marcara os planos de desenvolvimento até o II PND. Segundo COSTA ${ }^{458}$, é justamente a revisão deste modelo de desenvolvimento e de atuação do Estado que caracterizavam a integração competitiva, comprometida com uma intervenção indutora, mas dotada de uma racionalidade pragmática e convergente com a atuação dos demais veículos financeiros.

Uma das diretrizes deste novo plano de ação do Banco é destacada pela autora: a modernização do Sistema BNDES a partir de uma concepção empresarial adaptada às exigências do novo estilo de crescimento. ${ }^{459}$ A implementação deste tipo de atuação veio, por exemplo, com a maior aproximação do BNDES com relação às operações do mercado de capitais, a partir de 1988 e com a desvinculação de sua atuação com as políticas de desenvolvimento setorial, definidas pelo Governo Federal. Não por acaso, os programas dirigidos à inovação, desenvolvidos desde 1991, também têm as suas raízes nesta nova opção de intervenção, notabilizada por uma ação promotora do desenvolvimento, mas detentora de um concepção menos vinculada a um modelo Estado-centrado de crescimento econômico.

\subsection{A PERSISTÊNCIA DA ALTERNATIVA INSTITUCIONAL: A RELEVÂNCIA DO BNDES COMO AGENTE DE INTERVENÇÃO ESTATAL}

O que essas alterações ocorridas no sistema financeiro sugerem, afinal? Uma visão panorâmica das reformas poderia indicar que houve uma descaracterização da alternativa institucional brasileira. Isto é, em conjunto com a derrocada do paradigma fordista-desenvolvimentista o sistema financeiro brasileiro também teria alterado substancialmente as suas características organizacionais. A retração dos bancos públicos, o incremento das atividades bancárias, inclusive de crédito, e a ampliação do volume de operações no mercado de capitais revelariam a consolidação de um outro arranjo jurídicoinstitucional, diferente daquele que perdurou até a década de 1990 e deu consecução à plataforma desenvolvimentista. De fato, alguns dados colhidos do período de reformas

${ }^{458}$ COSTA, Karen Fernandez. A transformação do BNDES e sua influência na política de Estado do Brasil na década de 90, op. cit.

459 BNDES, Programa de Integração Competitiva, 1986, apud COSTA, Karen Fernandez. A transformação do BNDES e sua influência na política de Estado do Brasil na década de 90, op. cit. 
econômicas insinuam uma recomposição do sistema financeiro, sobretudo no que diz respeito à origem da propriedade do capital bancário. Entretanto, uma análise cuidadosa do funcionamento deste ambiente aponta em um sentido diferente: os bancos públicos, e o BNDES em particular, continuam sendo elementos constitutivos do financiamento corporativo brasileiro.

É inegável que tanto o mercado de créditos, como o mercado de capitais sofreram alterações importantes nas últimas décadas. Também parece incontroverso que a participação relativa dos bancos públicos estaduais tenha sido reduzida. No entanto, o BNDES, o Banco do Brasil e a Caixa Econômica Federal, continuam exercendo um papel expressivo na provisão de recursos de longo prazo. Mesmo com o incremento do sistema bancário privado, as operações financeiras de monta, voltadas aos projetos industriais, no caso do BNDES, ou ao setor agroexportador, no caso do Banco do Brasil, continuam sendo realizadas pelos bancos públicos federais. $\mathrm{O}$ incremento do segmento privado não modificou, na realidade, um dos elementos constitutivos da alternativa financeira brasileira: o papel dos agentes financeiros estatais na provisão dos recursos de longo prazo e de alto risco. ${ }^{460}$

Muito embora os bancos privados tenha ampliado a sua atuação na oferta de créditos, os dados apresentados pelo setor e as análises correspondentes apontam para uma concentração desta atividade em operações de curto prazo, voltadas ao financiamento do consumo das famílias. Em outras palavras, o objeto dos bancos privados tem sido majoritariamente os empréstimos pessoais e o financiamento das compras no varejo. Ao analisar o ciclo de crédito entre 1995 e 2005, Marcos Antonio Macedo CINTRA ${ }^{461}$ salienta a vinculação entre a ampliação da oferta de recursos e o seu direcionamento para as pessoas físicas. No período analisado pelo autor, este tipo de crédito teve um crescimento mais relevante do que a oferta de recursos para as pessoas jurídicas. Entre 2003 e 2005, por exemplo, o volume de crédito franqueado às pessoas físicas cresceu de 37,9\% do total para $47,2 \%$, ao passo que o crédito dirigido às pessoas jurídicas decresceu de $62 \%$ do total, para $52,8 \%$. Neste período também chama a atenção o crescimento do crédito consignado, instituído pela lei 10.820, de 17 de dezembro de 2003: de um patamar de 27,3\% das

\footnotetext{
${ }^{460}$ Para tanto, ver STALLINGS, Barbara \& STUDART, Rogério. Finance for Development, op. cit.

${ }^{461}$ Cf. CINTRA, Marcos Antonio Macedo. A reestruturação patrimonial do sistema bancário brasileiro e os ciclos de crédito entre 1995 e 2005, op. cit.
} 
operações de crédito pessoal, em 2003, essa modalidade alcançou o montante de 45,7\%, em $2005 .{ }^{462}$

O incremento da oferta de créditos para as pessoas físicas, a cargo do bancos privados, corrobora análises como a de STALLINGS \& STUDART, para quem há uma evidente segmentação qualitativa no setor financeiro brasileiro: enquanto os bancos privados oferecem crédito de baixo risco e curto prazo, compete aos bancos federais a oferta de recursos de maior risco e de longo prazo de maturação. ${ }^{463}$ A avaliação dos autores sustenta-se, por exemplo, na referência de que cerca de $60 \%$ de todo o financiamento de longo prazo do país é ainda garantido pelo BNDES ${ }^{464}$. Uma outra evidência indireta desta preponderância do BNDES no mercado de crédito é o volume de liberações financeiras ocorrido na última década. Desde 1994, o volume de desembolsos anuais do BNDES apresenta um crescimento substancial, passando dos dez bilhões de reais desembolsados em 1994, para os cerca de sessenta e cinco bilhões de reais, desembolsados em 2007. Essa evolução positiva sugere que a participação do BNDES na economia brasileira ainda desempenha um papel constitutivo do sistema financeiro nacional, apesar das citadas reformas finaceiras.

\footnotetext{
${ }^{462}$ A opção pelo crédito pessoal esteve associada a estratégias adotadas pelo setor bancário, que envidou esforços direcionados a ampliar a sua participação nesse mercado: os bancos privados adquiriram o controle de diversas empresas financeiras especializadas na concessão de crédito às pessoas físicas e firmaram parcerias com redes de lojas, tornando-se financiadores diretos das compras no varejo. A Finasa foi adquirida pelo Bradesco; a Losango, pelo HSBC; a Fininvest, pelo Unibanco e o Itaú constituiu a sua própria financeira - a Taií. Já no que toca às parcerias com as redes varejistas, tratou-se de uma aproximação entre os bancos e redes de vendas e supermercados, resultando assim na disponibilização de crédito para os clientes. Segundo o estudo de CINTRA, o Bradesco constituiu uma parceria com as Casas Bahia, o Itaú fez o mesmo com o grupo controlador dos supermercados Pão de Açúcar, Extra, CompreBem e Sendas e o HSBC passou a financiar as atividades de consumo na rede Panashop. Estas referências anedóticas têm amparo na evolução do setor de crédito, que indicou variação favorável ao crédito pessoal, no período. A esse respeito ver CINTRA, Marcos Antonio Macedo. A reestruturação patrimonial do sistema bancário brasileiro e os ciclos de crédito entre 1995 e 2005, op. cit., pp. 331-339.

${ }^{463}$ É ilustrativa nesse sentido, a seguinte passagem de STALLINGS \& STUDART: "the private and public banks display qualitative, as well as quantitative, differences. In particular, the private banks mainly provide short-term working capital, while the public banks provide longer-term investment funds. The interest rates are also quite distinct, as the private banks charge the very high rates just discussed, while the public banks lend at much lower, subsidized rates. The segmentation of the market is notable. (...) Overall, the foreign banks rended to mimic their domestic counterparts in making limited amounts of short-term loans, while earning high profits by holding government securities." STALLINGS, Barbara \& STUDART, Rogério. Finance for Development, op. cit. pp. 244-245.

${ }^{464}$ Cf. STALLINGS, Barbara \& STUDART, Rogério. Finance for Development, op. cit.
} 


\section{Evolução dos desembolsos anuais do BNDES}

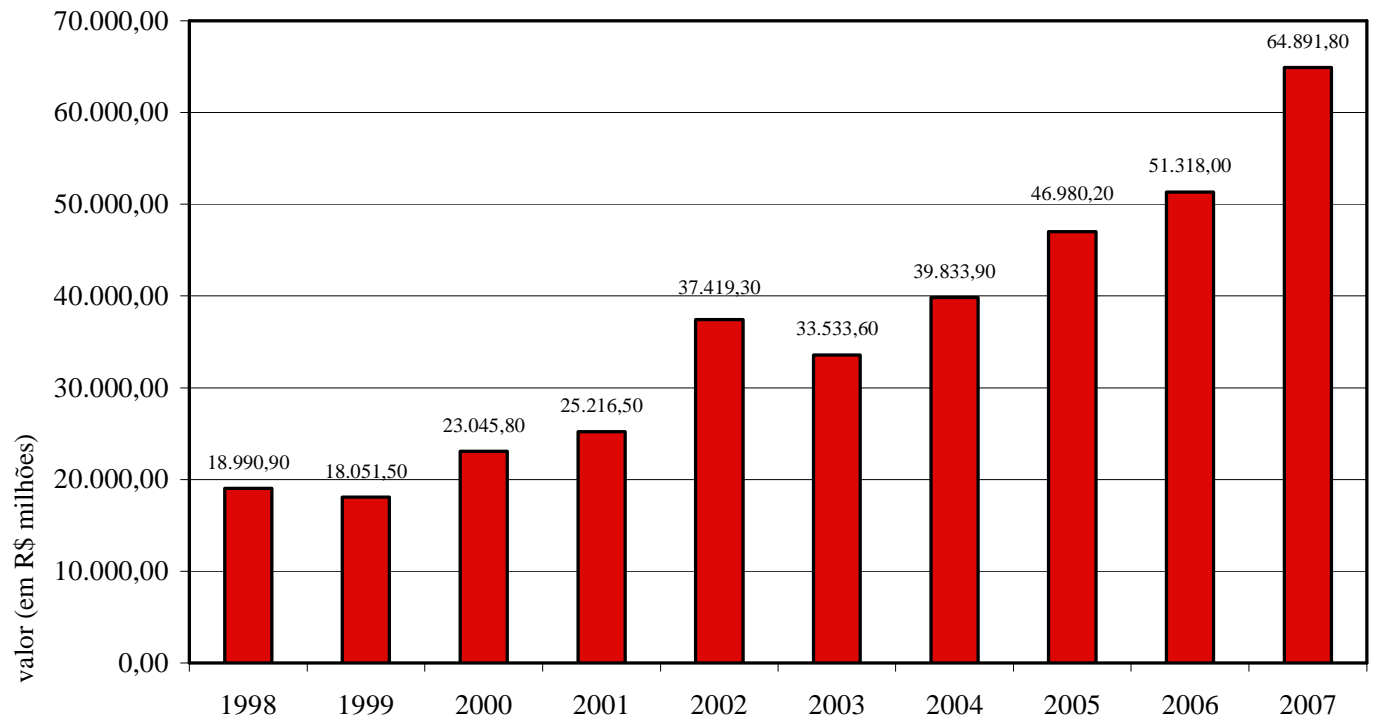

Gráfico 6. Fonte: BNDES.

A dificuldade do setor bancário privado em se consolidar como fonte financeira do setor corporativo, aos moldes do que ocorreu na Alemanha ou no Japão, pode ser associada ao valor dos juros praticados pelos operadores deste segmento. Em média, as taxas anuais de juros reais praticadas pelos bancos privados, sobre o valor do crédito contratado, superam o patamar de $50 \%$ ao ano. ${ }^{465}$ Revelam assim uma condição bastante desfavorável, sobretudo se se comparar esta taxa de juros aos valores praticados pelo BNDES, que disponibiliza recursos pelo valor da taxa de juros de longo prazo (TJLP), acrescida de custos operacionais e do risco do tomador. Uma equação que atinge uma taxa final de juros de cerca de $10 \%$ ao ano. A consequiência deste contraste é a reduzida participação dos bancos privados na oferta de crédito de longo prazo no país.

O mesmo pode ser dito dos bancos estrangeiros, de quem se esperava uma atuação mais pronunciada na oferta de créditos, compensando assim a histórica ausência do setor nacional. Apesar dessa expectativa, os bancos estrangeiros não inverteram o padrão de atuação do sistema bancário brasileiro: os competidores estrangeiros têm, na realidade, corroborado as falhas do mercado de crédito, concentrando as suas operações na aquisição de títulos da dívida pública e na oferta de recursos para o crédito pessoal e de curto prazo, em oposição às contratações corporativas de longo prazo. São reveladoras nesse sentido 
algumas de suas estratégias de atuação, bastante assemelhadas às dos bancos nacionais, tais como as aquisições de financeiras, dedicadas ao crédito pessoal, e a concentração das operações no financiamento do consumo das famílias. Portanto, seja no segmento sob controle nacional, seja no segmento sob controle estrangeiro, não parece ter havido uma reversão sensível do padrão de atuação do setor bancário.

Com algumas diferenças em relação ao diagnóstico do sistema bancário, a participação do mercado de capitais também não parece ter suprido o papel desempenhado pelos bancos públicos. Muito embora os anos recentes tenham registrado um crescimento significativo das operações no mercado de capitais, com destaque para os anos de 2006 e 2007, em que ocorreram respectivamente 41 e 64 operações de abertura de capital (em todos os mercados da Bovespa), não parece prudente afirmar que tenha havido uma consolidação definitiva deste ambiente como fonte estável de recursos para os empreendimentos corporativos. Note-se a esse respeito que o volume de emissões primárias de debêntures superou o montante anual de recursos disponibilizados pelo BNDES, apenas em 2006, sendo que o Banco também é um ator relevante neste mercado, seja como subscritor, seja como emissor de títulos de dívida. Nos demais anos, o BNDES desembolsou uma quantidade de recursos mais expressiva do que o volume de captações realizadas na BOVESPA e o montante disponibilizado pelo Banco tem apresentado uma variação anual crescente.

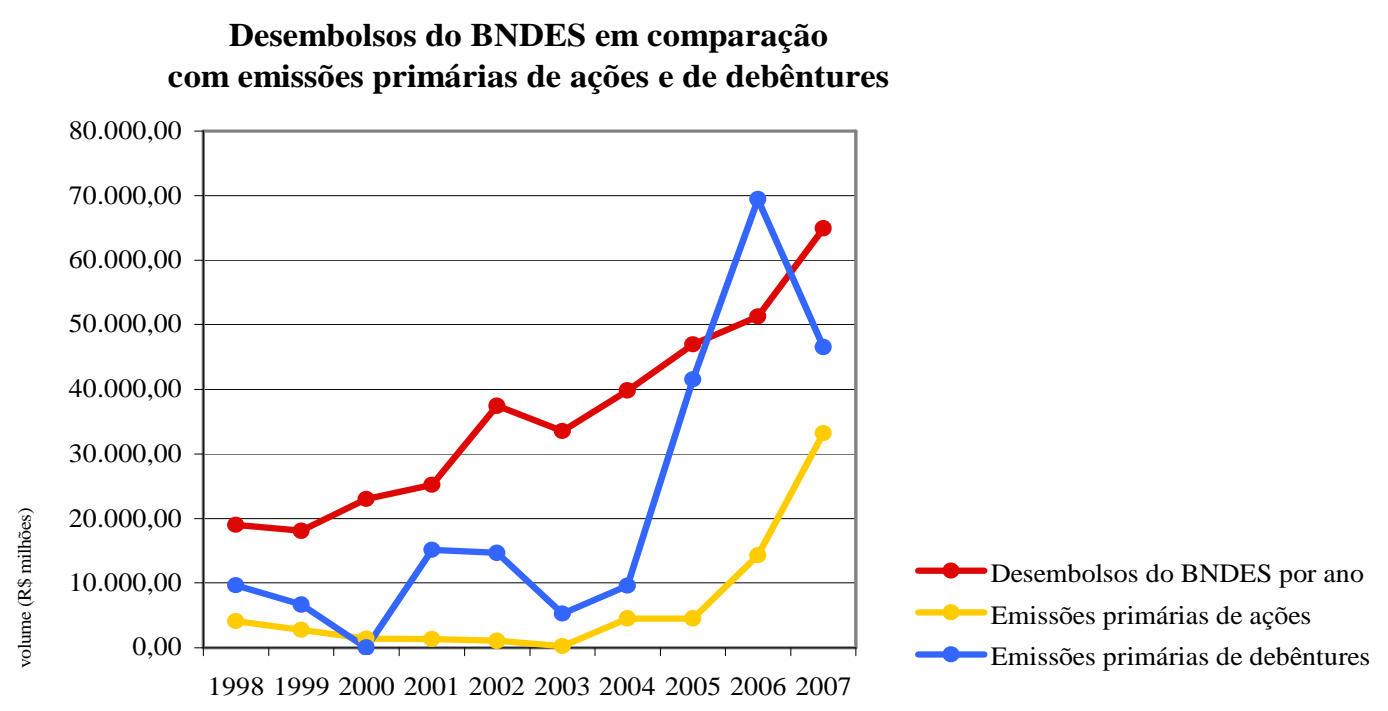


Um fator relevante a respeito do comportamento do mercado de capitais brasileiro é a relativa oscilação de seu desempenho. Uma análise do comportamento das captações de recursos na bolsa de valores e da performance do mercado secundário, na primeira década dos anos 2000, por exemplo, revela variações significativas deste ambiente financeiro. ${ }^{466}$ Basta ver que até o ciclo positivo de IPOs iniciado em 2005, alguns analistas apontavam para uma retração da amplitude do mercado, com o fechamento do capital de algumas empresas listadas. ${ }^{467}$ Nesse sentido, não deixa de ser ilustrativo a atuação do mercado de capitais doméstico no ano de 2008. Mesmo considerando a extensão e a intensidade da propalada crise financeira internacional, o impacto sofrido pelos mercados primário e secundário foi bastante expressivo: ao longo de todo o ano de 2008, apenas 12 empresas realizaram operações de abertura de capital na BOVESPA. Dados como esse indicam que o mercado de capitais brasileiro, embora tenha incrementado sensivelmente o seu ambiente institucional e a relevância de sua participação no financiamento corporativo, ainda apresenta, no médio prazo, um desempenho instável.

Tais evidências, relativas ao comportamento dos bancos privados e do mercado de capitais, apontam para uma persistência das falhas de mercado e conseqüentemente sugerem que os bancos estatais, e o BNDES em particular, ainda cumprem um papel regulador relevante no sistema financeiro, isso a despeito de todas as suas recentes mudanças jurídico-institucionais. Essa é uma circunstância especialmente verdadeira para aqueles setores econômicos com menor estabilidade e maior insegurança com relação ao seu retorno financeiro. Tipicamente as pequenas empresas e empresas em ramos ainda não consolidados contam sobremaneira com os agentes financeiros estatais, responsáveis por boa parte dos recursos existentes para este segmento.

A percepção de que a intervenção estatal ainda importa e constitui uma parcela significativa do arranjo financeiro nacional é compartilhada pelos estudos de STALLINGS \& STUDART, que realizaram uma análise comparada dos sistemas financeiros de três países latino-americanos: México, Chile e Brasil. Os seus apontamentos indicam que no caso brasileiro os bancos federais continuam desempenhando um papel chave, não suplantado pelos atores privados, seja no ramo bancário, seja no mercado de capitais. A seguinte passagem dos autores resume parte de suas conclusões:

${ }^{466}$ Cf. STALLINGS, Barbara \& STUDART, Rogério. Finance for Development, op. cit.

${ }^{467}$ Cf. STALLINGS, Barbara \& STUDART, Rogério. Finance for Development, op. cit. 
The public banks continue to play a vital role in Brazil, contrary to expectations. Both the government and those supporting the reforms in the 1990s believed the changes would revolutionize the credit market. In particular, they expected the entry of foreign banks to expand credit significantly and broaden access for those normally excluded, such as SMEs and poorer households. They further assumed that the public banking sector would continue to shrink because it was less competitive than private, especially foreign, banks. The results turned out differently than antecipated, however, and public banks continue to play a key role. ${ }^{468}$

Essas conclusões são particularmente verdadeiras para as empresas emergentes, cujas condições de acesso a recursos tendem a ser ainda mais escassas do que para as pequenas e médias empresas, com atividades já estabelecidas. Como relatado no estudo de caso, o BNDES tem tido uma dupla atuação no mercado brasileiro de venture capital: além de suprir as ausências do capital privado, mimetizando o comportamento de um venture capitalist, o Banco também tem incentivado a própria instalação deste segmento na economia brasileira - uma participação que, aliás, não é trivial. De um lado, o volume das operações diretas tem sido crescente e contado não apenas com as participações societárias, mas também com as operações de crédito formalizadas em contratos de tipo relacional, com renda fixa. A participação indireta por sua vez, esteve associada à própria constituição do segmento de fundos de investimento em empresas emergentes e ainda responde por uma presença expressiva neste mercado, participando de 15 dos 28 fundos registrados na CVM, em 2008.

No desempenho desta função de agência de fomento ao capital de risco, o BNDES tem também cumprido um papel indutor indireto: o seu experimentalismo institucional tem favorecido a consolidação da indústria nacional de venture capital no país - uma forma de atuação típica da de um banco de desenvolvimento, conforme assinala Beatriz de AGHION. ${ }^{469}$ As tentativas, erros e acertos do Banco em seus programas-piloto, como o CONTEC, têm contribuído para difundir, entre os investidores privados, alguns modelos de contratação financeira e regras de governança apropriados para regular os custos de agência em setores emergentes e dotados de ativos intangíveis. É este o caso, por exemplo, da participação ativa dos investidores nos comitês de investimento dos fundos - uma regra de governança originariamente introduzida pelo Banco em seus primeiros programas de

\footnotetext{
${ }^{468}$ Cf. STALLINGS, Barbara \& STUDART, Rogério. Finance for Development, op. cit. p. 245.

469 A esse respeito ver AGHION, Beatriz Armendáriz de. Development Banking, op. cit. A sua tese foi apresentada no capítulo 2 deste trabalho.
} 
venture capital e que se tornou uma prática recorrente no segmento de risco brasileiro. ${ }^{470} \mathrm{O}$ mesmo pode ser dito das experiências com debêntures, com ações resgatáveis e com a previsão de opções de venda nos acordos de acionistas. A disponibilidade em experimentar tais ferramentas e desenhos institucionais tem resultado em benefícios que ultrapassam as próprias linhas e programas do BNDES, favorecendo também os demais investidores, que passaram a compartilhar desse segmento.

Um exemplo dessa atuação com finalidades desbravadoras foi a constituição de um fundo de investimento voltado para empresas "semente" - o CRIATEC. Dado o elevado risco deste mercado, cujas empresas são ainda mais incipientes que as emergentes, há uma carência de investidores dedicados a este ramo econômico. Para contornar esta lacuna do mercado, a formação do CRIATEC assume uma dupla finalidade: (i) garantir imediatamente os recursos a estas firmas e (ii) constituir um novo programa piloto, capaz de incentivar, mediatamente, o segmento de investidores em empresas "semente". Nessa medida, o CRIATEC cumpre um papel semelhante ao exercido pelo CONTEC, na década de 1990, para as empresas emergentes: os parâmetros, métricas e ferramentas jurídicas que vierem a se mostrar adequados podem favorecer a disseminação de um novo setor privado de capital de risco, desta vez voltado para empresas ainda menores.

A análise dessas experiências revela que para além dos recursos financeiros disponibilizados, o BNDES também desempenha este outro papel chave no sistema financeiro nacional. As suas experiências e conseqüentes inovações jurídico-institucionais permitem o desenvolvimento de novos atores e mercados financeiros, em especial em setores dotados de incerteza e com menor garantia de resultados positivos. Ao menos no que toca aos segmentos típicos de uma economia baseada no conhecimento, a intervenção estatal tem impulsionado o funcionamento do ambiente financeiro, disponibilizando ferramentas, favorecendo a formação de parcerias público-privadas e garantido, com isso, novas opções de negócios.

\footnotetext{
${ }^{470}$ Essa observação foi feita por Luis Eugênio Figueiredo, Presidente da ABVCAP (associação brasileira de private equity e venture capital), em entrevista. A prevalência do comitê de investimento participativo, em que o investidor participa ativamente da política de investimentos da gestora dos fundos é confirmada pelo censo brasileiro private equity e venture capital. Ver a respeito CARVALHO, Antonio Gledson de; RIBEIRO, Leonardo de Lima e FURTADO, Cláudio Vilar. A Indústria de Private Equity e Venture Capital primeiro censo brasileiro, op. cit.
} 
Sendo assim, apesar das reformas institucionais realizadas na década de 1990, a atuação dos bancos estatais e do BNDES, em especial, persiste como um atributo característico do ambiente financeiro nacional. Essa persistência é tanto mais evidente para os setores não plenamente desenvolvidos, como o venture capital, ou para as operações de longo prazo, que encerram a realização de novos projetos corporativos. Em boa medida, a relevância dos bancos públicos e do Banco de Desenvolvimento seguem suprindo lacunas e carências dos mercados, notadamente naquelas operações financeiras eivadas de incerteza e de longa maturação.

Como compreender a persistência deste modelo, mesmo depois do rearranjo institucional ocorrido com o desfecho do projeto desenvolvimentista? A próxima seção situará as evidências do sistema financeiro brasileiro no debate teórico sobre os padrões jurídico-institucionais de governança corporativa, buscando apontar as suas tendências de acomodação face aos novos imperativos econômicos surgidos desde a crise do fordismo.

\section{COMO A LITERATURA DE DIREITO E FINANCIAMENTO INTERPRETA A PERSISTÊNCIA DA ALTERNATIVA INSTITUCIONAL? A DEPENDÊNCIA DA TRAJETÓRIA E OS LIMITES DA TESE DA CONVERGÊNCIA}

As modificações pelas quais passou o ambiente institucional brasileiro e que relativizaram em parte o absoluto protagonismo dos agentes estatais na organização do sistema financeiro não foi um fenômeno localizado. Em diversos outros países, a crise do fordismo foi concomitante não só com a aparição de um novo paradigma tecno-produtivo, amparado em conhecimentos e inovações, mas também com a intensificação das transações comerciais e financeiras internacionais - originando assim a polissêmica idéia de globalização. Diante disso, a literatura dedicada aos estudos comparados dos padrões de governança corporativa tem se dedicado a interpretar a extensão e as conseqüências da aproximação dos mercados e da relativa diluição dos aparatos regulatórios nacionais.

Desde o final da década de 1990 e início dos anos 2000, têm sido apresentadas teses conflitantes sobre a reação dos arranjos jurídico-institucionais às modificações causadas pela nova etapa de organização econômica. Para alguns intérpretes, a globalização econômica e a retração da participação dos Estados apontariam para uma convergência dos modelos institucionais, o que colocaria em xeque as idiossincrasias nacionais, forjadas pelos distintos dispositivos regulatórios específicos de cada país. Para 
outros, no entanto, a retração da intervenção pública e a internacionalização das economias, conquanto possam ter representado modificações nos espaços nacionais, não indicam uma convergência das alternativas institucionais, que persistem com seus atributos constitutivos. ${ }^{471} \mathrm{O}$ panorama do sistema financeiro brasileiro alimenta este debate, muito embora, como se procurará assinalar a seguir, os elementos analisados indiquem para uma limitação explicativa da tese da convergência.

A tese da convergência institucional tem uma particular dedicação aos sistemas financeiros. Suas descrições e análises normativas sugerem que a constituição de uma economia internacionalizada e a integração dos mercados teriam como efeito a migração dos diversos tipos nacionais de financiamento para um modelo convergente - assumido como o padrão mais eficiente de governança financeira. Para Sigurt VITOLS ${ }^{472}$, os teóricos da convergência assumem como pressupostos a perda de capacidade regulatória dos estados nacionais, o crescimento das empresas multinacionais e o adensamento das tecnologias da informação, fatores que teriam diluído o espaço para as diferenças nacionais e favorecido as transações privadas em uma escala mundial. A conformação deste ambiente de mercado internacional, segue o argumento da convergência, ampliaria o universo de possibilidades de contratação financeira, mas ao mesmo tempo acirraria a competição entre firmas e sistemas financeiros nacionais.

Diante disso, os arranjos nacionais ver-se-iam premidos por uma pressão em favor de padrões mais eficientes de governança, capazes de atrair recursos financeiros para as suas economias. No limite, a possibilidade de deslocamento das empresas e a facilidade de

${ }^{471}$ Um boa parte deste debate pode ser lida em um livro recente organizado por Jeffrey GORDON e Mark ROE, que reúne ambas as visões: textos vinculados à idéia de convergência e à noção de persistência dos modelos. GORDON, Jeffrey \& ROE, Mark (Ed.). Convergence and Persistence in Corporate Governance, New York, Cambridge, 2004.

$472 \mathrm{O}$ ponto de vista de VITOLS é crítico a este argumento de convergência. Na seguinte passagem o autor resume esta perspectiva: "Thus, to summarize the convergence argument, the basis of state-based and bankbased financial systems have eroded through the decreasing efficacy of financial regulation, forcing regulatory agencies to sooner or later move towards a regulatory regime characterized by the free play of market forces. The type of financial institution emerging within this environment is the internationally-active 'financial supermarket', offering a wide range of FEE-for-service products and taking advantage of economies of scale created through size, diversified product offerings and the capacity to seek refinancing where it is cheapest. Unlike the traditional universal German Hausbank with its long-term relationships with customers, however, this financial supermarket is characterized by competition with other similar institutions on the basis of short-term price orientation for a pool of price-discriminating customers." Para tanto ver VITOLS, Sigurt. Financial Systems and Industrial Policy in Germany and Great Britain: the limits of convergence, WZB, discussion paper FS I 95-311, 1995, disponível em http://papers.ssrn.com/sol3/papers.cfm?abstract_id=608203, acesso em 22.12.2008. p. 5. 
captação de recursos nas mais variadas bolsas de valores do mundo teria como conseqüência a difusão dos padrões institucionais bem sucedidos. Os países e as companhias que insistissem na manutenção de padrões de governança nacionalmente confeccionados, desatentos para os parâmetros internacionais de eficiência e desempenho, tenderiam a permanecer a reboque de uma economia financeira, internacionalmente articulada. A globalização dos mercados apontaria, portanto, para uma convergência dos sistemas financeiros, via de regra, orientada para o modelo do mercado de capitais.

É a partir deste referencial que autores como HANSMANN \& KRAAKMAN ${ }^{473}$ constroem a tese de que não há mais alternativas para o direito societário. A sua história teria chegado ao fim: os diferentes modelos de governança tendem a desaparecer e os sistemas nacionais, a cristalizar um padrão único de organização financeira - centrado na proteção aos acionistas e nas operações do mercado de capitais. No artigo The End of History for Corporate Law, a partir de referências qualitativas e anedóticas, os autores apresentam um argumento normativo, segundo o qual os diferentes padrões de governança caminhariam para um destino uniforme. Sistemas como o Alemão, baseado nos bancos e na participação dos trabalhadores ou arranjos como o asiático, associados à participação estatal, apresentariam evidentes desvantagens comparativas em relação ao paradigma shareholder-orientado, e por esta razão seriam sobrepujados por este último. ${ }^{474}$ Somente em modelos de governança shareholder-orientados, assinalam os autores, pode-se presumir um funcionamento eficiente das companhias: os dispositivos de proteção aos acionistas garantiriam administradores responsivos aos interesses da firma, ao mesmo

${ }^{473}$ HANSMANN, Henry \& KRAAKMAN, Reinier. The End of History for Corporate Law, em GORDON, Jeffrey \& ROE, Mark (Ed.). Convergence and Persistence in Corporate Governance, op. cit. pp. 33-68.

${ }^{474}$ Os autores analisam quatro tipos de arranjos jurídico-institucionais de financiamento corporativo: (i) o modelo administrador-orientado (manager-oriented), (ii) o modelo trabalhador orientado (labor oriented model), (iii) o modelo Estado orientado e o modelo stakeholder-orientado. O primeiro dos modelos teria vigorado nos Estados Unidos, nas décadas compreendidas entre os anos 1930 e 1960, e representa a fase em que se julgava positiva a garantia de discricionariedade de gestão para os administradores, em razão de sua competência técnica. Os problemas de agência e a possibilidade de negociações desinteressantes para os acionistas ocorridas à sombra de seu controle evidenciaram se tratar de uma estrutura viciada, dizem os autores. Igualmente gerador de decisões ineficientes é, de acordo com essa visão, tanto o modelo voltado a garantir participação dos trabalhadores como o orientado para os stakeholders. A idéia de coodeterminação verificada na Alemanha, em que investidores e trabalhadores têm poder de voto nas instâncias sociais e as propostas de incluir stakeholders nas deliberações traria para a sociedade ora paralisias, ora decisões inadequadas. Por fim, o modelo baseado no Estado, em que as empresas estatais são veículos importantes de coordenação econômica é meramente desacreditado pelos autores como sendo um modelo em desuso depois da hegemonia das reformas de mercado das décadas de 1980 e 1990. Cada um destes paradigmas apresenta falhas que associadas às virtudes do modelo orientado para os acionistas levam a uma irresistível convergência institucional. HANSMANN, Henry \& KRAAKMAN, Reinier. The End of History for Corporate Law, op. cit. 
tempo em que os desperdícios e gestões discricionárias tendem a ser evitados. Em suma, este padrão seria o mais eficaz na mitigação dos custos de agência, o que o torna um sistema de governança corporativa mais efetivo.

Com a integração dos mercados esta superioridade tende a ser difundida, de tal forma que firmas e formuladores de políticas públicas acabariam por se render às suas vantagens comparativas, propiciando assim a esperada convergência dos modelos de governança. Para HANSMANN \& KRAAKMAN ${ }^{475}$, a consolidação deste paradigma de organização teria a seu favor alguns veículos de profusão, tais como: (i) a lógica e a persuasão - as suas vantagens seriam racionalmente apreensíveis pelos agentes econômicos; (ii) o efeito demonstração das empresas e países mais bem sucedidos no financiamento corporativo e (iii) a pressão competitiva amplificada pela globalização, capaz de selecionar este arranjo como o mais adequado para as finalidades econômicas de empresas e investidores. Seja por qual meio for, o fato central do argumento é o reconhecimento de uma irresistível superioridade deste sistema de governança, que é associada a um arranjo baseado no mercado de capitais e em seus correspondentes atributos conformadores, típicos de uma economia liberal de mercado: (i) laços descontínuos; (ii) dispersão acionária; (iii) representação interna a cargo do conselho de administração e (iv) monitoramento externo exercido pelo risco potencial de ofertas hostis de controle.

A expectativa dos autores afinados com a tese da convergência é que a uniformidade dos sistemas seja um processo paulatino, mas inexorável. O primeiro passo da homogeneização das diferenças ocorreria no âmbito das práticas voluntárias, com os agentes de mercado adotando padrões e comportamentos assemelhados aos de seus concorrentes internacionais. O segundo e definitivo passo viria por meio de reformas legislativas, voltadas a compatibilizar os regulamentos societários e econômicos, com vistas a constituir um arranjo jurídico-institucional dotado dos patamares adequados de eficiência econômica. Tais proposições dialogam com proximidade com as análises formuladas no campo da Law and Finance. Também nesse terreno vigora, como já observado, o reconhecimento de que os modelos de governança assentados em determinados mecanismos de proteção aos investidores são superiores aos demais, o que 
tem gerado recomendações de política, particularmente direcionadas a alavancar os sistemas financeiros de países em desenvolvimento. ${ }^{476}$

Em alguma medida, foi essa a matriz das reformas institucionais ocorridas no sistema financeiro brasileiro, na década de 1990. As medidas adotadas partilhavam do diagnóstico de que a retração do Estado e o impulso dos mercados eram condições necessárias para a constituição de um ambiente financeiro competitivo, capaz de atrair investimentos externos. Nesse sentido, é compreensível que, de um lado, os programas federais tenham alvejado a desestatização do setor bancário, enquanto as alterações legislativas e regulatórias, de outro, procuraram induzir o robustecimento do mercado de capitais doméstico.

No entanto, apesar da suposta superioridade do modelo de mercado e da amplitude das reformas institucionais brasileiras, o sistema financeiro nacional, como visto, continua sensivelmente baseado na intervenção dos bancos estatais, ao menos no que tange às operações de longo prazo e com setores emergentes. Esse fato sugere que a tese da convergência, conquanto seja persuasiva, é limitada na sua capacidade explicativa, ao menos da evolução do sistema brasileiro. Muito embora possa fazer sentido que a internacionalização dos mercados exerça uma pressão competitiva nos ambientes nacionais, os arranjos institucionais não são tão maleáveis como supõem os teóricos e os policy makers da convergência. A rigor, o exemplo brasileiro corrobora uma outra tese, a da persistência e da dependência da trajetória institucional - que contrariam as apostas de uniformização.

$\mathrm{O}$ argumento da persistência sugere que os arranjos institucionais são relativamente rígidos e as suas alterações não sucedem livres de constrangimentos. As mudanças pelas quais passam tais ambientes sujeitam-se a uma dependência da trajetória

\footnotetext{
${ }^{476}$ A seguinte passagem de Ross LEVINE é bastante eloqüente neste sentido: "The policy implications are clear. Although changing legal codes and improving the efficiency with which legal systems enforce laws and contracts is difficult, the economic returns to improving the legal environment appear very large. For many countries, these reforms could begin at the level of regulation and implementation. For example, it may be prohibitively difficult - or undesirable - to change a country's law that imposes an automatic stay on the assets of a firm upon filling a reorganization petition. Nevertheless, corporate reorganization procedures could be improved to reduce delays and uncertainty, so that bankers feel greater confidence about receiving the full present value of their loans. Thus this paper's results emphasize the prominent role that legal reforms - defined broadly - can have in stimulating economic development by improving the functioning of the banking system." LEVINE, Ross. The Legal Environment, Banks, and Long-Run Economic Growth, op. cit. p. 611 .
} 
(path dependence), isto é, os atributos passados importam e influenciam o ritmo das mudanças futuras. Isso porque um arranjo jurídico-institucional não é uma estrutura vazia de direitos e obrigações, plasmada asceticamente e de modo descontextualizado. Antes disso, trata-se da formalização de interesses e de composições de força, que são cristalizados em uma composição de princípios, regras e estipulações de competência e procedimentos. Este ambiente jurídico-institucional, por sua vez, reforça as posições e os interesses incrustrados em seus elementos constitutivos, consolidando tais posições. Com isso, as possibilidades de mudança institucional apresentam limites, representados pela conjugação estável firmada entre o direito e as organizações sociais subjacentes. Por esta razão, uma parte da literatura dedicada às possibilidades de reforma dos arranjos institucionais reconhece a predisposição para que tais processos obedeçam a uma dada trajetória. ${ }^{477}$ É como se as mudanças institucionais fossem circunscritas às margens dos correspondentes dutos históricos.

Com a governança financeira não é diferente. A associação entre os padrões de propriedade corporativa, as regras regedoras deste sistema e os grupos de interesse induzem a uma path dependence, como assinalam Lucian BEBCHUK \& Mark ROE. ${ }^{478}$ Isso significa que as estruturas de propriedade e os estilos de regulação incidentes sobre agentes em um dado contexto condicionam a forma de sua organização e o respectivo regime normativo no período subseqüente. Em primeiro lugar, a forma de organização da propriedade, seja ela pulverizada ou concentrada, induz as companhias a preservarem a sua herança, já que alterações podem estar associadas a necessidades de inúmeras adaptações, na própria firma e no ambiente externo - o que envolve custos financeiros e políticos. ${ }^{479}$

477 Cf. TREBILCOCK, Michael; PRADO, Mariana Mota \& WILSON, James. Path Dependence Theory, Economic Development and the Dynamics of Institutional Reform, paper, mimeo, 2008.

478 BEBCHUK, Lucian \& ROE, Mark. A Theory of Path Dependence in Corporate Ownership and Governance, em GORDON, Jeffrey \& ROE, Mark (Ed.). Convergence and Persistence in Corporate Governance, op. cit. pp. 69-113.

${ }^{479}$ A alteração de um regime de governança relacional para uma alternativa descontínua, por exemplo, reclamaria, entre outros, uma reorganização dos mecanismos internos de monitoramento, a reversão dos incentivos e controles, bem como uma alteração do próprio macro sistema de organização corporativa, já que o controle externo via mercado passaria a ser relevante. Com isso as companhias tendem a perceber benefícios na sua constituição, ao passo que associam as modificações substantivas a custos e dificuldades operacionais nem sempre compensatórios. Ainda que se admitisse que a superioridade do modelo descontínuo, shareholder-orientado, mas que compensasse todos os custos de alteração societária e a companhia viesse a ganhar com a migração para este regime, há que se considerar que as companhias não são um organismo uníssono. É plausível supor que dentro de uma firma existam grupos de interesse, possivelmente favorecidos pela atual forma de organização da companhia e que por tal razão resistam às modificações esperadas por HANSMANN \& KRAAKMAN. Um exemplo disso, discutido por BEBCHUK \& ROE, é o sistema alemão de co-determinacão, em que os trabalhadores participam ativamente da vida 
Em segundo lugar, as regulações societárias e econômicas favorecem a constituição de determinados estilos de organização corporativa e tendem a ser preservadas pela atuação dos respectivos grupos de interesse favorecidos.

Em suma, a regulação pública contribui para estabelecer os macro padrões dos sistemas financeiros nacionais e os seus atributos característicos tendem a ser preservados pelos respectivos segmentos beneficiados. As disposições normativas, ao disporem de um conjunto de incentivos e sanções, balizam os comportamentos privados e assim conformam o ambiente corporativo; os principais atores deste meio, por sua vez, agem para preservar os atributos deste aparato regulatório - ensejando assim uma preservação institucional. ${ }^{480}$

Este é o caso dos bancos federais brasileiros, que tendem a reagir a alterações no ambiente legislativo, para assim preservar a sua predominância neste ambiente institucional, que lhes é favorável. O prestígio e o capital político constituídos pelo BNDES, pela Caixa Econômica Federal e pelo Banco do Brasil, em decorrência de um longo período de atuação na ordem financeira nacional, resultou, por exemplo, na sua exclusão do programa nacional de desestatização. Um indicador semelhante desta preservação das propriedades do modelo pode ser verificado na limitação do escopo das reformas institucionais ocorridas na década de 1990: embora voltadas a favorecer uma organização mercado-orientada, não desfizeram os mecanismos de poupança compulsória previstos constitucionalmente - um fato que não deixa de ser em si relevante. Em primeiro lugar, porque a Constituição Federal recebeu sucessivas emendas para permitir a desestatização de setores, como gás, petróleo e telecomunicações e mesmo assim manteve a estrutura organizacional do sistema financeiro. Segundo, porque, no ambiente acadêmico, foi travado um debate sobre a conveniência de se alterar os mecanismos de poupança compulsória - indicando com isso a existência de propostas concretas, como a de Pérsio

societária, elegendo metade dos representantes do conselho de administração das empresas: por que razão os trabalhadores abririam mão deste benefício, em prol de um aparato de governança que embora mais eficiente, é centrado apenas no direito dos acionistas? Também parece ser este o caso do modelo brasileiro de venture capital, em que os investidores conquistaram a possibilidade de participar dos comitês de investimento. Ainda que esta posição desagrade os fundos de investimento, porquanto possa delongar o processo decisório, por que razão aportadores como o BNDES recusariam, em prol da eficiência, o direito de controlar a política de investimentos dos veículos de que fazem parte? Ver a respeito BEBCHUK, Lucian \& ROE, Mark. A Theory of Path Dependence in Corporate Ownership and Governance, op. cit.

${ }^{480}$ BEBCHUK, Lucian \& ROE, Mark. A Theory of Path Dependence in Corporate Ownership and Governance, op. cit. 
ARIDA $^{481}$, para a alteração do ambiente jurídico-institucional. Mesmo assim, as trajetórias seguiram o seu curso, reforçando a idéia de path dependence e sugerindo que a organização societária é em si acometida de uma rigidez. ${ }^{482}$

Na realidade, os elementos que contribuem para esta persistência dos padrões de governança são ainda mais complexos do que os esposados por BEBCHUK \& ROE e ultrapassam a relação entre estruturas societárias, grupos de interesse e marcos regulatórios. Para além dessa associação, que em si limita a capacidade de transplantes e de adaptações dos modelos nacionais, há uma resistência oferecida pela complementaridade existente entre as diferentes instituições de um sistema nacional. De acordo com essa leitura, apresentada por HALL \& $\operatorname{SOSKICE}^{483}$, as alternativas institucionais são conformadas por um feixe de direitos e estruturas sociais, reciprocamente imbricados, o que sugere a idéia de uma densa teia institucional. Em outros termos, há uma conexão entre os elementos institucionais constitutivos de uma alternativa nacional, de tal modo que os ambientes financeiros, os regimes contratuais, as regras societárias e a regulação do trabalho, por exemplo, são mutuamente concatenados e reforçam-se uns aos outros.

No que diz respeito aos sistemas nacionais de governança corporativa, em particular, ocorre o mesmo fenômeno: a teia de instituições complementares reforça as características de cada um dos arranjos financeiros. Isso significa que a prevalência dos bancos públicos, no Brasil, dos bancos privados na Alemanha ou no Japão e do mercado de capitais, nos países anglo-saxões, está imersa em um universo de regras e dispositivos,

${ }^{481}$ Ver a respeito ARIDA, Pérsio. Mecanismos Compulsórios e Mercados de Capitais: propostas de política econômica, op. cit. Ver também a resposta formulada por Ernani Teixeira TORRES FILHO ao artigo de Arida, TORRES FILHO, Ernani Teixeira. A Reforma do Sistema FAT-BNDES: críticas à proposta Arida, em Revista do BNDES, Rio de Janeiro, v. 12, $\mathrm{n}^{\circ}$. 24, pp. 31-42, 2005.

${ }^{482}$ Um caso exemplificativo desta dependência da trajetória são as sucessivas legislações brasileiras voltadas a formar mecanismos de poupança compulsória. A garantia de recursos públicos para o exercício do crédito direcionado, conquanto tenha tido o papel de suplantar as lacunas privadas, teve também o efeito de forjar um padrão de governança corporativa baseado nos agentes financeiros estatais - a quem foi atribuído uma fonte financeira estável. É o caso do art. 239, parágrafo primeiro, da Constituição Federal, que alocou $40 \%$ dos recursos do Fundo de Amparo ao Trabalhador para o BNDES, fortalecendo a sua atuação como banco público. Em comparação com os bancos privados, por exemplo, o BNDES conta com uma vantagem financeira: capta os montantes do FAT com uma taxa de juros (TJLP - 6,25\% ao ano) menor do que a utilizada pelos bancos privados. Além disso, se os recursos do FGTS e do FAT fossem diretamente administrados pelo titulares, isto é, se não fossem compulsoriamente geridos pelo Estado, os indivíduos poderiam, em tese, aplicar os seus recursos em outros veículos financeiros, tais como o mercado de capitais. Ambos os casos, ilustram que as disposições normativas exercem um papel relevante na definição dos padrões de governança - a hegemonia dos bancos públicos no financiamento corporativo esteve também associada à organização jurídica do próprio sistema financeiro brasileiro, em especial às suas regras de mobilização de capital.

${ }^{483}$ Cf. HALL, Peter \& SOSKICE, David. Varieties of Capitalism, op. cit. 
formais e informais, que conformam a sua estabilidade e a sua trajetória. Os países assentados na idéia de pleno emprego, por exemplo, são mais tolerantes com a idéia de participação dos trabalhadores nas firmas e cultivam laços societários externos ao mercado, o padrão de governança é relacional. Já os países orientados pelas relações econômicas descontínuas favorecem as transações impessoais, com isso fomentam a rivalidade típica de mercado e sendo assim conformam relações de governança acometidas da persecução de resultados lucrativos, no curto prazo. Todos esses fatores contribuem para a preservação e a persistência das alternativas institucionais. ${ }^{484}$

Um exemplo do desempenho das complementaridades institucionais na persistência dos arranjos financeiros pode ser notado na segmentação do mercado de créditos brasileiro. Distintamente dos bancos públicos federais, a contraparte privada tem se concentrado no fornecimento de crédito de curto prazo e na aquisição dos títulos da dívida pública - emitidos pelo Governo Federal. Um dos fatores que contribui para essa segmentação, além da própria trajetória do segmento bancário privado brasileiro, reside na atuação deste outro conjunto institucional, assentado em uma coordenação pública da economia, o que interfere no funcionamento do sistema financeiro. Em razão da manutenção do Poder Público em alguns segmentos econômicos, como a previdência social, há a necessidade de financiamento das contas do governo, por meio da emissão de títulos da dívida pública. Isso tem gerado um incentivo distorcido para o segmento bancário, qual seja, a possibilidade de aplicar os recursos financeiros na aquisição destes títulos: uma opção rentável e potencialmente menos arriscada que a concessão do crédito de longo prazo.

Esse incentivo é ainda alimentado por uma outra variável institucional: as medidas da política monetária dirigidas ao controle da inflação. A oscilação positiva da taxa SELIC, um dos principais remédios administrados pelas autoridades monetárias brasileiras para controlar a escalada dos preços relativos, repercute na remuneração dos títulos da dívida pública brasileira e alimenta os estímulos para as operações de tesouraria dos bancos privados. Circunstâncias como essa, e muitas outras, como a carência dos investidores privados em setores de maior risco, indicam que a teia institucional brasileira também contém as suas complementaridades.

${ }^{484}$ Cf. HALL, Peter \& SOSKICE, David. Varieties of Capitalism, op. cit. 
Em síntese, os sistemas de governança são constituídos por uma sucessão de elementos complementares, todos eles incrustrados nas trajetórias históricas e culturais dos respectivos países. É por esta razão que, mesmo quando sucedem reformas institucionais, em alguns casos vigorosas o suficiente para confrontar os grupos de pressão existentes, as características centrais das alternativas de organização financeira podem perdurar. A depender da densidade do arranjo jurídico-institucional, as alterações pontuais podem não conseguir reverter as propriedades funcionais de um dado sistema econômico. $\mathrm{O}$ caso brasileiro é um exemplo típico: não obstante as alterações ocorridas nos sistemas financeiros, os bancos públicos federais, e sobretudo o BNDES, ainda prevalecem nas operações de longo prazo ${ }^{485}$ e na indução de novos segmentos, como a indústria do venture capital.

Uma visão panorâmica sobre o comportamento de alguns países da OCDE, especificamente nos mecanismos de indução das empresas emergentes, revela outros exemplos dessa tendência à persistência dos arranjos e à conseqüente preservação das alternativas institucionais. Em especial, o grau de intervenção dos Estados varia conforme o tipo de sistema econômico nacional.

\subsection{Alguns EXemplos da PRimazia das alternativas institucionais: a EXPERIÊNCIA DOS PAÍSES DA OCDE}

A persistência do Estado e a participação do BNDES como agente estatal no financiamento das inovações e na articulação de um segmento de capital de risco no Brasil encontra precedentes em alguns países da OCDE. Nestes, com a consolidação de uma economia baseada no conhecimento, a agenda de atuação dos governos na promoção da economia passou a incorporar também a implementação de políticas públicas dirigidas a prover recursos para o financiamento de atividades inovadoras. Reconhecendo a relevância da capacidade de inovação para a competitividade de suas economias, os países desenvolvidos têm procurado conceber meios e instrumentos que assegurem uma maior destinação de investimentos em empreendimentos emergentes e portadores de futuro. Um indicativo desse envolvimento pode ser constatado com um dado expressivo e datado de

${ }^{485}$ A esse respeito ver STALLING, Barbara \& STUDART, Rogerio. Finance for Development, op. cit. pp. 242-243. 
dez anos: já em 1997, os governos dos países da OCDE alocavam um montante de US\$ 3 bilhões (três bilhões de dólares), só no financiamento de pequenas empresas emergentes ${ }^{486}$.

Notadamente, três conjuntos de medidas têm sido identificadas como as mais regulares entre as iniciativas de políticas públicas destes Estados, podendo ser classificadas da seguintes maneira: (i) medidas fiscais e financeiras; (ii) medidas de regulação dos agentes econômicos e (iii) medidas de participação direta dos governos na provisão de recursos de venture capital. ${ }^{487} \mathrm{O}$ quadro abaixo sintetiza essas possibilidades e procura exemplificar os meios pelos quais estas atuações ocorrem.

\begin{tabular}{|c|c|}
\hline \multicolumn{2}{|c|}{ QUADRO 22 } \\
\hline TIPOLOGIA DA PARTICIPAÇão DOS GOVERNOS DA OCDE NOS PROGRAMAS DE VENTURE CAPITAL \\
\hline Tipo de participação & \multicolumn{1}{c|}{ Propósito } \\
\hline $\begin{array}{c}\text { Atuação direta } \\
\text { participação societária }\end{array}$ & $\begin{array}{l}\text { Garantir recursos diretamente para firmas emergentes, por meio de } \\
\text { subscrição de valores mobiliários ou indiretamente, em fundos de } \\
\text { capital de risco. }\end{array}$ \\
\hline $\begin{array}{c}\text { Investimento governamental via } \\
\text { empréstimos }\end{array}$ & $\begin{array}{l}\text { Garantir recursos diretamente para empresas emergentes, por meio de } \\
\text { empréstimos com taxas diferenciadas de juros ou através de aportes } \\
\text { não reembolsáveis. }\end{array}$ \\
\hline Incentivos financeiros e fiscais & Reduzir o custo capital e assim induzir o investimento. \\
\hline Incentivos tributários & $\begin{array}{l}\text { Prover garantias, como uma espécie de seguro público, para diminuir } \\
\text { os riscos envolvidos nestes financiamento. }\end{array}$ \\
\hline Garantias públicas & $\begin{array}{l}\text { Criar incentivos por meios regulatórios, como é o caso dos } \\
\text { regulamentos que autorizam fundos de pensão a destinar recursos } \\
\text { para o capital de risco. }\end{array}$ \\
\hline Medidas regulatórias & \\
\hline Regras de investimento & \\
\hline Elaboração própria, a partir de OECD (1997)
\end{tabular}

No que se refere às participações indutivas indiretas, os governos têm procurado intervir com a utilização de medidas fiscais e financeiras, e também regulatórias. No primeiro grupo, figuram os instrumentos tributários que, ao isentarem o custo de utilização dos recursos, incentivam a sua aplicação nas atividades de inovação. Neste caso, a participação pública se faz presente pela renúncia das receitas fiscais. Além disso, o governo pode constituir um fundo de recursos para garantir em parte as perdas sofridas por investidores privados e com isso pode promover um maior interesse dos financiadores em aportar recursos para empreendimentos de risco.

\footnotetext{
${ }^{486}$ Ver OECD, Government Venture Capital for Technology-Based Firms, Paris, OECD, 1997, pp. 2-34.

${ }^{487}$ Cf. OECD, Government Venture Capital for Technology-Based Firms, op. cit.
} 
Uma outra forma indireta de incentivar as inversões em empresas inovadoras tem ocorrido pela via das medidas regulatórias. Com a criação ou a alteração de regulamentos sobre o sistema financeiro, pode-se obter como resultado o favorecimento de investimentos em segmentos de risco. Um exemplo nesse sentido é a experiência norte-americana com o Employment Retirement Income Security Act (ERISA), que em meados dos anos 1980 alterou as regras de funcionamento dos fundos de pensão, autorizando-os a aplicar os seus recursos em capital de risco. Essa medida foi um importante estímulo, que garantiu um incremento significativo de recursos para o financiamento da nova economia.

Além dos mecanismos indiretos, fiscais e regulatórios, verifica-se também no cenário internacional a participação direta dos governos na provisão de recursos públicos para o financiamento de empresas inovadoras. Nessa circunstância, que é semelhante à vivenciada pelo BNDES, o poder público desempenha um papel de venture capitalist, na medida em que é o próprio governo quem assume a incumbência de financiar os empreendimentos emergentes. No exercício desta função, o poder público tem atuado por meio de dois mecanismos de governança: (i) a provisão de recursos por meio de participação acionária (equity) e (ii) a concessão de empréstimos, por meio de contratos de crédito, com baixas taxas de juros ou mesmo com uma natureza não reembolsável. A aposta de alguns países no envolvimento direto das agências públicas na alocação de recursos para estes investimentos encontra justificativas nas lacunas percebidas nos mercados financeiros, que muitas vezes são reticentes em garantir financiamentos para empreendimentos com altas taxas de incerteza.

Um exemplo de um programa de venture capital governamental pode ser extraído da experiência finlandesa, que resultou na constituição de uma empresa estatal para aportes de risco. A empresa TESI, criada em 1994, com um capital social de US\$ 67.000.000 (sessenta e sete milhões de dólares), integralizados exclusivamente pelo poder público, tinha como missão destinar recursos para fundos privados de capital de risco. A proposta da TESI era a de funcionar como um "fundo dos fundos", isto é, sua missão seria induzir o funcionamento de fundos privados de investimento, para o quê garantiria recursos com a finalidade de atrair outros sócios privados. A atuação da estatal era ainda articulada com outros fundos públicos regionais, administrados pelas estatais SITRA e KERA LTD, que tanto financiavam diretamente as empresas, como investiam em fundos de capital de risco. Esta última empresa, KERA, também atuava no segmento de renda fixa, garantindo 
recursos por meio de operações de crédito (financiamentos), com juros inferiores aos praticados na banca privada. Para garantir a sustentabilidade de suas operações, o Estado finlandês amparava as perdas financeiras da KERA, provenientes de eventuais empréstimos não bem sucedidos ${ }^{488}$.

Outros países, como Irlanda e Suécia, também têm apresentado programas de venture capital público, aos moldes do verificado na Finlândia. Na Irlanda, por exemplo, a Forbait Agency tem desenvolvido participações societárias em pequenas empresas de base tecnológica, por meio da subscrição de ações como a ferramenta de aporte do capital. Já na Suécia, o Estado é controlador de dois fundos de investimentos, "Atle" e "Bure". Ambos os fundos têm autorização para alocarem os seus recursos tanto em firmas emergentes, diretamente, como também em outros fundos e companhias de investimentos em capital de $\operatorname{risco}^{489}$.

A descrição do panorama internacional indica, portanto, que não há uma hierarquia entre as várias formas de intervenção do Estado desenhadas com a finalidade de promover o financiamento das inovações. A esse respeito, o relatório da OCDE aponta que o tipo de atuação pública predominante é correspondente ao perfil de cada economia ${ }^{490}$. Os países que, como os Estados Unidos, apresentam um mercado de capitais denso e com capacidade de financiar diversos estágios do desenvolvimento produtivo, tendem a implementar políticas de incentivo indireto. A razão para tanto deve-se ao fato de que nestes países os recursos financeiros para estas inversões existem, de tal forma que o papel do governo é subsidiário: cinge-se a criar estímulos para que o capital seja canalizado para os ramos econômicos portadores de futuro. Entretanto, a situação é diferente naquelas economias ou naqueles segmentos do capital de risco em que o problema verificado é a lacuna financeira do mercado.

Os países que não contam com um modelo de financiamento baseado no mercado de capitais ou aqueles em que os mercados apresentam limitações para cobrir toda a cadeia da inovação, reclamam a confecção de mecanismos de intervenção direta. Nestes casos, a variável crítica a ser superada não é apenas canalizar recursos disponíveis para setores

\footnotetext{
${ }^{488}$ Cf. OECD, Government Venture Capital for Technology-Based Firms, op. cit.

${ }^{489}$ Cf. OECD, Government Venture Capital for Technology-Based Firms, op. cit.

${ }^{490}$ Cf. OECD, Government Venture Capital for Technology-Based Firms, op. cit
} 
arriscados, mas sim gerar recursos financeiros não disponíveis no mercado financeiro. Um exemplo disso é a carência, percebida em alguns países, de investimentos em capital "semente", dirigidos a uma fase empresarial que apresenta um grau de risco ainda maior do que o constatado em firmas emergentes. A seguinte passagem do relatório da OCDE aponta para esta diversidade de formas de atuação dos governos:

\begin{abstract}
The most important determinant as to which venture capital support programmes are appropriate is the size and condition of private sector venture capital. The shortcomings of the private sector should help determine the government role and the design of its programmes. Thus, programmes will differ along a spectrum of venture capital supply factors, ranging from the well-developed venture capital market in the United States through the less well-developed markets in Europe and Japan to the nascent markets in Central and Eastern Europe. The role that the state may play in filling funding gaps will also depend on broader economic, social and budgetary factors. The long-term goal of most programmes is to create vibrant private sector venture capital that will reduce the need for government programmes. (...) Even though there is a panoply of programmes, particularly, when account is taken of incentives at the state level, it can be argued that the US government minimises its involvement in that investment decision making is left to the private sector. This is possible due to a highly-developed pool of expertise in banking and venture capital and to the framework of sophisticated financial markets. For other countries with less developed SME financing, the lesson is that building a network of skilled intermediaries is essential. (G.N.) ${ }^{491}$
\end{abstract}

O excerto do relatório indica que as alternativas institucionais são uma variável importante nas análises referentes aos mecanismos de financiamento. O tipo de arranjo jurídico-institucional e a racionalidade da intervenção do Estado não se dissociam das vicissitudes econômicas, sociais e históricas de cada contexto particular. No limite, as observações conduzidas pela OCDE mostram que a fórmula do one size fits all presente na literatura de viés Law and Finance é parcial e não responde satisfatoriamente a diversidade de formas e meios oferecidos pelo direito na organização e funcionamento dos sistemas financeiros.

O reconhecimento de que a variedade de alternativas institucionais importa para o desenho dos programas públicos de capital de risco não impede, no entanto, que a OCDE apresente recomendações para o seu funcionamento. Com base na expectativa de que a participação direta dos governos seja, tanto quanto possível, indutora do mercado de

${ }^{491}$ OECD, Government Venture Capital for Technology-Based Firms, op. cit. p. 11. 
capitais, as recomendações buscam enfatizar que os programas devem ser orientados por uma lógica de complementaridade e coordenação, entre os agentes públicos e privados. A tabela abaixo sintetiza algumas destas recomendações.

\begin{tabular}{|c|c|}
\hline \multicolumn{2}{|c|}{$\begin{array}{c}\text { QUADRO } 23 \\
\text { RECOMENDAÇÕES DA OCDE PARA A PARTICIPAÇÃO DIRETA DO ESTADO NOS PROGRAMAS DE } \\
\text { VENTURE CAPITAL }\end{array}$} \\
\hline Itens & Recomendações \\
\hline Racionalidade da intervenção & $\begin{array}{l}\text { O Estado deve atuar uma racionalidade de parceria, suprindo lacunas } \\
\text { de financiamento e estimulando a formação do segmento. Exemplo } \\
\text { disso é o aporte de recursos em fundos mistos de investimentos. }\end{array}$ \\
\hline Duração do programa & $\begin{array}{l}\text { Os programas devem ser limitados pela sua necessidade. O Estado } \\
\text { deve atuar sempre como um indutor (pump-priming). }\end{array}$ \\
\hline Viabilidade do programa & $\begin{array}{l}\text { A atuação deve buscar mecanismos de indução que não sejam } \\
\text { absolutamente artificiais, fazendo com que as empresas investidas se } \\
\text { tornem dependentes da fonte pública de recursos. }\end{array}$ \\
\hline Perfil da gestão & $\begin{array}{l}\text { A gestão do programa deve obedecer critérios profissionais, a fim de } \\
\text { evitar distorções e a criação de ambientes artificiais. }\end{array}$ \\
\hline Tipo de apoio & $\begin{array}{l}\text { Os financiamentos devem se fazer acompanhar de apoio técnico que } \\
\text { contribua para o fortalecimento da firma como agente de mercado. }\end{array}$ \\
\hline & \\
\hline
\end{tabular}

Em última instância, o extrato das recomendações da OCDE alinha-se ao tipo de intervenção que vem sendo conduzida pelo BNDES. Como será relatado a seguir, a participação do governo não tem procurado uma erradicação do mercado, substituindo-o plenamente, de modo a aniquilar a sua formação, o que a literatura financeira chamaria de efeito crowding out. Ao contrário disso, tanto as políticas da OCDE, quanto a experiência do BNDES, têm apontado para um modelo de ação pública voltado para a articulação e impulso de um mercado de capital de risco, seja suprindo as suas falhas, seja fomentando o seu crescimento.

\section{A DiNÂMiCA NA ALTERNATIVA INSTITUCIONAL: NOVOS PARÂMETRos PARA A INTERVENÇÃO DO ESTADO}

A despeito dos apontamentos da tese da convergência e das expectativas dos formuladores das reformas financeiras, o padrão de governança corporativa nacional continua baseado nos bancos públicos e, em especial, na intervenção do BNDES - ao menos no que toca às operações de risco e de longo prazo de maturação. A persistência desse modelo, no entanto, não significa que não tenham ocorrido modificações na forma de atuação do agente financeiro estatal: a forma de intervenção do Estado tem assumido

${ }^{492}$ OECD, Government Venture Capital for Technology-Based Firms, op. cit. 
novos parâmetros, particularmente visíveis na utilização, pelo BNDES, de ferramentas societárias e contratuais bastante ajustadas ao mercado de capital de risco.

Tais mecanismos, constituídos para amparar os investimentos em inovação, sobretudo em empresas emergentes, distinguem-se do modo com o que o Banco desempenhou a regulação institucional em contextos anteriores. Isso sugere que, apesar da persistência do arranjo financeiro, tenha ocorrido uma acomodação dinâmica na forma de atuação do agente estatal. Se, de um lado, o sistema financeiro nacional guarda propriedades institucionais herdadas do contexto desenvolvimentista; de outro, a forma e o modo da intervenção estatal assentam-se em outras bases, menos comprometidas com a direção e a persecução de resultados substantivos no processo econômico.

Notadamente no caso do BNDES, desde o final do II PND, a sua intervenção tem se afastado de um tipo puro de instituição financeira de desenvolvimento. Como visto no segundo capítulo deste trabalho, até o início da década de 1980, o Banco condicionava a sua atuação econômica ao atendimento das prioridades setoriais, definidas nos planos de desenvolvimento, estabelecidos pelo Governo Federal. ${ }^{493}$ Tratava-se, portanto, de uma intervenção substantiva, isto é, assentada na concretização de resultados: uma intervenção orientada para a perseguição de finalidades prévia e detalhadamente estipuladas ${ }^{494}$, foi este o caso do financiamento de setores prioritários, tais como o de transporte, o de energia, o de bens de capital e de insumos básicos. Não por a caso, o exame das prioridades e a estipulação dos programas de desembolso financeiro levavam em conta o mérito do projeto e a sua capacidade de promover o desenvolvimento econômico. ${ }^{495}$

Ao longo dos anos 1980 e 1990, no entanto, respondendo à crise do Estado, ao embaraço dos planos de desenvolvimento, que vieram a ser abandonados após o II PND, e às reformas institucionais do setor financeiro, essa forma de atuação sofreu modificações.

\footnotetext{
493 Cf. CURRALERO, Claudia Regina Baddini. A Atuação do Sistema BNDES como Instituição Financeira de Fomento no Período 1952-1996, op. cit.

${ }^{494}$ Enquanto a plataforma do direito liberal limitava-se à regulação formal, desonerando-se das efetivas e reais conseqüências das ações sociais, a atuação do direito substantivo é voltada à consecução de fins previamente estipulados. Por esta razão, pode-se dizer que, se o direito formal era orientado para a observação de regras universais (rule-oriented), o direito substantivo é voltado para a obtenção de resultados (goal-oriented), para a produção de efeitos sociais e econômicos. Ver a respeito NONET, Philippe \& SELZNICK Philip. Law and Society in Transition - toward responsive law, $2^{\mathrm{a}}$ Ed., Transaction Publishers, New Jersey, 2008, pp. 73-113 e TEUBNER, Gunther. Substantive and Reflexive Elements in Law, op. cit 495 Cf. CURRALERO, Claudia Regina Baddini. A Atuação do Sistema BNDES como Instituição Financeira de Fomento no Período 1952-1996, op. cit.
} 
O BNDES, como visto, não só foi desincumbido de condicionar a sua intervenção aos desígnios dos projetos de desenvolvimento, como também passou a incorporar critérios de verificação de risco nas suas operações de crédito, um dispositivo típico das instituições financeiras privadas. Com isso, o retorno das operações passou a ser uma variável relevante nas operações de colaboração financeira, que até há pouco balizavam-se no potencial de externalidades positivas dos projetos demandantes de recursos.

É neste contexto de mudança institucional que se enquadram, por exemplo, os programas de venture capital, oferecidos às empresas brasileiras desde 1991, quando foi implementado o programa piloto CONTEC. A utilização desta ferramenta financeira, como se procurou narrar no estudo de caso, tem como pressuposto uma racionalidade de atuação compatível com a de um agente do mercado de capitais. A habilidade do Banco nesse setor pressupõe a capacidade de atuar com ferramentas societárias e contratuais, próprias de investidores profissionais, utilizando-se, por exemplo, do ambiente da bolsa de valores para alienar as participações societárias e assim reaver o capital investido nas empresas emergentes. O mesmo pode ser dito da sua participação em fundos privados de investimento, em que o agente estatal figura literalmente como sócio de outros atores financeiros, públicos ou privados. Também nas operações realizadas por meio de contratos de crédito, as chamadas operações de renda fixa, em que as taxas de juros são favoráveis e há dispensa de garantias, a parceria do Banco não é artificial e pauta-se na viabilidade técnica e comercial do projeto. Portanto, ao menos no que concerne aos programas referidos no estudo de caso, pode-se dizer que o Banco tem atuado em linha com os demais agentes de mercado, indicando assim uma intervenção menos orientada para a persecução de um resultado econômico estabelecido politicamente, e mais voltada a constituir um ambiente financeiro propício aos investimentos de risco.

Essas modificações na racionalidade da intervenção estatal não contrariam as teses de dependência da trajetória e da complementaridade institucional, com as quais se procurou interpretar a prevalência dos bancos públicos federais no sistema financeiro nacional. A rigor, a existência de constrangimentos institucionais, particularmente derivados da trajetória pregressa dos arranjos, não significa que não ocorram mudanças nestes ambientes. $\mathrm{Na}$ realidade, os arranjos institucionais reagem dinamicamente às movimentações ocorridas nas correlações sociais de força e no panorama econômico, do contrário tenderia a existir uma contínua incompatibilidade entre os dispositivos 
reguladores e a dinâmica das organizações sociais. Sucede, no entanto, que esta acomodação não é livre de balizamentos e condicionalidades: as alternativas jurídicoinstitucionais também sofrem alterações, mas estas não tendem a ser nem radicais e muito menos unidirecionais.

As adaptações institucionais são, via de regra, incrementais e são guiadas pelas recomposições entre os grupos de interesse e as disposições normativas. Os processos de reacomodação são construídos normalmente a partir da base institucional existente, de tal forma que a dinâmica deste processo não favorece as alterações abruptas e repentinas. Antes disso, como sugere a literatura, tratam-se de eventos de longo prazo e eivados de gradualismo. $^{496}$ É também por esta razão que o sentido destas mudanças não é unidirecional, isto é, as diversas alternativas institucionais não tendem a convergir para um modelo homogêneo. Ao contrário disso, as distinções na forma de organização dos arranjos tendem a persistir, ainda que no tempo ocorram alterações na forma de atuação dos atores. No caso do arranjo brasileiro, o exemplo do BNDES é particularmente ilustrativo: o Banco manteve uma participação prevalecente no ambiente financeiro nacional, mas assumiu ferramentas e desenvolveu mecanismos de ação coadunados com uma economia baseada no conhecimento - uma adaptação institucional gradual. Qual o sentido desta adaptação? Que tipo de intervenção do Estado forja-se a partir daí?

\subsection{A MUdANÇA DE RACIONALIDAdE NA ATUAÇÃo do ESTAdo No SISTEMA FINANCEIRO NACIONAL}

Conceitualmente, o sentido desta acomodação dinâmica pode ser compreedindo, nos termos das categorias da teoria do direito e da sociologia econômica, como a adoção de uma distinta racionalidade regulatória e de um outro estilo de atuação do Estado no domínio econômico. Para a teoria do direito, o modo de intervenção do BNDES no financiamento das inovações sugere uma racionalidade jurídica com inspiração reflexiva, isto é, uma ação reguladora menos voltada para a direção da economia e mais afinada com a articulação de um ambiente de coordenação - de um espaço institucional propício à indução dos atores. Para a sociologia econômica, esta racionalidade é consentânea com um estilo de intervenção estatal menos hierárquico e mais propenso a estipular arranjos

\footnotetext{
${ }^{496}$ Cf. HALL, Peter \& SOSKICE, David. Varieties of Capitalism, op. cit.
} 
horizontais de governança entre as esferas pública e privada. Para Bob JESSOP ${ }^{497}$, trata-se de uma travessia - from government to governance. Para Seán Ó RIAIN ${ }^{498}$, de um tipo de Estado Desenvolvimentista que age como parteiro, mas não mais como um demiurgo do processo de desenvolvimento: o Estado induz, mas não assume a incumbência do resultado econômico.

Para JESSOP ${ }^{499}$, a emergência de um outro regime de acumulação, em que o conhecimento, as inovações e as empresas emergentes figuram como novos elementos da dinâmica econômica, traz consigo uma reflexão acerca do conseqüente modo de regulação desta nova economia, sobretudo em razão da revisão do Estado keynesiano. As falhas e contradições deste novo regime agregam novas questões aos problemas típicos das economias de mercado, o que demanda uma nova arquitetura institucional capaz de acomodar os interesses, estabilizar os conflitos e garantir a sustentação econômica do novo paradigma.

A administração destes novos conflitos tende a ser realizada por um Estado Schumpeteriano $^{500}$, capaz de balizar a sua atuação no apoio das estratégias empresariais baseadas em conhecimento. Para tanto, a sua intervenção deve balancear os estímulos e os incentivos voltados a mitigar a incerteza dos agentes, como as medidas de fomento econômico e defesa da propriedade intelectual, com a constituição de um arranjo propício à geração e difusão de conhecimento. O tipo ideal de Estado para esta economia tem como função, portanto, a constituição de um ambiente sistêmico de promoção da competitividade baseada em inovações. O objetivo de sua intervenção é menos produzir um resultado econômico definido e mais produzir as condições institucionais para que os empreendedores possam contar com maior segurança, com incentivos materiais e assim

\footnotetext{
497 A seguinte passagem de JESSOP citando Ó RIAIN, apresenta alguns contornos desta nova forma de intervenção do Estado: "for what Ó RIAIN is beginning to describe is a specific variant of the Schumpeterian Workfare Post-National regime that is tendentially replacing the Listian Workfare National State. He has correctly identified the increased importance of innovation and entrepreneurship to international competitiviness, the shift from a primarily national scale of regulation, and the growing role of networking and other forms of self-organized governance in the current round of capitalist restructuring". JESSOP, Bob. Developmental State and Knowledge-Driven Economies, paper, mimeo, disponível em http://www.bulgariagateway.org/bg/150/DevelopmentalStatesandKE.PDF, acesso 08.12.08. p. 24.

${ }^{498}$ Ó RIAIN, Séan. The Politics of High-Tech Growth - developmental network states in the global economy, Cambridge, 2004.

499 Ver a respeito, JESSOP, Bob. The Future of Capitalist State, op. cit., pp. 95-139 e JESSOP, Bob. Developmental State and Knowledge-Driven Economies, op. cit.

500 JESSOP, Bob. The Future of Capitalist State, op. cit
} 
sejam capazes de implementar um programa schumpeteriano de competição, ou seja, com inovações permanentes. Vale-se, para tanto, de medidas regulatórias, fiscais e financeiras:

The importance of innovation and entrepreneurship in post-Fordism is reflected in new state strategies. The competition state engages in technological intelligence gathering, helps to create independent technological capacities and promotes innovative capacities, technical competence and technology transfer so that as many firms as possible benefit from new technological opportunities created by R\&D activities undertaken is in specific parts of the economy. It develops, first, institutions and structures that directly support entrepreneurs, existing or potential; and second, institutions and structures that sustain an entrepreneurial climate. These measures include venture capital provision, subsidies, business park, technology transfer mechanisms and technical assistance, investment in knowledge production through public $R \& D$ or locally oriented R\&D consortia, industry service centres, local and regional development funds and public procurement policies. ${ }^{501}$

A atuação do Estado, portanto, não é propriamente diretiva do ambiente econômico, nem tampouco exerce estas atribuições por meio de um planejamento macroeconômico. Respondendo às necessidades de impulso da economia do conhecimento, mas refletindo o contexto institucional pós-keynesiano, a intervenção estatal volta-se, isto sim, à coordenação ou à governança do atores privados. Atua nesta medida, sob uma lógica de parceria, balizando a ação privada, mas sem com isso exercer o controle das relações de economia mista.

Também para Ó RIAIN, o traço característico do chamado Estado Desenvolvimentista em Rede (Developmental Network States) é a constituição de ambientes sistêmicos de promoção econômica. ${ }^{502}$ A proposta deste tipo de Estado, cuja caracterização é resultante da análise de Ó RIAIN sobre o modelo irlandês, não é a de implementar políticas setoriais, visando à consecução de resultados econômicos específicos, o que pressuporia a disposição de dirigir o curso do desenvolvimento industrial. O teor de sua intervenção volta-se, isto sim, a constituir um universo econômico provedor de competitividade industrial, capaz de induzir o surgimento e a consolidação de

${ }^{501}$ JESSOP, Bob. The Future of Capitalist State, op. cit, pp. 127-128.

${ }^{502}$ A primeira designação apresentada por Ó RIAIN foi a de Estado Desenvolvimentista Flexível, em um trabalho de 2000 (The Flexible Developmental State: globalization, information technology, and the 'Celtic Tiger', Politics \& Society, vol. 28, $\mathrm{n}^{\mathrm{o}}$ 2, 2000). Em um livro publicado posteriormente, o autor alterou a denominação para Developmental Network State, por se tratar, segundo o autor, de um titulo mais correspondente às funções desempenhadas por este Estado. Ver Ó RIAIN, Séan. The Politics of High-Tech Growth - developmental network states in the global economy, op. cit. 
empresas emergentes. Nessa medida, o Estado em Rede apresenta diferenças para a clássica forma da intervenção desenvolvimentista:

Developmental states are the most likely candidates for boosting an economy beyond the narrow logic of private investment and thereby improving its position in the international division of labor. They achieve their goals in the contemporary era not by taking on the tasks of development themselves but by shaping the capabilities of society and the market to do so. Researchers have moved from an emphasis on an authoritarian directive style of state intervention to an understanding of how the state pokes and prods domestic firms to compete in the global economy and to constantly upgrade their organizational and technical capabilities to that end. The state assists in the birth and growth of domestic national firms through its role as 'midwife' of new firms and sectors and by tending to the 'husbandry' of these growing industries. ${ }^{503}$

A noção de Estado em Rede tem em conta que a participação pública continua a desempenhar um papel chave nas estratégias de desenvolvimento, ultrapassando a mera provisão de um arcabouço jurídico-institucional seguro e previsível, como sugerem as fórmulas de "rule of law" indicadas pelo Banco Mundial para os países emergentes. No entanto, o objeto desta intervenção estatal distingue-se da plataforma desenvolvimentista, adotada pelos países da periferia ao longo da constituição de seus parques produtivos. A sua atuação tem como propósito a constituição de arranjos institucionais capazes de estimular a competição e a cooperação entre empresas inovadoras e não propriamente selecionar discricionariamente os grupos vencedores, como faziam as classicamente políticas industriais. Ao invés de definir setores e grupos empresariais estratégicos, beneficiários de estímulos e medidas de incentivo, a intervenção deste novo tipo de Estado volta-se a incrementar a competitividade do sistema empresarial, nos termos de Ó RIAIN, trata-se de forjar vencedores (making winners) e não de apontar os campões nacionais (picking winners). ${ }^{504}$

As políticas industriais e a atuação financeira das agências de fomento partem do pressuposto de que a internacionalização das economias impõe limites para as medidas de proteção comercial e de favorecimento a setores inefetivos, sob pena de serem sancionadas, seja pelas autoridades do comércio internacional, seja pela rivalidade do

503 Ó RIAIN, Séan. The Flexible Developmental State: globalization, information technology, and the 'Celtic Tiger', Politics \& Society, vol. 28, nº 2, 2000. p. 163.

${ }^{504}$ Ó RIAIN, Séan. The Flexible Developmental State, op. cit. 
mercado. Sendo assim, se é verdade que a indução de novos grupos reclama uma atuação positiva do Estado, sobretudo para a provisão de capital de risco nas fases iniciais dos empreendimentos, as políticas públicas pressupõem a necessidade de integração das empresas apoiadas ao ritmo da competição de mercado. É esta a função da agência irlandesa FORBAIT, que administra um programa público de venture capital, cujo papel excede a mera provisão de recursos: a sua intervenção volta-se também para medidas de aprimoramento dos regimes de governança corporativa das empresas emergentes, para o aconselhamento administrativo e para a articulação entre essas empresas, as universidades e os possíveis investidores, clientes e fornecedores.

A organização burocrática do Estado em Rede permite uma intervenção pública ainda mais articulada e fragmentada, que a do Estado Desenvolvimentista ${ }^{505}$. Em comparação com este último, o Estado em Rede apresenta uma dupla inserção econômica: atua tanto no âmbito internacional, como no local. No ambiente externo, as agências de fomento atuam para captar recursos e investimentos. No âmbito interno, a atuação é descentralizada, com agências de fomento capacitadas a prover capital de risco de forma capilarizada para empresas emergentes, em diversas localidades do país. Uma organização burocrática menos centralizada e mais afinada com a estipulação de relações de associação com agentes privados.

Sendo assim, o Estado schumpeteriano de JESSOP ou o Estado em Rede de Ó RIAIN, afora a identidade da pauta de intervenção, igualmente voltada à promoção das inovações e das empresas emergentes, têm em comum a forma de atuação do agente público. Para ambos os intérpretes, as heterarquias, isto é, os espaços de governança, parecem suplantar os arranjos hierárquicos e diretivos que informaram o Estado

\footnotetext{
${ }^{505} \mathrm{O}$ panorama institucional dos países retardatários contou, via de regra, com um estilo de organização burocrática e um modo de intervenção regulatória que habilitavam uma direção pública do processo de desenvolvimento. Ao invés de uma burocracia insularizada, resguardada de quaisquer liames com os agentes privados e de um direito formal, encarregado de estabelecer regras universais para todos os atores sociais, as propostas de superação do subdesenvolvimento contaram normalmente com uma burocracia inserida e com uma regulação econômica substantiva. A burocracia inserida, diferentemente da burocracia insularizada, classicamente descrita por Max WEBER, tem o propósito de constituir os meios adequados para uma interveção ativa dos Estados na coordenação econômica. Partindo desta noção de burocracia, Peter EVANS assinala que as estratégias de desenvolvimento demandavam uma burocracia igualmente profissional e autônoma, mas com capacidade de se articular aos grupos empresariais, para assim impulsionar as estratégias de desenvolvimento - vem daí o nome de seu livro Embedded Autonomy, ou seja, uma burocracia com autonomia, mas articulada aos setores industriais. A esse respeito, ver EVANS, Peter. Embedded Autonomy state and industrial transformation, Princeton, Princeton University Press, 1995, pp. 3-20.
} 
Keynesiano/Desenvolvimentista. Para essas duas leituras também, a persecução de resultados e metas foi suplantada pela constituição de espaços de coordenação, nos quais o papel da política pública é o de promover as condições sistêmicas de organização privada, que resultem em incentivos para os comportamentos socialmente desejados. Esta virada de página parece estar associada, por sua vez, a uma racionalidade reflexiva na regulação desempenhada pelo direito.

No âmbito da teoria do direito, autores como TEUBNER ${ }^{506}$ e HABERMAS ${ }^{507}$ têm apresentado uma formulação conceitual sobre a forma e a função de um Direito que é compatível com um Estado pós-fordista. Partindo do diagnóstico de sobrecarga institucional do ambiente regulatório e da complexidade apresentada pela organização social e econômica, os autores têm apresentado uma proposição normativa para estipular a racionalidade deste novo tipo de intervenção jurídica ${ }^{508}$, capaz de, a um só tempo, garantir a regulação das falhas de mercado e iniqüidades sociais, sem com isso atribuir ao direito a responsabilidade pelo resultado específico destas atividades. Isto é, uma racionalidade jurídica que ultrapasse os limites do direito formal, entendendo que a proteção das autonomias privadas não é sufuciente para prover uma substantiva coordenação dos problemas sociais e econômicos, mas que não centralize na regulação pública a persecução de todos os fins políticos estipulados. Trata-se, para TEUBNER ${ }^{509}$, de uma racionalidade regulatória reflexiva, ou como assinala SCHEUERMAN uma conciliação entre dois paradigmas de direito:

Reflexive law is then conceived as aiming to avoid both the Charybdis of formal law and the Scylla of materialized substantive law (...) Like substative law, it is guided by the aim of subjecting social and economic activities to broader regulatory purposes. Yet it hopes to do so without dictating specific outcomes and thereby contributing to the rigidity and ineffectiveness of some existing forms of regulatory law (...) Reminiscent of classical formal law, reflexive law hopes to preserve the relative autonomy of distinct social spheres; simultaneously, it breaks with laissez-faire notions of a 'natural' market economy by acknowledging the existence of inequalities endemic to modern capitalism. ${ }^{510}$

\footnotetext{
506 TEUBNER, Gunther. Substantive and Reflexive Elements in Law, op. cit

${ }^{507}$ HABERMAS, Jürgen. Paradigms of Law, Cardozo Law Review, vol. 17, 1995, pp. 771-784

${ }^{508}$ A racionalidade compreende três planos de análise: (i) a justificativa interna do direito; (ii) a sua função externa e (iii) as estruturas internas, que viabilizam o seu programa de intervenção. Ver TEUBNER, Gunther. Substantive and Reflexive Elements in Law, op. cit

${ }^{509}$ TEUBNER, Gunther. Substantive and Reflexive Elements in Law, op. cit

510 SCHEUERMAN, William. Reflexive Law and the Challenges of Globalization, The Journal of Political Philosophy, vol. 9, nº 1, 2001, p. 84.
} 
A justificativa interna do direito reflexivo situa-se, de fato, a meio caminho, entre a noção de autonomia privada e a de regulação pública pormenorizada. A sua concepção de atuação baliza-se pela idéia de autonomia social, isto é, espaços sociais de governança, que sejam capazes de superar os limites de uma ordem jurídica individual, sem com isso eliminar a diversidade de arranjos e compromissos, que podem resultar de uma sociedade funcionalmente diversificada. Portanto, o direito reflexivo assenta-se neste duplo reconhecimento: os limites do individualismo formal e os excessos da regulação hierárquica, para um ambiente diversificado. A sua função externa distingue-se de ambos os tipos de racionalidade regulatória prevalecentes até então - a formal e a substantiva. A proposta de confeccionar este aparato regulatório aponta para um papel de coordenação e de constitução de arranjos institucionais que permitam a governança dos respectivos atores. $^{511}$

Neste modelo, a regulação pública ainda desempenha um papel relevante, qual seja, o de balizar e procedimentalizar o funcionamento dos espaços de auto-coordenação. No lugar dos comandos hipotéticos, gerais e abstratos, do direito formal e dos regulamentos, empresas e autarquias constituídos para garantir uma regulação minuciosa e concreta, do direito substantivo, tomam assento normas voltadas a situações particulares, porém com maior grau de abstração e menos conteúdo material: a sua finalidade é organizar o processo decisório dos espaços de auto-coordenação.

Com esse tipo de racionalidade regulatória, enfim, compõe-se o arranjo institucional de uma economia baseada no conhecimento. O Estado keynesiano, a burocracia inserida e o direito substantivo são suplantados pelos tipos ideais Estado schumpeteriano/em rede, burocracia descentralizada e articulada internacionalmente e direito reflexivo.

\footnotetext{
${ }^{511} \mathrm{Na}$ realidade, esta fórmula já havia sido apresentada por NONET \& SELZNICK, em 1978, cuja noção de direito responsivo já atribuía ao direito uma nova função, a de articular desenhos institucionais para permitir a responsividade às questões da realidade. Ver NONET, Philippe \& SELZNICK Philip. Law and Society in Transition, op. cit.
} 


\begin{tabular}{|c|c|c|c|}
\hline \multicolumn{4}{|c|}{$\begin{array}{c}\text { QUADRO } 24 \\
\text { CIPOS DE ESTADO E RACIONALIDADES REGULATÓR }\end{array}$} \\
\hline & Capitalismo liberal & Paradigma fordista & $\begin{array}{l}\text { Economia baseada no } \\
\text { conhecimento }\end{array}$ \\
\hline Tipo de estado & Estado Liberal & $\begin{array}{l}\text { Estado Keynesiano/ } \\
\text { Desenvolvimentista }\end{array}$ & $\begin{array}{l}\text { Estado Schumpeteriano/ } \\
\text { Estado em Rede }\end{array}$ \\
\hline Organização burocrática & $\begin{array}{c}\text { Burocracia } \\
\text { Insularizada }\end{array}$ & Burocracia Inserida & $\begin{array}{c}\text { Burocracia } \\
\text { Descentralizada }\end{array}$ \\
\hline Racionalidade regulatória & Direito Formal & Direito Substantivo & Direito Reflexivo \\
\hline Justificativa do direito & $\begin{array}{c}\text { Garantia da } \\
\text { autonomia privada }\end{array}$ & $\begin{array}{l}\text { Regulação social e } \\
\text { econômica }\end{array}$ & $\begin{array}{l}\text { Constituição da } \\
\text { Autonomia social }\end{array}$ \\
\hline Função externa do direito & $\begin{array}{l}\text { Preservar espaços de } \\
\text { liberdade individual }\end{array}$ & $\begin{array}{c}\text { Corrigir falhas de } \\
\text { mercado e injustiças } \\
\text { sociais }\end{array}$ & $\begin{array}{l}\text { Articulação de arranjos } \\
\text { para auto-governança }\end{array}$ \\
\hline $\begin{array}{l}\text { Estrutura interna do } \\
\text { direito }\end{array}$ & $\begin{array}{l}\text { Comandos } \\
\text { hipotéticos }\end{array}$ & $\begin{array}{c}\text { Regulamentos e } \\
\text { dispositivos } \\
\text { interventivos }\end{array}$ & Normas organizacionais \\
\hline
\end{tabular}

É a partir desse quadro teórico que se pode compreender as diferenças na forma de intervenção do BNDES em relação ao contexto desenvolvimentista. No financiamento de empresas emergentes e inovadoras, as suas linhas e programas indicam a disposição de constituir um ambiente institucional favorável às operações de risco, sem, no entanto, assumir responsabilidade pelo desfecho específico desta intervenção. Ao invés de escolher vencedores e implantar parques produtivos, a sua intervenção propõe-se, isto sim, a constituir um mercado financeiro de risco no país, no qual o Banco e os demais agentes privados venham a figurar como alternativas financeiras para as empresas emergentes. Trata-se, portanto, de concentrar a sua atuação no desenho de um arranjo institucional, que garanta capacidade de financiamento para os projetos privados de inovação e não propriamente de determinar ex ante o perfil da especialização tecnológica nacional, favorecendo discricionariamente grupos empresariais.

Diferentemente do ocorrido nos planos de desenvolvimento econômico, a atuação do BNDES no segmento de inovação não tem como lógica subjacente a constituição de setores da economia, tal como fôra o caso dos ramos de insumos básicos e bens de capital, durante o II PND. Isso é particularmente perceptível na estratégia do Banco em participar dos fundos privados de venture capital. O propósito desta atuação é o de constituir um ambiente financeiro propício aos investimentos de risco, é, portanto, voltado a criar um mercado, a partir do quê os grupos interessados poderão estruturar as suas operações. 
$\mathrm{Na}$ constituição deste mercado de risco, a atuação do Estado vai além das recomendações de política afinadas com a literatura da Law and Finance. A intervenção pública não se limita a estabelecer apenas as regras formais, a partir das quais os agentes privados supostamente passarão a desempenhar os atributos de capitalistas de risco, tal como verificado no ambiente norte-americano. Reconhecendo a primazia das alternativas institucionais e a rigidez oferecida pela dependência da trajetória, o BNDES tem articulado, no exercício de sua regulação institucional, uma alteração incremental na forma de sua intervenção como Banco de Desenvolvimento: tem envidado esforços para constituir, por meio de uma intervenção direta do Estado, um mercado de risco no Brasil.

Esta forma de atuação tem um paralelo no registro que Katharina PISTOR \& Chenggang XU ${ }^{512}$ fazem da criação do mercado de capitais na China, em que o Estado tem atuado diretamente na condução das operações de abertura de capital das empresas, que contam ainda com a sociedade do governo. Este modelo de criação de mercado, em que o Estado se comporta como um verdadeiro agente do mercado de capitais, participando de empresas e selecionando as firmas que devem ser listadas na bolsa, é denominado pelos autores por administrative governance, em oposição ao modelo legal governance, empregrado pela Rússia, cujas reformas financeiras assumiram as recomendações de tipo Law and Finance, concentrando-se no ambiente legal - no "rule of law".513

$\mathrm{O}$ administrative governance conduzido pelo BNDES no terreno das empresas emergentes sugere uma intervenção reflexiva, isto é, voltada a constituir um espaço de governança horizontal - um mercado capaz de prover recursos para as firmas inovadoras. Chama particulamente a atenção o fato de que a intervenção do Banco não substitui o mercado, isto é, a sua ação não é concorrente com o mercado de capitais. Trata-se, isto sim, de uma atuação complementar - o BNDES fortalece o mercado de risco. Daí o porquê de autores como Luciano COUTINHO e Bráulio BORGES rejeitarem a noção de incompatibilidade institucional entre os mecanismos de poupança compulsória, que constituem a ação do BNDES, e a ativação dos demais veículos financeiros de

${ }^{512}$ PISTOR, Katharina \& XU, Chenggang. Governing Emerging Stock Markets: legal vs administrative governance. Blackwell publishing, vol. 13, $\mathrm{n}^{\circ}$ 1, 2005, pp. 5-10.

${ }_{513}$ Cf. PISTOR, Katharina \& XU, Chenggang. Governing Emerging Stock Markets: legal vs administrative governance, op. cit. 
capitalização corporativa, como é o caso do mercado de capitais ${ }^{514}$. Isso é notadamente perceptível na evolução do segmento de fundos mútuos de investimento: em 1999, o Banco participava dos 5 fundos existentes no país; já em 2008, essa participação segue expressiva, mas passou a representar cerca de metade do setor. Essa evolução revela que a participação do Banco tem como propósito induzir o mercado de risco brasileiro.

Uma atuação semelhante, embasada nesse mesmo tipo de racionalidade, preside também as operações diretas, seja por meio das participações societárias, seja pelos contratos de crédito. Em ambos os casos, o BNDES, ao utilizar ferramentas jurídicas próprias do direito patrimonial privado, atua com os mesmos mecanismos dos agentes do sistema financeiro - age alinhado, portanto, com os mercados de capitais e de créditos. Isso é especialmente evidente nas transações com renda variável, em que o BNDES mimetiza a atuação de um venture capitalist.

Mesmo nas operações de crédito, em que o Banco não se utiliza de dispositivos societários e nem conta com a possibilidade de realizar o desinvestimento na bolsa de valores, a lógica subjacente à transação é a de não induzir artificialmente o financiamento de projetos. Ainda que as taxas de juros para os empreendimentos de inovação sejam favoráveis, a distorção dos preços relativos é limitada e o beneficiário do projeto deve apresentar ao banco o potencial de viabilidade de sua proposta. Há nesse sentido uma diferença com o tipo de contratação de crédito ocorrida durante o II PND, por exemplo, quando o Banco assumia as despesas decorrentes da inflação, ao não repassar a correção monetária de forma integral aos contratos de colaboração financeira, gerando assim uma privatização de recursos públicos com vistas a permitir a consolidação dos setores estratégicos.

No limite, ao utilizar ferramentas típicas do mercado e estruturar operações de crédito financeiramente sustentáveis, a intervenção do BNDES permite um efeito de

\footnotetext{
${ }^{514}$ Desde a década de 1990, alguns autores têm apontado que a poupança compulsória drena recursos passíveis de serem alocados pelo mercado, de tal forma que o direcionamento estatal do crédito provocaria uma compressão das demais fontes de recursos - um crowding out. Entretanto, a racionalidade subjacente aos programas de inovação do Banco sugere na realidade a prevalência de um fenômeno de complementaridade financeira, um crowding in, em que há a sinergia entre a intervenção estatal e os demais atores financeiros. Sobre o crowding in, ver COUTINHO, Luciano \& BORGES, Bráulio Lima. A Consolidação da Estabilização e o Desenvolvimento Financeiro do Brasil, em PINHEIRO, Armando Castelar \& OLIVEIRA FILHO, Luiz Chrysostomo (org.). Mercado de Capitais e Bancos Públicos, op. cit., pp. 345-365.
} 
crowding in, de forma que o resultado de suas operações contribuem para o conjunto do sistema financeiro. Na realidade, ambas as formas de intervenção, a direta e a indireta, estão assentadas em um mesmo pressuposto, qual seja, o de compor o sistema financeiro, permitindo assim a disponibilização de recursos para atividades de risco e de longo prazo, mas sem com isso tornar os mercados de crédito e de capital instrumentos para o alcance de resultados econômicos setorialmente especificados. Trata-se, enfim, de uma intervenção estatal cujo resultado aponta para a organização de um ambiente financeiro, capaz de suprir as diversificadas demandas de recursos apresentadas pelos mais diferentes setores da economia.

Mesmo com a estipulação da Política Industrial, Tecnológica e de Comércio Exterior, em 2004, e com a Política de Desenvolvimento Produtivo, em 2008, que contam com a atuação do BNDES como instrumento financeiro do governo, a racionalidade de intervenção do Banco não indicou alteração. Ao menos no que tange aos setores inovadores, ambas as políticas, embora apresentem setores prioritários (como software, bens de capital, fármacos, entre outros), resultaram em programas e linhas com caráter horizontal $^{515}$ : o BNDES não seleciona vencedores nos setores de fármacos ou de software, por exemplo. Os recursos são disponíveis para o segmento, mas não como objeto de planejamento econômico: a intervenção estatal não garante desde antes o resultado a ser alcançado pelos setores. Trata-se, na verdade, da definição de medidas de incentivo, voltadas a induzir o nível de atividade e o dispêndio com inovações, sem no entanto estabelecer minuciosamente metas, prazos e produtos. O fim último da intervenção é o de constituir um ambiente sistêmico de promoção da competitividade. Para isso, estrutura operações financeiras alinhadas com o mercado e favorece os investimentos na formação de um novo tipo de empresa, dedicada a inovar de maneira permanente. É nessa medida que a intervenção é dotada de um viés reflexivo - comprometido com a organização dos espaços e a correspondente definição dos incentivos.

515 Sobre a distinção entre a PITCE e as demais políticas industriais brasileiras, assinalam Milton CAMPANÁRIO, Marcello Muniz da SILVA e Tiago Ribeiro COSTA: "A principal mudança de enfoque em relação às políticas industriais pretéritas (ver quadro 1) é a busca explícita de obtenção de vantagens comparativas dinâmicas, associadas à maior valorização da inovação e da difusão horizontal de tecnologia, bem como de capacitações e de competências institucionais, sem apontar para um estilo intervencionista direto, mas simplesmente regulador." ver CAMPANÁRIO, Milton. SILVA, Marcello Muniz da \& COSTA, Tiago Ribeiro. Política Industrial, Tecnológica e de Comércio Exterior (PITCE): análise de fundamentos e arranjos institucionais, paper apresentado no XI Seminário Ibero-americano de Gestion Tecnologica, 2005, pp. 10-11, disponivel em http://www.redetec.org.br/publique/media/pitce.pdf, acesso 04.12.2008. 
A diferença em relação ao modelo de TEUBNER fica por conta da persistência do Estado como agente financeiro. Para os autores do direito reflexivo, a ação reguladora do Estado tende a ser substituída pelas normas procedimentais, estipuladoras de uma autoregulação, no bojo da qual os agentes estipulam laços de governança privada. Não é esse o caso do BNDES. Como já argumentado ao longo desta tese, o paradigma da economia baseada no conhecimento não suplantou a regulação institucional exercida pelo banco estatal, um elemento que é típico de uma racionalidade substantiva do direito - fruto de um período de intensa intervenção pública na economia. Sendo assim, não seria correto interpretar essas mudanças como sendo resultantes da consolidação de um novo paradigma no direito brasileiro, o que poderia sugerir, equivocadamente, que a primazia da intervenção estatal teria dado lugar a uma auto-regulação privada (uma prevalência do direito reflexivo). Não é disso que se trata: a alternativa institucional nacional continua baseada, em boa medida, em uma coordenação pública da economia, sobretudo no que se refere aos setores emergentes. O que se pretendeu mostrar é que, conquanto a regulação institucional siga como um atributo característico do modelo brasileiro, a forma de sua intervenção tem assumido novos parâmetros. Pela lente da teoria do direito, pode-se observar uma atuação mais indutora e menos dirigente e, com as devidas ressalvas que o caso comporta, localizar uma inspiração reflexiva para esta intervenção direta do Estado na economia. Afinal de contas, o agente de coordenação deste ambiente financeiro de risco é o BNDES e não as normas procedimentais de auto-regulação.

\section{CONSIDERAÇÕES FINAIS}

Como interpretar a atuação do BNDES no financiamento da nova economia? Foi esta a questão que balizou este capítulo final, dedicado a recuperar os debates travados ao longo desta tese, para assim oferecer uma leitura capaz de contribuir na compreensão deste novo formato de intervenção do Estado. Para responder a esta pergunta, este capítulo procurou alinhavar dois argumentos tensos, porém complementares: a persistência e a dinâmica.

De um lado, é inegável a persistência da alternativa institucional, caracterizada no capítulo 2 deste trabalho: inobstante as privatizações de bancos públicos, a adoção de uma lógica privada para os agentes estatais, a internacionalização do setor bancário e o adensamento do mercado de capitais, os bancos do Estado e o BNDES, em especial, 
continuam desempenhando um papel relevante. O Banco, em particular, não só persiste como o grande provedor dos recursos de longo prazo e de alto risco, como verificado no segmento de empresas emergentes, como também segue desempenhando papéis típicos de um ator de desenvolvimento: é o BNDES quem ainda atua para desbravar as fronteiras do mercado de risco no país. Este comportamento, verificável recentemente na estruturação de um fundo de capital "semente", tem sido a marca característica da sua intervenção, sobretudo, na nova economia: basta ver que o segmento de fundos de investimento contou com o Banco como um dos seus principais articuladores.

De outro lado, no entanto, a persistência deste arranjo não significa a sua inércia: a regulação institucional exercida pelo BNDES tem se valido de uma nova racionalidade. No lugar dos parâmetros substantivos que orientaram a sua atuação, no contexto desenvolvimentista, em que o Estado assumia o encargo de selecionar os vencedores e dirigir os rumos do processo de industrialização, tem sobressaído uma lógica reflexiva: o agente estatal atua alinhado com os demais integrantes do sistema financeiro e volta-se a constituir um mercado de risco no país. O comando centralizado e a substituição do mercado cedem lugar a uma regulação institucional balizada pela intenção de constituir um ambiente favorável à competitividade. Essa forma de atuação é bastante evidente quando o BNDES associa-se a investidores privados, para assim formar fundos mistos de investimento. Mas está presente também quando o Banco adota ferramentas jurídicas afinadas com as expectativas do agentes privados.

É, pois, disso que se trata: um banco de desenvolvimento, mas diante de uma economia baseada no conhecimento. 


\section{CONCLUSÃO \\ O QUE A TESE RESPONDE?}

Em um artigo intitulado Bootstrapping Development: rethinking the role of public intervention in promoting growth ${ }^{516}$, Charles SABEL retoma um argumento que tem embalado os pesquisadores heterodoxos em ciências sociais, ao menos nos últimos vinte anos, qual seja, a relevância do experimentalismo e da confecção nacional de políticas e de instituições. O trabalho de SABEL vai ao encontro, portanto, de teses e proposições sustentadas, recentemente, em diversos círculos acadêmicos e que têm procurado refutar uma concepção bastante influente nos anos 1990: a noção de ausência de alternativas e da possibilidade de se firmar consensos acerca de medidas institucionais, tidas como corretas para alavancar o desenvolvimento dos países subdesenvolvidos.

De fato, ao longo dos 90, acadêmicos e formuladores de políticas públicas enredaram-se no pressuposto de que os caminhos estavam trilhados e o estoque de soluções existentes, para os problemas sociais e econômicos, havia sido constituído. Era quase inexorável que o progresso econômico e o alívio da pobreza tivessem de contar com os atributos institucionais "corretos", tais como: a defesa da propriedade, a reforma do Estado, o impulso dos mercados, enfim, a garantia do "rule of law". Vem desta chave de análises, voltadas a realizar estudos de comparação entre os países, a pretensão de hierarquizar os seus fatores institucionais, assumindo como parâmetro um suposto funcionamento adequado de mercados e sociedades. A régua destes estudos dirige-se, assim, a medir o êxito dos países em realizar o seu programa de desenvolvimento, ancorada na idéia subjacente de uma democracia liberal, marcada pelas transações econômicas privadas. Não raro, partidários destas leituras costumam identificar as diferenças institucionais como deficiências e as alternativas, como equívocos. É nesse ambiente que se localizam os artigos da Law and Finance e as propostas de HANSMANN \& KRAAKMAN sobre a convergência dos modelos de financiamento corporativo.

$\mathrm{O}$ artigo de SABEL contraria justamente esta plataforma intelectual, que tematiza o desenvolvimento econômico como sendo um fenômeno caudatário de uma

516 SABEL, Charles. Bootstrapping Development: rethinking the role of public intervention in promoting growth, paper apresentado na conferência Ética Protestante e o Espírito do Capitalismo, na Universidade de Cornell, $\quad$ mimeo, $\quad 2004, \quad$ disponível em http://www2.law.columbia.edu/sabel/papers/bootstrapping\%20deve\%20send5.doc, acesso em 21.01.09. 
espécie de dotação dos fatores institucionais (endowments). Para os autores afinados com essa matriz, é como se existisse uma dotação acertada de fatores, cuja existência responderia pela alavancagem econômica dos países. No limite, regulamentos, regras, sistemas jurídicos e políticas públicas passaram a ser tratados como se fossem atributos naturais, tal como o potencial agrícola, ou a existência de recursos minerais. Um exemplo disso é a simpatia de muitos desses autores pelo regime de common law, entendida como uma dotação mais satisfatória do que o sistema de civil law. Em oposição a esta linha de análise, SABEL argumenta que as experiências bem sucedidas de crescimento econômico resultam não de um conjunto pré-moldado de arranjos jurídico-institucionais, mas sim da capacidade de experimentação dos arranjos, isto é, da descoberta de soluções satisfatórias às vicissitudes e particularidades dos respectivos países.

Nessa medida, a idéia de um Bootstrapping Development, isto é, de um desenvolvimento alicerçado em suas próprias bases, converge com a produção de outros autores, igualmente críticos às proposições de fim da história e de convergência institucional, como se fossem resultados necessários de uma economia pós-fordista. É este o caso de MANGABEIRA UNGER ${ }^{517}$, que situa este debate no direito, ao contrapor duas concepções: (i) o fetiche institucional e (ii) a imaginação institucional. De um lado figurariam os fetichistas institucionais, autores que assumem um certo fetiche por um determinado conjunto de instituições, como é caso do mercado de capitais e da pulverização acionária - a ausência destes elementos estaria associada a patamares depreciados de desenvolvimento e progresso. De outro lado, MANGABEIRA sustenta o direito como sendo um instrumento de imaginação institucional, ou seja, assume que a organização das sociedades não é um livro fechado e que a experiência de novas fórmulas é o que pode garantir o florescimento de novos caminhos e soluções. Por detrás desta compreensão reside, tanto para MANGABEIRA, como para SABEL, uma admiração pela construção norte-americana do New Deal, forjado à base de um experimentalismo institucional com o propósito de alterar o destino manifesto daquela sociedade.

Em boa medida, esta tese é tributária deste entendimento, que vê no experimentalismo e na imaginação a possibilidade de construção de soluções customizadas às necessidades nacionais. A compreensão de que existem alternativas jurídico-

517 UNGER, Roberto Mangabeira. O Direito e o Futuro da Democracia, (trad. Caio Farah Rodriguez e Marcio Grandchamp), São Paulo, Boitempo, 2004. 
institucionais e de que a alternativa brasileira conta com o Estado como um agente financeiro relevante tem como antecedente uma rejeição às teses fetichistas: o banco de desenvolvimento é assumido neste trabalho não como uma distorção, mas sim como uma circunstância local, instituído para oferecer respostas adequadas às particularidades de um país, cujo desafio é superar o quadro de tensão estabelecido entre a pretensão do desenvolvimento e as carências de financiamento.

Partindo desse entendimento, a tese procurou mostrar como as experiências realizadas no âmbito desta alternativa nacional têm garantido uma adaptação aos imperativos da nova economia. A atuação do BNDES nos segmentos inovadores, valendose de ferramentas societárias e contratuais, alinhadas com os demais atores do sistema financeiro, sugere uma nova relação público-privada, menos diretiva e mais voltada à coordenação e à indução dos agentes privados. Nessa medida, pode-se dizer que sim, a regulação institucional persiste como um atributo constitutivo da organização financeira nacional, mas tem sido capaz de desenvolver mecanismos ajustados a um ambiente privatizado e informado por empresas emergentes e inovadoras.

Eis, enfim, a resposta oferecida por este trabalho: não há uma resposta única para o arranjo jurídico-institucional de uma economia baseada no conhecimento. No caso brasileiro, a resposta nacional tem contado, em boa medida, com a regulação institucional, baseada, no entanto, em novos parâmetros de intervenção. 


\section{BIBLIOGRAFIA}

AGHION, Beatriz Armendáriz de. Development Banking, Journal of Development Economics, vol. 58, 1999.

ALÉM, Ana Cláudia. O Desempenho do BNDES no Período Recente e as Metas da Política Econômica, Texto para Discussão, nº. 65, BNDES, 1998.

ALLEN, Franklin \& GALE, Douglas. Comparing Financial Systems, Cambridge, London, MIT Press, 2000.

ALTMAN, Edward \& McKINNEY, Mary Jane. Handbook of Corporate Finance, John Wiley \& Sons, s/d.

ALVEAL, Carmen. Os Desbravadores - a Petrobrás e a construção do Brasil industrial, Rio de Janeiro, Relume Dumará: ANPOCS, 1994.

AMSDEN, Alice \& SINGH, Ajit. The Optimal Degree of Competition and Dynamic Efficiency in Japan and Korea, European Economic Review, nº. 38, 1994.

AOKI, Masahiko \& DINÇ, Serdar. Relational Financing as an Institution and its Viability under Competition, paper, mimeo, Stanford University, 1997, disponível em http://www-econ.stanford.edu/faculty/workp/swp97011.pdf

AOKI, Masahiko, PATRICK, Hugh \& SHEARD, Paul. The Japanese Main Bank System: an introductory overview, in AOKI, Masahiko \& PATRICK, Hugh. The Japanese Main Bank System - its relevance for developing and transforming economies, Reprinted, New York, Oxford University Press, 1998.

APPEL, Steven. Small Business finance: sources of capital, em ALTMAN, E. I. Handbook of Corporate Finance, New York, Wiley, 1986.

ARBIX, Glauco. Inovar ou Inovar - a indústria brasileira entre o passado e o futuro, São Paulo, Papagaio, 2007.

ARIDA, Pérsio; BACHA, Edmar \& LARA-RESENDE, André. Credit, Interest, and Jurisdictional Uncertainty: Conjectures on the Case of Brazil, Instituto de Política Econômica Casa das Garças, Rio de Janeiro, 2004, disponível em http://www.econ.pucrio.br/material/macroii/Incerteza\%20Jurídica.pdf

ARIDA, Pérsio. A Pesquisa em Direito e em Economia: em torno da historicidade da norma, versão revisada do paper apresentado no Simpósio $O$ que é pesquisa em Direito, organizado pela Direito GV, 2002, disponível em http://iepecdg.com/DISK\%201/Arquivos/Leiturassugeridas/Pesquisa\%20em\%20Econo mia\%20e\%20em\%20Direito.25042005.pdf 
ARIDA, Pérsio. Mecanismos Compulsórios e Mercados de Capitais: propostas de política econômica, Instituto Casa das Garças, Texto para Discussão nº 8, 2005, disponível em http://iepecdg.com/DISK\%201/Arquivos/TPD/TPD8IEPE.pdf

ARIENTI, Wagner Leal. Do Estado Keynesiano ao Estado Schumpeteriano, Revista de Economia Política, vol. 23, nº 4, 2003.

ATIYAH, P. S. The Liberal Theory of Contract, em ATIYAH, P. S. Essays on Contract, Oxford, Clarendon Press, 1986.

AYRES, Ian \& CRAMTON, Peter. Relational Investing and Agency Theory, Cardozo Law Review, vol. 15, 1994.

BASTOS, Valéria Delgado. Incentivo à Inovação: tendências internacionais e no Brasil e o papel do BNDES junto às grandes empresas, Revista do BNDES, Rio de Janeiro, v. 11, $n^{\circ} .21$, jun, 2004.

BAUMOL, William. PANZER, J. \& WILLIG, D. Contestable Markets and the Theory of Industrial Structure, Nova York, Harcourt Brace Jovanovich, 1982.

BEBCHUK, Lucian \& ROE, Mark. A Theory of Path Dependence in Corporate Ownership and Governance, em GORDON, Jeffrey \& ROE, Mark (Ed.). Convergence and Persistence in Corporate Governance, New York, Cambridge, 2004.

BECK, Thorsten \& LEVINE, Ross. Legal Institutions and Financial Development, working paper 10417, National Bureau of Economic Research, 2004.

BECK, Thorsten; DEMIRGÜÇ-KUNT, Asli \& LEVINE, Ross. Law, Politics and Finance, paper, mimeo, 2001, disponível em http://papers.ssrn.com/sol3/papers.cfm?abstract_id=269118.

BERCOVICI, Gilberto. Desigualdades Regionais, Estado e Constituição, São Paulo, Max Limonad, 2003.

BERCOVICI, Gilberto. O Ainda Indispensável Direito Econômico, paper, mimeo, 2007.

BERCOVICI, Gilberto. O Estado Desenvolvimentista e seus Impasses: uma análise do caso brasileiro, em Separata do Boletim de Ciência Econômicas, Universidade de Coimbra, nº. XVLI, 2004.

BERLE, Adolf \& MEANS, Gardiner. The Modern Corporation \& Private Property, $9^{\mathrm{a}}$ Ed. New Jersey, Transaction Publishers, 2007.

BLACK, Bernard \& GILSON, Ronald. Venture Capital and the Structure of Capital Markets - banks versus stock markets, Journal of Financial Economics v. 47, 1998.

BNDES, Políticas Operacionais, 2005.

BNDES, Relatório Anual 1999, disponível em www.bndes.gov.br 
BNDES, Relatório Anual 2000, disponível em www.bndes.gov.br

BNDES, Relatório Anual 2001, disponível em www.bndes.gov.br

BNDES, Relatório Anual 2003, disponível em www.bndes.gov.br

BNDES, Relatório Anual 2005, disponível em www.bndes.gov.br

BONELLI, R. Ensaios sobre Política Econômica e Industrialização no Brasil, Rio de Janeiro, SENAI/DITEC/DPEA, CIET, 1995.

BRESSER PEREIRA, Luiz Carlos. Crise Econômica e Reforma do Estado - para uma nova interpretação da América Latina, (trad. Ricardo Ribeiro e Martha Jalkauska), São Paulo, 34, 1996.

BRESSER PEREIRA, Luiz Carlos. Reforma do Estado nos Anos 90 - lógica e mecanismos de controle, Lua Nova Revista de Cultura e Política, ${ }^{\circ}$. 45, 1998.

BREYER, Stephen. Regulation and its Reform, Harvard, Harvard University Press, 1982.

CAMPANÁRIO, Milton de Abreu \& SILVA, Marcello Muniz da. Fundamentos de uma Nova Política Industrial, em FLEURY, Maria Tereza Leme \& FLEURY, Afonso (org.). Política Industrial 1, São Paulo, PubliFolha/FEA-USP, 2004.

CAMPANÁRIO, Milton. SILVA, Marcello Muniz da \& COSTA, Tiago Ribeiro. Política Industrial, Tecnológica e de Comércio Exterior (PITCE): análise de fundamentos e arranjos institucionais, paper apresentado no XI Seminário Ibero-americano de Gestion Tecnologica, 2005, disponivel em http://www.redetec.org.br/publique/media/pitce.pdf

CARNEIRO, Ricardo. Desenvolvimento em Crise - a economia brasileira no último quartel do século XX, São Paulo, IE - Unicamp, 2002.

CARNEY, Michael \& GEDAJLOVIC, Eric. East Asian Financial Systems and the Transition from Investment-Driven to Innovation-Driven Economic Development, International Journal of Innovation Management, vol. 4, nº 3, 2000.

CARVALHO, Antonio Gledson de; RIBEIRO, Leonardo de Lima \& FURTADO, Cláudio Vilar. A Indústria de Private Equity e Venture Capital - primeiro censo brasileiro, São Paulo, Saraiva, 2006.

CARVALHO, Vinicius Marques de. Estado e Setor Privado na Gestão dos Serviços de Saneamento Básico no Brasil: uma análise jurídica a partir do exemplo francês. Tese de Doutorado, apresentada no Departamento de Direito Comercial da Faculdade de Direito da USP em co-tutela com a Universidade de Paris I, 2007.

CASPER, Steven. The Legal Framework for Corporate Governance: the influence of contract law on corporate strategies in Germany and United States, em HALL, Peter \& SOSKICE, David Varieties of Capitalism - the institutional foundations of comparative advantage, New York, Oxford Press, 2001. 
CEPAL, O Desenvolvimento Recente do Sistema Financeiro da América Latina, em SERRA, José. (coord.) América Latina - ensaios de interpretação econômica, $2^{\mathrm{a}}$ Ed. Rio de Janeiro, Paz e Terra, 1979.

CHANG, Ha-Joon. The Economics and Politics of Regulation, Cambridge Journal of Economics, nº. 21, 1997.

CHANG, Ha-Joon. The Political Economy of Industrial Policy, New York, St Martin's Press, 1994.

CINTRA, Marcos Antonio Macedo. A reestruturação patrimonial do sistema bancário brasileiro e os ciclos de crédito entre 1995 e 2005, em CARNEIRO, Ricardo. A Supremacia dos Mercados - e a política econômica do Governo Lula, São Paulo, UNESP, 2006.

COMPARATO, Fábio Konder. O Indispensável Direito Econômico, in Revista dos Tribunais, vol. 353, 1965.

COSTA, Karen Fernandez. A transformação do BNDES e sua influência na política de Estado do Brasil na década de 90, paper apresentado no XXVIII encontro anual da ANPOCS, 2004.

COUTINHO, Luciano \& BORGES, Bráulio Lima. A Consolidação da Estabilização e o Desenvolvimento Financeiro do Brasil, em PINHEIRO, Armando Castelar e OLIVEIRA FILHO, Luiz Chrysostomo (org.). Mercado de Capitais e Bancos Públicos - analise e experiências comparadas, Rio de Janeiro, São Paulo, Contra Capa, ANBID, 2007.

COUTINHO, Luciano \& REICHSTUL, Henri-Philippe. O Setor Produtivo Estatal e o Ciclo, em MARTINS, Carlos Estevam (org.). Estado e Capitalismo no Brasil, São Paulo, Hucitec - CEBRAP, 1977.

COUTINHO, Luciano. Brasil e Coréia do Sul - paralelos, sucessos e desastres, em FIORI, José Luís (org.). Estados e Moedas no Desenvolvimento das Nações, Petrópolis, Vozes, 1999.

CURRALERO, Claudia Regina Baddini. A Atuação do Sistema BNDES como Instituição Financeira de Fomento no Período 1952-1996, Dissertação de Mestrado apresentada no Instituto de Economia da UNICAMP, 1998.

DAIN, Sulamis. Empresa Estatal e Política Econômica no Brasil, em MARTINS, Carlos Estevam (org.). Estado e Capitalismo no Brasil, São Paulo, Hucitec - CEBRAP, 1977.

DEMSETZ, Harold. Why Regulate Utilities, Journal of Law and Economics, Vol. 11, 1968.

DOSI, Giovanni. Mudança Técnica e Transformação Industrial - a teoria e uma aplicação à indústria de semicondutores, (trad. Carlos D. Szlak), Campinas, Unicamp, 2006. 
DOSI, Giovanni. The Nature of Innovative Process, em DOSI, Giovanni; FREEMAN, Chris; NELSON, Richard; SILVERBERG, G. \& SOETE, Luc. (ed.). Technical Change and Economic Theory, London, Pinter Publishers, 1988.

EIZIRIK, Nelson; GAAL, Ariádna; PARENTE, Flávia \& HENRIQUES, Marcus de Freitas. Mercado de Capitais - regime jurídico, $2^{\mathrm{a}}$. ed., Rio de Janeiro, Renovar, 2008.

ENEI, José Virgilio Lopes. Project Finance - financiamento com foco em empreendimentos (parcerias público-privadas, leveraged buy-outs e outras figuras afins), São Paulo, Saraiva, 2007.

EVANS, Peter. A Tríplice Aliança - as multinacionais, as estatais e o capital nacional no desenvolvimento dependente brasileiro, (trad. Waltensir Dutra), $2^{a}$ ed. Rio de Janeiro, Zahar, 1982.

EVANS, Peter. Embedded Autonomy - state and industrial transformation, Princeton, Princeton University Press, 1995.

FERREIRA, Carlos Kawal Leal; FREITAS, Maria Cristina Penido de. \& SCHWARTZ, Gilson. Formato Institucional do Sistema Monetário e Financeiro - um estudo comparado, em CINTRA, Marcos Antonio Macedo \& FREITAS, Maria Cristina Penido de. Transformações Institucionais dos Sistemas Financeiros - um estudo comparado, São Paulo, Fundap, Fapesp, 1998.

FINGERL, Eduardo Rath. Congresso ABVCAP 2008 - investimento, energia e infraestrutura, apresentação de PowerPoint, paper mimeo, 2008.

FINGERL, Eduardo Rath. Desenvolvendo a Governança Corporativa, 2006, apresentações da Alta Administração do BNDES, disponível em www.bndes.gov.br

FREEMAN, Chris \& SOETE, Luc. The Economics of Industrial Innovation, $3^{\mathrm{a}} \mathrm{ed}$, Massachusetts, MIT Press, 1999.

FREEMAN, John. Venture Capitalist and Modern Capitalism, em NEE, Victor \& SWEDBERG, Richard. The Economic Sociology of Capitalism, New Jersey, Princeton, 2005.

FRIEDMAN, Lawrence. American Law in the $20^{\text {th }}$ Century, New Haven, Yale University Press, 2002.

FURTADO, Celso. Introdução ao Desenvolvimento - enfoque histórico-estrutural, $3^{\mathrm{a}}$ Ed., Rio de Janeiro, Paz e Terra, 2000.

GERSCHENKRON, Alexander. Economic Backwardness in Historical Perspective - a book of essays, $3^{\text {a }}$ reimpressão, Cambridge, London, Belknap Press, 1976.

GILSON, Ronald \& ROE, Mark. Understanding the Japanese Keiretsu: overlaps between corporate governance and industrial organization, Yale Law Journal, Vol. 102, $\mathrm{n}^{\mathrm{o}}$. 4, 1993. 
GOETZ, Charles \& SCOTT, Robert. Principles of Relational Contracts, Virginia Law Review, Vol. 67, n. 6, 1981.

GOMPERS, Paul \& LERNER, Josh. The Venture Capital Revolution. The Journal of Economic Perspectives, vol. 15, nº 2 (Spring), 2001.

GONÇALVES, Eduardo. Financiamento de Empresas de Base Tecnológica: algumas evidências da experiência brasileira, Revista Econômica do Nordeste, v. 33, nº. 1, janmar, 2002.

GORDON, Jeffrey \& ROE, Mark (Ed.). Convergence and Persistence in Corporate Governance, New York, Cambridge, 2004.

GORDON, Jeffrey. Institutions as Relational Investors: a new look at cumulative voting. Columbia Law Review, vol 94, nº 1, 1994.

GORDON, Robert. Macaulay, Macneil e a Descoberta da Solidariedade e do Poder no Direito Contratual, (tradução Marcos de Campos Ludwig, Revisão técnica José Rodrigo Rodrigues), Revista Direito GV, nº. 5, 2007.

GRANOVETTER, Mark \& SWEDBERG, Richard. The Sociology of Economic Life, $2^{\mathrm{a}}$ ed., Colorado, Westview Press, 2001.

GRANOVETTER, Mark. Economic Action and Social Structure: The Problem of Embeddedness, V.91, $\mathrm{n}^{\circ}$. 3, The American Journal of Sociology, 1985.

GRAU, Eros Roberto. A Ordem Econômica na Constituição de 1988. 5a ed., São Paulo, Malheiros, 2000.

GREMAUD, Amaury Patrick \& PIRES, Julio Manuel. II Plano Nacional de Desenvolvimento - II PND (1975-1979), em KON, Anita (org.) Planejamento no Brasil II, São Paulo, Perspectiva, 1999.

HABERMAS, Jürgen. Paradigms of Law, Cardozo Law Review, vol. 17, 1995.

HALL, Peter \& SOSKICE, David. Introduction, em HALL, Peter \& SOSKICE, David Varieties of Capitalism - the institutional foundations of comparative advantage, New York, Oxford Press, 2001.

HANSMANN, Henry \& KRAAKMAN, Reinier. Agency Problems and Legal Strategies, em KRAAKMAN, Reinier Reinier, et al. The Anatomy of Corporate Law - a comparative and functional approach, (reimpressão), New York, Oxford, 2006.

HANSMANN, Henry \& KRAAKMAN, Reinier. The Basic Governance Structure, em KRAAKMAN, Reinier Reinier, et al. The Anatomy of Corporate Law - a comparative and functional approach, (reimpressão), New York, Oxford, 2006. 
HANSMANN, Henry \& KRAAKMAN, Reinier. The End of History for Corporate Law, em GORDON, Jeffrey \& ROE, Mark (Ed.). Convergence and Persistence in Corporate Governance, New York, Cambridge, 2004.

HARVEY, David. A Condição Pós-Moderna - uma pesquisa sobre as origens da mudança cultural, (trad. Adail Ubirajara Sobral \& Maria Stela Gonçalves), São Paulo, Loyola, 1989.

HERTIG, Gerard \& KANDA, Hideki, Creditor Protection, em KRAAKMAN, Reinier, et al. The Anatomy of Corporate Law - a comparative and functional approach, (reimpressão), New York, Oxford, 2006.

HOLLAND , Stuart. State Entrepreneurship and State Intervention, em HOLLAND, Stuart. (editor) The State as Entrepreneur - new dimensions for public entreprise: the IRI state shareholding formula, New York, International Arts and Sciences Press Inc, 1972.

JENSEN, Michael \& MECKLING, William. Theory of the firm: managerial behaviour, agency costs and ownership structure, Journal of Financial Economics, v. 3, no . 4, 1976.

JESSOP, Bob. Developmental State and Knowledge-Driven Economies, paper, mimeo, disponível em http://www.bulgariagateway.org/bg/150/DevelopmentalStatesandKE.PDF

JESSOP, Bob. The Future of Capitalist State, (Reimpressão), Cambridge, Polity Press, 2005.

KAPLAN, Steven \& STRÖMBERG, Per. Venture Capitalists as Principals: contracting, screening and monitoring, The American Economic Review, vol. 91, nº. 2, 2001.

KNIGHT, Frank. Risk, Uncertainty and Profit, New York, Dover, 2006.

KOBAYASHI, Ichiro. The Interaction Between Japanese Corporate Governance and Relational Contract Practice, New York University, Journal of Legal \& Business, $\mathrm{n}^{\circ}$. 269, 2005/2006.

LA PORTA, Rafael; LOPEZ-de-SILANES, Florencio; SHLEIFER, Andrei. Government Ownership of Banks, Harvard Institute of Economic Research, Discussion Paper $\mathrm{n}^{\circ}$. 1890, 2000.

LA PORTA, Rafael; LOPEZ-de-SILANES, Florencio; SHLEIFER, Andrei \& VISHNY, Robert. Law and Finance, Journal of Political Economy, vol. 106, nº. 6, 1998.

LA PORTA, Rafael; LOPEZ-de-SILANES, Florencio; SHLEIFER, Andrei \& VISHNY, Robert. Legal Determinants of External Finance, The Journal of Finance, vol. 52, no. 3, 1997. 
LA PORTA, Rafael; LOPEZ-de-SILANES, Florencio; SHLEIFER, Andrei \& VISHNY, Robert. Investor Protection and Corporate Governance, Journal of Financial Economics, $\mathrm{n}^{\circ} .58,2000$.

LAFER, Celso. JK e o Programa de Metas - processo de planejamento e sistema político no Brasil (1956-1961), (trad. Maria Victoria Benevides), Rio de Janeiro, FGV, 2002.

LAFER, Celso. O Planejamento no Brasil - observações sobre o Plano de Metas (19561961), em LAFER, Betty Mindlin. Planejamento no Brasil, $3^{\mathrm{a}}$ ed., São Paulo, Perspectiva, 1975.

LASTRES, Helena Maria Martins \& FERRAZ, João Carlos. Economia da Informação, do Conhecimento e do Aprendizado, em LASTRES, Helena \& ALBAGLI (org.), Sarita. Informação e Globalização na Era do Conhecimento, Rio de Janeiro, Campus, 1999.

LEVINE, Ross. The Legal Environment, Banks, and Long-Run Economic Growth, Journal of Money, Credit and Banking, vol. 30, $\mathrm{n}^{\circ}$. 3, 1998.

MACAULAY, Stewart. Non-Contractual Relations in Business: a Preliminary Study, American Sociological Review, v. 28, 1963.

MACNEIL, Ian. Contracts: adjustment of long-term economic relations under classical, neoclassical and relational contract law. Northwestern University Law Review, v. 72, $\mathrm{n}^{\mathrm{o}} .6,1988$.

MANTEGA, Guido. O BNDES e o Novo Ciclo de Desenvolvimento, Revista do BNDES, Rio de Janeiro, v. 12, $\mathrm{n}^{\circ} .23,2005$.

MARQUES NETO, Floriano Azevedo. A Nova Regulação Estatal e as Agências Independentes, em SUNDFELD, Carlos Ari. Direito Administrativo Econômico, São Paulo, Malheiros, 2000.

MARTINS, Luciano. Estado Capitalista e Burocracia no Brasil pós-64, Rio de Janeiro, Paz e Terra, 1985.

MELO, Luiz Martins de. O Financiamento da Inovação Industrial, Tese de Doutorado apresentada no Instituto de Economia da Universidade Federal do Rio de Janeiro, 1994.

MELO, Luiz Martins de. O Financiamento das Empresas Inovadoras: alternativas para discussão, paper, mimeo, 2005, disponível em www.ie.ufrj.br/eventos/seminarios/pesquisa/texto_11_10.pdf

MENDONÇA, Paulo Augusto Furtado. A Intervenção do Estado Brasileiro no Setor Financeiro: estudo sobre o Banco Nacional de Desenvolvimento Econômico e Social, Dissertação de Mestrado apresentada na Faculdade de Direito da USP, São Paulo, 2005. 
MONTEIRO FILHA, Dulce. Aplicação dos Recursos Compulsórios pelo BNDES na Formação da Estrutura Setorial da Indústria - 1952-1989, Mimeo, Tese de Doutorado apresentada ao Instituto de Economia da UFRJ, 1994.

MOREIRA, Maurício Mesquita \& PUGA, Fernando Pimentel, Como a Indústria Financia o seu Crescimento. Uma análise do Brasil Pós-Real, Revista de Economia Contemporânea - vol. 5, Edição Especial, 2000.

NONET, Philippe \& SELZNICK Philip. Law and Society in Transition - toward responsive law, $2^{\mathrm{a}}$ ed., Transaction Publishers, New Jersey, 2008.

NORTH, Douglas. Institutions, Institutional Change and Economic Performance, Cambridge, Cambridge University Press, 1990.

NOVAES, Ana. Intermediação Financeira, Bancos Estatais e o Mercado de Capitais: a experiência internacional, em PINHEIRO, Armando Castelar e OLIVEIRA FILHO, Luiz Chrysostomo (org.). Mercado de Capitais e Bancos Públicos - análise e experiências comparadas, Rio de Janeiro, São Paulo, Contra Capa, ANBID, 2007.

NUSDEO, Ana Maria de Oliveira. Defesa da Concorrência e Globalização Econômica - o controle da concentração de empresas, São Paulo, Malheiros, 2002.

NUSDEO, Fábio. Banco de Desenvolvimento, em Enciclopédia Saraiva do Direito, v. 10, São Paulo, Saraiva, 1977.

NUSDEO, Fábio. Banco Nacional de Desenvolvimento Econômico, em Enciclopédia Saraiva do Direito, v. 10, São Paulo, Saraiva, 1977.

NUSDEO, Fábio. Bancos de Investimento, em Enciclopédia Saraiva do Direito, v. 10, São Paulo, Saraiva, 1977.

Ó RIAIN, Séan. The Flexible Developmental State: globalization, information technology, and the 'Celtic Tiger', Politics \& Society, vol. 28, n' 2, 2000.

Ó RIAIN, Séan. The Politics of High-Tech Growth - developmental network states in the global economy, Cambridge, 2004.

OECD, A New Economy? - the changing role of innovation and information technology in growth, Paris, 2000.

OECD, Government Venture Capital for Technology-Based Firms, Paris, OECD, 1997.

OECD, Manual de Oslo - proposta de diretrizes para a coleta e interpretação de dados sobre inovação tecnológica, (trad. Paulo Garchet), OECD - FINEP, 1997.

OLIVEIRA, Francisco. O Ornitorrinco, em OLIVEIRA, Francisco. Crítica da Razão Dualista - O Ornitorrinco, São Paulo, Boitempo, 2003. 
OLIVEIRA, Francisco. O Surgimento do Antivalor - capital, força de trabalho e fundo público, em OLIVEIRA, Francisco. Os Direitos do Antivalor - a economia política da hegemonia imperfeita, Petrópolis, Vozes, 1997.

PINHEIRO, Armando Castelar. Bancos Públicos no Brasil: para onde ir? em PINHEIRO, Armando Castelar \& OLIVEIRA FILHO, Luiz Chysostomo (org). Mercado de Capitais e Bancos Públicos - análise e experiências comparadas, Rio de Janeiro, São Paulo, Contra Capa, ANBID, 2007.

PINHEIRO, Armando Castelar. Privatização no Brasil: Por que? Até onde? Até quando? em GIAMBIAGI, Fábio \& MOREIRA, Mauricio Mesquita. A Economia Brasileira nos Anos 90, Rio de Janeiro, BNDES, 1999.

PINTO, Luciane Gorgulho. Capital de Risco: uma alternativa de financiamento às pequenas e médias empresas de base tecnológica - o caso do CONTEC, revista do BNDES, Rio de Janeiro, nº. 7, jun, 1997.

PINTO JUNIOR, Mario Engler. A Capitalização da Companhia, em FINKELSTEIN, Maria Eugênia Reis \& PROENÇA, José Marcelo Martins. Direito Societário, São Paulo, Saraiva, 2007.

PIORE, Michael \& SABEL, Charles. The Second Industrial Divide - possibilities for prosperity, New York, Basic Books, 1984.

PISTOR, Katharina \& XU, Chenggang. Governing Emerging Stock Markets: legal vs administrative governance. Blackwell publishing, vol. 13, $\mathrm{n}^{\mathrm{o}}$ 1, 2005.

PISTOR, Katharina. Legal Ground Rules in Coordinated and Liberal Market Economies, working paper $n^{\circ} .30 / 2005$, Columbia Law School, 2005.

POLANYI, Karl. La Economia como Actividad Institucionalizada, em POLANYI, Karl. Comercio y Mercado en los Imperios Antiguos, Trad. Alberto Nicolás, $1^{\text {a }}$ ed., Barcelona, Labor Universitaria, 1976.

POLANYI, Karl. A Grande Transformação - as origens da nossa época, Trad. Fanny Wrobel, $2^{a}$ ed., Rio de Janeiro, Campus, 2000.

POSSAS, Mario, Concorrência Schumpeteriana, em KUPFER, David \& HASENCLEVER, Lia. Economia Industrial - fundamentos teóricos e práticas no Brasil, Rio de Janeiro, Campus, 2002

POSSAS, Mario. Competitividade: Fatores Sistêmicos e Política Industrial - implicações para o Brasil, em CASTRO, Antônio Barros de; POSSAS, Mario Luiz \& PROENÇA, Adriano. Estratégias Empresariais na Indústria Brasileira: discutindo mudanças, Rio de Janeiro, Forense, 1996.

PREBISCH, Raul. O Desenvolvimento Econômico da América Latina e Alguns de seus Problemas Principais, em BIELSCHOWSKY, Ricardo (org). Cinqüenta Anos de Pensamento na CEPAL, (Trad. Vera Ribeiro), Rio de Janeiro, Record, 2000. 
ROE, Mark. Some Differences in Corporate Structure in Germany, Japan and the United States, The Yale Law Journal, Vol. 102, nº. 8, Symposium: Economic Competitiveness and the Law, 1993.

ROMANO, Roberta. Corporate Law and Corporate Governance, vol. 3, nº. 2, 1996.

ROMANO, Roberta. Foundations of Corporate Law, New York, Foundation Press, 1993.

SABEL, Charles. Bootstrapping Development: rethinking the role of public intervention in promoting growth, paper apresentado na conferência Ética Protestante e o Espírito do Capitalismo, na Universidade de Cornell, paper, mimeo, 2004, disponível em http://www2.law.columbia.edu/sabel/papers/bootstrapping\%20deve\%20send5.doc

SABEL, Charles. Mudança de Modelos de Eficiência e suas Implicações para a Industrialização no Terceiro Mundo, em FOXLEY, Alejandro; MCPHERSON, Michael \& O’DONNELL, Guillermo. Desenvolvimento e Política e as Aspirações Sociais - o pensamento de Albert O. Hirschman, (Trad. Adail Sobral \& Evelyn Massaro), São Paulo, Vértice, 1988.

SAHLMAN, William A. The Structure and Governance of Venture-Capital Organizations, Journal of Financial Economics, 27, 1990.

SALOMÃO FILHO, Calixto. Direito Concorrencial - as estruturas, São Paulo, Malheiros, 1998.

SALOMÃO FILHO, Calixto. Efeitos Concorrenciais do Direito Societário, em SALOMÃO FILHO, Calixto. O Novo Direito Societário, São Paulo, Malheiros, 1998.

SANTOS, Durval Soledade, et al. Fundos de Empresas Emergentes: novas perspectivas de capitalização para pequenas e médias empresas, Revista do BNDES, s/n., disponível em http://www.bndes.gov.br/conhecimento/revista/durval.pdf.

SCHAPIRO, Mario Gomes. Estado, Direito e Economia no Contexto Desenvolvimentista: breves considerações sobre três experiências - governo Vargas, Plano de Metas e II PND. em SANTI, Eurico Marcos Diniz de. (org.). Curso de Direito Tributário e Finanças Públicas - do fato à norma, da realidade ao conceito jurídico. São Paulo: Saraiva, 2007.

SCHAPIRO, Mario Gomes. Política Industrial e Disciplina da Concorrência pósReformas de Mercado - uma avaliação institucional do ambiente de inovação tecnológica, Dissertação de Mestrado defendida na Faculdade de Direito da USP, 2005.

SCHEUERMAN, William. Reflexive Law and the Challenges of Globalization, The Journal of Political Philosophy, vol. 9, n 1, 2001.

SCHUMPETER, Joseph. A Teoria do Desenvolvimento Econômico - uma investigação sobre lucros, capital, crédito, juro e o ciclo econômico (trad. Maria Silvia Possas), $3^{\text {a }}$ ed., São Paulo, Nova Cultural, 1988. 
SHLEIFER, Andrei \& VISHNY, Robert, A Survey of Corporate Governance, The Journal of Finance, vol. 52, no. 2, 1997.

STALLINGS, Barbara \& STUDART, Rogerio. Finance for Development - Latin America in Comparative Perspective, Economic Comission for Latin America and the Caribbean - UN, Washington, 2006.

STEINER, Philippe. Sociologia Econômica, (trad. Maria Helena Trylinski), São Paulo, Atlas, 2006.

STIGLER, George. The Theory of Economic Regulation, The Bell Journal of Economics and Management Science, $\mathrm{n}^{\circ} .2,1971$.

STLIGTZ, Joseph. Government, Financial Markets, and Economic Development, Working Paper $n^{\circ} .3669$, National Bureau of Economic Research,1991.

STIGLITZ, Joseph \& UY, Marilou. Financial Markets, Public Policy, and The East Asian Miracle, World Bank Research Observer, vol. 11, n. 2, 1996.

STIGLITZ, Joseph. Os Exuberantes Anos 90 - uma interpretação da década mais próspera da história, (trad. Sylvia Maria Cristovão dos Santos, Dante Mendes Aldrighi, José Francisco de Lima Gonçalves e Roberto Mazzer Neto), São Paulo, Companhia das Letras, 2003.

SUZIGAN, Wilson \& VILLELA, Annibal. Industrial Policy in Brazil, Campinas, Unicamp, 1997.

SWEDBERG, Richard \& SMELSER, Neil. Introducing Economic Sociology, em SWEDBERG, Richard \& SMELSER, Neil (Editors), The Handbook of Economic Sociology, 2a . ed, New York, Princeton University Press, 2005.

SWEDBERG, Richard. Max Weber e a Idéia de Sociologia Econômica, (Trad. Dinah Abreu Azevedo), Rio de Janeiro, UFRJ , 2005.

TEIXEIRA, Natermes Guimarães. Origem do Sistema Multibancário Brasileiro, Campinas, Unicamp, 2000.

TEUBNER, Gunther. Legal Irritants: how unifying law ends up in new divergences, em

HALL, Peter \& SOSKICE, David Varieties of Capitalism - the institutional foundations of comparative advantage, New York, Oxford Press, 2001.

TEUBNER, Gunther. Substantive and Reflexive Elements in Law, Law \& Society Review, vol. $17, \mathrm{n}^{\circ} .2,1983$.

TORRES FILHO, Ernani Teixeira. A Reforma do Sistema FAT-BNDES: críticas à proposta Arida, em Revista do BNDES, Rio de Janeiro, v. 12, nº. 24, pp. 31-42, 2005.

TORRES FILHO, Ernani Teixeira. Direcionamento do Crédito: o papel dos bancos de desenvolvimento e a experiência recente do BNDES, em PINHEIRO, Armando 
Castelar e OLIVEIRA FILHO, Luiz Chrysostomo (org.). Mercado de Capitais e Bancos Públicos - analise e experiências comparadas, Rio de Janeiro, São Paulo, Contra Capa, ANBID, 2007.

TREBAT, Thomas. Brazil's State-Owned Enterprises - a case study of the state as entrepreneur, New York, Cambridge, 1983.

TREBILCOCK, Michael; PRADO, Mariana Mota \& WILSON, James. Path Dependence Theory, Economic Development and the Dynamics of Institutional Reform, paper, mimeo, 2008.

TRIANTIS, George. Financial Contract Design in the World of Venture Capital, Chicago Law Review, v. 68, 2001.

TRUBEK, David. Toward a Social Theory of Law: an essay on the study of law and development. Yale Law Journal, vol. 82, nº. 1, 1972.

UNGER, Roberto Mangabeira. O Direito e o Futuro da Democracia, (trad. Caio Farah Rodriguez e Marcio Grandchamp), São Paulo, Boitempo, 2004.

UNGER, Roberto Mangabeira. Uma Nova Faculdade de Direito no Brasil, disponível em www.law.harvard.edu/unger/portuguese/docs/projetos6.doc

VENÂNCIO FILHO, Alberto. A Intervenção do Estado no Domínio Econômico - o direito público econômico no Brasil, Edição Fac-similar da de 1968, Rio de Janeiro, Renovar, 1998.

VITOLS, Sigurt. Financial Systems and Industrial Policy in Germany and Great Britain: the limits of convergence, WZB, discussion paper FS I 95-311, 1995, disponível em http://papers.ssrn.com/sol3/papers.cfm?abstract_id=608203

VITOLS, Sigurt. Varieties of Corporate Governance: comparing Germany and the UK, em HALL, Peter \& SOSKICE, David. Varieties of Capitalism - the institutional foundations of comparative advantage, New York, Oxford Press, 2001.

WILLIAMSON, Oliver. Corporate Finance and Corporate Governance, The Journal of Finance, vol. 43, nº. 3, 1988.

WILLIAMSON, Oliver. The Economic Institutions of Capitalism - firm, markets, relational contracting, New York, Free Press, 1985.

WILLIAMSON, Oliver. Transaction Cost Economics and Organization Theory, em SMELSER, Neil \& SWEDBERG, Richard. The Handbook of Economic Sociology, Princeton, Princeton University Press, 1994.

WRIGHT, Mike \& ROBBIE, Ken. Venture Capital and Private Equity: a review and sinthesis, Journal of Business Finance \& Accounting, 25, (june/july) 1998. 
YAZBEK, Otávio. Regulação do Mercado Financeiro e de Capitais, Rio de Janeiro, Elsevier, 2007.

YEYATI, Eduardo Levy; MICCO, Alejandro \& PANIZZA, Ugo. Should the Government be in the Banking Sector? The Role of State-Owned and Development Banks, paper apresentado no seminário Governments and Banks: Responsibilities and Limits, InterAmerican Development Bank (IDB), Lima, Peru, 2004, diponível em http://www.bid.org.uy/res/publications/pubfiles/pubWP-517.pdf

ZYSMAN, John. Governments, Markets, and Growth - financial systems and the politics of industrial change, New York, Cornell Paperback, 1984. 


\section{ENTREVISTAS REALIZADAS}

Durval Soledade Santos - Ex-Diretor da BNDESpar e ex-Diretor da CVM;

Eduardo Rath Fingerl - Diretor da Área de Mercado de Capitais do BNDES;

Eduardo Sá - Chefe do Departamento de Área de Mercado de Capital do BNDES;

Ernani Teixeira Torres Filho - Secretaria de Assuntos Econômicos do BNDES;

Fabio Sotelino - Superintendente de Capital Empreendedor do BNDES;

Luis Eugênio Figueiredo - Presidente da ABVCAP (Associação Brasileira de Venture Capital e Private Equity);

Marcelo Cabrera - Diretor de Departamento do BNDES, na Área de Mercado de Capitais;

Nestor Perini - Presidente da Lupatech S.A. (por comunicação eletrônica);

Thomas Tosta de Sá - Ex-Presdidente da CVM;

Yolanda Ramalho - Superintendente de Planejamento do BNDES. 


\section{RESUMO}

O objetivo desta tese é analisar os novos caminhos da intervenção direta do Estado na economia, notadamente no ambiente financeiro nacional, em que prevalece a atuação de um banco público de desenvolvimento - o BNDES.

O trabalho parte do pressuposto de que há uma variedade de alternativas institucionais de organização financeira, que refletem as trajetórias históricas dos países. É por esta razão que se pode identificar, por exemplo, diferenças entre o modelo norteamericano e o modelo nipo-germanico: enquanto o primeiro é baseado nas operações do mercado de capitais, o segundo conta com os investidores institucionais e com os bancos. A partir daí, pode-se igualmente reconhecer que a alternativa institucional constitutiva do sistema financeiro nacional conta com os agentes estatais: os seus principais atores financeiros. Destes todos, o BNDES é o exemplo mais significativo.

Diante disso, uma vez caracterizado que a intervenção direta do Estado, também chamada no trabalho de regulação institucional, é o elemento característico do modelo brasileiro de desenvolvimento, a tese procurar mostrar que esta ação pública tem sofrido alterações, em um contexto recente. Em razão de um novo paradigma econômico, a economia baseada no conhecimento, pode-se reconhecer modificações na forma de atuação do agente estatal. Um estudo de caso revela que não só o financiamento das inovações passou a assumir um caráter relevante na agenda do BNDES, como, principalmente, esta atividade esteve associada a uma nova racionalidade de intervenção. Diante da nova economia, o Banco atua em convergência com os demais agentes financeiros e com isso assume um papel de indutor tanto das empresas emergentes, como do próprio de mercado de capital de risco.

Esta constatação aponta para dois atributos que compõem, então, esta nova rodada da regulação direta da economia: a persistência e a dinâmica. A persistência porque apesar das modificações advindas de uma economia baseada no conhecimento, o Estado e, em especial o BNDES, continua a desempenhar um papel chave no financiamento do desenvolvimento brasileiro, particularmente em áreas não consolidadas e portadoras de futuro, como, ora, são as inovações. A dinâmica porque esta prevalência do agente estatal no financiamento corporativo assenta-se em novas ferramentas e assume uma distinta racionalidade, compatível com uma economia privatizada e aberta à concorrência internacional.

É, pois, disso que trata esta tese: da regulação institucional de um banco de desenvolvimento em uma economia baseada no conhecimento.

Palavras-chave:

Estado, BNDES, Alternativas Institucionais, Ferramentas Jurídicas, Economia Baseada no Conhecimento, Venture Capital, Desenvolvimento Econômico 


\section{RIASSUNTO}

L'obiettivo di questa tesi è analizzare i nuovi cammini dell'intervenzione diretta dello Stato nella economia, marcatamente nell'ambiente finanziero nazionale, in cui prevale l'attuazione di una banca pubblica - BNDES (Banca Nazionale dello Sviluppo Economico e Sociale).

Il lavoro parte del pressuposto che esiste una varietà di alternative istituzionali dell'organizzazione finanziaria. É per questa ragione che si può identificare, per esempio, le diferenze tra il modello nord-americano e il modello nippo-tedesco: il primo basato nelle operazioni del mercato del capitale; il secondo, negli investitori istituzionali e le banche. Da questo punto, é possibile stabilire ugualmente che l'alternativa istituzionale costitutiva del sistema finanziario nazionale include gli agenti dello Stato: i suoi principali attori. Fra tutti, BNDES è l'esempio più significativo.

Davanti a questo, una volta caratterizzato che l'intervenzione diretta dello Stato, anche denominata in questo lavoro regolazione istituzionale, è l'elemento caratteristico del modello brasiliano di sviluppo, la tesi intende dimostrare che l'azione pubblica ha subito alterazioni in un contesto recente. In ragione di un nuovo paradigma economico, l'economia basata nella conoscenza, si possono identificare modificazioni nella maniera di attuazione dell'agente dello Stato. Un studio di caso rivela che non soltanto il finanziamento delle innovazioni ha preso un valore rilevante nell'agenda del BNDES, come, e principalmente, questa attività è stata associata a una nuova razionalità dell'intervenzione. Davanti alla nuova economia, la Banca (BNDES) agisce di maniera convergente agli altri agenti finanziari e cosí assumisce un ruolo de induttore tanto delle impresi emergenti, come del stesso mercato del capitale del rischio.

Questa constatazione indica due atributti che compongono, cosí, la nuova serie della regolazione diretta dell'economia: la persistenza e la dinamica. La persistenza, perché, nonostante le modificazioni venute dall'economia basata nella conoscenza, lo Stato e, in modo speciale il BNDES, continua svolgendo un ruolo chiave nel finanziamento del sviluppo brasiliano, particolarmente nell'aree non consolidate e portatori di futuro, come adesso sono le innovazioni. La dinamica, perché la prevalenza dell'agente dello Stato nel finanziamento corporativo si appoggia nelle nuove attrezzi e assumisce una diversa razionalità, compatibile con una economia privatizzata e aperta alla concorrenza internazionale.

È, dunque, di ciò che tratta questa tesi: della regolazione istituzionale di una banca di sviluppo in una economia basata nella conoscenza.

Parole-chiave:

Stato, BNDES (Banca Nazionale dello Sviluppo Economico e Sociale), Alternative Istituzionali, Atrezzi Giuridici, Economia basata sulla conoscenza, Venture Capital, Sviluppo Econômico 


\begin{abstract}
The objective of this dissertation is to examine the new ways of direct State intervention in the economy, especially in the domestic financial environment, which has a prevailing public bank for development - the BNDES.

The work is based on the assumption that there are a variety of alternatives to institutional financial organization, which reflect the historical trajectories of the countries. It is for this reason that we can identify, for example, differences between the U.S. model and the Japanese-German model: while the former is based on the operations of the capital market, the latter deals with institutional investors and the banks. Hence, we can also recognize that the alternative institutional constituent of the national financial system takes into account state agents, their main financial players. Of them all, the BNDES is the most significant example.

Thus, once established the direct intervention of the state, also called institutional regulation, as the main feature of the Brazilian model of development, the dissertation examines the changes it recently underwent. Because of a new economic paradigm, the knowledge based economy, there have been changes in the way state acts in economy. A case study shows that not only that the financing of innovation has become paramount within the BNDES agenda, but also this activity has been associated with a new rationale for intervention. Facing this new economy, the Bank operates in convergence with other financial agents, thus taking a role in inducing both emerging companies and venture capital.
\end{abstract}

This finding points to two attributes that make up, thus, this new stage of direct regulation of the economy: persistence and dynamics. Persistence because despite changes resulting from a knowledge based economy, the state and, in particular the BNDES, continues to play a key role in the financing of Brazilian development, particularly in nonconsolidated and future bearing areas, as innovations. Dynamics, because the prevalence of the state agent in corporate finance is based on new tools and takes a different rationale, consistent with a privatized economy, open to international competition.

That is, therefore, with the core issue of the present dissertation: the institutional regulation of a development bank within a knowledge-based economy.

Keywords:

State, BNDES, Institutional Alternatives, Legal Tools, Knowledge Based Economy, Venture Capital, Economic Development 